\title{
Free movement of persons within the European Community : cross-border access to public benefits
}

Citation for published version (APA):

van der Mei, A. P. (2001). Free movement of persons within the European Community : cross-border access to public benefits. [Doctoral Thesis, Maastricht University]. Universiteit Maastricht. https://doi.org/10.26481/dis.20010628am

Document status and date:

Published: 01/01/2001

DOI:

10.26481/dis.20010628am

Document Version:

Publisher's PDF, also known as Version of record

\section{Please check the document version of this publication:}

- A submitted manuscript is the version of the article upon submission and before peer-review. There can be important differences between the submitted version and the official published version of record.

People interested in the research are advised to contact the author for the final version of the publication, or visit the DOI to the publisher's website.

- The final author version and the galley proof are versions of the publication after peer review.

- The final published version features the final layout of the paper including the volume, issue and page numbers.

Link to publication

\footnotetext{
General rights rights.

- You may freely distribute the URL identifying the publication in the public portal. please follow below link for the End User Agreement:

www.umlib.nl/taverne-license

Take down policy

If you believe that this document breaches copyright please contact us at:

repository@maastrichtuniversity.nl

providing details and we will investigate your claim.
}

Copyright and moral rights for the publications made accessible in the public portal are retained by the authors and/or other copyright owners and it is a condition of accessing publications that users recognise and abide by the legal requirements associated with these

- Users may download and print one copy of any publication from the public portal for the purpose of private study or research.

- You may not further distribute the material or use it for any profit-making activity or commercial gain

If the publication is distributed under the terms of Article $25 \mathrm{fa}$ of the Dutch Copyright Act, indicated by the "Taverne" license above, 
FREE MOVEMENT OF PERSONS WITHIN THE EUROPEAN COMMUNITY CROSS-BORDER ACCESS TO PUBLIC BENEFITS

A.P. van der Mei 

Free Movement of Persons within the European Community

\section{Cross-Border Access to Public Benefits}

PROEFSCHRIFT

ter verkrijging van de graad van doctor aan de Universiteit Maastricht, op gezag van

de Rector Magnificus, Prof. dr. A.C. Nieuwenhuijzen Kruseman volgens het Besluit van het College van Decanen, in het openbaar te verdedigen op donderdag 28 juni 2001 om 14.00 uur door

Anne Pieter van der Mei 
Promotor: $\quad$ Prof. dr. B.E.F.M. de Witte

Beoordelings-

commissie: Prof. dr. H.E.G.S.S. Schneider (voorzitter)

Prof. dr. G.J.J. Heerma van Voss (Universiteit Leiden)

Dr. E.I.L. Vos

A Commercial Edition of this book will be published by Hart Publishing Ltd, Oxford. 


\section{ACKNOWLEDGEMENTS}

Writing a book requires patience. This does not only hold true for the author, but also, and probably much more, for those who work and live with him. Being grateful to many, I would like to thank a few persons in particular. These are first of all the members of the Examining Committee (Beoordelingscommissie). Hildegard Schneider, Guus Heerma van Voss and Ellen Vos have been so very kind to accept the burden of reading and reviewing the entire book. My promotor, Bruno De Witte, deserves a special thanks. He has been a rich source of inspiration and his advice and comments have contributed to the quality of this book. Any omissions and errors remain, of course, my responsibility alone. Further, I would like to express my sincere gratitude to my parents and, above all, to my dear Evelyn for her unwavering support.

I have striven to state the law on cross-border access to public benefits within the European Community and the United States as it stood on 1 January 2001, although a few legal developments that have occured after this date have been included.

Maastricht, 15 april 2001

Anne Pieter van der Mei 

For Atta Panyin and Atta Kaakra 



\section{CONTENTS}

Acknowledgements $\quad$ v

Contents $\quad$ Ix

$\begin{array}{ll}\text { Abbreviations } & \text { Xix }\end{array}$

Table of Cases $\quad$ Xxiii

Bibliography $\quad$ Xxxv

\section{Chapter 1 INTRODUCTION}

1

Introduction $\quad 3$

Freedom of Movement versus the Protection of Public Benefit Systems

Public Benefits

Welfare State Benefits: Solidarity, Territoriality and 5 Nationality

2.3 Immigration Policy and the Welfare State 10

$2.4 \quad$ Free Movement of Persons and Cross-Border Access to 13 Welfare State Benefits

Definition of the Subject

$\begin{array}{lll}3.5 & \text { Structure of the Book } & 23\end{array}$ 


\section{Chapter 2 FREE MOVEMENT OF PERSONS: HISTORY, LEGAL FRAMEWORK AND BASIC PRINCIPLES}

Free Movement of Workers: a Brief History

Right to Reside

Right to Equal Treatment in Matters not Related to

Non-Economic Residents

Towards a General Right of Residence: A Brief History Right to Reside

Right to Equal Treatment

Non-Residents

Third Country Nationals under the Community Provisions on the Free Movement of Persons Direct Discrimination on Grounds of Nationality 
The United States

\section{Chapter 3 MINIMUM SUBSISTENCE BENEFITS}

Minimum Subsistence Benefit Schemes and the 
Right to Reside

Right to Claim Minimum Subsistence Benefits

Family Members

Right to Reside

Right to Claim Minimum Subsistence Benefits $\quad 158$

Conclusions

Non-Economic Residents

Introduction

Right to Reside

Right to Claim Minimum Subsistence Benefits $\quad 167$

Lawful Residence

Conclusions

Non-Residents

Article 10 of Regulation No 1408/71 175

Article 10a

Third Country Nationals 190

EEA Nationals $\quad 190$

Maghreb Nationals $\quad 191$

Turkish Nationals 196

8

Conclusions 


$\begin{array}{llr}9.4 .4 & \text { Saenz } v \text { Roe } & 220 \\ 9.5 & \text { Non-Residents } & 223 \\ 9.6 & \text { Aliens } & 225 \\ 9.6 .1 & \text { Permanent Residents } & 226 \\ 9.6 .2 & \text { Undocumented Aliens } & 227 \\ 9.7 & \text { Summary and Conclusions } & 229 \\ & & \\ \mathbf{1 0} & \text { Towards a General Right of Residence in the } & 232 \\ & \text { European Community } \\ 10.1 & \text { Introduction } & 232 \\ 10.2 & \text { Freedom of Movement versus the Financial Stability of } & 234 \\ & \text { Social Assistance Schemes } \\ 10.2 .1 & \text { Race to the Bottom Hypothesis } & 234 \\ 10.2 .2 & \text { A Race to the Bottom in the European Community? } & 236 \\ 10.3 & \text { Legislative Options } & 239 \\ 10.4 & \text { Judicial Options } & 245 \\ 10.4 .3 & \text { Conclusions } & 252\end{array}$

\section{Chapter 4 HEALTH CARE}

Health Care and the Common Market and Basic Principles of the Rules on the Co-ordination of Health Insurance Schemes 
xiv

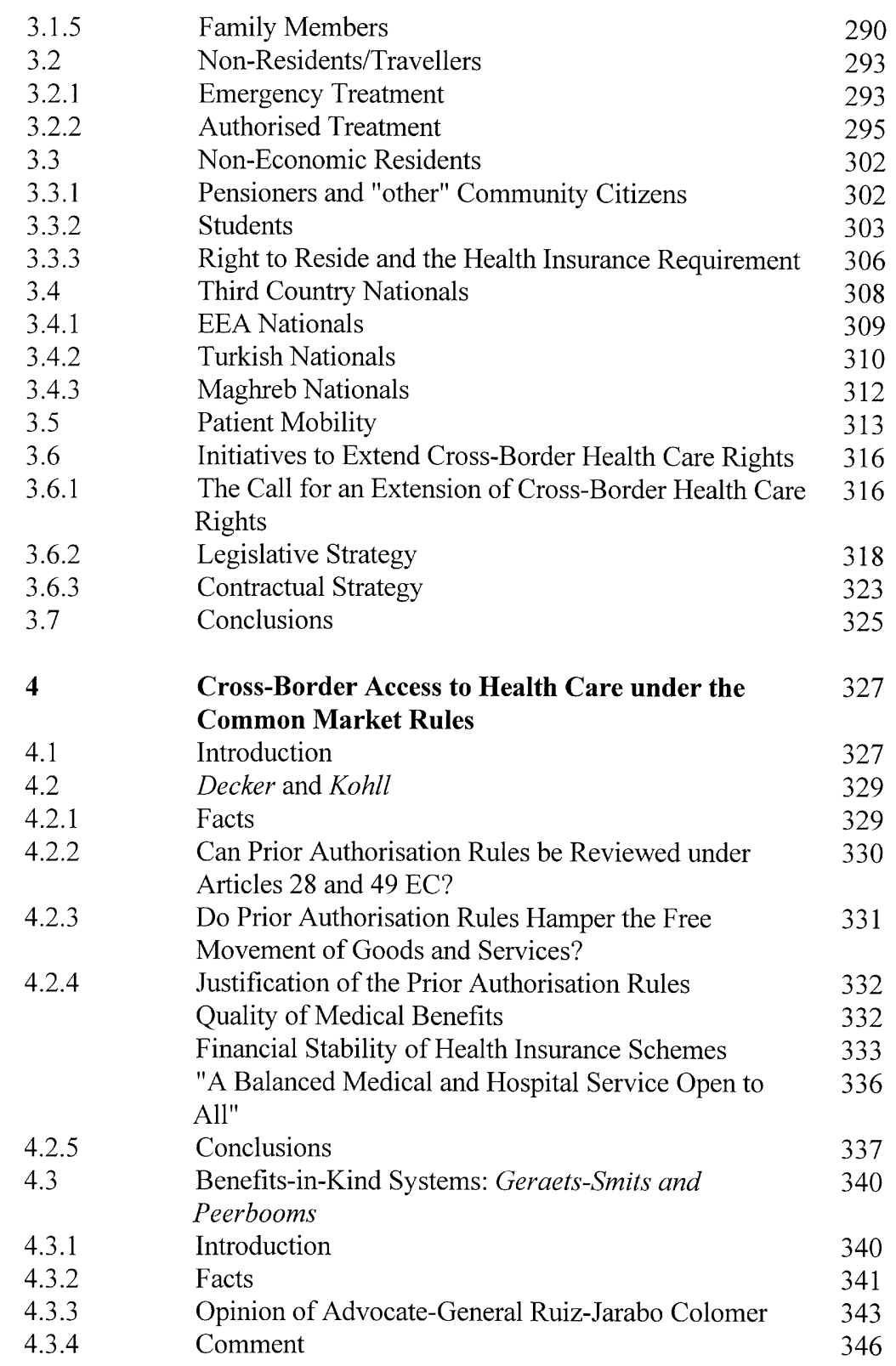


$\mathrm{XV}$

$4.4 \quad$ Intramural and Extramural Care 352

$4.5 \quad$ Waiting Lists 356

4.6 National Health Services 359

4.7 Medical Benefits not Covered by Insurance Packages 363

$4.8 \quad$ Third Country Nationals 368

$\begin{array}{lll}4.9 & \text { Conclusions } & 371\end{array}$

$5 \quad$ The United States 373

5.1 The American Health Care System 374

$\begin{array}{lll}5.2 & \text { Residents } & 377\end{array}$

$\begin{array}{lll}5.3 & \text { Non-Residents } & 381\end{array}$

$\begin{array}{lll}5.4 & \text { Aliens } & 383\end{array}$

5.4.1 Permanent Residents 384

5.4.2 Non-Immigrants and Undocumented Aliens 386

5.5 Lessons for the European Community? 388

6 Conclusions 389

\section{Chapter 5 EDUCATION}

$1 \quad$ Introduction 393

$2 \quad$ Education and the European Community 397

2.1 Educational Systems of the Member States 397

$2.2 \quad$ Conditions of Access 400

2.3 The Common Educational Policy 402

$3 \quad$ Economic Residents 410

3.1 The Community's Power to Grant Educational Rights 410

$3.2 \quad$ Community Workers 412

3.2.1 Admission to Education 412

3.2.2 Study Grants 413

3.2.3 Status of Community Worker 417

$3.3 \quad$ Children of Community Workers 421

3.3.1 Admission to Education 421

3.3.2 Study Grants $\quad 422$

3.3.3 Status of Child of a Community Worker 429 
xvi

Community Students

Right to Reside

The "other" Non-Economic Residents Introduction

Conditions of Access

Non-Residents

Permanent Residents 
xvii

9

9.1

9.2

9.2.1

9.2 .2

9.3

9.3 .1

9.3 .2

9.4

9.4 .1

9.4 .2

9.4 .3

9.5

\section{Chapter 6}

\section{CONCLUSIONS}

\section{1} 2

Member States
Future of the Free Movement of Students 498

Introduction 498

Free Movement of Students versus the Protection of 499 Educational Systems

Race to the Bottom Hypothesis 499

A Race to the Bottom in the European Community? 501

Options for Promoting Student Mobility 503

Study Grants $\quad 504$

A Right to Export Study Grants? 505

Fahmi and Esmoris Cerdeiro-Pinedo Amado 507

Article 7(2) of Regulation No 1612/68: Children of 509

Community Workers

Article 12(1) EC: Community Students 514

Overlap of Study Grants $\quad 517$

Right to Reside and the Financial Means Requirement 519

Options for Protecting the Educational Interests of the 521

Reimbursement Mechanisms $\quad 521$

Differential Tuition Policies $\quad 523$

Quantitative Restrictions $\quad 526$

Conclusions $\quad 528$

Introduction $\quad 531$

Residents $\quad 532$

Introduction $\quad 532$

Community Workers 533

Family Members of Community Workers 537

Non-Economic Residents $\quad 541$

Lawful Residence $\quad 543$

Conclusions $\quad 546$

Non-Residents

Introduction $\quad 547$

Nationality Requirements $\quad 549$

Residence Requirements 554 
xviii

3.3 .1

3.3 .2

3.3 .3

4

5
Article 49 EC or Article 12(1) EC?

Article 12(1) EC: The Prima Facie Illegality of Residence Requirements for Access to Public Services Justification of Residence Requirements for Entitlement to Public Services

Third Country Nationals

Conclusions

Samenvatting

Curriculum Vitae 


\section{ABBREVIATIONS}

AA

ActduDr

AICL

AJCL

AJLM

AlaLRev

Annals AAPSS

APSRev

Arbbl

AP

AS

ASAL

ASICL

ASRev

BayV

BarbBl

$\mathrm{BB}$

BDIP

BMJ

BostCTWLJ

BrooklLRev

BTSZ

CalLRev

CapULRev

CaseWLRev

CathLaw

CatoJ

CDE

ChicLRev

CMLRep

CMLRev

ColJLSP

ColLRev

ConstComm

DB

DöV

DS

Duke JCL

Duke LJ

DuR

DVB1

EA

ECR

ECBull

$\mathrm{Ed}(\mathrm{s})$

ECTaxRev

EJE
Ars Aequi

Actualités de Droit

American Journal of International and Comparative Law American Journal of Comparative Law American Journal of Law and Medicine Alabama Law Review

Annals of the American Academy of Political and Social Science American Political Science Review Arbeitsblad American Prospect Acta Sociologica Annual Survey of American Law African Society of International and Comparative Law American Sociological Review Bayerische Verwaltungsblätter

Bundesarbeitsblatt Betriebsberater

Blätter für deutsche und internationale Politik British Medical Journal Boston College Third World Law Journal Brooklyn Law Review Belgisch Tijdschrift voor Sociale Zekerheid California Law Review Capital University Law Review Case Western Reserve Law Review Catholic Law Cato Journal Cahiers de Droit européen Chicago Law Review Common Market Law Reports Common Market Law Review Columbia Journal of Law and Social Problems Columbia Law Review Constitutional Commentary Der Betrieb

Die öffentliche Verwaltung Droit social

Duke Journal of International and Comparative Law Duke Law Journal Demokratie und Recht Deutsches Verwaltungsblätter Europa-Archiv European Court Reports Bulletin of the European Communities

Editor(s)

EC Tax Review

European Journal of Education 
$\mathrm{XX}$

EJELP

EJHL

EJIL

EJML

EJPH

EJSS

ELJ

ELRev

ELSA

EPL

EBLRev

EuR

EurTax

EuZW

FordLJ

GeorgeLJ

$\mathrm{GuG}$

HA

HarvLRev

HoustLRev

HP

Hrsg.

ICLQ

ILRev

IM

IndLJ

IndLRev

InfAusiR

Info RIZIV

IJLPFamily

IM

IowaLRev

IP

IS

ISSRev

JdT

JCMS

JF

$\mathrm{JZ}$

JLH

JHR

JoP

JpolEc

JSWFL

JurbContL

TvAR

KentLJ

KritV
European Journal for Education Law and Policy

European Journal of Health Law

European Journal of International Law

European Journal of Migration and Law

European Journal of Public Health

European Journal of Social Security

European Law Journal

European Law Review

The European Law Students' Association Law Review European Public Law

European Business Law Review

Europarecht

European Taxation

Europäisches Zeitschrift für Wirtschaftsrecht

Fordham Law Journal

Georgetown Law Journal

Gesundheit und Gesellschaft

Health Affairs

Harvard Law Review

Houston Law Review

Health Policy

Herausgeber

International Comparative Law Quarterly

International Labour Review

International Migration

Industrial Law Journal

Indiana Law Review

Informationsbrief Ausländerrecht

Info Rijksinstituut voor Ziekte- en Invaliditeitsverzekering

International Journal of Law, Policy and the Family International Migration

Iowa Law Review

International Politics

International(e) Spectator

International Social Security Review

Journal des Tribunaux

Journal of Common Market Studies

Jura Falconis

Juristen Zeitung

Journal of Law and Health

Journal of Human Resources

Journal of Politics

Journal of Political Economy

Journal of Social Welfare Law

Journal of Urban and Contemporary Law

Tijdschrift voor Antilliaans Recht - Justicia

Kentucky Law Journal

Kritische Vierteljahresschrift für Gesetzgebung und

Rechtswissenschaft 
xxi

LIEI
LCP
LJL
MAE
MichLRev
MC
MMF Quart
MR
MJ
MLRev
NebLRev
NewMexLRev
NJB
NJW
NorthwULRev
NTER
NTG
NTOR
NVwZ
NYULRev
NZfV
NZAS
OJ
PhW
PubLaw
Publius
Red.
RJB
RMC
RMUE
RTDE
RutgCLJ
RW
RZA
SCRev
SEW
SJ
SMA
SocSecBull
SouthCalLRev
SouthwLJ
SPA
SR
StanfLRev
SS
SuffULRev
SW
SZ
S\&W

Legal Issues of European Integration Law and Contemporary Problems Leiden Journal of International Law Ministres des Affaires Etrangères Michigan Law Review Medisch Contact

Milbank Memorial Fund Quarterly Migrantenrecht

Maastricht Journal of European and Comparative Law Modern Law Review Nebraska Law Review New Mexico Law Review Nederlands Juristenblad

Neue Juristische Wochenschrift Northwestern University Law Review Nederlands Tijdschrift voor Europees Recht Nederlands Tijdschrift voor Gezondheidsrecht Nederlands Tijdschrift voor Onderwijsrecht Neue Zeitschrift für Verwaltungsrechts New York University Law Review Neue Zeitschrift für Verwaltungsrechts Neue Zeitschrift für Arbeits- und Sozialrecht Official Journal of the European Communities Pharmaceutisch Weekblad Public Law Publius - The Journal of Federalism Redactie/Redacteur Recht der Jugend und des Bildungswesens Revue du Marché commun Revue du Marché commun et de l'Union européenne Revue trimestrielle de droit européen Rutgers \& Campden Law Journal Rechtskundig Weekblad Rechtspraak Zorgverzekering Supreme Court Review

Sociaal-Economische Wetgeving La Semaine Juridique Social Maandblad Arbeid Social Security Bulletin South California Law Review Southwestern Law Journal Social Policy and Administration Nederlands Tijdschrift voor Sociaal recht Stanford Law Review Die Soziale Sicherheit Suffolk University Law Review Social Work Soziale Sicherheit School \& Wet 
TexILJ

TexLRev

THOM

TOO

TulLRev

TvA

TvV

UCDLRev

UCLALReV

Uitg.

UMKCLRev

UpennLRev

UpittLRev

USLWeek

USZ

ValpULRev

VdbiltLRev

VirgLRev

WashULQ

WiscLRev

WissR

W\&MLRev

YaleLJ

YaleLPR

YEL

ZfRV

ZIAS

ZAR

ZfaöR

ZföR

ZFSH/SGB

ZSR
Texas International Law Journal

Texas Law Review

Tijdschrift voor Hoger Onderwijs \& Management

Tijdschrift voor Onderwijsrecht en Onderwijsbeleid

Tulane Law Review

Tijdschrift voor Arbeidsvraagstukken

Tijdschrift voor Vreemdelingenrecht

University of California Davies Law Review

University of California Los Angeles Law Review

Uitgever

University of Missouri at Kansas City Law Review University of Pennsylvania Law Review

University of Pittsburg Law Review United States law Week

Uitspraken Sociale Zekerheid

Valporaiso University Law Review Vanderbilt Law Review Virginia Law Review

Washington University Law Quarterly Wisconsin Law Review Wissenschaftsrecht

Wlliam \& Mary Law Review Yale Law Journal

Yale Law \& Policy Review Yearbook of European Law

Zeitschrift für Rechtsvergleichung Zeitschrift für ausländisches und internationales Arbeits- und Sozialrecht

Zeitschrift für Ausländerrecht und Ausländerpolitik Zeitschrift für ausländisches öffentliches Recht und Völkerrecht

Zeitschrift für öffentliches Recht

Zeitschrift für Sozialhilfe und Sozialgesetzbuch 
xxiii

\section{TABLE of CASES}

\section{Court of Justice of the European Communities}

A

Abrahamson

Acciardi

Adoui

Agegate

Akman

Alaimo

Albany

Allué I

Allué II

Alpine Investments

d'Amico

Angenieux

Angonese

AOK Mittelfranken

Antonissen

Arblade

Asscher

ASTI

Aulich

Awoyemi

Baars

Babahenini

Bachmann

Baglieri

Barr

Barra

Beerens

Belhouab

Bernini

Bertini

Bettray

Biason

Bickel

Biehl

van Binsbergen

Birden

Blaizot

Bleis

\author{
Case C-407/98 [2000] ECR I-0000 \\ Case C-66/92 [1993] ECR I-4567 \\ Joined Cases 115 and 116/81 [1982] ECR 1665 \\ Case 3/87 [1989] ECR 4459 \\ Case C-210/97 [1998] ECR I-7519 \\ Case 68/74 [1975] ECR 109 \\ Case C-67/96 [1999] ECR I-0000 \\ Case 33/88 [1989] ECR 1591 \\ Joined Cases C-259, 331 and 33/92 [1993] ECR I-4309 \\ Case C-384/93 [1995] ECR I-1141 \\ Case 20/75 [1975] ECR 891 \\ Case 13/73 [1973] ECR 935 \\ Case C-281/98 [2000] ECR I-0000 \\ Case 818/79 [1980] ECR 2729 \\ Case C-292/89 [1991] ECR I-745 \\ Case C-376/96 [1999] ECR I-0000 \\ Case C-107/94 [1996] ECR I-3089 \\ Case C-213/90 [1991] ECR I-3507 \\ Case 103/75 [1976] ECR 697 \\ Case C-230/97 [1998] ECR I-6781
}

Case C-251/98 [2000] ECR I-0000 Case C-113/97 [1998] ECR I-183

Case C-204/90 [1992] ECR I-249

Case C-257/92 [1993] ECR I-5211

Case C-355/89 [1991] ECR I-3479

Case 309/85 [1988] ECR 355

Case 35/77 [1977] ECR 2249

Case 10/78 [1978] ECR 1915

Case C-3/90 [1992] ECR I-1071

Joined Cases 98, 162 and 258/85 [1986] ECR 1885

Case 344/87 [1989] ECR 1621

Case 24/74 [1974] ECR 999

Case C-274/96 [1998] ECR I-7637

Case C-175/88 [1990] ECR I-1779

Case 33/74 [1974] ECR 1299

Case C-1/97 [1998] ECR I-7747

Case 24/86 [1988] ECR 379

Case C-4/91 [1991] ECR I-562 
xxiv

Bond van Adverteerders Bonsignore

Borawitz

Bosman

Bostock

Bouchereau

Bouchoucha

Boukhalfa

Bozkurt

Brack

Brandy

Bristol-Myers

Broekmeulen

Brown

Buhari Haji

\section{C}

Calfa

Callemeyn

Camera

Cabanis-Issarte

Calle Grenzshop

Campus Oil

Casagrande

Castelli

Centros

Cicco

Ciola

Clean Car

Coccioli

Coenen

Collins

Commission Austria

Commission v Belgium

Commission v Belgium

Commission v Belgium

Commission v Belgium

Commission v Belgium

Commission v Belgium

Commission v Belgium

Commission v Belgium

Commission v Belgium

Commission v Belgium

Commission v Belgium

Commission v Belgium

Commission v Belgium

Commission v Belgium
Case 352/85 [1988] ECR 2085

Case 67/74 [1975] ECR 297

Case C-124/99 [2000] ECR I-0000

Case C-415/93 [1995] ECR I-4291

Case C-2/92 [1994] ECR I-955

Case 67/74 [1975] ECR 1999

Case C-61/89 [1990] ECR I-3551

Case C-214/94 [1995] ECR I-2253

Case C-434/93 [1995] ECR I-1475

Case 17/76 [1976] ECR 1429

Case C-217/91 [1993] ECR I-3923

Joined Cases C-427, 429 and 436/93 [1996] ECR I-3457

Case 246/80 [1981] ECR 2311

Case 197/86 [1988] ECR 3205

Case C-105/89 [1990] ECR 4211

Case C-348/96 [1999] I-11

Case 187/73 [1974] ECR 553

Case 92/81 [1982] ECR 2213

Case C-87/94 [1996] ECR I-2097

Case C-425/93 [1995] ECR I-269

Case 72/83 [1084] ECR 2727

Case 9/74 [1974] ECR 773

Case 261/83 [1984] ECR 3199

Case C-212/98 [1999] ECR I-1459

Case 19/68 [1968] ECR 658

Case C-224/97 [1999] ECR I-0000

Case C-350/96 [1998] ECR I-2521

Case 139/78 [1979] ECR 991

Case 39/75 [1975] ECR 1547

Joined Cases C-92 and 326/92 [1993] ECR I-5145

Case C-205/98 [2000] I-0000

Case 7/61 [1961] ECR 317

Case 149/79 [1980] ECR 3881

Case 275/83 [1985] ECR 1097

Case 221/85 [1987] ECR 719

Case 293/85 [1988] ECR 305

Case 42/87 [1988] ECR 5445

Case 321/87 [1989] ECR 997

Case C-249/88 [1989] ECR I-1275

Case C-253/90 [1992] ECR I-531

Case C-326/90 [1992] ECR I-5517

Case C-37/93 [1993] ECR I-6295

Case C-47/93 [1994] ECR I-1593

Case C-273/94 [1996] ECR I-3265

Case C-278/94 [1996] ECR I-4307 
$\mathrm{xxV}$

Commission v Belgium Commission v Belgium Commission v Belgium Commission v Council (Erasmus)

Commission v France

Commission v France

Commission v France

Commission v France

Commission v France

Commission v France

Commission v France

Commission v France

Commission v Germany

Commission v Germany

Commission v Germany

Commission v Germany

Commission v Germany

Commission v Greece

Commission v Greece

Commission v Greece

Commission v Greece

Commission v Greece

Commission v Greece

Commission v Greece

Commission v Greece

Commission v Greece

Commission v Ireland

Commission v Ireland

Commission v Ireland

Commission v Italy

Commission v Italy

Commission v Italy

Commission v Italy

Commission v Italy

Commission v Italy

Commission v Italy

Commission v Italy

Commission v Luxembourg

Commission v Luxembourg

Commission v the Netherlands

Commission $\mathrm{v}$ the Netherlands

Commission v Spain

Commission v Spain

Commission $\mathrm{v}$ the United Kingdom

Coonan

Coppola

Corsica Ferries
Case C-344/95 [1997] ECR I-1035

Case C-347/98 [2001] ECR I-0000

Case C-347/98 [2001] ECR I-0000 Case 242/87 [1989] ECR 1425

Case 167/73 [1974] ECR 359

Case 307/84 [1986] ECR 1725

Case 96/85 [1986] ECR 1475

Case 236/88 [1988] ECR I-3163

Case C-154/89 [1991] ECR I-569

Case C-57/90 [1992] ECR I-75

Case C-334/94 [1996] ECR I-1307

Case C-35/97 [1998] ECR I-5325

Case 205/84 [1986] ECR 3755

Case 427/85 [1988] ECR 1123

Case 249/86 [1989] ECR 1263

Case C-96/95 [1997] ECR I-1653

Case 24/97 [1998] ECR I-2133

Case 147/86 [1988] ECR 1637

Case 38/87 [1988] ECR 4415

Case C-305/87 [1989] ECR 1461

Case 30/88 [1989] ECR I-3711

Case C-198/89 [1991] ECR I-4221

Case C-306/89 [1991] ECR I-5863

Case C-290/94 [1996] ECR I-3285

Case C-185/96 [1998] ECR I-1095

Case C-123/94 [1995] ECR I-1457

Case 206/84 [1986] ECR 3817

Case C-93/89 [1991] ECR I-4569

Case C-151/96 [1997] ECR I-3327

Case 168/85 [1986] ECR 2945

Case 225/85 [1987] ECR 2625

Case 63/86 [1988] ECR 29

Case 69/86 [1987] ECR 773

Case C-3/88 [1989] ECR 4035

Case C-180/89 [1991] ECR I-709

Case C-58/90 [1991] ECR I-4193

Case C-424/98 [2000] ECR I-0000

Case C-351/90 [1992] ECR I-3945

Case C-111/91 [1993] ECR I-817

Case C-68/89 [1991] ECR I-2637

Case C-353/89 [1991] ECR I-4069

Case C-375/92 [1994] ECR I-923

Case C-45/93 [1994] ECR I-911

Case C-246/89 [1991] ECR I-4585

Case 100/79 [1980] ECR 1445

Case 150/82 [1983] ECR 43

Case C-18/93 [1994] ECR I-1783 
xxvi

Costa
Cowan
Cristini
D
Dafeki
Daily Mail
Dassonville
Data Delecta
Deak
Decker
Dekker
Delavant
Deliège
Demirel
Diatta
Djabali
Donà
Duphar
van Duyn
Dzodzi

E Echternach EEA Opinion Einberger

Elsen

van der Elst

El-Yassini

Ergat

Eroglu

Erpelding

ERT

Ertanir

Eurim-Pharm

Even

Eyüp

F

Fahmi

Fédération Francaise

Fedicini

Ferlini

Fernández de Bobadilla

Fitzwilliam
Case 39/74 [1974] ECR 1251

Case 186/87 [1988] ECR 195

Case 32/75 [1975] ECR 1085

Case C-336/94 [1997] ECR I-6761

Case 81/87 [1988] ECR 5483

Case 8/74 [1974] ECR 837

Case C-43/95 [1996] ECR I-4661

Case 94/84 [1985] ECR 1873

Case C-120/95 [1998] ECR I-1831

Case 33/65 [1965] ECR 1135

Case C-451/93 [1995] ECR I-1545

Joined Cases C-51 and C-191/97 [2000] ECR I-0000

Case 12/86 [1987] ECR 3719

Case 267/83 [1985] ECR 567

Case C-314/96 [1998] ECR I-1149

Case 13/76 [1976] ECR 1333

Case 238/82 [1984] ECR 523

Case 41/74 [1974] ECR 1337

Joined Cases C-297/88 and C-197/89 [1990] ECR I-3763

Joined Cases 389 and 390/87 [1989] ECR 723

Opinion 1/91 [1991] ECR I-6079

Case 294/82 [1984] ECR 1177

Case C-135/99 [2000] ECR I-0000

Case C-43/93 [1994] ECR I-3803

Case C-416/96 [1999] ECR I-1209

Case C-329/97 [2000] ECR I-0000

Case C-329/93 [1994] ECR I-5113

Case C-16/99 [2000] ECR I-0000

Case 260/89 [1991] ECR I-2925

Case C-98/96 [1997] ECR I-5193

Case C-347/89 [1991] ECR I-1747

Case 207/78 [1979] ECR 2019

Case C-65/98 [2000] ECR I-0000

Case C-33/99 [2001] ECR I-0000

Case C-244/94 [1995] ECR I-4013

Case C-17/92 [1993] ECR I- 2239

Case C-411/98 [2000] ECR I-0000

Case C-234/97 [1999] ECR I-4773

Case C-202/97 [2000] ECR I-0000 
xxvii

Forcheri

Fossi

Frascogna

Frascogna

Frilli

G

Gaal

Gallagher

GB-INNO-BM

Gebhard

Van Gend and Loos

Geraets-Smits

Germany v Parliament and Council Giagounidis

Giletti

Gillard

Gilly

Gouda

Graf

Gravier

Gregg and Gregg

Grzelczyk

Groener

Groenveld

Grogan

Gül

Gullung

Günayadin

\section{H}

Haim I

Haim II

Hallouzi-Choho

Hayes

Heylens

Hocsman

Hoeckx

Hoever

Höfner

ten Holder

Hubbard

Hughes

Huijbregts
Case 152/82 [1983] ECR 2323

Case 79/76 [1977] ECR 667

Case 157/84 [1985] ECR 1739

Case 256/86 [1987] ECR 3431

Case 1/72 [1972] ECR 457

Case C-7/94 [1995] ECR I-1031

Case C-175/94 [1995] ECR I-4523

Case C-362/88 [1990] ECR I-667

Case C-55/94 [1995] ECR I-4165

Case 26/62 [1963] ECR 1

Case C-157/99 (Opinion Advocate General Ruiz-Jacabo

Colomer - http://www.curia.eu.int)

Case C-376/98 [2000] ECR I-0000

Case C-376/89 [1992] ECR I-1069

Joined Cases 379-381/85 and 93/86 [1987] ECR 955

Case 9/78 [1978] ECR 1661

Case C-336/96 [1998] ECR I-2793

Case C-288/89 [1991] ECR I-4007

Case C-190/98 [2000] ECR I-0000

Case 293/83 [1985] ECR 593

Case C-216/97 [1999] ECR I-0000

Case C-184/99 (Opinion of Advocate General Alber -

http://www.curia.eu.int/jurisp)

Case 379/87 [1989] ECR 3967

Case 15/79 [1979] ECR 3409

Case C-159/90 [1990] ECR I-4685

Case 131/85 [1986] ECR 1573

Case 292/86 [1988] ECR ECR 111

Case C-36/96 [1997] ECR I-5159

Case C-319/92 [1994] ECR I-425

Case C-424/97 [2000] ECR I-0000

Case C-126/95 [1996] ECR I-4807

Case C-323/95 [1997] ECR I-1711

Case 222/86 [1987] ECR 4097

Case C-238/98 [2000] ECR I-0000

Case C-249/83 [1985] ECR 973

Case C-312/94 [1996] ECR I-4895

Case C-41/90 [1991] ECR I-1979

Case 302/84 [1986] ECR 1821

Case C-20/92 [1993] ECR I-3777

Case C-78/91 [1992] ECR I-4839

Case C-131/95 [1996] ECR I-1409 
Humbel

Hurd

I

Internationale Handelsgesellschaft Inzirillo

Iorio

Italy v Commission

J

Jauch

Janssen

Jordens-Voster

K

Kaba

Kadiman

Kaur

Keck

Kenny

Kempf

Kermaschek

Khalil

Kirk

Kits van Heyningen

Klaus

Klopp

Knoch

Knoeller

Kocak

Kohll

Kol

Konstantinidis

Kraus

Kremzow

Krid

Kuchlenz-Winter

Kulzer

Kus

Kuusijärvi

Kuyken

Kuypers

Kziber xxviii

Case 263/81 [1988] ECR 5365 Case 44/84 [1986] ECR 29

Case 11/70 [1970] ECR 1125

Case 63/76 [1976] ECR 2057

Case 298/84 [1986] ECR 247

Case 13/63 [1963] ECR 165

Case C-215/99 [2001] ECR I-0000

Case 23/71 [1971] ECR 859

Case 69/79 [1980] ECR 75

Case C-356/98 [2000] ECR I-0000

Case C-351/95 [1997] ECR I-2133

Case C-192/99 [2001] ECR I-0000

Joined Cases C-267 and 268/91 [1993] ECR I-6097

Case 1/78 [1978] ECR 1489

Case 139/85 [1986] ECR 1741

Case 40/76 [1976] ECR 1669

Case C-180/99 (Opinion of Advocate General Jacobs http://www.curia.eu.int/jurisp) Case 63/83 [1984] ECR 2689

Case 2/89 [1990] ECR 1755

Case C-482/93 [1995] ECR I-3551

Case 107/83 [1984] ECR 2971

Case C-102/91 [1992] ECR I-4341

Case 93/81 [1982] ECR 951

Joined Cases C-102/98 and C-211/98 [2000] ECR I-0000

Case C-158/96 [1998] ECR I-1931

Case C-285/95 [1997] ECR I-3069

Case C-168/91 [1993] ECR I-1191

Case C-19/92 [1993] ECR I-1689

Case C-299/95 [1997] ECR I-2629

Case C-103/94 [1995] ECR I-719

Case T-66/95 [1997] ECR II-637

Case C-194/96 [1998] ECR I-921

Case C-237/91 [1993] ECR I-6781

Case C-275/96 [1998] ECR I-0000

Case 66/77 [1977] ECR 2311

Case 276/81 [1982] ECR 3027

Case C-18/90 [1991] ECR I-199 
L

Lair

Lawrie-Blum

Lebon

Leclere

Lehtonen

Lemmens

di Leo

Levin

Lopez Brea

Luisi and Carbone

Le Manoir xxix

Case 39/86 [1988] ECR 3161

Case 66/85 [1986] ECR 2121

Case 316/85 [1987] ECR 2811

Case C-43/99 (Opinion of Advocate General Jacobs -

http://www.curia.eu.int/jurisp)

Case C-176/96 [2000] ECR I-0000

Case C-226/97 [1998] ECR I-3711

Case C-308/89 [1990] ECR I-4185

Case 53/81 [1982] ECR 1035

Joined Cases C-330/ and 331/90 [1992] ECR I-323

Joined Cases 286/82 and 26/83 [1984] ECR 377

Case C-27/91 [1992] ECR I-5531

\section{$\mathbf{M}$}

Mac Quen

Marsman

Martínez Sala

Matteucci

Meade

Mediawet

Meeussen

Meints

Mesbah

Messner

Michel S.

Micheletti

Miethe

Molenaar

Morais

Morson

Mouthaan

Movrin

$\mathrm{Mr}$ and Mrs F.

Mutsch

$\mathbf{N}$

Nazli

Newton

Noij

Nonnenmacher
Case C-108/96 [2001] ECR I-0000 Case 44/72 [1972] ECR 1243

Case C-85/96 [1998] ECR I-2691

Case 235/86 [1988] ECR 5589 Case 283/83 [1984] ECR 2631

Case C-288/89 [1991] ECR I-4007

Case C-337/97 [1999] ECR I-0000

Case C-57/96 [1997] ECR I-6689

Case C-179/98 [1999] ECR I-0000

Case C-265/88 [1989] ECR 4209 Case 76/72 [1973] ECR 457

Case C-369/90 [1992] ECR I-4239 Case 1/85 [1986] ECR 1837

Case C-160/96 [1998] ECR I-843

Case C-60/91 [1992] ECR I-2085 Joined Cases 35 and 36/82 [1982] 3723 Case 39/76 [1976] ECR 1901

Case C-73/99 [2000] ECR I-0000 Case 7/75 [1975] ECR 679

Case 137/84 [1985] ECR 2681

Case C-340/97 [2000] ECR I-0000 Case C-356/89 [1991] ECR I-3017 Case C-140/88 [1991] ECR I-387 Case 92/63 [1963] ECR 583 
$\mathrm{XXX}$

O

Offermans

O'Flynn

Ortscheit

Österreichischer

Gewerkschaftsbund

De Paep

Paletta I

Paletta II

Di Paolo

Parliament $v$ Council

Paraschi

Parodi

Partridge

Pavlov

Pescataing

Petrie

Petroni

Pieck

Pierik I

Pierik II

Pinna I

Pinna II

Piscitello

Poirrez

Poucet

Prodest

\section{R}

Ramrath

Raulin

Regina

Reibold

Reina

Reed

Rewe-Zentral

Rindone

Romero

van Roosmalen

Rossi

Roux

Royer

Rückdeschel
Case C-85/99 [2001] ECR I-0000

Case C-237/94 [1996] ECR-2617

Case C-320/93 [1994] ECR I-5243

Case C-195/98 [2000] ECR I-0000

Case C-196/90 [1991] ECR I-4815

Case C-45/90 [1992] ECR I-3423

Case C-206/94 [1996] ECR I-2357

Case 76/76 [1977] ECR 315

Case C-295/90 [1992] ECR I-4193

Case C-349/87 [1991] ECR I-4501

Case C-222/95 [1997] ECR I-3899

Case C-297/96 [1998] ECR I-3467

Joined Cases C-180 and 184/98 [2000] ECR I-0000 Case 98/79 [1980] ECR 691

Case C-90/96 [1997] ECR I-6527

Case 24/75 [1975] ECR 1149

Case 157/79 [1980] ECR 2171

Case 117/77 [1978] ECR 825

Case 182/78 [1979] ECR 1977 Case 41/84 [1986] ECR 1

Case 359/87 [1989] ECR 585

Case 139/82 [1983] ECR 1427

Case C-206/91 [1992] ECR I-6685

Joined Cases C-159 and 160/91 [1993] ECR I-637 Case 237/83 [1984] ECR 3153

Case C-106/91 [1992] ECR I-3351

Case C-357/89 [1992] ECR I-1027

Case 131/79 [1980] ECR 1585

Case C-216/89 [1990] ECR I-4163

Case 65/81 [1982] ECR 33

Case 59/85 [1986] ECR 1283

Case 120/78 [1979] ECR 649

Case 22/86 [1987] ECR 1339

Case C-131/96 [1997] ECR I-3659

Case 300/84 [1986] ECR 3097

Case 100/78 [1979] ECR 832

Case C-363/89 [1992] ECR I-273

Case 48/75 [1975] ECR 497

Joined Cases 117/76 and 16/77 [1977] ECR 1769 
Rundgren

Rush Portuguesa

Rutili

\section{$\mathbf{S}$}

Säger

Sagulo

Saldanha

Savas

Schindler

Scholz

Schöning-Kougebetopoulou

Scrivner

Schmid

Schumacker

Schumacker

Seco

Sehrer

Sevince

Shingara

Singh

Skanavi

Smith

Snares

Sodemare

Sotgiu

Spotti

Stanton

Steen

Steen

Steinhauser

Steymann

Stöber

Sürül

Svensson and Gustavsson

Swaddling

Taflan-Met

Taghavi

Terhoeve

Tessier

Testa

Tetik

Thieffry

Thijssen $\mathrm{xxxi}$

Case C-389/99 [2001] ECR I-0000

Case C-113/89 [1990] ECR I-1417 Case 36/75 [1975] ECR 1219

Case C-76/90[1991] ECR I-4221 Case 8/77 [1977] ECR 1495 Case C-122/96 [1997] ECR I-5325

Case C-37/98 [2000] ECR I-0000

Case C-275/92 [1994] ECR I-1039

Case C-418/92 [1994] ECR I-505

Case C-15/96 [1998] ECR I-47

Case 122/84 [1985] ECR 1027

Case C-310/91 [1993] ECR I-3011 Case 215/87 [1989] ECR 617

Case C-279/93 [1995] ECR I-225

Joined Cases 62 and 63/81 [1982] ECR 223

Case C-302/98 [2000] ECR I-0000

Case C-192/89 [1990] ECR I-3461

Case C-65/95 [1997] ECR I-3343

Case C-370/90 [1992] ECR I-4265

Case C-193/94 [1996] ECR I-929

Case C-201/94 [1996] ECR I-5819

Case C-20/96 [1997] ECR I-6057

Case C-70/95 [1996] ECR I-215

Case 152/73 [1974] ECR 153

Case C-272/92 [1993] ECR I-5185

Case 143/87 [1988] ECR 3877

Case C-332/90 [1992] ECR I-341

Case C-132/93 [1994] ECR I-2715

Case 197/84 [1985] ECR 1819

Case 196/87 [1988] ECR 6159

Joined Cases C-4 and 5/95 [1997] ECR I-511

Case C-262/96 [1999] ECR I-0000

Case C-484/93 [1995] ECR I-3955

Case C-90/97 [1999] ECR I-1075

Case C-277/94 [1996] ECR I-4085

Case C-243/91 [1992] ECR I-4401

Case C-18/95 [1999] ECR I-345

Case 84/77 [1978] ECR 7

Joined Cases 41, 121, 796/79 [1980] ECR 1979

Case C-171/95 [1997] ECR I-329

Case 71/76 [1977] ECR 765

Case C-42/92 [1993] ECR I-4047 
xxxii

Tileorassi
Tögel
Toia
Torrekens
Tsiotras

U

Uecker

Ugliola

Unger

United Kingdom v Council

United Kingdom v Council

Upjohn

Vaassen-Goebbels

Case C-260/89 [1991] ECR I-2925

Case C-76/97 [1998] ECR I-5357

Case 237/78 [1979] ECR 2645

Case 28/68 [1969] ECR 125

Case C-271/91 [1993] ECR I-2925

Joined Cases C-64 and 65/96 [1997] ECR I-3171

Case 15/69 [1969] ECR 363

Case 75/63 [1964] ECR 369

Case 56/88 [1989] ECR 1615

Joined Cases C-51, 90 and 94/89 [1991] ECR I-2757

Case C-379/97 [1999] ECR I-0000

Case 61/65 [1966] ECR 257

\section{V}

Vanbraekel

Vestergaard

Vlassopolou

Voeten

de Vos

Vougioukas

W

Wachauf

Walrave

Walsh

Watson and Belmann

Werner

Wielockx

Wijsenbeek

Wirth

Wolf

van der Woude

$\mathbf{Y}$

Yaa Konadu Yiadom

Yousfi

$\mathbf{Z}$

Zaoui

Zurstrassen

Case 5/88 [1989] ECR 2609

Case 36/74 [1974] ECR 1405

Case 143/79 [1980] ECR 1639

Case 118/75 [1976] ECR 1185

Case C-112/91 [1992] ECR I-429

Case C-80/94 [1995] ECR I-2493

Case C-378/97 [1999] ECR I-0000

Case C-109/92 [1993] ECR I-6447

Joined Cases 154 and 155/87 [1988] ECR 3897

Case C-222/98 [2000] ECR I-0000

Case C-357/88 [2000] ECR I-0000

Case C-103/93 [1994] ECR I-1353

Case 147/87 [1987] ECR 5511

Case C-87/99 [2000] ECR I-0000 
XXXiii

\title{
Supreme Court of the United States
}

\author{
Adarand \\ Ambach v Norwick \\ Aptheker v Secretary of State \\ Att.General of New York v Soto-Lopez) \\ Baldwin v Fish \\ Barnard v Thorstenn \\ Blake v McClung \\ Bolling v Sharpe \\ Brown-Forman Distillers v New York States Liqor Auth \\ Cabell v Chavez-Salido \\ Califano v Torres \\ Colgate v Harvey \\ Craig v Boden \\ Crandall v Nevada \\ Dandridge v Williams \\ Doe v Bolton \\ Dunn v Blumstein \\ Edwards v California \\ Elkins v Moreno \\ Evansville \\ Foley v Connelie \\ Graham v Richardson \\ Hampton v Mow Sun Wong \\ Hicklin v Orbeck \\ Hirabayashi v United States \\ Jones v Helms \\ Kent v Dulles \\ Korematsu v United States \\ Lindsey v Natural Carb. Gas Co. \\ Madden v Kentucky \\ Maine v Taylor \\ Martinez v Bynum \\ Massachusetts Board of Retiremen v Murgia \\ Romer v Evans \\ Matthews v Diaz \\ McCready v Virginia \\ Memorial Hospital v Maricopa County \\ Metropolitan Life Insurance Co. v Ward \\ Mills v Babluetzel \\ Mississipi University for Women v Hogan \\ New York v O'Neill \\ Pike v Bruce \\ Puerto Rico v Branstad \\ Orr v Orr
}

515 US 200 (1995)

441 US 68 (1979)

378 US 500 (1964)

46 US 898 (1986)

436 US 371 (1978)

489 US $546(1989)$

172 US 239 (1889)

347 US 497 (1954)

476 US 573 (1986)

454 US 432 (1982)

435 US 1 (1978)

296 US 404 (1935)

428 US 190 (1976)

73 US 35 (1867)

397 US 471 (1970)

410 US 179 (1973)

405 US 330 (1972)

314 US $160(1941)$

435 US 647 (1978)

405 US 707 (1972)

435 US 291 (1978)

403 US 365 (1971)

426 US 88 (1976)

437 US 518 (1978)

320 US 81 (1943)

452 US 412 (1981)

357 US 116 (1958)

323 US 214 (1944)

220 US 61 (1911)

309 US 83 (1940)

477 US 131 (1986)

461 US 321 (1982)

427 US 307 (1976)

517 US 620 (1996)

426 US 67 (1976)

94 US 391 (1877)

415 US 250 (1974)

470 US 869 (1985)

456 US 91 (1982)

458 US 718 (1982)

359 US 1 (1959)

397 US 137 (1970)

483 US 219 (1987)

440 US 268 (1979) 
xxxiv

Paul v Virginia

Philadelphia v New Jersey

75 US 168 (1869)

Plyler v Doe

437 US 617 (1978)

Reed $v$ Reed

Reeves, Inc. $v$ Stake

Saenz v Roe

San Antonio Indep. School Dist. v Rodriguez

Shapiro v Thompson

Slaughter-House Cases

Smith v Turner

Sosna v Iowa

South-Central Timber Dev. v Wunnicke

Sporhase v Nebraska ex rel. Douglas

Soto-Lopez

Sugarmann v Dougall

Supreme Court of New Hampshire v Piper

Takahashi v Fish

Toll v Moreno

Toomer v Witsell

Truax v Raich

United States v Curtiss-Wright Export Corp.

457 US 202 (1982)

404 US 71 (1971)

447 US 429 (1980)

119SCt 1518 (1999)

411 US 1 (1973)

394 US 618 (1969)

16 Wall36 (1873)

48 US 283 (1849)

419 US 393 (1975)

467 US 82 (1984)

458 US 941 (1982)

476 US 898 (1986)

413 US 634 (1973)

470 US 274 (1985)

334 US 410 (1948)

458 US 1 (1982)

334 US 385 (1948)

239 US 33 (1915)

299 US 304 (1936)

304 US 144 (1938)

United States v Guest

Vance v Bradley

White v Massachusetts Council of Construction Employers, Inc.

383 US 745 (1966)

440 US 93 (1978)

Yick Wo v Hopkins

460 US 204 (1982)

Zemel v Rusk

118 US 365 (1886)

Zobel v Williams

381 US 1 (1965)

457 US 55 (1982) 


\section{BIBLIOGRAPHY}

A

Abel-Smith Abel-Smith/Maynard, De Organisatie, Financiering en Kosten van de Gezondheidszorg in de Europese Gemeenschap (Brussel, Commissie van de Europese Gemeenschappen, 1978).

Abriel Rethinking Preemption for Purposes of Aliens and Public Benefits, in: UCLALRev (1995) pp.1597-1630.

Adams $\quad$ State Control of Interstate Migration of Indigents, in: MichLRev (1942) pp.711-733.

Adler The 'Habitual Residence Test' in the UK, in: Eichenhofer (Ed.), Social Security of Migrants in the European Union of Tomorrow (Osnabrück, Rasch, 1997) pp.53-59

Alanat Freizügigkeit als Prüfstein der Assoziation EWG-Türkei - General Framework of the Association, in: Lichtenberg et al (Hrsg.), Gastarbeiter Einwanderer - Bürger? Die Rechtstellung der türkischen Arbeitnehmer in der Europäischen Union (Baden-Baden, Nomos, 1996) pp.17-26.

Alexander Free Movement of non-EC nationals: A Review of the Case Law of the Court of Justice, in: Schermers et al (Eds), Free Movement of Persons in Europe (Dordrecht, Martinus Nijhoff Publishers, 1993) pp.485-502.

Allard Revisiting Shapiro: Welfare Magnets and State Residency Requirements in the 1990s, in: Publius (1998) pp.45-66.

Allen Equal Treatment, Social Advantages and Obstacles: In Search of Coherence in Freedom and Dignity, in: Guild (Ed.), The Legal Framework and Social Consequences of Free Movement of Persons in the European Union (the Hague, Kluwer Law International, 1999) pp.31-48.

Alston Alston (Ed.), The EU and Human Rights (Oxford, Oxford University Press, 1999).

Altmaier Europäisches koordinierendes Sozialrecht - Ende des Territorialitätsprinzip?, in: Eichenhofer/Zuleeg (Hrsg.), Die Rechtsprechung des Europäischen Gerichtshof zum Arbeits- und Sozialrecht im Streit (Köln, Bundesanzeiger, 1995) pp.71-91.

Altmaier Altmaier/Verschueren, The Extension of the Scope of Regulation 1408/71 to Nationals of Non-member Countries, in: Commission of the European Communities/Departemento de Relações Internaçionais e Convenções de Segurança Social, Social Security in Europe - Equality Between Nationals and Non-Nationals (Lisbon, 1995) pp.245-261.

Altmeyer People on the Move: Effect of Residence Requirements for Public Assistance, in: SocSecBull (1946) pp.4 et seq.

Anderson Anderson/Lutes, The Demise of the Durational residence Requirement, in: SouthwLJ (1972) pp.538-568.

André $\quad$ André de la Porte/Zegveld, Mobiliteit van Studenten binnen de Europese Unie (Amsterdam, Nuffic, 1996)

André André de la Porte/Zegveld, Het Europa van de Student - Studentenmobiliteit binnen de Europese Unie, in: AA (1995) pp.685-693

Antieau Pauls's Perverted Privileges or the True Meaning of the Privileges and Immunities Clause of Article IV, in: W \& M LRev (1967) pp.1-38.

Arnull The European Union and its Court of Justice (Oxford, Oxford University Press, 1999). 


\section{$\mathrm{xxxV}$}

Arnull

Arnull

Avenarius

Badoux

Baeyens

Ballon

Balthasar

Barents

Barents

Barents

Barents

Barnard

Barnard

Barnard

Barnard

Barnard

Barr

Barr

Barry

Bauböck

Bean

Beckedorf

Becker

Behrens

Belcher
The General principles of EEC Law and the Individual (London, Leicester University Press, 1990)

Of Strip Cartoonists, Vets and Gunsmiths, in: ELRev (1988) pp.260-267.

Zugangsrecht von EG-Ausländern im Bildungswesen der Bundesrepublik Deutschland, in: NZfV (1988) pp.385-393.

Dertig Jaar Vrij Verkeer van Personen, in: Fernhout (Red.), Dertig Jaar Vrij Verkeer van Werknemers (Nijmegen, 1999)

Free Movement of Goods and Services in Health Care: A Comment on the Cases Decker and Kohll from a Belgian Point of View, in: EJHL (1999) pp.373-383.

Ballon/Pieters, Het Europese Kartelrecht en de Ziekenfondsen (Antwerpen, Maklu, 1997)

Inländerdiskriminierung in der EU nach dem EWG-Vertrag und aus österreicher Sicht, in: ZföR (1988) pp.143-216.

De Communautaire Rechtsorde (Deventer, Kluwer, 2000)).

De Tabaksrichtlijn in Rook Opgegaan, in: NTER (2000) pp.327-331.

Het Verdrag van Amsterdam in Werking (Kluwer, Deventer, 1999).

Het Verdrag van Amsterdam (Kluwer, Deventer, 1997).

Fitting the Remaining Pieces into Goods and Persons Jigsaw?, in: ELRev (2001) pp.35-59.

EC Employment Law (Oxford, Oxford University Press, 2000).

Regulating Competitive Federalism in the European Union? The Case of EC Social Policy, in: Shaw (Ed.), Social Law and Policy in an Evolving European Union (2000) pp.49-69.

Social Dumping and Race to the Bottom: Some Lessons for the EU from Delaware?, in: ELRev (2000) pp.57 et seq

Article 13: Through the Looking Glass of Union Citizenship, in: O'Keeffe/Twomey (Eds), Legal Issues of the Amsterdam Treaty (Hart Publishing, Oxford, 1999) pp.375-394.

The Economics of the Welfare State (Weidenfeld and Nicolson, London, 3d Ed., 1998).

The Economics of the Welfare State (Weidenfeld and Nicolson, London, 2d Ed., 1993).

Self-Government Revisited, in: Miller/Siedentrop, The Nature of Political Theory (Oxford, Clarendon Press, 1983).

Transnational Citizenship - Membership and Rights in International Migration (Aldershot, Edward Elgar, 1994).

Bean et al, Social Europe: One for All (London, CEPR, 1998).

Beckedorf/Henze, Neuere Entwicklungen in der Bildungspolitik der Europäischen Gemeinschaft, in: NVwZ (1993) pp.125-130.

Freizügigkeit in der EU - Auf dem Weg vom Begleitrecht zur Bürgerfreiheit, in: EuR (1999) pp.522-533.

Die Konvergenz der wirtschaftlichen Freiheiten im europäischen Gemeinschaftsrecht, in: EuR (1990) pp.145 et seq.

The Role of the European Union in Healthcare (Zoetermeer, Council for Health and Social Service, 1999). 


\section{xxxvii}

Bell

Bell

Bell

Bend

Bender

Bennet

Bennet

Bercusson

Berg

Bergreen

Bernard

Bertola

Betten

Bieback

Bieback

Bijzondere

Blake

Blasi

Bloch

Blois

Bobinski

Equality and Diversity: Anti-Discrimination Law after Amsterdam, in Shaw (Ed.), Social Law and Policy in an Evolving European Union (2000) pp. $157-170$.

The New Article 13 EC Treaty: A Sound Basis for European Anti-Discrimination Law?, in: MJ (1999) pp.5-23.

Bell/Waddington, The 1996 Intergovernmental Conference and the Prospects of a Non-Discrimination Treaty Article, in: IndLJ (1996) pp.320326.

van der Bend, Aanbestedingsrecht in de Gezondheidszorgsector - Verdient het Aanbestedingsrecht in de Gezondheidszorgsector meer Zorg?, in: NTG (1999) pp.359-369.

Die Sozialhilfe im System Ausländerrechts, in: DuR(1974) pp.36-42.

The Threat of the Wandering Poor: Welfare Parochialism and its Impact on the Use of Housing Mobility as an Anti-Poverty Strategy, in: FordhLJ (1995) pp.1207 et seq.

Bennet/Sullivan, Disentitling the Poor: Waivers and Welfare "Reform", in: UMJLR (1993) pp.741-784.

European Labour Law (London, Butterworths, 1996).

Gesundheitsschutz als Aufgabe der EU - Entwicklung, Kompetenzen, Perspektiven (Baden-Baden, Nomos, 1997)

Das Bildungswesen nach Maastricht - Auswirkungen der Beschlüsse von Maastricht auf den Bildungsföderalismus, in: RJB (1992) pp.436 et seq. Discrimination and Free Movement in EC Law, in: ICLQ (1996) pp.82108.

Bertola, et al, EU Welfare Systems and Labor Markets: Diverse in the Past, Integrated in the Future?, in: Bertola et al, Welfare and Employment in a United Europe (2000) pp.23-122.

Betten/Grief, EU Law and Human Rights (London, Longman, 1999).

Krankheit und Mutterschaft, in: Eichenhofer (Hrsg.), Reform des Europäischen koordinierenden Sozialrechts (Köln, Heymann, 1993) pp.55-73.

Soziale Sicherung für den Fall der Krankheit und Mutterschaft, in: Europäisches Sozialrecht - Bundestagung des Deutschen Sozialrechtverbandes e.V. 9. bis 11. Oktober 1991 (1992) pp.51-69.

Bijzondere Euregionale Commissie Grensoverschrijdende Zorg, Zorg Dichtbij oòk over de grens - Advies over Grensoverschrijdende Zorg in de Euregio Maas-Rijn (Maastricht, 1994).

Family Life in Community Law: The Limits of Freedom and Dignity, in: Guild, The Legal Framework and Social Consequences of Free Movement of Persons in the European Union (the Hague, Kluwer Law International, 1999) pp.7-17.

Constitutional Limitations on the Power of States to Regulate the Movement of Goods in Interstate Commerce, in: Sandalow/Stein (Eds), Courts and Free Markets: Perspectives from the United States and Europe (Oxford, Clarendon Press, 1982). pp.174-221.

Auswirkungen des Europäischen Binnenmarktes auf die gesetzliche Krankenversicherung, in: BB (1989) pp.2405-2410.

De Blois, Europees Gemeenschapsrecht en Onderwijs, in: SEW (1991) pp. 513-537.

Unhealthy Federalism: Barriers to Increasing Health Care Access for the Uninsured, in: UCDLRev (1990) pp.255-348. 


\section{xxxviii}

Bogaert

Bogen

Böhning

Böhning

Bokeloh

Bolly

Bongen

Boni

Boonk

Bork

Bosco

Bossche

Bovbjerg

Braeutigam

Broek

Broek

Broekmans

Brouwer

Brouwer

Brubaker

Van den Bogaert, The Consequences of the Gaygusuz Judgement for Belgian Social Security, in: Van den Bogaert (Ed.), Social Security, NonDiscrimination and Property (Antwerpen, Maklu, 1997) pp.123-148. Privileges and Immunities Clause of Article IV, in: Case WestLRev (1987) pp.794-861

The Scope of the EEC System of Free Movement of Workers - A Rejoinder, in: CMLRev (1973) pp.81-86.

The Migration of Workers in the United Kingdom and the European Community (London, Oxford University Press, 1972).

Export von Pflegeleistungen innerhalb der Europäischen Union, in: Zentrum für Europäischen Wirtschaftsrecht, Die Krankenversicherung in der Europäischen Union (Bonn, 1997) pp.115-162.

Droit d'Entrée et de Sejour des Ressortissants communautaire: Développements récents, in: ActduDr (1990) pp.735-748.

Schranken der Freizügigkeit aus Gründen der öffentlichen Ordnung und Sicherheit im Recht der Europäischen Wirtschaftsgemeinschaft (Berlin, Duncker \& Humblot, 1975)

Freizügigkeit und Integration. Struktur und integrationspolitike Bedeutung der Arbeitsmarktverflechtung zwischen den Mitgliedstaaten der Europäischen Wirtschaftsgemeinschaft (Frankfurt am Main, Lang, 1976)

Openbare Orde als Grens aan het Vrij Verkeer van Goederen, Personen en Diensten in de E.E.G. (Alphen aan de Rijn, Tjeenk Willink, 1977).

The Impossibility of Finding Welfare Rights in the Constitution, in: WashULRev (1979) pp.695 et seq.

Are National Social Protection Systems under Threat? Observations on the Recent Case Law of the Court of Justice (Groupement d'Etudes et de Recherches Notre Europe, 2000)

Van den Bossche, Elders Gaan Studeren op Andermans Kosten?, in: NJB (1992) pp.792-797.

Bovbjerg/Kopit, Coverage and Care for the Medically Indigent: Public and Prvate Opitions, in: IndiLRev (1986) pp.857 et seq.

Das Problem des "gemeinsamen" Marktes unter sozialem Aspekt, in: Aussenwirtschaft (1956) pp.170-189

tenBroek, California's Dual System of Family Law: Its Origin, Development and Present Status, in: StanfLRev (1964) pp.257 et seq.

tenBroek, The Constitution and the Right to Free Movement (New York, National Travelers Aid Association, 1955).

Broekmans et al, Europees Geneesmiddelenbeleid in Ontwikkeling, in: Roscam Abbing/van Berkestijn, Gezondheidsbeleid in Europa (Houten, Bohn Stafleu van Loghum, 1995) pp.109-127.

Het Nederlandse Gezondheidszorgstelsel in Europa - Een Economische Verkenning (Zoetermeer, Raad voor de Volksgezondheid en Zorg, 1999). De Europese Gemeenschap en Onderwijs: Geschiedenis van de Samenwerking en het Communautair Beleid op Onderwijsterrein (Baar, BKE, 1996).

Membership without Citizenship: The Economic and Social Rights of Non-Citizens, in: Brubaker (Ed.), Immigration and the Politics of Citizenship in Europe and North America (Lanham, University Press of America, 1989). 


\section{xxxix}

Brubaker Citizenship and Naturalization: Policies and Politics, in: Brubaker (Ed.), Immigration and the Politics of Citizenship in Europe and North America (Lanham, University Press of America, 1989). pp.99-125.

Brüggemann Die Freizügigkeit der Arbeitnehmer im Bereich der Europäischen Gemeinschaften (Würzburg, 1973)

Buchanan Who Should Distribute What in a Federal System, in: Hochman/Peterson (Eds), Redistribution Through Public Choice (New York, Columbia University Press, 1974)

Bulterman Annotation Bickel, in: CMLRev (1999) pp.1325-1334

Bulterman Annotation El-Yassini, in: CMLRev (1999) pp.1357-1364

Burnham Introduction to the Law and Legal System of the United States (St.Paul, West Publishing, 1995).

Busquin De Sociale Slang en het Europees Programma ter Bestrijding van Armoede, in: BTSZ (1990) pp.557 et seq.

Buys Met het EG-Recht Strijdige Belastingstelsels en de Rechtsbescherming van de Burger (Arnhem, Gouda Quint, 1994)

Buyser De Buyser, Grensoverschrijdende Gezondheidszorg, in: Jorens, Grensarbeid (Brugge, Die Keure, 1997) pp.129-160.

C

Cabral Cross-Border Medical Care in the European Union - Bringing Down a First Wall, in: ELRev (1999) pp.387-395.

Calabresi 'A Government of Limited and Enumerated Powers': In Defense of United States v. Lopez, in: MichLRev (1995) pp.752-831.

Callens De Arresten Kohll en Decker: Implicaties voor Grensoverschrijdende Zorg, in: Essers et al (Red.), Grensoverschrijdende Zorg - Marktwerking vs. National Zorgbewaking (Lelystad, Koninklijke Vermande, 2000) pp.11-13.

Camissa From Rhetoric to Reform? - Welfare Policy in American Politics (Boulder, Westview Press, 1998)

Capron United States of America, in: Fuenzalida-Puelma/Scholle Connor (Eds), The Right to Health in the Americas (Washington, World Health Organisation, 1989) pp.498-520.

Carens Immigration and the Welfare State, in: Gutmann (Ed.), Democracy and the Welfare State (Princeton, Princeton University Press, 1988) pp.207-230.

Carlier Proportionality and Citizenship in relation to the Free Movement of Persons, in: Carlier/Verwilghen, Thirty Years of Free Movement of Workers in Europe (Luxembourg, Office for Official Publications of the European Communities, 2000) pp.41-57.

Casparie Casparie et al, Competitive Health Care in Europe - Future Prospects (Aldershot, Dartmouth, 1990).

Cassese Cassese et al, European Union - The Human Rights Challenge (BadenBaden, Nomos, 1991).

Castro Castro Oliveira, The Position of Resident Third Country Nationals: Is it Too Early to Grant Them Union Citizenship?, in: La Torre (Ed.), European Citizenship: An Institutional Challenge (The Hague, Kluwer Law International, 1998) pp.185-199.

Cath Blijft het Tobben of Onstaat er Iets Moois? Decker en Kohll Spoken door Europa (2), in: MC (1999) pp.468-471. 
Centel

Center

Chafee

Chambers

Chang

Charalambis

Chardon

Cholewinski

Christensen

Clapham

Clark

Clarke

Classen

Clermonts

Closa

Closa

Closon

Coenen

Cohen

Cohen
Europa en Vrij Verkeer - Consequenties voor de Zorgsector, in: PhW (1999) pp.1779-1780

Vuurwerk of Veenbrand? Decker en Kohll Spoken door Europa (1), in: MC (1999) pp.466-467.

The Social Security of the Turkish Workers in Europe within the Framework of the Association Agreement, in: Jorens/Schulte (Eds), European Social Security Law and Third Country Nationals (Bruxelles, Die Keure, 1998) pp.281-197.

Center on Social Welfare Policy and Law, Living at the Bottom: An Analysis of AFDC Benefits Levels (New York, 1993).

Three Human Rights in the Constitution of 1787 (Lawrence, University Press of Kansas, 1956).

Residence Requirements for Welfare Benefits: The Consequences of their Unconstitutionality, in: SW (1969) pp.29-37.

Immigrants under the New Welfare Law: A Call for Uniformity, a Call for Justice, in: UCLALRev (1997) pp.205-280

Die Arbeitnehmer im EWG-Recht (Nürnberg, 1970).

Principles of Co-ordination, in: Jorens/Schulte (Eds), Coordination of Social Security Schemes in Connection of the Accession of Central and Eastern European States: "the Riga Conference" (Brugge, Die Keure, 1999) pp.43-79.

Migrant Workers in International Human Rights Law - Their Protection in Countries of Employment (Oxford, Clarendon Press, 1997).

Christensen/Malmstedt, Lex Loci Laboris versus Lex Loci Domicilii - An Inquiry into the Normative Foundations of European Social Security Law, in: EJSS (2000) pp.69 et seq.

Human Rights and the European Community: A Critical Overview, in: Cassese et al (Eds), European Union - The Human Rights Challenge (Baden-Baden, Nomos, 1991 (1991) pp.29-61.

Does Welfare Affect Migration? (Washington, Urban Institute, 1990)

Validity of Discriminatory Nonresident Tuition Charges in Public Higher Education under The Privileges and Immunities Clause, in: NebLRev (1971) pp.31-64.

Bildungspolitische Förderprogramme der EG - Eine kritische Untersuchung der vertragsrechtlichen Grundlagen, in: EuR (1990) pp.10-19.

Clermonts et al, Verblijfsrecht en Gebruik van Collectieve Voorzieningen door Immigranten (Nijmegen, Katholieke Universiteit, 1991) pp.52-57.

Citizenship of the Union and Nationality of Member States, in: CMLRev (1995) pp.487-519.

The Concept of Citizenship of the European Union, in: CMLRev (1992) pp. $1137-1170$

Closon et al, Public Health Policy in the European Community, in: Holland/Mossialos (Eds), Public Health in the European Union (Aldershot, Ashgate, 1999) pp.49-67.

State User Fees and the Dormant Commerce Clause, in: vdbiltLRev (1997) pp. 795-844.

Discrimination Against New State Citizens: An Update, in: ConstComm (1994) pp.73 et seq.

Equal Treatment for Newcomers: The Core Meaning of National and State Citizenship, in: ConstComm (1984) pp.9-19. 
Cohen Europa en het Onderwijs(recht), in: Postma (Red.), Europa en het Onderwijs (Voorburg, Stichting Bijzondere Leerstoelen Onderwijsrecht, 1993) pp. $21-42$.

Committee Committee for the Study of the Future of Public Health, The Future of Public Health (Washington, National Academy Press, 1988).

Conrad Die Rechtsprechung des Gerichtshofs der Europäischen Gemeinschaften auf dem Gebiet des Bildungswesen, in: WissR (1989) pp.97-110.

Constan.. Constantinesco, La Citoyenetté de l'Union, in: Schwarze (Ed.), Vom Binnenmarkt zur Europäischen Union Beiträge zur Aktuellen Entwicklung des Gemeinschaftsrecht (Baden-Baden, Nomos, 1993) pp.25 et seq.

Coomans Recht op Onderwijs, Ook voor 'Illegale' Vreemdelingen, in: MR (1996) pp.57-60.

Coomans De Internationale Bescherming van het Recht op Onderwijs (Leiden, Stichting NJCM-Boekerij, 1992).

Cornelissen The Principle of Territoriality and the Community Regulations on Social Security (Regulations 1408/71 and 574/72), in: CMLRev (1996) pp.439 et seq.

Cornett The Treaty of Maastricht: From Conception to Ratification (Harlow, Longman, 1993)

Coughlin Coughlin et al, Medicaid since 1980): Costs, Coverage and the Shifting Alliance between the Federal Government and the States (Washington, Urban Institute Press, 1994).

Coussins The EC Recommendations on Social Protection: A Case Study in EC Social Policy, in: SPA (1993) pp. 286 et seq.

Covar Covar/Simon, La Citoyenette de l'Union, in: CDE (1993) pp.285-316.

Craig Carig/de Bùrca, EU Law - Text, Cases \& Materials (Oxford, Oxford University Press, 1998).

Craye.. $\quad$ van Crayenest, La Nature juridique des Résolutions sur la Coopération en Matière d'Education, in: De Witte, European Community Law of Education (Baden-Baden, Nomos, 1989) pp.127 et seq.

Cremona Citizens of Third Countries: Movement and Employment of Migrant Workers within the European Union, in: LIEI (1996) pp.87-113.

Creutz Accord européen Concernant l'Octroi des Soins médicaux aux Personnes en Séjour temporaire, in: RISS (1985) pp.42-49

Creutz The European Agreement Concerning the Provision of Medical Care during Temporary Residence, in: ISSRev (1985) pp.38-45

Crijns EG-recht en Onderwijs, in: NTOR (1989) pp.23-41.

Cullen From Migrants to Citizens? European Community Policy on Intercultural Education, in: EJFL (1996) pp.109-129.

Curall Bildung und Ausbildung im Recht der Europäischen Gemeinschaft, in: RJB (1991) pp.139-161.

Curall Education Rights under the EC Treaty, in: X, Mobility of People in the European Community (Dublin, Irish Center for Law/Trinity College, 1990) pp.13-32. 
D

Dahlberg The E.E.C. Commission and the Politics of the Free Movement of Labour, in: JCMS (1968) pp.310-322.

Dalichow Academic Recognition within the European Community, in: EJE (1987) pp.39-58.

Davies

Davis

Davis

Defalque

Degen

Delperee

Denys

Denys

Denys

Devroe

Dimako.

Dittmann

Dohms

Dollat

Domhof

Dommers

Donner

Douglas

Dowell

Drijber

Driver

Druesne

The EU Higher Education Exchange and Mobility Programmes (London, University of North London, 1997).

The Evolving Right to Travel: Saenz v Roe, in: Publius (1999) pp.95-110. Davis/Rowland, Uninsured and UndeservedL Inequities in Health Care in the United States, in: MMF Quart (1983) pp.157 et seq Annotation Echternach, in: JT (1989) pp.426 et seq.

Die Unionsbürgerschaft nach dem Vertrag über die Europäische Union unter besonderer Berücksichtigung des Wahlrechts, in: DöV (1993) pp. 749-758.

De Gemeenschappelijke Arbeidsmarkt en het Vrije Arbeidskrachtenverkeer, in: Arbbl (1956) p.177-205.

Het Burgerschap: Meer dan een Schim?, in: NTER (1998) pp.21()-213.

Grote Schoonmaak in de Overheidssector, in: NTER (1996) pp.221-224

Het Begrip Kind, in: NTER (1995) pp.115-116.

Devroe/Wouters, De Europese Unie (Leuven, Peeters, 1995).

Dimakopoulos, Wanderarbeitnehmer aus der Türkei in der Europäischen Gemeinschaft - Zur Zukunft der Gastarbeiderfrage in Europa, in: InfAuslR (1988) pp.309-315.

Dittmann/Fehrenbacher, Die Bildungdrechtliche Harmonisierungsverbote (Art.126 Abs.4 EGV, Art.127 Abs.4 EGV) und ihre Bedeutung für die nationale Bildungshoheit, in: RJB (1992) pp.478 et seq.

Die Kompetenz der EG im Bildungsbereich der algemeinen Bildung nach Artikel $126 \mathrm{EGV}$, in: RJB (1992) pp.451 et seq.

Libre Circulation des Personnes et Citoyenneté européenne: Enjeux et Perspectives (Bruxelles, Bruylant, 1998).

Untersuchung zur Entstehung der Richtlinie des Rates der Europäischen Gemeinschaften von 25.7.1977 über die schulische Betreuung der Kinder von Wanderarbeitnehmern, in: X (source unknown) (1979).

An Introduction to European Union Health Law, in: EJHL (1997) pp.1941

De Ontwikkeling van het Vrije Verkeer van Personen binnen de Europese Gemeenschappen en de Overeenkomst ter Uitvoering van het Akkoord van Schengen, in: SEW (1990) pp.766 et seq.

Douglas-Scott/Kimbell, The Adams Exclusion Order Case: New Enforcable Civil Rights in the post-Maastricht European Union?, in: PubLaw (1995) pp.516-525.

State and Local Government Responsibilities to Provide Medical Care for the Poor, in: JLH (1988-89) pp.1-45.

Gelijke Behandeling van Studenten uit de EEG - Zijn er nog Grenzen?, in NJB (1988) pp.22-29.

Die Integration des europäischen Arbeitsmarktes (Köln, Photostelle Universität Köln, 1962)

Remarques sur le Champ d'Application personnel du Droit communautaire: des "Discriminations à Rebours" Peuvent-elles Tenir en Echec la Liberté de Circulation des Personnes, in: RTDE (1979) pp.429-439. 
xliii

Dworkin Dworkin/Steyger, Aids Victims in the European Community and the United States: Are They Protected from Unjustified Discrimination?, in: TexILJ (1989) pp.295-329.

Dummett The Acquisition of British Citizenship. From Imperial Traditions to National Definitions, in: Bauböck (Ed.), From Aliens to Citizens: Redefining the Status of Immigrants in Europe (Aldershot, Avebury, 1994) pp. $75-84$.

Due

Due/Friedländer, Government Finance - Economics of the Publi Sector (Georgetown, Irwin-Dorsey, 1977).

Dye The Policy Consequences of Intergovernmental Competition, in: CatoJ (1990) pp.59-73.

E

Eardley et al, Social Assistance in OECD Countries: Country Reports (HSMO, Department of Social Security Research, 1996)

Eardley Eardley et al, Social Assistance in OECD Countries: Synthesis Report (HSMO, Department of Social Security Research, 1996).

Eichenhofer How to Simplify the Co-ordination of Social Security, in: EJSS (2000) pp. 229 et seq.

Eichenhofer Dienstleistungsfreiheit und Freier Warenverkehr als Rechtsgrundlagen für Grenzüberschreitenden Behandlungsleistungen, in: Zentrum für Europäisches Wirtschaftsrecht, Grenzüberschreitenden Behandlungsleistungen im Binnenmarkt (Bonn, 1998) pp.1-20.

Eicke The Third Country Agreements: The Right to Work and Reside in the First Generation Agreements, in: Guild (Ed.), The Legal Framework and Social Consequences of Free Movement of Persons in the European Union (The Hague, Kluwer Law International, 1999) pp. 89-103.

Einerhand Bijstand een Internationale Vergelijking, in: SMA (1997) pp.207-220.

Einerhand Sociale Zekerheid: Een Europese Vergelijking, in: TvA (1997) pp.5-20.

Einerhand Sociale Zekerheid: Stelsels en Regelingen in Europese Landen ('s Gravenhage, VUGA, 1995)

Elman The Limits of Citizenship: Migration, Sex Discrimination, and Same-Sex Partners in EU Law, in: JCMS (2000) pp.729-749.

Entzinger De Andere Grenzen van de Verzorgingsstaat - Migratiestromen en Migratiebeleid: in: Engbersen et al (Eds), Zorgen in het Europese Huis - De Grenzen van Nationale Verzorgingsstaaten (Amsterdam, Boom, 1994) pp. 142-172.

Eschmann Die Freizügigkeit der EG-Bürger und der Zugang zur öffentlichen Verwaltung - Eine Untersuchung zur gemeinschafts- und verfassungsrechtlichen Stellung der EG-Bürger im öffentlichen Dienst der Bundesrepublik Deutschland (Baden-Baden, Nomos, 1992).

Esping Esping-Andersen, Comment, in: Bertola et al, EU Welfare Systems and Labor Markets: Diverse in the Past, Integrated in the Future?, in: Bertola et al, Welfare and Employment in a United Europe (2000) pp.127-143.

Esping Esping-Andersen, Three Worlds of Welfare Capitalism (Princeton, Princeton University Press, 1990)

Euzeby Financement de la Protection sociale, Efficacité économique et Justice sociale, in: RMCU (1997) pp.253 et seq. 
xliv

Euzeby Le Financement de la Protection sociale dans les Pays de la CEE: Problèmes et Perspectives, in: X, Quel Avenir pour l'Europe sociale: 1992 et Après (Bruxelles, 1990)

Evans Union Citizenship and the Constitutionalization of Equality in EU Law, in: La Torre, European Citizenship: An Institutional Challenge (the Hague, Kluwer Law International, 1998) pp.267-291.

Evans Third Country Nationals and the Treaty on European Union, in: EJIL (1994) pp.199 et seq.

Evans

Evans

Nationality Law and European Integration, in: ELRev (1992) pp.190-215. European Citizenship, in: MLRev (1982) pp.497-515.

Evans Evans/Jesserun d'Oliveira, Nationality and Citizenship, in: Cassesse et al (Eds), Human Rights and the European Community: Methods of Protection (Baden-Baden, Nomos, 1991) pp.298-345.

Everling Das Niederlassungsrecht in der Europäischen Gemeimschaft, in: DB (1990) pp.1853-1859

Everling Von der Freizügigkeit der Arbeitnehmer zum Europäisches Bürgerrecht?, in: EuR (1990) Beiheft I pp.81-103.

Everling Zur Rechtsprechung des Europäischen Gerichtshofs über die Beschäftigung von EG-Ausländern in der öffentlichen Verwaltung, in: DVBl (1990) pp. $225-231$

Everling Vertragsverhandlungen 1957 und Vertragspraxis 1987 dargestellt an den Kapiteln Niederlassungsrecht und Dienstleistungen des EWG-Vertrages, in: Mestmäcker et al (Hrsg.), Eine Ordnungspolitik für Europa - Festschrift für von der Groeben (Baden-Baden, Nomos, 1987) pp.111-130.

Everson The Legacy of the Market Citizen, in: Shaw/More (Eds), New Legal Dynamics of European Union (Oxford, Clarendon Press, 1995) pp.73-90.

F

Farber

National Security, the Right to Travel, and the Court, in: SCRev (1981) pp. 263-290.

Felmer Gemeinschaftsrecht und Nationales (Aus-)bildungsrecht, in: RJB (1989) pp. 175 et seq

Fernhout Fernhout (Red.), Dertig Jaar Vrij Verkeer van Werknemers (Nijmegen, Reeks Recht \& Samenleving, 1999).

Fernhout 'De Verenigde Staten van Europa zijn Begonnen', Maar voor Wie (Zwolle, Tjeenk Willink, 1992).

Feuchthofer Europäische Förderprogramme in Bildungswesen, in: RJB (1992) pp.180192.

Field European Dimensions - Education, Training and the European Union (London, Jessica Kingsley Publishers, 1998).

Fierstra Annotatie Vlassopoulou, in: SEW (1992) pp.640-649.

Flath Noch Einmal: Freizügigkeit in der EWG, in: der Landskreis (1968) pp. 342-344.

Flynn Gravier: Suite de Feuilleton, in: De Witte (Ed.), European Community Law of Education (Baden-Baden, Nomos, 1989) pp.95-112

Flynn Vocational Training in Community Law and Practice, in: YEL (1989) pp.59-85.

Foblets Extra-Collegegeld voor Buitenlandse Studenten aan Belgische Universiteiten?, in: JF (1985) pp.535-544. 
Forde $\quad$ Social Assistance and the EEC's Regulations, in: LIEI (1978) pp.9-28.

Fox Fox Piven, The Race Among the States in Welfare Benefits: A Comment, in: Publius (1998) pp.39-43.

Frazier L'Education et L'Union européenne, in: RMC (1997) pp.476-491.

Frazier L'Education et la Communauté européenne (1995).

Freeman Migration and the Political Economy of the Welfare State, in: Annals AAPSS (1986) pp.51-63.

Fries $\quad$ Fries/Shaw, Citizenship of the Union: First Steps in the European Court of Justice, in: EPL (1998) pp.533-559.

Fuchs $\quad$ Bildung ohne Grenzen, in: DV (1990) pp.245-246.

Furrow Furrow et al, Health Law (St.Paul, West Publishing, 1991).

G

Gacon Gacon-Estrada, The Co-operation Agreements Concluded between the European Community and the Maghreb Countries, in: Jorens/Schulte, European Social Security Law and Third Country Nationals (Bruxelles, Die Keure, 1998) pp.323-331.

Gans de Gans, Annotatie Molenaar, in: in RZA (1999) pp.252-260

Gans de Gans, Kroniek - Persoonsgebonden Budget, in: RZA (1998) pp.15.

Gardner The European Agency for the Evaluation of Medicines and European Regulation of Pharmaceuticaks, in: ELJ (1996) pp.48-82.

Garot A New Basis for European Citizenship: Residence?, in: La Torre (Ed.), European Citizenship: An Institutional Challenge (The Hague, Kluwer Law International, 1998) pp.229-248.

Garrone La Libre Circulation des Personnes - Liberté de Mouvement, Egalité, Liberté économique - Etude de Droit communautaire et suisse (Zürich. Schulthess, 1995).

Garrone La Discrimination indirecte en droit communautaire: Vers une Théorie générale, in: RTDE (1994) pp.425-449.

Garth Migrant Workers and Rights of Mobility in the European Community and the United States: A Study of Law, Community and Citizenship in the Welfare State, in: Cappelletti et al, Integration Through Law - Europe and the American Federal Experience (Baden-Baden, Nomos, 1986) Vol.I, pp. $85-163$

Gassner Pflegeversicherung und Arbeitnehmerfreizügigkeit, in: NZS (1998) pp.313318 .

Geddes Free Movement of Pharmaceuticals within the Community: The Remaining Barriers, in: ELRev (1991) pp.295 et seq.

Gazan Gazan/Oomen, Internationaliseringsprogramma's en het Nederlandse Hoger Onderwijs - van Erasmus naar Socrates in de Europese Unie, in: IS (1995) pp. 155 et seq.

Gergen The Selfish State and the Market, in: TexLRev (1988) pp.1099-1153.

Gerven Van Gerven et al, Kartelrecht - Europese Gemeenschap (Kluwer, 1997).

Gerven Van Gerven/van den Bossche, Freedom of Movement and Equal Treatment for Students in Europe: An Emerging Principle?, in: Schermers et al (Eds), Free Movement of Persons in Europe: Problems and Experiences (Dordrecht, Martinus Nijhoff Publishers, 1993) pp.405-426. 
xlvi

Gilliams Van "Gravier" tot "Erasmus": Over de Bijdrage van het Hof van Justitie tot de Uitbouw van een Europees Onderwijsbeleid, in: RW (1989-1990) pp.494-504

Gobrecht National Reactions to Kohll and Decker, in: Eurohealth (1998) pp.16-17.

Godry Krankenbehandlung ohne Grenzen - Anmerkungen zu einem Modellprojekt im niederländischen-deutschen Grenzgebiet, in: ZFSH/SGB (1997) pp.416 et seq.

Gonzalez The Interstate Privileges and Immunities: Fundamental Rights or Federalism, in: CapULRev (1986) pp.493-513.

Goodwin Goodwin-Gill, International Law and the Movement of Persons Between States (Oxford, Clarendon Press, 1978).

Gordon Gordon/Jallade, 'Spontaneous' Student Mobility in the European Union: A Statistical Survey, in: EJE (1996) pp.133-151.

Gordon Gordon/Jallade, Student Mobility within the European Union: A Statistical Analysis (http://europa.eu.int/comm/education/socrates/erasmus/statisti/index.html, 1995)

Gori External Relations in Community Education and Vocational Training Policies", in: MJ (1998) pp.25-51.

Gould Equality of Access to Education, in: MLRev (1989) pp. $497 \mathrm{et} \mathrm{seq}$

Gouloussis Equality of Treatment and the Relationship between Regulations 1612/68 and 1408/71, in: Commission of the European Communities/Departemento de Relações Internaçionais e Convenções de Segurança Social, Social Security in Europe - Equality between Nationals and Non-Nationals (1995) pp. $75-88$.

Grabitz Europäisches Bürgerrecht zwischen Marktbürgerschaft und Staatsbürgerschaft (Köln, Europa Union Verlag GmbH, 1970).

Gramlich Gramlich/Laren, Migration and Income Redistribution Responsibilities, in: JHR (1984) pp.489-511.

Grand Le Grand et al, The Economics of Social Problems (Basingstoke, MacMillan, 1993).

Greenwood Nationality and the Limits of the Free Movement of Persons in Community Law, in: YEL (1987) pp.7 et seq.

Greenwood Limits on the Free Movement of Persons in EEC Law, in: YEL (1987/1988) pp.185-210.

Grewal Economic Criteria for the Assignment of Functions in a Federal System, in: Advisory Council for Inter-Governmental Relations - Towards Adaptive Federalism (1981) at p.27.

Groenendijk The Growing Relevance of Article 39 (ex 48) EC Treaty for Third Country Nationals, in: Carlier/Verwilghen, Thirty Years of Free Movement of Workers in Europe (Luxembourg, Office for Official Publications of the European Communities, 2000) pp.207-223.

Groenendijk De Betekenis van Artikel 39 EG-Verdrag voor Werknemers uit Landen buiten de Europese Unie, in: Fernhout (Red.), Dertig Jaar Vrij Verkeer van Werknemers (nijmegen, Reeks Recht \& Samenleving, 1999) pp.35-49.

Groeben von der Groeben et al (Hrsg.), Kommentar zum EWG-Vertrag (BadenBaden, Nomos, 1997)

Groeben von der Groeben et al (Hrsg.), Kommentar zum EWG-Vertrag (BadenBaden, Nomos, 1991)

Groof De Groof/Friess, Opportunities for a European Educational Policy, in: EJELP (1997) pp.9-17. 
xlvii

Groot de Groot, The Relationship between the Nationality Legislation of the Member States of the European Union and European Citizenship, in: La Torre, European Citizenship - An Institutional Challenge (The Hague, Kluwer Law International, 1998) pp.115-147

Groot de Groot, Staatsangehörigkeitrecht im Wandel - Eine rechtsvergleichende Studie zu den Erwerb- und Verlustgründen der Staatsangehörigkeit (Köln, Heymann, 1989)

Groot De Groot, De Wettelijke Verzekering van Geneeskundige Verzorging en Ziekengeld binnen het Kader van de EEG-Verordeningen, in: Boot et al, Europees Sociaal Verzekeringsrecht (Deventer, Kluwer, 1978) pp.91-110.

Grunwald Grunwald/Smit, Grensoverschrijdende Zorg - Zorg op Maat in de Euregio Maas-Rijn; Evaluatie van een Experiment (Utrecht, Nzi, 1999)

Guendel.. Guendelsberger, Equal Protection and Resident Aliens Access to Public Benefits in France and the United States, in: TulLRev (1993) pp.631-676.

Guild Guild/Harlow (Eds), Implementing Amsterdam - Immigration and Asylum Rights in EC Law (Oxford, Hart Publishing, 2000).

Guild Guild/Peers, Deference or Defiance? The Court of Justice's Jurisdiction over Immigration and Asylum, in: Guild/Harlow (Eds), Implementing Amsterdam - Immigration and Asylum Rights in EC Law (Oxford, Hart Publishing, 2000) pp.267-289.

Guild Guild/Niesen, The Developing Immigration and Asylum Policies of the European Union - Adopted Conventions, Resolutions, Decisions and Resolutions (the Hague, Kluwer Law International, 1996).

Guild European Community Law from a Migrant's Perspective (Nijmegen, 1999)

Gümrükcü EU-Türkei-Beziehungen im Spannungsfeld zwischen Assoziation und Vollmitgliedschaft - Werdegang einer ungleichen Partnerschaft, in: Lichtenberg et al (Hrsg.), Gastarbeiter - Einwanderer - Bürger? Die Rechtstellung der türkischen Arbeitnehmer in der Europäischen Union (BadenBaden, Nomos, 1996) pp.27-60

Guttmann Die Assoziationsfreizügigkeit Türkischer Angehöriger (Baden-Baden, Nomos, 1999)

Gunther Constitutional Law (Mineola, Foundation Press, 1985)

Gunther The Supreme Court 1971 Term - Foreword: In Search of Evolving Doctrine on a Changing Court: A Model for a Newer Equal Protection, in HarvLRev (1972) pp.1-48

Gyselen Annotation Albany, in: CMLRev (2000) pp.425-448.

H

Hagen University Co-operation and Academic Recognition in Europe: The Council of Europe and the Communities, in: EJE (1987) pp.77-83.

Hailbronner Die Entscheidung des EuGH zur Freizügigkeit türkischer Arbeitnehmer, in: NVwZ (1988) pp.220-224.

Hailbronner Die neuere Rechtsprechung zum EG-Freizügigkeitsrecht, in: ZAR (1988) pp.3-13.

Hailbronner Aufenthaltbeschränkungen gegenüber EG-Angehörigen und neuere Entwicklungen im EG-Aufenthaltsrecht, in: ZAR (1985) pp.108-116. 


\section{xlviii}

Hailbronne

Hänlein

Hänlein

Hall

Hall

Hamilton

I Iamilton

Hammar

Hammar

Hammer.

Hampel

Hancher

Hancher

Handoll

Handoll

Hanekuijck

Hansen

Hartley

Hartley

Hartley

Hartley

Harmaeckers
Hailbronner/Polakiewicz, Non-EC Nationals in the European Community: The Need for a Co-ordinated Approach, in: DukeJICLaw (1992) pp.49 et seq.

Problems Concerning Decision No $3 / 80$ of the Council of Association - A Point of View from a EU Perspective, in: Jorens/Schulte (Eds), European Social Security Law and Third Country Nationals (Bruxelles, Die Keure, 1998) pp.299-322.

Fehlende unmittelbare Wirkung der Bestimmungen des Assoziationsratsbeschlusses EWG-Türkei über 'Invalidität' und Renten bei 'Alter und Tot', in: EASr (1997) pp,21-23.

Nationality, Migration and Citizenship of the Union (Dordrecht, Nijhoff, 1995)

The ECHR and Public Policy Exceptions to the Free Movement of Workers under the EEC Treaty, in: ELRev (1991) pp.466 et seq.

Interne Markt en (Aanvullende) Ziektekostenverzekeringen, in: NTG (2001) pp.37-48.

Annotatie Decker-Kohll, in: TvG (1998) pp.394-397.

Legal Time of Residence and the Status of Immigrants, in: Bauböck, From Aliens to Citizens - Redefining the Status of Immigrants in Europe (Aldershot, Avebury, 1994) pp.187-197.

Democracy and the Nation State: Aliens, Denizens and Citizens in a World of International Migration (Aldershot, Avebury, 1990).

Hammerstrom, Constitutional Law - Equal Protection - Residency Requirements, in: CaseWRLRev (1970) pp.unknown.

Einwanderungsgesetzgebung und innereuropäische Wanderung - Die rechtlichen Regelungen der Zulassung ausländischer Arbeitnehmer in fünfzehn europäischen Staaten (Kiel, Institut für Weltwirtschaft Universität Kiel, 1957)

Creating the Internal Market for Pharmaceutical Medicines - An Echternach Jumping Procession, in: CMLRev (1991) pp.821 et seq.

The European Pharmaceutical Market: Problems of Harmonisation, in: ELRev (1990) pp.9 et seg.

Free Movement of Persons in the EU (Chicester, Wiley, 1995).

Article 48(4) and Non-National Access to Public Employment, in: ELRev (1988) pp.223-242.

Het Recht op Vrijheid van Migratie (Leiden, Sijthoff, 1957).

A European Citizenship or a Europe of Citizens? - Third Country Nationals in the EU, in: JEMS (1998) pp.751-768.

Free Movement of Persons, in: Green et al, The Legal Foundations of the Single European Market (Oxford, Oxford University Press, 1991).

La libre Circulation des Etudiants en Droit communautaire, in: CDE (1989) pp.325 et seq.

EEC Immigration Law (Amsterdam, North-Holland Publishing Company, 1978) pp.77-80.

The International Scope of the Community Provisions Concerning Free Movement of Workers, in: Jacobs (Ed.), European Law and the Individual (Amsterdam, North-Holland Publishing Company, 1976) pp.19-37.

Fiscal Sovereignty and Tax Harmonization in the EC, in: EurTax (1991) pp. 173 et seq. 
Harvith

Hatzopoulos

Hatzopoulos

Hedemann

Hedemann

Heise

Hellmuth

Hendriks

Hennis

Hepple

Hershkoff

Hermans

Hermans

Hermans

Hermans

Hermans

Hermans

Hermans

Hermans

Hermans

The Constitutionality of Residence Tests for General and Categorical Assistance Programs, in: tenBroek (Ed.), The Law of the Poor (San Fransisco, Chandler, 1966) pp.243-317.

Recent Developments of the Case Law of the ECJ in the Field of Services, in: CMLRev (2000) pp.43-82.

Annotation Svensson, in: CMLRev 91996) pp.569 et seq

Hedemann-Robinson, From Object to Subject?: Non-EC Nationals and the Draft Proposal of the Commission for a Council Act Establishing Rules for the Admission of Third Country Nationals to the Member States, in: YEL (1998) pp.289-335.

Hedemann-Robinson, Third Country Nationals, European Union Citizenship and Free Movement of Persons: A Time for Bridges Rather than Division, in: YEL (1997) pp.321-362.

Les Possibilités d'une Harmonisation social des Régimes d'Assurance sociale dans les Etats Membres de la Communauté Economique Européenne, in: DS (1966) pp.580-589.

Residency for Tuition Purposes: A Study of the Rules in Use at the Fifty State Universities (1981)

The Right to Freedom of Movement and the (un)lawfulness of Aids/HIV Specific Travel Restrictions from a European Perspective, in: NJIL (1990) pp. 86 et seq.

Access to Education in the European Communities, in: LJIL (1990) pp.3544.

Welfare legislation and Wage Labour, in: Hepple (Ed.), The Making of Labour Law in Europe - A Comparative Study of Nine Countries up to 1945 (London, Mansell, 1986) pp.115-153.

Positive Rights and State Constitutions: The Limits of Federal rationality Review, in: HarvLRev (1999) pp.1131-1196.

Access to Health Care and Health Services in the European Union: Regulation 1408/71 and the E 111 Process, in: Leidl (Ed.), Health Care and its Financing in the Single European Market (Amsterdam, IOS Press, 1998) pp.324-343.

Patients' Rights in the European Union - Cross-Border Care as an Example of the Right to Health Care, in: EJPH (1997) pp.11-17.

The Socrates Programme: From Negotiation to Implementation, in: EJELP (1997) pp.19-39.

Gezondheidszorg bij Tijdelijk Verblijf over de Grens: Toepassing Verordening 1408/71 (E111) in de Europese Praktijk, in: SR (1996) pp.343-348.

Europese Unie en de Gezondheidszorg - De Gevolgen van de Eenwording voor de Nederlandse Gezondheidszorg (Deventer, Kluwer, 1994).

Hermans/Buijsen, Aanbesteden van Medisch-Specialistische Zorg, in: SR (2000) pp.282-292.

Hermans/den Exter, Cross-border Alliances in Health Care: International Co-operation between Health Insurers and Providers in the Euregio MeuseRhine, in: CMJ (1999) (http://www.mefst.hr/cmj/1999/4002/400219.htm). Hermans et al, Zorg in het Buitenland: Gevolgen voor Patiënten en Zorgverzekeraars, in: Staatscourant (1998) p.5.

Hermans et al, Zorgverzekeraars en Uitvoeringsorganen Sociale Zekerheid Ondernemingen in het Licht van het EG-Recht, in: SMA (1996) pp.227238 . 
Hermans

Hermesse

Hermesse

Hermesse

Hermesse

Hervey

Hervey

Heynig

Hilf

Hilson

Hinnekens

Hirsch

Hochbaum

Hochbaum

Hoepelman

Hofmann

Hollmann

Holloway

Hoogen.

Hoogen.
Hermans et al, Health Care in Europe after 1992 (Aldershot, Dartmouth Publishing Company, 1992)

Opening Up the National Borders to Patients - The Economic Consequences, in: Association Internationale de la Mutualité/ European Institute of Social Security, Health Care without Frontiers within the European Union - Free Movement of Goods and Services in the Health Care Sector (Luxembourg, AIM, 1999) pp.49-58

Hermesse et al, Patient Mobility within the European Union, in: EJPH (1997) pp.4-10.

Hermesse et al, Gezondheidsbescherming in de Europese Gemeenschap (Brussel, Sauer, 1991).

Hermesse/Lewalle, L'Accès aux Soins en Europe - Quelle Mobilité du patient? (Bruxelles, Academia, 1993).

Up in Smoke? Community (Anti-)Tobacco Law and Policy, in: ELRev (2001) pp.101-125.

Social Solidarity: A Buttress Against Internal Market Law?, in: Shaw (Ed.), Social Law and Policy in an Evolving European Union (2000) pp.31-47.

Freizügigkeit in der Europäischen Wirtschaftgemeinschaft Endgültig Hergestellt, in: BB (1968) pp.337-339.

Europäisches Gemeinschaftsrecht und Drittstaatsangehörige, in: Hailbronner et al (Hrsg.), Staat und Völkerrechtordnung - Festschrift für Karl Doehring (Berlin, Springer-Verlag, 1989) pp.339-364.

Discrimination in Community Free Movement Law, in: ELRev (1999) pp.445-462.

Compatability of Bilateral Tax Treaties with European Community law The Rules, in: ECTaxRev (1994) pp.146-146.

Europäische Sozialunion durch Richterrecht?, in: FAZ (1998) pp.18 et seq. The Federal Structure of Member States as a Limit to Common Educational Policy: The Case of Germany, in: De Witte (Ed.), European Community Law of Education (Baden-Baden, Nomos, 1989) p.145 et seq.

Politik and Kompetenzen der Europäischen Gemeinschaften im Bildungswesen, in: BayV (1987) pp.481-49().

Het Verblijfsrecht van Studenten uit EU-Staten: De Praktijk aan een Nederlandse Universiteit, in: Fernhout (Red.), Dertig Jaar Vrij Verkeer van Werknemers (Nijmegen, Reeks Recht \& Samenleving, 1999) pp.103-116. Hofmann/Kocks, Freier Zugang zu Gesundheitsleistungen im Grenzgebieten - Grenzübershreitendes Projekt in der Euregio Maas/Rhein, in: ZFSH/SGB (1998) pp.306 et seq.

Der Einfluss der EG auf das Gesundheitswesen der Mitgliedstaaten, in: ZIAS (1998) pp.180-214.

Social Policy Harmonisation in the European Community (Famborough, Hants., 1981).

Hoogenboom, Free Movement and Integration of Non-EC nationals and the Logic of the Internal Market, in: Schermers et al (Eds), Free Movement of Persons in Europe (Dordrecht, Martinus Nijhoff Publishers, 1993) pp.497-511.

Hoogenboom, Integration into Society and Free Movement of non-EC Nationals, in: EJIL (1992) pp.36 et seq. 
House

Hull

Hull

Hull

Hulst

Hurk

Hurst

Hurwitz

Hyman

I

Ingelse

Ipsen

Isaac

J

Jackson

Jacobs

Jakubowski

Jansen

Jarvis

Jesserun

Jesserun
House of Lords, Select Committee on European Communities, 27th Report on Student Mobility in the European Community (1998).

Undocumented Alien Children and Free Public Education: An Analysis of Plyler v. Doe, in: UPittLRev (1983) pp.431 et seq.

Resident Aliens and the Equal Protection Clause: The Burger Court's Retreat From Graham v Richardson, in: BrooklLRev (1980) pp.1-42.

Without Justice for All - The Constitutional Rights of Aliens (Westport, Greenwood Press, 1980)

Studiefinanciering in Zes Europese Landen (Zoetermeer, Ministerie van Onderwijs en Wetenschappen, 1995).

van der Hurk, The European Court of Justice Knows its Limits, in: EC Tax Rev (1999) pp.211-223.

Reforming Health Care in Seven European Nations, in: HA (1991) pp.110.

The Free Circulation of Physicians within the European Communities (Aldershot, Avebury, 1990).

Public Finance - A Contemporary Application of Theory to Policy (Fort Worth, The Dryden Press, 1999).

International Labour Office, Analysis of the Immigration laws and Regulations of Selected Countries (Geneva, International Labour Office, 1954). Verplichting tot Vergoeding van in andere Lid-Staten Gemaakte Ziektekosten: Decker en Kohll in Nederland, in: SMA (2000) pp.208-211.

Europäisches Gemeinschaftsrecht, in: NJW (1964) pp.340 et seq.

L'Enseignement supérieur et le champt d'apllication du Traité CEE, in Philip (Ed.), L'Enseignement supérieur et la Dimension européenne (Paris, Economica, 1989) pp.11-18.

Persons of Equal Worth: Romer v Evans and the Politics of Equal Protection, in: UCLALRev (1997) pp.453-501.

Jacobs/Goddard, Social Health Insurance Systems in European Countries The Role of the Insurer in the Health Care System: A Comparative Study of Four European Countries (York, Centre for Health Economics, 2000) Jakubowski/Busse, Health Care Systems in the EU - A Comparative Study (Luxembourg, European Parliament - Directorate General for Research, 1998).

Vrij Verkeer van Turkse Werknemers in de EG?, in: MR (1986) pp.261263.

The Application of EC law on the Free Movement of Goods by National Courts of the Member States (Oxford, Clarendon Press, 1997).

Jesserun d'Oliveira, Vrij Verkeer voor Geregistreerde Partners in de Europese Unie, in: NJB (2001) pp.205-210.

Jesserun d'Oliveira, Nationality and the European Union after Amsterdam, in: O'Keeffe/Twomey, Legal Issues of the Amsterdam Treaty (Oxford, Hart Publishing, 1999) 
Jesserun

Johnson

Jonghe

Jorens

Jorens

Jorens

Jorens

Jørgensen

Joris

Joris

\section{K}

Kaiser

Kalen

Kam

Kampf

Kampf

Kanavos

Kapteyn

Karst

Katz

Jesserun d'Oliveira, Is Reverse Discrimination still Permissible under the Single European Act, in: de Boer et al (Eds), Forty Years On: The Evolution of Postwar Private International Law in Europe (Deventer, Kluwer, 1990) pp.71-86

Johnson/O'Keeffe, From Non-Discrimination to Obstacles to Free Movement: Recent Developments Concerning Free Movement of Workers, in: CMLRev (1994) pp.1313-1346.

De Jonghe/Dillo, Access to Higher Education (Brussels, Commission of the European Communities, 1991).

Annotatie Decker-Kohll, in: RZA (1998) pp.303-309.

Non-European Union Nationals and the Co-ordination of European Social Security Law: The International Agreements Concluded by the European Union with Third Countries and Conflict Rules in European Social Security Law, in: Jorens/Schulte (Eds), European Social Security Law and Third Country Nationals (Bruxelles, Die Keure, 1998) pp.1-110.

De Rechtspositie van Niet-EU-Onderdanen in het Europees Socialezekerheidsrecht (Brugge, Die Keure, 1997).

Wegwijs in het Europees Sociaal Zekerheidsrecht (Brugge, Die Keure, 1995).

Union Citizens - Free Movement and Non-Discrimination (Denmark, Jurist - og Okonomforbundets Forlag, 1996).

Het Hof van Justitie van de Europese Gemeenschappen en het Vrije verkeer van Turkse Werknemers: De Zaak Demirel, in: TvV (1988) pp.320 .

Joris/Veny, Bijkomende Inschrijvingsgelden voor Buitenlandse Studenten Welke Wetgeving is van Toepassing?, in: RW (1988) pp.735-740.

Kaiser et al, Public Expenditure on Higher Education - A Comparative Study in the Member States of the European Community (London, Jessica Kingsley, 1992).

Durational residency Requirements and the Equal Protection Clause: Zobel v Williams, in: JUrbContL (1983) pp.329-359.

De Kam et al, Kluwer Schets Leer van de Social Zekerheid (Deventer, Kluwer, 1989).

La Directive 90/366/Cee relative au Droit de Séjour des Etudiants communautaires: sa Transposition en France, in: RMCE (1992) pp.303-317.

Die "richtige" Rechtsgrundlage der Richtlinie über das Aufenthaltsrecht der Studenten, in: EuR (1990) pp.397-404.

Cross Border Health Care in Europe - European Court Rulings Have Made Governments Worried, in: BMJ (1999) pp.1157-1158.

Kapteyn/Verloren van Themaat, Introduction to the Law of the European Communities (London, Kluwer Law International, 1998).

The Supreme Court 1976 Term - Foreword: Equal Citizenship under the Fourteenth Amendment (1977), in: HarvLRev (1977) pp.1 et seq.

More Equal Than Others, The Burger Court and the Newly Arrived State Resident, in: NewMexLRev (1989) pp.329-376. 
Kemenade

Ketelsen

Kesteloot

Kirkman

Klarman

Klein

Klein

Kleinman

Knobbe

Koch

Knolle

Koenig

Kokkini

Kommers

Kon

Konrad

Kraus

Kuile

Kuile van Kemenade, Health Care in Europe 1997 - The Finance and Reimbursement Systems of 18 European Countries (Maarssen, Elsevier/De Tijdstroom, 1997).

Einreise, Aufenthalt und Ausweisung von Ausländern aus Drittstaaten, in: ZfRV (1991) pp.115-127.

Kesteloot et al, The Reimbursement of the Expenses for Medical Treatment Received by 'Transnational' Patients in EU-countries, in: HP (1995) pp.43 et seq.

Kirkman/Liff, Stelselwijzigingen in Enkele Andere landen, in: Elsinga/van Kemenade, Van Revolutie naar Evolutie - Tien Jaar Stelselwijziging inde Nederlandse Gezondheidszorg (Utrecht, De Tijdstroom, 1997).

An Interpretive History of the Modern Equal Protection, in: MichLRev (1991) pp.213-316.

De Klein/Collaris, Sociale Ziektenkostenverzekeringen in Europees Perspectief ('s Gravenhage, Staasuitgeverij, 1987)

De Klein/Collaris, The Choices in Care: A European Problem? (Zeist, 1991).

Kleinman/Piachaud, European Social Policy - Conception and Choices, in JESP (1993) pp.1-19.

Knobbe-Keuk, Niederlassungsfreiheit: Diskriminierungs- or Beschränkungsverbot? - Zur Dogmatik des Art.52 EWG-Vertrag - am Beispiel einiger gesellschaftsrechtlicher Beschränkungen, in: DB (1990) pp.2573-2584.

Die Entscheidung des EuGH zum Leistungsexport des Pflegegeldes vom 5. März 1998 (Rs C-160/96), in: ZFSH (1998) pp.451-454.

Freizügigkeit der Arbeitnehmer - Zur Verordnung Nr.15 der Europäischen Wirtschaftgemeinschaft, in: BArbBl (1961) pp.674-679.

Koenig/Pechstein, Die Europäische Union - Der Vertrag von Maastricht (Tübingen, Mohr, 1995).

Kokkini-Iatridou et al, Een Inleiding tot het Rechtsvergelijkende Onderzoek (Deventer, Kluwer, 1988)

Kommers/Waelbroeck, Legal Integration and the Free Movement of Goods: The American and the European Experience, in: Cappeletti et al, Integration Through Law - Europe and the American Federal Experience (Berlin, De Gruyter, 1985) pp.165-227.

Aspects of Reverse Discrimination in Community Law, in: ELRev (1981) pp. $75-101$.

Die internationale Arbeitsmobilität in der Europäischen Wirtschaftsgemeinschaft (Würzburg, 1969).

Niederlassungsfreiheit der freien Berufe in der Europäischen Gemeinschaft unter besonderer Berücksichtigung der Apotheker (Würzburg, 1989).

ter Kuile, Onzekerheden over de Invloed van Gemeenschapsrecht op de Nationale Gezondheidszorg (Deventer, Kluwer, 1997).

ter Kuile, Nationale Gezondheidszorg en Gemeenschapsrecht, in: TvG (1989) at pp.275-291. 
L

LaFrance Welfare Law: Structure and Entitlement in a Nutshell (St. Paul, West Publishing, 1979)

Lane New Community Competences under the Maastricht Treaty, in: CMLRev (1993) pp.939-979.

Lanfranchi Droit communautaire et Travailleurs migrants des Etats tiers - Entrée et Circulation dans la Communauté européenne (Paris, Economica, 1994).

Langer Probleme der Koordinierung beim Public/Privat-Mix von Gesundheitsleistungen, in: ZSR (1999) pp.716-734.

Langer Künftliche rechtliche Koordinierung der Pflegeversicherung in Europa, in: Sieveking (Hrsg.), Soziale Sicherung bei Pflegebedürftigkeit in der Europäischen Union (Baden-Baden, Nomos, 1998) pp.251-272.

Lannes International Mobility of Manpower in Western Europe: II, in: ILRev (1956) pp.135-149.

Laske The Impact of the Single European Market on Social Protection for Migrant Workers, in: CMLRev (1993) pp.515-540.

Laslett The Mutual Recognition of Diplomas, Certificates and other Evidence of Formal Qualifications in the European Community, in: LIEI (1990) pp.166.

Laursen Constitutional Protection of Foreign Travel, in: CollRev (1981) pp.902931.

Laycock Equal Citizens of Equal and Territorial States: The Constitutional Foundations of Choice of Law, in: ColLRev (1992) pp.249-337.

Layton Layton-Henry, Citizenship or Denizenship for Migrant Workers, in: Layton-Henry (Ed.), The Political Rights of Migrant Workers in Western Europe (London, Sage, 1990) pp.186-195.

Leenen Leenen et al, Trends in Health Legislation in Europe (Paris, Masson, 1986).

Leenknegt Vrijheid van Onderwijs in Vijf Europese Landen - Een Rechtsvergelijkend Onderzoek naar de Gemeenschappelijke Beginselen op het Gebied van Onderwijs in België, Duitsland, Engeland, Frankrijk en Nederland (Deventer, Tjeenk Willink, 1997).

Leenknegt Onderwijs en Europese Integratie, in: S\&W (1993) pp.50-55.

Legomsky Immigration, Federalism and the Welfare State, in: UCLA LRev (1995) pp.1453-1474.

Leibfried Leibfried/Pierson, Halbsouveräne Wohlfahrtsstaaten - Soziale Sicherung in der europäischen Mehrebenen-Politik, in: BDIP (1997) pp.45 et seq.

Leibfried Leibfried/Pierson, Multitiered Institutions and the Making of Social Policy, in: Leibfried/Pierson (Eds), European Social Policy - Between Fragmentation and Integration (Washington D.C, The Brookings Institution, 1995) pp. 1-40.

Leibfried Leibfried/Pierson, Semisovereign Welfare States: Social Policy in a Multitiered Europe, in: Leibfried/Pierson (Eds), European Social Policy Between Fragmentation and Integration (Washington D.C, The Brookings Institution, 1995) pp.43-77. 
Leingärtner Diskussionsbeitrag zur Kritik and der Rechtsprechung des EuGH in den Rechtsachen C-160/96, C-120/95, C-158/96, Molenaar, Decker u. Kohl aus der Sicht der Lesitungsberechtigten, in: Schulte/Barwig (Hrsg.), Freizügigkeit und Soziale Sicherheit - Die Durchführung der Verordnung Nr.1408/71 über die soziale Sicherheit der Wanderarbeitnehmer in Deutschland (Baden-Baden, Nomos, 1999) pp.117-121.

Lenaerts Education in European Community Law, in: CMLRev (1994) pp.7-41.

Lenaerts Het Onderwijs in het Europees Recht na "Maastricht", in: TOO (19921993) pp. 264-281

Lenaerts Erasmus: Legal Basis and Implementation, in: De Witte, European Community Law of Education (Baden-Baden- Nomos, 1989) pp.113-126.

Lenz Zuständigkeiten und Initiativen der Europäischen Gemeinschaft im Bereich des Bildungswesen, in: EG-Forum, Beilage zu IBW-Heft (1990) pp.183208

Lenz Die Rechtsprechung des Europäischen Gerichtshofs im Bereich des Bildungswesen, in: EA (1989) pp.125-134.

Lenz The Public Service in Article 48(4) EEC with Special Reference to the Law in England and the Federal Republic of Germany, in: LIEI (1989) pp. $75-122$.

Levi The Equal Treatment of Aliens: Preemption or Equal Protection?, in: StanfLRev (1979) pp.1069-1091.

Levi-Sandri Free Movement of Workers in the European Community, in: EC Bull (1968) pp.5 et seq.

Levmore Interstate Exploitation and Judicial Intervention, in: VirgLRev (1983) pp.563-630.

Lhernould Avantages sociaux et Egalité de Traitement - Une nouvelle Etape dans la Jurisprudence de la CJCE, in: DS (1999) pp.938-939.

Lhoest Annotation Boukhalfa in CMLRev (1998) pp.247-267.

Lichtenberg Freizügigkeit und Bildungswesen in der Europäischen Gemeinschaft an der Schwelle zum Gemeinsamen Binnenmarktes, in: Baur et al (Hrsg.), Festschrift für Ernst Steindorff zum 70. Geburtstag am 13. März 1990) (Berlin, De Gruyter, 199()) pp.1269-1286.

Linders De Arresten Kohll en Decker: Impact op de Tariefstelling in de Gezondheidszorg, in: Essers et al (Red.), Grensoverschrijdende Zorg - Marktwerking vs. National Zorgbewaking (Lelystad, Koninklijke Vermande, 2000) pp. 14-18.

Lippert Gleichbehandlung bei sozialen Vergünstigungen und Arbeitnehmerfreizügigkeit in der Europäischen Gemeinschaft - Eine Analyse von Art.7 II (EWG) Nr.1612/68 auf der Basis der Rechtsprechung des Europäischen Gerichtshofes (Augsburg, Heuser, 1993).

Loenen Verschil in Gelijkheid - De Conceptualisering van het Juridische Gelijkheidsbeginsel met Betrekking tot Mannen en Vrouwen in Nederland en de Verenigde Staten (Zwolle, Tjeenk Willink, 1992).

Loffredo If You Ain't Got the Do, Re, Mi" The Commerce Clause and State Residence Restrictions on Welfare, in: YaleLPR (1993) pp.147-202.

Loffredo Poverty, Democracy and Constitutional Law, in: UPennLRev (1993) pp.1277 et seq.

LoGatto Residence Laws - A Step Forward or Backward?, in: CathLaw (1961) pp.101 et seq. 
lvi

\begin{tabular}{|c|c|}
\hline Lonbay & $\begin{array}{l}\text { Picking over the Bones: Rights of Establishment Revisted, in: ELRev } \\
\text { (1991) pp.507-520. }\end{array}$ \\
\hline Lonbay & $\begin{array}{l}\text { Education and Law: The Community Context, in: ELRev (1989) pp.363- } \\
387 .\end{array}$ \\
\hline Long & $\begin{array}{l}\text { Poverty States and Receipt of of Welfare Among Migrants and Nonmi- } \\
\text { grants in Large Cities, in: ASRev (1974) pp.46-56. }\end{array}$ \\
\hline Loozen & $\begin{array}{l}\text { CAO's, Bedrijfspensioenen en het EG-Mededingingsrecht, in: NTER } \\
\text { (1999) pp.274-284. }\end{array}$ \\
\hline Lottman & $\begin{array}{l}\text { Lottman/van der Wilt, Eindrapportage Project Grensoverschrijdende Zorg } \\
\text { in de EU-Region Rijn/Waal (1999). }\end{array}$ \\
\hline Lundström & $\begin{array}{l}\text { Family Life and the Freedom of Movement of Workers in the European } \\
\text { Union, in: IJLPFamily (1996) pp.250-280. }\end{array}$ \\
\hline van Look & $\begin{array}{l}\text { Het Vrije Verkeer van Werknemers in de EEG nu een Realiteit, in: SEW } \\
\text { (1969) pp.274-288. }\end{array}$ \\
\hline Lyon-Caen & $\begin{array}{l}\text { Social Security and the Principle of Equal Treatment in the EC Treaty and } \\
\text { Regulation No.1408/71, in: Commission of the European Communities/De- } \\
\text { partemento de Relações Internacionais e Convençoes de Segurança Social, } \\
\text { Social Security in Europe - Equality Between Nationals and Non-Nationals } \\
\text { (1995) pp.45-73. }\end{array}$ \\
\hline Lyon-Caen & $\begin{array}{l}\text { La Libre Circulation des Travailleurs (Règlement et Directive des Commu- } \\
\text { nautés européennes du } 15 \text { octobre 1969), in: Juris-Classeur Periodique } \\
\text { (1969) nr.2222. }\end{array}$ \\
\hline
\end{tabular}

M

Macheret L'Immigration étrangère en Suisse a l'Heure de l'Integration Européenne (Genève, Georg, 1969).

Madra

Migrant Workers and International Law (Nijmegen, Ars Aequi Libri, 1986).

Maduro Europe's Social Self: 'The Sickness unto Death', in: Shaw (Ed.), Social Law and Policy in an Evolving European Union (2000) pp.325-349.

Maduro Striking the Elusive Balance Between Economic Freedom and Social Rights in the EU, in: Alston (Ed.), The EU and Human Rights (1999) pp.449-472.

Maduro We the Court - The European Court of Justice \& the European Economic Constitution (Oxford, Hart, 1998).

Maertens De Geografische Mobiliteit van Werknemers in de Europese Gemeenschap (Antwerpen, 1969).

Mancini $\quad$ The Free Movement of Workers in the Case-Law of the European Court of Justice, in: Curtin/O'Keeffe (Eds), Constitutional Adjudication in European Community and National Law - Essays for the Hon. Mr. T.F. O'Higgins (Dublin, Butterworths, 1992) pp.67-77.

Mandelker Exclusion and Removal Legislation, in: WLRev (1956) pp.57 et seq.

Mandelker The Settlement Requirement in General Assistance, in: WashULQ (1955) pp.355-377.

Marenco The Notion of Restriction on the Freedom of Establishment and the Provision of Services in the Case-Law of the Court, in: YEL (1992) pp. $111-150$ 


\section{lvii}

Maresceau Komt Toegang tot het Onderwijs ook Binnen de Werkingssfeer van het EEG-Verdrag?, in: Van den Bogaert et al (Uitg.), Beschouwingen Rond het Project "Versterking Integrale Planning" - Liber Amicorum Van Den Bogaert (1989) pp.165-185.

Marias European Citizenship in Action: From Maastricht to the Intergovernmental Conference, in: La Torre, European Citizenship - An Institutional Challenge (the Hague, Kluwer Law International, 1998) pp.293-316.

Marias

From Market Citizen to Union Citizen, in: Marias, European Citizenship (Maastricht, European Institute of Public Administration, 1994) pp.1-23.

Mariner Access to Health Care and Equal Protection of the Law: The Need for Heightened Scrutiny, in: AJLM (1987) PP.345-380.

Marmor Understanding Health Care Reform (New Haven, Yale University Press, 1994).

Martin Discriminations, Entraves et Raisons impérieur, in: CDE (1998) pp.561 et seq, at p.614 et seq.

Martin Martin/Guild, Free Movement of Persons (London, Butterworths, 1996).

Massart Massart-Pierard, Vers une Politique Commune de la Sante?, in: MassartPierard (Hrsg.), L'Europe de la Santé. Hasard et/ou Nécessité? (Louvainla-Neuve, Academia, 1988) pp.27 et seq.

Mavridis La Fin des Doubles Cotisations en Europe?, in: DS (2000) pp.1104-1113.

Mavridis Une Libéralisation des Soins de Santé - Un premier Diagnostic après les arrêts CJCE Kohll et Decker, in: DS (1999) pp.172-175.

Mavridis Le Citoyen européen Peut-il se Faire Soigner dans l'Etat de son Choix?, in: DS (1996) pp.1086-1094

Maydell von Maydell, Wenn Schutzzäune fallen .. Das Kohll-Decker-Urteil des Europäischen Gerichtshofes (EuGH) hat Fragen Aufgeworfen: Gefährdet die Grenzöffnung die Deutschen Krankenversicherung? Oder verheisst der Richterspruch mehr Markt im Gesundheitswesen?, in: GuG (1998) p.3.

Maydell von Maydell, Treatment of Third Country Nationals in the Member States of the European Union and the European Economic Area in Terms of Social Law, in: Commission of the European Communities/Departemento de Relações Internacionais e Convenções de Segurança Social, Social Security in Europe - Equality Between Nationals and Non-Nationals (Lisbon, 1995) pp.137-154.

Masters Comment - Nonresident Tuition Charged By State Universities in Review, in: UMKCLRev (1970) pp.341-354

McConn "Round Table: Positions and Reactions of the Public Actors", in: Association Internationale de la Mutualité/ European Institute of Social Security, Health Care without Frontiers within the European Union - Free Movement of Goods and Services in the Health Care Sector (1999) pp.39-40.

McCoy Recent Equal Protection Decisions - Fundamental Right to Travel or "Newcomers" as a Suspect Class, in: VdBiltLRev (1975) pp.987-1023.

McMahon Education and Culture in European Community Law (London, The Athlon Press, 1995)

Meade Free Movement of Students: Access to Higher Education in another Member State, in: MR (1988) pp.260-263.

Mégret Mégret et al (Eds), Commentaire Mégret Le Droit de la CEE (Bruxelles, Université de Bruxelles, 1992) at pp.60 et seq.

Mei van der Mei, Vrij Verkeer van Studenten en Export van Studiefinancering. in: USZ (2001), forthcoming. 
lviii

Mei

Mei

Mei

Mei

Mei

Mei

Mei

Mei

Mei

Mei

Mei

Mei

Mei

Mei

Mei

Mei

Mei

Mei

Mei

Meinhold

Meijers van der Mei, Annotation Meeusen, in: USZ (1999) pp.687-688.

van der Mei, De Rechtmatigheid van Woonplaatsvereisten voor Bestaansminimumuitkeringen onder het EG-Recht, in: SMA (1999) pp.451-459.

van der Mei, The European Court of Justice and the Co-ordination of Health Insurance Schemes, in: Association Internationale de la Mutualité/ European Institute of Social Security, Health Care without Frontiers within the European Union - Free Movement of Goods and Services in the Health Care Sector (1999) pp.18-25.

van der Mei, Cross-Border Access to Medical Care Within the European Union: Some Reflections on the Judgments in Decker and Kohll, in: MJ (1998) pp.277-297.

van der Mei, Decker and Kohll: Op Weg Naar een Vrij Verkeer voor Patiënten in de Europese Gemeenschap?, in: SR (1998) pp.187-196.

van der Mei, The Kohll and Decker Rulings: Revolution or Evolution?, in: Eurohealth (1999) pp.14 et seq.

van der Mei, Grensoverschrijdende Toegang tot de Gezondheidszorg in de Europese Gemeenschap, in: USZ (1998) pp.462-471.

van der Mei, Het Arrest Molenaar: Export van het Persoonsgebonden Budget?, in: USZ (1998) pp.407-412.

van der Mei, The Elusive and Exclusive Concept of Union Citizenship, A Review Essay, in: MJ (1998) pp.391-402

van der Mei, Het Vrij Verkeer van Personen binnen de Europese Gemeenschap en de (Niet-)Exporteerbaarheid van 'Gemengde' Bestaansminimumuitkeringen, in: USZ (1997) pp.895-902.

van der Mei, Patients' Access to Cross-Border Care and Insurance Cover, in: Alliance Nationale des Mutualités Chrétiennes/Association Internationale de la Mutualité, Competition and Solidarity - Can They Co-exist in Europe's Health Care Systems? (1997) at pp.68-75.

van der Mei, Artikel 118A EG-Verdrag en Arbeidstijden in Europa, in: Sociaal Recht (1997) pp.108-115.

van der Mei, The Bosman Case and the Legal Status of Third Country Nationals under European Community Law, in: ASICLaw, Proceedings of the 8th Annual Conference (1996) pp.144-158.

van der Mei, EG-recht en Onderwijs, in: Jaarboek voor Onderwijsrecht en Onderwijsbeleid (1995-1996) pp.17-26

van der Mei, Kinderen van EG-werknemers: Het Recht op Onderwijs en Studiefinanciering, in: NTOR (1995) pp.211-217.

van der Mei, Nogmaals: Inschrijvingsgelden voor EG-Studenten, in: NTOR (1995) pp.202-208

van der Mei, Vrij Dienstenverkeer in de EG en Toegang tot het Onderwijs, in: NTOR (1994) pp.102-107

van der Mei, EG-recht en Onderwijs, in: Jaarboek voor Onderwijsrecht en Onderwijsbeleid (1993-1994) pp.17-26.

van der Mei/Waddington, Public Health and the Treaty of Amsterdam, in: EJPH (1998) pp.129-154.

Notwendigkeit und Möglichkeit der Harmonisierung von Sozialleistungen im EWG-Raum, in: DVZ (1964) pp.1-4.

Meijers et al (Eds), Schengen - Internationalisation of Central Chapters of the Law on Aliens, Refugees Privacy, Security and Police (Leiden, Stichting NJCM-Boekerij, 1992). 
lix

Mendelsohn

Mijn

Miller

Miller

Ministerie

Misson

Mitchell

Mohr

Moore

Moor

More

Mortelmans

Mortelmans

Mortelmans

Mortelmans

Müller

Münnich

Musgrave

Muus

N

Nachbauer Art.52 EWGV - Mehr als nur ein Diskriminierungsverbot?, in: EuZW (1991) pp.470-472.

Nationaal Nationaal Ziekenhuisinstituut/Deutsche Krankenhausinstitut, Grensoverschrijdende Gezondheidszorg - Duits-Nederlandse Samenwerking in de Gezondheidszorg in de Euregio Rijn-Waal ('s Heerenberg, 1995).

National National Travellers Aid Ass'n, One Manner of Law - A Handbook on Residence Requirements in Public Assistance (1961). et seq.

van der Mijn, Kansen en Bedreigingen voor Beroepsbeoefenaren bij een Vrije Europese markt, in: TvG (1989) pp.305-315.

Freizügigkeit in der EWG, in: der Landskreis (1968) pp .56-58.

ten, in: BArbBl (1968) pp.590-594

Ministerie van Volksgezondheid, Welzijn en Sport, De Gevolgen van de Kohll en Decker voor het Nederlandse Stelsel van Ziektekostenkeringen (Den Haag, 1998)

Years of Free Movement of Workers in Furope (Luxembourg Office for Official Publications of the European Communities, 2000) pp.79-87. Recent Progress, in: EJVT (1996) pp.43-54.

Europese Gemeenschappen, 1990)

Annotation Cabanis-Issarte, in: CMLRev (1997) pp.727-739.

Article 7 of the Treaty of Rome Bites, in: MLRev (1985) pp.452-459.

The Principle of Equal Treatment: From Market Unifier to Fundamental Craig/de Burca (Eds), The Evolution of EU Law (Oxford, Oxford University Press, 1999) pp.517-551.

Omgekeerde Discriminatie en het Gemeenschapsrecht, in: SEW (1979) pp.654-674. ring van de Interne Markt of Bescherming van de Volksgezondheid, in: AA (2001) pp.114-130

Mortelmans/Temmink, Het Vrije Personenverkeer tussen de Nederlandse Antillen en Aruba en de Europese Gemeenschap, in: Justicia - TvAR 1992) Vol.1.

(Bonn, Economica-Verlag, 1993)

Art 7 EWGV und Inländerdiskriminierung, in: ZfRV (1992) pp.92-100.

Musgrave/Musgrave, Public Finance in Theory and Practice (Tokyo, McGraw-Hill - Kogakusha, 1976) Bijzondere Anch voor de Europese Gemeenschap en Nederlan (Amsterdam, SUA, 1993). 
Neave

Neave

Neipp

Neuman

Neuman

Neumann

Neumann

Neumann

Neuwahl

Nickless

Nielsen

Nihoul

Norberg

Note

Note

Note

Note

Note

Note

Note
The Role of Education in European Integration, in: IP (1986) pp.277-284 The EEC and Education (Trentham-Stock-on-Trent, Trentham Books for the European Institute on Education and Social Policy, 1984)

Das Gesundheitswesen der USA: Ein Vorbild für die Gesetzliche Krankenversicherung? (Baden-Baden, Nomos, 1988)

Aliens as Outlaws: Government Services, Proposition 187, and the Structure of Equal Protection Doctrine, in: UCLALRev (1995) pp.1425-1452.

Territorial Discrimination, Equal Protection and Self-Determination, in: UPennLRev (1987) pp.261-382.

Neuman-Duesberg, Defizite, Probleme und Perspektiven bei der Umsetzung des Europäischen koordinierenden Sozialrechts - Verordnungen Nr. 1408/71 und Nr.574/72 - Leistungen bei Krankheit und Pflegebedürftigkeit, in: Schulte/Barwig, Freizügigkeit und Soziale Sicherheit - Die Durchführung der Verordnung Nr.1408/71 über die soziale Sicherheit der Wanderarbeitnehmer in Deutschland (Baden-Baden, Nomos, 1999) pp.89108 .

Neumann-Duesberg, Grenzüberschreitenden Behandlungsleistungen - Die Praxis der gesetzlichen Krankenversicherung, in: Zentrum für Europäisches Wirtschaftsrecht, Grenzüberschreitende Behandleistungen im Binnenmarkt (Bonn, 1998)

Neumann-Duesberg, Kohll-Decker-Urteile "Die EuGH-Position ist Angreifbar", in: GuG (1998) pp.22-27.

Neumann-Duesberg, Krankenversicherung, in: Schulte/Zacher, Wechselwirkungen zwischen dem europäischen Sozialrecht und dem Sozialrecht der Bundesrepublik Deutschland (Berlin, Duncker \& Humblot, 1991) pp.83-109.

The Treaty on European Union: A Step Forward in the Protection of Human Rights?, in: Neuwahl/Rosas (Eds), The European Union and Human Rights (The Hague, Nijhoff, 1995) pp.1 et seq.

Kohll and Decker: A New Hope for Third Country Nationals, in: Eurohealth (1999) pp.20-22.

Nielsen/Szyszczak, The Social Dimension of the European Union (Copenhagen, Handelshojskolens Forlag, 1997).

Le Minerval Réclamé aux Etudiants communautaires en Belgique, in: JdT (1994) pp.705-712.

The Agreement on a EEA, in: CMLRev (1992) pp.1171 et seq.

Welfare Reform: Treatment of Legal Immigrants, in: HarvLRev (1997) pp.1191 et seq.

Devolving Welfare Programs to the States: A Public Choice Perspective, in: HarvLRev (1996) pp.1984-2001

State Burdens on Residents Aliens: A New Preemption Analysis, in: YaleLJ (1980) pp.940-961.

A Dual Standard for State Discrimination Against Aliens, in: HarvLRev (1979) pp. 1516 et seq.

Durational Residence Requirements From Shapiro through Sosna: The Right to Travel Takes a New Turn, in: NYULRev (1979) pp.622 et seq.

Durational Residence Requirements From Shapiro Through Sosna: The Right to Travel Takes a New Turn, in: NYULRev (1975) pp.622-680.

The Right to Travel - Quest for A Constitutional Source, in: RutgCLJ (1974) pp.122-143. 
$1 x i$

Note

Note

Note

Note

Note

Note

Nourissat

Novak

Nowak

Nuffel

Nuffel

Nyborg

Nys

\section{O}

Oates

Oertzen

Oijen

O'Keeffe

O'Keeffe

O'Keeffe

O'Keeffe

O'Keeffe
Residence Requirements for Tuition: An Unresolved Dilemma, in: IndLRev (1972) pp.283 et seq.

State University's One-Year Waiting Period Requirement to Attain Resident Status for Tuition Payment does not Violate Fourteenth Amendment, in: AlaLRev (1971) pp.147-162.

The Constitutionality of Nonresident Tuition. in: MinnLRev (1971) pp.1139-1162.

Shapiro v. Thompson: Travel, Welfare and the Constitution, in: NYU LRev (1969) pp.989-1013.

Residence Requirement for Public Relief: An Arbitrary Preriquisite, in: ColJLSP (1966) pp.133-143.

Residence Requirements in State Public Welfare Statutes-I, in: IowaLRev (1966) pp.1080-1095.

Quand Panacée Rejoint Europe ou Comment la Cour de Justice Consacre la Liberté des Soins dans la Communauté, in: SJ (1999) 10002.

EG-Grundfreiheiten und Europäisches Sozialrecht, in: EuZW (1998) pp.366-369.

Realizing the Standards of Review under the Equal Protection Guarantee Prohibited, Neutral and Permissive Classifications, in: GeorgeLJ (1974) pp. 1071 et seq.

van Nuffel, Een Bijna Algemeen Verblijfsrecht in de Europese Gemeenschap - Commentaar op de Verblijfsrecht-richtlijnen van 28 juni 1990, in: SEW (1990) pp.887-903

van Nuffel, Het Algemeen Stelsel van Erkenning van Diploma's, in: SEW (1996) pp.371-380

International Student Mobility: The Nordic Experience, in: EJE (1996) pp.193-203.

Patiënt in Europa - Op Zoek naar een Europees Geneeskundig Dienstverleningsrecht (Maastricht, Universitaire Pers, 2000).

Fiscal Federalism (New York, Harcourt, 1972).

Bildung und Berufsausbildung in den Europäischen Gemeinschaften - Eine Analyse der Kompetenzgrundlagen und der subjecktiven Rechte im Rahmen des EWG-Vertrages (München, Verlag V. Florentz GmbH, 1992). Oijen et al, International Comparative Study of Financial Assistance to Students in Higher Education (Zoetermeer, Ministerie van Onderwijs en Wetenschappen, 1990)

Recasting the Third Pillar, in: CMLRev (1995) 893-920

Annotation Raulin, in: CMLRev (1992) pp.1215-1228

Union Citizenship, in: O'Keeffe/Twomey (Eds), Legal Issues of the Maastricht Treaty (London, Wiley Cahncery Law, 1994) pp.87-107.

Judicial Interpretation of the Public Service Exception to the Free Movement of Workers, in: Curtin/O'Keeffe (Eds), Constitutional Adjudication in European Community and National Law - Essays for the Hon. Mr Justice T.F. O’Higgins (Dublin, Butterworth, 1992) pp.89 et seq.

The Agreement on the European Economic Area, in: LIEI (1992) pp.1 et seq. 
O'Keeffe

O'Keeffe

O'Keeffe

O'Leary

O'Leary

O'Leary

O'Leary

O'Jeary

O'Leary

O'Leary

O'Leary

O'Leary

Oliver

Oliver

Oliver

Olssen

Onslow-Cole

Ooik

Oosterbeek

Oosterman

The Schengen Convention: A Suitable Model for European Integration, in YEL (1991) pp.185 et seq.

Equal Rights for Migrants: The Concept of Social Advantages in Article 7(2), Regulation 1612/68, in: YEL (1986) pp.93-123

Practical Difficulties in the Application of Article 48 of the EEC Treaty, in: CMLRev (1982) pp.35-60

Putting Flesh on the Bones of European Union Citizenship, in: ELRev (1999) pp.68-79.

The Free Movement of Persons and Services, in: Craig/de Búrca, The Evolution of EU Law (Oxford, Oxford University Press, 1999) pp.377415.

Employment and Residence for Turkish Workers and their Families: Analogies with the Case Law of the Court of Justice on Article 48 EC, in: Scritti in Onore do Giuseppe Federico Mancini (1998).

The Principle of Equal treatment on Grounds of Nationality in Article 6 EC - A Lucrative Source for Member State Nationals? in: O'Leary/Tiilikainen (Eds), Citizenship and Nationality Status in the New Europe (London, Sweet \& Maxwell, 1998) pp.105-136.

European Union Citizenship - Options for Reform (London, Institute for Public Policy Research, 1996)

The Evolving Concept of Community Citizenship - From the Free Movement of Persons to Union Citizenship (The Hague, Kluwer Law International, 1996).

The Social Dimension of Community Citizenship, in: Rosas/Antola, A Citizens' Europe - In Search of a New Order (London, Sage, 1995) pp. 156-181

Annotation Case C-295/90 Parliament v Council, in: CMLRev (1993) pp.639-651

Nationality Law and Community Citizenship: A Tale of Two Uneasy Bedfellows, in: YEL (1992) pp.353 et seq.

Some Further Reflections on the Scope of Art.28-30 (30-36) EC, in: CMLRev (1999) pp. 783-806.

Free Movement of Goods in the European Community (London, Sweet \& Maxwell, 1996)

Non-Community Nationals and the Treaty of Rome, in: YEL (1985) pp.57-92.

Welfare State Research Inc. - The Growth of a Crises Industry, in: AS (1987) pp.371-378.

The Right of Establishment and Provision of Services: Community Employers and Third Country Nationals, in: Guild (Ed.), The Legal Framework and Social Consequences of Free Movement of Persons in the European Union (The Hague, Kluwer Law International, 1999) pp.63-71.

van Ooik, Omgekeerde Discriminatie van EEG-Onderdanen, in: MR (1990) pp.83-86.

An Economic Analysis of Student Financial Aid Schemes, in: EJE (1998) pp. $21-29$.

Oosterman-Meulenbeld, Quality Regulation on Professional Health Care Practitioners in the European Community, in: LIEI (1993) pp.61 et seq. 


\section{1xiii}

Oppermann Von der EG-Freizügigkeit zur gemeinsamen europäischen Ausbildungspolitik? Die "Gravier"-Doktrin des Gerichtshofs der Europäischen Gemeinschaften (Berlin, De Gruyter, 1988).

Oppermann Europäisches Gemeinschaftsrecht und Deutsche Bildungsordnung - Gravier und die Folgen (Bad Honnef, Bock, 1987).

Pabon

Pais

Palm

Papastamkos

Parent

Parmet

Parmet

Parret

Peers

Peers

Peers

Peers

Peers

Peers

Peers

Peers

Pennings

Pennings

Pennings

Pennings
Het Vrije Verkeer van Werknemers, in: SMA (1969) pp.83-95

Pais Macedo van Overbeek, AIDS/HIV Infection and the Free Movement of Persons within the European Community, in: CMLRev (1990) pp.791824

Palm et al, Implications de la Jurisprudence récente Concernant la Coordination des Systèmes de Protection contre Le Risque de Maladie (Bruxelles, AIM, 2000).

Die Erweiterung der EG-Freizügigkeit auf griechische Arbeitnehmer (Berlin, Duncker \& Humblot, 1983).

Tuition Residence Requirements: A Second Look in Light of Zobel and Martinez, in: IndLJ (1986) pp.287-314.

Regulation and Federalism: Legal Impediments to State Health Care Reform, in: AJLM (1993)pp.121-144.

Parmet/O'Connell, Rehnquist's Road to Serfdom: The Ominious Message from Rust $v$ Sullivan, in: AP (1992) at pp.94 et seq

EG-Recht en Sport: Is Sport Anders, in: SEW (2001) pp.53-61.

Dazed and Confused: Family Members' Residence Rights and the Court of Justice, in: ELRev (2001) pp.76-83

Aliens, Workers, Citizens or Humans? Models for Community Immigration Law, in: Guild/Harlow (Eds), Implementing Amsterdam - Immigration and Asylum Rights in EC Law (Oxford, Hart Publishing, 2000) pp.291308

Annotation Akman, in: CMLRev (1999) pp.1027-1042.

Annotation Sürül, in: ELRev (1999) pp.627-637.

Justice and Home Affairs in Europe (Harlow, Longman, 1999)

Raising Minimum Standards, or Racing to the Bottom? - The Commission's proposed Migration Convention, in: Guild (Ed.), The Legal Framework and Social Consequences of Free Movement of Persons in the European Union (The Hague, Kluwer Law International, 1999) pp.149. 166.

Equality, Free Movement and Social Security, in: ELRev (1997) pp.342351 .

Towards Equality: Actual and Potential Rights of Third-Country Nationals in the European Union, in: CMLRev (1996) pp.7-50.

Grondslagen van het Europese Socialezekerheidsrecht (Deventer, Kluwer, 2000)

Het Einde van de Exporteerbaarheid van Wajong-uitkeringen?, in: MR (2000) pp.71-74

Het Arrest Sürül: Een Arrest dat Knaagt aan de Koppelingswet, in: SMA (1999) pp.442-450

Introduction to European Social Security Law (The Hague, Kluwer Law International, 1998). 
1xiv

Pennings

Pennings

Penninx

Perrin

Perry

Perry

Pertek

Pertek

Peterson

Peterson

Pickup

Pieters

Pieters

Pieters

Pieters

Pieters

Pieters

Pieters

Poppe

Plender

Plender
"Bijstandsuitkeringen" en het Recht op Vrij Verkeer van Werknemers, in: MR (1992) pp.146-155.

Pennings/Essers, Het Voorstel van de Europese Commissie tot Vereenvoudiging van Verordening 1408/71, in: SMA (2000) pp.512-525.

Penninx/Muus, No Limits for Migration after 1992? - The Lessons of the Past and a Reconnaisance of the Future, in: IM (1989) pp.373-388.

Les Prestations non contributive et la Sécurité sociale, in: DS (1961) pp. 179-188.

Modern Equal Protection: A Conceptualization and Appraisal, in: ColLRev (1979) pp.1023-1084

Equal Protection, Judicial Activism, and the Intellectual Agenda of Constitutional Theory: Reflections on, and Beyond, Plyler $\mathrm{y}$ Doe, in: UPittLRev (1983) pp.329-351.

L'Europe des Diplomes et des Professions (Bruxelles, Bruylant, 1994).

Free Movement of Professionals, in: YEL (1992) pp.293-324.

Peterson/Rom, Welfare Magnets - A New Case for a National Standard (Washington, The Brookings Institution, 1991).

Peterson/Rom, American Federalism, Welfare Policy, and Residential Choices, in: APSRev (1989) pp.711-728.

Reverse Discrimination and Freedom of Movement for Workers, in: CMLRev (1986) pp. 135-156.

De Nederlandse Zorgverzekering in het Licht van het Recht van de EG Onderzoek naar de Verenigbaarheid van het Nederlandse Zorgstelsel met het Recht op Vrij Dienstenverkeer en het Europese Mededingingsrecht (Raad voor de Volksgezondheid en Zorg, 1999).

Enquiry into the Legal Foundations of a Possible Extension of Community Provisions on Social Security to Third Country Nationals Legally Residing and/or Working in the EU, in: Commission of the European Communities/Departemento de Relações Internaçionais e Convenções de Segurança Social, Social Security in Europe - Equality Between Nationals and NonNationals (Lisbon, 1995) pp.189-243.

Pieters et al, Inleiding to het Sociale Zekerheidsrecht van de Landen van de Europese Gemeenschap (Ministerie van Sociale Zaken en Werkgelegenheid, Den Haag, 1990)

Pieters/Vansteenkiste, The Thirteenth State - Towards a European Community Social Insurance Scheme for Intra-Community Migrants (Leuven, 1993).

Brengt "1992" Coördinatie en Harmonisatie van de Sociale Zekerheid?, in: NJB (1989) pp.831 et seq.

Sociale Zekerheid na 1992: Eén over Twaalf (Katholieke Universiteit Brabant, Tilburg, 1989).

Pieters/van den Bogaert, The Consequences of European Competition Law for National Health Policies (Antwerpen, Maklu, 1997).

Defining the Scope of the Equal Protection Clause with Respect to Welfare Waiting Periods, in: ChicLRev (1994) pp.291-323.

Competence, European Community Law and Nationals of non-Member States, in: ICLQ (1990) pp.599-610.

International Migration Law (Dordrecht, Nijhoff, 1988). 
Ixv

$\begin{array}{ll}\text { Plender } & \text { An Incipient Form of European Citizenship, in: Jacobs (Ed.), European } \\ & \text { Law and the Individual (Amsterdam, North-Holland Publishing Company, } \\ & \text { 1976) pp.39-53. } \\ \text { Comment: A Constitutional Analysis of the Right to Travel Intra-State, in: } \\ \text { NorthwULRev (1992) pp.820-857. } \\ \text { du Pré, Het EG-Verdrag door een Ziekenfondsbrilletje, in: SMA (1998) } \\ \text { pp.364-376. } \\ \text { du Pré, Public and Private Harmonisation of Vocational Training Qualifi- } \\ \text { cations in the EC: The Case of Denturists, in: EJHL (1996) pp.273-293. } \\ \text { Pré } \\ \text { du Pré, Klein Duimpje en de Nederlandse Ziektekostenverzekeringen, in: } \\ \text { Pré } \\ \text { SRé (1993) pp.138-141. } \\ \text { du Pré/Sevinga, De Gemeenschap en de Gezondheidszorg: een Terreinver- } \\ \text { kenning, in: SEW (1990) pp.350-378. }\end{array}$

R

Raad Raad voor de Volksgezondheid, Europa en de Gezondheidszorg (Zoetermeer, Raad voor de Volksgezondheid en Zorg, 1999).

Raepenbusch van Raepenbusch, La libre Choix par les Citoyens européens des Produits médicaux et des Prestataires de Soins, Conséquence sociale de Marché interieur, in: CDE (1998) pp.683-697.

Raepenbusch van Raepenbusch, La Securité sociale des Personnes qui Circulent a l'Intérieur de la Communauté économique européenne (Gent, StoryScientia, 1991).

Rambags Samenloop Ziekenfondsverzekering (EG-verordeningen 1408/71 en 574/72) en Reisverzekering, in: De Beursbengel (1988) p.448 et seq.

Reese Reese/Green, That Elusive Word, "Residence", in: VdBiltLRev (1953) p.561 et seq.

Redish Redish/Nugent, The Dormant Commerce Clause and the Constitutional Balance of Federalism, in: Duke LJ (1987) pp.569 et seq.

Reich Bürgerrechte in der Europäische Union (Baden-Baden, Nomos, 1999).

Reisner National Regulation of the Movement of Workers in the European Community, in: AJCL (1964) pp.360-384.

Renardel Renardel de Lavalette, Facetten van het Vrij Verkeer van Werknemers in de Europese Gemeenschappen, in: SMA (1983) pp.213-227.

Ribas Ribas et al, Traité de Droit social européen (Paris, Presses Universitaires de France, 1978).

Riesenfeld The Formative Era of American Public Assistance Law, in: CalLRev (1955) pp.175 et seq.

Roberts The Rulings of the European Court of Justice on the Association and Cooperation Agreements in Matters Concerning Social Security, in: Jorens/Schulte, European Social Security Law and Third Country Nationals (Bruxelles, Die Keure, 1998) pp.209-234.

Rombouts Grensoverschrijdende Gezondheidszorg? Een Onderzoek naar de Huidige en Toekomstige Mogelijkheden en Knelpunten van Grensoverschrijdende Gezondheidszorg (1990)

Romero Migration as an Issue in European Interdependence and Integration: The Case of Italy, in: Milward et al (Eds), The Frontier of National Sovereignty 1945-1992: History and Theory (London, Routledge, 1993) pp.3358 . 
1xvi

Roorda

Ros

Rosberg

Rosberg

Rosberg

Roscam

Roscam

Roscam

Roscam

Roscam

Roscam

Rosen

Rosenheim

Rossi

Röttinger

Rotunda

Rubio Marín

Rubio Marín

Rutten
Het Vormgeven van de Rust; of: De Teloorgang van de Wet op de Studiefinanciering, in: NTOR (1994) pp.2-16.

Ros/van der Zee, Grensoverschrijdende Zorg - Vooronderzoek naar de Haalbaarheid van een Experiment in een Grensgebied betreffende Verruiming van Mogelijkheden voor Grensoverschrijdend Zorgverkeer - Uitgevoerd door het NIVEL in opdracht van de Ziekenfondsraad (Utrecht, Nivel, 1996).

Discrimination Against the "Nonresidents" Alien, in: UPittLRev (1983) pp.399 et seq.

Free Movement of Persons in the United States, in: Sandalow/Stein (Eds), Courts and Free Markets - Perspectives from the United States and Europe (Oxford, Clarendon Press, 1982) pp.275-362

The Protection of Aliens from Discriminatory Treatment by the National Government, in: SCRev (1977) pp.275-339.

Roscam Abbing, Editorial: Public Health Insurance and Freedom of Movement within the European Union (Cases Kohll and Decker), in: EJHL (1999) pp.1-6.

Roscam Abbing, Volksgezondheid in het Verdrag van Amsterdam - Een Beknopte Analyse, in: TvG (1998) pp.75-80.

Roscam Abbing, Quality of Medical Practice and Professional Misconduct in the European Union, in: EJHL (1997) pp.273-278.

Roscam Abbing, The Right of the Patient to Quality of Medical Practice and the Position of Migrant Doctors within the EU, in: EJHL (1997) pp.347-360.

Roscam Abbing, Patiënt en Gezondheidszorg in het Recht van de Europese Gemeenschap (Utrecht, Vereniging voor Gezondheidsrecht, 1993).

Roscam Abbing, International Organizations in Europe and the Right to Health Care (Deventer, Kluwer, 1979)

Public Finance (Homewood, Irwin, 1985)

Shapiro $v$ Thompson 'The Beggars are Coming to Town', in: SCRev (1969) pp.303-346.

The Taxation Aspects of the Free Movement of Persons, in: Carlier/Verwilghen, Thirty Years of Free Movement of Workers in Europe (Luxembourg, Office for Official Publications of the European Communities, 2000) pp.127-142.

Bedeutung der Rechtsgrundlage einer EG-Richtlinie und Folgen einer Nichtigkeit, in: EuZW (1993) pp.117-121.

Rotunda/Nowak, Treatise on Constitutional Law (St.Paul, West Publishing, 1992).

Stranger in Your Own Home - The Incorporation of Resident Aliens into the Political Community: Theory and Constitutional Practice in Germany and the United States (Florence, EUI, 1997)

Equal Citizenship and the Difference that Residence Makes, in: La Torre, European Citizenship: An Institutional Challenge (The Hague, Kluwer Law International, 1998) pp.210-227.

Elasticity in Constitutional Review: Adarand Constructors, Inc. $v$ Pena and Continuing Uncertainty in the Supreme Court's Equal Protection Jurisprudence, in: SouthCalLRev 91997) pp.591-642. 
lxvii

$\mathrm{S}$

Sakslin

Sayari

Shanks

Schechner

Scheiffers

Schell

Schermers

Schieffer

Schink

Schlachter

Schlosberg

Schmidt

Schmidt

Schneider

Schneider

Schneider

Schockweiler

Scholsem

Schoukens

Schoukens

Schram
The Agreements on the European Economic Area, in: Jorens/Schulte (Eds), European Social Security Law and Third Country Nationals (Bruxelles, Die Keure, 1998) pp.1-110,

Migration Policies of Sending Countries: Perspectives on the Turkish Experience, in: Heisler/Schmitter-Heisler (Eds), From Foreign Workers to Settlers? Transnational Migration and the Emergence of New Minorities The Annals of the American Academy of Political and Social Science (1986) pp.86-97

European Social Policy, Today and Tomorrow (Oxford, Pergamon Press, 1977)

Constitutional Law - Equal Protection - Shapiro v. Thompson, 394 U.S. 618 (1969), in: SuffULRev (1969) pp.572-585

Openbare Aanbesteding van Zorgcontracten, in: Essers et al (Red.), Grensoverschrijdende Zorg - Marktwerking vs. National Zorgbewaking (Lelystad, Koninklijke Vermande, 2000) pp.33-38.

Schell/Pieters, De Middelentoets in Rechtsvergelijkend Perspectief (Den Haag, Ministerie van Sociale Zaken en Werkgelegenheid, 1989).

De Minerval voor Buitenlanders, in: AA (1986) pp.37-40

De Europese Arbeidsmarkt. Het Vrije Verkeer en de Migratie van Werknemers (Leiden, Stenfert Kroese, 1961)

Kompetenzweiterung im Handlungssystem der Europäischen Gemeinschaft: Eigendynamik und Policy Entrepreneurs (Baden-Baden, Nomos, 1993)

Discrimination à Rebours - Die Inländerdiskriminierung nach der Rechtsprechung des EuGH und des französischen Conseil d'Etat (Frankfurt, Fischer, 1984)

Not-Qualified Immigrants' Access to Public Health and Emergency Services After the Welfare Law (http://www.healthlaw.org/pubs/19980112immigrant.html).

Die arbeitsrechtliche und sozialversicherungsrechtliche Stellung der europäischen Wanderarbeiter in Rahmen der europäischen Wirtschaftsgemeinschaft (Würzburg, 1963).

Schmidt-Räntsch, Erlass von Förderprogrammen durch den Rat der EG aufgrund Art.128 EWGV, in: NJW (1989) pp.3071-3072.

The Impact of Welfare Reform on Medicaid, in: Publius (1998) pp.161174

Die Anerkennung von Diplomen in der Europäischen Gemeinschaft (Antwerpen, Maklu, 1995)

Schneider et al, Gesundheitssysteme im internationalen Vergleich (Augsburg, Basys, 1989)

La Portée du Principle de Non-Discrimination del'Article 7 du Traité CEE, in: RDE (1991) pp.3 et seq.

A Propos de la Circulation des Etudiants: Vers un Federalisme Financier Européen?, in: CDE (1989) pp.306-323.

Coördinatiebepalingen inzake Gezondheidszorg: het overige Europees Recht (Antwerpen, Maklu, 1993)

Coördinatiebepalingen inzake Gezondheidszorg: het Communautaire Recht (Antwerpen, Maklu, 1992).

Schram/Kruger, 'Welfare Magnets' and Benefit Decline: Symbolic Pro- 


\section{lxviii}

blems and Sunbstantive Consequences, in: Publius (1994) pp.61-82.

Schrauwen

Schreiber

Schuler

Schuler

Schulte

Schulte

Schulte

Schulz

Schulz

Schulz

Schutte

Schutyser

Schuyt

Schwartz

Schweitzer

Segal

Selmer

Sewandono

Sewandono

Shanks

Shaw

Annotatie Martínez Sala, in: SEW (1999) pp.426-430.

Europese Overeenkomst betreffende het Verlenen van Geneeskundige Verzorging bij Tijdelijk Verblijf, in: Info RIZIV (1981) pp.199-203.

Das Internationale Sozialrecht der Bundesrepublik Deutschland (BadenBaden, Nomos, 1988)

Equal Protection and the Undocumented Immigrant: California's Proposition 187, in: BostCTWLJ (1996) pp.275-312.

Pflegeleistungen zwischen Sozialer Sicherheit und Sozialer Hilfe - Aspekte der Europarechtlichen Abgrenzung, in: Sieveking (Hrsg.), Soziale Sicherung bei Pflegebedürftigkeit in der Europäischen Union (Baden-Baden, Nomos, 1998) pp.143-159.

Social Security Legislation in the European Communities: Co-ordination, Harmonization and Convergence, in: Pieters, Social Security in Europe (Antwerpen, Maklu, 1991) pp.153-168.

Schulte/Trenk Hinterberger, Sozialhilfe, eine Einführung (Heidelberg, Müller Juristischer Verlag, 1986)

Freizügigkeit für Unionsbürger (Frankfurt am Main, Peter lang, 1997).

Freier Arbeitsmarkt und Niederlassungsfreiheit in der Europäischen Wirtschaftsgemeinschaft - Unter besonderer Berücksichtigung der Grenzund Gastarbeitnehmer (Würzburg, 1967).

Schulz-Weidner, Rechtliche Entwicklungen bei Krankenkassenleistungen in Ausland, in: KrV (1998) pp.241-245.

Schengen: Its Meaning for the Free Movement of Persons in Europe, in: CMLRev (1991) pp.549 et seq.

"Round Table: Positions and Reactions of the Private Actors", in: Association Internationale de la Mutualité/ European Institute of Social Security, Health Care without Frontiers within the European Union - Free Movement of Goods and Services in the Health Care Sector (1999) pp.63-65.

Het Rechtskarakter van de Verzorgingsstaat, in: van Doorn/Schuyt, De Stagnerende Verzorgingsstaat (Meppel, Boom, 1982) pp.73-96.

Super Chief - Earl Warren and his Supreme Court - A Judicial Bibliography (New York, University Press, 1983)

Bildungspolitik und EWG-Vertrag - Eine Bestandsaufnahme, in: ZfRV (1991) pp. 14-25.

Residency, Tuition and the Twelve Month Dilemma, in: HoustLRev (1969) pp.241-256

Die öffentlichen Sicherheit und Ordnung als Schranke der ArbeitnehmerFreizügigkeit gemäss Art.48 Abs.3 EWG-Vertrag, in: DöV (1967) pp.328334.

Het Commissievoorstel tot Wijziging van Verordening (EEG) nr.1612/68: Meer Bescherming van Familie- en Gezinsleven en Meer Gelijke Behandeling, in: SEW (1999) pp.284-290.

Werknemersverkeer en Gezinsleven (Deventer, Kluwer, 1998).

European Social Policy, Today and Tomorrow (Oxford, Pergamon Press, 1977)

From the Margins to the Centre: Education and Training Law and Policy, in: Craig/De Búrca, The Evolution of EU Law (Oxford, Oxford University Press, 1999) pp.555-595. 


\section{lxix}

Shaw

Shaw

Shi

Sieveking

Sieveking

Simm

Simson

Singer

Sørensen

Spiegel

Staples

Staples

Starkle

Steen

Steen

Steen

Steen

Steen

Steen

Steen

Steen

Steen

Steen

Stefano

Stein

The Nature and Extent of 'Educational Rights' under EC Law, in: JSWFL (1998) pp.203 et seq

Vocational Training and Education in the European Community, in EBLRev (1991) pp.279-282.

Shi/Singh, Delivering Health Services in America - A Systems Approach (Gaithersburg, Aspen Publishers, 1998).

Bildung im Europäischen Gemeinschaftsrecht, in: KritV (1990) pp.344373

Europäisierung der Bildungspolitik?, in: ZAR (1987) pp.99-108.

Der Gerichtshof der Europäischen Gemeinschaften im föderalen Kompetenz Konflikt - Kontinuität und Neubesinnung in der Rechtssprechung vor und nach 'Maastricht' (Baden-Baden, Nomos, 1998).

Discrimination Against Nonresidents and the Privileges and Immunities Clause of Article IV, in: UPennLRev (1979) pp.379-401.

Free Movement of Workers in the European Economic Community: The Public Policy Exception, in: StanfLRev (1977) pp.1283-1297.

The Exclusive European Citizenship - The Case for Refugees and Immigrants in the European Union (Aldershot, Avebury, 1996).

Der EuGH Als (Wiederentdecktes) Feindbild, in: SS (1998) pp.665-668.

De Associatieovereenkomst EEG-Turkije - Een Leidraad voor de Rechtshulp, in: MR (1999) pp.179-188.

The Legal Status of Third Country Nationals Resident in the European Union (the Hague, Kluwer Law International, 1999).

Extension du Principe de Non-Discrimination en Droit communautaire au Ressortissant d'un Etat membre licitement Installé dans un autre Etat membre, in: CDE (1984) pp.672 et seq.

van der Steen, Horizontale Werking van de Vier Vrijheden en van het Discriminatieverbod van Artikel 12 EG. in: NTER (2001) pp.4-9. van der Steen, Studiefinanciering ook voor Kinderen van Grensarbeiders, in: NTER (1999) pp.210-215.

van der Steen, Verbod van Nationaliteitsdiscriminatie op het Gebied van Arbeidsvoorwaarden: Gevolgen voor het Verblijfsrecht, in: NTER (1999) pp. 137-139.

van der Steen, De Europese Burger Krijgt Handen en Voeten, in: NTER (1998) pp. 163-166.

van der Steen, Vergoeding van Medische Zorg over de Grens: Alleen bij Toestemming Vooraf?, in: NTER (1998) pp.159-163.

van der Steen, Vrij Verkeer van Overheidswerknemers en CAO's in de Publieke Sector, in: SMA (1998) pp.484-486.

van der Steen, Annotatie Cabanis, in: SEW (1997) pp.207 et seq. van der Steen, Controle bij Ziekte in het Buitenland, in: NTER (1996) pp. 176-178.

van der Steen, Vrij Verkeer en Sociale Zekerheid van Ambtenaren, in NTER (1996) pp.53-56.

van der Steen, Medische Zorg voor Gezinsleden van Grensarbeiders, in: NTER (1995) pp.121-122

Di Stefano, La Libre Circulation des Travailleurs dans la Communauté économique européenne (Toulouse, 1968)

Annotation Vlassopoulou, in: CMLRev (1992) pp.625-636 
$1 \mathrm{xx}$

Steinbach Constitutional Protection for Freedom of Movement: A Time for Decision, in: KentLJ (1968-69) pp.417-438.

Steindorff Ausbildungsrechte im EG-Recht, in: NJW (1983) pp.1231-1233.

Steindorff Dienstleistungsfreiheit im EG-Recht, in: RIW (1983) pp.831-839.

Steiner The Right to Welfare: Equality and Equity under Community Law, in: ELR (1987) pp.477 et seq.

Steiner Annotation Gravier, in: CMLRev (1985) pp.348-352.

Steiner $\quad$ Recipients of Services - Some More Equal than Others, in: ELRev (1985) pp.348 et seq.

Steinmeyer Familienleistungen und Ausbildungsförderung, in: Deutschen Sozialrechtsverbandes, Europäisches Sozialrecht (Wiesbaden, Verlag Chmielorz, 1992) pp. 169-192.

Steyger De Neveneffecten van het Vrij Verkeer op Specifiek Nationale Beleidsterreinen, in: SEW (1999) pp.226-233.

Steyger Het Europees Recht en Stelsels van Sociale Zekerheid, in: SMA (1994) pp.8-19 and pp. $71-78$

Stiemer Sickness Insurance - Viewpoint from the EU-Member States, in: Jorens/Schulte (Eds), Coordination of Social Security Schemes in Connection of the Accession of Central and Eastern European States: "the Riga Conference" (Brugge, Die Keure, 1999) pp.225-253.

Stiemer Ziekte en Moederschap - Arbeidsongevallen en Beroepsziekten, in: Pieters, Europees Sociale Zekerheidsrecht - Commentaar (Apeldoorn, Maklu, 1988) pp.69-88.

Stone Why States Can't Solve the Health Care Crisis, in: American Prospect (1992) pp.51 et seq.

Stone

Stuijck

Swart

Szczekalla Stone et al, Constitutional Law (Boston, Little Brown \& Co., 1986). Stuijck/Looijetijn-Clearie (Eds), The European Economic Area EC-EFTA: Institutional Aspects and Financial Services (Deventer, Kluwer Law and Taxation Publishers, 1993).

De Toelating and Uitzetting van Vreemdelingen (Deventer, Kluwer, 1978). EuGH: Begriff des "Kindes" in Art.12 Verordnung (EWG) Nr.1612/68, in: EuZW (1995) pp.670-672.

T

Taschner

Free Movement of Students, Retired Persons and other European Citizens - A Difficult Legislative Process, in: Schermers et al (Eds), Free Movement of Persons in Europe (Dordrecht, Martinus Nijhof Publishers, 1993) pp. $427-436$.

Teichler Europäische Hochschulsysteme. Die Beharrlichkeit vielfältiger Modelle (Frankfurt, Campus, 1990).

Teichler Teichler/Maiworm, The Erasmus Experience - Major Findings of the Erasmus Evaluation Research Project (Luxemboug, Office for Official Publications of the European Communities, 1997).

Thiele Die Rechtssprechung des Gerichtshofs der Europäischen Gemeinschaften zum Recht auf Gleichbehandlung von EG-Ausländern beim Zugang zu Bildungseinrichtungen und auf Studiefinanzierung, in: ZfRV (1993) pp. 185-197. 


\section{lxxi}

Thomas

Thomson

Tiebout

Timmermans

Timmermans

Timmermans

Titmuss

Tits

Tits

TMC

Toebes

Tomscheid

Tomuschat

Toner

Toner

Trattner

Traversa

Tribe

Troclet

Tushnet

Tusman

U

Ulleroe

Union
Summing Up and Points of Comparison, in: Thomas (Ed.), Immigrant Workers in Europe: Their Legal Status, A Comparative Study (Paris, UNESCO Press, 1982) pp.211 et seq.

The Right to Travel - Its Protection and Application Under the Constitution, in: UMKCLRev (1971-1972) pp.66-96.

A Pure Theory of Local Expenditures, in: JPolEc (1956) pp.416 et seq

Free Movement of Persons and the Division of Powers between the

Community and its Member States - Why Do It the Intergovernmental Way?, in: Schermers et al (Eds), Free Movement of Persons in Europe (Dordrecht, Martnus Nijhof Publishers, 1993) pp.352-388

Annotatie Gravier in: SEW (1986) pp.86-94.

Annotation Luisi and Carbone, in: SEW (1984) pp.753-759.

Social Policy, an Introduction (London, Allen and Unwin, 1974)

Van Tits/Gemmel, Een Grensoverschrijdende Verkenning van Belangen. Ziekenhuiszorg in Zeeuwsch-Vlaanderen en Belgisch Vlaanderen (Tilburg, 1995).

Van Tits/Gemmel, Haalbaarheidsonderzoek Samenwerkingsnetwerk Ziekenhuizen in de Euregio Scheldemond (Tilburg, 1995).

T.M.C. Asser Instituut, Studiefinanciering Buiten Nederland in het Licht van de Europese Jurisprudentie ('s Gravenhage, 2000).

The Right to Health as a Human Right in International Law (Antwerpen, Intersentia Hart, 1999)

EG-Binnenmarkt Rüttelt an den nationalen Sozialversicherungssystemen, in: $\mathrm{KrV}(1998)$ pp.246-250.

Annotation Martinez Sala, in: CMLRev (2000) pp.449-457.

Judicial Interpretation of European Union Citizenship - Transformation or Consolidation?, in: MJ (2000) pp.158-182.

Passport Controls at Borders between Member States, in: ELRev (2000) pp.415-424.

From Poor Law to Welfare State - A History of Social Welfare Law in America (London, Collier MacMillan, 1984).

L'Interdiction de Discrimination en Raison de la Nationalité en Matière d'Accès à l'Enseignement, in: RTDE (1989) pp.45-69.

American Constitutional Law (Mineola, Foundation Press, 1988).

Europees Sociaal Recht - Institutioneel Kader, Rechtsinstrumenten, Sociale Problemen en hun Oplossing (Amsterdam, Scheltema \& Holkema, 1971)

Rethinking the Dormant Commerce Clause, in: WisLRev (1979) pp.125165.

Tusman/ten Broek, The Equal Protection of the Laws, in: CalLRev (1949) pp. 341-381.

Le Budget de l'Etudiant et son Financement en Europe (Amsterdam, European Association for Education, 1994).

Union des Caisses de Maladie, Avis officiel aux Assurés des Caisses de Maladie (Luxembourg, 1998). 
lxxii

V

Valk

Vanistendael

Vanistendael

Vansteenkiste

Varat

Varat

Ven

Ven

Ven

Ven

Veen

Verbelen

Veil

Verbruggen

Verbruggen

Verli

Vermeulen van der Valk, Van Pauperszorg tot Bestaanszekerheid - Een Onderzoek naar de Ontwikkeling van Armenzorg in Nederland tegen de Achtergrond van de Overgang naar de Algemene Bijstandswet 1912-1965 (Delft, Eburon, 1986).

Annotation Gilly in: CMLRev (2000) pp.167-179.

The Consequences of Schumacker and Wielockx: The Steps Forward in the Tax Procession of Echternach, in: CMLRev (1996) pp.255-269.

The Idea of the Thirteenth State System: Towards a Competition between a Federal Social Insurance System and the National Social Security System, in: Colloqui international sobre Seguretat social. Cap a la Competencia entre Sistemes de Proteccio social (Escaldes-Engordany, Caixa Andorrana de Seguretat social, 1991).

Economic Integration and Interregional Migration in the United States Federal System, in: Tushnet (Ed.), Comparative Constitutional Federalism - Europe and America (New York, Greenwood Press, 1990) pp.21-66.

'State Citizenship' and Interstate Equality, in: ChicLRev (1981) pp.487 et seq.

van der Ven, De Europese Unie en de Nederlandse Studiefinanciering, in: De Staat van de Studiefinanciering ('s Gravenhage, OCenW, 1999) pp.3761.

van der Ven, Onderwijsrecht en Onderwijsbeleid in Nederland en de Europese Unie - Ontwikkelingen voor Hoger Onderwijs na Maastricht (Den Haag, Nuffic, 1996).

van der Ven, Europees Onderwijsrecht na Maastricht, in: NTOR (1994) pp. 140-152.

van der Ven, Naar een Europese Studiefinanciering?, in: NTOR (1992) pp. 156-166.

van der Veen, De Wankele Verzorgingsstaat - Een Vergelijkende Analyse van Verzorgingsstaten in het Licht van Internationaliseringsprocessen, in: Engbersen et al (Eds.), Zorgen in het Europese Huis - De Grenzen van Nationale Verzorgingsstaaten (Amsterdam, Boom, 1994) pp.59-88.

The United States' Health Care System. Invisible Hand, Visible Effects (Antwerpen, Maklu, 1995).

Report of the High Level Panel on the Free Movement of Persons (Luxembourg, Office for Offical Publications of the European Communities, 1998).

The Commission's Green paper "Education, Training, research: The Obstacles to Transnational Mobility": Content and Comment, in: EJELP (1997) pp.41-48.

Toegang tot het Onderwijs en Studiefinanciering, in: TOO (1992-1993) pp. 282-290.

Verli-Wallace, Le nouveau Programme communautaire 'Socrates', in: RMCUE (1995) at p.517-520.

Vermeulen/Kuijer, Toegang tot het Onderwijs binnen de Europese Unie Juridische Aspecten van de Toegang tot Onderwijsvoorzieningen voor Middelbaar en Hoger Onderwijs voor EG-migranten en Derdelanders binnen de Europese Unie in een Drietal Lidstaten (Utrecht, Nederlands Centrum Buitenlanders, 1997) 


\section{Ixxiii}

Vermeylen Elementen van het Juridisch Statuut van de Vreemdeling in Europa, in: Deslé et al (Eds), Denken over Migranten in Europa (Brussel, VuBPress, 1983) pp.211-228.

Verschueren The Sürül Judgment: Equal Treatment for Turkish Workers in Matters of Social Security, in: EJML (1999) pp.371 et seq.

Verschueren The Commission's Proposal to Extend Regulation (EEC) No 1408/71 to Third Country Nationals, in: Jorens/Schulte (Eds), European Social Security Law and Third Country Nationals (Bruxelles, Die Keure, 1998) pp. 187-208.

Verschueren EC Social Security Coordination Excluding Third Country Nationals: Still in Line with Fundamental Rights after the Gaygusuz Judgment?, in CMLRev (1997) pp.991-1017.

Verschueren Na het Arrest Taflan-Met: Is er Leven na de Dood? - Besluit 3/80 (Sociale Zekerheid) van de Associatieraad EEG-Turkije Bestudeerd, in: MR (1997) pp.29-34.

Verschueren Libre Circulation des Personnes et Protection Sociale Minimale, in: RMUE (1996) at pp.83-105

Verschueren Les Prestation spéciales à Caractère non contributif et le Règlement Communautaire, in: DS (1995) pp.921-930.

Verschueren Het Arrest Taghavi en de Tegemoetkoming aan niet-EG-familieleden van EG-werknemers, in: MR (1993) pp.74-75

Verschueren Vrij Verkeer van Werkzoekenden, in: MR (1992) pp.15-19.

Verschueren De toegang tot de Openbare Dienst voor EG-onderdanen - Macht en Onmacht van het Europese Gemeenschapsrecht, in: MR (1991) pp.211220

Verschueren De Buitenlandse Student, in: van Hoestenberghe (Red.), Studentenrecht De Sociale en Juridische Gids voor de Sudent Hoger Onderwijs (Leuven, Acco, 1991) pp.259-272

Verschueren Internationale Arbeidsmigratie (Lelystad, die Keure, 1990).

Verwers Towards a New EC Health Policy?, in: European Public Health Association Uniting Public Health in Europe (1992) pp.11-14.

Vila Costa The Quest for a Consistent Set of Rules Governing the Status of nonCommunity Nationals, in: Alston (Ed.), The EU and Human Rights (Oxford, Oxford University Press, 1999) pp.411-446.

Vilaras Freedom of Movement in the Public Sector - Developments and Prospects, in: Carlier/Verwilghen, Thirty Years of Free Movement of Workers in Europe (Luxembourg, Office for Official Publications of the European Communities, 2000) pp.89-104

Völker Passive Dienstleistungsfreiheit im Europäischen Gemeinschaftsrecht (Berlin, Duncker \& Humblot, 1990).

Conflicterend Conflictenrecht, in: SMA (2001) pp.150-161.

Vonk

De Coördinatie van Bestaansminimumuitkeringen in de Europese Gemeenschap (Deventer, Kluwer, 1991)

Vonk Het HvJEG-arrest in de zaak Kziber - Een Levenskus voor de Slapende Paragrafen in de EG-samenwerkingsovereenkomsten, in: MR (1991) pp.149-151.

Voogsgeerd Interstatelijkheid - De Aard en de Intensiteit van het Grensoverschrijdend Element in de Rechtspraak van het Hof van Justitie van de EG met Betrekking tot de Vier Vrijheden (Groningen, 2000).

Voogsgeerd Vrij Verkeer en Sociale Zekerheid (Deventer, Kluwer, 1999). 


\section{1xxiv}

Voogsgeerd Aspecten van Grensoverschrijdende Tewerkstelling, in: Pennings, Tewerkstelling over de Grenzen (Deventer, Kluwer, 1996) pp.129-163.

Vossensteyn

Access: Selection and Affordability - A Comparative Analysis of the Barriers for Entrance in Higher Education in Nine Western European Countries (Zoetermeer, Ministerie voor Onderwijs, Cultuur en Wetenschap, 1997).

Vossensteyn Studiefinanciering in Internationaal Perspectief, in: THOM (1996) nr.5.

Vught van Vught/Vossensteyn, De Toekomst van het Nederlandse Stelsel van Studiefinanciering in Europees Perspectief, in: Cohen et al, Expertbijdragen, Scenario's en Achtergondinformatie - Een Bundeling Bijdragen ten Behoeve van het College Toekomst Studiefinanciering (Zoetermeer, College Toekomst Studiefinanciering, 1997) pp.31-44.

Vreugdenhil Vreugdenhil/De Bruine, Gezondheidszorg in Europa - Structuur en Financiering van de Gezondheidszorg in enkele Europese Landen (Rotterdam, Erasmus Universiteit, 1992)

Waddington Testing the Limits of the EC Treaty Article on Non-Discrimination, in: IndLJ (1999) pp.133-151.

Wägenbauer L'Europe des Vétérinaires, in: RTDE (1979) pp.653-663.

Wägenbauer La libre Circulation des Médicins dans la Communauté européenne Problèmes actuels, in: CDE (1976) pp.707-735.

Waegenbauer Die Einbeziehung der Hochschulen in den Europäischen Integrationsprozess, in: ER (1990) pp.135-142.

Walzer Spheres of Justice - A Defense of Pluaralism and Equality (New York, Basic Books, 1983)

Wapenaar Personenverkeer binnen de Europese Unie - Het Communautaire Recht inzake Personenverkeer, met Bijzondere Aandacht voor de Positie van Derdelanders (Utrecht, Nederlands Centrum Buitenlanders, 1997).

Watson Wandering Students: Their Rights under Community law, in: Curtin/O'Keeffe, Constitutional Adjudication in European Community and National Law - Essays for the Hon. Mr. T.F. O'Higgins (Dublin, Butterworths, 1992) pp.79-88.

Watson Annotation Gravier, in: CMLRev (1987) pp.89-97.

Watson Social Security Law of the European Communities (London, Mansell, 1980).

Weatherill After Keck: Some Thoughts on How to Clarify the Clarification, in: CMLRev (1995) pp.991 et seq.

Weatherhill Annotation Cowan, in: CMLRev (1989) pp.563-588.

Weber Die Rechtsprechung des EuGH zum Vorbehalt der öffentlichen Ordnung und Sicherheit im Bereich der Freizügigkeit, in: EuGRZ (1978) pp.157160 .

Wedemeyer Wedemeyer/Moore, The American Welfare System, in: tenBroek Ed.), The Law of the Poor (San Fransisco, Chandler Pub.Co, 1966) pp.2-33.

Weiler

"Thou Shall Not Oppress a Stranger" (Ex.23:9): On the Judicial Protection of Human Rights of Non-EC Nationals, in: Schermers et al (Eds.), Free Movement of Persons in Europe (Dordrecht, Martnus Nijhoff Publishers, 1993) pp. $248-271$ 


\section{IXxv}

Weiler

Weiler

Weiss

Wells

Werner

White

White

White

Wienk

Wildenthal

Wilensky

Williams

Wilmowsky

Wimmer

Wismar

Witte

Witte

Witte

Witte

Witte

Witte

Witte

Methods of Protection: Towards a Second and Third Generation of Protection, in: Cassese et al (Eds), Human Rights and the European Community - Methods of Protection (Baden-Baden, Nomos, 1991) pp.575620 .

The Transformation of Europe, in: YaleLJ (1991) pp.2403-2483.

Inländerdiskriminierung zwischen Gemeinschaftsrecht und nationalem Verfassungsrecht, in: NJW (1983) pp.2721-2726.

Wells/Hellerstein, The Governmental-Proprietary Distinction in Constitutional Law, in: VirgLRev (1980) pp.1073 et seq.

Post-war Migration in Western Europe, in: IM (1986) pp.543-557.

EC Social Security Law (Harlow, Longman, 1999).

Children and Right to Education under Article 12 of Regulation 1612/68,

in: ELRev (1995) pp.501-507.

Competing Solutions - American Health Care Proposals and International Experience (Washington, Brookings Institution, 1995).

Europese Coördinatie van Aanvullende Pensioenen (Deventer, Kluwer, 1999).

State Parochialism, the Right to Travel, and the Priviliges and Immunities Clause of Article IV, in: StanfLRev (1989) pp.1557-1595.

The Welfare State and Equality: Structural and Ideological Roots of Public Expenditures (Berkeley, University of California Press, 1975)

Williams/Torrens, Introduction to Health Services (New York, Chicester, 1984)

von Wilmowsky, Zugang zu öffentlichen Leistungen anderer Mitgliedstaaten - Das Integrationskonzept des EWG-Vertrages in der Leistungsverwaltung, in: ZfaöR (1990) pp.231-281.

Freedom of Movement for Students under Community Law, in: ELSA (1992) pp.53-68.

Wismar/Busse, Freedom of Movement Challenges European Health Care Scenery, in: Eurohealth (1998) pp.13-15.

De Witte, The Influence of European Community Law on National Systems of Higher Education, in: Pertek (Ed.), General Recognition of Diplomas and Free Movement of Professional (1992) pp.73-88.

De Witte, The Past and Future Role of the European Court of Justice in the Protection of Human Rights, in: Alston, EU and Human Rights (Oxford, Oxford University Press, 1999) pp.859-897.

De Witte, The Scope of Community Powers in Education and Culture in the Light of Subsequent Practice, in: Bieber/Ress (Eds), Die Dynamik des Europäischen Gemeinschaftsrechts - Die Auslegung des Europäischen Gemeinschaftsrechts im Licht nachfolgender Praxis der Mitgliedstaaten und EG-Organ (Baden-Baden, Nomos, 1987) pp.261-181.

De Witte, Equivalentie van Studieperiodes en Erkenning van Diploma's, in: TOO (1992-1993) pp.290-296.

De Witte, Higher Education and the Constitution of the European Community, in: Gellert (Ed.), Higher Education in Europe (London, Jessical Kingsley Publishers, 1993) pp.186-202

De Witte, Het Europees Onderwijsrecht, in: Europa en het Onderwijs (1992) pp.13-44

De Witte, Recht op Onderwijs zonder Grenzen?, in: JF (1990) pp.535-549. 


\section{lxxvi}

Witte

Wittek

Wittkowski

Wohlfarth

Wood

Woude

Wouters

Wouters

Wouters

Zubler

Zuleeg

Zuleeg

Zwicker
De Witte (Ed.), European Community Law of Education (Baden-Baden, Nomos, 1989).

Eine Europäische Dimension von Ausländerpolitik - Zur Richtlinie der EG vom 25.7.1977, in: RJB (1982) pp.40-50.

von Wittkowski, Die Rechtsprechung des Europäischen Gerichtshofs zur Freizügigkeit und Gleichbehandlung von Angehörigen der EG-Mitgliedstaaten hinsichtlich des Besuchs von Ausbildungsstätten und deren Auswirkung für die Bundesrepublik Deutschland (Frankfurt am Main, Lang, 1991).

Wohlfarth et al, Die Europäische Wirtschaftsgemeinschaft - Kommentar zum Vertrag (Berlin, Vahlen, 1960)

"Public Policy" Discrimination in the EEC: A Proposal for Assuring the Free Movement of Workers, in: FordhILJ (1985) pp.447-478.

van der Woude, Belastingen Begrens: De Doorwerking van het Discriminatieverbod en de Richtlijnen van de Eg op Nationale Belastingen (Delft, Eburon, 2000).

The Principle of Non-Discrimination in European Community Law, in: EC Tax Review (1999) pp.98-106.

European Citizenship and the Case-law of the Court of Justice of the European Communities on the Free Movement of Persons, in: Marias (Ed.), European Citizenship (Maastricht, European Institute of Public Administration, 1994) pp.25 et seq.

The Case-Law of the European Court of Justice on Direct Taxes: Variations Upon a Theme, in: MJ (1994) pp.179-220.

Unenforced Boundaries: Illegal Immigration and the Limits of Judicial Federalism, in: HarvLRev (1995) pp.1643-1660.

Developments in Law - Immigration Policy and the Rights of Aliens, in: HarvLRev (1983) pp.1286-1465.

The Recognition of Diplomas and its Impact on Educational Policies, in: De Witte, European Community Law of Education (Baden-Baden, Nomos, 1989) pp.51-70

Contemporary Transnational Migrations in Historical Perspective: Patterns and Dilemmas, in: Kritz (Ed.), U.S. Immigration and Refugee Policy (1983) at pp.36 et seq.

The Right to Migrate and Welfare Reform: Time for Shapiro v. Thompson to Take a Hike, in: ValpULRev (1997) pp.893-950.

Das Urteil Taflan-Met des Europäischen Gerichtshofs, in: ZASR (1997) pp. 170 et seq.

International Instruments on Equal treatment in Social Security Matters, in: Commission of the European Communities/Departemento de Relações Internaçionais e Convenções de Segurança Social, Social Security in Europe - Equality between Nationals and Non-Nationals (1995) pp.89-101. Equal Protection III: Non-Resident Discrimination, in: ASAL (1986) pp.469-494 
Chapter 1

INTRODUCTION 


\section{Introduction}

This book examines the rules of European Community law governing cross-border access to public benefits (or services). ${ }^{1}$ More specifically, the book aims to explore the extent to which the Community's rules on freedom of movement and non-discrimination confer upon individuals the right to obtain minimum subsistence benefits, health care and education in other Member States

Lurking beneath virtually all questions on cross-border access to public services lies a potential conflict between, on the one hand, the Community's goal of realising a free movement of persons and, on the other hand, the need to develop and maintain public services within the Community. Whatever its precise meaning and scope, a right to freedom of movement which is relevant and practical would seem to require that beneficiaries are able to gain access to certain public benefits while staying or residing in the territory of other Member States. For instance, beneficiaries might be discouraged from exercising their free movement rights if these did not encompass e.g. a right to claim medical assistance, a right to be admitted to schools and universities or if cross-border movement were to lead to a loss of social benefits. Further, on a broad construction, the free movement objective might include a right to move to other States for the purpose of obtaining welfare state services. A too broadly interpreted free movement of persons, however, might affect the funding and/or organisation of public services within the European Community. An unconditional and unlimited freedom of movement for patients, students and persons in need of social benefits could possibly jeopardise welfare state facilities. To some degree, the Member States' ability to maintain public services would seem to depend on the capacity to exclude nationals and/or residents of other States.

Besides addressing numerous concrete questions regarding crossborder access to public services, this book seeks to establish how European Community law has sought to reconcile the potentially conflicting interests of promoting freedom of movement and preserving public benefit systems

\footnotetext{
${ }^{1}$ The terms "public benefits" and "public services" will be used interchangeably in this book. The title of the book refers to public benefits in order to avoid any possible confusion with the public service exception contained in Article 39(4) of the EC Treaty.
} 

Benefit Systems

\section{$2.1 \quad$ Public Benefits}

In order to gain some insight into the subject of cross-border access to public benefits it is worth taking a closer look at public services. Even though it would have been appropriate, no attempt is made here to define the term "public benefits" or "public services". Public benefits are simply too diverse. ${ }^{2}$ They include facilities such as education, public roads and transport facilities, social insurance for risks such as unemployment, disability and old-age, public parks and librairies, police and fire services as well as subsidies for cultural activities, housing subsidies and programmes, social assistance and child benefit schemes, court and legal aid systems, health care and insurance, national defence, etc. Moreover, public services are organised, financed and administered in different ways. Public benefit programmes can be initiated by governments at municipal, provincial, state and/or federal level and they may be publicly provided or merely publicly funded. Public services can be funded from various sources (taxes, premiums, co-payments) ${ }^{3}$ and they are administered by public, semi-public and/or private bodies. The range of public benefit schemes is so vast that it is virtually impossible to include them all in a single definition that would have much analytical or other additional value.

A typology of public benefits, however, can be given. Although the lines of demarcation are fluid, three groups of public benefits can be distinguished. A first group consists of benefits such as defence, police and fire protection, court systems and other "facilities" which are primarily aimed at ensuring public security or safeguarding law and order. These benefits may be seen as "products" of the classical "night-watch state". A second group of benefits can be attributed to the role that governments play in the "industrial welfare state". These services include e.g. public roads and transport facilities, tax benefits for companies, telecommunications facilities, etc. By offering such public facilities governments provide individuals and companies with the basic tools and facilities needed to operate in the private market. Minimum subsistence benefits,

\footnotetext{
${ }^{2}$ Compare Clermonts et al, Verblijfsrecht en Gebruik van Collectieve Voorzieningen door Immigranten (1991) pp.52-57.

${ }^{3}$ E.g. co-payments for medical care, tuition and enrollment fees for public schools or the price of membership cards for public librairies.
} 
education and health care fall primarily within the last group of benefits with which governments seek to modify or correct market outcomes. This concerns "welfare state benefits".

Among the numerous and diverse welfare state benefits two further distinctions can be made. First, such benefits may come in the form of "benefits in kind" or in the form of "cash benefits". The former include e.g. health care and educational facilities. In economic terms, such services can be seen as "commodities" which could in principle be provided by private "actors". For various reasons, however, governments have often withdrawn such "products" from the private market and taken it upon themselves to provide such services "in kind", and often largely free of charge, to the population. Cash benefits, such as social assistance benefits and child allowances, consist of payments which enable beneficiaries to purchase "commodities" on the private market. Second, within the scheme of welfare state benefits, contributory and non-contributory benefit schemes can be distinguished. The former are insurance based programmes which (usually) oblige the insured to pay premiums and entitle them to (most often cash) benefits when the insured risk (unemployment, sickness, disability, retirement, etc.) occurs. Non-contributory benefits are funded out of tax-revenues. Usually, enjoyment of, or entitlement to, such benefits is not linked to or conditional upon the actual payment of tax-contributions.

\subsection{Welfare State Benefits: Solidarity, Territoriality and Nationality}

Welfare state services, which this book is primarily concerned with, come in multiple forms. They do share, however, a number of common features which may be described by with three concepts: solidarity, territoriality and nationality.

The first two concepts relate to, and result from, the very essence of the welfare state. The notion of the "welfare state" defies precise definition, ${ }^{4}$ but, highly simplified, it may be viewed as a state (or other political community) whose "members" have collectively decided to set, and to work towards, a number of social objectives ${ }^{5}$ which the private

\footnotetext{
${ }^{4}$ See Barr, The Economics of the Welfare State (1993) at p.6.

Besides objectives of social justice, public intervention in the private market is motivated by reasons of efficiency. See Barr (1993) supra footnote 4, chapter 4 and Kleinman/Piachaud, European Social Policy: Conceptions and Choices, in: JESP (1993) pp.1-19, at pp.3-5. In economic terms, efficiency implies that resources are used over a given period of time in such a way as to make it impossible to increase the well-being of
} 
market is unable to achieve. ${ }^{6}$ In the private market place individuals are

any one person without reducing the well-being of any other person (Pareto-optimality). See Hyman, Public Finance - A Contemporary Application of Theory to Policy (1999) at p.53. Markets can only be (Pareto-)efficient when a number of assumptions hold true: perfect information (i.e. consumers and firms are well-informed about the nature, quality and prices of products), perfect competition (i.e. economic agents of equal power are able to determine the price they are willing to pay) and the absence of market failures (which may arise in the form of public goods, external effects or increasing returns to scale). When all standard assumptions are present, the market is considered Pareto-efficient; no State intervention is necessary. When one of the assumptions fails, intervention in the market is required. Government intervention can take different forms: regulation (e.g. rules concerning the quality of products or mandatory affiliation to social insurance schemes), finance (e.g. subsidies or taxes which influence the price of certain products), income transfers (social benefits such as pensions) and public production (State provision of certain goods such as education or medical care).

${ }^{6}$ The disparities among the welfare states which have developed in post-war Europe are considerable. Some States have invested far more in the development of welfare state facilities than others (see e.g. Olssen, Welfare State Research Inc. - The Growth of a Crises Industry, in: AS (1987) pp.371-378) and the ways in which they have organised the welfare state varies. These disparities have inspired some authors to develop a typology of welfare states. One of the most well-known typologies is the one offered by Titmuss. Looking at the specific features of social services and rights, he distinguishes three types of welfare state: $(i)$ a "residual welfare model" in which the State assumes responsibility for not much more than social assistance schemes; (ii) an "industrial achievement-performance model" in which social rights are largely based on merit and investment and (iii) an "institutional redistributive model" in which social benefits are made available on the basis of need rather than merit. See Titmuss, Social Policy (1974) pp.30 et seq. Another classification is made by EspingAndersen who looks inter alia at the degree to which social rights decrease dependency of beneficiaries on the market ("decommodification"). He distinguishes: (i) "liberal welfare states" which stress the predominance of the private market and only provide for minimal and means-tested welfare benefits; (ii) "conservative-corporatistic welfare states" in which States play a significant role in society and primarily intend to protect status and the family and (iii) "social-democratic welfare states" which are characterised by universal benefits and a high degree of "decommodification". See Espings-Andersen, Three Worlds of Welfare Capitalism (1990) at pp.26-28. See further van der Veen, De Wankele Verzorgingsstaat Een Vergelijkende Analyse van Verzorgingsstaten in het Licht van Internationaliseringsprocessen, in: Engbersen et al (Eds), Zorgen in het Europese Huis - De Grenzen van Nationale Verzorgingsstaaten (1994) pp.59-88, at pp.69-74.

Bertola et al have classified the Community's Member States in four groups. The first comprises the Nordic States and the Netherlands. These countries come from a tradition of universal welfare provision. They have the highest levels of social expenditure, a high share of benefits offered in kind and a very low level of income inequality. The second group consist of countries which have a Bismarckian tradition such as Austria, Belgium, France and Germany. Income inquality is modest in these countries which have relatively high minimum wages, high unemployment benefits and quite strict employment protection. The Anglo-Saxon countries constitute a third group. They are closer to the Beveredgian tradition. Social assistance plays a comparatively important role, unemployment benefit levels are rather low and employment is less well protected. The last group comprises the 
responsible for their own financial well-being. They are supposed to gain the means needed to meet the cost of living by pursuing economic activities. Not all individuals, however, are able to generate sufficient private income. Incomes may be too low to cover the often high costs of housing, medical care or education. Due due to illness, disability, dismissal, retirement, pregnancy or lack of jobs, individuals may be faced with drastic reductions in income or even be deprived of any financial means. Social justice, as it is commonly understood in European countries, demands that all members of society have the minimum means at their disposal to meet the basic costs of living (food, clothing, shelter) and that they are all to some extent protected against sudden or drastic reductions in income caused by reasons beyond their control (disability, involuntary uneployment, etc). Furthermore, social justice requires that, regardless of economic status or place of residence within the national territory, members of society have access to certain essential facilities (education, medical care). In order to meet these objectives the private market rule of distribution of resources in accordance with individual economic performance is (to be) partly replaced by some form of re-distribution in accordance with principles of "human need", "solidarity" and "mutual aid".

The territoriality of the welfare state and its public benefit schemes implies mainly two things. First, public benefits are preserved for persons residing or working within the state territory to the exclusion of those living or working outside the state borders. ${ }^{8}$ The afore mentioned re-

southern Member States. Welfare states in Greece, Italy, Spain and Portugal have been developed more recently. Social expenditure is relatively low; income inequality is considerable. See further Bertola et al, EU Welfare Systems and Labor Markets: Diverse in the Past, Integrated in the Future?, in: Bertola et al, Welfare and Employment in a United Europe (2000) pp.23-122, at pp.50-53.

${ }^{7}$ See Freeman, Migration and the Political Economy of the Welfare State, in: Annals AAPSS (1986) pp.51-63, at p.52.

8 Welfare states are often described as territorially closed systems. The "idea of redistributive justice presupposes a bounded world; a group of people committed to dividing, exchanging and sharing social goods, first of all among themselves". Walzer, Spheres of Justice (1983) at p.31. See further Bauböck, Transnational Citizenship - Membership and Rights in International Migration (1994) at p.19; Entzinger, De Andere Grenzen van de Verzorgingsstaat - Migratiestromen en Migratiebeleid: in: Engbersen et al (Eds), Zorgen in het Europese Huis - De Grenzen van Nationale Verzorgingsstaaten (1994) pp.142-172, at p.142 and Freeman (1986) supra footnote 7. It is often argued that the intended commitment depends on some kind of "identification with a particular group" (Kleinman/Piachaud (1993) supra footnote 5, at p.7), "kinship" (Freeman (1986) supra footnote 7, at p.52), "a sense of common bonds" (Carens, Immigration and the Welfare State, in: Gutmann (Ed.), Democracy and the Welfare State (1991) pp.207-230, at p.209) or a "fellow feeling" which "facilitates cooperation on common projects and makes redistribution within the polity more acceptable" 
distribution and solidarity cannot be achieved on a voluntary basis. They need to be organised by governments which have the power to take the necessary measures, to make affiliation to public benefits systems compulsory for all, or the majority, of the population and to enforce duties to pay taxes or premiums. Welfare states are based on a notion of "membership" which not only entails rights ${ }^{9}$ to enjoy or claim benefits, but also duties to contribute to the financing of benefit systems. ${ }^{10}$ In the case of social insurance, this link between rights and duties is imposed at the level of the individual beneficiary. As a rule, benefits can only be enjoyed by individuals who(se employers) have paid, or who(se employers) can be required to pay, premiums. Individual enjoyment of tax-funded benefits is not linked to actual payment of, or duties to pay, taxes, but this link does exist at "group-level". An efficient supply of tax-funded benefits requires that the group consuming the benefits largely coincides with the group that can be required to contribute to the financing of these benefits. ${ }^{11}$ Governments lack effective powers to collect tax-contributions from those residing outside the State territory and such persons therefore cannot claim enjoyment of benefits as "equal members". Second, territoriality implies that welfare state benefits are to be consumed within the State borders. Public benefits such as education, housing or health care often can only be effectively provided and consumed in the State territory and for many cash benefits territoriality basically implies that they cannot be transferred abroad. Numerous reasons account for the non-exportability of cash benefits, but they include, for instance, the fact that the movement to other States is interpreted as a giving up of membership and, hence, entitlement to benefits and the fact that governments lack sufficient

(Barry, Self-Government Revisited, in: Miller/Siedentrop, The Nature of Political Theory (1983) at p.141)

${ }^{9}$ Welfare states and public benefit systems entail more than just private or public charity. The "essence of the welfare state is government protected minimum standards of income, nutrition, health, housing, and education assured to every citizen as a political right, not as charity". Wilensky, The Welfare State and Equality: Structural and Ideological Roots of Public Expenditures (1975) at p.1. See also Schuyt, Het Rechtskarakter van de Verzorgingsstaat, in: van Doorn/Schuyt, De Stagnerende Verzorgingsstaat (1982) pp.73-96.

${ }^{10}$ See also Altmaier, Europäisches koordinierendes Sozialrecht - Ende des Territorialitätsprinzip?, in: Eichenhofer/Zuleeg, Die Rechtsprechung des Europäischen Gerichtshof zum Arbeits- und Sozialrecht im Streit (1995) pp.71-91, at pp.73-74.

${ }^{11}$ Public finance theories of fiscal federalism teach that in federal political settings public benefits can only be efficiently provided for at local level if the persons who make the collective choices are also the ones who finance and consume the benefits. Bertola et al (2000) supra footnote 6, at p.90 and Scholsem, A Propos de la Circulation des Etudiants: Vers un Federalisme Financier Europécn?, in: CDE (1989) pp.306-323, at pp.309-310. 
powers to effectively supervise and enforce conditions of eligibility ${ }^{12}$ in other States. ${ }^{13}$

The third common feature concerns, as said, the notion of nationality. The logic of the welfare state would seem to imply a membership status which is defined in terms of residence or employment in the State territory. As a rule, nationality is an immaterial factor as regards duties to make tax or premium contributions and one might expect the same to hold true for the right to enjoy public benefits. Welfare states, however, have been developed by, and within the legal-political framework of, nation States which have a specific bond with, and hold a specific responsibility towards, their own nationals. National laws may contain provisions which make entitlement to (in particular non-contributory) ${ }^{14}$ benefits conditional upon the nationality of the State or which impose additional eligibility criteria on non-nationals. Further, and most prominently, the distinction between nationals and non-nationals is reflected in the States' immigration policies. States are under an obligation to allow their own nationals to enter and reside in their territory, ${ }^{15}$ and nationals who actually establish residence there are usually offered access to public benefit schemes, provided they meet substantive eligibility criteria. In principle,

\footnotetext{
${ }^{12}$ E.g. the duty to actively seek new employment for entitlement to unemployment benefits or, as regards means-tested benefits, the possibility to establish the resources of beneficiaries. See e.g. Chapter 3 Section 5 (exportability of minimum subsistence benefits), Chapter Section 2.4 (right to sickness benefits for persons staying or residing in other States) and Chapter 5 Sections 3 and 4 (right to claim study grants for studies outside the State of residence).

${ }^{13}$ A third, for the moment less relevant, aspect of the territoriality principle is that national rules only allow facts which occur, or have occured, within the State borders to be taken into account. For instance, death grants may be limited to the family members of persons who have died within the State borders and child benefits may be preserved for persons whose children are also residing in the State concerned.

${ }^{14}$ See e.g. von Maydel, Treatment of Third Country Nationals in the Member States of the European Union and the European Economic Area in Terms of Social Law, in: Commission of the European Communities/Departemento de Relações Internaçionais e Convenções de Segurança Social, Social Security in Europe - Equality Between Nationals and NonNationals (1995) pp.137-154, at pp.148-150.

${ }^{15}$ See Staples, The Legal Status of Third Country Nationals Resident in the European Union (1999) at p.24 and Goodwin-Gill, International Law and the Movement of Persons Between States (1978) at pp.136-137.
} 
however, States are under international law free to deny and regulate the access of non-nationals to their territories, ${ }^{16}$ labour markets and welfare state benefit systems.

\subsection{Immigration Policy and the Welfare State}

Welfare states are thus territorially operating systems based on some kind of membership which implies both rights to enjoy, and duties to contribute to the financing of, public services. In a world where cross-border trade and migration have always been factual realities, States have recognised that they need to regulate and control this welfare state membership. The required balance between revenue and expenditure could not be maintained if tax-paying members were to respond to any increase of tax- or premium duties by moving to other States with a more favourable "tax climate" or if States were to allow non-nationals unconditional access to their territory and public services. For the purposes of this book, it is particularly useful to briefly consider how States have traditionally regulated the admission of non-nationals to their territories and welfare state services. Immigration policies and policies concerning the access of non-nationals to public benefit systems have always been closely linked to each other. In pursuing immigration policies, States consider whether, or to what extent, non-nationals are (expected to become) in need of public benefits ${ }^{17}$ and entitlement to public benefits is often linked to the specific immigration status of non-nationals. ${ }^{18}$ The States' policies can be best

\footnotetext{
${ }^{16}$ International law provides for only two exceptions: $(i)$ the right to family life (e.g. Article 8 of the European Convention on Fundamental Freedoms) can found a claim to reside in a State of which individuals do not hold the nationality and (ii) persons are entitled to remain in another territory if the only alternative is to return to a place or State were they fear inhuman treatment (e.g. UN Convention on the Status of Refugees of 1951 and the Protocol of 1967). See Guild, European Community Law From a Migrant's Perspective $(2000)$ at p. 1

${ }^{17}$ The question whether non-nationals will be(come) net-contributors to or net-beneficiaries of the welfare state is in practice of course quite difficult to answer. Zolberg, Contemporary Transnational Migrations in Historical Perspective: Patterns and Dilemmas, in: Kritz (Ed.), U.S. Immigration and Refugee Policy (1983) at pp.36 et seq.

${ }^{18}$ On the relationship between immigration status and access to social benefits see e.g. Brubaker, Membership without Citizenship: The Economic and Social Rights of Noncitizens, in: Brubaker, Immigration and the Politics of Citizenship in Europe and North America (1989) pp.145-162 and Vermeylen, Elementen van het Juridisch Statuut van de Vreemdeling in Europa, in: Deslé et al (Eds), Denken over Migranten in Europa (1983) pp.211-228.
} 
described as a form of gate-keeping. ${ }^{19}$

At the first gate, States decide on the grant of visas which entitle tourists, business people or other foreign "visitors" to enter the national territory and to stay there for a brief period of time. Usually, States do not engage in an in-depth analysis of the possible access to, or need for access to, welfare state benefits because, as a rule, non-residents are only offered limited access to public services. Generally, non-resident foreigners can only benefit from services which de facto cannot be denied or whose financing is not (seriously) affected by an increase in the numbers of beneficiaries (e.g. street-lightning, public roads or parks) ${ }^{20}$ or services which cannot be denied for humanitarian reasons (e.g. emergency care, police protection). As a rule, foreign visitors have no right to services as non-emergency care, study grants and other social benefits. Entitlement to such benefits is made conditional upon (a minimum period of) residence or employment in and/or nationality of the State.

At the second gate, States apply rules concerning admission for temporary residence. In deciding on the grant of temporary residence permits to, for instance, seasonal, posted and temporary workers and students, States usually consider the purpose of residence as well as the question whether or not non-nationals are (likely to become) in need of public benefits. Foreign students can be required to demonstrate that they have health insurance and/or that they can provide for themselves and workers may have to prove that their job entitles them to a wage not falling below the minimum subsistence level. As temporary residents, non-nationals can be required to pay taxes or pay social security premiums and they may be entitled to take advantage of certain public benefits such as housing programs, child support systems or public education. ${ }^{21}$

\footnotetext{
19 See Hammar, Democracy and the Nation State: Aliens, Denizens and Citizens in a World of International Migration (1990) at pp.9-26; Hammar, Legal Time of Residence and the Status of Immigrants, in: Bauböck, From Aliens to Citizens - Redefining the Status of Immigrants in Europe (1994) pp.187-197 and Sørensen, The Exclusive European Citizenship - The Case for Refugees and Immigrants in the European Union (1996) Chapter 3.

${ }^{20}$ In economic theories such benefits are classed as public goods which are characterised by absence of rivalry in consumption (i.e. increases in the number of beneficiaries or users do not increase costs) and non-excludability (people cannot be prevented from using the good). Barr (1993) supra footnote 4, at pp.81-82. National defence and street-lighting are typical examples of a "pure" public goods; public parks and roads can be classed as "congestible" public goods (i.e. goods of which the marginal costs of additional beneficiaries may be minimal but not wholly zero). Hyman (1999) supra footnote 5, at p.139.

${ }^{21}$ The legal status of migrant workers has been strengthened by various international human rights instruments. For an overview see e.g. Madra, Migrant Workers and International Law (1986) and, in particular, Cholewinski, Migrant Workers in International I Iuman
} 
Access to benefits such as non-emergency medical care, study grant systems and certain social benefit schemes, however, is often denied by rules which make enjoyment of these benefits conditional upon a minimum period of residence or employment in the State. Lack of sufficient financial means may even lead to the loss of the temporary residence permit and be a ground for expulsion. ${ }^{22}$

The third gate concerns admission for permanent resident status. As a rule, it concerns non-nationals who have passed the second gate and who thus already have lived, worked and paid taxes in the State for a number of years. ${ }^{23}$ In deciding on the grant of permanent residence, States usually consider the past, current and the expected future employment status of the non-nationals and they may include in their considerations whether, or to what extent, they have been, are or are expected to become a burden on the "public purse". Once admitted for permanent residency, non-nationals can be required to pay an equal share in the financing of public benefits and they are offered access to these benefits under the same conditions as the nationals of the host State. Their residence status is not, or is no longer, affected by their possible use or need of public services.

The States' immigration policies are tailed at a fourth gate at which States apply rules and procedures for acquiring their nationality. ${ }^{24}$ Usually, non-nationals must have passed the third gate of permanent residence status before they can apply for the host State's nationality. Non-nationals may be required to demonstrate their "good moral character", that they have sufficient knowledge of the host State's language, and/or that they have integrated into the State's society. As a rule, questions concerning their need of public benefits are not addressed at this

\footnotetext{
Rights Law - Their Protection in Countries of Employment (1997)

${ }^{22}$ See further Chapter 3 Section 2.2 .

${ }^{23}$ The period of previous residence required for obtaining permanent resident status is often about five years but may in some countries go up to even 20 years. See Thomas, Summing Up and Points of Comparison, in: Thomas (Ed.), Immigrant Workers in Europe: Their Legal Status, A Comparative Study (1982) pp.211 et seq, at pp.221-222 and Cholewinski (1997) supra footnote 21, at p.384.

${ }^{24}$ In some States non-nationals are given a right to naturalisation when certain conditions are met, whilst in others the grant of nationality is merely a privilege which governments may but do not have to give. See e.g. Brubaker, Citizenship and Naturalization: Policies and Politics, in: Brubaker, Immigration and the Politics of Citizenship in Europe and North America (1989) pp.99-125. On the laws concerning the attribution and acquistion of nationality in the Member States of the European Community see in particular de Groot, Staatsangehörigkeit im Wandel - Eine rechtsvergleichende Studie zu den Erwerb- und Verlustgründen der Staatsangehörigkeit (1989) (with numerous references to other litcraturc).
} 
stage. As a rule, acquisition of nationality or citizenship does not imply a significant extension of social rights, but it does entitle the persons concerned to political rights which enable them to participate in the decision-making process concerning the welfare state.

In more general terms, the States' admission policies can be viewed in terms of granting of membership status. Non-nationals who have been allowed to pass the first gate of entry to the State territory are not offered any membership status. Foreign visitors cannot be required to contribute equally to and, hence, are in principle denied access to welfare state benefits. They are supposed to be members of the welfare state of the State where they reside. Non-nationals who have passed the second gate are granted a partial or conditional membership status. Temporary residents have not paid contributions for long enough to acquire "full" membership status of the welfare state. That status is only granted at the third gate. The non-nationals who have been allowed to pass this gate can be classed as "denizens", a concept which has been used to describe the status of non-nationals who have acquired a secure or permanent resident status and who enjoy the same rights as nationals with the exception of political rights such as the right to vote and stand as a candidate in elections. ${ }^{25}$ At the fourth gate this "denizenship" can be transformed into (nominal) citizenship. The (former) non-nationals are not only granted "membership" of the welfare state but also membership of the nation State.

\subsection{Free Movement of Persons and Cross-Border Access to Welfare} State Benefits

In the late 1950s, when the European (Economic) Community was established and the foundations for the current welfare states were laid, States in western Europe made full use of their powers to regulate the admission of non-nationals to their territories, labour markets and welfare states. Generally, the States' policies were restrictive and self-serving. Non-nationals were only admitted in order to fill job vacancies for which no national workers were available and residence permits were restricted to the duration of employment. During their stay foreign workers were

${ }^{25}$ Hammar (1990) supra footnote 19, at pp.12-13; Layton-Henry, Citizenship or Denizenship for Migrant Workers, in: Layton-Henry (Ed.), The Political Rights of Migrant Workers in Western Europe (1990) pp.186-195, at p.188 and Brubaker (1989) supra footnote 24 
required to pay taxes and premiums, but they were only offered access to a few welfare state benefits. Foreign guestworkers had been invited to fuel the economy of the host State; they were not to become a burden on the welfare state. ${ }^{26}$ At the time, migration was not so much seen as a threat to the welfare state. Rather, by strictly regulating it, migration was regarded and served as a means for developing and strengthening welfare state regimes.

Against this background, it may come as no surprise that the 1957 Treaty of Rome imposed few limits on the States' powers to regulate access to their welfare states. The Member States had committed themselves to an integration of their private economic markets, but they had not given up their powers in the "public" fields of social security, education and health care. ${ }^{27}$ The national welfare states were not intended to be supplemented by, or transformed into, a "European welfare state". Furthermore, the free movement of persons was only foreseen for (full-time) workers (Article 48 EEC; now, after amendment, Article 39 EC) and selfemployed persons (Article $52 \mathrm{EEC}$; now Article 43 EC) who were expected to be able to provide for themselves. The Treaty did not contain any specific provision entitling the (self-)employed to social benefits, to be admitted to educational institutions or to claim health care services. To be sure, those drafting the Treaty had recognised that the realisation of free movement of persons would require the grant of certain social rights $^{28}$ to workers who due to illness, disability, unemployment or retirement were no longer able to generate an sufficient income. The 1957 Treaty of Rome entrusted the Council with the task of adopting "measures in the field of social security as are necessary to provide freedom of movement for workers" (Article 51 EEC; now, after amendment, Article 42 EC). The transfer of these social security powers, however, did not seem to have far-reaching implications for the Member States. The measures to be adopted were intended to be based on a number of bi- and

\footnotetext{
${ }^{26}$ See e.g. Böhning, The Migration of Workers in the United Kingdom and the European Community (1972) and Garth, Migrant Workers and Rights of Mobility in the European Community and the United States: A Study of Law, Community and Citizenship in the Welfare State, in: Cappelletti et al, Integration Through Law - Europe and the American Federal Experience (1986) Vol.I, pp.85-163, at pp.9()-96.

${ }^{27}$ See further Chapter 3 Section 2 (social benefits schemes), Chapter 4 Section 2 (health care) and Chapter 5 Section 2 (education)

${ }^{28}$ Compare Leibfried/Pierson, Multitiered Institutions and the Making of Social Policy, in: Leibfried/Pierson, European Social Policy - Between Fragmentation and Integration (1995) pp.43-77, at p.52 and Romero, Migration as an Issue in European Interdependence and Integration: The Case of Italy, in: Milward et al (Eds), The Frontier of National Sovereignty 1945-1992: I listory and Theory (1993) pp.33-58.
} 
multi-lateral social security conventions which the States had already voluntarily signed in the pre-Community period. Furthermore, they only offered social security rights in as far as these did not affect the interests of States with comparatively better developed benefit systems. In addition, the social security measures that were envisaged could only be adopted, and amended, by a unanimous decision of the Council. In brief, by joining the European Community the Member States had agreed to open the doors to their national labour markets for each others nationals ${ }^{29}$ but the same did not hold true for the doors to their welfare states. Access to public benefits would remain regulated by national law and/or Community rules which the Member States had voluntarily agreed to.

Over the years, however, the Community rules on the free movement of persons have undergone a significant evolution during which the Member States' powers to control and regulate access to their territories and admission to their welfare states have increasingly been curtailed. First, the Community legislator has been willing to confer upon workers a number of rights which are not expressly mentioned in Article 39. It has developed a comprehensive system for the co-ordination of social security schemes and it has included students, pensioners and even all Community citizens in the free movement regime. ${ }^{30}$ Second, the European Court of Justice has assumed a very active role in promoting a genuine free movement of persons which is relevant and practical. In hundreds of judgements decided under the Community's social security rules, the Court has given quite a broad interpretation of many provisions and concepts. It has imposed on Member States obligations which they had not foreseen and/or agreed to, when they, as members of the Council, adopted the regulations. ${ }^{31}$ In addition, the Court has given a particularly broad interpretation of the general Community provisions governing, or relevant to, the free movement of persons such as Article 39 EC, secondary legislation and 12(1) EC, which prohibits "within the scope of application of" the Treaty "any discrimination on grounds of nationality".

As a result of the various legislative and judicial initiatives, the conflict between the goal of promoting freedom of movement, on the one hand, and the need to develop and maintain adequate welfare state benefits, on the other hand, has gradually come to the surface. The Community institutions, and the Court of Justice in particular, have been

\footnotetext{
29 See, however, Chapter 2 Section 2.1.

${ }^{30}$ See further Chapter 2 Section 3.

${ }^{31}$ Occasionally, the Court has not hesitated to overrule the Council by invalidating certain provisions of the regulations as being incompatible with the Treaty. See e.g. Case 41/84 Pinna [1986] ECR 1.
} 
faced with delicate and fundamental questions. For instance, those drafting the original EEC Treaty had assumed that Article 39 would only apply to full-time workers. In light of more recent developments in the labour markets, however, it could very well be argued that part-time workers should also be able to benefit from Article 39 EC. States have resisted and claimed that such workers may often earn an income falling below the minimum subsistence level and that they are likely to become a burden on their social assistance schemes. The financing of these schemes could be affected if all "foreign" part-timers were to be given supplementary social benefits. Should Member States be obliged, then, to admit part-time workers to their territory and/or benefits schemes or are their financial concerns of sufficient weight to deny such workers residence and/or social benefits? Furthermore, Community citizens may be deterred from taking up employment in another Member State if the unforeseen loss of employment would lead to a loss of the right to reside and/or enjoyment of public benefits. States have claimed, however, that unemployed workers must have worked and paid taxes for a given period of time before they can be classed as "members of the welfare state" and become eligible for unemployment benefits, social assistance benefits or access to re-training programmes. Can such unemployed workers claim rights under Article $39 \mathrm{EC}$ and, if so, is the length of employment or residence of any relevance in this regard? Further, conflicts arise as regards frontier workers. Often such workers will be taxable in the State of residence. Does this imply that the State of employment can consider, and treat, frontier workers as "non-members" who do not contribute to and, hence, can be denied access to public benefits? Should any distinction be made in this regard between tax-funded benefits and social insurance programmes? Furthermore, freedom of movement would be deprived of much significance if workers could not be joined by their family members. Member States have always insisted though that the number of family members entitled to accompany workers should be limited and that these members should not be offered benefits aimed at covering living or maintenance costs such as study grants or social assistance benefits. Who should take financial responsibility for the family members: the host State or the workers themselves? Member States have expressed even stronger objections as regards the access of economically inactive nationals of other Member States. The efforts of Community institutions, and the Commission and the European Parliament in particular, to realise a general non-economically determined right to reside freely within the 
Community $^{32}$ have been impeded by fears of Member States that large influxes of non-nationals solely moving to their territories for the purpose of obtaining social benefits, education or other public services would undermine the capacity to maintain such public services. Are Member States indeed obliged to admit such non-economically active nationals of other States to their territories? If so, are such persons to be treated as "members of the welfare state" or can they be viewed as "non-members" or "partial members" who can de denied public benefits or be expelled when they become in need of social assistance benefits or apply for study grants? In answering these questions, is it of any relevance whether, or to what extent, "welfare tourism" (may) actually occur(s)?

Even more controversial issues (may) arise as regards Community citizens who merely (wish to) visit other Member States. Does Community law confer upon individuals the right to travel to other States, and if, so, are the beneficiaries of this right also entitled to gain access to public benefit systems during their stay? Do Community citizens have the right to travel to other States for the sole purpose of collecting public benefits? From the perspective of individual Community citizens, affirmative answers would seem in order. Such rights would enable them to gain access to educational courses which are not offered in the State of their residence or to avoid waiting-lists for medical treatment. States, however, may, and often indeed do, claim that their systems should remain closed for non-residents who do not, and cannot be required, to contribute their equal share of the financing of public benefits. A free movement of students could lead to overcrowded class-rooms, affect teacher-student ratios or limit the housing facilities for the States "own" students. Upon graduation, students may often decide to return to, and work in, their own State and use the acquired knowledge and skills in, and to the benefit of the economies of, this State. Spill-over effects might even incite States to lower investments in education in the hope that free-riders will move to other States. Similarly, a large influx of foreign patients could lead to an increase in health care expenditure or cause waiting-lists, whilst a netoutflow of patients may cause problems of underutilisation which may force States to eliminate certain facilities or to close down hospital clinics.

More examples could be given, but the above may suffice to demonstrate that a broadly interpreted freedom of movement may indeed conflict with, and have implications for, the States' policies concerning the access to their territories and public benefits systems and their ability to maintain these systems. This book seeks to explore how Community

\footnotetext{
${ }^{32}$ See further Chapter 2 Section 3.
} 
law has sought to settle the conflict between the competing claims of promoting freedom of movement and protecting the welfare state benefits systems

\section{Definition of the Subject}

3.1 Economic Residents, Non-Economic Residents, Non-Residents and Third Country Nationals

Having introduced the subject of cross-border access to public benefits within the European Community, the precise scope and aim of this book need to be defined. Some choices have to be made. The first concerns the categories of the beneficiaries whose free movement and cross-border welfare rights will be studied. Over the years, the personal scope of the free movement of persons has been expanded and increasingly fragmented. Where the original Treaty of Rome merely conferred free movement and equal treatment rights upon (full-time) workers, the self-employed beneficiaries of the right of establishment and providers of services, Community law on the free movement of persons today also grants rights to work-seekers, ${ }^{33}$ part-time workers, ${ }^{34}$ unemployed workers, ${ }^{35}$ "student-workers", ${ }^{36}$ retired workers, ${ }^{37}$ posted workers, ${ }^{38}$ recipients of economic services ${ }^{39}$ (such as students, patients, ${ }^{40}$ business persons and tourists), pensioners, ${ }^{41}$ "travellers", ${ }^{42}$ Union citizens ${ }^{43}$ and, regardless of their nationality, ${ }^{44}$ family members of the various categories. ${ }^{45}$

For the purpose of this book there is no need to discuss and analyse the cross-border welfare rights of each of these categories separa-

\footnotetext{
${ }^{33}$ See e.g. C-292/89 Antonissen [1991] ECR I-745.

${ }^{34}$ See e.g. Case 53/81 Levin [1983] ECR 1035.

${ }^{35}$ See e.g. Case C-57/96 Meints [1997] ECR I-6689.

${ }^{36}$ See e.g. Case 39/86 Lair [1988] ECR 3161

${ }^{37}$ See Regulation No $1251 / 70$

${ }^{38}$ See e.g. Case C-113/89 Rush Portuguesa [1990] ECR I-1417.

${ }^{39}$ See e.g. Joined Cases 286/82 and 36/83 Luisi and Carbone [1984] ECR 377.

${ }^{40}$ See e.g. Case C-158/96 Kohll [1998] ECR I-1931.

${ }^{41}$ See Directive No $90 / 365$.

${ }^{42}$ See e.g. Case C-378/97 Wijsenbeek [1999] ECR I-0000.

${ }^{43}$ See e.g. Case C-85/96 Martínez Sala [1998] ECR I-2691.

${ }^{44}$ See Case C-94/84 Deak [1985] ECR I-1873.

${ }^{45}$ Sec c.g. Case C-337/97 Meeusen [1999] ECR I-0000.
} 
tely. Formally, the legal status of the various categories may be based on, and governed by, different provisions, but the case law of the Court of Justice reveals a convergence of the principles governing the status of the various categories. More than once, the Court has indicated that the provisions concerning the free movement of workers, the right to establishment and the free movement of services are based on, and to be interpreted in accordance with, the same principles as regards both the free movement and the equal treatment rights. ${ }^{46}$ Further, the Court has increasingly referred to a general class of persons ${ }^{47}$ covered by the free movement regime using terms as "persons enjoying the protection of Community law", 48 "persons to whom Community law gives the right to equal treatment"49 or nationals of the Member States "lawfully residing in the territory of another Member State". ${ }^{50}$ The formal fragmentation of the personal scope of the free movement of persons has gone hand in hand with a "de-fragmentation" of the substantive principles governing the legal status of the various categories. ${ }^{51}$

The process of "de-fragmentation", however, has not gone so far as to render distinctions among the various categories wholly superfluous. For the purpose of this book, four groups are (to be) distinguished. ${ }^{52}$ The first category whose cross-border welfare rights will be discussed consists of Community citizens who stay in or have acquired ${ }^{53}$ the right to reside in other Member States on the basis of Articles 39 or 43 of the EC Treaty. This category may be labelled the "economic residents". The prime focus will be on the rules and principles governing the rights of workers and their family members, the basic assumption being that the

\footnotetext{
${ }^{46}$ See e.g. Case 48/75 Royer [1976] ECR 497 at 12 and Case 118/75 Watson and Belmann [1976] ECR 1185 at 9.

${ }^{47}$ Handoll, Free Movement of Persons in the EU (1995) at p.61.

${ }^{48}$ Case 8/77 Sagulo [1977] ECR 1495 at 8.

${ }^{49}$ Case C-43/95 Data Delecta [1996] ECR I-4671 at 12.

${ }^{50}$ Case C-85/96 Martinez Sala [1998] ECR I-2691 at 61.

${ }^{51}$ This de-fragmentation is of particular interest for the subject of the cross-border access to public benefits. For instance, the main reason why Community law makes a distinction between employed and self-employed persons is that the legal obstacles to cross-border pursuit of economic activities by the two categories have traditionally differed. These differences in the "economic" obstacles, however, are of much less, if any, relevance for the rights concerning the access to "welfare state benefits" of these "economic beneficiaries".

${ }^{52}$ For more precise definitions, and the main rules and principles governing the legal status, of the four categories of beneficiaries see Chapter 2.

${ }^{53}$ For purposes of the present study, the category of economic residents includes in principle also frontier workers or other (self-)employed persons who have acquired under Articles 39 or $43 \mathrm{EC}$ the right to reside but have decided not to make use of this right.
} 
self-employed and their family members enjoy the same social, educational and health care rights.

The second category of beneficiaries to be studied comprises the "non-economic residents". It concerns Community citizens whose right to reside in other Member States is not governed by Article(s) 39 (and 43) EC, but by the Directives No 93/96, No 90/365 and No 90/364. More specifically, the non-economic residents include students, pensioners and the residual category of the "other" Community citizens. The conditions under which these three categories can establish residence in other Member States differ from the ones to be met by the economic residents. Their legal status raises some specific questions which do not arise as regards the beneficiaries of Article(s) 39 and (43) EC.

The third category comprises the "non-residents". It concerns Community citizens who only go to other States for a limited period of time without relocating their economic base or private residence. As follows from the brief discussion in Section 2, questions concerning the cross-border access of this category differ profoundly from the ones arising as regards the economic and the non-economic residents. As regards the non-residents the core question is not whether, or to what extent, they can become "members" of the host State's welfare state, but rather whether, as "non-members", they can benefit from public benefits schemes to which they cannot be required to contribute.

The last category consists of third country nationals. As will be demonstrated, ${ }^{54}$ this category is in principle still excluded form the free movement regime. This is not to say, however, that Community law has nothing to offer to them in the fields of social, health care and educational policy. The Community and its Member States have concluded various association and co-operation agreements with third States under which the nationals of these States are offered free movement and/or equal treatment rights. This book mainly discusses the rights guaranteed by the Agreement on the European Economic Area, the Association Agreement with Turkey and the agreements which have been concluded with the Maghreb countries Morocco, Algeria and Tunisia.

\footnotetext{
${ }^{54}$ See in particular Chapter 2 Section 5.
} 


\subsection{Minimum Subsistence Benefits, Health Care and Education}

A second choice to be made concerns benefits to be included in the book As stated in Section 1, three benefits have been selected for analysis: social assistance (and other minimum subsistence) ${ }^{55}$ benefits, health care and education. These benefits have been chosen for two separate, albeit related, reasons. The first is that the conflict between the Community's goal to realise a free movement of persons and the Member States' "welfare state interest" arises as regards each of these benefits. The three benefits are all of vital significance for (the beneficiaries of) the free movement of persons. Community citizens might actually be deterred from moving elsewhere if this did not include a right to obtain medical treatment, to gain access to education or lead to a loss of the basic means of subsistence. Indeed, Community citizens might attach so much importance to these benefits that they might move to other States for the sole purpose of obtaining these benefits. At the same time, social assistance, education and health care are all public benefits which are vulnerable to increases in the number of beneficiaries. An influx of non-nationals or non-residents claiming such benefits could affect the States' ability to develop and maintain the systems. The second reason is that Community institutions, and the Court of Justice in particular, have frequently been faced with questions concerning cross-border access to minimum subsistence benefits, education and health care. The number of Court judgments and legislative measures is large enough to engage in a useful and systematic analysis of the way in which Community law has sought to settle the previously mentioned conflict.

\subsection{The United States of America}

The subject of cross-border access to public services within the European Community has only come to the surface in the last two decades. In spite of an increasing number of Court judgments and legislative initiatives, the Community is still quite inexperienced in settling the conflict between promoting freedom of movement and the need to preserve adequate public benefits systems. The Community can (still) learn, or draw inspiration, from the experiences of other "multi-level systems of government" with the cross-border access to public services. This book will examine whe-

\footnotetext{
5s For a further clarification of the notions of "social assistance" and "minimum subsistence benefits" see Chapter 3 Section 2.1 .
} 
ther, and if so, what, lessons can be learnt from the United States.

Of course, one has to be careful in comparing European Community law and American constitutional law, and this particularly holds true for the free movement of persons. ${ }^{56}$ The historical, political, socioeconomic and legal backgrounds against which the subject of the free movement of persons and cross-border access to public benefits is to be placed differ profoundly on both sides of the Atlantic. In the United States a free movement of persons never had to be created and this freedom has never been seen as functional, or subordinate, to the process of economic integration. ${ }^{57}$ From the nation's inception more than two hundred years ago, the right to travel, as the notion of a free movement of persons is commonly known, ${ }^{58}$ has been assumed to exist as a fundamental right for all United States citizens. Furthermore, American views on the welfare state and social policy differ profoundly from the European perceptions. In the United States there is greater emphasis on the private market is far more stressed and, by comparison with most European States, governments in the United States have assumed a rather limited welfare responsibility $v i s-\grave{a}$-vis their populations.

Nonetheless, the above and other differences do not imply that no meaningful comparisons can be made. The core questions and issues raised by the subject of cross-border access to public benefits are quite similar. In brief, both the United States and the European Community may be regarded as multi-level governmental entities in which $(i)$ the public task of developing welfare state services is primarily carried out at State or local level and (ii) in which a right to move and reside freely among States is "constitutionally" protected. Just as are the Member States of the European Community, the individual American States are faced with problems concerning the access of "outsiders" to their public benefits systems. Both European Community law and American constitutional law ${ }^{59}$ have to settle the potential conflict between the "free movement interest" and the interest of maintaining adequate "welfare systems".

\footnotetext{
${ }^{56}$ Compare e.g. Varat, Economic Integration and Interregional Migration in the United States Federal System, in: Tushnet (Ed.), Comparative Constitutional Federalism - Europe and America (1990) at pp.21-66, at p.49 and Rosberg, Free Movement of Persons in the United States, in: Sandalow/Stein, Courts and Free Markets - Perspectives from the United States and Europe (1982) pp.275-362, at pp.276-278

${ }^{57}$ See Chapter 2 Section 8 .

${ }^{58}$ See Rosberg (1982) supra footnote 56 , at p.275.

${ }^{59}$ Compare e.g. Varat, 'State Citizenship' and Interstate Equality, in: ChicLRev (1981) pp.487 et seq.
} 


\subsection{Aims of the Book}

The main goal of this book is to examine the rules and principles of European Community law governing the degree to which individuals can move to, and claim in, other Member States access to minimum subsistence benefit schemes, public health care and public education. The book seeks to establish how Community law has settled the potential conflict between the goal of promoting freedom of movement, on the one hand, and the need to develop and maintain adequate public benefit schemes, on the other hand. This is done by considering whether, or the extent to which, the Member States' rules governing access of non-nationals and non-residents to the territory, (labour) market and public benefit schemes are compatible with the Community rules on freedom of movement and equality of treatment. In addition, the book will investigate whether, and if so, how, Community law governing access to these three types of public benefits, as it stands today, can, or may have to, be adjusted or improved and whether in doing so, some lessons can be drawn from American constitutional (or, where applicable federal) law.

\subsection{Structure of the Book}

This book consists of six chapters. After this introductory chapter, the book commences in Chapter 2 with a general introduction to the free movement of persons within the European Community and the United States. The chapter aims to put the subject of cross-border access to public benefits in its proper legal-historical context by describing how the main rules and principles on the free movement of persons have been developed over the years and what they entail, in the context of the present state of European Community law and American constitutional law. Chapter 2 may serve as a guide for readers throughout the course of the book. The subsequent three chapters analyse the degree to which European Community law and American constitutional law entitle individuals to move to and to claim access to minimum subsistence benefits schemes, health care systems and education systems respectively in other Member States. The structure of Chapters 3, 4 and 5 is quite similar. After an introduction, each of the three Chapters first puts the subject in its proper context by describing the main features of the national benefits systems under consideration, the ways in which the Member States have traditionally regulated access to these systems and the activities of the Community institutions in the respective fields which are not directly related to the free movement of persons. The subsequent sections consider 
in further detail the degree to which Community law entitles the four categories of economic residents, non-economic residents, non-residents and third country nationals to move to and/or to claim access to the respective benefit schemes. After a brief summary and evaluation, Chapters 3, 4 and 5 then proceed with a description of the degree to which American constitutional law entitles individuals to move to and to claim in other States access to minimum subsistence benefits schemes, health care and public education. After having compared the degree to which individuals enjoy cross-border "welfare rights" on both sides of the Atlantic, the three chapters are rounded off with a Section in which the findings are summarised and evaluated. In the final sections the question is addressed whether European Community law on cross-border access to the benefits in question can possibly be improved or adjusted and whether, and if so, how, the American experiences can be of help in this regard. In Chapter 6 the findings of this book are summarised. Some "horizontal" comparisons will be drawn with a view to establishing the more general principles governing cross-border access to public benefits. 
Chapter 2

FREE MOVEMENT OF PERSONS WITHIN THE EUROPEAN COMMUNITY AND THE UNITED STATES:

HISTORY, LEGAL FRAMEWORK AND BASIC PRINCIPLES 

This chapter aims to put the subject of cross-border access to public benefits in its proper legal-historical context. As noted in the introductory chapter, questions concerning access to public benefits in other Member States have only gradually come up. In the view of those drafting the original EEC Treaty free movement rights would only be granted in order to facilitate the free pursuit of economic activities across inter-State borders. The rights to move and reside freely were preserved for (self)employed persons and the right to equal treatment would, in principle, be limited to matters related to work and income. Since the Community's inception, however, the free movement of persons has developed in a way and direction which the drafters had probably never foreseen. Over the years, many more categories of persons have become entitled to free movement rights and the material scope of the right to equal treatment has been extended to include many rights and benefits which are not related to the pursuit of, involvement in, economic activities. During this development, many questions and problems regarding the right to gain access to public benefits have arisen. In some cases the Community institutions have responded by adopting specific legislative measures, but most questions on cross-border access to public benefits have been, and must be, answered (by the Court of Justice) on the basis of the general provisions on the free movement of persons. In this respect European Community law parallels American constitutional law. The history of, and the main rules and principles governing, the so-called right to travel differ, but specific legislative measures governing access to public benefits in other States have not, or hardly, been taken in the United States. Issues regarding cross-border access to public benefits have mainly been, and are to be, settled (by the Supreme Court) on the basis of clauses contained in the American Constitution.

This Chapter analyses the way in which the main rules and principles governing the rights to freedom of movement and equality of treatment of the various categories of beneficiaries have been shaped over the years. In addition, it looks at what they entail, in the light of current European Community and American law. For the purpose of this book, there is no need to describe the relevant rules and principles in detail. ${ }^{1}$ In

\footnotetext{
1. For more extensive descriptions of Community law on the free movement of persons see e.g. Dollat, Libre Circulation des Personnes et Citoyenneté européenne: Enjeux et Perspectives (1998); Schulz, Freizügigkeit für Unionsbürger (1997); Wapenaar, Personenverkeer binnen de Europese Unie - Het Communautaire Recht inzake Personenverkeer, met Bijzondere Aandacht voor de Positie van Derdclanders (1997); Jørgensen, Union Citizens - Free Movement and Non-Discrimination (1996);
} 
particular, this chapter does not intend to set out the precise conditions under which (self-)employed persons may pursue economic activities in other Member States. The focus will be on the rules and principles which are directly or indirectly relevant to the cross-border access to public benefits.

\section{Economic Residents}

For the purpose of this book four categories of beneficiaries of free movement of persons within the European Community have been identified: economic residents, non-economic residents, non-residents and third country nationals. ${ }^{2}$ This section examines the category of economic residents which consists of those Community citizens who stay or have acquired the right to reside in other Member States on the basis of Articles 39 or 43 of the EC Treaty. The discussion primarily focuses on the rules and principles governing the rights of Community workers and their family members

\subsection{Free Movement of Workers: a Brief History}

For a proper understanding of the Community rules governing freedom of movement of workers, it is necessary to establish why Community law provides for this freedom. It is generally claimed that Article 48 (now 39) was included in the original EEC Treaty with a view to realising freedom of movement for the production factor labour. ${ }^{3}$ In support of this view,

\footnotetext{
Martin/Guild, Free Movement of Persons (1996); O'Leary, The Evolving Concept of Community Citizenship - From the Free Movement of Persons to Union Citizenship (1996); Garrone, La Libre Circulation des Personnes - Liberté de Mouvement, Egalité, Liberté économique - Etude de Droit communautaire et suisse (1995); Handoll, Free Movement of Persons under EC Law (1995); Schermers et al (Eds), Free Movement of Persons in Europe (1993) and Hartley, Free Movement of Persons, in: Green et al, The Legal Foundations of the Single European Market (1991) Chapters 813.

2. For a brief description of the various categories see Chapter 1 Section 3.1.

3. See e.g. Wohlfahrt et al, Die Europäische Wirtschaftgemeinschaft - Kommentar zum Vertrag (1960) at pp.150-151; Plender, An Incipient Form of European Citizenship, in: Jacobs (Ed.), European Law and the Individual (1976) pp.39-53, at p.39; Holloway, Social Policy Harmonisation in the European Community (1981) at p.235; Verschueren, Internationale Arbeidsmigratie (1990) at pp.236-237; Vonk, De Coördinatie van Bestaansminimumuitkeringen in de Europese Gemeenschap (1991) at p.248 and Evans, Union Citizenship and the Constitutionalization of Equality in EU Law, in: La Torre, European Citizenship: An Institutional Challenge (1998) pp.267-291, at p.270.
} 
reference is often made to the Spaak-report. This report was based on macro-economic theories which demonstrated that integration of national markets could best be achieved if both products (goods, services) and production factors (labour, capital) could move freely across inter-State borders. ${ }^{4}$ The Spaak-report, however, merely served as the basis for the 1956-1957 Treaty negotiations ${ }^{5}$ and during the deliberations in Val Duchesse most States expressed objections to the introduction of free labour mobility. At the time, western European countries had virtually full control over immigration and admission to their labour markets. Most of them regulated migration in accordance with the needs of their national labour markets. ${ }^{6}$ Foreign workers were invited merely to fill the job vacancies for which no national workers were available; they were not entitled to bring their family members and after the "job had been done" the workers were supposed to return to their country of origin. During their "visit" foreign workers did not enjoy a strongly protected legal status. The guestworkers from abroad had been invited to fuel the economy of the host State; they were not supposed to benefit from, or to

\footnotetext{
4. The realisation of a free movement of goods, services and producers was expected to lead to a restructuring and relocation of the production process. In order to avoid unemployment in certain regions and to provide producers with the labour they needed, workers should have the possibility of moving to the places where their labour was required. Rapport des Chefs de Délégation aux Ministres des Affaires etrangères (1956) at pp.17-18; Braeutigam, Das Problem des "gemeinsamen" Marktes unter sozialem Aspekt, in: Aussenwirtschaft (1956) pp.170-189; Driver, Die Integration des europäischen Arbeitsmarktes (1962) pp.170-189 and Verschueren (1990) supra footnote 3, at pp.236237.

5. It is to be noted though that the theoretical justifications for freedom of movement of the production factor labour were not widely accepted. See Boni, Freizügigkeit und Integration - Struktur und integrationspolitike Bedeutung der Arbeitsmarktverflechtung zwischen den Mitgliedstaaten der Europäischen Wirtschaftsgemeinschaft (1976) at p.221. Also the drafters of the Spaak-report had doubts: "On ne doit pas surestimer l'ampleur des mouvements de main-d'oeuvre qui se produiraient dans un marché commun entièrement libre. On connaît la rétitence aux changements de métier ou de résidence, fût-ce à l'intérieur d'un meme pays. ... En outre, on reconnaît de plus en plus que l'émigration ne constitue pas une solution économique pour un pays surpeuplé, car elle risque de proter essentiellement sur la population active, et conséquent, d'acrroître la proportion de population á charge. Pour toutes ces raisons, la tendance la plus récente est aux efforts de développement et de création d'emploi sur place". Rapport des Chefs de Délégation aux Ministres des Affaires etrangères (1956) at p.88.

6. Foreign workers were only admitted upon the grant of a labour permit and a residence permit. For further details see e.g. International Labour Office, Analysis of the Immigration Laws and Regulations of Selected Countries (1954); Hampel, Einwanderungsgesetzgebung und innereuropäische Wanderung - Die rechtlichen Regelungen der Zulassung ausländischer Arbeitnehmer in Fünfzehn europäischen Staaten (1957) and Reisner, National Regulation of the Movement of Workers in the European Community, in: AJCL (1964) pp.360-384.
} 
become a burden, on the welfare state. ${ }^{7}$ The States feared free labour mobility; a liberalisation of labour market admission rules ran counter to the interests of most States. ${ }^{8}$ Among the States present in Val Duchess only Italy had a concrete interest in introducing a free movement for workers, seeing the introduction of a free labour mobility as a means to solving its unemployment problem. ${ }^{9}$

In the end the Member States did agree "to bring about, by progressive stages, freedom of movement". ${ }^{10}$ The wording of Article 39 EC, however, suggests that this provision has never been included in the Treaty with a view to actually realising free labour mobility. Two examples illustrate the point. First, if the Member States had really wanted free factor mobility, Article 39 should have provided for free movement rights for all workers established in the Member States regardless of their nationality. ${ }^{11}$ Article 39 merely speaks of "workers of the Member States", but the absence of an explicit reference to Member State nationality does not imply that the drafters wished to leave room to include third country nationals in the free movement regime. The omission of a reference to

7. On the notion of "guestworker" see in particular Böhning, Böhning, The Migration of Workers in the United Kingdom and the European Community (1972) and Garth, Migrant Workers and Rights of Mobility in the European Community and the United States: A Study of Law, Community and Citizenship in the Welfare State, in: Cappelletti et al, Integration Through Law - Europe and the American Federal Experience (1986) Vol.I, pp.85-163, at pp.90-96.

8. Prior to the negotiations on the EEC Treaty, various attempts to liberalise labour market admission rules in western Europe had already been made within the context of international organisations such as the OECD and the Council of Europe. See e.g. Delperee, De Gemeenschappelijke Arbeidsmarkt en het Vrije Arbeidskrachtenverkeer, in: Arbbl (1956) p.177-205; Lannes, International Mobility of Manpower in Western Europe: II, in: ILRev (1956) pp.135-149; Hanekuijck, Het Recht op Vrijheid van Migratie (1957); Schieffer, De Europese Arbeidsmarkt. Het Vrije Verkeer en de Migratie van Werknemers (1961); Driver (1962) supra footnote 4; Schmidt, Die arbeitsrechtliche und sozialversicherungsrechtliche Stellung der europäischen Wanderarbeiter im Rahmen der europäischen Wirtschaftsgemeinschaft (1963); Schulz, Freier Arbeitsmarkt und Niederlassungsfreiheit in der Europäischen Wirtschaftsgemeinschaft - Unter besonderer Berücksichtigung der Grenz- und Gastarbeitnehmer (1967); Troclet, Europees Sociaal Recht - Institutioneel Kader, Rechtsinstrumenten, Sociale Problemen en hun Oplossing (1970) and Boni (1976) supra footnote 5.

9. It was also Italy which took most of the initiatives during the Treaty negotiations as regards the free movement of workers. On the role of Italy see Romero, Migration as an Issue in European Interdependence and Integration: the Case of Italy, in: Milward et al (Eds), The Frontier of National Sovereignty - History and Theory 1945-1992 (1993) pp.33-58. This is not to say that all other States objected to the free movement of workers. The Netherlands, for instance, did favour such a freedom of movement. On the position which the various Member States' delegations took during the negotiations see also Renardel de Lavalette, Facetten van het Vrij Verkeer van Werknemers in de Europese Gemeenschappen, in: SMA (1983) pp.213-227.

10. Article 40 (formerly 49) E(E)C.

11. Compare Hoogenboom, Free Movement and Integration of Non-EC nationals and the Logic of the Internal Market, in: Schermers et al (Eds), Free Movement of Persons in Europe (1993) pp.497511 and Hedemann-Robinson, Third Country Nationals, European Union Citizenship and Free Movement of Persons: $\Lambda$ Time for Bridges Rather than Division, in: YEL (1997) pp.321-362. 
Member State nationality is explained by the fact that the Member States did not wish to include all nationals, and especially those from the overseas territories, in the free movement regime. ${ }^{12}$ Second, a free mobility of the production factor labour which was practical and relevant would have required a right for individuals to look for work in other Member States. The grant of such a right was discussed during the negotiations, ${ }^{13}$ but in the end it was rejected. Article 39(3) EC merely speaks of a right to move to other States "in order to accept offers of employment actually made". Presumably, the majority of the States held to the view that labour mobility should continue to be determined by the needs of national labour markets. ${ }^{14}$

12. The drafters of the Spaak-report had intended to include third country nationals established within the Community in the scope of the free movement of workers. Rapport des Chefs de Délégation aux Ministres des Affaires etrangères (1956) at pp.88-91. Residence in the Community rather than the nationality of a Member State would determine who could benefit from this freedom of movement. Verschueren (1990) supra footnote 3, at pp.302-303. By analogy with the free movement of goods and services a common policy for all workers in the Community, irrespective of their nationality, would have been envisaged. See e.g. Plender, International Migration Law (1988) at pp.197-198 and Plender, Competence, European Community Law and Nationals of Non-Member States, in: ICLQ (1990) pp.599 et seq. See further also Lanfranchi, Droit communautaire et Travailleurs migrants des Etats tiers - Entrée et Circulation dans la Communauté européenne (1994) at pp.20-33. The reports of the Treaty negotiations in Val Duchessse (hereinafter referred to by their MAE-numbering (Ministres des Affaires Etrangères)) strongly suggest, however, that the Member States' delegations did not support the views of the drafters of the Spaak-report. All the drafts for the article(s) on the free movement of workers which were presented during the negotiations spoke of a free movement of "travailleurs nationaux". See e.g. MAE 175/56 and MAE 437/56. In a footnote in MAE $88 \mathrm{f} / 57 \mathrm{dvl}$ it was stated that the extent to which the term "travailleurs nationaux" should be altered should be considered in order to deal with some problems concerning the overseas countries and territories. In MAE $653 / 57$ it was further held that a general provision should be drafted with a view to defining the term. It was only in the last draft that the term "travailleurs nationaux" was replaced by the term "travailleurs des Etats membres". See MAE 776 f/57 mts. Article 135 (now 186) was inserted which provides that freedom of movement for workers from overseas countries and territories shall be governed by agreements to be concluded with the unanimous approval of Member States. On the basis of the above mentioned texts of the documents no definite conclusion can be drawn as to the precise motives of the Member States delegations, but the documents do suggest that the term "workers of the Member States" was used in order to leave the option open to exclude some nationals of the Member States from the oversees countries and territories from the free movement of workers. Compare also van der Mei, The Bosman Case and the Legal Status of Third Country Nationals under European Community Law, in: ASICL, Proceedings of the 8th Annual Conference (1996) pp.144-158, at p.153.

13. See e.g. MAE 437f/56 and MAE 474f/56.

14. A third indication that the drafters were not driven by the goal to realise a free mobility for the production factor labour can be found in Article 39(3)d EC which states that workers shall have the right to remain in the territory of a Member State after having been employed in that State under conditions to be determined by the European Commission. Compare e.g. Groenendijk, De Betekenis van Artikel 39 EG-V.erdrag voor Werknemers uit Landen buiten de Europese Unie, in: Fernhout (Rcd.), Dertig Jaar Vrij Verkeer van Werknemers (1999) pp.35-49, at p.38. 
Thus, it does not seem very likely that the Member States which signed and ratified the EEC Treaty ever intended to translate the theoretical notion of a free factor mobility into practical reality. In fact, when they included Article 39 in the Treaty, the six States did not seem to have had any theoretical notion in mind. Probably, Article 39 was not much more than the product of a political compromise which implied that "the five" would gradually soak up the Italian labour surplus during a transitional period of twelve years. ${ }^{15}$

As it stands today, Community law on the free movement of workers took shape, and was only given a more defined objective, during the 1958-1970 transitional period. The 1960s were the heyday of the guestworker-system and the prospects for implementing Article 39 in time through measures based on Article 40 (fomerly 49) E(E)C did not seem too promising. ${ }^{16}$ Nonetheless, the Community institutions managed to realise the free movement of workers two years before the end of the transitional period when they adopted Regulation No 1612/68 and Directive No 68/360. In addition, the institutions were able to give this freedom a much broader meaning than the Member States had had in mind in the late 1950s. Many factors may account for this progress, but the most important is that Article $39 \mathrm{EC}$ was implemented during a time of virtual full employment. In the course of the 1960s, economic growth had largely solved the Italian unemployment problem. Italy had gradually become a labour-importing country itself; like the other Member States, it started to recruite workers from "third" countries. Labour mobility between Member States and third countries increased considerably, whilst labour mobility of European workers between the Member States virtually came to a standstill. As a result, Member States no longer had strong motives for

\footnotetext{
15. Compare Romero (1993) supra footnote 9, at p.54.

16. And indeed, the negotiations in the Council proved to be difficult. The free movement of workers was realised in three stages. See Regulation No 15/61 (OJ 1961 1073), Regulation No 38/64 (OJ 1964 965) and Regulation No 1612/68 (OJ 1968 L 257). For descriptions of the realisation of the free movement of workers during the 1960s see inter alia Heynig, Freizügigkeit in der Europäischen Wirtschaftgemeinschaft Endgültig Hergestellt, in: BB (1968) pp.337-339; Miller, Völlige Freizügigkeit der Arbeitskräfte in den Europäischen Gemeinschaften, in: BArbB1 (1968) pp.590-594: Miller, Freizügigkeit in der EWG, in: der Landskreis (1968) pp.56-58; Flath, Noch Einmal: Freizügigkeit in der EWG, in: der Landskreis (1968) pp.342-344; Di Stefano, La Libre Circulation des Travailleurs dans la Communauté économique européenne (1968); Lyon-Caen, La Libre Circulation des Travailleurs (Règlement et Directive des Communautés européennes du 15 octobre 1969), in: Juris-Classeur Periodique (1969) nr.2222; Macheret, L'Immigration étrangère en Suisse a 1'Heure de l'Integration Européenne (1969); Maertens, De Geografische Mobiliteit van Werknemers in de Europese Gemeenschap (1969); Pabon, Het Vrije Verkeer van Werknemers, in: SMA (1969) pp.83-95; van Look, Het Vrije Verkeer van Werknemers in de EEG nu een Realiteit, in: SEW (1969) pp.274-288; Charalambis, Die Arbeitnehmer im EWG-Recht (1970) and Brüggemann, Die Freizügigkeit der Arbeitnehıner im Bereich der Europäischen Gemeinschaften (1973).
} 
obstructing or delaying the realisation of free movement of workers provided third country nationals ${ }^{17}$ and workers from overseas territories $^{18}$ would not be included in the free movement regime. The mobility of European workers was no longer socially and politically dangerous. ${ }^{19}$ This development in the labour market paved the way for the European Commission which, through its right of initiative, could take the lead in the legislative process. From the beginning the Commission had rejected the view that the free movement of workers should be conceived in macro-economic terms of free movement of the production factor labour. Possible problems of unemployment should not be solved by promoting labour mobility, but rather through other means such as the free movement of capital and a regional policy. Work should be brought to the unemployed and not the other way round. ${ }^{20}$ In the Commission's view another role was envisaged for the free movement of persons. Freedom of movement should be seen as a personal freedom, a fundamental individual right for European citizens to choose the place where they wish to work. $^{21}$ With less opposition from the Member States, the Commission was able to have the free movement of workers realised by the Council and to give it an interpretation which went beyond the strict wording of Article 39 EC. In the preamble to Regulation No 1612/68 freedom of movement was referred to as a fundamental right for workers which may be exercised in "freedom and dignity" and which includes the elimination of all obstacles to "the worker's right to be joined by his family and the conditions for the integration of that family into the host country". ${ }^{22} \mathrm{~A}$

17. See Articles 1(1) and 7(1) of Regulation No 1612/68 which, unlike Article 39 of the Treaty, explicitly state that only nationals of the Member States have the right to work in other Member States. See further van der Mei (1996) supra footnote 12, at pp.152-154. The creation of a genuine common labour market in which third country nationals could also move freely would have required the establishment of a common policy regarding the admission of third country workers. Such a common market and common policy was never (seriously) considered during the 1960s. As regards workers, only a free trade area was envisaged. Hartley, The International Scope of the Community Provisions Concerning Free Movement of Workers, in: Jacobs (Ed.), European Law and the Individual (1976) pp.19-37, at p.33.

18. The agreements referred to in Article $186 \mathrm{EC}$ (the former $135 \mathrm{E}(\mathrm{E}) \mathrm{C}$ - see footnote 12 above) have never been concluded. See also Article 42(3) of Regulation No 1612/68 where it is stated that workers from the overseas countries and territories could not benefit from the free movement of workers. Quite difficult questions arise as to when nationals of the Member States are to be regarded as workers from the overseas territories. See e.g. Verschueren (1990) supra footnote 3, at pp.309310; Mortelmans/Temmink, Het Vrije Personenverkeer tussen de Nederlandse Antillen en Aruba en de Europese Gemeenschap, in: Justicia - TvAR (1992) Vol.1 and Hartley, EEC Immigration Law (1978) pp.77-80

19. Romero (1993) supra footnote 9, at p.55.

20. See Commission Recommendation and Opinion of 7 July 1965 (OJ 1965 2293).

21. Evans, European Citizenship, in: MLRev (1982) pp.497-515, at pp.498-500

22. Sce the fifth indent of the preamble to Regulation No 1612/68. 
right to look for work was (informally) recognised ${ }^{23}$ and workers were granted a right to equal treatment as regards vocational training, ${ }^{24}$ social advantages ${ }^{25}$ trade union rights ${ }^{26}$ and public housing. ${ }^{27}$ In addition, family members were given the right to reside with the worker in the host State $^{28}$ and children were granted the right to gain access to education. ${ }^{29}$

Shortly after the adoption of Regulation No 1612/68 and Directive No 68/360 the Vice-President of the European Commission referred to the free movement of workers as an "embryonic form of European Citizenship". ${ }^{30}$ This notion of citizenship was vague and ill-defined but it did reflect two factors which have been decisive for the realisation of the free movement of workers during the 1960s and have influenced the development of this freedom of movement ever since. First, the use of the term "citizenship" underlines that the free movement of workers is not to be conceived in macro-economic terms of a free movement for the production factor labour. Rather, it is seen as a fundamental individual right to work in other Member States for all nationals of the Member States. The Court of Justice, which has largely been responsible for the further development of the free movement of workers since the early 1970s, has frequently stressed the fundamental nature of this individual freedom and therefore interpreted Article $39 \mathrm{EC}$ and provisions of secondary legislation broadly. Second, the fact that reference was made to an "European" citizenship underlines the position of third country workers. The main

\footnotetext{
23. The right to look for work was not mentioned in the Regulation itself; it was only recognised in the minutes of the Council meeting of 15 October 1968 at which Regulation No 1612/68 was adopted. The minutes contained a Declaration in which it was stated that: "Nationals of a Member State as referred to in article 1 (of Directive 68/360) who move to another Member State in order to seek work there shall be allowed a minimum period of three months for the purpose; in the event of their not having found employment by the end of that period, their residence in the territory of this second State may be brought to an end. However, if the above-mentioned persons should be taken charge of by national assistance (social welfare) in the second State during the aforesaid period they may be invited to leave the territory of this second State". The conditions laid down in this declaration were subsequently implemented in the legislation of many Member States. Vonk (1991) supra footnote 3, at p.272 and Hartley, EEC Immigration Law (1978) at p.193.

24. Article 7(3) of the Regulation No $1612 / 68$.

25. Article 7(2) of Regulation No $1612 / 68$.

26. Article 8 of Regulation No $1612 / 68$.

27. Article 9 of Regulation No $1612 / 68$.

28. Article 10 of Regulation No $1612 / 68$.

29. Article 12 of Regulation No $1612 / 68$.

30. Levi-Sandri, Free Movement of Workers in the European Community, in: Bull.EC (1968) 11, at p.5. See further also Plender (1976) supra footnote 3, at p.40. The reference to European Citizenship was not wholly new. In 1961 the European Commission had already held that the right to work in other Member States granted by Article 39 EC was to be regarded as "le premier aspect d'une citoyenncté curopćenne". Debs. EP no.48, 135, 22 November 1961.
} 
concern of the Member States in the 1960s was to secure their power to regulate the immigration of guest workers from third countries. The free movement of workers could only be realised because third country nationals were excluded from the benefits of free movement of workers and ever since no attempts have been made to bring them into the scope of the free movement regime. ${ }^{31}$

\subsection{Community Workers}

\subsubsection{Right to Work}

The main purpose of Article $39 \mathrm{EC}$ is to enable Community citizens to take up and to pursue economic activities as employed persons throughout the Community. ${ }^{32}$ This right to work in other ${ }^{33}$ Member States ${ }^{34}$ has been interpreted broadly by the Court. The right is legally enforcable ${ }^{35}$ and, notwithstanding the text of Article 39(3) EC, it encompasses a Treaty-based right to look for work in other Member States. ${ }^{36}$ In see-

31. See further Section 5 .

32. Compare Case 143/87 Stanton [1988] ECR I-3877 at 13; Case C-415/93 Bosman [1995] ECR I4921 at 94 and Case C-18/95 Terhoeve [1999] ECR I-345 at 37.

33. Article $39 \mathrm{EC}$ only grants Community citizens the right to take up employment in other Member States. Community law does not apply to "purely internal situations" which have been defined as cases in which the activities "are confined in all respects within a single Member State". See e.g. Case C-41/90 Höfner [1991] ECR I-1979 at 37 and Case C-332/90 Steen [1992] ECR I-341 at 9 Community citizens can only invoke Article 39 EC against their own Member States after they have made use of the right to move to other States. See e.g. Case C-419/92 Scholtz [1994] ECR I-505; Case C-370/89 Singh [1992] ECR I-4625 at 21 and Case C-107/94 Asscher [1996] ECR I-3089 at 34 The requirement of an "interstate element" may lead to so-called reverse discriminations which occur when Member States treat their own nationals less favourably than nationals of other Member States. See further Section 7.4 of the present Chapter.

34. The territorial scope of the free movement of workers is in principle limited to the territory of the Member States. Article 299 (formerly 227) EC. See further Martin/Guild (1996) supra footnote 1, at pp.48-49 and Hartley (1976) supra footnote 17. This does not imply, however, that Article 39 EC cannot have effect outside the Community. It is settled case-law that Community law may apply to activities pursued outside the territory of the Community as long as the employment relationship retains a "sufficiently close link with the Community". See Case 237/83 Prodest [1984] ECR 3153 at 63 and Case C-214/94 Boukhalfa [1995] ECR I-2253 at 15. On this requirement of a "sufficiently close link" see e.g. Lhoest, Annotation Boukhalfa, in: CMLRev (1998) pp.247-267.

35. Article 39 produces direct effect. Case 41/74 Van Duyn [1974] ECR 1337 at 6-7.

36. Community citizens are entitled to stay in other Member States for "a reasonable period of time" in order to apprise themselves of offers of employment and to take the necessary steps in order to be engaged. Case C-292/89 Antonissen [1991] ECR I-745 at 21. See also Case C-271/91 Tsiotras [1993] ECR I-2925 and Case C-344/95 Commission v Belgium [1997] ECR I-1035. The duration of the right 
king $^{37}$ and accepting employment, Community citizens are to be treated equally by governmental organisations, private bodies such as the $\operatorname{bar}^{38}$ and sports associations ${ }^{39}$ which regulate certain economic activities in a collective manner, and individual ${ }^{40}$ employers. ${ }^{41}$ Once employed in another State, Community citizens must be treated equally as national workers in all matters related to employment. ${ }^{42}$ Both direct and indirect ${ }^{43}$ discri-

to stay is extended for as long as job-seekers provide evidence that they are still seeking employment and that they have genuine chances of finding employment. Case C-292/89 Antonissen [1991] ECR I-745 at 21. In Antonissen the Court held that the declaration which the Council had adopted in 1968 (see above Section 2.1 footnote 23) had no legal significance and that the three month period mentioned in the declaration therefore could not be decisive. Case C-292/89 Antonissen [1991] ECR $\mathrm{I}-745$ at 18 . On (this judgment and) the right to look for work see e.g. Verschueren, Vrij Verkeer van Werkzoekenden, in: MR (1992) pp.15-19 and Badoux, Dertig Jaar Vrij Verkeer van Personen, in: Fernhout (Red.), Dertig Jaar Vrij Verkeer van Werknemers (1999) pp.13-24, at pp.14-16.

37. Community citizens enjoy equality of treatment with nationals of the host State in all matters related to looking for work. In particular, they enjoy the same assistance from employment offices. See Article 5 of Regulation No 1612/68. Unemployment benefits, however, fall outside the field of access to employment in the strict sense. Case C-278/94 Commission v Belgium [1996] ECR I-4307 at 39

38. See e.g. Case 71/76 Thieffry [1977] ECR 765.

39. See e.g. Case 36/74 Walrave [1974] ECR 1405 and Case C-415/93 Bosman [1995] ECR I-4291.

40. Case C-281/98 Angonese [2000] ECR I-0000 at 36. See further van der Steen, Horizontale Werking van de Vier Vrijheden en van het Discriminatieverbod van Artikel 12 EG, in: NTER (2001) pp.4-9. Prior to Angonese the horizontal effect of Article $39 \mathrm{EC}$ was still quite controversial. See e.g. Zuleeg, in: Groeben et al (Eds), Kommentar zum EWG-Vertrag (1991) at pp.170 et seq and Durand in: Mégret et al (Eds), Commentaire Mégret Le Droit de la CEE (1992) at pp.60 et seq.

41. The prohibition of discrimination on grounds of nationality does not only apply to rules or provisions which wholly exclude non-nationals from certain activities but also to rules which reserve a certain number of positions to nationals of the host State. Compare the French Seamen case in which the Court held that a French rule which reserved $75 \%$ of the jobs on board French fishing boats to French nationals was contrary to Article 39 EC. Case 167/73 Commission v France [1974] ECR 359. Further, the prohibition does not only apply to legislative rules but also to administrative practices. Case C-185/96 Commission v Greece [1998] ECR I-1095 at 24. Equality of treatment must further be guaranteed in, or by, collective agreements concluded between social partners. Discriminatory clauses in such agreements are null and void. See Article 7(4) of Regulation No 1612/68 and Case C-15/96 Schöning-Kougebetopoulou [1998] ECR I-47. Finally, Article 39 EC can also be invoked by employers. Case C-350/96 Clean Car [1998] ECR I-2521 at 19.

42. Article 7(1) specifies that the right to equal treatment applies to remuneration, dismissal and in case of unemployment, reinstatement and re-employment. See further Case 15/69 Ugliola [1969] ECR 363 (disadvantages resulting from obligations to fulfil military service); Case 44/72 Marsman [1972] ECR 1243 (protection against dismissal); Case 152/73 Sotgiu [1974] ECR 153 (seperation allowances); Case 225/85 Commission v Italy [1987] ECR 2625 (protection and aspects of job security like the duration and extension of labour contracts); Case 33/88 Allué [1989] ECR 1591 (employment contracts of limited duration); Joined Cases C-259/91, C-331/91 and C-332/91 Allué II [1993] ECR I-4309 (idem); Case C-272/92 Spotti [1993] I-5185 (idem); Case C-90/96 Petrie [1997] ECR I-6843 (fulfilment of specific tasks) and Case C-35/97 Commission v France [1998] ECR I5325 (supplementary pension rights in cases of early retirement). Member States cannot discriminate against nationals of other Member States with regard to conditions of work by invoking article 39(4). Furthermore, Article 8 of the regulation provides for a right to equal treatment as regards membership of trade unions and the exercise of trade union rights (see e.g. Case C-213/90 ASTI [1991] ECR 
mination on grounds of nationality are prohibited. Even nationality-neutral rules which hamper the right to work in other Member States are said to be caught by Article 39. ${ }^{44}$ The public service exception contained in Article 39(4) EC has been interpreted narrowly to allow Member States to exclude nationals of other Member States only from certain posts in the public service. $^{45}$

\subsubsection{Right to Reside}

Community citizens who have made use of their right to take up employment in another Member State may become entitled to a whole set of corollary rights. The first is a right to establish residence in the Member State concerned. The right of residence is based on Article 39(3) EC; the details concerning the exercise of the right, and the administrative formalities to be fulfilled, are set out in Directive No 68/360. ${ }^{46}$ The right to

I-3507) and vocational training (see Article 7(3) of Regulation No 1612/68).

43. On the concepts of direct and indirect discriminations on grounds of nationality see Sections 7.1 and 7.2 of the present Chapter.

44. See e.g. Case C-415/93 Bosman [1995] ECR I-4291 and Case C-18/95 Terhoeve [1999] ECR I345. See further Section 7.3.

45. Once Community citizens have been appointed to public service posts of another Member State, they can be classed as workers and enjoy the right to equal treatment. The very fact that nationals of another Member State have been appointed shows that the interests which may have justified an exception to the free movement of workers and the principle of non-discrimination are presumably not present. Case 152/73 Sotgiu [1974] ECR 153 at 4 . On the status of Community workers employed in the public sector see e.g. van der Steen, Vrij Verkeer van Overheidswerknemers en CAO's in de Publieke Sector, in: SMA (1998) pp.484-486. See further also Section 7.1.

46. The right is evidenced by a document entitled "Residence Permit for a National of a Member State of the EEC". See Article 4 of Directive No 68/360. This residence card only has declaratory effect; the right to reside itself follows directly from the Treaty. Case $48 / 75$ Royer [1976] ECR 497 at 31-33; Case 8/77 Sagulo [1977] ECR 1495 at 8 and Case 157/79 Pieck [1980] ECR 2171 at 13. In order to become entitled to the residence card workers must produce a valid passport or identity card and a document proving that they have found employment. See Article 4(3) of Directive No 68/360. The passport or identity card must be valid (Case C-68/89 Commission $v$ the Netherlands [1991] ECR I-2637 at 15), but it is not required that the passport or identity card entitles holders to leave the territory of the issuing Member State (Case C-376/89 Giagounidis [1991] ECR I-1069 at 15 and 19). The residence card is valid throughout the territory of the host State. Article 6(1) of Directive No 68/360. According to Article 9, the residence card can be obtained or renewed free of charge or on payment of an amount not exceeding the dues and taxes charged for the issue of identity cards to nationals. Completion of the formalities for obtaining the residence card do not hinder the right to start employment. See Article 5. Member States are entitled to require from nationals of other Member States to report their presence to the competent authorities in order to obtain knowledge of population movements in their territory. See Article 8(2) and Case 118/75 Watson [1976] ECR 1185 at 18-19. A period of three days is too short though. Case C-265/88 Messner [1989] ECR 4209 at 912. Member States are entitled within certain limits to impose penalties for the non-fulfilment of administrative formalitics. See Case 118/75 Watson \& Bclmann [1976] ECR 1185; Casc 8/77 Sagulo 
reside may be temporary or permanent in nature. Workers who are employed for less than a year have the right to reside in the host State for the duration of the employment. ${ }^{47}$ Community workers who have found work which is expected to last for more than a year obtain the right to reside in the Member State of employment for five years. If after five years workers are still in employment, they obtain the right to reside in the host State permanently. ${ }^{48}$ Workers who voluntarily give up employment lose the right to reside in the host State; ${ }^{49}$ involuntary unemployment does not end the right of residence. ${ }^{50}$ Community workers who definitively have ended their working-career either because of permanent incapacity or retirement formally lose the right to reside in the host State as a Community worker, although they may become entitled to the socalled "right to remain". 51

[1977] ECR 1495; Case 157/79 Pieck [1980] ECR 2171; Case C-265/88 Messner [1989] ECR 4209; Case C-363/89 Roux [1992] ECR I-273 and Case C-24/97 Commission v Germany [1998] ECR I2133

47. Directive No $68 / 360$ makes a distinction between workers who have found employment which is not expected to exceed three months and workers who have an employment contract for more than three months but less than one year. Just as frontier workers and seasonal workers working for less than three months, the former may work without having to obtain the residence card referred to in the previous footnote. See Article 8 of Directive No 68/360. Workers who have found employment for a period between three and twelve months are entitled to a residence card which may be limited to the duration of the expected period of employment. Article 6(3).

48. The right to reside may not depend on possession of a residence card (see supra footnote 46), but the wording and objective of Directive No 68/360 suggest that the right to reside will not be lost as as long as workers hold such a card. The residence card referred to in the previous footnotes must be valid for five years and be automatically renewable. Article 6(1)b of Directive No 68/360. The residence card, and with that the right to reside, remains valid when workers become involuntarily unemployed. Article 7(1). Thus, workers who have found employment for more than one year and who become unemployed against their will, remain entitled to reside as workers in the host State for at least five years. After the expiration of this period the residence card is in principle automatically renewable. In case where workers have been unemployed for twelve consecutive months at the moment of renewal of their card, the new residence card may be limited to a period of twelve months. Article 7(2). Basically, workers who have found employment in another Member State for more than one year, are ensured of a right to reside in that Member State for at least six years. The workers become entitled to reside permanently in the host State if at the end of the sixth year they are (still) in employment.

49. Article 7(1) and (2) of Directive No 68/360 (a contrario). This is different as regards workers who have voluntarily given up up employment with a view to taking up studies which are in some way linked to the previous employment. See Case 39/86 Lair [1988] ECR 3161; Case 197/86 Brown [1988] ECR 3205; Case C-357/89 Raulin [1992] ECR I-1027 and Case C-3/90 Bernini [1992] ECR I-1071. On this category see in particular Chapter 5 Section 3.2.3.

137. Case 293/83 Gravier [1985] ECR 293 at 19-25. 


\subsubsection{Right to Equal Treatment in Matters not Related to Employment}

In addition to a right of residence, employment in another Member State may entitle Community citizens to equal treatment rights in areas which are not or are only tenuously related to the employment issues expressly mentioned in Article 39(2) EC. Regulation No 1612/68 provides for equality of treatment as regards public housing (Article 9), ${ }^{52}$ fiscal advantages $^{53}$ and social advantages (Article 7(2)). ${ }^{54}$ Most importantly, the Court has given a very broad interpretation of the concept of "social ad-

52. On this provision see Case C-305/87 Commission v Greece [1989] ECR 1461. Equality of treatment as regards housing also extends to public loans or public rent allowances. See Case 63/86 Commission v Italy [1988] ECR 29. The latter case concerned self-employed persons and the judgement was based on Article 52 (now 43) EC. The rationale of the judgment, however, applies mutatis mutandis to Community workers. See further Hartley (1991) supra footnote 1, at pp.149-150 and Jørgensen (1996) supra footnote 1, at pp.235-238.

53. In recent years the Court has increasingly been confronted with cases concerning the right to equal treatment of (self-)employed persons in fiscal matters. Most of these cases were not decided on the basis of Article 7(2) of Regulation No 1612/68, but on the provisons of the Treaty itself. See e.g. Case C-175/88 Biehl [1990] ECR I-1779; Case C-204/90 Bachmann [1992] ECR I-249; Case C112/91 Werner [1993] ECR I-4017; Case C-279/93 Schumacker [1995] ECR I-225; Case C-80/94 Wielockx [1995] ECR I-2493; Case C-107/94 Asscher [1996] ECR I-3089; Case C-336/96 Gilly [1998] I-2793; Case C-251/98 Baars [2000] ECR I-0000 and Case C-87/99 Zurstrassen [2000] ECR I-0000. On this case-law see e.g. Rossi, The Taxation Aspects of the Free Movement of Persons, in: Carlier/Verwilghen, Thirty Years of Free Movement of Workers in Europe (2000) pp.127-142; van der Woude, Belastingen Begrensd: De Doorwerking van het Discriminatieverbod en de Richtlijnen van de EG op Nationale Belastingen (2000); Vanistendael, The Consequences of Schumacker and Wielockx: The Steps Forward in the Tax Procession of Echternach, in: CMLRev (1996) pp.255-269; Buys, Met het EG-Recht Strijdige Belastingstelsels en de Rechtsbescherming van de Burger (1994) and Wouters, The Case-Law of the European Court of Justice on Direct Taxes: Variations Upon a Theme, in: MJ (1994) pp.179-220.

54. Regulation No 1612/68 implements, and determines the scope of, Article 39 EC. The regulation does not create any "new" rights. Compare Case 48/75 Royer [1976] ECR 4875. 


\section{vantages" ${ }^{55}$ The concept covers all rights or benefits}

"which, whether or not linked to a contract of employment, are generally granted to national workers primarily because of their objective status as workers or by virtue of the mere fact of their residence on the national territory and whose extension to workers who are nationals of other Member States therefore seems likely to facilitate the mobility of such workers within the Community". 56

In applying this definition, the Court has classed numerous social security(-like) benefits, ${ }^{57}$ study grants, ${ }^{58}$ benefits to cover funeral expenses, ${ }^{59}$

55. In addition, Article $39 \mathrm{EC}$ guarantees equality of treatment as regards rights or benefits which are essential to the workers' well-being and can be regarded as a corollary of the right to freedom of movement. Case C-334/94 Commission v France [1996] ECR I-1307 at 21. The case concerned French legislation which preserved the right to register maritime pleasure boats to French nationals. In the view of Advocate General Fennelly this right could not be regarded as a social advantage for the purposes of Article 7(2). He argued, however, that Regulation No 1612/68 does not provide for an enumerative lists of rights to equality of treatment and that workers may rely on Article 39 of the Treaty in order to claim rights or benefits which are essential to their well-being and which can be regarded as a corollary to the right to freedom of movement. The Advocate General concluded that the right to register maritime pleasure boats, and more generally opportunities for social and leisure activities, are to be regarded as a corollary to the right to freedom of movement. Opinion of Advocate General Fennelly in Case C-334/94 Commission v France [1996] ECR I-1307 at point 41-44. The Court seemed to support this line of reasoning. Access to leisure activities such as the registration of leisure crafts are a corollary to the right to freedom of movement and thus covered by the Community provisions relating to freedom of movement. See Case C-334/94 Commission v France [1996] ECR I-1307 at 21-22. See also Case C-151/96 Commission v Ireland [1997] ECR I-3327 at 8-11. Further, Community workers may rely on Article 12(1) EC in order to claim equal treatment in cases where no social advantages are asked for. See e.g. Case C-411/98 Ferlini [2000] ECR I-0000 and van der Steen (2001) supra footnote 40.

56. Case 207/78 Even [1979] ECR 2019 at 22: Case C-249/83 Hoeckx [1985] ECR 973 at 20 and Case C-122/84 Scrivner [1985] ECR 1027 at 24. Initially, the Court interpreted the concept of social advantages so as to apply only to benefits connected with employment. Case 76/72 Michel S. [1973] ECR 457 at 9. Two years later, however, the Court gave a much broader meaning to Article 7(2) which was extended to cover all social advantages "whether or not attached to the contract of employment". Case 32/75 Cristini [1975] ECR 1085 at 12-13. This interpretation of the concept of Article $7(2)$ was very far-reaching. It even suggested that the scope of the right to equal treatment would be unlimited: all aspects whether or not connected to the contract of employment seemed to be covered by the concept. This left room for the conclusion that Community workers could also enjoy equality of treatment as regards political rights such as the right to vote and stand as a candidate in elections. In Even, however, the Court took a small step backwards. The concept of "social advantages" does not include rights or benefits which are political in nature and closely linked to the nationality of a State.

57. These include e.g. childbirth loans (Case 65/81 Reina [1982] ECR 33), minimum income benefits for old people (Case 261/83 Castelli [1984] ECR 3199), social assistance(-like) benefits (Case 249/83 Hoeckx [1985] ECR 973 and Case 122/84 Scrivner [1985] ECR 1027), special old-age allowances (Case 157/84 Frascogna [1985] ECR 1739), unemployment benefits (Case 94/84 Deak [1985] ECR 1873; Case 57/96 Meints [1998] ECR I-6689 and Case C-278/94 Commission v Belgium [1996] ECR I-4307) and family benefits (Joined Cases C-245/94 and C-312/94 Hoever [1996] ECR I-4895 and Case C-85/96 Martinez Sala [1998] ECR I-2691).

58. Case 39/86 Lair [1988] ECR 3161 
the right to live together in the host State with an unmarried partner ${ }^{60}$ and the right to use one's own language in Court ${ }^{61}$ as "social advantages". ${ }^{62}$ Virtually all social and economic benefits are covered. The fact that many of the rights or benefits covered by Article 7(2) of Regulation No 1612/68 fall under, or derive from, policy areas which have not as such been brought within the ambit of the Treaty has never been a reason for the Court to deny the application of the right to equal treatment. In determining the scope of this right a functional criterion is to be applied; ${ }^{63}$ equal treatment is guaranteed as regards rights or benefits which may facilitate the right to work in other Member States or promote the integration of the worker into the host State's society.

The right to equal treatment may be broad but it is not unlimited. Political rights such as the rights to vote and to stand as a candidate in elections and certain rights linked to the performance of military servi$\mathrm{ce}^{64}$ fall outside the scope of the provisions on free movement of workers. ${ }^{65}$ In sum, both as workers and residents of the host State, ${ }^{66} \mathrm{Com}-$

59. Case C-237/94 O'Flynn [1996] ECR I-2617.

60. Case 59/85 Reed [1986] ECR 1283

61. Case 137/84 Mutsch [1985] ECR 2681.

62. For an overview of the case law see e.g. O'Keeffe, Equal Rights for Migrants: The Concept of Social Advantages in Article 7(2), Regulation 1612/68, in: YEL (1986) pp.93-123; Jørgensen (1996)

supra footnote 1. Chapter 7; Lippert, Gleichbehandlung bei sozialen Vergünstigungen und Arbeitnehmerfreizügigkeit in der Europäischen Gemeinschaft - Eine Analyse von Art.7 II (EWG) Nr.1612/68 auf der Basis der Rechtsprechung des Europäischen Gerichtshofes (1993) and Allen, Equal Treatment, Social Advantages and Obstacles: In Search of Coherence in Freedom and Dignity, in: Guild (Ed.), The Legal Framework and Social Consequences of Free Movement of Persons in the European Union (1999) pp.31-48.

63. See e.g. Case 9/74 C'asagrande [1974] ECR 773 at 12 and Case C-18/95 Terhoeve [1999] ECR I345 at 33-35/USZ 1999/67 (with annotation van der Mei). See further De Witte, The Scope of Community Powers in Education and Culture in the Light of Subsequent Practice, in: Bieber/Ress (Eds), Die Dynamik des Europäischen Gemeinschaftsrechts (1987) pp.261-181.

64. See e.g. Case 207/78 Even [1979] ECR 2019 (the right of war veterans to early retirement on full pension) and Case C-315/94 de Vos [1996] ECR I-1417 (pension contributions concerning military service).

65. Such political-like rights are not covered by Article 7(2) and cannot, as one may assume, be regarded as a corollary to the right to freedom of movement (see footnote 55 above). The notion of corollary rights to the right to freedom of movement is rather vague. In Commission $v$ France Advocate General Fennelly suggested that the bounds of these rights have to be defined "by reference to the essential human as well as economic needs of those who avail themselves of the primary Treaty right". Opinion of Advocate General Fennelly in Case C-334/94 Commission v France [1996] ECR I-1307 at 42. Under Article 19 of the Treaty, however, Community workers have, as citizens of the Union, the right to vote and to stand as a candidate in municipal elections (Article 19(1)) juncto Council Directive 94/80 - OJ 1994 L 368/38) and elections for the European Parliament (Article 19(2) juncto Council Directive 93/109 - OJ 1993 L 329/34). Community law does not provide for voting rights in elections for national parliaments. See further O'Leary (1996) supra footnote 1 , Chapter 6. 
munity workers have the right to be treated equally with the nationals of the host State. ${ }^{67}$ Community law does not require, however, that they must be treated as though they actually were nationals of the host State

\subsubsection{Status of Community Worker}

All Community citizens have the right to move to other Member States in order to take up employment. However, not all Community citizens who exercise this right are entitled to establish residence or to claim benefits under Article 7(2) of Regulation No 1612/68. In order to become entitled to the full panoply of rights discussed in this section, Community citizens must possess the status of Community worker. In order to avoid Member States excluding certain Community citizens from the provisions on the free movement of workers and the rights provided thereunder, ${ }^{68}$ the Court has consistently held that the concept of Community worker may not be defined by reference to national laws. The concept has a Community meaning. ${ }^{69}$ From the case law, and the rulings in Levin $(1982)^{70}$ and Lawrie-Blum (1986) ${ }^{71}$ in particular, it follows that the status of Community worker ${ }^{72}$ can be obtained by nationals ${ }^{73}$ of the Member

\footnotetext{
66. The rights covered by Article 7(2) do not necessarily have to be enjoyed in the State of employment. For instance, a Member State which gives national workers the opportunity of pursuing vocational training in another Member State by making student financial aid available, must grant such aid under the same conditions to Community workers domiciled in its territory. See Case 235/87 Matteucci [1988] ECR 5589 at 16. Further, temporary employment outside the territory of the host State does not necessarily imply that a worker cannot invoke Article $7(2)$. Case 237/83 Prodest [1984] ECR 3153 at 10.

67. O'Keeffe (1986) supra footnote 62, at p.105.

68. Case 53/81 Levin [1982] ECR 1035 at 11.

69. Case 75/63 Unger [1964] ECR 177 at 22-24 and Case C-27/91 Le Manoir [1991] ECR I-5531 at 7. By stating that the concept has a Community meaning the Court conferred upon itself a "hermeneutic monopoly" to counteract possible unilateral restrictions on the application of rules relatinng to the free movement of workers by the Member States. Mancini, The Free Movement of Workers in the Case-Law of the European Court of Justice, in: Curtin/O'Keeffe, Constitutional Adjudication in European Community and National Law (1992) pp.67-77, at p.68.

70. Case 53/81 Levin [1982] ECR 1035.

71. Case 66/85 Lawrie-Blum [1986] ECR 2121

72. See further Vilá Costa, The General Concept of Worker, in: Carlier/Verwilghen, Thirty Years of Free Movement of Workers in Europe (2000) pp.69-77.

73. The concept of Community worker has a Community meaning, but the question who is to be regarded as a national is to be answered by reference to national law. Case C-360/90 Micheletti [1992] ECR I-4239. See further Declaration No 2 on nationality of a Member State annexed to the Final Act of the Treaty on European Union which states that the question "whether an individual possesses the nationality of a Member State shall be settled solely by reference to the national law of the Member State concerned". In Micheletti the Court also held, however, that in applying their nationality laws, Member States must give due regard to the requirements of Community law. Case
} 
States $^{74}$ who are pursuing effective and genuine economic activities under the direction of an employer established in another Member State and who, in return for their activities, receive a renumeration. ${ }^{75}$ The Court's definition is quite broad. The nature of the work, ${ }^{76}$ the specific features of the employment relationship ${ }^{77}$ and the context ${ }^{78}$ or the sec-

C-360/90 Micheletti [1992] ECR I-4239 at 10. On this rather ambigious observation, the judgment in Micheletti and/or, more generally, the difficult relationship between Community law and nationality law see e.g. Jesserun d'Oliveira, Nationality and the European Union after Amsterdam, in: O'Keeffe/Twomey (Eds), Legal Issues of the Amsterdam Treaty (1999) pp.395-412; O'Leary (1996) supra footnote 1, Chapter 2; Closa, Citizenship of the Union and Nationality of Member States, in: CMLRev (1995) pp.487-519; Hall, Nationality, Migration and Citizenship of the Union (1995) Chapter 3; Evans, Nationality Law and European Integration, in: ELRev (1992) pp.190-215; O'Leary, Nationality Law and Community Citizenship: A Tale of Two Uneasy Bedfellows, in: YEL (1992) pp.353 et seq, Evans/Jesserun d'Oliveira, Nationality and Citizenship, in: Cassesse et al (Eds), Human Rights and the European Community: Methods of Protection (1991) at pp.298-345 and Greenwood, Nationality and the Limits of the Free Movement of Persons in Community Law, in YEL (1987) pp.7 et seq. Germany and the United Kingdom have adopted unilateral declarations in which they define the term "nationals" for purposes of Community law, and the free movement of persons in particular. In Kaur (2001) the Court accepted the validity of the United Kingdom's definitions because ( $i$ ) the other Member States were fully aware of the content of the British declaration and (ii) the declaration did not have the effect of depriving any person of rights guaranteed by Community law. Case C-192/99 Kaur [2001] ECR I-0000 at 23-27.

74. Community workers must be nationals of one of the Member States. A national who died before his country acceded to the Community does not hold the status of worker. Case C-131/96 Romero [1997] ECR I-3659 at 17.

75. The requirements of work, subordination and remuneration were laid down by the Court in Lawrie-Blum. Case 66/85 Lawrie-Blum [1986] ECR 2121 at 17. The additional requirement that the work or the economic activities must also be "effective and genuine" was introduced in Levin. Case 53/81 Levin [1982] ECR 1035 at 17. In Lawrie-Blum the Court also held that Community workers must pursue economic activities "for a certain period of time". The phrase does not seem to have a substantive meaning. Community law does not require that employment contracts must be concluded within a minimum period of time or that a certain period of occupational activity must be completed before a person can invoke the status of worker. On the latter point see Case 39/86 Lair [1988] ECR 3161 at 42 and Case 197/86 Brown [1988] ECR 3205 at 22. The facts that activities are only pursued for a short period of time or that they are perhaps of a non-recurring character relate to the amount of work performed by a person and must be taken into account when establishing the "effective and genuine" or "marginal and ancillary" nature of activities. Case C-357/89 Raulin [1992] ECR I-1027 at 14 .

76. Prostitution, for instance, can be classed as an economic activity. See Joined Cases 115 and 116/81 Adoui and Cornaille [1982] ECR 1665 and in particular the Opinion of Advocate General Capotorti. See further Verschueren (1990) supra footnote 3, at p.288.

77. Joined Cases 389/87 and 390/87 Echternach [1989] ECR 723 (employment for international organizations); Case C-357/89 Raulin [1992] ECR I-1027 at 11 ("on-call contracts") and Case C 337/97 Meeusen [1999] ECR I-0000 (spouse of director and sole shareholder of undertaking).

78. See e.g. Steymann in which the Court held that the mere fact that activities are performed in the context of a community based on religion (in casu the Bagwhan community) does not preclude the possibility that employees can be classed as Community workers. Case 196/87 Steymann [1988] ECR 6159 
tor $^{79}$ in which work is performed are in principle all irrelevant for obtaining the status of Community worker. Furthermore, the Court has given due regard to the growing importance of part-time work and rejected the view that only full-time workers may obtain the status of Community worker. ${ }^{80}$

The concept of Community worker, however, is not unlimitedly broad. Not all part-time workers can claim to be a Community worker. In order to obtain this status a Community citizen must perform "effective and genuine" activities. Activities which are on such a small scale that they have to be regarded as "purely marginal and ancillary" do not suffice for acquiring the status of Community worker. ${ }^{81}$ What precisely is to be understood by "effective and genuine" work is hard to say, but, roughly speaking, one could say that a Community citizen must work at least half of the normal working-hours in a given sector in order to be classed as a Community worker. ${ }^{82}$ Community citizens who do not meet this mini-

79. Professional sports people, for instance, can obtain the status of Community worker. See Case 36/74 Walrave \& Koch [1974] ECR 1405; Case 13/76 Doná [1976] ECR 1333; Case 222/86 Heylens [1987] ECR 4097; Case C-118/91 Bosman [1995] ECR I-4291; Joined Cases C-51/96 and C-191/97 Deliège [2000] I-0000 and Case C-176/96 Lehtonen [2000] ECR I-0000. See further Parret, EGRecht en Sport: Is Sport Anders, in: SEW (2001) pp.53-61 and Misson, The Sporting Side of Community Law, in: Carlier/Verwilghen, Thirty Years of Free Movement of Workers in Europe (2000) pp.79-87.

80. Case 53/81 Levin [1982] ECR 1035 at 16 and Case C-106/91 Ramrath [1992] ECR I-3351 at 25. 81. Ibid, at 17 .

82. Jørgensen (1996) supra footnote 1, at p.31. The Court has never laid down clear criteria for determining how much work has to be done or how many hours must be worked. In Lawrie-Blum and Kempf the Court seems to have accepted that the work of teachers who gave 11 or 12 lessons a week could be classed as "effective and genuine". Case 66/85 Lawrie-Blum [1986] ECR 2121 and Case 139/85 Kempf [1986] ECR 1741. Including the time teachers need for preparing classes, one could therefore conclude that $50 \%$ of the normal working-hours in a given sector suffices. See also Opinion of Advocate General Slynn in Case 139/85 Kempf [1986] ECR 1741 at p.1743. In determining whether "effective and genuine" activities are pursued, only the activities performed in the host Member State can be considered. Activities pursued in other Member States cannot be taken into account. Case C-357/89 Raulin [1992] ECR I-1027 at 17-19. In every individual case the number of working hours is to be considered and compared to the normal working hours in the particular sector under consideration. See Opinion Advocate General Slynn in Case 139/86 Kempf [1986] ECR 1741 at p.1743.

The requirement of "effective and genuine" work does not only have implications for the amount of work or the number of working hours, but also for the nature of the work. A typical example concerns Bettray (1989). The case concerned the Dutch Social Employment Law which intended to provide work for persons who could not work under normal conditions due to physical and mental illness. Special jobs were created in undertakings or associations solely set up for the retraining and rehabilitation of such persons. The law sought to promote reintegration of the persons into the normal work process. Although the Court admitted that the basic criteria were fulfilled in case of employment under the Social Employment Law, it denied that the persons concerned could be regarded as workers for the purposes of Community law. In the Court's view the activities carried out under such a scheme were merely a means of rehabilitation or reintegration and could therefore 
mum requirement are entitled to pursue "marginal and ancillary" activities in other Member States, and they must be treated equally as regards all employment-related issues. Yet, they do not enjoy the right to reside under Article 39 EC and they cannot rely on Article 7(2) of Regulation No 1612/68 with a view to claiming social advantages.

Community citizens do not in all circumstances have to continue to meet the criteria developed in Levin and Lawrie-Blum in order to retain the status of Community worker. Unemployment ${ }^{83}$ does in principle lead to the loss of the status of worker, but, as the Court held in Martinez Sala (1998), this status "may produce effects after the employment relationship

not be regarded as "effective and genuine" activities. The social and therapeutic nature of the activities were predominant and the activities therefore could not be regarded as "effective and genuine" economic activities. Case 344/87 Bettray [1989] ECR 1621 at 17-19. For criticism on this judgment see in particular O'Leary (1996) supra footnote 1, at pp.93-98. Bettray must, however, be interpreted in light of the particular characteristics of the employment scheme at issue. Not all sheltered forms of employment are excluded from Article $39 \mathrm{EC}$. Compare Case C-1/97 Birden [1998] ECR I-7747 at 31.

The mere fact that part-time workers often earn less than the minimum subsistence level in the host State, does not prevent them from being classed as a Community worker. An income must be earned, but this may be supplemented by private resources, earnings of an accompanying family member (Case 53/81 Levin [1982] ECR 1035 at 16) or even social assistance benefits (Case 139/85 Kempf [1986] 1741 at 14 - see Chapter 3 Section 3.1.1). A remuneration must be received, but the Court has never indicated what the minimum level should be. Logically, purely symbolic payments do not suffice, but a general and uniform minimum level of remuneration applicable throughout the Community cannot be given. The least one could say is that the remuneration must be a real quid pro quo for the pursuit of "effective and genuine" activities. In other words, an "effective and genuine" remuneration is required. It is not required that the compensation from the employer for the work has to be paid out in money. This compensation can also consist of e.g. board and lodging. Case 196/87 Steymann [1988] ECR 6159 at 12 and 14. Further, the fact that the payment depends on the productivity of the workers or of the group in which they are working, is immaterial with respect to the status of worker. Case C-3/87 Agegate [1989] ECR 4459 at 36-37. The fact that the remuneration is largely provided by subsidies from the public funds is of no significance. Case $344 / 87$ Bettray [1991] ECR 1621 at 15.

83. The loss of nationality does not imply the loss of the status of worker or the right and benefits linked to it. Various situations may be distinguished. One concerns Community citizens who have moved to another Member State and have acquired that State's nationality and lost the nationality of the State of origin. Such Community citizens have exercised their right to freedom of movement and may rely on the provisions for free movement of workers against the State of which they (now) hold the nationality. A so-called "internal situation" (see supra footnote 33) is not present. Compare Case C-419/92 Scholz [1994] ECR I-505. A second situation relates to Community citizens who have acquired the status of workers in another Member State and subsequently lose their nationality and are left only with the nationality of a non-Member State. Strictly speaking, such "third country nationals" do no meet the criteria for the status of Community worker, but by analogy with the jugdment in Scholz it may be assumed that the loss of nationality will not affect their status under Community law in the host State. Compare also de Groot, The Relationship between the Nationality Legislation of the Member States of the European Union and European Citizenship, in: La Torre, European Citizenship - An Institutional Challenge (1998) pp.115-147. 
has ended". ${ }^{84}$ The Court has never fully explained what these effects are, but, arguably, a distinction is to be made between involuntary unemployment and voluntary unemployment. Community citizens who have voluntarily given up employment lose the right to reside as a worker in the host State $^{85}$ and the equal treatment rights which Community law confers upon workers. ${ }^{86}$ The involuntary unemployed, however, may retain the right of residence or, in the case of retirement or permanent incapacity, acquire the right to remain. In both cases the persons concerned can still benefit from the equal treatment rights discussed in Section $2.2 .3{ }^{87}$ For as long as they continue to live in the host State by virtue of either the right to reside or the right to remain, ${ }^{88}$ the involuntary unemployed remain entitled to the rights they initially enjoyed as Community workers. For the purposes of this book this category will be dealt with as though they were still holding the status of Community worker. ${ }^{89}$

84. Case C-85/96 Martinez Sala [1998] ECR I-2691 at 32.

85. See above Section 2.2.2

86. This may be different for Community workers who have given up work with a view to commencing studying. Provided the studies concerned are linked to the previous employment, such Community citizens retain the right to rely on Article 7(2) in order to claim equal treatment as regards "social advantages". See Case 39/86 Lair [1988] ECR 3161; Case 197/86 Brown [1988] ECR 3205; Case C-357/89 Raulin [1992] ECR I-1027 and Case C-3/90 Bernini [1992] ECR I-1071. See further Chapter 5 Section 3.2.3.

87. As regards the beneficiaries of the right to remain this is explicitly provided for in Article 7 of Regulation No 1251/70. As regards the other category, it could either be argued that for as long as Community citizens enjoy the residence rights regulated by Directive No 68/360, they retain the rights to equal treatment guaranteed by Regulation No 1612/68, and Article 7(2) in particular, or that they enjoy these rights under Article 12 of the Treaty. All rights and benefits covered by the equal treatment provisions of Regulation No $1612 / 68$ also fall within the ambit of Aricle $12 \mathrm{EC}$. See Case C-85/96 Martinez Sala [1998] ECR I-2691 at 57 and Section 3 below.

88. The right to equal treatment guaranteed by Article 7(2) of Regulation No 1612/68 does not extend to workers who, after ceasing to exercise occupational activities in the host State, decide to return to the State of origin. Case C-33/99 Fahmi [2001] ECR I-0000 at 47. This right can only be retained in special circumstances. See Case C-57/96 Meints [1997] ECR I-6689.

89. Compare also Wapenaar (1997) supra footnote 1 , at p.41. In the literature a distinction has been made between a core concept and an extended concept of workers. See e.g. Jørgensen (1996) supra footnote 1, at pp.28-36 and Hartley (1991) supra footnote 1, at pp.93-95. The former concept would cover all Community citizens who at a given moment fulfil all the criteria for the status of Community worker. This category would enjoy all rights provided for by the provisions for the free movement of workers. The extended concept of workers would consist of Community citizens who do derive rights from Article 39 but who do not yet, or no longer, meet the standard criteria for the concept of Community worker. Some of the "extended-workers" would enjoy only some of the rights granted to workers (e.g. work-seekers - see Case C-85/96 Martinez Sala [1998] ECR I-2691 at 32), whilst others would qualify for all rights granted to Community workers (e.g. the beneficiaries of the right to remain). The present Chapter does not use this distinction between a core concept and an extended concept. For purposes of the present Chapter, Community workers are all EC nationals who are pursuing effective and genuine economic activities under the direction of an employer established in another Member state and who, in return for their activities, receive a renumeration as well as 


\subsection{Family Members}

When the Community institutions implemented Article 48 (now 39) $\mathrm{E}(\mathrm{E}) \mathrm{C}$ during the 1960s, they recognised that a genuine free movement of workers could not be realised without eliminating the obstacles to "the worker's right to be joined by his family and the conditions for the integration of that family into the host country". ${ }^{90}$ Article 10 of Regulation No 1612/68 entitles the worker's spouse, ${ }^{91}$ their (grand)children who are under the age of 21 years or dependent ${ }^{92}$ and their dependent (grandparents to reside ${ }^{93}$ with the worker in the host State. ${ }^{94}$ The nationality

those who after the involuntary loss of employment still hold the right to reside in the host State under Article 39.

90. See the tifth indent of the preamble to Regulation No 1612/68 and Case C-356/98 Kaba [2000] ECR I-0000. On the status of the family members see further Sewandono, Werknemersverkeer en Gezinsleven (1998) and Lundström, Family Life and the Freedom of Movement of Workers in the European Union, in: IJLPF (1996) pp.250-280.

91. The concept of spouse does not have a Community meaning. It only refers to the marital relationship as defined by national law. See e.g. Case 267/83 Diatta [1985] ECR 567 and Case 58/85 Reed (1986) ECR 1283. Community law does not require that spouses live together under the same roof: "..the marital relationship cannot be regarded as dissolved so long as it has not been terminated by the competent authority. It is not dissolved merely because the spouses live seperately, even where they intend to divorce at a later date". Case 267/83 Diatta [1985] ECR 567 at 20. For the purposes of Article 10 cohabitees do not have to be treated as spouses. Case 59/85 Reed [1986] ECR 1283 at 11-13. Yet, residence rights for unmarried partners can be classed as a social advantage in the sense of Article 7(2) of Regulation No 1612/68. Case 59/85 Reed (1986) ECR 1283 at 22 and 28. 92. The Court has never specified what exactly should be understood by "dependence" or "dependent family member". The mere fact that a family member applies for a social assistance benefit does not prevent a family member from being regarded as a dependent family member. Case 316/85 Lebon [1987] ECR 2811 at 20. See further Chapter 3 Section 3.2. In Lebon the Court further held that the status of dependent family member "is the result of a factual situation. The person having that status is a member of the family who is supported by the worker and there is no need to determine the reasons for recourse to the worker's support or to raise the question whether the person concerned is able to support himself by taking up paid employment". Case 316/85 Lebon [1987] ECR 2811 at 22 . On a very strict interpretation of the Regulation one could reason that family members who exercise the right to work granted by Article 11 of the Regulation can no longer be regarded as dependent on the Community worker. Yet, if this were actually the case Article 11 would be deprived of all usefu effect. Oliver, Non-Community Nationals and the Treaty of Rome, in: YEL (1985) pp.57-92, at p.74 Verschueren (1990) supra footnote 3, at p.320 and van der Mei, Kinderen van EG-werknemers, in NTOR (1995) pp.211-217, at p.213.

93. The formalities to be fulfilled regarding the right to reside (as laid down in Directive No 68/360 and Regulation No 1251/70) are essentially the same as those applicable to the workers. See Section 2.2.2. Some special provisions apply to family members though. Next to a valid passport or identity card family members can be required to present a document issued by the State of origin giving their relationship with the worker and, where applicable, a document testifying that they are dependent on the worker or that they live(d) under the roof of the worker in the State whence they came. Article 4(3) Directive No 68/360. Furthermore, as regards family members who do not hold the nationality of one of the Member States, the authorities of the host State may demand the presentation of an entry visa or an equivalent document. Article 3(2) of Directive No 68/360. 
of the family members is of no relevance..$^{95}$

The right of family members to reside ${ }^{96}$ in the host State derives from the right of residence of the worker himself. As a result, family members can in principle only take up residence if the worker himself does so and they will lose their right at the moment that the worker gives up or loses his residence. ${ }^{97}$ In order to promote the integration of the worker's family into the host State, Article 11 entitles family members to work in that State $^{98}$ and Article 12 confers upon the children of Community workers the right to be admitted to educational institutions under the same conditions as the nationals of the host State. ${ }^{99}$ The rights granted by Articles 11 and 12 do not suffice for a full and effective integration of the family member in the host State. The Court has recognised this. In Cristini (1976) it held that family members can rely on Article 7(2) in

94. Article 10(2) further states that the Member States shall "facilitate the admission" of other family members who are dependent on the worker or who were living in the Member State of origin under the same roof. These other family members do not have a legally enforcable right to reside in the State of employment. Hartley (1978) supra footnote 23, at p.132.

95. See e.g. Case 94/84 Deak [1985] ECR 1874 and Case C-243/91 Taghavi [1992] ECR I-4401.

96. The right of family members to reside is subject to the condition that the worker must have available for his family housing "considered as normal for national workers in the region where the worker is employed". Article 10(3) of Regulation No 1612/68. The condition only applies, however, at the moment the family members wish to install themselves with the worker. If, later on, the housing can for some reason no longer be considered "normal" the right to reside is not affected. Case 249/86 Commission v Germany [1989] ECR 1290 at 11.

97. In some cases, however, family members can retain their right to reside. For instance, under certain circumstances they may keep their right in order to complete studies. See Joined Cases 389 and 390/87 Echternach [1989] ECR 723. On this judgment see Chapter 5 Section 3.3.3. Furthermore, family members may become entitled to the right to remain (permanently) in the host State when $(i)$ the worker has become entitled to the right to remain himself (Article 3(1) of Regulation No 1251/70)) or (ii) in the case where the worker dies before having acquired the right to remain provided the worker had resided continuously in the host State for at least two years, his death resulted from an accident at work or an occupational disease or the surviving spouse is a national of the host State or lost nationality of this State by marriage to the worker (Article 3(2)).

98. In practice, Article 11 is only relevant for family members who do not hold the nationality of one of the Member States. Family members who possess such nationality can directly invoke Article 39 EC. The right to work granted by Article 11 is limited to the territory of the State where the worker is employed. Family members must possess the professional qualifications required by the national rules of the host State and they must observe the specific rules governing the pursuit of occupations. Case 131/85 Gül (1986) ECR 1573 at 15 and Case 292/86 Gullung [1988] ECR 111 at 29. Dependent (grand)parents and grandchildren are not mentioned in Article 11. Yet, the right to work no doubt contributes to the integration of such family members in the host State and can probably be classed as a "social advantage" in the sense of Article 7(2) of the Regulation. Oliver (1985) supra footnote 92, at p.74.

99. On Article 12 see Chapter 5 Section 3.3. 
order to claim equality of treatment as regards "social advantages" ${ }^{100}$ In Lebon (1987) the Court specified, however, that family members qualify only indirectly for the equal treatment granted by Article 7(2). They may only rely on this provision as regards benefits which can be regarded as social advantages for the worker himself and this seems to imply that the right to claim benefits under Article 7(2) is preserved for family members who are dependent on the worker. ${ }^{101}$

\subsection{Self-Employed Persons and their Family Members}

The category of economic residents also includes the self-employed beneficiaries of the right of establishment guaranteed by Article 43 (formerly 52) EC and their family members. The rights of the selfemployed are governed by different provisions, but the Court has frequently held that Articles 43 and 39 EC are based on the same principles. ${ }^{102}$ Thus, Community citizens may move to other Member States in order to set up a business and in so doing they are protected against any rule or measure which treats them less favourably than the nationals of the host State. Even non-discriminatory rules which hamper the right of

\footnotetext{
100. Case 32/75 Cristini [1975] ECR 1085 at 15. Initially, the Court interpreted Article 7(2) rather restrictively by holding that this provision can only be relied upon by workers in matters connected with employment. Family members were expressly excluded by the Court from the equal enjoyment of social advantages. Case 76/72 Michel S. [1972] ECR 457 at 9-10.

101. Case 316/85 Lebon [1987] ECR 2811 at 2. In Lebon itself, for instance, the Court ruled that Article 7(2) could not be applied to a child who was no longer dependent on the worker. The social benefit at issue (social assistance benefit) could not be classed as a "social advantage" for the worker himself. Once it is established that a benefit also favours the worker, family members can enforce the right to equal treatment in the national courts themselves. Case C-3/90 Bernini [1993] ECR I1071 at 29 . Article $7(2)$ can be applied to all family members falling within the scope of Article 10 of the Regulation (Case 261/83 Castelli [1984] ECR 3199 at 9-10 and Case 316/85 Lebon [1987] ECR 2811 at 12) including family members who do not possess an EC-nationality (Case 94/84 Deak [1985] ECR 1873 at 26). Article 7(2) can also be invoked by family members who do not, or no longer, reside with the worker in the host State. Article 7(2) does not contain a residence requirement. Case C-3/90 Bernini [1993] ECR I-1071 at 29. It could be argued, however, that the "independent" family members can claim social advantages under Article 12 EC. See Case C-85/96 Martinez Sala [1998] ECR I-2691; Fries/Shaw, Citizenship of the Union: First Steps in the European Court of Justice, in: EPL (1998) pp.533-559, at p.550 and Chapter 3 Section 3.2 of the present study. 102. See e.g. Case 48/75 Royer [1976] ECR 497 at 12; Case 118/75 Watson and Belmann [1976] ECR 1185 at 9; Case C-363/89 Roux [1991] ECR I-273 at 23; Case C-106/91 Ramrath [1992] ECR I-3351 at 17 and Case C-24/97 Commission v Germany [1998] ECR I-2133 at 11. See further Voogsgeerd, Interstatelijkheid - De Aard en de Intensiteit van het Grensoverschrijdend Element in de Rechtspraak van het Hof van Justitie van de EG met Betrekking tot de Vier Vrijheden (2000) pp.233-235.
} 
establishment may be prohibited. ${ }^{103}$ The self-employed who have established themselves in another Member State obtain a right to reside there (for themselves and for their family members) which is governed by provisions which are very similar to the ones applicable to workers ${ }^{104}$ and they are entitled to equality of treatment in many matters which are not or barely related to the pursuit of economic activities. A "self-employed" equivalent of Regulation No 1612/68 has never been adopted, but the self-employed may rely on Article 43 EC in order to claim the various social rights which Community workers enjoy under Regulation No $1612 / 68$. Such social rights and advantages may be regarded as a corollary of the right of establishment. ${ }^{105}$ As noted in the introductory chapter, ${ }^{106}$ this book is based on the assumption that the rules and principles governing, or relevant for, cross-border access to public benefits of the self-employed are in principle the same as the ones applicable to workers and for this reason the legal status of the self-employed will not be discussed seperately.

\subsection{Conclusions}

Looking back, one must conclude that Community law on the free movement of workers has undergone significant changes since the coming into force of the EEC Treaty. The drafters of the Treaty had only agreed to a rather limited freedom of movement which would not include much more than a right to accept offers of employment in other States made and a right to equal treatment in employment-related matters. Today, however, the right to work in other Member States is regarded as a fundamental right for European citizens which includes a firmly protected right of residence, a right to be treated equally in virtually all social and economic aspects and a right to be joined by family members who also enjoy a far-reaching right to equal treatment in the host State. In order to

\footnotetext{
103. Compare Case C-55/94 Gebhard [1995] ECR I-4165. See further Reich, Bürgerrechte in der Europäischen Union (1999) pp.181-188.

104. See Directives No 73/148 (OJ 1973 L 172 - right to reside) and No 75/34 (OJ 1975 L 14 - right to remain).

105. Compare Opinion of Advocate General Fennelly in Case C-334/94 Commission v France [1996] ECR I-1307 at 41-44. See further e.g. Case 197/84 Steinhauser [1985] ECR 1819; Case 63/86 Commission v Italy [1989] ECR 29 and Case C-151/96 Commission v Ireland [1997] ECR I-3327. On this point see also e.g. van der Steen, Studiefinanciering ook voor Kinderen van Grensarbeiders, in: NTER (1999) pp.210-215; Craig/De Búrca, EU Law - Text, Cases \& Materials (1998) at p.754 and Jørgensen (1996) supra footnote 1, at pp.278-287. 106. See Chapter 1 Section 3.1 .
} 
become entitled to the full panoply of rights, however, the Court has laid down a threshold requirement. The status of Community worker, and thus all the rights linked to that status, can only be obtained when "effective and genuine" employed activities are performed in another Member State. Community citizens who do not meet this minimum requirement do have the right to work in other Member States, but they cannot rely on Article $39 \mathrm{EC}$ and the secondary legislation adopted on the basis of Article 40 $\mathrm{EC}$ in order to claim residence rights and equality of treatment in matters not related to employment. They can only claim such rights in their capacity as non-economic residents. ${ }^{107}$

\section{Non-Economic Residents}

The second category of beneficiaries of free movement of persons whose legal status will be examined in this book consists of the "non-economic residents". It concerns Community citizens whose right to reside in other Member States is governed by Directives No 93/96, No 90/365 and No 90/364. More specifically, the non-economic residents include students, pensioners and the residual category of the "other" Community citizens". ${ }^{108}$ It is worthwhile beginning the discussion of the legal status of non-economic residents with a brief history.

107. The fact that the legal foundations for freedom of movement have been laid does not imply that freedom of movement for workers has increased in practice. See Carlier/Verwilghen, Proportionality and Citizenship in Relation to teh Free Movement of Workers, in: Carlier/Verwilghen, Thirty Years of Free Movement of Workers in Europe (2000) pp.41-57, at p.42-43. For an overview of research and literature on migration patterns within the Community, see O'Leary, The Free Movement of Persons and Services, in: Craig/de Búrca, The Evolution of EU Law (1999) pp.377-415, at pp.386392.

108. The beneficiaries of the three residence directives of 1990 are often referred to as "noneconomically active". The term is appropriate in that it indicates that the residence rights of the persons concerned are not linked to or conditional upon the pursuit of economic activities. The term is somewhat misleading as far as it suggests that these persons do not perform economic activities. This may very well be the case. For instance, Community citizens who have taken up relatively small jobs which are to be classed as "marginal and ancillary" do not become entitled to the residence right which Article $39 \mathrm{EC}$ confers upon Community workers. Such Community citizens are economically active but, as far as the right to reside in the State of employment is concerned, they have to rely on one of the 1990 residenec directives and/or possibly Article 18(1) EC. 


\subsection{Towards a General Right of Residence: A Brief History}

In 1968 the Vice-President of the Commission referred to the free movement of workers in terms of a European citizenship. ${ }^{109}$ This citizenship was still limited in scope. At the time, it did not entail much more than the right to choose the place of work within the Community. ${ }^{110}$ Over the years, Community provisions on the free movement of workers have been construed broadly, but up until today the enjoyment of the rights guaranteed by Article $39 \mathrm{EC}$ has been conditional upon the pursuit of economic activities in other Member States. For this reason, the free movement of workers has aptly been described in terms of a market citizenship. ${ }^{11}$

From the early 1970s, however, the political Community institutions have taken several initiatives to transform this market citizenship into a genuine European citizenship. ${ }^{112}$ As members of the European Community, nationals of the Member States would be granted a number of "special" rights"113including a general right of residence. The right to establish residence in other Member States would no longer be subordinate to, or dependent on, the pursuit of economic activities; it would be granted as an independent right which nationals of Member States could enjoy simply in their capacity as European citizen. In furtherance of this policy objective, the European Commission submitted to the Council in 1979 a proposal for a directive on a "right of residence for nationals of the member States in the territory of another Member State". ${ }^{114}$ The

109. See Section 2.1

110. Evans (1982) supra footnote 21, at p.501.

111. The term was first introduced by Ipsen. See Ipsen, Europäisches Gemeinschaftsrecht, in: NJW (1964) at p.340 (footnote 2). See further Grabitz, Europäisches Bürgerrecht zwischen Marktbürgerschaft und Staatsbürgerschaft (1970); Everling, Von der Freizügigkeit der Arbeitnehmer zum Europäisches Bürgerrecht?, in: EuR(1990) Beiheft I pp.81-103, at pp.81; Verschueren (1990) supra footnote 3, at pp.448-450 and Everson, The Legacy of the Market Citizen, in: Shaw/More (Eds), New Legal Dynamics of European Union (1995) pp.73-90.

112. The European Citizen should be brought "into the construction of Europe" by establishing a "European Citizenship which would be in addition to the citizenship which the inhabitants" of the Member States already possess. Bull.EC 11-1972, at 37. See further O'Leary (1996) supra footnote 1 , at pp. 17-20

113. In 1974 the Heads of States and Governments assigned the European Commission the task of studying the conditions under which nationals of Member States could be given "special rights" with a view to developing a "Citizens' Europe". The right to reside in other Member States was regarded as one of these special rights. Bull.EC 12-1974, at 1104 and Bull.EC, Suppl.7/75, at p.25. See further the chapter "Towards a Europe of Citizens" of the Tindemans report (Bull.EC 8-1975); the Scelba Report (PE Doc.346/77) and European Parliament, Proceedings of the Round Table on Special Rights and a Charter of the Rights of the Citizens of the European Community (1979).

114. OJ 1979 C 204; COM(79) 215 tinal. 
draft directive was based on Articles 308 (formerly) 235 and 46(2) (formerly 56(2)) $\mathrm{E}(\mathrm{E}) \mathrm{C}$ which implied that the Council should be unanimous in order to adopt the directive. The directive was intended to supplement the existing free movement provisions; the right of residence would have to be granted to all nationals of the Member States and their family members who did not already enjoy such a right under Articles 39 or 43 EEC. In recognition of the fear of many Member States that they might be faced with an influx of "needy" citizens from other Member States moving for the sole purpose of collecting comparatively high social benefits, the Commission proposed that Member States could require citizens "to provide proof of sufficient resources for their own needs and the dependent members of their family". ${ }^{15}$ Because of this "financial means requirement", one might have expected that the directive would be adopted relatively easy, but this did not turn out to be the case. On the contrary, negotiations in the Council proved to be very difficult. The fear of "social tourism" was too strong. After some years the European Commission had to conclude that the likelihood of the Council reaching a unanimous decision had been reduced to virtually zero. ${ }^{116}$ In 1985 , however, the Commission received some unexpected support from the Court of Justice. In Gravier the Court ruled that Community citizens could invoke Article $12 \mathrm{EC}$ (at the time 7 EEC) order to get access to vocational training in other Member States. ${ }^{117}$ In the Commission's view the judicially created right to study in other Member States necessarily encompassed a right to reside in those States. ${ }^{118}$ There was no longer a need to grant students a right of residence and the Commission subsequently decided to exclude students from the original draft directive. ${ }^{119}$ The Council, however, was still not willing to adopt the proposal

\footnotetext{
115. Article 4(2) of the 1979 draft directive.

116. More specifically, during the negotiations the Member States could not reach agreement on the definition of family members who would be given the right to join the principal beneficiaries and on the question of whether students should have to prove that they possess adequate financial means. On the Council negotiations on the 1979 draft directive see e.g. Schulz, Freizügigkeit für Unionsbürger (1997) at pp.53-64; O'Leary (1996) supra footnote 1, at pp.109-118; Bolly, Droit d'Entrée et de Sejour des Ressortissants communautaire: Développements récents, in: ActduDr (1990) pp.735-748; Taschner, Free Movement of Students, Retired Persons and other European Citizens - A Difficult Legislative Process, in: Schermers et al (Eds), Free Movement of Persons in Europe (1993) pp.427436 and van Nuffel, Een Bijna Algemeen Verblijfsrecht in de Europese Gemeenschap - Commentaar op de Verblijfsrecht-richtlijnen van 28 juni 1990, in: SEW (1990) pp.887-903.

117. Case 293/83 Gravier [1985] ECR 593. See further Chapter 5 Section 4. In the same year the Commission also received support from the Adonnino Committee which stressed that a general right of residence was essential for a "People's Europe". See Bull.EC Suppl.7/85 at p.12.

118. This conclusion has later been confirmed by the Court in Case C-357/89 Raulin [1992] ECR I1027 at 34 . See further Chapter 5 Section 4.1 and 4.4

119. OJ 1985 C 171; COM(85) 292 final.
} 
and this urged the Commission to alter its strategy. In 1989 the Commission withdrew its proposal and replaced it with three new proposals for specific directives for rights of residence for students, ${ }^{120}$ pensioners ${ }^{121}$ and "all other Community citizens". ${ }^{122}$ The "splitting-up" of the 1979 proposal enabled the Commission to give due regard to the Member States diverse objections to residence rights for the various categories of beneficiaries $^{123}$ and to base two of its proposals on Treaty provisions which allow for decision-making by a qualified majority within the Council. ${ }^{124}$ The Commission's new strategy proved successful. In June 1990 the Council adopted the three directives which had to be implemented by 30 June $1992 .{ }^{125}$

By adopting the directives the Council had contributed to a strengthening of the notion of European citizenship, but this contribution was still quite modest. The citizens who could benefit from "non-economic residence rights" were often persons who in many cases would already have been entitled to reside in other Member States on the basis of national law. ${ }^{126}$ For Community citizens who were not able to provide for themselves not much progress had been made; they still did not enjoy the right to establish residence in other Member States. During the 19901991 Intergovernmental Conferences, which ultimately led to the Treaty on European Union, some Member States proposed that the planned political and economic union should be accompanied by a strengthened European citizenship. This would entail a number of political rights among which an unlimited general right to freedom of movement which

\footnotetext{
120. OJ 1989 C 191

121. Ibid.

122. Ibid.

123. Taschner (1993) supra footnote 116 , at p.433

124. The draft directive for students was based on Article 7(2) EEC (now Article 12(2) EC qualitied majority) and the proposal for the pensioners directive was based on Articles 49 (now 40) and 54 (now 54) of the Treaty (qualified majority). The directive for the residual category of "other Community citizens" was based on Article 100 (now 94) of the Treaty (unanimity).

125. Directive No 90/366/EEC (students - OJ 1990 L 180); Directive No 90/365/EEC (pensioners OJ 1990 L 180 and Directive No 90/364 ("other" Community citizens - OJ 1990 L 180). The Council did not base the directives on the proposed legal bases but on article 235 (now 308) EC. The European Parliament objected and claimed that the students directive should have been based solely on Article 7(2) of the EEC Treaty. It started a procedure under Article 173 (now 230) EC asking the Court to annull Directive No 90/366 on the ground of an improper legal basis. The Court concluded that the residence directive should indeed have been based on Article 7(2) alone. Case C-295/90 Parliament v Council [1992] ECR I-4193 at 18. Subsequently, the original Directive 90/366 was replaced by Directive No 93/96 which, qua substance, was virtually identical to the directive of 1990 OJ 1993 L 317. See further Chapter 5 Section 4.4. On the (non-)implementation of the directives see C-96/95 Commission v Germany [1997] ECR I-1653.

126. See O'Leary (1996) supra footnotc 1, at pp.119-120.
} 
would be included in the Treaty itself. ${ }^{127}$ Ultimately, Member States could reach agreement on formally introducing a Citizenship of the Union (Article $8 \mathrm{EC}$; since "Amsterdam": Article $17 \mathrm{EC})^{128}$ which encompasses rights to vote and stand for election in European and municipal elections $^{129}$ and a right for all Union citizens to move and reside freely among the Member States (Article 8a EC; now Article 18 EC). The Member States could not agree, however, on extending free movement rights. Article $18 \mathrm{EC}$ explicitly provides that free movement rights are subject "to the limitations and conditions laid down in this Treaty and by the measures adopted to give it effect" ${ }^{130}$ By inserting Article 18 EC the Member States did not intend to do more than codify the acquis communautaire in the field of the free movement of persons. In their view, progress was to be made by the Council which, according to Article 18(2) EC, was granted the power to adopt (unanimously) provisions aimed at facilitating the exercise of the free movement rights mentioned in Article 18(1) EC.

\subsection{Right to Reside}

The limitations and conditions upon the right to reside of students, pensioners and the remaining Union citizens, are set out in further detail in the three directives of 1990. In the preambles to the three directives it is stipulated that beneficiaries must not become an unreasonable burden on

127. Agence Europe, 11 May 1990, at p.3. In a memorandum which was presented during the Intergovernmental Conference the Spanish Government had proposed to grant Community citizens an unlimited right to move and reside freely and to adopt legislation which would lay down "provisions to ensure a fair distribution of the resulting burden on the Member States, particularly in the area of social protection". See the Spanish Memorandum on European Citizenship as published in Cornett, The Treaty of Maastricht (1993) at p.156. On the negotiations during the Intergovernmental Conference see further O'Leary (1996) supra footnote 1, at pp.23-30.

128. On the notion of Union citizenship see e.g. O'Keeffe, Union Citizenship, in: O'Keeffe/Twomey (Eds), Legal Issues of the Maastricht Treaty (1994) pp.87-107; Closa, The Concept of Citizenship of the European Union, in: CMLRev (1992) pp.1137-1170; Covar/Simon, La Citoyenette de l'Union, in: CDE (1993) pp.285-316 and Constantinesco, La Citoyenetté de l'Union, in: Schwarze (Ed.), Vom Binnenmarkt zur Europäischen Union (1993) pp.25 et seq.

129. See Article 19 EC. See further Dollat (1998) supra footnote 1, at pp.467-504; Marias, European Citizenship in Action: From Maastricht to the Intergovernmental Conference, in: La Torre, European Citizenship - An Institutional Challenge (1998) pp.293-316; O'Leary (1996) supra footnote 1, Chapters 6 and 7 and Degen, Die Unionsbürgerschaft nach dem Vertrag über die Europäische Union unter besonderer Berücksichtigung des Wahlrechts, in: DöV (1993) pp.749-758. See further Case C327/97 Commission v Belgium [1998] ECR I-0000.

130. Thus, as Community law stands at present, the rights of Community citizens in other Member States are not unconditional. Case C-356/98 Kaba [2000] ECR I-0000 at 30. 
the public finances of the host Member State. This financial safeguard for Member States is specified in Article 1 of each of the directives. Pensioners shall be granted the right of residence ${ }^{131}$ when they receive invalidity, early retirement or other pensions or old age benefits of an amount sufficient to avoid becoming a burden on the social security system of the host State. The residual class of "other Community citizens" must have sufficient means to provide for themselves and their family members. ${ }^{132}$ Pensions and resources are deemed sufficient where they are higher than the level at which Member States grant social assistance benefits to its nationals. ${ }^{133}$ Students only have to assure the relevant national authority that they have enough resources in order to avoid becoming a "public burden". ${ }^{134}$ In order to avoid beneficiaries becoming a financial burden on the host State, beneficiaries must also be covered by sickness insurance in respect of all risks. ${ }^{135}$ As regards pensioners and the category of "other" Community citizens", the right to reside is also granted to the spouse and the dependent (grand)children and (grant)parents of pensioners and "other Community citizens". Students are only entitled to be joined by their spouse and their dependent children. The financial means and health insurance requirements must be met throughout the period of residence in the host State. Otherwise, the right to reside will be lost. ${ }^{136}$

131. The pensioners directive applies to persons who wish to reside in a Member State other than the one in which they have worked (or the State of their nationality). Community citizens who have worked in other Member States and who wish to remain there afterwards are covered by Regulation No 1251/70 (or, in case of the self-employed, Directive No 73/41). See further Section 2.2.2.

132. As in the case of Community workers, the right of residence shall be evidenced by a "Residence Permit for a National of a Member State of the EEC". The validity of this permit may be limited to five years on a renewable basis. See further Article 2 of both Directives. In applying the financial means requirements contained in Directives No 90/364 and No 90/365, Member States enjoy a certain discretion which implies that they do not, at least in as far as applied to family members, have to phrase and apply the requirements identically to the various categories. Case C-424/98 Commission v Italy [2000] ECR I-0000 at 26.

133. Where this requirement cannot be applied in a Member State, the resources are deemed sufficient when they are higher than the level of the minimum social security pension paid by the host Member State. See Article 1(1), third paragraph of both directives. The pensioners directive requires that the pension or the benefit which is received must be "sufficient". This could imply that a Community citizen who receives a pension which is relatively low and falls under the minimum subsistence level in other Member States, cannot rely on Directive No 90/365. Such a pensioner may however possess other financial resources which together with the pension would be "sufficient". In such cases the pensioner may rely on Directive No 90/364. See Martin/Guild (1996) supra footnote 1 , at p. 220 .

134. On the right of residence of students see Chapter 5 Section 4.4 .

135. For further details on this requirement see Chapter 4 Section 3.3.3.

136. Articles 3 of Directives No 90/364, No 90/365 and No 93/96. Pursuant to Article 5 of each of the three directives, the Member States had to implement the directives by 30 June 1992. Most Member States did not meet the dead-line. The Commission subsequently started infringement procedures for non-transposition which were terminated at the moment the States concerned adopted the 


\subsection{Right to Equal Treatment}

Community citizens who have exercised their "non-economic" right of residence are entitled to be treated equally with the nationals of the host State. In as far as the pursuit of economic activities is concerned, equality of treatment is guaranteed by Community provisions on free movement for (self-)employed persons. In "non-economic" matters, Article 12(1) EC is to be relied upon prohibiting "within the scope of application" of the Treaty "any discrimination on grounds of nationality". The number of cases decided under Article 12 EC is still relatively small and until recently the scope of the right to equal treatment of the non-economic residents was uncertain. In the first cases in which it had to determine the scope of Article $12 \mathrm{EC}$, the Court considered the degree to which the powers in a given policy area had been transferred to the Community in order to determine whether or not a given right, opportunity or matter is covered by the Treaty. Thus, in Gravier (1985), after having referred to various measures Member States and Community institutions had taken in the field of vocational training, the Court concluded that access to such training falls within the scope of the Treaty. ${ }^{137}$ Following a comparable line of reasoning, the Court concluded in Lair (1988), however, that Article $12 \mathrm{EC}$ (then $7 \mathrm{EEC}$ ) does not in principle cover student financial aid. Study grants were considered matters of educational and social policy which as such had not yet been brought within the competence of the Community. ${ }^{138}$

From an educational perspective these two judgments were no doubt revolutionary. The Court read into Article 7 EEC (read together with Article 128 EEC) much more than the drafters of the Treaty had envisaged. $^{139}$ Nonetheless, t"transfer-of-power-approach" also seemed rather restrictive because it basically implied that Article 12(1) EC could not be relied upon by Community citizens in the numerous policy areas (still) falling within the domain of the Member States. Furthermore, the

required implementation measures. The procedure against Germany was not ended and was finally referred to the Court. The Court ruled against Germany for not adopting measures for implementing Directives Nos 90/364 and 90/365 and it rejected Germany's argument that there were no grounds for the action because beneficiaries could rely on the Directive itself. Case C-96/95 Commission v Germany [1997] ECR I-1653. The Commission also started various infringement procedures against Member States which had not transposed the directives correctly. Upon proper transposition, most of the proceedings were terminated; only the procedure against Italy was continued. See Case C-424/98 Commission v Italy [2000] ECR I-0000.

137. Case 293/83 Gravier [1985] ECR 293 at 19-25

138. Case 39/86 Lair [1988] ECR 3161 at $14-15$.

139. On this point sec further Chapter 5 Section 4.1. 
approach followed in Gravier and Lair differed from the case law on the free movement of workers in which the Court had rejected the view that the scope of the right to equal treatment would depend on the degree to which powers in substantive policy areas have been transferred to the Community. ${ }^{140}$ In interpreting the scope of Article 39 EC and Article $7(2)$ of Regulation No 1612/68 the Court has taken a functional approach: equality of treatment is to be ensured in all matters facilitating freedom of movement and the integration of the worker and his family in the host State's society.

In various cases concerning the right to equal treatment of nonresidents under Article 12(1) EC the Court had already adopted a comparable approach. ${ }^{141}$ The recent judgment in Martinez Sala (1998) suggests that the scope of Article 12 is now to be determined by the same criteria as the ones the Court has applied in the context of the free movement of workers. Ms Martínez Sala was a Spanish national who lived and received a social assistance benefit in Germany. After the birth of her daughter she applied for a child-raising allowance, but this benefit was refused because she did not hold German nationality and could not produce a residence permit. In determining whether the child-raising allowance fell within the scope of Article 12, the Court referred to its judgment in Hoever (1996) in which it had already held that the allowance in question constituted a social advantage in the sense of Article 7(2) of Regulation No 1612/68. ${ }^{142}$ The Court concluded that the allowance therefore "indisputably" fell within the scope of Community law and that Mrs Martínez Sala could as a "national of a Member State lawfully residing in the territory of another Member State" rely on Article 12 EC in claiming the allowance. ${ }^{143}$ The observations of the Court on this point were rather short, but they do suggest that the scope of Article 12 $\mathrm{EC}$ is to be determined by the same criteria as the ones which have been applied under the provisions on the free movement of workers. Thus, noneconomic residents enjoy equal treatment as regards all matters which

\footnotetext{
140. See above Section 2.2.3.

141. See below Section 4.2

142. Joined Cases C-245/94 and C-312/94 Hoever [1996] ECR I-4895.

143. Case C-85/96 Martinez Sala [1998] ECR I-2691 at 57-61. On Martinez Sala see e.g. Tomuschat, Annotation Martinez Sala, in: CMLRev (2000) pp.449-457; Becker, Freizügigkeit in der EU Auf dem Weg vom Begleitrecht zur Bürgerfreiheit, in: EuR (1999) pp.522-533; O'Leary, Putting Flesh on the Bones of European Union Citizenship, in: ELRev (1999) pp.68-79; Fries/Shaw, Citizenship of the Union: First Steps in the European Court of Justice, in: EPL (1998) pp.533-559; Schrauwen, Annotatie Martinez Sala, in: SEW (1999) pp.426-430; Denys, Het Burgerschap: Meer dan een Schim?, in: NTER (1998) pp.210-213 and van der Steen, De Europese Burger Krijgt Handen en Voeten, in: NTER (1998) pp.163-166.
} 
may facilitate the exercise of their residence rights and the integration of their family into the society of the host State.

It is to be noted, however, that this right to national treatment of non-economic residents is not protected as securely as the equivalent right of Community workers. In Martinez Sala the Court did not go into an analysis of Article $18 \mathrm{EC}$ and this implies that, until the Court rules otherwise, the Community still allows Member States to end legal residence when the Community citizen concerned no longer meets the requirements laid down in the 1990 residence directives. Thus, equality of treatment in socio-economic matters seems guaranteed only for as long as the host State has not made use of its right to end residence.

\section{$4 \quad$ Non-Residents}

The third category of beneficiaries of free movement of persons whose legal status under Community law will be examined in this book consists of "non-residents". It concerns Community citizens who go to other States for a limited period of time without relocating their private residence or place of economic establishment. The legal status of these "Community travellers" is mainly governed by Articles 49, 18 and 12 EC. ${ }^{144}$

\subsection{The Right to Travel Freely within the Community}

Under the original EEC Treaty, the right to travel to other Member States was a functional right granted only in order to enable self-employed persons to provide services in Member States other than the one in which they are established. From the early years, however, Community institutions have recognised that the right to cross the inter-Member State borders could not be confined to providers of services. In particular, the institutions took the view that a genuine free movement of services required that the recipients of services should also have the right to move to other

144. For the purposes of this study, the category of non-residents does not include Community citizens who through the pursuit of "effective and genuine" work have acquired the status of Community worker, but who have decided not to exercise their right to reside as a worker in the State of employment. The legal status of frontier workers is governed by Article $39 \mathrm{EC}$, not by Articles 49,18 and $12 \mathrm{EC}$ 
Member States. ${ }^{145}$ In the absence of a specific reference in the Treaty to a right to travel for service recipients the issue remained in dispute for quite some time. ${ }^{146}$ In Luisi and Carbone (1984), however, the Court confirmed that the Treaty provisions on the free movement of services indeed also guarantee a right to move to other Member States in order to receive services. The latter right was said to be a corollary of the former right. ${ }^{147}$ Strictly speaking, the right of service recipients to go to other States was still economically determined in the sense that the right was solely recognised in order to make the right to provide economic services effective. The practical effect of Luisi and Carbone, however, reached much further. In a "sweeping statement"148 the Court added that tourists, patients, business travellers and students could be regarded as recipients of services. ${ }^{149}$ This basically implied that virtually all Community citizens

145. A right to move to other Member States for the purpose of receiving services had already been recognised in secondary legislation. See e.g. Title II of the General Program for the Abolition of restrictions on Freedom to Provide Services (OJ Spec.Ed. (2nd Series) IX, at p.3; Article 1 of Directive No 64/221 and Article 1 Directive No 73/148. Probably, even the authors of the Treaty were of the opinion that recipients of services would be covered. See Everling, Vertragsverhandlungen 1957 und Vertragspraxis 1987 dargestellt an den Kapiteln Niederlassungsrecht und Dienstleistungen des EWG-Vertrages, in: Festschrift für von der Groeben (1987) pp.111-130, at p.121. In the Spaak-report reference had already been made to the hotel sector as one of the areas in which the free movement of services would be of particular significance. Rapport des Chefs de Délégations (1956) supra footnote 12, at p.40.

146. In his Opinion in Watson and Belmann Advocate General Trabucchi claimed that the practical effect of the inclusion of recipients of services would be an extension of the right of freedom of movement to all EC-nationals since everyone is actually or potentially a recipient of services. This would not accord with the wording of article 59 (now 49) EC and would be inconsistent with the structure of the Treaty which only provides for a freedom of movement for specific categories of persons. See the Opinion of Advocate General Trabucchi in Case 118/75 Watson and Belmann [1976] ECR 1185 at 1201.

147. Joined Cases $286 / 82$ and $36 / 83$ Luisi and Carbone (1984) ECR 377 at 16 . See further Case C224/97 [1999] ECR I-000 at 11. Compare also GB-INNO-BM where the Court held that the free movement of goods "requires, particularly in frontier areas, that consumers resident in one Member State may travel freely to the territory of another Member State to shop under the same conditions as the local population". Case C-362/88 GB-INNO-BM [1990] ECR I-667 at 8.

The Treaty provisions on the free movement of services may cover four situations. Next to cases where the (i) provider or the (ii) recipient moves from one Member States to another, these are situations in which (iii) both the provider and recipient cross the inter-State borders and cases in which (iv) neither the provider or the recipient but solely the service itself crosses the borders. An example of the third situation concerns travel agencies which organise holidays in other States. See e.g. the Tourist Guide cases (Case C-154/89 Commission v France [1991] ECR I-569; Case C-180/89 Commission v Italy [1991] ECR I-709 and Case C-198/89 Commission v Greece [1991] ECR I-4221) and Case C-55/98 Vestergaard [1999] ECR I-7641. The fourth type of cases concerns e.g. financial and telecommunication services. See e.g. Case C-353/89 Commission $v$ the Netherlands [1991] ECR I-4069; Case C-76/90 Säger [1991] ECR I-4421 and Case C-384/93 Alpine Investments [1995] ECR I-1141.

148. Timmermans, Annotation Luisi and Carbone, in: SEW (1984) pp.753-759, at p.755.

149. Joined Cases 286/82 and 36/83 Luisi and Carbone (1984) ECR 377 at 16. 
enjoy the right to travel freely throughout the Community. This conclusion was confirmed in Commission $v$ the Netherlands (1991) where the Court held that Community nationals are generally to be considered beneficiaries of the right to enter other Member States, and as recipients of services in particular, and that, in order to cross the borders of the Member States, they only have to produce a valid passport or identity card. ${ }^{150}$ In practice, all Community citizens enjoy a right to travel freely across the intra-Community borders under the Treaty. ${ }^{151}$ This case law now seems codified in Article $18 \mathrm{EC}$. The right to move freely within the Community facilitates the provision or receipt of services in other States, but no longer seems granted solely for this purpose. The right to move freely within the Community may be regarded as a non-economic right which nationals of the Member States enjoy as citizens of the Union. ${ }^{152}$

\subsection{Right to Equal Treatment}

In the territory of the Member State they visit, Union citizens have the right to provide and receive services under the same conditions as the nationals of the host State. Article 49 prohibits the application of all national rules which directly or indirectly discriminate against nationals or residents $^{153}$ of other Member States as well as non-discriminatory rules

150. The purpose of the travel was held to be irrelevant. According to the Court, immigration officers are not even entitled to ask questions as to the purpose and duration of the stay in the territory of the State concerned. Case C-68/89 Commission v the Netherlands [1991] ECR I-2637 at 13.

151. Compare also the judgment in Bickel in which the Court held that Article 49 EC covers al Community citizens "who, independently of other freedoms guaranteed by the Treaty, visit another Member State where they intend or are likely to receive services" (ital.: APvdM). Case C-274/96 Bickel [1998] ECR I-7637 at 15. The right to enter another State logically includes the right to stay in the territory of that State for a certain period of time. The duration of this right to stay is limited (Case 196/87 Steymann [1989] ECR 6159 at 17), but so far no clear criteria have been developed as to the precise duration of the right. The most one could say is that the duration of the right to stay is of "equal duration with the period during which the services are provided" (Article 4(1) of Directive No $73 / 148)$

152. There is, however, no absolute certainty. In Wijsenbeek, for instance, the Court avoided the question whether the right to travel is now actually based on Article 18 EC. Case C-378/97 Wijsenbeek [1999] ECR I-0000 at 43. Compare Toner, Passport Controls at Borders between Member States, in: ELRev (2000) pp.415-424, at p.420 and Bulterman, Annotation Bickel, in CMLRev (1999) pp.1325-1334, at pp.1333-1334.

153. National rules which make the right to provide services conditional upon residence in the host State are prohibited since they would deprive the right to provide services in other Member States of all useful effect. Case 33/74 van Binsbergen [1974] ECR 1299 at 11. 
which impinge on the rights to provide and receive services. ${ }^{154}$ The concept of services, however, is limited. Article 50 (formerly 60) EC stipulates that services shall be considered "services" when they are "normally provided for remuneration". Public services which are mainly funded out of public funds are not services for the purposes of Articles 49 et seq. ${ }^{155}$ This is not to say, however, that Community travellers can never rely on Community law in order to claim such public benefits. They may do so under Article 12 EC. Consider Cowan (1989). ${ }^{156}$ The case concerned a British tourist who was assaulted at a metro station in Paris. Mr Cowan sought financial compensation for his injuries under a French compensation scheme for victims of crime. His request was rejected on the ground that he was neither a French national nor a resident of France. It was beyond doubt that the benefit Mr Cowan applied for could not be regarded as a service, but he argued that, as a recipient of touristic services, he fell within the personal scope of the Treaty and that he therefore was entitled to rely on Article 7 EEC (now Article 12 EC) in order to claim the desired benefit. The French government objected by arguing that the national rules $\mathrm{Mr}$ Cowan challenged did not in any relevant way impinge on freedom of movement. The Court did not agree. Whenever:

"Community law guarantees a natural person the freedom to go to another Member State the protection of that person from harm in the Member State in question, on the same basis as that of nationals residing there, is a corollary of that freedom of movement". ${ }^{157}$

The French Government had also argued that Mr Cowan could not rely on Article 7 EEC because the compensation rules in question were part of criminal law and procedure, areas falling within the competence of the Member States. The Court refused to follow such a "transfer-of-powersapproach" in determining the material scope of Article 7 EEC. Criminal law and procedure are indeed matters for which Member States are responsible, but Community law does impose certain limits on the powers of the Member States. Member States, the Court concluded, "may not discriminate against persons to whom Community law gives the right to equal treatment or restrict the fundamental freedoms guaranteed by

154. See e.g. Case C-55/94 Gebhard [1995] ECR I-4165 at 37 and Case C-19/92 Kraus [1993] ECR I- 1663 at 32.

155. Case 263/86 Humbel [1988] ECR 5365 at 17-18 and Case C-109/92 Wirth [1993] ECR I-6447 at 19 .

156. Case 186/87 Cowan [1989] ECR 195. On Cowan see Weatherhill, Annotation Cowan, in: CMLRev (1989) pp.563-588.

157. Case 186/87 Cowan [1989] ECR 195 at 17. 
Community law". ${ }^{158}$

In later cases the Court followed a similar line of reasoning as regards the rights to visit public museums, ${ }^{159}$ to get access to courts ${ }^{160}$ and to use minority languages in court proceedings. ${ }^{161}$ The case law thus indicates that in determining the material scope of the right to equal treatment there is no need to determine whether or to what extent the powers in the policy area concerned have been transferred to the Community. A functional criterion is to be applied. Equality of treatment is ensured as regards rights or benefits which may be regarded as a corollary of or which may enhance the exercise of the right to move to other Member States. ${ }^{162}$

\section{5}

\section{Third Country Nationals}

Community provisions on the free movement of persons apply in principle only to Community citizens. ${ }^{163}$ Article 39 EC merely speaks of "workers of the Member States", but the omission of an explicit reference to a nationality of one of the Member States was never intended, ${ }^{164}$ and does not mean, ${ }^{165}$ that workers from third countries are included in the

158. Ibid, at 19.

159. Compare Case C-45/93 Commission v Spain [1994] ECR I-911 (implicitly).

160. Case C-43/95 Data Delecta [1996] ECR I-4661 at 12-14; Case C-323/95 Hayes [1997] ECR I-

1711 at 13 and Case C-122/96 Saldanha [1997] ECR I-5325 at 17.

161. Case C-274/96 Bickel [1998] ECR I-7637.

162. Ibid, at 16-18. The judgment in Martinez Sala suggests that in determining the scope of the right to equal treatment of non-residents there is no longer a need to establish whether or not a given right of benefit is to be regarded as a corollary of the right to travel to other Member States. The judgment suggests that the scope of the travellers' right to equal treatment is as broad as the scope of the right to equal treatment of economic and non-economic residents. See further Chapter 6 Section 3.2 .

163. Persons who hold the nationality of a Member State and the nationality of a third country are Community citizens for purposes of Community law. See e.g. Case C-360/90 Micheletti [1992] ECR I-4239 at 15 and Case C-122/96 Saldanha [1997] ECR I-5325 at 15

164. See Section 2.1 above.

165. See e.g. Article 7(1) of Regulation No 1612/68. The judgment in Meade (Case 283/83 [1984] ECR 2631) suggested (see e.g. Staples, The Legal Status of Third Country Nationals Resident in the European Union (1999) at pp.34-35; Arnull, The General principles of EEC Law and the Individual (1990) at p.10; Greenwood (1987) supra footnote 73, at pp.205-206; Oliver (1985) supra footnote 92, at p.62 and the Opinion of Advocate General Jacobs in Joined Cases C-95/99, C-98/99 and C180/99 Khalil (http://www.curia.eu.int/jurisp) at 19), but did not compel the conclusion (see e.g. Verschueren (1990) supra footnote 3, at p.303 and van der Mei (1996) supra footnote 12, at p.156) that third country nationals are excluded from Article $39 \mathrm{EC}$. The more recent judgment in Awoyemi (1998), however, confirms this exclusion. The case concerned a Nigerian national who was living in Belgium and who was charged with driving a motor vehicle on the public highway in Belgium 
free movement regime. Third country nationals have also never been considered as possible beneficiaries of the general, non-economic, right of residence. From the early 1970s, this right was planned to be a right which nationals of the Member States would enjoy as citizens of the European Community. Article 18 EC as well as the three 1990 residence directives specifically state that the right of residence is conferred upon nationals of the Member States. As regards the right to move or travel among the Member States, the position of third country nationals has been more controversial, but up until today the required harmonisation of national immigration, visa and asylum policies has not been realised. ${ }^{166}$ Community law does not yet provide for a border control free Community in which third country nationals are also entitled to move freely. ${ }^{167}$ The non-Community citizens from third countries only enjoy rights under the free movement regime when, or in as far as, these rights facilitate free-

without being in possession of a valid driving licence. The Court ruled that Mr Awoyemi could not invoke the Community provisions on the free movement of persons in order to challenge the imposed penalty because these provisions would only apply to nationals of the Member States. Case C-230/97 Awoyemi [1998] ECR I-6781 at 29-30.

166. Article 14 (formerly $7 \mathrm{a}) \mathrm{E}(\mathrm{E}) \mathrm{C}$ speaks of the internal market as an area "without internal frontiers" in which a free movement of persons is ensured. The European Commission and the European Parliament have interpreted this provision so as to require the elimination of all border controls for "all persons, irrespective of their nationality". COM (97) 230 at 4 . This view, however, was contested by various Member States which insisted on retaining powers as regards the immigration of third country nationals. Due to the uncertainties about the meaning of Article $14 \mathrm{EC}$ and the powers of the Community to abolish border controls (see e.g. Timmermans, Free Movement of Persons and the Division of Powers between the Community and its Member States - Why Do It the Intergovernmental Way?, in: Schermers et al (Eds), Free Movement of Persons in Europe (1993) pp.352-388 and the Opinion of Advocate General Cosmas in Case C-378/97 Wijsenbeek [1999] ECR I-0000 at 37-42), most of the initiatives as regards the abolition of border controls were taken outside the framework of the Community in the context of the Schengen Treaty (see e.g. Meijers et al (Eds), Schengen - Internationalisation of Central Chapters of the Law on Aliens, Refugees Privacy, Security and Police (1992); O'Keeffe, The Schengen Convention: A Suitable Model for European Integration, in YEL (1991) pp. 185 et seq; Schutte, Schengen: Its Meaning for the Free Movement of Persons in Europe, in: CMLRev (1991) pp.549 et seq and Donner, De Ontwikkeling van het Vrije Verkeer van Personen binnen de Europese Gemeenschappen en de Overeenkomst ter Uitvoering van het Akkoord van Schengen, in: SEW (1990) pp.766 et seq.) and, later, the third pillar of the Treaty on European Union on "Justice and Home Affairs" (see e.g. O'Keeffe, Recasting the Third Pillar, in: CMLRev (1995) 893-920 and Peers, Justice and Home Affairs in Europe (1999)). The Treaty of Amsterdam has brought virtually all issues concerning immigration and the abolition of border controls under the first pillar of the Treaty on European Union comprising inter alia the EC Treaty. In the new Article 61 the goal is to progessively establish "an area of freedom, security and justice" and Article 62 provides that the Council shall, within a period of five years after the entry into force of Treaty of Amsterdam, adopt measures "with a view of ensuring .. the absence of any controls on persons, be they citizens of the Union or nationals of third countries". See further (the various contributions in) Guild/Harlow (Eds), Implementing Amsterdam - Immigration and Asylum Rights in EC Law (2001); Guild, European Community Law From a Migrant's Perspective (2000) and Staples (1999) supra footnote 165 , Chapter 5 .

167. Compare Casc C-378/89 Wijsenbeek [1999] ECR I-0000 at 39-40. 
dom of movement for Community citizens. In particular, third country nationals can only enjoy rights in their capacity as family members of one of the categories of principal beneficiaries. ${ }^{168}$

Community provisions on the free movement of persons, as described so far in this chapter, however, do not present the whole picture. The Community and its Member States have concluded various association and co-operation agreements with third States under which the nationals of these States are offered free movement and/or equal treatment rights. The provisions of the agreements, and the various measures adopted thereunder, form an integral part of Community $1 \mathrm{lw}^{169}$ and, having regard to their wording and the purpose of and nature of the agreement, they may produce direct effect. ${ }^{170}$ As noted in the introductory chapter, this book will discuss the rights which third country nationals enjoy under the Agreement on the European Economic Area, the Association Agreement with Turkey and the agreements which have been concluded with the Mahgreb countries Morocco, Algeria and Tunisia. ${ }^{171}$

168. In addition, third country nationals may, as employees of providers of services, enjoy certain benefits from the provisions on the free movement of services. See Case C-113/89 Rush Portuguesa [1990] ECR I-1417 (where the Court held that providers of services may move with their employees to other Member States) as interpreted by the Court in Case C-43/93 van der Elst [1994] ECR 3803 (where it was held that the nationality of the employees is of no significance). See further Directive No $97 / 71$ on the posting of workers in the framework of the provision of services (OJ 1997 L. 18) See also Case C-376/96 Arblade [1999] ECR I-0000. See further Onslow-Cole, The Right of Establishment and Provision of Services: Community Employers and Third Country Nationals, in: Guild (Ed), The Legal Framework and Social Consequences of Free Movement of Persons in the European Union (1999) pp.63-71; Jorens, De Rechtspositie van Niet-EU-Onderdanen in het Europees Socialezekerheidsrecht (1997) at pp.357-367 and Voogsgeerd, Aspecten van Grensoverschrijdende Tewerkstelling, in: Pennings, Tewerkstelling over de Grenzen (1996) pp.129-163.

169. Case 12/86 Demirel [1987] ECR 3719 at 7 and Case 30/88 Commission v Greece [1989] ECR 3711 at $12-13$.

170. Case C-192/89 Sevince [1990] ECR I-3461 at 15 and Case C-18/90 Kziber [1991] ECR I-199 15. See further Jorens, Non-European Union Nationals and the Co-ordination of European Social Security Law: The International Agreements Concluded by the European Union with Third Countries and Conflict Rules in European Social Security Law, in: Jorens/Schulte, European Social Security Law and Third Country Nationals (1998) pp.1-110, at pp.25-59.

171. On the legal status of third country nationals under Community law see e.g. Groenendijk, The Growing Relevance of Article 39(ex 48) EC Treaty for Third Country Immigrants, in: Carlier/Verwilghen, Thirty Years of Free Movement of Workers in Europe (2000) pp.207-223; Vilá Costa, The Quest for a Consistent Set of Rules Governing the Status of non-Community Nationals, in: Alston (Ed.), The EU and Human Rights (1999) pp.411-446; Cremona, Citizens of Third Countries: Movement and Employment of Migrant Workers within the European Union, in: LIEI (1996) pp.87113; Peers, Towards Equality: Actual and Potential Rights of Third-Country Nationals in the European Union, in: CMLRev (1996) pp.7-50; Sørensen, The Exclusive European Citizenship - The Case for Refugees and Immigrants in the European Union (1996); Alexander, Free Movement of non-EC nationals: A Review of the Case Law of the Court of Justice, in: Schermers et al (Eds), Free Movement of Persons in Europe (1993) pp.485-502; Evans, Third Country Nationals and the Treaty on European Union, in: EJIL (1994) pp.199) et seq; Hailbronncr/Polakicwicz, Non-EC Nationals in 


\subsection{EEA Nationals}

In 1992 the then twelve EC Member States concluded with the then seven EFTA States the agreement on the European Economic Area (EEA). ${ }^{172}$ After the refusal of Switzerland to ratify the agreement, and the accession of Austria, Finland and Sweden to the European Union, the EEA Agreement now governs the relationship between the EC Member States and Norway, Iceland and Liechtenstein. The aim of the agreement is to "promote a continuous and balanced strengthening of trade and economic relations" between the contracting parties with a view to creating a "homogeneous European Economic Area" which entails inter alia a free movement of goods, persons, services, and capital. ${ }^{173}$ The rules governing the free movement of persons are set out in Articles 28 up to 35 EEA. Article 28 EEA provides that a free movement of workers shall be secured among the EC Member States and the three EFTA States. The wording of the Article largely coincides with Article $39 \mathrm{EC}$ and the main measures of secondary legislation adopted under Article 40 EC. Regulation No 1612/68 and Directive No 68/360 have been extended, for example, in order to apply, with a small number of adjustments, to the free movement of workers within the entire European Economic Area. ${ }^{174}$ Even though some of the provisions may have to be interpreted different$1 y$ in the context of the EEA Agreement, ${ }^{175}$ it may be assumed that the legal status of EEA workers and their family members is governed by the same principles as the status of Community workers and their family members. Basically, the EEA agreement has extended Community law on the free movement of workers, as described in Section 2 of this chapter,

the European Community: The Need for a Co-ordinated Approach, in: Duke JICL (1992) pp.49 et seq; Hoogenboom, Integration into Society and Free Movement of non-EC Nationals, in: EJLL (1992) pp.36 et seq; Ketelsen, Einreise, Aufenthalt und Ausweisung von Ausländern aus Drittstaaten, in: ZfRV (1991) pp.115-127; Plender. Competence, European Community Law and Nationals of nonMember States, in: ICLQ (1990) pp.599-610; Hilf, Europäisches Gemeinschaftsrecht und Drittstaatsangehörige, in: Hailbronner et al (Eds), Staat und Völkerrechtordnung - Festschrift für Karl Doehring (1989) pp.339-364 and Oliver (1985) supra footnote 92, at pp.57-92.

172. OJ 1995 L 86. For general descriptions of the EEA Agreement see e.g. Norberg, The Agreement on a EEA, in: CMLRev (1992) at pp.1171 et seq; O'Keeffe, The Agreement on the European Economic Area, in: LIEI (1992) pp. 1 et seq and Stuijck/Looijetijn-Clearie, The European Economic Area EC-EFTA (1993). For a description of the EEA provisions on the free movement of persons see further Sakslin, The Agreements on the European Economic Area, in: Jorens/Schulte, European Social Security Law and Third Country Nationals (1998) pp.1-110, at pp.399-417.

173. Article 1 of the EEA Agreement (EEA).

174. Article 28(5) EEA juncto Annex V to the Agreement

175. Compare Opinion $1 / 91$ on the Draft Agreement Relating to the Creation of the European Economic Area [1991] ECR 6079 at p.6102. Further, under certain circumstances Iceland and Licchtenstcin may take safeguard measures. See further Handoll (1995) supra footnote 1, at p.319. 
to the territory and the nationals of Norway, Iceland and Liechtenstein The same holds true for the Community provisions on the free movement of services (Article 36-39 EEA). ${ }^{176}$ As a result, EEA nationals enjoy the right to move to other States in order to receive services and, following the judgments of the Court of Justice in Luisi and Carbone and Commission $v$ the Netherlands, all EEA nationals can, as tourists, business persons or patients, cross the internal "EEA-borders" simply upon the production of a valid passport. In addition, the three 1990 residence directives for students, pensioners and "other" Community citizens have been extended to EEA-nationals. EEA-nationals, however, do not hold the right to travel and the non-economic right to residence by virtue of the fact that they possess Norwegian, Icelandic or Liechtenstein nationality. The EEA Agreement does not provide for equivalents of Articles 17 (Union citizenship) and 18 (general right to freedom of movement) EC. ${ }^{177}$

\subsection{Turkish Nationals}

In 1963 the Community and its Member States concluded in Ankara an Association Agreement with Turkey which was designed to promote "the continuous and balanced strengthening of trade and economic relations between the parties" and to prepare Turkey for an eventual accession to the Community. ${ }^{178}$ Among other things, ${ }^{179}$ the contracting partners agreed to be "guided" by Articles 48-50 EEC (now 39-41 EC) for the purpose of progressively securing freedom of movement for workers

176. See also Articles 31-35 EEA as regards the right of establishment.

177. Compare Sakslin (1998) supra footnote 172, at p.409.

178. Article 2 of the Agreement establishing an Association between the European Economic Community and Turkey. OJ $1963 \mathrm{C} 113$. Prior to this agreement the Community and its Member States had already concluded a comparable association agreement with Greece. See further Papastamkos, Die Erweiterung der EG-Freizügigkeit auf griechische Arbeitnehmer (1983).

179. The EEC Treaty has served as a model for the gradual integration of Turkey to the Community. The planned free movement of workers was supposed to supplement the establishment of a customs union which would in time have to develop into an economic union. See further Alanat, Freizügigkeit als Prüfstein der Assoziation EWG-Türkei - General Framework of the Association, in: Lichtenberg et al (Eds), Gastarbeiter - Einwanderer - Bürger? Die Rechtstellung der türkischen Arbeitnehmer in der Europäischen Union (1996) pp.17-26, at p.17 and Gümrükcü, EU-Türkei-Beziehungen im Spannungsfeld zwischen Assoziation und Vollmitgliedschaft - Werdegang einer ungleichen Partnerschaft, in: Lichtenberg et al (Hrsg.), Gatsarbeiter - Einwanderer - Bürger? Die Rechtstellung der türkisher Arbeitnehmer in der Europäischen Union (1996) pp.27-60, at pp.30-41. 
between them. ${ }^{180}$ Article 36 of the Additional Protocol of $1970^{181}$ entrusted the EEC-Turkey Association Council with the task of adopting measures necessary for securing, in three consecutive stages, the free movement of workers no later than 1 December 1986. In furtherance of this task, the Association Council adopted Decisions No 2/76 and No $1 / 80,{ }^{182}$ but a third decision which would govern the third and final stage in which the free movement for workers would finally be realised, was never adopted. ${ }^{183}$ As a result, Turkish nationals do not have the right to move to the Community's Member States in order to take up employment. It is up to the Member States to determine the conditions under which Turkish nationals are admitted to their territory and labour market. $^{184}$

Once admitted, however, Turkish workers enjoy a number of rights under Decision No 1/80. As regards conditions of work and remuneration, Turkish workers must be treated equally with the nationals of the host State $^{185}$ and, by virtue of Article 6(1) of Decision No $1 / 80,{ }^{186}$

180. Article 12 of the Ankara Agreement. All contracting parties seemed to have agreed with this objective. At the time, the EC Member States were in need of foreign labour and had already recruited large numbers of Turkish workers, whilst Turkey saw the progressive realisation of a free movement of workers as a means to solve its social problems which included considerable unemployment. See further Sayari, Migration Policies of Sending Countries: Perspectives on the Turkish Experience, in: Heisler/Schmitter-Heisler (Eds.), From Foreign Workers to Settlers? Transnational Migration and the Emergence of New Minorities - Annals AAPSS (1986) pp.86-97.

181. OJ 1973 L 293.

182. Council of Association Decision 1/80 (Council Doc.8795/1/80). Decision 1/80 replaced Decision 2/76 which is no longer of significance. Compare Case C-434/93 Bozkurt [1995] ECR I-1475 at 14.

183. See further Jansen, Vrij Verkeer van Turkse Werknemers in de EG?, in: MR (1986) pp.261263. The fact that the Association Council did not fulfil its obligation to realise a free movement for Turkish workers by 1 December 1986 implies that Turkish workers have no legally enforcable right to freedom of movement. As with Article 12 of the 1963 Agreement, Article 36 of the Additional Protocol is of a programmatic character. The provision is not precise and unconditional enough to be directly effective. Case 12/86 Demirel [1987] ECR 3719 at 23. See further Hailbronner, Die Entscheidung des EuGH zur Freizügigkeit türkischer Arbeitnehmer, in: NVwZ (1988) pp.220-224; Joris, Het Hof van Justitie van de Europese Gemeenschappen en het Vrije verkeer van Turkse Werknemers: De Zaak Demirel, in: TvV (1988) pp.3-20 and Dimakopoulos, Wanderarbeitnehmer aus der Türkei in der Europäischen Gemeinschaft - Zur Zukunft der Gastarbeiderfrage in Europa, in: InfAuslR (1988) pp.309-315.

184. Case C-237/91 Kus [1992] ECR I-6781 at 25; Case C-351/95 Kadiman [1997] ECR I-2133 at 31 and Case C-36/96 Günayadin [1997] ECR I-5159 at 22.

185. Article 37 of the Additional Protocol and Article 10 of Decision No $1 / 80$

186. In order to benefit from the rights granted by Article 6(1) a Turkish worker must be "duly registered as belonging to the labour force" of the Member State concerned. On this requirement see Case C-434/93 Bozkurt [1995] ECR I-1475 at 22-23 (the requirement demands that the employment relationship can be located within the territory of a Member State or retains a sufficiently close link with that territory); Case C-171/95 Tetik [1997] ECR I-329 (concluding that a Turkish worker who after eight years of employment in a Member State, voluntarily gives up employment, still belongs to that State's labour force, provided he is genuinely seeking new employment) and Case C-1/97 Birden 
Turkish workers are given the right to gradually integrate into the labour force of the host member States. After one year of legal employment ${ }^{187}$ Turkish workers are entitled to renewal of their work permit for the same employer, ${ }^{188}$ after three years of employment they may take up another offer of employment in the same occupation and after four years of employment Turkish workers enjoy free access to any paid paid employment in the State concerned. Furthermore, after three years of legal residence in the host State, ${ }^{189}$ family members of Turkish workers enjoy the right to respond to any offer of employment subject to priority being given to Community nationals under Article 7 of the Decision No 1/80; after five years of legal residence they have free access to any paid employment of their choice. ${ }^{190}$ In addition, Turkish children must be admitted to courses of general education, apprenticeship and vocational training under the same educational entry qualifications as the children of nationals of that Member State (Article 9). ${ }^{191}$

In interpreting Articles 6(1) and 7, the Court has drawn inspiration from the principles developed in its case law on the free movement of

[1998] ECR I-7747 at 51 (holding that the requirement cannot be interpreted as applying to the labour market in general as opposed to a specific market with a social objective supported by public authorities).

187. The legality of employment presupposes a stable and secure situation as a member of the labour force of a Member State. Case C-192/89 Sevince [1990] ECR I-3461 at 30; Case C-237/91 Kus [1992] ECR I-6781 at 12; Case C-285/95 Kol [1997] ECR I-3069 at 27 and Case C-1/97 Birden [1998] ECR I-0000 at 55-69.

188. Article 6(1), first indent, merely aims to ensure continuity of employment with the same employer. Case C-355/93 Eroglu [1994] ECR I-5113 at 13. The provision cannot be relied upon by Turkish workers who in the first year of employment, with the permission of the national authorities, have worked for different employers and who wish to continue employment with their last employer (Case C-386/95 Eker [1997] ECR I-2697). The same holds true for workers who have worked for an employer for more than one year and, who after having worked for almost one year for another, wish to continue employment with the first employer. Case C-355/93 Eroglu [1994] ECR I-5113 at 15.

189. Article 7 is designed to create conditions conducive to family unity in the host State. Therefore, Member States may require that the family members live together with the worker uninterruptedly for three years in the host State, even though there may be objective reasons to justify the family member concerned living apart from the Turkish migrant worker. Case C-351/95 Kadiman [1997] ECR I-2180. See also Case C-329/97 Ergat [2000] ECR I-0000 at 38-39.

190. Children of Turkish workers who have completed a course of vocational training in the host State may respond to any offer of employment there, irrespective of the length of time they have been resident in that State, provided one of the parents has been legally employed in the Member State concerned for at least three years. Article 7, paragraph 2. Article 7 does not require that the Turkish parent is still working or residing in the host State at the time when the child wishes to gain access to the employment market. Case C-210/97 Akman [1998] ECR I-7519 at 51.

191. See Case C-210/97 Akman [1998] ECR I-7519. See further Peers, Annotation Akman, in: CMLRev (1999) pp.1027-1042. 
workers within the Community. ${ }^{192}$ Both Article $6(1)$ and 7 produce direct effect. ${ }^{193}$ Employment rights guaranteed by these provisions encompass a right of residence in the host State ${ }^{194}$ and the concept of worker covers persons who perform on behalf of and at the direction of another person, genuine and effective economic activities in return for which they receive a remuneration. ${ }^{195}$ The Court, however, has only transposed principles governing Article $39 \mathrm{EC}$ to the rights conferred by Decision No 1/80 "as far as possible". ${ }^{196}$ Decision No $1 / 80$ merely governs the second stage of the free movement of workers during which Turkish workers who have been admitted by a Member State to employment for the first time, are after one year given the right to gradually integrate into the host State's labour force. The absence, in the Decision of a provision comparable to Article 7(2) of Regulation No 1612/68, has limited the Court's power to strengthen the legal status outside the

192. See further O'Leary, Employment and Residence for Turkish Workers and their Families: Analogies with the Case Law of the Court of Justice on Article 48 EC, in: Scritti in Onore di Giuseppe Federico Mancini - Volume II Diritto Dell'Unione Europea (1998) pp.731-767.

193. Case C-192/89 Sevince [1990] ECR I-3461 at 26; Case C-355/93 Eroglu [1994] ECR I-5113 at 11; Case C-351/95 Kadiman [1997] ECR I-2133 at 28 and Case C-36/96 Günayadin [1997] ECR I5159 at 24 .

194. Case C-171/95 Tetik [1997] ECR I-329 at 24; Case C-237/91 Kus [1992] ECR I-6781 at 27-36 and Case C-355/93 Eroglu [1994] ECR I-5113 at 20 and 23. These residence rights are based on Articles 6 or 7 ; administrative documents concerning this right of residence only have declaratory effect. Case C-434/93 Bozkurt [1995] ECR-I1475 at 30.

195. See Case C-98/96 Ertanir [1997] ECR I-5193 at 43; Case C-36/96 Günayadin [1997] ECR I515931 and in particular Case C-1/97 Birden [1998] ECR I-7747 at 23-32 (which held that a Turkish worker who had a job sponsored by the State with public funds and which was meant to enable him to enter or re-enter "real" working life could be classed as a worker for the purposes of Article 6(1) of Decision No 1/80)

196. The main principles governing the public policy exception (see Section 7.1) are by analogy to be applied to the similarly phrased provisions contained in Decision No 1/80. See Case C-340/97 Nazli [2000] ECR I-0000 at 56. See further Demirel (1987) in which the Court considered whether Article 8 of the European Convention on Human Rights (right to family life) had any bearing on the question whether family members enjoy free movement rights under the Ankara Agreement. The Court recognised that it is its duty to ensure observance of fundamental rights in the field of Community law, but it held that it did not have the power to examine whether a national law or regulation is compatible with the European Convention. In the absence of Community provisions defining the free movement rights of family members of Turkish workers established in the Community, the Member States did not have to implement Community law and this implied, according to the Court, that it had no jurisdiction to determine whether national rules were compatible with the principles enshrined in the Convention. Case 12/86 Demirel [1987] ECR 3719 at 28. For a critique see Weiler, "Thou Shall Not Oppress a Stranger" (Ex.23:9): On the Judicial Protection of Human Rights of Non-EC Nationals, in: Schermers et al (Eds), Free Movement of Persons in Europe (1993) pp.248-271. 
employment context and to promote the integration of workers and their families into the host State's society as it has done as regards Community workers and their family members. ${ }^{197}$

\subsection{Maghreb Nationals}

In 1976 the Community and its Member States concluded co-operation agreements with Algeria, ${ }^{198}$ Morocco $^{199}$ and Tunisia. ${ }^{200}$ The Agreements, which came into force on 1 November 1978, aimed to promote overall co-operation between the contracting parties with a view to contributing to the economic and social development of the respective Maghreb country. More recently, the agreements with Tunisia and Morocco have been replaced by Euro-Mediterranean agreements which have established associations between the Community and its Member States, on the one hand, and Tunisia and Morocco, on the other hand. ${ }^{201}$ The Maghreb Agreements do not provide (nor do they envisage) a freedom of movement for workers (or persons) between these North-African countries and the EC Member States or a freedom of movement for Maghreb nationals among the Member States. It is up to Member States to determine whether Algerian, Moroccan or Tunisian nationals are admitted to their national labour markets and territories. Further, neither Maghreb workers nor their family members are offered a right to gradually integrate the labour market of the host Member State. Maghreb nationals merely enjoy a right to equal treatment as regards working conditions, remuneration and, so far as Tunisian and Moroccan nationals are concerned, dismissal. ${ }^{202}$ In interpreting the provisions of Maghreb agreements the Court has shown more restraint than it has as regards the agreement and decisi-

197. On the legal status of Turkish workers and nationals see further e.g. Staples, De Associatieovereenkomst EEG-Turkije - Een Leidraad voor de Rechtshulp, in: MR (1999) pp.179-188 and Guttmann, Die Assoziationstreizügigkeit Türkischer Angehöriger (1999).

198. OJ 1978 L 263.

199. OJ 1978 L 264

200. OJ 1978 L 265.

201. OJ 1998 L 97 (Tunisia) and OJ 2000 L 70 (Morocco).

202. For Morocco see Article 40 of the 1976 agreement and Article 64 of the assocation agreement; for Tunisia see Articles 39 and 64 respectively and for Algeria Article 38 of the 1976 agreement. The afore mentioned provisions are all sufficiently clear and unconditional in order to have direct effect. Martin/Guild (1996) supra footnote 1, at 14.12. See further e.g. Eicke, The Third Country Agreements: The Right to Work and Reside in the First Generation Agreements, in: Guild (Ed.), The Legal Framework and Social Consequences of Free Movement of Persons in the European Union (1999) pp. 89-103. 
ons regarding Turkey. ${ }^{203}$ The principles developed in the case law on the rules governing the EEC-Turkey association cannot be applied by analogy to the Maghreb agreements. In particular, employment in one of the Member States does not guarantee Maghreb nationals a right to reside there. ${ }^{204}$

\section{Co-ordination of Social Security Schemes: EC Regulations No} $1408 / 71$ and No $574 / 72$

For a proper understanding of the numerous issues involved in the subject of cross-border access to public services, some discussion of social security Regulations No $1408 / 71$ and No $574 / 72$ is necessary. ${ }^{205}$

203. By comparison with the 1976 co-operation agreements, the new association agreements with Tunisia and Morocco foresee a strengthening of the relationship between the contracting parties and this may have consequences for the interpretation of provisions of the agreements. Martin/Guild (1996) supra footnote 1 , at 14.3

204. Consider El-Yassini (1999). Mr El-Yassini was a Moroccan national who through marriage with a British national had obtained the right to reside and work in the United Kingdom. He seperated from his wife and, while still lawfully employed, he applied for an extension of his right to reside in the United Kingdom. El-Yassini claimed that Article 40 of the EEC-Morocco Agreement, which guarantees equality of treatment as regards working conditions and remunerations, should by analogy with the case-law on the EEC-Turkey association be interpreted as to encompass a residence right for the duration of employment. The Court accepted that Article 40 could be relied upon in court (Case C-416/96 El-Yassini (1999) ECR I-0000 at 32), but rejected El-Yassini's substantive claim. Provisions of the various agreement the Community concludes with third States must be interpreted in light of both their object and context. Unlike the Turkey agreement, however, the agreement with Morocco is not intended to progressively secure freedom of movement for workers and since there are no implementation measures comparable to the Decision adopted by the Turkey Association Council, the Court concluded, that the principles developed in the case-law on the rules governing the EEC-Turkey association cannot be applied by analogy to the Morocco agreement. Member States are under no obligation to extend the residence permit of Moroccan nationals where the initial reason for the grant of such a permit (in casu marriage to a British national) no longer exists. The fact that persons as $\mathrm{Mr}$ El-Yassini would be forced to terminate his employment relationship could not alter this conclusion. The situation would according to the Court only have been different if Mr El-Yassini had been granted specific rights in relation to employment which were more extensive than the granted residence rights and that would only have been the case where the duration of the work permit would exceed the duration of the initial residence permit. Case C-416/96 El-Yassini (1999) ECR I-0000 at 64-66. On El-Yassini see Bulterman, Annotation El-Yassini, in: CMLRev (1999) pp.1357-1364 and van der Steen, Verbod van Nationaliteitsdiscriminatie op het Gebied van Arbeidsvoorwaarden: Gevolgen voor het Verblijfsrecht, in: NTER (1999) pp.137-139.

205. For general descriptions of the co-ordination mechanism established by the two Regulations see e.g. Pennings, Grondslagen van het Europese Sociale Zekerheidsrecht (2000); Voogsgeerd, Vrij Verkeer en Sociale Zekerheid (1999); White, EC Social Security Law (1999); Pennings, Introduction to European Social Security Law (1998); Jorens, Wegwijs in het Europees Sociaal Zekerheidsrecht (1995) and van Raepenbusch, La Securité sociale des Personnes qui Circulent a l'Intérieur de la Communauté économique européenne (1991). 
Within the European Community it has never been disputed that it is for the Member States to organise, administer and finance social security schemes. $^{206}$ A harmonisation of national social security systems ${ }^{207}$ or the establishment of a common social security system have never been seriously considered. However, it has always been recognised that the existence of different territorially organised social security systems could have a deterrent effect on the exercise of free movement rights guaranteed by Community law. If it were left to national law alone, ${ }^{208}$ movement to other Member States could lead to a loss of social security rights. Rights acquired in the Member State of origin may not be transferable abroad and in the host State workers may not be eligible for social benefits because they have not worked, resided or been insured there long enough. In order to overcome the various obstacles resulting from the territoriality principle, Article 42 (formerly 51) EC empowers the Council to adopt

206. See e.g. Case C-18/95 Terhoeve [1999] ECR I-345 at 33; Case C-70/95 Sodemare [1996] ECR I-3422 at 27 and Case 238/82 Duphar [1984] ECR 523 at 16

207. To be sure, from the early years discussions have been held regarding a possible harmonisation of social security systems. For some of the earliest debates see e.g. Meinhold, Notwendigkeit und Möglichkeit der Harmonisierung von Sozialleistungen im EWG-Raum, in: DVZ (1964) pp.1-4; Heise, Les Possibilités d'une Harmonisation social des Régimes d'Assurance sociale dans les Etats Membres de la Communauté Economique Européenne, in: DS (1966) pp.580-589 and Holloway, Social Policy Harmonization in the European Community (1981). For more recent discussions (which have primarily been motivated by the fear of "social dumping" after "1992") see Pieters, Brengt "1992" Coördinatie en Harmonisatie van de Sociale Zekerheid?, in: NJB (1989) pp.831 et seq Pieters, Sociale Zekerheid na 1992: Eén over Twaalf (1989) and Schulte, Social Security Legislation in the European Communities: Co-ordination, Harmonization and Convergence, in: Pieters, Social Security in Europe (1991) pp.153-168. Generally, harmonisation of social security is not (or no longer) considered to be desirable or feasible; discussions have shifted in the direction of (stimulating) a "spontaneous" convergence of the national systems. See e.g. Council Recommendation No 92/442 of 27 July 1992 (OJ 1992 L 245)

208. To be sure, next to the Community measures discussed in this Section, numerous bi- and multilateral treaties (e.g. the European Interim Agreements concluded within the framework of the Council of Europe and the various conventions adopted by the International Labour Conference) have been concluded which intend to offer migrants social security protection. For an overview see e.g. Eichenhofer, Internationales Sozialrecht (1994). In order to avoid possible conflicts with the rules laid down in these international instruments, Article 6 of Regulation No 1408/71 stipulates, in brief, that the regulation replaces other social security conventions which bind two or more Member States. Regulation No $1408 / 71$ prevails even if the application of international conventions would be more advantageous to migrant workers. This may only differ in cases where the persons concerned had already acquired social security rights under an international convention prior to the coming into force of the social security regulation. See Case 82/72 Walder [1973] ECR 599 at 6-8; Case C227/89 Rönfeldt [1991] ECR I-323 at 26-29; Case C-475/93 Thevenon [1995] ECR I-3813 at 27 and Case C-95/99 Thelen [2000] ECR I-0000. See further Jorens, Non-European Union Nationals and the Co-ordination of European Social Security Law: The International Agreements Concluded by the European Union with Third Countries and Conflict Rules in European Social Security Law, in: Jorens/Schulte (Eds), European Social Security Law and Third Country Nationals (1998) pp.1-110, at pp. 68-110. 
measures necessary for securing a free movement of workers in the field of social security. In furtherance of this goal, in 1958 the Council adopted Regulations No 3 and No 4 which established a co-ordination mechanism aimed at preventing a loss of social security rights caused by the exercise of free movement of workers. ${ }^{209}$ In response to the Court of Justice case law and developments in the national social security systems, the two regulations were replaced in 1971 by Regulations Nos $1408 / 71^{210}$ and $574 / 72{ }^{211}$ The former regulation sets out the rights which migrants enjoy; the latter contains the administrative rules for the implementation of these rights.

The two regulations aim to promote freedom of movement by coordinating the national social security systems in such a away that beneficiaries enjoy "constant social security protection". ${ }^{212}$ The regulations are based on four basic principles. The first is laid down in Article 3(1) of Regulation No 1408/71. The provision stipulates that beneficiaries "shall be subject to the same obligations and enjoy the same benefits under the legislation of a Member State as nationals of that State". Equality of treatment is the Regulation's starting; nationality should not play a role as regards the social security status of migrants. The second principle implies that migrants can only be compulsorily affiliated to the social security system of one Member State. In the absence of any rules, in moving to another Member State migrants might not have access to any social security system or they might be required to pay social insurance contributions (and be entitled to obtain benefits) in more than one Member State. Articles 13 to 17 of Regulation No 1408/71 contain rules determining the applicable national legislation. ${ }^{213}$ The starting-point is that beneficiaries are insured in the State of employment. ${ }^{214}$ The third princi-

209. For a brief description of Regulations No 3 and No 4 see e.g. Troclet, Europees Sociaal Recht Institutioneel Kader, Rechtsinstrumenten, Sociale Problemen en hun Oplossing (1971) pp.282 et seq. 210. OJ 1971 L 149

211. OJ 1972 L 74.

212. Watson, Social Security Law of the European Communities (1980) at p.249.

213. The conflict rules have exclusive and binding effect. Exclusive effect is relevant for situations in which, on the basis of national laws, more than one piece of legislation would be applicable (positive conflict of laws). The conflict rules determine which of the national legislation is exclusively applicable. The "other" legislation is overruled by the conflict rule. See e.g. Case 92/63 Nonnenmacher [1964] ECR 583 and Case 302/84 Ten Holder [1986] ECR 1821. Binding effect is relevant in case, on the basis of national laws, no legislation would be applicable (negative conflict of laws). The conflict rules determine which of the legislations must be applied. See e.g. Case 276/81 Kuijpers [1982] ECR 3027 and Case C-196/90 De Paep [1991] ECR 4815.

214. The choice for the State of employment is explained by the fact that the original Member States all had (Bismarckian) social security schemes based on the pursuit of economic activities. The costs of social security benefits are to be borne by the State where workers pay their contributions. See Chardon, Principles of Co-ordination, in: Jorens/Schulte, Co-ordination of Social Security Schemes in 
ple is that of aggregation. It implies that the competent national authorities whose legislation makes the enjoyment of social security rights conditional upon the completion of periods of insurance, employment or residence in the host state, must take such periods completed in other Member States into account as if they had been completed under their own legislation. ${ }^{215}$ The fourth ${ }^{216}$ principle concerns the exportability of benefits. The payment of benefits to which a worker is entitled cannot be made conditional upon residence in the State responsible for paying the benefit. The co-ordination system deterritorialises the national systems in order to ensure that migrants are entitled to benefits on the basis of their own insurance record. ${ }^{217}$

The material scope of Regulation No $1408 / 71$ is defined in Article 4. According to Article 4(1), the regulation applies to legislation ${ }^{218}$ concerning sickness and maternity benefits, invalidity benefits, old age benefits, survivors' benefits, benefits in respect of accidents at work and occupational diseases, death grants, unemployment benefits and family

Connection with the Accession of Central and Eastern European States - "The Riga Conference" (1999) pp.43-79, at p.67. Many States which later joined the Community (as well as the EEA States), however, have social benefits systems which are based on residence. Debates have started as to whether the current principle of being insured in the State of employment should be replaced by the principle of insurance in the State of residence. See e.g. Christensen/Malmstedt, Lex Loci Laboris versus Lex Loci Domicilii - An Inquiry into the Normative Foundations of European Social Security Law, in: EJSS (2000) pp.69 et seq.

215. Regulation No $1408 / 71$ contains aggregation rules for various types of benefits. See e.g. Article 18 (sickness and meternity benefits), Article 67 (unemployment benefits) and Article 72 (family benefits). This rule is not applied as regards long-term benefits such as invalidity, survivors' and oldage pensions. See further Pennings (1998) supra footnote 214, at pp.133-134. In some cases a duty to take into account periods of insurance or employment fulfilled in other Member States can directly follow from Articles 48 and 51 of the Treaty. See e.g. Case C-443/93 Vougioukas [1995] I-4033. Indeed, aggregation can be analysed as an extended form of equal treatment. Lyon-Caen, Social Security and the Principle of Equal Treatment in the EC Treaty and Regulation No.1408/71, in Commission of the European Communities/Departemento de Relações Internaçionais e Convenções de Segurança Social, Social Security in Europe - Equality Between Nationals and Non-Nationals (1995) pp.45-73, at p.52

216. In its case law the Court has in fact developed a fifth principle according to which migrant workers should not lose autonomous rights they have acquired under national law. See e.g. Case 24/75 Petroni [1975] ECR 1149.

217. Migrants should be able to receive benetits anywhere within the Community irrespective of the Member State where the insurance contributions are paid. Arnull (1990) supra footnote 165, at p.130. The general export provision contained in Article 10 of Regulation No 1408/71 aims to promote the free movement of persons by ensuring that individuals retain their right to benefits if they move to another Member State. Case 139/82 Piscitello [1983] ECR 1427 at 15 and Case C73/99 Movrin [2000] ECR I-0000 at 33. For unemployment benefits exportability is limited to a maximum period of three months. See Article 69 of Regulation No 1408/71 and Case 139/78 Coccioli [1979] ECR 991

218. The regulation only applies to statutory social security schemes. In principle, it does not apply to schemes set up by industrial or collective agreements. See Article 4(1) juncto Article 1(j). 
benefits. ${ }^{219}$ Article 4(4), however, excludes "social and medical assistance, benefits schemes for victims of war or its consequences" ${ }^{1220}$ from the scope of the regulation's application. ${ }^{221}$

219. The list contained in Article 4(1) is exhaustive. See e.g. Case C-66/92 Acciardi [1993] ECR I4567 and Case 122/84 Scrivner [1985] ECR 1029 at 19. The social security benefits covered by the Regulation can also be classed as "social advantages" for purposes of Article 7(2) of Regulation No $1612 / 68$. For quite some time it was not entirely clear whether both regulations could be applied to a given benefit simultaneously or whether the regulations would mutually exclude each other. See Gouloussis, Equality of Treatment and the Relationship between Regulations 1612/68 and 1408/71, in: Commission of the European Communities/Departemento de Relações Internaçionais e Convenções de Segurança Social, Social Security in Europe - Equality between Nationals and NonNationals (1995) (1995) pp.75-88. The issue could be particularly relevant because the personal scope of the two Regulations is not identical. Martin/Guild (1996) supra footnote 1, at p.136. In some cases the Court made "procedural preference" to Regulation 1408/71 (Vonk (1990) supra footnote 3, at p.354 and O'Keeffe (1986) supra footnote 62, at p.97) which implied that the Court first established whether a benefit fell under Regulation No $1408 / 71$ and that in case of an affirmative answer, Article 7(2) of Regulation No 1612/68 was deemed not to be applicable. See e.g. Case 1/72 Frilli [1972] ECR 457 at 4 and Case 122/84 Scrivner [1985] ECR 1027 at 16. In case a benefit did not fall within the scope of Regulation No 1408/71, Article 7(2) could be apllied as a "safety netclause". See e.g. Case 249/83 Hoeckx [1985] ECR 982. In other cases the Court held that both Regulations could be applied. See e.g. Case 94/84 Deak [1985] ECR 1873; Case 147/87 Zaoui [1987] ECR 5511 and Case C-111/91 Commission v Luxembourg [1993] I-817 at 21. Recently, the Court concluded that since "Regulation No $1612 / 68$ is of general application regarding the free movement of workers, Article 7(2) thereof may be applied to social advantages which at the same time fall specifically within the scope of Regulation No 1408/71". Case C-85/96 Martinez Sala [1998] ECR I-2691 at 27. The simultaneous application of both regulations may not, however, be justified in all cases. See e.g. the Opinion of Advocate General in Case C-160/96 Molenaar [1998] ECR I-0000 at point 99-100). In case application of the rules of Regulation No 1612/68 would run counter to the specific rules of Regulation No 1408/71, the rules of the latter regulation are to be applied as the lex specialis. See Article 42(3) of Regulation No 1612/68 ("This Regulation shall not affect measures taken in accordance with Article 51 (now 42: APvdM) of the Treaty".

In 1998 a special Directive was adopted for supplementary pension rights. Directive 98/49 (OJ 1998 L 209). See further Schulte, Pensions and Social Security, in: Carlier/Verwilghen, Thirty Years of Free Movement of Workers in Europe (2000) pp.143-158 and Wienk, Europese Coördinatie van Aanvullende Pensioenen (1999).

220. Until recently, Article 4(4) also excluded "special schemes for civil servants and persons treated as such" from the scope of application of the Regulation. In response to the judgment of the Court in Vougioukas (Case C-443/93 [1995] ECR I-4033) special schemes for civil servants have been brought within the scope of the Regulation. OJ 1998 L 209. See further Vilaras, Freedom of Movement in the Public Sector - Developments and Prospects, in: Carlier/Verwilghen, Thirty Years of Free Movement of Workers in Europe (2000) pp.89-104 and van der Steen, Vrij Verkeer en Sociale Zekerheid van Ambtenaren, in: NTER (1996) pp.53-56.

221. A given benefit (scheme) falls within the scope of the regulation when (i) the legislation under which the benefit is granted place claimants in a legally defined position as a result of which they have an absolute right to benefit (Case 1/72 Frilli [1972] ECR 457 at 18 and Case 139/82 Piscitello [1983] ECR 1471 at 11) and when (ii) the benefit covers one of the risks enumerated in Article $4(1)$ (Case 249/83 Hoeckx [1985] ECR 982 at 12 and Case 122/84 Scrivner [1985] ECR 1029 at 19). Occasionally, the Court has applied a third criterion according to which a benefit only falls within the scope of the Regulation when the recipient has been subject to the social security system of the State under whose legislation the benefit is made available. Case C-356/89 Newton [1991] ECR I- 
The personal scope of Regulation No 1408/71 has been expanded over the years. Initially, the Regulation only applied to workers holding the nationality of one of the Member States ${ }^{22}$ and who are or have been subject to the legislation of one or more Member States. Subsequent amendments have brought the self-employed ${ }^{223}$ and students ${ }^{224}$ within the scope of the Regulation and proposals have been made to include all insured Union citizens. ${ }^{225}$ The concept of "worker" for the purposes of the Regulation does not coincide with the notion of "worker" in Article 39 EC. Article 1 of Regulation No 1408/71 indicates that a "worker" is any EC national who is insured under a social security scheme for (self-)employed persons. Thus, also Community citizens who do not perform "effective and genuine" activities may be classed as a "worker" for purposes of Regulation No $1408 / 71 .^{226}$ Also, family members of workers may benefit from the Regulation, but their status under the Regulation has been rather ambiguous. Since family members derive their rights from workers, discussions have taken place as to whether they can rely on Regulation $1408 / 71$ only with respect to rights or benefits which they

3017 at 19. Generally, the Court seems to favour a broad interpretation of the material scope of Regulation No $1408 / 71$, but this is not to say that all benefits are covered. See e.g. Case C-25/95 Otte [1996] ECR I-3745.

222. See Article 2 of the Regulation. The fact that third country nationals are in principle excluded is explained by the fact that the Regulation is aimed at facilitating the exercise of free movement rights which are preserved for nationals of the Member States. On the question whether or when a person must be considered as a national of one of the Member States for purposes of Regulation No 1408/71 see Case 10/78 Belhouah [1978] ECR 1915 and Case C-105/89 Buhari Haji [1990] ECR 4211. Stateless persons and refugees, however, are covered by Regulation No 1408/71. In Joined Cases C-95/99 to $98 / 99$ and C-180/99 Khalil the Court has been asked whether stateless persons and refugees are indeed covered by the Regulation even though they do not enjoy the right to freedom of movement. The case is still pending. In his Opinion of 30 November 2000 (http://www.curia.eu.int/jurisp) Advocate General answered the question in the affirmative.

223. See Regulation 1390/81 (OJ 1981 L 143). Prior to Regulation No 1390/81 the Court had already held that self-employed persons could under certain conditions fall within the scope of the Regulation. See e.g. Case 19/68 De Cicco [1968] ECR 475; Case 23/71 Janssen [1971] ECR 859 and Case 17/76 Brack [1976] ECR 1429. The Court accepted the extension of the regulation to self-employed persons in Case 300/84 Van Roosmalen [1986] ECR 3097.

224. Regulation No 307/1999 (OJ 1999 L 38) has extended the personal scope of Regulation No $1408 / 71$ in its entirety to students. Article 2 of Regulation No 1408/71 was amended and now provides that in addition to (self-)employed students who are or have been subject to the legislation of one or more Member States also fall within the scope of the Regulation.

225. $\operatorname{COM}(1998) 779$ final. Article 1 of the proposed new social security regulation provides that all "persons who are or have been subject to the social security legislation of one or more Member States" shall be covered. Even third country nationals are proposed to be included even though they do not enjoy independent free movement rights. On the Commission's proposal, which aims at a simplication of the entire regulation, see Pennings/Essers, Het Voorstel van de Europese Commissie tot Vereenvoudiging van Verordening 1408/71, in: SMA (2000) pp.512-525. 226. See e.g. Casc 2/89 Kits van Heijningen [1990] ECR 1755. 
enjoy in their capacity as family members or whether they could enjoy benefits in their own right. In Kermaschek (1976) the Court chose the first option $^{227}$ which seemed to imply that family members can only rely on the Regulation as regards benefits payable to family members such as survivor's benefits, death grants or sickness benefits for which the family members are co-insured. For a long time the Court clung to the rather restrictive rule laid down in Kermaschek. ${ }^{228}$ In Cabanis-Issarte (1996), however, the Court largely abandoned the distinction between derived rights and rights which may be enjoyed "in person". The Court held that being unable to claim rights which may not be regarded as derived rights could adversely affect the free movement of workers. The judgment in Cabanis-Issarte seems to imply that family members can rely on all provisions of Regulation No 1408/71 except for those which apply to benefits to which only workers are entitled such as unemployment benefits. $^{229}$

In principle, third country nationals are excluded from the coordination mechanism set up by the two social security regulations. Some of them, however, may enjoy social security rights under (measures adopted within the framework of) the agreements which the Community and its Member States have concluded with the country of which they hold the nationality. The most extensive social security protection is enjoyed by EEA nationals. Article 29 EEA repeats the wording of Article 42 EC and, by virtue of Annex VI to the EEA Agreement, Regulations Nos $1408 / 71$ and 574/72 have been extended to the territories and nationals of Liechtenstein, Iceland and Norway. ${ }^{230}$ Turkish workers are offered social security protection by Decision No 3/80 which the EEC-Turkey Association Council has adopted in furtherance of Article 39 of the Additional Protocol of $1970 .^{231}$ Decision No $3 / 80$ largely resembles

227. The Court held that the Regulation: "refers to two clearly distinct categories: workers on the one hand, and the members of their family and their survivors on the other. (.) Whereas the persons belonging to the first category can claim rights to benefits covered by the regulation as rights of their own, the persons belonging to the second category can only claim derived rights, acquired through their status as a member of the family or survivor of a worker ...". Case 40/76 Kermaschek [1976] ECR 1669 at 7.

228. See e.g. Case 157/84 Frascogna [1985] ECR 1739; Case 94/84 Deak [1985] ECR 1873 and Case C-243/91 Taghavi [1992] ECR I-4401. The Court, however, has not applied the rule following from Kermaschek univocally. This is particularly true in as far as mixed benefits for disabled persons are concerned. See e.g. Case $7 / 75 \mathrm{Mr}$ and Mrs F. [1975] ECR 679 and Case 63/76 Inzirillo [1976] ECR 2057.

229. Case C-87/94 Cabanis-Issarte [1996] ECR I-2097 at 30-44. See also Moore, Annotation Cabanis, in: CMLRev (1997) pp.727-739. Peers, Equality, Free Movement and Social Security, in ELRev (1997) pp.342-351 and van der Steen, Annotatie Cabanis, in: SEW (1997) pp.207 et seq. 230. See further Sakslin (1998) supra footnote 172.

231. See Section 5.3 above. 
Regulation No 1408/71. ${ }^{232}$ Albeit with deviations and exceptions, the Decision has extended the principles of equality of treatment, ${ }^{233}$ aggregation and exportability ${ }^{234}$ as well as the rules determining the applicable legislation to Turkish workers. ${ }^{235}$ Finally, Maghreb nationals enjoy various rights in the field of social security by virtue of the agreements which Morocco, Tunisia and Algeria have concluded with the Community and its Member States. These include inter alia a directly enforcable right to equal treatment and a right to aggregation as regards periods of insurance, employment and residence fulfilled in other Member States. ${ }^{236}$

\section{Judicial Review of National Rules and Measures under the Community Provisions on the Free Movement of Persons}

Community citizens and, to a lesser extent, third country nationals have acquired an increasing number of rights under Community law over the years. These rights have imposed significant limitations on the powers of Member States to regulate access of non-nationals and/or nonresidents to their territory, (employment) markets and welfare systems. The Community provisions, however, do not guarantee that beneficiaries can in all cases enter, reside and work in other Member States or enjoy social, economic

232. For more extensive descriptions see Centel, The Social Security of the Turkish Workers in Europe within the Framework of the Association Agreement, in: Jorens/Schulte (Eds), European Social Security Law and Third Country Nationals (1998) pp.281-297 and Hänlein, Problems Concerning Decision No $3 / 80$ of the Council of Association - A Point of View from a EU Perspective, in: Jorens/Schulte (Eds), European Social Security Law and Third Country Nationals (1998) pp.299-322.

233. Article 3 of Decision No 3/80. Article 3 only provides for a right to equal treatment under national social security law. It does not imply that Turkish workers can claim all the benefits of Regulation No 1408/71 under the same conditions as the nationals of the host State. See Jorens (1998) supra footnote 208 , at pp.9-10.

234. Turkish workers can export benefits to Turkey or another Member State (see Article 39(4) of the Additional Protocol and Article 6 of Decision No 3/80), but the application of the aggregation rules is only possible for Turkish workers moving within the Community. Compare Hänlein (1998) supra footnote 232 , at p.302.

235. As will be explained later on in this book, the practical significance of Decision No $3 / 80$ is still limited by the fact that it is not accompanied by an implementing decision which, like Regulation No $574 / 72$, contains the administrative rules necessary for implementing social security rights. See in particular Chapter 3 Section 7.3.

236. See further Roberts, The Rulings of the European Court of Justice on the Association and Cooperation Agreements in Matters Concerning Social Security, in: Jorens/Schulte, European Social Security Law and Third Country Nationals (1998) pp.209-234 and Gacon-Estrada, The Co-operation Agreements Concluded Between the European Community and the Maghreb Countries, in: Jorens/Schulte, European Social Security Law and Third Country Nationals (1998) pp.323-331. 
or political rights there. Community law has not taken from the Member States the power to lay down the conditions under which economic and social rights may be enjoyed. Community law merely prohibits rules or measures which discriminate against non-nationals or non-residents, or which hamper the free movement of persons. In addition, Member States are entitled, under certain conditions, to derogate from and to impose limitations on the free movement rights. This section sets out the rules, principles and tests which are to be applied (by courts) in order to determine whether or not a given national provision or measure is compatible with Community law. ${ }^{237}$ A distinction is made between national provisions or measures which directly discriminate against nationals of other Member States, measures which affect non-nationals only indirectly and nationality-neutral rules which hamper freedom of movement. ${ }^{238}$

\footnotetext{
237. Member States that wish to derogate from or impose restrictions on the free movement rights, are bound to observe fundamental human rights such as those enshrined in the European Convention on Human Rights. See e.g. Case 36/75 Rutili [1975] ECR 1219 and Case C-368/95 Familiapress [1997] ECR I-3869. The Charter of Fundamental Rights, as proclaimed at the recent summit in Nice, may enhance human rights' protection in future (see e.g. the Editorial Comments in CMLRev (2001) pp.1-6), but the precise degree to which fundamental rights are to be observed by the Member States is, at present, still quite uncertain. For this reason, the issue will not be discussed seperately in this Section. On the role of human rights in the European Union see e.g. Alston (Ed.), The EU and Human Rights (1999); Betten/Grief, EU Law and Human Rights (1999); De Witte, The Past and Future Role of the European Court of Justice in the Protection of Human Rights, in: Alston (1999) supra, at pp.859-897; Neuwahl, The Treaty on European Union: A Step Forward in the Protection of Human Rights?, in: Neuwahl/Rosas, The European Union and Human Rights (1995) pp.1 et seq; Clapham, Human Rights and the European Community: A Critical Overview, in: Cassese et al (1991) supra pp.29-61; Weiler, Methods of Protection: Towards a Second and Third Generation of Protection, in: Cassese et al (1991) supra, at pp.575-620 and Mendelsohn, The European Court of Justice and Human Rights, in: YEL (1981) pp.125 et seq.

238. In reviewing national rules courts will usually have to take two steps. The first concerns the question whether a national rule or practice directly or indirectly discriminates against non-nationals or whether it may hamper freedom of movement. This prima facie relevance test seeks to establish whether the rule in question is caught, in principle, by the prohibitions of Community law. When this first test has been passed, courts will have to take the second step concerning the possible justification of the rule in question. Sec Voogsgeerd (2000) supra footnote 102, at pp.417-418.
} 


\subsection{Direct Discrimination on Grounds of Nationality}

Article 12(1) EC and the various specific non-discrimination provisions $^{239}$ order the elimination ${ }^{240}$ of discrimination based on nationality. ${ }^{241}$ The prohibition covers direct (or overt) discrimination which occurs where differential treatment of two (groups of) persons by a single legal subject is based on the criterion of nationality. It concerns national provisions or practices ${ }^{242}$ which make the enjoyment of, or eligibility for, a certain right, benefit or opportunity explicitly conditional upon the nationality of the host State or upon conditions which only nationals from

239. Article 12 EC applies independently only in cases where none of the more specific provision guaranteeing equality of treatment are applicable. Case C-193/94 Skanavi [1996] ECR I-929 at 20 Case C-18/93 Corsica Ferries [1994] ECR I-1783 at 19 and Case C-176/96 Lehtonen [2000] ECR I0000 at 37. More generally, the relationship between the various equal treatment provisions is governed by the principle of lex specialis derogat lex generalis. This first implies that a national provision which violates a specific equal treatment provision is by definition also contrary to the more general provision which the specitic provision implements. Thus, a national provision which is contrary to e.g. Article 7(2) of Regulation No 1612/68 also violates Article 39 EC (and Article 12 EC). In order to claim equality of treatment reliance on Article 7(2) of the Regulation suffices; a Community worker may, but does not have to, invoke Article 39 EC (or Article 12 EC). Furthermore, discriminatory treatment which is permitted by a specific provision is also compatible with the general equal treatment provision. Thus, a Community citizen who has been refused access to a post in the public service on the basis of Article 39(4) EC cannot claim access to such a post by relying on Article 12 EC. Compare the Opinion of Advocate General Jacobs in Joined Cases C-92/92 and C326/92 Collins [1993] ECR I-5145 at 14.

240. Following its case-law in the field of of sex discrimination, the Court has held that so long as national rules are not adapted to the non-discrimination principle, Member States must apply the more favourable rules applicable to their own nationals to non-nationals. See Case C-15/96 SchöningKougehetopoulou [1998] ECR I-47. On this "only valid point of reference case law" see further Wouters, The Principle of Non-Discrimination in European Community Law, in: ECTaxRev (1999) pp.98-106, at p.106.

241. The prohibition of discrimination on grounds of nationality is a "specific enunciation" of the general principle of equality, which is one of the "fundamental principles" (Joined Cases 117/76 and 16/77 Ruckdeschel [1977] ECR 1769) underlying Community law. According to this principle, similar situations should be treated equally and dissimilar situations unequally unless there is an objective justification for the (dis)similar treatment. See e.g. Case 13/63 Italy v Commission ("Italian Refrigarators") [1963] ECR 165 and Case C-217/91 Brandy [1993] ECR I-3923. A distinction is often made between formal and material discrimination. The former concerns the unequal treatment of equal cases, whilst the latter involves the equal treatment of unequal cases. In order to determine whether a given rule or measure violates the non-discrimination principle it has first to be established whether or not two cases are similar or comparable and after that the question of a possible justification of the (in)comparable situations may (have to) be addressed. The notions of formal and material discrimination, however, are rarely used under Community law. Community law merely probihits discrimination on specific grounds such as nationality and gender and one generally speaks of direct (or overt) and indirect (or covert) discrimination. Especially in cases concerning nationality based discrimination, the Court rarely engages in a comparability test. Within the scope of Communi-

ty law nationals of the various Member States are presumed to be in a comparable situation. See further Wouters (1999) supra footnote 240

242. See e.g. Case C-185/96 Commission v Greece [1998] ECR I-1095 at 24. 
other Member States have to meet. ${ }^{243}$ Nationality requirements are by their very nature at odds with the objectives of the Community. The common market could never have been realised, and could never operate effectively, if Member States were free to exclude nationals from other Member States from their territory and labour markets. The concept of a common European citizenship could never have been introduced, and would not develop any further, if Community citizens could be discriminated against for reason of their nationality. From the perspective of Community law, nationality requirements are "suspect" and the basic assumption is that such requirements cannot be validly applied. Yet, as broad as the Community's objectives may be, they are limited. The Community is not a State, it is not expected to be transformed into one and Union citizenship is not intended to replace Member State nationality. ${ }^{244}$ The Community consists of a number of nation States which have, or are based on, a special bond with their own nationals. Community law does not aim to abolish all State discriminations against nationals of other Member States in favour of its own nationals. Two situations are to be distinguished.

The first concerns rights such as the right to vote and stand as a candidate in national elections, benefits linked to the pursuit of military service and access to employment in the public service (Article 39(4) EC). ${ }^{245}$ These "political" rights fall outside the scope of Community law and the non-discrimination principle. Member States are entitled to make the enjoyment of these rights conditional upon "their" nationality. They are under no obligation to justify discrimination against non-nationals. Community law, however, does impose significant restrictions on the freedom of Member States to determine whether or when a given right, benefit or opportunity falls outside the scope of the non-discrimination principle. $^{246}$ This is particularly true for the public service exception. On

\footnotetext{
243. See e.g. Case 249/83 Hoeckx [1985] ECR 982 and Case 39/86 Lair [1988] ECR 3161 (both concerning requirements of a minimum period of residence or employment in the host State which only non-nationals were required to satisfy).

244. Compare the Preamble to Decision No $95 / 553$ regarding protection of citizens of the European Union by diplomats and consular representatives (OJ 1995 L 314 - Union citizenship "is different from and in no way a substitute for the concept of national citizenship").

245. National rules or measures cannot be regarded as exempt from the application of Community law solely because they have been adopted for reasons of demographic policy. See Case 65/81 Reina [1982] ECR 33 at 15 and Case C-185/96 Commission v Greece [1998] ECR I-1095 at 34.

246. Compare also the rulings in Even (Case 207/78 [1979] ECR 2019) and De Vos (Case C-315/94 [1996] ECR I-1417) in which the Court concluded that certain social benefits granted as compensation for the consequences of their obligation to perform military service could not be regarded as a social advantage for the purposes of Article $7(2)$ of Regulation No $1612 / 68$, with the judgment in Ugliola (Case 15/69 [1970] ECR 363) in which the non-discrimination principle was held not to
} 
the face of it, Article 39(4) EC seems to allow Member States to exclude non-nationals from their public service altogether. Yet, the Court has consistently held that the provision should, as an exception to the free movement of workers, be interpreted strictly. Member States can only rely on Article 39(4) as regards specific posts or functions "which involve direct or indirect participation in the exercise of the powers conferred by public law and duties to safeguard the general interests of the state or other public authorities" and which "presume on the part of those occupying them the existence of a special relationship of allegiance to the State and reciprocity of rights and duties which form the foundation of the bond of nationality" for their own nationals. ${ }^{247}$ The case law indicates that the Court carefully supervises Member States' use of Article 39(4) EC for its proper purpose and that it ensures that they do not "in times of

apply to a national rule under which a worker's security of employment was protected by having periods of military service taken into account in calculating the length of employment.

247. See Case 149/79 Commission v Belgium [1980] ECR 3881 at 10 and Case C-4/91 Bleis [1991] ECR I-562 at 7. The Court has thus opted for a functional test and rejected an institutional test under which the scope of the exception would be determined by reference to the organisation of the public service in the Member State or the national legal status (public or private?) of a post. Verschueren (1990) supra footnote 3, at pp.399-404. In applying this test the Court has ruled that Article 39(4) EC does not apply to railway workers, gardeners, painters (Case 149/79 Commission v Belgium [1982] ECR 1845), primary school teachers (Case C-473/93 Commission v Luxembourg [1996] ECR I-3207), secondary school teachers (Case C-4/91 Bleis [1991] ECR I-5627), trainee teachers (Case 66/85 Lawrie Blum [1986] ECR 2121) and nurses (Case 307/84 Commission v France [1986] ECR 1725). The Article does cover posts in the judiciary, tax authorities and the diplomatic corps as well as certain supervisory or security functions, the position of municipal architect (Case 149/79 Commission v Belgium [1982] ECR 1845) and certain research positions (Case 225/85 Commission v Italy [1987] ECR 2625). See further Case 147/86 Commission v Greece [1988] ECR 1637; Case C290/94 Commission v Greece [1996] ECR I-3285 and Case C-273/94 Commission v Belgium [1996] ECR I-3265. In the literature Article 39(4) and the case-law have been discussed extensively. See e.g. Vilaras (2000) supra footnote 220; Denys, Grote Schoonmaak in de Overheidssector, in: NTER (1996) pp.221-224; O'Keeffe, Judicial Interpretation of the Public Service Exception to the Free Movement of Workers, in: Curtin/O'Keeffe (Eds), Constitutional Adjudication in European Community and National Law (1992) at pp.89 et seq; Eschmann, Die Freizügigkeit der EG-Bürger und der Zugang zur öffentlichen Verwaltung (1992); Verschueren, De Toegang tot de Openbare Dienst voor EG-onderdanen - Macht en Onmacht van het Europese Gemeenschapsrecht, in: MR (1991) pp.211-220; Verschueren (1990) supra footnote 3, at pp.399-417; Everling, Zur Rechtsprechung des Europäischen Gerichtshofs über die Beschäftigung von EG-Ausländern in der öffentlichen Verwaltung, in: DVBl (1990) pp.225-231; Lenz, The Public Service in Article 48(4) EEC with Special Reference to the Law in England and the Federal Republic of Germany, in: LIEI (1989) pp.75-122 and Handoll, Article 48(4) and Non-National Access to Public Employment, in: ELRev (1988) pp.223-242. It has been argued that the introduction of Union citizenship and the grant of voting rights in municipal elections could (or should) affect the scope of the public service (see e.g. O'Keeffe (1992) supra pp.89 et seq), but so far the case law does not provide for any examples actually supporting this argument 
high unemployment" rely on the public service "as a convenient reservoir of posts". ${ }^{248}$

The second situation in which non-nationals may be directly discriminated against concerns rights which do fall within the scope of Community law. In principle, ${ }^{249}$ these rights can only be denied to nonnationals when and in as far as this is necessary for the protection of "public policy, public security or public health". ${ }^{250}$ Unlike the public

248. Opinion of Advocate General Mancini in Case 307/84 Commission v France [1986] ECR 1725. 249. Case 15/69 Ugliola [1970] ECR 363 at 6; Case 352/85 Bond van Adverteerders [1988] ECR 2085 at 32-33 and Case C-484/93 Svensson and Gustavsson [1995] ECR I-3955 at 15. There are some exceptions to this rule. For instance, the exercise of free movement rights can be made subject to fulfilment of certain administrative formalities. See e.g. Section 2.2.2 above. Further, the Court has occasionally left room for some "unwritten" exemptions. The first, and the most well-known, example concerns the composition of sports teams. In Donà (1976) and Bosman (1995) the Court accepted that Community law does not prohibit rules or practices which exclude non-national players from certain matches which are not of an economic nature but rather of a sporting interest. These include matches between national teams (Case 13/76 Donà [1976] ECR 1333 at 14-15), but not matches in national leagues between club teams (Case C-415/93 Bosman [1995] ECR I-4291 at 127).

A second unwritten exception was applied in Gilly in which the Court accepted that in the absence of any unifying or harmonising Community measures, Member States are competent to define the criteria including nationality to be used for allocating fiscal powers in bilateral conventions aimed at eliminating double taxation. Case C-336/96 Gilly [1998] ECR I-2793 at 30. See van der Hurk, The European Court of Justice Knows its Limits, in: EC Tax Rev (1999) pp.211-223; Vanistendael, Annotation Gilly in: CMLRev (2000) pp.167-179; Hinnekens, Compatability of Bilateral Tax Treaties with European Community law - The Rules, in: EC Tax Rev (1994) pp.146146 and Harmaeckers, Fiscal Sovereignty and Tax Harmonization in the EC, in: EurTax (1991) pp.173 et seq.

One cannot entirely exclude the possibility that the Court will accept more unwritten exceptions to the prohibition of direct discriminations on grounds of nationality. Yet, in light of the "suspect" nature of nationality requirements the utmost restraint is to be exercised. In spite of judgments as Donà, Bosman and Gilly, the basic assumption still must be that within the scope of Community law discrimination by reason of nationality can only be justified where these can be brought within the realm of the public policy proviso.

250. See Article 39(3) EC (Community workers and their family members), Article 46(1) EC (selfemployed persons and recipients of services); Articles 2(2) of the three 1990 residence directives (non-economic residents); Article 28(3) and 33 EEA (EEA nationals) and Article 14 of Decision No $1 / 80$ (Turkish workers and their family members). The literature has dealth with the public policy exception extensively. See e.g. Duarte, Rights of Residence of Community Workers and Derogations: Reflections on the Meaning of 'Worker-Citizen', in: Carlier/Verwilghen, Thirty Years of Free Movement of Workers in Europe (2000) pp.177-190; Hartley (1991) supra footnote 1, Chapter 10; Verschueren (1990) supra footnote 3, pp.389-394; Wood, "Public Policy" Discrimination in the EEC: A Proposal for Assuring the Free Movement of Workers, in: FordILJ (1985) pp.447-478; O'Keeffe, Practical Difficulties in the Application of Article 48 of the EEC Treaty, in: CMLRev (1982) pp.3560; Hartley (1978) supra footnote 23, Chapter 5; Weber, Die Rechtsprechung des EuGH zum Vorbehalt der öffentlichen Ordnung und Sicherheit im Bereich der Freizügigkeit, in: EuGRZ (1978) pp.157-160; Boonk, Openbare Orde als Grens aan het Vrij Verkeer van Goederen, Personen en Diensten in de E.E.G. (1977); Singer, Free Movement of Workers in the European Economic Community: The Public Policy Exception, in: StanflRev (1977) pp.1283-1297; Bongen, Schranken der Freizügigkeit aus Gründen der öffentlichen Ordnung und Sicherheit im Recht der Europäischen Wirtschaftsgcmcinschaft (1975) and Selmer. Die öffentlichen Sicherheit und Ordnung als Schranke 
service exception, the public policy proviso does not relate to, and does not entitle States to exclude non-nationals from, certain activities. The proviso is concerned with the behaviour or specific characteristics of nonnationals $^{251}$ and allows derogation from migration rights. ${ }^{252}$ Both the Community legislator and the Court of Justice have limited the power of Member States to invoke the proviso. According to Article 4 of Directive No $64 / 221,253$ entry to or residence in the territory of another Member State can only be refused on public health grounds as regards (contagious) diseases or disabilities which are listed in an Annex to Directive No $64 / 221 .{ }^{254}$ The concepts of public policy and public security are nowhe-

der Arbeitnehmer-Freizügigkeit gemäss Art.48 Abs.3 EWG-Vertrag, in: DöV (1967) pp.328-334. The wording of the various public policy provisions is not identical, but there is no doubt that, at least in as far as Community citizens are concerned, the provisions applicable to the various categories are to be interpreted in the same way. Arnull (1990) supra footnote 165, at p.93. The Commission has proposed to include in Directive No $68 / 360$ (workers) a new provision which states that in applying the public policy Member States shall take into account the degree to which the person concerned has been integrated into their territory. COM(1998) 394 def.

251. Craig/De Búrca (1998) supra footnote 105, at p.787. The right of Member States to restrict freedom of movement on public health grounds, for instance, is not intended to permit the States to exclude the public health sector as a sector of economic activity from the free movement rules, but merely to allow the States to refuse access to or residence in their territory to persons whose presence would in itself constitute a danger to public health. Case 131/85 Gül [1986] ECR 1573 at 17.

252. The Community provisions suggest that the public policy proviso primarily allows for derogation from migration rights, but the exercise of the right to work (Case 44/72 Marsman [1974] ECR 1243 at 4) and the rights to provide and receive services (Case C-158/96 Kohll [1998] ECR I1931 at 50-51) may also be limited on public policy, security or health grounds.

253. OJ 1963/1964 Spec.Ed. 117. For the Commission's recent views on the interpretation of this directive see European Commission, Communication to the Council and the European Parliament on the Special Measures Concerning the Movement and Residence of Citizens of the Union which are Justified on Grounds of Public Policy, Public Security and Public Health.

254. Article 4(1) of Directive No 64/221. If a disease or disability manifests itself after a first residence permit has been granted it cannot justify expulsion or a refusal to renew the said permit Article 4(2) of Directive No 64/221. The diseases are listed under two headings. The first concern the contagious diseases which are listed in International Health Regulation No. 2 of the World Health Organization as being subject to quarantine (tuberculosis of the respiratory system in an active state or showing a tendency to develop; syphilis; other infectious diseases or contagious parasitic disease if they are the subject of provisions for the protection of nationals of the host country); the second category consists of diseases and disabilities which can justify exclusion or expulsion on the ground of public policy or public security (drug addiction, profound mental disturbance; manifest conditions of psychotic disturbance with agitation, delirium, hallucinations or confusion). In the literature it has been debated whether Member States are entitled to restrict the free movement rights of persons infected by the HIV-virus or suffering from AIDS. See for instance Hendriks, The Right to Freedom of Movement and the (Un)lawfulness of Aids/HIV Specific Travel Restrictions from a European Perspective, in: NJIL (1990) pp.86 et seq; Pais Macedo van Overbeek, AIDS/HIV Infection and the Free Movement of Persons within the European Community, in: CMLRev (1990) pp.791-824 and Dworkin/Steyger, Aids Victims in the European Community and the United States: Are They Protected from Unjustificd Discrimination?, in: Texas ILJ (1989) pp.295-329. 
re defined in the directive. It is in principle up to individual Member States to determine when a threat to public policy or security exists with the result that the circumstances in which migration rights may be restricted may vary from Member State to Member State and from time to time. ${ }^{255}$ Article 3(1) of Directive No 64/221 provides, however, that measures taken on grounds of public policy or public security must be based on the personal conduct of the person concerned; ${ }^{256}$ Article 3(2) adds that previous criminal convictions do not in themselves constitute a valid ground for refusing entrance or residence or expulsion. The Court has interpreted the two provisions strictly. The public policy ground may only be invoked where the presence or the individual behaviour of a nonnational constitutes a genuine and sufficiently serious threat to fundamental interests of society. ${ }^{257}$ More generally, the case law suggests that in combatting crime and the inherent threats to public policy and security, Member States must first rely on their powers under criminal law and procedure. In principle, immigration powers may only be used in last resort. $^{258}$ Furthermore, Article 2 of Directive No 64/221 states that the

255. Case 41/74 Van Duyn [1974] ECR 1337 at 18

256. See e.g. Case 67/74 Bonsignore [1975] ECR 297 (where it was held that the public policy exception cannot be relied upon for reasons of a "general preventive nature"). On specific circumstances in which preventive measures may be justified as regards gatherings attented by large numbers of people such as in the case of sport events, see e.g. Council Recommendation of 22 April 1996 on guidelines for preventing and restraining disorder connected with football matches, OJ 1996 C 131 .

257. Case 67/74 Bouchereau [1975] ECR 1999 at 35 and Case C-348/96 Calfa [1999] ECR I-11 at 25. Logically, failures to comply with immigration formalities do not suffice for constituting a threat to public order. Case 48/75 Royer [1976] ECR 497 at 38-39. In relying on the proviso Member States must observe the principle of proportionality (see further Arnull (1990) supra footnote 165, at p.99) as well as fundamental rights such as those enshrined in the European Convention (see e.g. Case C-260/89 Tileorassi [1991] ECR I-2925; Case 36/75 Rutili [1975] ECR 1219 and Hall, The ECHR and Public Policy Exceptions to the Free Movement of Workers under the EEC Treaty, in: ELRev (1991) pp.466 et seq). In relying on the public policy exception the principle of proportionality is to be observed and this would seem to imply that States have to take into consideration the length of residence and the degree to which the persons concerned have integrated into their society. Compare also the Commission proposal for amending Directive No 68/360 (COM(1998) 394 fin).

258. Consider Calfa. The case involved an Italian national who was charged with possession and use of prohibited drugs while staying as a tourist in Greece. The Court held that a Member State may consider that the use of drugs constitutes a danger for society and that such a State may take "special measures" against foreign nationals. However, an expulsion order against a Community citizen as Ms Calfa can only be made if, besides her having committed an offence under drug laws, her personal conduct creates "a genuine and sufficiently serious threat affecting one of the fundamental interests of society". Case C-348/96 Calfa [1999] ECR I-11 at 25. In some cases, however, Member States seem entitled to refuse entry or residence to a national of another Member State even if it does not criminalisze certain activities. See e.g. Case 41/74 Van Duyn [1974] ECR 1337 (which held that a non-national who wished to work for the Church of Scientology could be refused entry to the United Kingdom even though the undesirable and harmful practice of scientology was not prohibited in this Member State). 
public policy exception may not be invoked for economic ends. Member States cannot limit the free movement rights of nationals of other Member States in order to safeguard the employment opportunities of its own nationals $^{259}$ or to secure the financing of public advertising funds. ${ }^{260}$ The mere fact, however, that as well as objective reasons based on public security or public health, economic objectives are strived for does not necessarily exclude the possibility of relying on the exception. ${ }^{261}$

\subsection{Indirect Discrimination on Grounds of Nationality}

Besides direct (or overt) discrimination, Community provisions on the free movement of persons prohibit indirect (or covert) discrimination on grounds of nationality. These concern cases in which Member States apply other criteria of differentiation which lead in fact to the same result as nationality criteria. ${ }^{262}$ The rationale behind the concept and prohibition of indirect discrimination is not hard to find. If Community law were merely to prohibit nationality requirements, the right to equal treatment of Community citizens would be deprived of much of its practical effect. Member States could circumvent the prohibition of discrimination on grounds of nationality by making the enjoyment of rights conditional upon language, ${ }^{263}$ diploma $^{264}$ or other requirements which non-nationals are often unable to meet. Over the years, the Court has interpreted the notion of indirect discrimination quite broadly. It is of no relevance whether a Member State has the intent to discriminate against non-nationals. The effect of the application of a given criterion is decisive. The notion applies to national rules containing criteria which can be more

259. Craig/de Búrca (1998) supra footnote 105, at p.787.

260. Case C-352/85 Bond van Adverteerders [1988] ECR 2124 at 24.

261. Compare Case 72/83 Campus Oil [1984] ECR 2727 at 36 and Case C-158/96 Kohll [1998] ECR I-0000 at 50-51. See further Chapter 4 Section 4. Articles 6-9 of Directive No 64/221 contain several procedural provisions which require that each Member State grants to nationals of other Member States the possibility of challenging administrative measures concerning restrictions on the exercise of the free movement rights. On these provisions see Case C-357/98 Yiadom [2000] ECR I-0000; Joined Cases C-65/95 Shingara [1997] ECR I-3343; Case C-175/94 Gallagher [1995] ECR I-4523; Case C-197/89 Dzodzi [1990] ECR I-3763; Joined Cases 115/81 and 116/81 Adoui [1982] ECR 1665; Case 131/79 Regina [1980] ECR 1585 and Case 98/79 Pescataing [1980] ECR 691.

262. Case 152/73 Sotgiu [1974] ECR 153 at 10 and Case C-237/94 O'Flynn [1996] ECR I-2617 at 17. On the notion of indirect discrimination see in particular Garrone, La Discrimination indirecte en Droit communautaire: Vers une Théorie générale, in: RTDE (1994) pp.425-449.

263. See e.g. Case 379/87 Groener [1989] ECR 3967.

264. See e.g. Case 222/86 Heylens [1987] ECR 4097 and Case C-340/89 Vlassopoulou [1991] ECR I-3257. 
easily satisfied by nationals ${ }^{265}$ or which essentially affect non-nationals. ${ }^{266}$ Even the mere risk that a certain requirement "may operate to the particular detriment" of non-nationals may suffice for it to be classified as indirect discrimination. ${ }^{267}$ Besides language and diploma requirements, the concept of indirect discrimination on grounds of nationality, may extend to residence ${ }^{268}$ requirements. ${ }^{269}$

The prohibition of indirect discrimination is not as strict as the prohibition of direct discrimination. National provisions which (may) mainly affect non-nationals often serve wholly legitimate interests which deserve protection under Community law. For instance, nobody would seriously question the validity of a national rule which requires national language teachers in primary and high schools to have an adequate knowlegde of that language, even though such a rule would mainly work to the benefit of nationals. Similarly, virtually anybody would agree that Member States cannot be required to grant social assistance benefits to residents and non-residents alike. Residence requirements for such benefits will generally work to the disadvantage of non-nationals but they would appear necessary for maintaining social assistance benefit schemes. Language, residence and other indirect discriminatory requirements are simply not as "suspect" as nationality requirements are. The Court has recognised this and has consistently ruled that indirect discriminatory rules may be justified "by objective considerations independent of the nationality" and if they are necessary for, and proportionate to, the legitimate aim pursued by the national law. ${ }^{270}$

265. Case C-349/87 Paraschi [1991] ECR I-4501 at 23.

266. Case 41/84 Pinna [1986] ECR 1 at 24 and Case 33/88 Allué [1989] ECR 1591 at 12.

267. Case C-175 Biehl [1990] ECR I-1779 at 14; Case C-237/94 O'Flynn [1996] ECR I-2617 at 18 and Case C-124/99 Borawitz [2000] ECR I-0000 at 30-31.

268. See e.g. Case C-224/97 Ciola [1999] ECr I-0000 at 14; Case C-350/96 Clean Car [1998] ECR I-2521 at 29; Case C-326/90 Commission v Belgium [1992] ECR I-5517; Case C-175/88 Biehl [1990] ECR 1779 and Case 41/84 Pinna [1986] ECR 1;. Residence requirements do not in all cases meet this requirement. See e.g. Case C-18/95 Terhoeve [1999] ECR I-345.

269. In the context of the free movement of services, it is often far from easy to establish whether a national rule is discriminatory or non-discriminatory. The case law does not provide for crystal-clear criteria on this point. In some cases the Court has indeed held that national rules or measures which do not formally lay down different rules for providers of services established "at home" and providers based "abroad" are to be regarded as indistinctly applicable (see e.g. Case C-204/90 Bachmann [1990] ECR I-249), whilst in other cases it has held that discriminatory rules include those which indirectly give rise to unequal treatment of providers based in other Member States (Case C-484/93 Svensson and Gustavsson [1995] ECR I-3955). On this point see also the Opinion of Advocate General Tesauro in Case C-120/95 Decker and Case C-158/96 Kohll [1998] ECR I-1831 at 44-50.

270. Case C-111/91 Commission v Luxembourg [1993] ECR I-817 at 12; Case C-332/91 Allué [1993] ECR I-4309 at 15 and Case C-237/94 O'Flynn [1996] ECR I-2617 at 18 
In determining whether or not a given national provision can be justified the Court generally establishes first whether the provision pursues an objective and legitimate aim; it then considers whether the requirement is actually necessary for, and proportionate to, the aim in question. ${ }^{271}$ Two examples may illustrate the contours of the indirect discrimination test. The first is O'Flynn (1989). ${ }^{272}$ The case concerned an Irish national working in the United Kingdom who had taken responsibility for the funeral of his son in Ireland. Mr O'Flynn applied in the United Kingdom for a funeral payment which was intended to cover the costs of the funeral, but his application was denied on the ground that the burial had not taken place in the United Kingdom. The Court considered the funeral payment to be a social advantage in the sense of Article 7(2) of Regulation No 1612/68 and held that the group of persons who, on the death of a family member, have to arrange a funeral in another Member State will mainly consist of non-nationals; thus a national provision which makes the payment of funeral expenses subject to the condition that the funeral takes place in the United Kingdom, constitutes in principle an indirect discrimination. ${ }^{273}$ It was argued that the requirement of having the funeral in the United Kingdom was aimed at avoiding unacceptable increases in costs and the Court (implicitly) accepted this as a legitimate objective. However, the Court did not accept that the requirement in question was really necessary for this purpose. Expenditure could just as well be kept under control if payment for the funeral abroad were limited to a sum fixed by reference to the costs of funerals in the United Kingdom. The requirement could thus not be regarded as proportional to the valid aim of controlling expenditure. ${ }^{274} \mathrm{~A}$ second example concerns Vlassopoulou $(1993)^{275}$ in which the Court was asked to determine whether the refusal of German authorities to admit to the bar a Greek national who had obtained a Greek law degree and who had practised German law for several years on the ground that he had not passed the relevant German

271. In some cases the Court follows another approach. Consider Schumacker in which the Court was asked whether a national rule which reserved certain tax advantages for workers residing in the territory of the State concerned, was compatible with Article 39 EC. The Court accepted that such a residence requirement can work to the detriment of nationals of other Member States, but it held that discrimination can only be present when different rules are applied to comparable situations or when the same rule is applied to different situations. As regards direct taxation, however, according to the Court the situations of residents and non-residents generally are not comparable. Case C-279/93 Schumacker [1995] ECR I-225. In such cases there is in principle no discrimination and no need to consider possibilities for justification.

272. Case C-237/94 O'Flynn [1996] ECR I-2617.

273. Ibid, at 21-22

274. Ibid, at 28-29

275. Case 340/89 Vlassopoulou [1993] ECR 2357. 
exams, was compatible with Article 43 EC. The requirement of passing German exams was likely to affect non-Germans more than Germans and was thus in principle indirectly discriminatory. The right to lay down conditions for admission to the bar may be a justification for such a requirement, but, according to the Court, only when on deciding for an application for the bar a Member State takes the diplomas, certificates or other qualifications obtained by the person concerned into consideration and compare these to qualifications required by national law. If the foreign qualification is found to be equivalent, it must be recognised; if not, the Member State may require the applicant to demonstrate that he has acquired the required skills, knowledge or qualifications. ${ }^{276}$

\subsection{Non-Discriminatory Rules Hampering the Free Movement of Persons}

The development of the concept of indirect discrimination has significantly contributed to a strengthening of the free movement of persons. Since the early 1990s, however, the Court has appeared willing to go one step further by holding that non-discriminatory rules which hamper the exercise of free movement rights may also be prohibited. The roots of this prohibition are to be found in the case law of the Court on the free movement of goods. Since Dassonville (1974) and Cassis de Dijon (1979) the Court has consistently ruled that all national rules which "directly or indirectly, actually or potentially" burden the intra-Community trade in goods are prohibited being, as measures having equivalent effect to quantative restrictions, unless they are necessary to satisfy mandatory requirements. ${ }^{277}$ The Court has applied this approach first to the freedom to provide services; ${ }^{278}$ then to the right of establishment ${ }^{279}$ and

276. Ibid., at 16-22. The line of reasoning followed by the Court is similar to the approach the Community legislator has adopted in Directive No $89 / 48$ on the mutual recognition of highereducation diplomas. OJ 1989 L 19. On this directive, and the recognition of diplomas in general, see in particular Schneider, Die Anerkennung von Diplomen in der Europäischen Gemeinschaft (1995) (with numerous references to other literature).

277. Case 8/74 Dassonville [1974] ECR 837 at 5 and Case 120/78 Rewe-Zentral (Cassis de Dijon) [1979] ECR 649. On the case-law on the free movement of goods see e.g. Voogsgeerd (2000) supra footnote 102; Poiares Maduro, We the Court - The European Court of Justice \& the European Economic Constitution (1998); Jarvis, Application of EC law on the Free Movement of Goods by National Courts of the Member States (1997) and Oliver, Free Movement of Goods in the European Community (1996).

278. Case C-76/90 Säger [1991] ECR I-4221 and Case C-384/93 Alpine Investsments [1995] ECR I1141. 
more recently to the free movement of workers. ${ }^{280}$ It now seems established case law that the provisions on freedom of movement:

"preclude all national provisions ... which, although applicable without discrimination on grounds of nationality, are nevertheless liable to hinder or make less attractive the exercise of the fundamental freedoms guaranteed by the EEC Treaty by Community citizens". ${ }^{281}$

As the Court ruled in Gebhard (1995), as long as no harmonisation measures have been adopted, nationality-neutral rules or measures which may hamper the exercise of fundamental freedoms guaranteed by the Treaty can only be justified when they are $(i)$ applied in a non-discriminatory manner, (ii) justified by imperative requirements in the general interest and (iii) when they are suitable and necessary for attaining this imperative requirement. ${ }^{282}$ The "justification test" to be applied in the case of non-discriminatory rules is, at least on the face of it, the same as in the case of indirect discrimination on grounds of nationality. The main significance of the case law on non-discriminatory measures is that the justification test is to be applied in a greater number of cases. ${ }^{283}$

279. See e.g. Case 107/83 Klopp [1984] ECR 2971 and Case C-175/88 Biehl [1990] ECR I-1779. On Article $43 \mathrm{EC}$ and the prohibition of non-discriminatory rules see e.g. Hilson, Discrimination in Community Free Movement Law, in: ELRev (1999) pp.445-462; Marenco, The Notion of Restriction on the Freedom of Establishment and the Provision of Services in the Case-Law of the Court, in YEL (1992) pp.111-150; Everling. Das Niederlassungsrecht in der Europäischen Gemeimschaft, in: DB (1990) pp.1853-1859 and Knobbe-Keuk, Niederlassungsfreiheit: Diskriminierungs- or Beschränkungsverbot? - Zur Dogmatik des Art.52 EWG-Vertrag - am Beispiel einiger gesellschaftsrechtlicher Beschränkungen, in: DB (1990) pp.2573-2584

280. See Case C-415/93 Bosman [1995] ECR I-4291 and Case C-18/95 Terhoeve [1999] ECR I-345. 281. Case C-19/92 Kraus [1993] ECR I-1663 at 32 and Case C-55/94 Gebhard [1995] ECR I-4165 at 37. See further Simm, Der Gerichtshof der Europäischen Gemeinschaften im föderalem Kompetenzkonflikt - Kontinuität und Neubesinnung in der Rechtsprechung vor und nach "Maastricht"(1998) pp.156-201; Bernard, Discrimination and Free Movement in EC Law, in: ICLQ (1996) pp.82-108; Behrens, Die Konvergenz der wirtschaftlichen Freiheiten im europäischen Gemeinschaftsrecht, in EuR (1990) pp.145 et seq and the Opinion of Advocate General Lenz in Case C-415/93 Bosman [1995] ECR I-4921 at pp.4984-5010. In terms of terminology, the case law on the four common market freedoms shows a clear convergence as to the scope of the prohibitions. In the application of a particular test, however, differences still exist. In particular, a distinction stil needs to be made between cases involving the cross-border border movement of products and the movement of persons. See e.g. Barnard. Fitting the Remaining Pieces into the Goods and Persons Jigsaw?, in: EL.Rev (2001) pp.35-59; Voogsgseerd (2000) supra footnote 102, Chapter 8; Martin, Discriminations, Entraves et Raisons impérieur, in: CDE (1998) pp.561 et seq, at p.614 et seq and Behrens (1992) supra.

282. Case C-55/94 Gebhard [1995] ECR I-4165 at 37. See also Case C-19/92 Kraus [1993] ECR I1663 at 32 and Case C-212/89 Centros [1999] ECR I-0000 at 34.

283. The new approach may, however, in some cases also be a step back. In Bosman the Court was asked to rule upon the validity of the so-called nationality clauses according to which only a limited number of foreign playcrs could be ficlded in matches between club teams. The rules implied direct 
In the context of the free movement of goods, the result of the prohibition of non-discriminatory rules has been that virtually any national rule which regulates the marketing of goods had become susceptible to judicial review. The resulting work-load on the judiciary has compelled the Court to limit the definition of the notion of measures having equivalent effect in order to exclude certain national rules concerning selling arrangements. ${ }^{284}$ There are reasons to believe, however, that the implications of the prohibition of non-discriminatory measures for the free movement of persons will not be as far-reaching. ${ }^{285}$ The cases in which the prohibition of non-discriminatory rules has so far been applied often concerned rules which seemed to affect non-nationals more than nationals and which could therefore have been decided under the indirect discrimination test. ${ }^{286}$ For instance, in Vlassopolou, discussed above, the Court spoke in terms of a prohibition of non-discriminatory rules but the rules in question concerning admission to the German Bar obviously affected nonnationals more than nationals. ${ }^{287}$

The cases that have been decided so far by the Court suggest that the added value of the prohibition of non-discriminatory rules for the free movement of persons primarily concerns the possibility of challenging rules imposed by the State of origin which hamper the right to work in other Member States. Consider Terhoeve (1999). The case concerned a Dutch national who, during a given year, had been working in the United Kingdom and the Netherlands. The social security contributions $\mathrm{Mr}$ Terhoeve had to pay in the Netherlands were greater than if had worked there throughout the year. Mr Terhoeve claimed that the Dutch legislation constituted indirect discrimination on grounds of nationality since it made a distinction on the basis of residence. This argument could not succeed. The residence requirement mainly affected nationals rather than non-

\footnotetext{
discrimination on grounds of nationality and, following settled case law, this would have implied that the rules could only be justified under the public policy proviso. The Court, however, held that the rules constituted an obstacle to the free movement of workers and subsequently considered whether the rules could possibly be justified. The Court concluded that the nationality rules could not be justified, but the application of the new approach did enable the Court to uphold nationality criteria applied in the context of matches between national football teams. Case C-415/93 Bosman [1995] ECR I-4291 at 121-137.

284. See Joined Cases C-267 and C-268/91 Keck [1993] ECR I-6097. See further Poiares Maduro (1998) supra footnote 277 and Weatherill, After Keck: Some Thoughts on How to Clarify the Clarification, in: CMLRev (1995) pp.991 et seq.

285. "Keck" has so far not been extended to the other freedoms. On the question whether Keck can be transposed to the other freedoms see Voogsgeerd (2000) supra footnote 102, at pp.428-434. 286. Compare the Opinion of Advocate General Fennelly in Case C-190/98 Graf [2000] ECR I-0000 at 21 .

287. Compare also Casc C-204/90 Bachnann [1992] ECR I-249.
} 
nationals. The Court ruled, however, that national provisions which preclude or deter Community citizens from moving to or taking up employment in other Member States may be caught by Article 39 EC. ${ }^{288}$ The more recent judgment in Elsen (2000) demonstrates that the Member States of origin can also be prohibited from applying rules which impinge on non-economic free movement rights. The case concerned a German national who was living with her husband and son in France. Ms Elsen, who had worked in Germany but never in France, requested the German social security institutions to take into consideration periods she had spent raising her son as insurance periods for the purposes of her oldage pension. The German institutions refused on the ground that under the relevant German rules they could only do so if the child-rearing had taken place in Germany. The Court ruled that the German rules were disadvantageous to Community citizens who wished to exercise their non-economic free movement rights and that Article $18 \mathrm{EC}$ required the periods in question to be taken into consideration. ${ }^{289}$

288. Case C-18/95 Terhoeve [1999] ECR I-345 at 39. See also USZ (1999) nr.67 (with annotation van der Mei). See further also Bosman (1995) (where the Court held that the transfer rules in professional football may be caught by Article $39 \mathrm{EC}$ since this provision not only intends to ensure equality of treatment in other Member States but also prohibits the Member State of origin from hindering the right to work in other Member States (Case C-415/93 Bosman [1995] ECR I-4291 at 97) and Weatherill, Annotation Bosman, in: CMLRev (1995) pp.991 et seq) and Case C-303/98 Sehrer [2000] ECR I-0000.

289. Case C-135/99 Elsen [2000] ECR I-0000 at 34-36. The judgment in Graf (2000) demonstrates that there are limits to the prohibition for the Member State of origin to apply rules which may hamper the right to move to other Member States. The case involved a German national who voluntarily terminated his employment in Austria in order to take up a new job in Germany. Mr Graf claimed that he was, under Austrian law, entitled to a compensation from his former employer, but the latter refused to pay the compensation on the ground that the law in question provides that no compensation has to paid where the worker gives notice, leaves prematurely or is responsible for premature dismissal. Graf claimed that the law impeded the free movement of workers and was inconsistent with Article 39 EC. The Court of Justice did not agree. The Court confirmed that nondiscriminatory national rules which preclude or deter a worker from moving to other Member States may be covered and prohibited by Article $39 \mathrm{EC}$, but in order to constitute an obstacle to freedom of movement such rules must affect access of workers to the labour market in other Member States. The Court held that this was not the case with the Austrian law in question because the compensation payment was not dependent on a decision of a worker whether or not to stay with the employer, but rather on the "future and hypothetical event" that the labour contract is terminated by their employer without such termination being at the initiative or attributable to the worker. Such an event, the Court concluded, is "too uncertain and indirect a possibility for legislation to be capable of being regarded as liable to hinder the free movement of workers where it does not attach to termination of a contract of employment by the worker himself the same consequence as it attaches to termination which was not at his initiative or is not attributable to him". Case C-190/98 Graf [2000] ECR I-0000 at 23-25. 


\subsection{Reverse Discriminations}

Throughout its case law the Court has interpreted Community provisions on the free movement of persons broadly. In one ${ }^{290}$ significant respect, however, the Court has shown considerable restraint. Treaty provisions such as Articles 18 and 39 EC speak of freedom of movement (with)in the territory of the Member States, and on the face of it, the Articles thus seem to imply that Community citizens can rely on these provisions in all Member States including their own. Yet, from the early years the Court has interpreted the Treaty provisions so as to cover only rights to move to, to be economically active in and to be treated equally in other Member States. Community citizens who have never exercised their free movement rights fall outside the scope of Community provisions on the free movement of persons. They and their family members cannot benefit from any of the rights discussed in this chapter. Consider Morson (1982). The case concerned two Surinamese nationals who wished to reside in the Netherlands with their children who were already working and living there. Under Dutch law Mrs Morson and Mrs Jhanjan did not enjoy the right to reside in the Netherlands, but they claimed that they had as "dependent family members in the ascending line" such a right under Article 10 of Regulation No 1612/68. The Court rejected their claim. The provisions on freedom of movement could not be relied upon because the children were Dutch nationals who had never worked in another Member State. In the view of the Court there was no factor linking the case to situations where Community law applies. ${ }^{291}$

This is not to say that Community citizens can never invoke the free movement provisions vis-à-vis their own Member State. When a socalled inter-State element is present they may do so. In particular, such an element is present when Community citizens have been employed or have resided in another Member State and subsequently return to their own Member State. In Singh (1992), for instance, the Court held that the Indian spouse of a UK national, who had worked in Germany and subsequently returned to the United Kingdom, could rely on Community law in order to claim the right to enter and reside in the United Kingdom. In

290. To be sure, in some cases the Court also shows restraint by holding that a link between a certain case and Community law is too indirect or uncertain for Community law to apply. See e.g. Case C-190/98 Graf [2000] ECR I-0000 (see previous footnote); Case C-299/95 Kremzow [1997] ECR I-2629 and Case C-379/92 Peralta 1994] ECR I-345.

291. Community law on the free movement of persons does not apply to such "purely internal situations" in which activities "are confined in all respects within a single Member State". See e.g. Case C-41/90 IIöfner [1991] ECR I-1979 at 37 and Casc C-332/90 Steen [1992] ECR I-341 at 9. 
Scholz (1994), a case brought against an Italian government body, it was accepted that a former German national who had moved to Italy and, through marriage, had acquired Italian and lost German nationality, could rely on Article $39 \mathrm{EC}^{292}$

Morson and Jhanjan is an example of a case leading to so-called reverse discrimination. This occurs when Member States treat (family members of) their own nationals less favourably than (family members of) nationals of other Member States. ${ }^{293}$ At first glance, reverse discrimination seems at odds with the prohibition of discrimination on grounds of nationality. Singh and Scholz demonstrate, however, that the States' own nationals are not discriminated against on grounds of their nationality, but rather on the ground that they have never exercised their free movement rights. In situations where reverse discrimination occurs, there is no differential treatment of nationals and non-nationals but of "free movers" and "non-movers". In Uecker (1997) the Court held that such reverse discrimination does not run counter to Article 17 which has established a

292. Case C-419/92 Scholz [1994] ECR I-505. Until recently, it seemed that private residence in another Member State did not suffice to establish an inter-State element for the purposes of economic provisions for the free movement of workers and the right of establishment. Consider Werner (1993) This case concerned a German national who resided in the Netherlands and worked as a selfemployed dentist in Germany where he earned most of his income. The Court denied Mr Werner the right to rely on Article $43 \mathrm{EC}$ in order to challenge a German law which in Werner's unlawfully discriminated against non-residents because the case was, in brief, purely internal. Case C-112/91 Werner [1993] I-429. It may be assumed, however, that Werner no longer stands. In Elsen (2000) the Court accepted that a (former) German frontier worker living in France could invoke Articles 18, 39 and $42 \mathrm{EC}$ in order to challenge a German social security rule. See Case C-135/99 Elsen [2000] ECR I-0000 at 34-36.

293. In the literature the notion of reverse discrimination (in the context of the free movement of persons, services and goods) has been discussed extensively. See e.g. Vooggsgeerd (2000) supra footnote 102; Balthasar, Inländerdiskriminierung in der EU nach dem EWG-Vertrag und aus österreicher Sicht, in: ZföR (1998) pp.143-216; Münnich, Art 7 EWGV und Inländerdiskriminierung, in: ZfRV (1992) pp.92-100; Jesserun d'Oliveira, Is Reverse Discrimination still Permissible under the Single European Act, in: Centre of Foreign Law and Private International Law - University of Amsterdam, Forty Years On: The Evolution of Postwar Private International Law in Europe (1990) pp.71-86; van Ooik, Omgekeerde Discriminatie van EEG-Onderdanen, in: MR (1990) pp.83-86; Greenwood, Limits on the Free Movement of Persons in EEC Law, in: YEL (1987/1988) pp.185210; Pickup, Reverse Discrimination and Freedom of Movement for Workers, in: CMLRev (1986) pp.135-156; Schlachter, Discrimination à Rebours - Die Inländerdiskriminierung nach der Rechtsprechung des EuGH und des franzöischen Conseil d'Etat (1984); Weiss, Inländerdiskriminierung zwischen Gemeinschaftsrecht und nationalem Verfassungsrecht, in: NJW (1983) pp.2721-2726; Kon, Aspects of Reverse Discrimination in Community Law, in: ELRev (1981) pp.75-101; Druesne, Remarques sur le Champ d'Application personnel du Droit communautaire: des "Discriminations a Rebours" Peuvent-elles Tenir en Echec la Liberté de Circulation des Personnes, in: RTDE (1979) pp.429-439 and Mortelmans, Omgekeerde Discriminatie en het Gemeenschapsrecht, in: SEW (1979) pp.654-674. 
Union citizenship. That provision, the Court held, "is not intended to extend the scope ratione materiae of the Treaty also to internal situations which have no link with Community law" ${ }^{\prime 294}$.

\section{The United States}

Having set out the main rules and principles governing the free movement of persons within the European Community, the discussion now proceeds with a description and initial analysis of American constitutional law of the so-called right to travel, as the notion of free movement of persons is generally referred to in the United States. After a brief history, this section describes what the right to travel entails and how the American Supreme Court reviews State rules which burden freedom of movement or discriminate against those who have exercised the right

\subsection{The Right to Travel: A Brief History}

Nowhere does the United States Constitution mention the right to travel, a right to freedom of movement or any comparable notion. The omission of a reference to the right to travel has never been seen as a denial of the right. On the contrary, the framers of the Constitution probably took the right to travel so much for granted that they considered any reference to

\footnotetext{
294. Joined Cases C-64/96 and C-65/96 Uecker and Jacquet [1997] ECR I-3171 at 23. In cases which have no link with Community law, national courts remain free to review national rules under national constitutions. Case C-132/93 Steen [1994] ECR I-2715. See Johnson/O'Keeffe, From Discrimination to Obstacles to Free Movement: Recent Developments Concerning the Free M0ovement of Workers, in: CMLRev (1994) pp.1313-1346, at p.1338.

The Community obligation to observe fundamental human rights (see footnote 229 above) does not exist in "purely internal cases". Consider Kremzow (1997). The case concerned an Austrian national who had been convicted of murder. In 1993 the European Court of Human Rights, however, held that criminal proceedings against Mr Kremzow had been in breach of Article 6 of the European Convention. Mr Kremzow started an action for damages against the Austrian State. In doing so he claimed, inter alia, that the prison sentence prevented him from exercising his free movement rights under Community law and that Austria was liable in damages under Community law. The Court of Justice, however, held that it had no jurisdiction. The situation of Mr Kremzow was "not connected in any way with any of the situations contemplated" by the EC Treaty. The deprivation of liberty actually prevented Mr Kremzow from moving to other Member States but was, according to the Court, not sufficiently closely connected with the right to freedom of movement as to bring the situation within the realm of Community law. See Case C-299/95 Kremzow [1997] ECR I-2629.
} 
the right superfluous. ${ }^{295}$ Ever since the nation's inception, no one has ever questioned the constitutional status of the right to travel. The right simply exists and the absence of an explicit reference to it may, if anything, symbolise how deeply the notion of freedom of movement is rooted in American thinking.

Throughout constitutional history, the Supreme Court and several Justices have stressed the fundamental importance attached to the right to travel. ${ }^{296}$ In 1849, for instance, Chief Justice Taney wrote in the Passenger Cases:

"For all the great purposes for which the Federal government was formed, we are one people with one common country. We are all citizens of the United States; and as members of the same community, must have the right to pass and repass every part of it without interuption, as freely as in our own States". 297

Almost one hundred years later, Justice Jackson held in Edwards $v$ California (1941) that it:

"is a privilege of citizenship of the United States protected from State abridgement, to enter any State of the Union either for temporary sojourn or for the establishment of permanent residence therein .. If national citizenship means less than this it means nothing". ${ }^{298}$

295. Chafee, Three Human Rights in the Constitution of 1787 (1956) at p.185; Rosberg, Free Movement of Persons in the United States, in: Sandalow/Stein, Courts and Free Markets - Perspectives from the United States and Europe (1982) pp.275-362, at p.281. Article IV of the Articles of Confederation -the predecessor of the Constitution- provided that "to secure and perpetuate mutual friendship and intercourse among the people of the different States in this Union, the free inhabitants of each of these States ... shall have free ingress and egress to and from any other State..". The framers of the Constitution, however, dropped the phrase "free ingress and regress". The Constitution of 1787 converted the confederation of largely sovereign States into a federal Union. The right to travel was so elementary that it "was conceived from the beginning to be a necessary concomitant of the stronger Union the Constitution created". United States v Guest, 383 US 745 (1966) at 757-758. 296. Justices of the Supreme Court and scholars have debated where the right to travel should be located in the Constitution. The right has been read into various constitutional provisions such as the Due Process Clause of the Fifth Amendment, the Commerce Clause, the Privileges and Immunities Clause of Article IV and the Privileges or Immunities Clause of the Fourteenth amendment. See Note, The Right to Travel - Quest for A Constitutional Source, in: RutgCLJ (1974) pp.122-143. In order to prove that the right exists there is, however, no need to ascribe the right to travel to a particular constitutional provision. Shapiro v Thompson, 394 US 618 (1969); Soto-Lopez, 476 US 898 (1986) at 902 and Saenz v Roe, 119 SCt 1518 (1999).

297. Sinith v Turner (the Passenger Cases) 48 US 283 (1849) at p.492 (Chief Justice Taney, dissenting).

298. Edwards v California, 314 US 160 (1941) at 183 (Jackson, concurring) 
Later, in Shapiro v Thompson (1969), Justice Brennan stated that

"the nature of our Federal Union and our constitutional concepts of personal liberty unite to require that all citizens be free to travel throughout the length and breadth of our land uninhibited by statutes, rules, or regulations which unreasonably burden or restrict this movement". 299

These glowing descriptions demonstrate that the right to travel has a "national" as well as a personal value. This right is an important instrument of national unity which strengthens the notion of United States citizens as one people. It has played an important role in the transformation of the several States into a single Nation ${ }^{300}$ and it now prevents "the Balkanization of the Nation". ${ }^{301}$ At the same time, the right to travel is a highly valued personal right ${ }^{302}$ which enables individuals to "explore new horizons" and to pursue their interests in the State of their choice. The right is incidental to United States citizenship and valued as a personal liberty "as close to the heart of the individual as the choice of what he eats, or wears, or reads". ${ }^{303}$

Unlike the right to freedom of movement within the European Community, the American right to travel has never been perceived as functional or subordinate to the process of economic integration. The Constitution does aim at integration of the economies of the various States and, obviously, the right to travel serves this process by enabling persons to do business or work in other States. Economic integration, however, is only of secondary importance. The Constitution provides, above all, the legal framework for a political Union. The personal right to move freely from State to State is a product of this political Union ${ }^{304}$ and occupies within the constitutional system "a more protected position .. than does the movement of cattle, fruit, steel and coal across statelines". ${ }^{305}$

299. Shapiro v Thompson, 394 US 618 (1969) at 629.

300. Attorney General of New York v Soto-Lopez. 476 US 898 (1986) at 902.

301. New York y O'Neill, 359 US 1 (1959) at 7-8.

302. Chafee (1956) supra footnote 296 , at p.188.

303. Kent v Dulles, 357 US 116 (1958) at 126.

304. Varat, Economic Integration and Interregional Migration in the United States Federal System, in: Tushnet (Ed.), Comparative Constitutional Federalism - Europe and America (1990) pp.21-66, at pp.31-34.

305. Edwards v. California, 314 US 160 (1941) at 177. Illustrative of the predominantly political nature of the right to travel is the Supreme Court's decision in Truax v Raich. With respect to State restrictions on the employment of aliens, who as we will see also enjoy the freedom to move within the United States, the Court held: "The assertion of an authority to deny to aliens the opportunity of earning a livelihood when lawfully admitted to the State would be tantamount to the assertion of the right to deny them entrance and abode, for in ordinary cases they cannot live where they cannot work". Truax v Raich, 239 US 33 (1915). 


\subsection{Beneficiaries and their Free Movement Rights}

The fundamental importance attached to the right to travel is reflected in the personal scope of the right. This scope is, in principle, unlimited. All persons present within the United States enjoy the right to cross inter-state boundaries and all persons entitled to reside in the United States can choose the State in which they wish to live. By comparison with the freedom of movement within the European Community, two differences exist. First, not only United States citizens but also foreigners enjoy the right to move and reside freely within the United States. With respect to nationals of other States, immigration powers are entrusted to the Federal authorities. $^{306}$ The latter hold the exclusive power $^{307}$ to determine which foreigners shall be admitted and for how long they are entitled to remain. States, in principle, hold no power to refuse foreigners entry to or presence on their territory. As the Supreme Court found in Truax v. Raich (1915), foreigners are "admitted with the privilege of entering and abiding in the United States, and hence of entering and abiding in any state in the Union". ${ }^{308}$ Second, indigents enjoy the right to reside freely within the United States. As will be demonstrated in Chapter 3 of this book, the difference between the European Community, where indigents do not enjoy this right, and the United States is explained by the fact that in the United States poverty is perceived as a national problem for which not only the States but also the Federal authorities hold a responsibility. States cannot isolate themselves from this shared problem ${ }^{309}$ by closing their borders. The "purpose of deterring the in-migration of indigents .. is constitutionally impermissible". 310

306. The Constitution does not explicitly confer upon Congress the power to regulate immigration. Yet, this power may be read into various provisions such as the federal power over foreign affair (United States v. Curtiss-Wright Export Corp., 299 US 304 (1936) at 318), the power to make a uniform rule on naturalization (Article I $\$ 8$, cl.4 ) or the power to regulate foreign commerce (Article I $\$ 8$, cl.3). See further Note, State Burdens on Aliens: A New Preemption Analysis, in: YaleLJ (1980) pp.940-961, at pp. 944-945.

307. Truax $v$ Raich, 239 US 33 (1915) at 42 .

308. Ibid, at 52. In light of the classification of the right to travel as "an incident of national citizenship" it is debatable whether the right to travel of foreigners is protected by the Constitution. See e.g. Graham v Richardson, 403 US 365 (1971) at 375. There is no doubt, however, that the right is at least implicit in the federal immigration scheme. See Rosberg (1982) supra footnote 295, at pp.294-295.

309. Edwards v California, 314 US 160 (1941) at 173. See further Chapter 3 Section 9.3

310. Shapiro $v$ Thompson, 394 US 618 (1969) at 630. 
At its core, the right to travel inter-State ${ }^{311}$ consists of three rights: the right to leave a State, the right to enter another and the right to establish residence in any State. ${ }^{312}$ At the time the Constitution was adopted, States did not attempt to hinder or restrict the exercise of these rights. Legal barriers to cross-border movement hardly existed. Over the years, however, States have, for various reasons, imposed limits on inter-state movement. The Supreme Court has always strongly resisted any attempt to hinder or restrict the exercise of the right to travel. In brief, any ${ }^{313}$ State $^{314}$ measure which hampers cross-border movement or the establishment of residence is unconstitutional unless shown to be necessary for the promotion of an overriding or compelling State interest. ${ }^{315}$ The

311. The terms right to travel and right to inter-state travel will be used interchangeably in this Chapter. It is to be noted though that the notion "right to travel" also covers the right to travel abroad and the rights to move and reside freely within the seperate States. The rights to foreign travel and intra-state travel will not be discussed any further in this Chapter. On the right to travel abroad see Farber, National Security, The Right to Travel, and the Court, in: SCRev (1981) pp.263290 and Laursen, Constitutional Protection of Foreign Travel, in: ColLRev (1981) pp.902-931. See further Kent v Dulles, 357 US 116 (1958); Aptheker v Secretary of State, 378 US 500 (1964) and Zemel v Rusk, 381 US 1 (1965). On the right to travel intra-state see Porter, Comment: A Constitutional Analysis of the Right to Travel Intra-State, in: NorthwULRev (1992) pp.820-857.

312. The right to travel includes, as a right of personal liberty, also the right not to move at all. See tenBroek, The Constitution and the Right to Free Movement (1955) pp.3-6.

313. Even the smallest burdens on the rights are prohibited. Illustrative is the nineteenth century decision in Crandall $v$ Nevada. The Court invalidated a State tax of 1 dollar on every person leaving the State. Obviously, the amount of the tax was too small to prevent anyone from actually leaving the State, but the Court reasoned that if "the State can tax a .. passenger one dollar, it can tax him thousand dollars. If one State can do this, so can every other State. And thus one or more States .. may totally prevent or seriously burden all transportation of passengers from part of the country to another". Crandall v Nevada, 73 US 35 (1867) at 39. Crandall does not necessarily imply that States can never charge inter-state travellers. A burden on the exercise of the right to travel must be present. In Evansville, for instance, the Court upheld a charge by a State of 1 dollar per airline passenger to help defray the costs of airport construction and maitenance. The Court denied that the charge burdened the right to travel. The facilities which were provided and paid out of the charges facilitated rather than hindered the right to travel. Evansville-Vanderburgh Airport Authority District v Delta Airlines, 405 US 707 (1972).

314. The Federal government and private persons are equally prohibited to hinder or restrict the exercise of the right to travel. In United States $v$ Guest, which concerned the prosecution of persons who had attacked African-Americans and civil rights workers in order to deprive them of a number of constitutional rights including the right of inter-state travel, the Court held: "the constitutional right to travel is a right secured against interference from any source whatever, whether governmental or private". United States v Guest, 383 US 745 (1966) at 759 (footnote 17). The Supreme Court has never been asked whether the Federal government would be entitled to impose limits upon the right to inter-state travel. In the doctrine it is generally assumed, however, that the Federal Government (Congress) does not hold such a power. The right to travel is "too fundamental" to be limited by any government. Varat (1990) supra footnote 305, at p.46. See also Rosberg (1982) supra footnote 295 , at pp.302-303.

315. Thomson, The Right to Travel - Its Protection and Application Under the Constitution, in: UMKCLRev (1971-1972) pp.66-96, at p.95 
number of cases in which a State can demonstrate such a compelling State interest is limited. A State cannot close its borders in order to protect the employment opportunities of its residents, to limit the number of users of its public roads, to "keep aliens out" or, as said, earlier on, to prevent indigents from moving to the State for the sole purpose of obtaining welfare benefits. Probably the only circumstances in which States are permitted to stop cross-border movement concern suspects or convicts of a crime. Such persons may be detained ${ }^{316}$ and simply cannot "claim freedom to migrate". ${ }^{317}$ An exception to freedom of movement similar to the public policy proviso under European Community law does not exist under American constitutional law. ${ }^{318}$ The right to establish residency is granted unconditionally. The motive for establishing residence in a State is irrelevant ${ }^{319}$ and individuals do not, as in the European Community, have to prove that they have found employment or possess sufficient financial means to provide for themselves and their family.

\subsection{Concept of State Citizenship}

The right to take up residence in the State of one's choice, has one important consequence as far as United States citizens are concerned. The Citizenship Clause of the Fourteenth Amendment states that "all persons born or naturalised in the United States, and subject to the jurisdiction thereof, are citizens of the State wherein they reside". The right of United States citizens to choose the State in which they wish to live implies the right to choose which State they wish to be a citizen of. Residence and

\footnotetext{
316. Jones $v$ Helms, 452 US $412(1981)$ at 419.

317. Edwards v California, 314 US 160 (1941) at 184 (Jackson, concurring). States are even under an obligation to send back fugitives from justice to the State where they are charged with a crime. See Article IV, Section 2 of the Constitution. See also Puerto Rico v Branstad, 483 US 219 (1987).

318. States do not have the power to refuse entry to or deport persons whom it considers to be a threat to the public order or who are considered to be persona non grata. Like poverty, criminality is a national problem from which States cannot isolate themselves by closing their borders. Rosberg (1982) supra footnote 296, at p.291. States may restrict freedom of movement by using their powers under criminal procedural law, but they may not use their "immigration powers" in order to combat crime. As regards the extent to which states can close their borders for purposes of protecting public health, the situaton is less clear. States still seem to have the possibility of excluding persons suffering from contagious diseases albeit only in very exceptional situations. Rosberg (1982) supra footnote 295 , at pp.291-294.

319. A person can freely choose to live in another State. It "is immaterial what motives led the person to go there. It makes no difference whether these motives were good or bad or, more specifically, whether the move to the new location was for the purposes of health, to accept a job, to avoid taxation, to secure a divorce, to bring suit in the federal courts or even to facilitate a life of sin or crime". Martinez v Bynum, 461 US 321 (1982) fertnote 10 at 343 (Justice Marshall, dissenting).
} 
State citizenship coincide. ${ }^{320}$ From the moment United States citizens establish residence in a State they automatically become citizens of that State. States do not have the power to determine who its citizens are; they not only lack immigration powers but also "naturalisation" powers. The Supreme Court, however, has never indicated what is entailed in establishing residence in, and thus acquiring citizenship of, a State. Generally, residence requires physical presence in a State plus the intention to remain there for a certain period of time. The Court has admitted though that "residence" may have different meanings in different contexts. ${ }^{321}$ An intention to make a State a permanent home is not necessary, but on occasions the Court has, quite confusingly, also required the absence of a present intention to leave the State. In other cases, State citizenship is to be equated with domicile which is the State with which persons are most closely connected. Persons can have several residences but only one domicile. The difference between residence and domicile is, however, far from clear and in practice often difficult to determine. ${ }^{322}$

8.4 Right to Equal Treatment: Judicial Review under the Equal Protection Clause

The "virtually unqualified"1323 rights to move and reside freely across inter-State boundaries would have little practical significance if the beneficiaries did not enjoy constitutional protection on arrival in another State. If the States were free to treat persons coming from other States any way they liked, they could, in theory, deny those persons so many rights that not one of them would consider crossing inter-State borders. Several constitutional provisions protect the beneficiaries of the right to travel against discriminatory treatment in and by other States. The most relevant are the Equal Protection Clause of the Fourteenth Amendment, the Privileges and Immunities Clause of Article IV $\S 2$ of the Constitution and the Commerce Clause of Article I $\S 8$. The first of the three clauses offers persons who have established residence in another State (residents), people who merely visit other States (non-residents or visitors) and aliens

\footnotetext{
320. It is "a privilege of citizenship of the United States .. to enter any state of the Union .. for gaining resultant citizenship thereof ... State citizenship is ephemeral. It results only from residence and is gained or lost therewith". Edwards v California, 314 US 160 (1941) at 183.

321. Martinez v Bynum, 461 US 321 (1982) at 330.

322. On the concepts of residence and domicile see Reese/Green, That Elusive Word, "Residence", in: VdBiltLRev (1953) p.561 et seq.

323. Califano v Torres, 435 US 1 (1978) at 4 (footnote 6).
} 
(or foreigners) protection against discriminatory treatment. The latter two clauses are designed to protect non-residents from discriminatory treatment. Before the degree of equal protection offered by the clauses to the beneficiaries of the right to travel is explored, some introductory remarks are made about the Equal Protection Clause. Discrimination against the beneficiaries of the right to travel is only one form of discrimination prohibited by the Clause and the main principles governing the equal protection of the laws have been developed in areas other than those related to the right to travel.

The Equal Protection Clause states that no State shall "deny to any person within its jurisdiction the equal protection of the laws". ${ }^{324}$ Although originally merely intended to combat racial discrimination, the Clause nowadays applies to any State ${ }^{325}$ measure which distributes benefits unequally to different classes of persons. ${ }^{326}$ The Clause demands that persons similarly situated are to be treated similarly unless there is serious justification or "need" for dissimilar treatment. Equal protection analysis usually ${ }^{327}$ centres around the question whether the unequal treatment of equal cases can be justified. Courts apply a "means-end analysis". They first establish the purpose a State seeks to achieve and, assuming this purpose is legitimate, they then explore how closely the

324. The literature on the Equal Protection Clause is extensive. See e.g. Klarman, An Interpretive History of the Modern Equal Protection, in: MichlRev (1991) pp.213-316; Perry, Modern Equal Protection: A Conceptualization and Appraisal, in: ColLRev (1979) pp.1023-1084; Karst, The Supreme Court 1976 Term- Foreword: Equal Citizenship uder the Fourteenth Amendment (1977), in: HarvLRev (1977) pp.1 et seq; Gunther, The Supreme Court 1971 Term - Foreword: In Search of Evolving Doctrine on a Changing Court: A Model for a Newer Equal Protection, in: HarvLRev (1972) pp.1-48 and Tusman/ten Broek, The Equal Protection of the Laws, in: CalLRev (1949) pp.341-381. See further also the various handbooks on Constitutional Law such as Rotunda/Nowak, Treatise on Constututional Law (1992) Chapter 18; Tribe, American Constitutional Law (1988) Chapter 16; Stone/Seidmen/Sunstein/Tushnet, Constitutional Law (1986) Chapter 5 and Gunther, Constitutional Law (1985) Chapter 9

325. The Clause does not apply to the Federal government. However, the Due Process Clause of the Fifth Amendment - "No person shall be deprived of life, liberty, or property without due process of law" - prohibits the Federal Government from denying any persons equal protection of the laws. Bolling v Sharpe, 347 US 497 (1954).

326. "When a State distributes benefits unequally, the distinction it makes are subject to scrutiny under the Equal Protection Clause of the Fourteenth Amendment". Zohel v Williams, 457 US 55 (1982) at 60.

327. Strictly speaking, the justification question is to be preceded by the question whether or not persons are similarly situated. Persons do not have to be similar or similarly situated in all respects. Similarity is to be determined with respect to the purpose of the law. Tusman/tenBroek (1949) supra footnote 324 , at p.346. In most cases, however, courts do not explicitly establish the similarity of cases. Usually, and certainly in those concerning discrimination against the beneficiaries of the right to travel, courts turn directly to the question whether a differential treatment of presumably similar cases can be justified. 
classification applied or the distinction made is related to this purpose. ${ }^{328}$ How close this link between means and end must be, and more in general, whether a classification can be justified largely depends on the standard of review to be applied. The Supreme Court has formally adopted three standards of review. Each of these equal protection tests requires a different degree of correlation between means and end, and each reflects a different role of the judiciary vis $\grave{a}$ vis the State legislatures. ${ }^{329}$ The selection of one of the standards of review is often decisive for the ultimate decision in a given case and thus of the utmost importance.

The first standard involves the "rational relation test". A classification will be upheld when it is "rationally related to furthering a legitimate government interest" ${ }^{130}$ or when "it is conceivable that the classification bears a rational relationship to an end of government which is not prohibited by the Constitution". ${ }^{331}$ In applying this test court show considerable deference toward State legislatures. ${ }^{332}$ Laws are presumed to be lawful, classifications will only be invalidated when they are patently arbitrary. For persons challenging a classification it is almost impossible to prove unconstitutionality. Rational relation is to be applied to all State

\footnotetext{
328. In determining how "closely" a classification is related to the State purpose, courts do not require a classification to be perfect, i.e. when a classification treats all similarly situated persons alike and all persons not similarly situated unalike. A "classification having some reasonable basis does not offend equal protection merely because it is not made with mathematical nicety or because in practice it results in some inequality". Lindsey v Natural Carbonic Gas Co., 220 US 61 (1911). Perfect classifications hardly exist; classifications are usually overinclusive and/or underinclusive. Classifications are over-inclusive when they do not only burden or benefit similarly situated persons but also persons not so situated. They are under-inclusive when they burden or benefit only part of the similarly situated persons. For a further explanation of these terms see Rotunda/Nowak (1992) supra footnote 324 , at pp. $9-12$

329. In reviewing a certain classification the strength or the importance of the legislative purpose is also to be weighed. See Burnham, Introduction to the Law and Legal System of the United States (1995) pp.339 et seq.

380. Paul v Virginia, 75 US (8 Wall.) 168 (1869) at 180-181 as quoted in Baldwin v Fish, 436 US 371 (1978) at 380-381. See also the Slaughterhouse Cases where the Court held that the sole purpose of the Clause "was to declare to the several states, that whatever those rights, as you grant or establish them to your own citizens, or as you may limit or qualify, or impose restrictions on their exercise, the same, neither morc or lcss, shall be the measure of the rights of citizens of other states within your jurisdiction". Slaughtherhouse Cases, 83 US (16 Wall) 36 (1873) at 77.

381. Toomer $v$ Witsell, 334 US 385 (1948) at 395.
} 
classifications and is an expression of the broader principle that States, whenever they act or classify, must obey the minimum requirement of non-arbitrariness. ${ }^{333}$

For a long period of time rational relation was in fact the only test the Court applied. From the 1950s, however, the Supreme Court has heightened the level of scrutiny of certain classifications. Most importantly, the Court has developed the so-called "compelling State interest test". This test is in fact the opposite of the rational relation test. Courts do not presume the constitutionality but rather the unconstitutionality of a classification. "Strict scrutiny" is applied. Courts do not explore whether there is "some permissible State purpose" but require States to show that the classification serves a "compelling" or "overriding" end. In addition, courts require that the classification is "precisely tailored to serve" $\mathrm{e}^{1334}$ or "necessary to promote" 135 that compelling State interest. The State must demonstrate that there are no less "drastic means"336 available to accomplish the State purpose. The burden of proof is on the State under challenge. A State may have to submit statistical data, studies, etc. in order to defeat a challenge, but this is usually an insurmountable task. As a rule, strict scrutiny leads to the invalidation of a classification. The compelling State interest test, however, is applied in only two situations. The first concerns "suspect classifications" such as race, ethnic origin and nationality. In applying strict scrutiny courts offer members of a "suspect class" extra judicial protection. It concerns persons belonging to a "discrete and insular" minority who are incapable of protecting interests through the usual political process and who are often subject to pervasive discriminatory treatment. ${ }^{337}$ Suspect classifications are those which are thought to be irrelevant in a democratic society. The focus of the inquiry is on the nature of the classification, not on the nature of the benefits or rights denied by the classification. Thus, whenever a State uses a suspect classification strict scrutiny is applied regardless of the benefit denied or the

\footnotetext{
333. As lax as the rational relation test may, it is to be noted that the legislative purpose must be legitimate. See e.g. Metropolitan Life Insurance Co. v. Ward, 470 US 869 (1985) where the Supreme Court held that States may not enact laws which are solely aimed at protecting local businesses from out-of-state competition.

334. Plyler v Doe, 457 US 202 (1982) at 217

335. Shapiro v Thompson, 394 US 618 (1969) at 634

336. Dunn v Blumstein, 405 US $330(1972)$ at 343.

337. The classic statement is the one of Justice Stone in footnote four in United States v Carolene Products Co., 304 US 144 (1938): "Prejudice against discrete and insular minorities may be a special condition, which tends seriously to curtail the operation of those political processes ordinarily to be relied upon to protect minorities, and may call for a more searching judicial scrutiny".
} 
burden imposed by this classification. ${ }^{338}$ Strict scrutiny has further been applied to classifications which affect a fundamental interest or the exercise of a "fundamental right" such as the rights to freedom of speech, to a fair trial, to marriage and family life, to vote, access to justice and, as shown later on, the right to travel. Here, the focus is not so much on the classification itself, but rather on its effect, i.e. on the right the classifications impinge upon. ${ }^{339}$ The Court has limited the category of fundamental rights for purposes of equal protection analysis to rights which are explicitly or implicitly guaranteed by the Constitution. ${ }^{340}$

The third standard of review, the so-called "intermediate test", is as the "name" already suggests, to be situated anywhere between rational relation and strict scrutiny review. The test implies that any classification which does not have a "substantial" relationship to an "important" public interest violates the Equal Protection Clause. ${ }^{341}$ The intermediate test is more flexible than the other two. In applying the intermediate test courts presume a classification to be unconstitutional, but they leave more room for States to defeat a challenge. The outcome of the intermediate standard of review is less predictable and the test leaves much more room for a balancing of the constitutional value of equality of treatment against the State interests classifications assertedly serve. The test emerged against the background of the equal protection model as it existed in the late 1960s, early 1970s. Only two "equal protection tests" existed at the time: rational relation and strict scrutiny. This "two-tiered" model was very rigid. Virtually all classifications could pass the first test, almost none the second. This "all or nothing" model was severely criticised. It was not only argued that in reality the Court had not applied this two-tiered model strictly ${ }^{342}$ but also that it should not do so. From classifications such as gender it was thought that the need for strict scrutiny was not as great as

\footnotetext{
338. Wildenthal, State Parochialism, the Right to Travel, and the Privileges and Immunities Clause of Article IV, in: StanflRev (1989) pp.1557-1595, at p.1572.

339. Perry (1979) supra footnote 324 , at p. 1077.

340. San Antonio Indep. School Dist. v Rodriguez, 411 US 1 (1973) at 33-34.

341. Mills v Babluetzel, 456 US 91 (1982) at 99

342. In Rodriguez Justice Marshall wrote: "The Court apparently seeks to establish ... that equal protection cases fall into one of two neat categories which dictate the appropriate standard of review strict scrutiny and rational relation. But this Court's decisions in the field of equal protection defy such an easy categorization. A principled reading of what this Court has done reveals that it has applied a spectrum of standards in reviewing discrimination allegedly violative of the Equal Protection Clause. This spectrum clearly comprehends variations in the degree of care with which the Court will scrutinize particular classifications, depending I believe, on the constitutional and societal importance of the interest adversely affected and the recognized invidiousness of the basis upon which the particular classification is drawn". San Antonio Indep. School Dist. v Rodriguez, 411 US 1 (1973) at 98-99 (Marshall, J., dissenting). See also Dandridge v Williams, 397 US 471 (1970) at 520-521 (Marshall, J., dissenting).
} 
race, but that more careful review than mere rationality was appropriate Similarly, with respect to important interests such as welfare and education, it was claimed that, if they did not qualify for strict scrutiny, they would merit at least a more meaningful form of judicial review than the "mere rationality test". ${ }^{343}$ The most prominent critic within the Supreme Court, Justice Marshall, argued that the Court should adopt an approach in which due regard should be given to "the character of the classification in question, the relative importance to individuals .. of the governmental benefits that they do not receive, and the asserted state interests in support of the classification". ${ }^{344}$ The Court has never adopted such a "sliding scale", but the formal adoption of the intermediate test in a number of cases suggests that the criticism of people like Marshall has had at least some effect. ${ }^{345}$ The importance of the intermediate level of scrutiny is still rather limited though. So far, the Court has only applied this standard to "quasi-suspect" classifications of gender and illegitimacy. ${ }^{346}$

Notwithstanding the rise of the intermediate test, rational relation and strict scrutiny may up until today still be regarded as the most important standards of review. In practice, rational relation is applied in cases concerning "economics and welfare", strict scrutiny only when a fundamental right is impeded or a suspect classification is applied. The discussion below will explore how this general equal protection model is to be applied to discriminations against individuals who have exercised the right

343. Dandridge $v$ Williams, 397 US 471 (1970) at 520-521 (Marshall, J., dissenting).

344. Ibid, at 520-521 (Marshall, J., dissenting) and Martinez v Bynum, 461 US 321 (1982) at 345 (Marshall, J., dissenting).

345. In addition, the Court has not always applied the rational relation and strict scrutiny tests in the way described above. In some cases the Court applies the rational relation test with some "more bite". See e.g. Romer v Evans (1996) in which the Supreme Court struck down an amendment to the Colorado Constitution that would have prohibited public action aimed at protecting homosexuals from discriminatory treatment under the rational relation test. Romer $v$ Evans, 116 SCt 1620 (1996) On this decision see e.g. Jackson, Persons of Equal Worth: Romer v Evans and the Politics of Equal Protection, in: UCLALRev (1997) pp.453-501. Further, the decision in Adarand Constructors, Inc. v Pena (1995) suggests that the Court may be willing to apply the strict scrutiny test more flexibly. In Adarand (515 US 200 (1995)) the Court applied strict scrutiny to a federal programme that encouraged State and local governments to award construction contracts to minority firms, even if non-minority firms had submitted lower bids. The Court, however, dispelled the notion that strict scrutiny is "strict in theory, but fatal in fact" and this may portend some sort of "kinder and gentler strict scrutiny". See Rutten, Elasticity in Constitutional Review: Adarand Constructors, Inc. v Pena and Continuing Uncertainty in the Supreme Court's Equal Protection Jurisprudence, in: SouthCaILRev (1997) pp.591-642.

346. Rotunda/Nowak (1992) supra footnote 327, at p.17. See e.g. Reed v. Reed, 404 US 71 (1971); Craig v. Boden, 428 US 190 (1976); Orr v. Orr 440 US 268 (1979) and Mississipi University for Women v. Hogan, 458 US 718 (1982). On gender discrimination see further Loenen, Verschil in Gelijkheid - De Conceptualisering van het Juridische Gelijkheidsbeginsel met Betrekking tot mannen en Vrouwen in Nederland en de Verenigde Staten (1992). 
to travel. In principle, the discussion is limited to the question which of the available equal protection tests is to be applied. The question whether or not State discriminations can actually be justified will not be addressed here but only in the chapters on minimum subsistence benefits, health care and education. It may be recalled, however, that the choice for a certain test will often be decisive for the ultimate decision: the compelling State interest test generally results in the unconstitutionality of a classification, whilst most classifications can be upheld under the rational relation test. The intermediate test presumes but does not always lead to the unconstitutionality of a classification.

\subsection{Residents}

As a rule, United States citizens who have established residence in another State will not need a constitutional right to be treated equally with the citizens of that State. According to the first sentence of the Fourteenth Amendment, they are State citizens themselves and, in this capacity, they will usually be entitled to the full panoply of rights and benefits a State accords to its citizens. ${ }^{347}$ States, however, do not always treat residents as citizens from the moment they arrive in the State. The enjoyment of many rights or benefits such as welfare, voting and admission to the bar is often made conditional upon the fulfilment of durational residence requirements. These imply that persons must have resided in the State for a minimum period of time before they become eligible for certain rights or benefits. The requirements introduce a waiting-period during which "new", recently arrived, residents are either denied benefits/rights or have to fulfil conditions of eligibility which "old", long-term, residents do not have to meet. Until the expiration of the waiting-period, new citizens are still treated as "non-citizens", as outsiders. Waiting-period requirements are discriminatory in nature and at odds with the Fourteenth Amendment's definition of State citizenship. Yet, discrimination against newcomers is not unconstitutional for these reasons alone. Waiting-period requirements may serve legitimate and important State interests. ${ }^{348}$

347. "A citizen of the United States has a perfect constitutional right to go to and reside in any State he chooses, and to claim citizenship therein, and an equality of rights with every other citizen". Slaughter-House Cases, 16 Wall 36 (1873) at 80.

348. For instance, durational residence requirements for the right to vote in State elections are said to serve the "purity of the ballot box". They are aimed at preventing non-residents from temporarily invading the State, falsely swearing that they are residents eligible to vote and voting for a candidate in the elections who could win by fraud. Dunn v Blumstein, 405 US 330 (1972) at 345. In the ficld 


\subsubsection{Shapiro v Thompson}

Up until the late 1960s, durational residence requirements did not raise serious constitutional objections. Courts merely employed minimal scrutiny and upheld the requirements as being rationally related to the State interests they claimed to serve. In 1969, however, the Supreme Court abandoned much of its traditional deference vis à vis durational residence requirements. In Shapiro $v$ Thompson ${ }^{349}$ the Court invalidated one-year waiting-periods for welfare benefits under the compelling State interest test. The Court held that no longer rational relation but strict scrutiny was to be applied, because in

"moving from State to State .. appellees were exercising a constitutional right, and any classification which serves to penalize the exercise of that right, unless shown to be necessary to promote a compelling governmental interest, is unconstitutional". ${ }^{350}$

The fundamental right which triggered the compelling State interest test was the right to travel, not a "right to welfare". Since any durational residence requirement leads to the denial of a right or benefit for a certain period of time, it seemed that any durational residence requirement would, as a penalty on the right to travel, be subject to strict scrutiny and thus probably be unconstitutional. However, in "footnote 21 " the Court carefully avoided such a far-reaching conclusion:

"We imply no view on the validity of waiting period or residence requirements determining eligibility to vote, eligibility for tuition free education, to obtain a license to practice a profession, to hunt or fish, and so forth. Such requirements may promote compelling state interests on the one hand, or, on the other, may not be penalties upon the exercise of the constitutional right of interstate travel". ${ }^{351}$

Shapiro, and in particular footnote 21, puzzled many scholars. ${ }^{352}$ All

of welfare, waiting-periods are intended to discourage indigents from coming to the State in order to collect higher welfare benefits. In the absence of waiting-periods, States would, as they have always claimed, be subjected to substantial additional financial burdens.

349. Shapiro v Thompson, 394 US 618 (1969). See for a detailed analysis of the decision Chapter 3 Section 9.4 .

350. Shapiro v Thompson, 394 US 618 (1969) at 634.

351. Ibid, footnote 21 .

352. For first comments on Shapiro see e.g. Note, Shapiro v. Thompson: Travel, Welfare and the Constitution, in: NYULRev (1969) pp.989-1013; Schechner, Constitutional Law - Equal Protection Shapiro v. Thompson, 394 U.S. 618 (1969), in: SuffULRev (1969) pp.572-585; Hammerstrom, Constitutional Law - Equal Protection - Residency Requirements, in: CaseWRLRev (1970) (pp.unknown); Anderson/Lutes, The Demise of the Durational residence Requirement, in: SouthwLJ (1972) pp.538-568; Note, The Right to Travel - Quest for a Constitutional Source (1974) pp.122-143; 
durational residence requirements penalise the right to travel in that they all have negative consequences for persons who have recently moved to another State. Yet, the Court listed several requirements that did not constitute "penalties" on the right to travel which trigger strict scrutiny. What then was to be understood by the term "penalty" on the exercise of the right to travel? In particular, what durational residence requirements did not constitute "penalties" for the purposes of equal protection analysis?

One possible explanation could have been that Shapiro's penalty concept had to be read as an obstacle to the right to travel in the sense that only discrimination against newcomers which actually prevents or deters individuals from moving to other States would be covered by the penalty concept. ${ }^{353}$ The Court, however, rejected this "burden-explanation". In Dunn $v$ Blumstein ${ }^{354}$ (1972) the Court held that the argument that durational residence requirements for the right to vote and to stand as a candidate in local elections would not constitute a penalty on the exercise of the right to travel because such requirements would not abridge that right in any constitutionally relevant sense, was a "fundamental misunderstanding of the law". Neither Shapiro nor any other "right-to-travel case" relied on the presence of an actual deterrence; the unconstitutionality of durational residence requirements derived from the fact that they deny persons certain benefits or rights on the ground that they have exercised the fundamental right to travel. ${ }^{355}$ Thus, the Court's main concern with

Note, Durational Residence Requirements From Shapiro Through Sosna: The Right to Travel Takes a New Turn, in: NYULRev (1975) pp.622-680 and McCoy, Recent Equal Protection Decisions Fundamental Right to Travel or "Newcomers" as a Suspect Class, in: VdbiltLRev (1975) pp.9871023. Even Justices of the Supreme Court were confused. In Shapiro the dissenting Chief Justice Warren warned that "the Court's decision reveals only the top of the iceberg. Lurking beneath are the multitude of situations in which States have imposed residence requirements including eligibility to vote, to engage in certain professions or occupations or to attend a state-supported university. Although the Court takes pains to avoid acknowledging the ramifications of its decision, its implications cannot be ignored." Shapiro v Thompson, 394 US 618 (1969) at 655 (Chief Justice Warren, dissenting).

353. To be sure, it was beyond doubt that the Court had not intended to say that non-discriminatory State measures which burden the exercise of the right to travel were or might also be prohibited. Such a reading, which would resemble the case law of the Court of Justice on the prohibition of nondiscriminatory obstacles to freedom of movement (see Section 7.4), would clearly reach too far. Rosberg (1982) supra footnote 295, at p.306-309 and McCoy (1975) supra footnote 352, p.1025. In Shapiro the Court had indicated that the "problem" created by durational residence requirements was essentially a problem of equal protection. Shapiro v Thompson, 394 US 618 (1969) at 627.

354. Dunn v Blumstein, 405 US 330 (1972).

355. In subsequent case-law the Court has confirmed that Shapiro's penalty concept is not to be read as a burden on the right to travel. Ten years after Dunn, in Zobel v Williams (1982), it held that "the right to travel, when applied to residence requirements, protects new residents of a state from being disadvantaged because of their recent migration or from otherwise being treated differently from lon- 
waiting-period requirements was not that they hinder or burden the exercise of the right to travel, but rather that such requirements constitute, by their very nature, a discrimination against "newcomers". ${ }^{356}$ The requirements divide the group of State citizens in two categories: "new" citizens and "long-term" citizens. The former are, up until the expiration of the waiting-period, still treated as non-citizens, as outsiders. Waiting-periods requirements conflict with the Citizenship Clause of the Fourteenth Amendment and that Clause does not "provide for, and does not allow, degrees of citizenship based on length of residence". ${ }^{357}$

Yet, all waiting-periods create, by definition, different classes of State citizens based on the length of residence. This equal-citizenshipinterpretation of Shapiro would seem to imply, however, that all durational residence requirements were subject to strict scrutiny and thus, probably, unconstitutional. The Court, however, wished to leave room for some waiting-periods. It sought the solution for Shapiro's footnote 21 in the importance or the nature of the rights or benefits denied by durational residence requirements. Two years after Dunn, in Memorial Hospital $v$ Maricopa County ${ }^{358}$ (1974), the Court was asked to rule upon the constitutionality of a one-year residence requirement for free non-emergency medical care for indigents. The Court classed the waiting-periods as a "penalty". Whatever

"the ultimate parameters of the Shapiro penalty analysis (..), it is at least clear that medica care is as much "a basic necessity of life" to an indigent as welfare assistance". .. And, governmental privileges or benefits necessary to basic sustenance have often been viewed as being of greater constitutional significance than less essential forms of governmental entitlements". ${ }^{359}$

ger term residents". Zobel v Williams, 457 US 55 (1982) footnote 6. On Zobel see further Kalen, Durational Residency Requirements and the Equal Protection Clause: Zobel $v$ Williams, in JUrbContL (1983) pp.329-359 and Cohen, Equal Treatment for Newcomers: The Core Meaning of National and State Citizenship, in: Const.Comm. (1984) pp.9-19. See further Attorney General of New York v Soto-Lopez, 476 US 898 (1986) where the Court held that the right to travel "protects residents of a State from being disadvantaged, or from being treated differently, simply because of the timing of their migration, from other similarly situated residents" (at 904) and Memorial Hospital v Maricopa County, 415 US 250 (1974) in which the Court stated that Shapiro did "not rest upon a a finding that denial of welfare actually deterred travel" (at 258-259).

356. McCoy (1975) supra footnote 352, at p.1010.

357. Zobel v Williams, 457 US 55 (1982) at 69 (Justice Brennan, concurring). See Rosberg (1982) supra footnote 295, at p.309 and p.311; Garth (1986) supra footnote 7, at p.109; Cohen (1984) supra footnote 355, at p.17 and Justice Brennan in Zobel v Williams, 457 US 55 (1982) at 69-70 (Justice Brennan, concurring)

358. Memorial Hospital v Maricopa County, 415 US 250 (1974). See further on Memorial Hospital Chapter 5 Section 5.2 .

359. Ibid, at 259 . 
The right to interstate travel, the Court said, "must be seen as insuring new residents the same vital government benefits and privileges in the States to which they migrate as are enjoyed by other residents". ${ }^{360}$ In a footnote the Court suggested that tuition waiting-period requirements did not constitute "penalties" on the right to travel because these would not involve the "immediate and pressing need for preservation of life and health". ${ }^{361}$ Maricopa County thus implied that only durational residence requirements which lead to the denial of a "basic necessity of life" or "vital governmental benefit" would constititute a "penalty" on the exercise of the right to travel. ${ }^{362}$

\subsubsection{Saenz v Roe}

Maricopa County, however, did not end the debates on, and the controversy surrounding, Shapiro's penalty on the right to travel analysis. The Supreme Court had never explained why the meaning of the term "penalty" would have to depend on the "importance" of the right/benefit withheld $^{363}$ and it had failed to give sufficiently clear criteria for determining

360. Ibid, at 261 .

361. Ibid, at 260 (footnote 15 ).

362. In later rulings the Court confirmed Maricopa's "solution" for Shapiro (see e.g. Zobel v Willimas, 457 US 55 (1982) at 64 (footnote 11) and Attorney General of New York v Eduardo SotoLopez, 476 US 898 (1986) at 907-909)), even though the Court relaxed Maricopa somewhat. Poppe, Defining the Scope of the Equal Protection Clause with Respect to Welfare Waiting Periods, in: Chicago LRev (1994) pp.291-323, at p.298. In Soto-Lopez the Court held that a provision of the New York Constitution which granted a civil service employment preference only to those veterans who were residents of New York on the moment they entered the military service, "penalized" the right to travel. The Court found that even though the civil employment preference "may not rise to the same level of importance as the necessities of life and the right to vote, it is unquestionably substantial". Attorney General of New York v Eduardo Soto-Lopez, 476 US 898 (1986) at 908. A "penalty" on the right to travel did not have to deprive new residents of "basic necessities of life" in order to constitute a "penalty". The deprivation of a "very important" or "significant" right or benefit would suffice.

363. Indeed, the Court has never given a theoretically sound explanation as to why the importance of the right/benefits would have to be decisive. The Court had held that penalty-analysis falls under the fundamental rights branch of the equal protection model and the Court had chosen the right to travel as the fundamental right which may trigger the compelling State interest test. It was not understandable though why the presence of a penalty on the right to travel depended not on the degree to which travel is actually deterred but rather on the importance or nature of a right/benefit denied during the waiting-period. Furthermore, the true problem of waiting-periods is that they imply, by their very nature, discrimination against newcomers. The problem lies in the requirements themselves and one could therefore have concluded that in Shapiro the Court intuitively established newcomers as a suspect class for equal protection purposes. McCoy (1975) supra footnote 352, at p.1010. Suspect classifications are, however, as noted in Section 8.4, subject to strict scrutiny regardless of the benefit or right denied. In Maricopa and Soto-Lopez, however, the Court did make the application of 
the significance of the right or benefit. ${ }^{364}$ Moreover, the Court itself did not apply penalty-analysis consistently. ${ }^{365}$ In brief, the Court was accused of not having given sufficient guidance as to when a particular standard of review was to be applied; "penalty-on-the-right-to-travel-analysis" was classed as a "failure". The Court was called upon to develop an alternative framework for reviewing waiting-period requirements. The suggested alternatives all had in common that the Court should abandon the classic equal protection model and rely much more on an intermediate level of scrutiny which would enable courts to weigh the States' interests in discriminating against newcomers against the principle of equality of treatment. $^{366}$

strict scrutiny dependent upon the right/benefit denied and the judgments thus made clear that waiting-periods requirements were not treated as suspect classifications. In sum, penalty-analysis fits poorly into the classic equal protection model. It seems to fall somewhere in between the fundamental rights branch and the suspect classification branch of this model.

364. The Court seemed to determine the meant significance on an ad hoc-basis. It was virtually impossible to distil any criteria from the Court's case law. The Court had held that welfare, medical care and civil employment were "vital benefits", but it had also refused to class the right to file for a divorce (Sosna v Iowa, 419 US 393 (1975)) and education as "vital". Why was civil employment any more "vital" than the right to file for a divorce or education? Why were waiting-periods for civil employment subject to strict scrutiny and tuition waiting-periods merely to rational relation?

365. Consider Sosna v lowa, 419 US 393 (1975). The Court was asked to rule upon the constitutionality of a one-year residency requirement for the right to file for a divorce. In selecting the standard of review it would, in the light of Maricopa County, have been most logical if the Court had asked itself whether the right to divorce constituted a "basic necessity of life". The Court, however, did not apply penalty-analysis at all. It did not even indicate which equal protection test it applied. The Court merely asked itself whether Iowa's waiting-period requirement may "reasonably be justified". The Court, in employing what dissenting Justice Marshall called an "ad hoc balancing test", answered the question in the affirmative: "a State such as Iowa may quite reasonably decide that it does not wish to become a divorce mill for unhappy spouses". Sosna v Iowa, 419 US 393 (1975) at 407. Even though it is difficult to retrieve the Court's real motives, it seemed that the Court simply did not want to apply penalty-analysis because this would inescapably have lead to the conclusion that the waiting-period for the right to divorce would constitute a "penalty". The right to marriage has been recognized as a fundamental right and it may therefore have been somewhat "awkward" to argue that the right to dissolve a marriage would not be significant enough for the waiting-period to be classed as a penalty. In Sosna the Court argued that the durational residence requirement at issue in Sosna merely delayed her access to courts. Unlike the requirements challenged in Shapiro and Memorial Hospital, the Sosna-requirement did not prevent applicants from obtaining the benefit they claimed. This "mere delay" argument was not convincing. See Sosna v Iowa, 419 US 393 (1975) at 421-422 (Marshall, dissenting) and Note (1975) supra footnote 355, at p.664-665. Sosna suggested that the Court preserved for itself the opportunity not to apply penalty analysis where this analysis does not enable a presumably desired conclusion to be reached.

366. This result could for example have been reached by applying a balancing act similar to the one applied by the Court in Sosna (see previous footnote 365), by treating some waiting-periods requirements as "quasi suspect" classifications (see in particular Poppe (1994) supra footnote 362, at pp.303-314), by reviewing discriminations against new citizens under the Privileges and Immunities Clause of Article IV $\S 2$ of the Constitution (Zobel v Williams, 457 US 55 (1982) at 73-81 (Justice O'Connor, concurring), the Commcrec Clausc, the Citizenship Clause of the Fourtecnth Amendment 
Quite recently, the Court has indeed moved away from Shapiro's penalty analysis in Saenz v Roe (1999). As in Shapiro the Court was asked to rule upon the constitutionality of one-year residence requirements for welfare benefits. The debates about the appropriate standard of review to be applied to waiting periods requirements (for welfare benefits) ${ }^{367}$ persuaded the Court to focus on the source of the constitutional right to travel. The Court distinguished three different components of the right to travel: the right to leave and enter States, the right to equal treatment in States which beneficiaries visit and, for those who elect to become permanent residents of a State, a right to be treated like other citizens of that State. ${ }^{368}$ At issue in Saenz was this third aspect of the right to travel which involved "the right of the newly arrived citizen to the same privileges and immunities enjoyed by other citizens of the same State". ${ }^{369}$ The Court held that that right is protected not only by the new arrivals' status as a State citizen, but also by their status as citizens of the United States. The Court quoted the Privileges or Immunities Clause of the Fourteenth Amendment which provides that "No State shall make or enforce any law which shall abridge the privileges and immunities of citizens of the United States". The Court explained that despite fundamentally different views on the meaning of the Clause, ${ }^{370}$ it has always been common ground that this Clause protects the third component of the right to travel:

"The States have not now, if they ever had, any power to restrict their citizenship to any classes or persons. A citizen of the United States has a perfect constitutional right to go to and reside in any State he chooses, and to claim citizenship therein, and an equality of rights with every other citizen; and the whole power of the nation is pledged to sustain him in that right. He is not bound to cringe any superior, or to pray for any act of grace, as a means of enjoying all the rights and privileges enjoyed by other citizens"'". ${ }^{371}$

The Court further stated that newly arrived citizens "have two political capacities, one state and one federal" and this added special force to the

(see Cohen, Discrimination Against New State Citizens: An Update, in: ConstComm (1994) pp.73 et seq.) or the Privileges or Immunities of the Fourteenth Amendment. See further Zubler, The Right to Migrate and Welfare Reform: Time for Shapiro v. Thompson to Take a Hike, in: ValpULRev (1997) pp.893-950; Poppe (1994) supra footnote 362, at pp.293-303; Katz, More Equal Than Others, The Burger Court and the Newly Arrived State Resident, in: NewMexLRev (1989) pp.329-376 and Wildenthal (1989) supra footnote 337.

367. See further Chapter 3 Section 9.4.

368. Saenz v Roe, 119 S.Ct.1518 (1999).

369. Ibid.

370. Compare the majority opinion and the various dissenting opinions in the Slaughter House cases 83 US (16 Wall.) 36 (1873). See further, Stone et al (1986) supra footnote 324, at pp.698-707.

371. Saenz v Roe, 119 S.Ct.1518 (1999) (quoting the dissenting opinion of Justice Bradley in the Slaughter House Cases, 16 Wall.36 (1873). 
claim that such citizens have the same rights as others who share their citizenship. Neither mere rationality nor some intermediate standard of review should be used to judge the constitutionality of a State rule that discriminates against some of its citizens because they have been domiciled in the State for less than a year. The appropriate standard "may be more categorical than that articulated in Shapiro .., but it surely is no less strict".

In Saenz the Court thus did depart from the controversial penalty on the right to travel analysis it had developed in Shapiro. Discrimination against new, recently arrived, residents is to be reviewed under the Privileges or Immunities rather than the Equal Protection Clause of the Fourteenth Amendment. The new legal framework for reviewing waitingperiod requirements seems to do more justice to the true concerns of the Court regarding such requirements than penalty on the right to travel analysis. The requirements are not constitutionally controversial because they affect the right to travel, but rather because they divide the group of State citizens in two categories: "new" citizens and "long-term" citizens. It is a privilege of United States citizenship of which State one wishes to become a citizen; the right to travel is merely the means for choosing State citizenship. Saenz, however, does raise many questions as to how the validity of durational residence requirements is to determined under the Privileges or Immunities Clause. The Court invalidated welfare waiting-period requirements, but, as shown later on in this book, ${ }^{372}$ it also indicated that not all waiting-periods are unconstitutional. The Court did not provide much guidance as to how these conclusions are to be reached under the Privileges or Immunities Clause. In fact, the Court did not say much more than that the appropriate standard "may be more categorical" than the one articulated in Shapiro, but "it surely is no less strict". Until Saenz the Court had interpreted the Privileges and Immunities Clause in one decision only (the so-called Slaughter House cases $(1873)),{ }^{373}$ and in this decision it had held that the privileges and immunities guaranteed by the Fourteenth Amendment were limited to those "belonging to a citizen of the United States as such". ${ }^{374}$ The Clause was not intended "as a protection to the citizen of a State against the legislative power of his own State". ${ }^{375}$ Saenz "breathes new life into the previ-

372. See in particular Chapter 5 Section 5.2 .

373. To be sure, in Colgate v Harvey, 296 US 404 (1935) the Court did invoke the Clause in order to invalidate a State income tax leavied against in-State residents, but this decision was overuled five years later in Madden v Kentucky, 309 US 83 (1940)

374. Slaughter House Cases, 83 US (16 Wall.) 36 (1873) at 75.

375. Ibid, at 74 . 
ously dormant Privileges or Immunities Clause",376 but the decision does not reveal which principles are to be applied when reviewing durational residence requirements in areas other than welfare.

\subsection{Non-Residents}

States make the enjoyment of many rights and benefits (e.g. welfare, admission to the bar, free public education, voting, public employment, etc.) conditional upon residence in, and thus citizenship of, the State. Unlike durational residence requirements, simple residence requirements do not make a distinction between classes of State citizens (or residents). They distinguish residents and non-residents. Residence requirements do not conflict with the Fourteenth Amendments's demand for equal State citizenship. Therefore, non-residents' right to equal treatment is not as strongly protected as the equivalent right of "new" residents/citizens. Residence requirements are merely subject to the rational relation test under the Equal Protection Clause, ${ }^{377}$ and Saenz $v$ Roe indicates that the Privileges or Immunities Clause only objects to discrimination against residents, and not to non-resident discrimination.

\subsubsection{The Privileges and Immunities Clause}

United States citizens who visit other States are not, however, "true outsiders" or "strangers" who can be denied rights or benefits merely on the ground that they are not State citizens. They visit other States in their capacity as citizen of the United States and they enjoy in this capacity the specific protection offered by the Privileges and Immunities Clause of

\footnotetext{
376. See Saenz v Roe, 119 SCt 1518 (1999) (Chief Justice Rehnquist, dissenting).

377. Shapiro's penalty-analysis was of no relevance. In Maricopa County the Court said that "the right to travel was involved in only a limited sense in Shapiro. The Court there was only concerned with the right 'to migrate, resettle, find a new job, and start a new life'". Memorial Hospital v Maricopa County, 415 US 250 (1974) at 255. In Martinez v Bynum (1982) the Court further explained that a bona fide residence requirement "does not burden or penalize the right of interstate travel ...for any person is free to move to a State and to establish residence there. A bona fide residence requirement simply requires that the person does establish residence before demanding the services that are restricted to residents". Martinez v Bynum, 461 US 321 (1982) at 328-329. In Martinez the Court added that a residence requirement neither implicates a "suspect classification". Martinez v Bynum, 461 US 321 (1982) at 328 (footnote 7). In terms of citizenship, then, the Court prohibited in Shapiro only discrimination against "new" State citizens, not discriminations against citizens of other States.
} 
Article IV $\S 2$ of the Constitution. The Clause reads: "The Citizens of each State shall be entitled to all Privileges and Immunities of Citizens in the several States". ${ }^{378}$ The Clause is an equality provision which offers non-residents a right to equal treatment with respect to the privileges and immunities States grant to their own citizens. ${ }^{379}$ The purpose of the Clause is, as the Court held in Paul v Virginia (1869):

"to place the citizens of each State upon the same footing with citizens of other States, so far as the advantages resulting from citizenship in those States are concerned. It relieves them from the disabilities of alienage in other States; it inhibits discriminating legislation against them by other States; .., and it secures them in other States the equal protection of the laws. It has been justly said that no provision in the Constitution has tended so strongly to constitute the citizens of the United States one people as this. Indeed, without some provision of the kind removing from the citizens of each State the disabilities of alienage in the other States, and giving them equality of privilege with citizens of other States, the Republic would have constituted little more than a league of States; it would not have constituted the Union which now exists". 380

The Privileges and Immunities Clause is thus not only an individual rights provision which insures "a citizen of State A who ventures into State B

378. On the Privileges and Immunities Clause of Article IV $\S 2$ see e.g. Wildenthal (1989) supra footnote 338, at pp.1560-1564; Gergen, The Selfish State and the Market, in: TexLRev (1988) pp.1099-1153; Bogen, Privileges and Immunities Clause of Article IV, in: CaseWestLRev (1987) pp.794-861; Gonzalez, The Interstate Privileges and Immunities: Fundamental Rights or Federalism, in: CapUlRev (1986) pp.493-513; Zwicker, Equal Protection III: Non-Resident Discrimination. in: ASAL (1986) pp.469-494; Varat, 'State Citizenship' and Interstate Equality, in: ChicLRev (1982) pp.487 et seq; Simson, Discrimination Against Nonresidents and the Privileges and Immunities Clause of Article IV, in: UPennLRev (1979) pp.379-401 and Antieau, Pauls's Perverted Privileges or the True Meaning of the Privileges and Immunities Clause of Article IV, in: W\&MLRev (1967) pp. 1-38

379. Taken literally, the Clause could be read so as to guarantee all United States citizens a set of substantive rights which they can enjoy in every State of the Union. Bogen (1987) supra footnote 378 , at p.842. The Supreme Court has rejected such a reading of the Clause. Baldwin v Fish, 436 US 371 (1978) at 382. The Privileges and Immunities Clause of Article IV $\$ 2$ is an equality provision, it does not create privileges and immunities. Laycock, Equal Citizens of Equal and Territorial States: The Constitutional Foundations of Choice of Law, in: ColLRev (1992) pp.249-337, at p.262. A set of universal substantive rights is guaranteed, however, by the Priviliges or Immunities Clause of the Fourteenth Amendment. This Clause concerns incidents of national citizenship and includes e.g. the right to petition Congress, to enter public lands, to vote for national offices, and, as described in the previous sub-Section, a right for new residents to claim benefits under the same conditions as longterm residents.

380. Paul v Virginia, 75 US (8 Wall.) 168 (1869) at 180-181 as quoted in Baldwin v Fish, 436 US 371 (1978) at 380-381. See also the Slaughterhouse Cases where the Court held that the sole purpose of the Clause "was to declare to the several states, that whatever those rights, as you grant or establish them to your own citizens, or as you may limit or qualify, or impose restrictions on their exercise, the same, neither more or less, shall be the measure of the rights of citizens of other states within your jurisdiction". Slaughtherhouse Cases, 83 US (16 Wall) 36 (1873) at 77. 
the same privileges which the citizens of State B enjoy" ${ }^{1381}$ but also a "national unity" provision which "intends to fuse into one nation a collection of independent sovereign states". ${ }^{382}$ The Privileges and Immunities Clause "builds a bridge between personal rights and federalism"383 and it "facilitates federalism by preventing parochialism in the treatment by a state of citizens of other States". ${ }^{384}$

Even though the Clause is drafted in absolute, uncompromising terms, it does not prohibit all conceivable forms of discrimination against non-residents. Non-residents do not have to be treated as if they were residents of the State they visit. A State, as the Court held in Baldwin v Fish (1978), does not have to:

"apply all its laws or all its services equally to anyone. Some distinctions between residents and nonresidents merely reflect the fact that this is a Nation composed of individual States, and are permitted; other distinctions are prohibited because they hinder the formation, the purpose, or the development of a single Union of those States". ${ }^{385}$

The Supreme Court has developed a number of principles on how permissible differences in treatment should be distinguished from impermissible discrimination against non-residents. ${ }^{386}$ Usually, the Court follows a

\footnotetext{
381. Toomer $v$ Witsell, 334 US 385 (1948) at 395.

382. Ibid.

383. Tribe (1988) supra footnote 324 , at p.528.

384. Gonzalez (1986) supra footnote 382 , at p.497.

385. Baldwin v Fish, 436 US 371 (1978) at 383.

386. In determining which discrimination is valid against citizens of other States and which are not, the Court has relied on various other principles or exceptions. In a number of commercial cases the Court accepted a so-called "proprietary exception" to the Privileges and Immunities Clause according to which the Clause would not apply to State decisions regarding the use and distribution of "State property" (such e.g. natural resources) and which thus entitled States to preserve the benefits of this "property" for its own citizens. See e.g. McCready v Virginia, 94 US 391 (1877); Toomer v Witsell, 334 US 385 (1948) and Hicklin v Orbeck, 437 US 518 (1978). In theory, the exception could be relevant for the purposes of the subject of this study in the sense that one could argue that public benefits constitute the "common property" of the citizens of a State. Such collectively created and financed services would then fall outside the scope of the Clause and States would be free to exclude non-citizens from them. However, the Court has never applied the exception in welfare, health care and education cases and, though the Court has not wholly abandoned the exception (Baldwin v Fish, 436 US 371 (1978) at 386), the current relevance of the exception in general seems minimal. See in particular Varat (1981) supra footnote 382, at pp.494-498 and 505-508. See also Wells/Hellerstein, The Governmental-Proprietary Distinction in Constitutional Law, in: VirgLRev (1980) pp.1073 et seq. In cases decided under the Privileges and Immunities Clause (and the Commerce Clause) the Court has also applied a "market participant exception". The basic notion is that a State may use its resources to provide benefits to its own citizens and that it does not have to share those resources with citizens from other States. See e.g. Reeves, Inc. v Stake, 447 US 429 (1980) and White v. Massachusetts Council of Construction Employers, Inc., 460 US 204 (1982). On this market participation exception see further Varat (1981) supra footnote 382 and Levmore, Interstate Exploitation and Judicial Intervention, in: VirgLRev (1983) pp.563-630.
} 
two-step inquiry. The first step involves asking the question whether the rights or benefits involved constitute one of the privileges and immunities protected by the Clause. The Court has limited the scope of the Clause to privileges and benefits which are in their nature "fundamental" or which are "basic and essential activities, interference with which would frustrate the purposes of the formation of the Union". ${ }^{387}$ The Court has never given a general definition of the term "privileges and immunities". It has even explicitly refused to do so. ${ }^{388}$ Instead the Court has determined on a case-to-case basis whether certain privileges or activities are protected. So far it has classed as "fundamental" e.g. the right to do business, ${ }^{389}$ the right to practice law $^{390}$ and the right to secure abortions. ${ }^{391}$ Recreational activities such as e.g. elk-hunting ${ }^{392}$ are not fundamental for purposes of the Privileges and Immunities Clause. Whenever a right or activity is not considered to be "fundamental", the Court's inquiry under the Privileges and Immunities Clause ends. The residence requirement is then subject to the rational relation test of the Equal Protection Clause only and thus has a good chance of being upheld. In case a fundamental right or benefit is present, the Court proceeds to the second step of the inquiry under the Privileges and Immunities Clause. The Court asks (i) whether there is a substantial reason for the difference in treatment, (ii) whether the discrimination bears a substantial relationship to the State's objective and (iii) whether less restrictive means are available. ${ }^{393}$ The "substantial reason test" is to be located anywhere between the rational relation and the compelling state interest test of the Equal Protection Clause. The level of scrutiny comes close to the level exercised under the intermediate test of the Equal Protection Clause.

The Court's interpretation of the Privileges and Immunities Clause, and in particular the "fundamentality" requirement, has been severely criticised in legal doctrine. The Court has never adequately explained why the scope of the Clause should be limited to "fundamental" rights and

\footnotetext{
387. Baldwin v Fish, 436 US 371 (1978) at 383.

388. "We do not decide to the full range of activities that are sufficient basic to the livelihood of the Nation that States may not interfere with a nonresident's participation therein without similarly interfering with a resident's participation." Baldwin v Fish, 436 US 371 (1978) at 388.

389. See e.g. Toomer v Witsell, 334 US 385 (1948) and Hicklin v Orbeck, 437 US 518 (1978)

390. Supreme Court of New Hampshire v Piper, 470 US 274 (1985) at 281.

391. Doe v Bolton, 410 US 179 (1973).

392. Baldwin v Fish, 436 US 371 (19878) at 388

393. Supreme Court of New Hampshire v Kathryn Piper, 470 US 274 (1985) at 284 and Barnard v Thurstenn, 489 US $546(1989)$ at 552-553
} 
benefits $^{394}$ and, as said, it has not defined the term "fundamental". ${ }^{395}$ It has given some guidance by speaking of "basic and essential activities, interference with which would frustrate the purposes of the formation of the Union", ${ }^{396}$ but the Court has never indicated how or where the borderline between fundamental and non-fundamental privileges and immuni-

394. The argument that discrimination in the grant of "non-fundamental" privileges and immunities does not "bear upon the vitality of the Nation" or does not realistically threaten the social, economic and political unification, is not persuasive. Compare Varat (1981) supra footnote 382, at p.511. In the case of non-fundamental rights or benefits, discriminations against non-residents may be even more hostile or serious than in the case of fundamental rights. Do non-residents feel less an "outsider" when they are denied access to public parks or librairies than when they are refused admission to the bar? Any discrimination on the ground of non-residence simply implicates a "disability of alienage", conflicts with the notion of United States citizens as one people and potentially threatens national unity and cohesion. Arguably, such discrimination is at odds with the object of the Privileges and Immunities Clause.

395. The history of the Clause does not explain either why the Clause should be limited to "fundamental" privileges and immunities. The framers did not in any way indicate that the scope of the Clause should or would be limited to certain privileges and immunities. They saw the Clause as an equality provision intended to facilitate "an effective federal system by prohibiting states from asserting parochial interests to the detriment of an effective federal system". Gonzalez (1986) supra footnote 381, at pp.498-499. On the framers' purpose in drafting the Clause see further Bogen (1987) supra footnote 382 , at pp.843-845. The fundamentality requirement finds its roots in Corfield v Coryell (1823) where Justice Washington said: "What are the privileges and immunities of citizens in the several States? We feel no hesitation in confining these expressions to those privileges and immunities "which are, in their nature, fundamental; which belong, of right, to the citizens of free governments; and which have, at all times, been enjoyed by the citizens of the several states which compose the Union". Justice Washington mentioned inter alia the right to travel, the right to property, the right to claim the benefit of the "writ of habeas corpus". Corfield v Corryell as quoted in Baldwin v Fish, 436 US 371 (1978) at 395 (Brennan, dissenting). Justice Washington, however, did not read the Privileges and Immunities Clause as an equality provision, but rather as a Clause which guaranteed a number of uniform substantive "fundamental rights" or "natural rights" to all United States citizens which should be respected by all States regardless of the rights or benefits which a State grants to its own citizens. The language of the Clause leaves room for such an interpretation. Since Corfield, however, the Court has, in numerous cases, indicated that it does not consider that the Clause guarantees a number of "substantive rights". Since 1867, this role is fulfilled by the Privileges or Immunities Clause of the Fourteenth Amendment. Like the framers, the Supreme Court sees the Privileges and Immunities Clause of Article $\mathrm{V} \S 2$ as an anti-discrimination clause and it is therefore not easy to understand why the Court still adheres to Corfield's fundamentality requirement

396. Baldwin v Fish, 436 US 371 (1978) at 387 
ties is to be drawn. ${ }^{397}$ Therefore, arguments have increasingly been made that the "fundamentality" requirement should no longer be applied. $^{398}$

\subsubsection{Commerce Clause}

In addition to the equality of treatment guaranteed by the Equal Protection Clause and the Privileges and Immunities Clause, individuals are protected against discriminatory treatment in other States by the Commerce Clause. ${ }^{399}$ This Clause provides that Congress has the power "to regulate commerce .. among the several States ...". From the beginning, ${ }^{400}$ it has been recognised that the Clause not only entails an affirmative grant of congressional power, but also acts as a "self-executing limitation on the power of the States". ${ }^{401}$ with As the provisions of the EC Treaty on the

397. One thing is clear though, and that is that under the Privileges and Immunities Clause the term "fundamental" is to be defined other than under the Equal Protection Clause. Otherwise, the Priviliges and Immunities would be superfluous and empty. Varat (1981) supra footnote 382, at p.515 and Tribe (1988) supra footnote 324 , at p.535.

398. See e.g. Justice Brennan's dissenting opinion in Baldwin v Fish, 436 US 371 (1978) at 402 (Brennan, J., dissenting, joined by Marshall and White). See further e.g. Gonzalez (1986) supra footnote 382, at pp.510-513; Varat (1981) supra footnote 382, at pp.509-516 and Simson (1979) supra footnote 382 , at pp.383-386. The Justices and scholars who have expressed this view, thus contend that all residence requirements are to be scrutinised under the substantial relation test. The "nonimportance" of the benefit/right may, if at all, be one element to be considered in balancing non-residents' right to equal treatment against the States' interests in preserving these right/benefits to their own residents, but it is simply not clear why this "non-importance" should be given so much weight as to escape scrutiny under the Privileges and Immunities Clause.

399. The commerce clause is primarily concerned with cross-border commerce, whilst the Privileges and Immunities Clause more generally protects United States citizens in other States against unequal treatment on the ground that they lack citizenship of the State concerned. The material scope of the two clauses may overlap. The Privileges and Immunities Clause has for instance been applied in number of commercial cases (see e.g. Toomer v. Witsell 334 US 385 (1948)), whilst the Court has given a very wide interpretation to the scope of the Commerce Clause so as to include issues which are not typically trade related (see e.g. Edwards v. California, 314 US 160 (1941) - transportation of "indigents"). On the relationship between both clauses see further Varat (1981) supra footnote 382, at pp. 499-501. The personal scope of the Commerce Clause is broader than that of the Priviliges and Immunities Clause. Unlike the former, the latter does not apply to corporations (Paul v. Virginia, 75 US (8Wall.) 168 (1869) at 177-182) and aliens (Blake v. McClung, 172 US 239 (1889) at 247.

400. See Loffredo, If You Ain't Got The Do, Re, Mi: The Commerce Clause and State Residence Restrictions on Welfare, in: Yale LawPol Rev (1993) pp.147-202, at p.173 (footnote 166) stating that the drafters of the Constitution had already recognised this "negative" side of the Commerce Clause. 401. South-Central Timber Dev. v. Wunnicke, 467 US 82 (1984) at 87. See further Redish/Nugent, The Dormant Commerce Clause and the Constitutional Balance of Federalism, in: Duke LJ (1987) pp.569 et seq; Kommers/Waelbroeck, Legal Integration and the Free Movement of Goods: The American and the European Experience, in: Cappeletti et al, Integration Through Law - Europe and the American Fedcral Expcrience (1986) pp.165-227; Blasi, Constitutional Limitations on the Powcr 
free movement of goods, persons and services, the so-called "dormant" Commerce Clause may be regarded as a "negative integration provision" which acts as a constitutional check on State legislation even if no "positive" legislative measures have been taken by the political institutions at federal level. The main principle on which the dormant Commerce Clause is based is that "one State in its dealings with another may not place itself in a position of economic isolation .. by establishing an economic barrier against competitition with the products of another or the labor of its residents". ${ }^{402}$ The "negative" or dormant Commerce Clause primarily protects companies and individuals when doing business in other States, but the Supreme Court has construed the term "commerce" quite broadly.

Since the 1930s, the Court has followed a "two-tiered" approach in reviewing State legislation under the dormant Commerce Clause. ${ }^{403}$ As regards statutes or rules which directly or overtly discriminate against "economic actors" established in other States, the Court applies the "strictest scrutiny". ${ }^{404}$ Protectionist statutes and rules are in principle unconstitutional. In theory, States can escape unconstitutionality when they can demonstrate that that a particular regulation is narrowly tailored to achieve a legitimate and non-protectionist interest, but the case law indicates that this is virtually impossible. ${ }^{405}$ As regards such discriminatory measures, a virtual per se rule of invalidity is applied. State rules which are non-protectionist and non-discriminatory in aim and effect, and which only have minimal impact on interstate trade, are subject to a more

of States to Regulate the Movement of Goods in Interstate Commerce, in: Sandalow/Stein, Courts and Free Markets: Perspectives from the United States and Europe (1982) pp.174-221 and Tushnet, Rethinking the Dormant Commerce Clause, in: WisLRev (1979) pp.125-165.

402. Philadelphia v. New Jersey, 437 US 617 (1978) at 624

403. Brown-Forman Distillers v. New York State Liqor Auth., 476 US 573 (1986) at 578-579.

404. Sporhase v. Nebraska ex rel. Douglas, 458 US 941 (1982) at 958.

405. So far only one State rule has been upheld under the strict scrutiny of the Commerce Clause. See Maine v. Taylor, 477 US 131 (1986) in which the Court accepted that Maine could apply a statute which prohibited the importation of parasited baitfish which posed a unique threat to the environment of Maine. The State was able to convince the Court that there were no less discriminatory means sufficient to protect the environment. 
flexible test. In Pike v. Bruce (1970) the Court defined the basic countours of the test to be applied:

"Where the statute regulates evenhandedly to effectuate a legitimate local public interest, and its effects on interstate commerce are only incidental, it will be upheld unless the burden imposed on such commerce is clearly excessive in relation to the putative local benefits .. If a legitimate local purpose is found, then the question becomes one of degree. And the extent of the burden that will be tolerated will of course depend on the nature of the local interest involved, and on whetehr it could be promoted as well as with a lesser impact on interstate activities". 406

The "Pike-test" is thus a balancing test in which the Federal interest of promoting economic integration is weighed against non-protectionist State interests. ${ }^{407}$ As is inherent in such a balancing test, the judicial outcomes in individual cases are often hard to predict. ${ }^{408}$

\subsection{Aliens}

A third category of "out-of-staters" which, upon arrival in a State, is often faced with discriminatory treatment consists of aliens (or foreigners). As United States citizens, aliens may be discriminated against on the ground that they do not reside or have not resided long enough in the State concerned. This forms of discrimination is not to be discussed here. Constitutional law on residence and durational residence requirements, as described in the previous sub-sections, applies in principle equally to aliens. $^{409}$ The focus is here rather on discriminations based on alienage,

406. Pike v. Bruce, 397 US 137 (1970) at 142.

407. The test resembles the "rule of reason test" applied by the European Court of Justice, but it is to be noted that the Supreme Court is often less strict than its European counterpart. Many laws or regulations which would probably not have been able to pass the tests under Articles 28 and/or 49 of the EC Treaty, have been upheld under the American Commerce Clause. Kommers/Waelbroeck (1986) supra footnote 401 , at p.224.

408. In a number of cases decided under the Commerce Clause the Court has applied a "proprietary exception" and a "market participant exception" comparable to the ones applied under the Privileges and Immunities Clause. See further supra footnote 386

409. This conclusion is not entirely obvious. Aliens do not fall under the personal scope of the Privileges and Immunities Clause (Varat (1981) supra footnote 378 at p.525 and Simson (1979) supra footnote 382 , at p.380) and it is not entirely certain whether aliens enjoy the constitutional right to travel (Graham v Richardson, 403 US 365 (1971) at 375). It is debatable whether aliens challenging "nationality neutral" (durational) residence requirements can benefit from "Shapiro", the Privileges or Immunities Clause of the Fourteenth Amendment and/or the Privileges and Immunities Clause of Article IV $\S 2$. Aliens, however, do enjoy the protection of the Equal Protection Clause. The mere fact that they would not have the same opportunity as United States citizens to challenge "nationality-neutral" (durational) residence requircments, constitutes a discrimination based on 
i.e. the status of not being an United States citizen. ${ }^{410}$ It concerns discrimination which disadvantages aliens on the ground that they lack United States citizenship. ${ }^{411}$

\subsubsection{Equal Protection Analysis}

As the Supreme Court ruled as far back as in 1886, aliens enjoy equal protection of the laws. ${ }^{412}$ Yet, constitutional law on alienage classification began in fact only in 1971 with the decision in Graham $v$ Richardson ${ }^{413}$ Between 1886 and 1971 aliens' right to equal treatment did not have significant substance. Like durational residence requirements, alienage classifications were merely scrutinised under the rational relation test and generally upheld. The Court accepted a so-called "public interest doctrine" which implied, in short, that States had an interest in favouring citizens above aliens in the grant of rights and governmental benefits for as long as this interest entailed "something" more than a mere hostility toward aliens. ${ }^{414}$ Aliens were viewed and treated as "guests" invited to advance the welfare of United States-citizens. In Graham, however, the

\footnotetext{
alienage, which is (probably) subject to the compelling State interest test under the Equal Protection Clause. See Varat (1981) supra footnote 378 , at p.527.

410. A distinction is to be made between discriminations based on alienage and discriminations based on nationality. The former term covers discrimination against of aliens on the ground that they do not possess United States citizenship. It is of no relevance which specific nationality an alien possesses. The term discrimination based on alienage resembles the term discrimination based on nationality as used within the context of the EC Treaty. The notion of discrimination based on nationality (or national origin) applies under United States law to discrimination based on the specific nationality an alien may have. It concerns discriminatory treatment of e.g. a Dutch or Japanese person on the ground that they are Dutch or Japanese, not on the ground that they lack United States citizenship. Discrimination based on nationality comes close to discrimination based on race. Therefore, nationality is a suspect classification for equal protection purposes; the criterion can only withstand strict scrutiny in the most exceptional circumstances. See e.g. Korematsu v United States, 323 US 214 (1944) and Hirabayashi v United States, 320 US 81 (1943).

411. On constitutional law on State discrimination against foreigners see e.g. Rubio Marín, Stranger in Your Own Hone - The Incorporation of Resident Aliens into the Political Community: Theory and Constitutional Practice in Germany and the United States (1997); Rotunda/Nowak (1992) supra footnote $324, \S 18.11-\S 18.13$; X, Developments in Law - Immigration Policy and the Rights of Aliens, in: HarvLRev (1983) pp.1286-1465; Note, State Burdens (1980) supra footnote 306, at pp.940-961; Levi, The Equal Treatment of Aliens: Preemption or Equal Protection?, in: StanfLRev (1979) pp. 1069-1091; Hull, Without Justice for All - The Constitutional Rights of Aliens (1980) and Note, A Dual Standard for State Discrimination Against Aliens, in: HarvLRev (1979) pp.1516 et seq. 412. Yick Wo v Hopkins, 118 US 365 (1886). Aliens have a "right to enter and abide in any State of the Union .. on an equality of legal privileges with all citizens under non-discriminatory laws". Takahashi v Fish, 334 US 410 (1948) at 420.

413. Graham v Richardson, 403 US 365 (1971)

414. Rotunda/Nowak (1992) supra footnote 324, at p.221.
} 
Court considerably strengthened aliens' right to equal treatment. Aliens, the Court held, constitute a prime example of a "discrete and insular minority" for whom "heightened judicial solicitude" under the Equal Protection Clause is appropriate. ${ }^{415}$ The Court invalidated State statutes which denied welfare benefits to permanent resident aliens under the compelling State interest test. Strict scrutiny was to be applied not because alienage classifications in question impinged on the fundamental right to travel, but rather because they were said to be "inherently suspect". ${ }^{416}$

With Graham, however, also began the confusion. If alienage were actually a suspect classification, then all discrimination based on alienage would, regardless of the right or benefit denied, have to be strictly scrutinised and, thus, would probably have to be invalidated. It seemed unlikely, however, that the Court had intended to say that all aliens should be treated equally with United States citizens in all respects. Discrimination against aliens may serve legitimate and important interests. The Court has recognised this and created a number of exceptions to Graham. First, the Court has accepted a so-called "political community exception". States are entitled to preserve the "basic conception of a political community" by limiting to United States citizens voting rights and eligibility for office which "participate directly in the formulation, execution, or review of broad public policy". ${ }^{417}$ Political alienage classification does not have to be treated as suspect ${ }^{418}$ and is, under the Equal Protection Clause, merely subject to rational relation review. Second, the Court has held that undocumented aliens, because of their illegal presence, do not have to be treated as a suspect class. ${ }^{419}$ In principle, undocumented aliens enjoy only minimal protection from the rational relation

415. Graham v Richardson, 403 US 365 (1971) at 372.

416. Ibid, at 376

417. Sugarmann v Dougall, 413 US 634 (1973) at 647. See further e.g. Foley v Connelie, 435 US 291 (1978); Ambach v Norwick, 441 US 68 (1979) and Cabell v Chavez-Salido, 454 US 432 (1982) See further Rotunda/Nowak (1992) supra footnote 324, at pp.226-232; X. Developments in Law Immigration Policy and the Right of Aliens (1983) supra footnote 411, at pp.1405-1406 and Hull, Resident Aliens and the Equal Protection Clause: The Burger Court's Retreat From Graham v Richardson, in: BrookLRev (1980) pp.1-42.

418. The Court could have held that the "preservation of the political community" constitutes a compelling State interest and that political alienage classifications could withstand strict scrutiny. Yet, this would have required a loosening of the strict scrutiny standard and the Court may have been reluctant to do so because of the implications for the application of the test in other, and in particular, racial cases. See Levi (1979) supra footnote 411 , at p.1089.

419. Plyler v Doe, 457 US 202 (1982) at 223. 
test. ${ }^{420}$ Third, the Court has refused to treat alienage classifications applied by the Federal authorities as "suspect". In Matthews v Diaz ${ }^{421}$ (1976), the most important decision concerning Federal discrimination against foreigners, the Court stated that it is "the business of the political branches of the Federal Goverment, rather than of either the States or the Federal judiciary, to regulate the conditions of entry and residence of aliens". Immigration decisions "may implicate .. relations with foreign powers" which must be made "in the light of changing political and economic circumstances". The Supreme Court considers itself an inappropriate forum for making such decisions and it has therefore only applied the most minimum level of scrutiny to Federal alienage classifications. ${ }^{422}$ The Federal authorities are largely free to determine the conditions under which foreigners are admitted.

The Court's application of the Equal Protection Clause in alienage cases has been severely criticised. ${ }^{423}$ The Court has applied different standards of review but has failed to give sufficient guidance as to when a particular test is to be applied. The case law leaves one with the impression that the Court simply creates a new exception whenever it wishes to uphold discrimination against aliens thereby leaving it largely uncertain whether in future cases more alienage classifications will be exempt. The most notable omission is that the Court has never explicitly decided whether or not the biggest group of aliens, i.e. the non-immigrants which include temporary foreign workers, tourists, businessmen, etc., is to be treated as a suspect class. ${ }^{424}$ If the group of non-immigrants, as the Court seems to have suggested, ${ }^{425}$ is not covered by Graham, one would have to conclude that alienage constitutes a suspect classification only by

420. In exceptional circumstances, however, this may be different. In Plyler v Doe (1982) the Court applied the intermediate test to a Texas Statute which denied undocumented school-age children the access to free public education offered to other children. The Court, however, did not wish to limit itself to rational relation because the case involved, on the one hand, "innocent" children who could "affect neither their parents' conduct nor their own status" and, on the other hand, the case concerned education which was not just "some" governmental benefit. Plyler v Doe, 457 US 202 (1982) at 218224.

421. Matthews v Diaz, 426 US 67 (1976). See also Hampton v Mow Sun Wong, 426 US 88 (1976)

422. Federal discrimination against foreigners is not to be reviewed under the Equal Protection Clause of the Fourteenth Amendment but under the equal protection component of the Due Process Clause of the Fifth Amendment. The differential attitude of the Supreme Court towards Federal immigration authorities is not free from criticism. See Guendelsberger, Equal Protection and Resident Alien Access to Public Benefits in France and the United States, in: TulLRev (1993) pp.699-730.

423. See e.g. Rotunda/Nowak (1992) supra footnote 324, at pp.217-220; Note (1980) supra footnote 411; Levi (1979) supra footnote 411 and Note (1979) supra footnote 411.

424. Rosberg (1983) supra footnote 295 , at pp.401.

425. See Elkins v Moreno, 435 US 647 (1978). 
exception. Such a conclusion is at odds with Graham and implies an erosion of the equal protection of aliens. ${ }^{426}$

\subsubsection{Pre-emption Analysis}

The "failure" of the equal protection analysis has prompted a number of commentators to advocate another legal technique for evaluating alienage classifications: pre-emption analysis. Under the pre-emption doctrine State discrimination against aliens is judged on its compatability with the conditions of admission set by Federal immigration authorities. The starting-point is that immigration and alien policy falls within under the exclusive power of the Federal government. It is up to the Federal immigration authorities to decide which, and the conditions under which, aliens are admitted to the United States. States do not hold such powers. They are bound by the immigration conditions set by the Federal authorities. It "is not for the States to alter the terms of immigration with new burdens". ${ }^{427}$ State statutes which impose additional discriminatory burdens on aliens conflict with the exclusive federal power to regulate immigration and are, accordingly, invalid. In a number of alienage cases the Court has indeed applied pre-emption analysis. In Takahashi $v$ Fish ${ }^{428}$ (1948), for example, the Court invalidated a California Statute which denied fishing licences to resident aliens by engaging in pre-emption analysis. The Court held that resident aliens have been lawfully admitted to the United States and entitled to "enter and abide in any State in the Union on an equality of legal privileges with all citizens under non-discriminatory laws". ${ }^{429}$ The challenged statute was said to conflict with the exclusive power of the Federal government to regulate immigration and was thus not permissible. Similarly, in Graham v Richardson (1971) the Court invalidated the welfare statutes in question (also) on the basis of what it called "federal-state relations". Congress, the Court reasoned, had declared that "resident aliens who become public charges .. are not subject to

426. Furthermore, in cases in which strict scrutiny does not have to be applied, the Court would have given States too much discretion in discriminating against aliens. The "political community exception" would allow States to exclude aliens from governmental positions which are only tenuously related to the formulation or execution of high level policy. Hull (1980) supra footnote 411, at p.40. For similar criticism as regards Federal alienage classifications see Guendelsberger (1993) supra footnote 422 .

427. Levi (1979) supra footnote 411, at p.1070.

428. Takahashi v Fish, 334 US 410 (1948).

429. Ibid, at 420 
deportation, and that as long as they are here they are entitled to the full and equal benefit of all state laws for the security of persons and property". ${ }^{430}$ The State statutes at issue thus encroached upon exclusive Federal immigration power and were, consequently, invalid. ${ }^{431}$

\subsubsection{Pre-emption and/or Equal Protection Analysis?}

Advocates of pre-emption analysis claim that this technique recognises, much more than equal protection analysis, that immigration and alien policy are exclusively federal affairs. ${ }^{432}$ Furthermore, "pre-emption" would far better explain the results in alienage cases. For instance, the Federal authorities allow permanent resident aliens to establish domicile and would thus imply that such aliens are admitted as full members of America's "social-economic society". Admission for permanent residence, however, does not imply the grant of United States citizenship and the immigration authorities would thus implicitly allow States to deny immigrant aliens the right to vote and to exclude them from political offices. $^{433}$ The Court would, in cases in which it formally applied equal protection analysis, in fact, have followed "an unarticulated theory of preemption". ${ }^{434}$

Nonetheless, the argument for an increased use of pre-emption technique does not, and cannot, mean that equal protection analysis should be abandoned altogether. More than once, the Court has held that the Federal authorities do not hold the power to authorise States to violate the Equal Protection Clause. ${ }^{435}$ Pre-emption analysis is only useful when the Federal authorities indicate that aliens have to be treated equally. In cases in which the Federal authorities do not prescribe equality of treatment, one necessarily has to engage in equal protection analysis. Furthermore, pre-emption analysis does not in all cases enable courts to determine the (un)constitutionality of alienage classifications. The Federal government does not always indicate in detail which right/benefits aliens can(not)

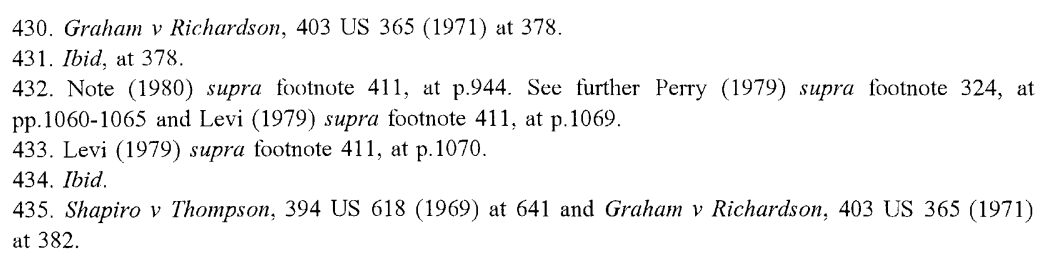


enjoy. This particularly holds true for the heterogeneous group of the nonimmigrants. It is, as the Court seems to have admitted, ${ }^{436}$ simply not always possible to "read into" Federal policy that a State must treat such aliens equally. Lastly, it would seem that the problem with the Court's application of the Equal Protection Clause does not so much lie in the Clause itself but rather in the fact that the Court has adhered to the classic two-tiered equal protection model. In Graham the Court wished to strengthen the legal status of aliens and the only opportunity the Court had, under the classic equal protection model, was to treat alienage as a suspect classification. ${ }^{437}$ The strictness of the compelling State interest test, however, has forced the Court to exempt an increasing number of alienage classifications from suspect treatment. The uncertainty regarding the test to be applied and the erosion of aliens' right to equal treatment are the almost inevitable result of the classic equal protection model. Yet, this is not to say equal protection analysis cannot provide an adequate technique for reviewing alienage classifications. Legal certainty and an adequate protection of aliens' right to equal treatment could be achieved if the Court would subject alienage classification to an intermediate level of scrutiny. This test allows courts to give due regard to both aliens' right to equal treatment and the States' interest in discriminating against aliens. Indeed, all the Court's decisions in alienage cases would appear to be quite consistent if the Court had applied the intermediary test. ${ }^{438}$

Pre-emption and equal protection analysis are not mutually exclusive. Rather, they are complementary legal methods for reviewing alienage classifications. Immigration and alien policy are predominantly Federal affairs and States should simply not be entitled to thwart these policies. Pre-emption is the starting-point. Whenever Federal policy demands or prescribes equality of treatment, States must act accordingly. In all other cases, one necessarily has to resort to equal protection analysis. Preferably, the Court should apply the intermediate level of scrutiny. For as long as the Court adheres to the classic two-tiered equal protection model, legal uncertainty as to the true principles underlying the Court's jurisprudence is likely to remain. ${ }^{439}$

436. Toll v Moreno, 458 US 1 (1982) at 12.

437. Nowak, Realizing the Standards of Review under the Equal Protection Guarantee - Prohibited, Neutral and Permissive Classifications, in: GeorgeLJ (1974) pp.1071 et seq, at p.1099.

438. Rotunda/Nowak (1992) supra footnote 324 , at p.217.

439. One could even argue that there is formally no need at all for pre-emption analysis. The Equal Protection Clause does allow courts to give due regard to the Federal interest in immigration and alien policy. One could simply argue that whenever Federal authorities prescribe that aliens have to be treated equally, States no longer have an interest which may justify a discrimination against aliens. Such discrimination might not, even under the rational relation test, withstand judicial 


\subsubsection{Categories of Aliens}

As chaotic and confusing as the Court's jurisprudence on discrimination against aliens may be, it is possible to bring some structure to constitutional rules applicable to State discrimination against aliens. The outcomes of the several alienage decisions reveal that aliens enjoy an ascending scale of rights as their contribution to society increases. In determining the validity of alienage classifications the Court appears to make a distinction between, at least, three categories of aliens.

The first category consists of aliens who have been lawfully admitted by the Federal authorities for permanent residence. Such immigrants or permanent residents are, of all aliens, the most like United States citizens. They have made the United States their permanent home, are fully taxable and integrated in social and economic life and they may even be called into the armed forces. The only difference between them and United States citizens is that they do not possess United States citizenship. ${ }^{440}$ The right to equal treatment is strongly protected. Under the Equal Protection Clause, permanent resident aliens enjoy the protection of the compelling State interest test except in cases concerning voting rights and public employment.

The second class consists of non-immigrant aliens. The category of non-immigrants is highly heterogenous and includes, for instance, aliens who merely visit the United States as well as aliens who have lived there for years without ever acquiring permanent resident status or United States citizenship. The principles governing the equal treatment of nonimmigrants are not as clear as in the case of permanent resident aliens. Toll $v$ Moreno $^{441}$ (1982) demonstrates that State alienage requirements are to be held invalid if the Federal immigration authorities have explicitly or implicitly indicated that non-immigrant aliens should be treated equally. ${ }^{442}$ In most other cases involving non-immigrants pre-emption analysis will not be of much help. One has to resort to equal protection analysis. The Court has never indicated which standard of review is to be

\footnotetext{
scrutiny. Basically, however, such a view implies an incorporation of the pre-emption doctrine in equal protection analysis. For purposes of clarity it is therefore preferable to speak of equal protection and pre-emption analysis as complementary legal techniques for evaluating alienage classifications.

440. Once aliens are admitted to permanent residence, they are "virtually full-fledged members of the American community, sharing the burdens of membership as well as the benefits". Rosberg, The Protection of Aliens from Discriminatory Treatment by the National Government, in: SC Rev (1977) pp.275-339, at p.337.

441. Toll v Moreno, 458 US 1 (1982).

442. Ibid, at 12-13.
} 
applied to State discrimination against non-immigrants, ${ }^{443}$ but, as argued earlier on, the Court should preferably apply the intermediate level of scrutiny.

Undocumented or illegal aliens constitute the third category of aliens. These are aliens who have entered the United States contrary to Federal law and aliens who have decided to stay after the expiration of the temporary period for which they were initially allowed to stay. In spite of their illegal presence in the United States, undocumented aliens are entitled to equal protection from the law. ${ }^{444}$ In Plyler $v$ Doe ${ }^{445}$ (1982) the Court held, as noted earlier on, that their illegal presence prevents them from being treated as a suspect class. ${ }^{446}$ State discrimination against undocumented aliens is, in principle, only scrutinised under the rational relation test ${ }^{447}$ with the result that States can deny illegal aliens virtually all benefits accorded to citizens and lawfully admitted aliens. ${ }^{448}$

\section{Conclusions}

As noted in Section 1, most questions concerning cross-border access to welfare state services within the European Community and the United States are to be answered on the basis of general rules and principles governing the free movement of persons. The discussion in the previous sections has demonstrated that there are significant differences between

\footnotetext{
443. Rosberg (1983) supra footnote 295 , at p.401.

444. The "protection of the Fourteenth Amendment extends to anyone, citizen or stranger, who is subject to the laws of a State .. That a person's initial entry into a State, was unlawful, .. cannot negate the simple fact of his presence within the State's territorial perimeter. Given such presence, he is entitled to the equal protection of the laws that a State may choose to establish". Plyler v Doe, 457 US $202(1982)$ at 215.

445. Plyler v Doe, 457 US 202 (1982). On Plyler and the equal treatment of undocumented aliens see Rosberg (1983) supra footnote 296; Perry, Equal Protection, Judicial Activism, and the Intellectual Agenda of Constitutional Theory: Reflections on, and Beyond, Plyler $\mathrm{v}$ Doe, in: UPittLRev (1983) pp.329 et seq and X, Developments in Law (1983) supra footnote 411, at pp.1400-1433.

446. Plyler v Doe, 457 US 202 (1982) at 223.

447. To be sure, States have to guarantee undocumented aliens the same equal protection as regards fundamental rights as they have to afford United States citizens and lawfully admitted aliens. See X, Developments in Law (1983) supra footnote 411, at pp.1445-1446. Fundamental rights trigger the compelling State interest test on their own and all classifications which impede these rights are subject to strict scrutiny regardless of the status of person whose rights are impeded.

448. In Plyler the Court held that "persuasive arguments support the view that a State may withhold its beneficence from those whose very presence within the United States is the product of their own unlawful conduct". Plyler y Doe, 457 US 202 (1982) at 219
} 
the rules governing this freedom of movement. Critics might even say that there are too many differences in order to make useful a comparative analysis of the degree to which European Community law and American constitutional law entitle individuals to gain access to public benefits systems in other States. Differences are decreasing however. In particular, European Community law on the free movement of persons has proven to be quite dynamic. Over the years, Community law has transformed the initial economically determined freedom of movement into a general freedom of movement which increasingly resembles the American right to travel. Freedom of movement is now a right which nationals of Member States enjoy merely in their capacity as citizens of the Union and upon arrival in another State, Union citizens enjoy a right to equal treatment which reaches almost as far as the right to equal treatment enjoyed by the beneficiaries of the American right to travel. Both European and American law entitle citizens who have moved to other States to gain (equal) access to social and public benefits and, at least on the face of it, the nondiscrimination tests applied by the European Court of Justice and the American Supreme Court show clear similarities. For instance, both courts are very strict as regards State rules or measures which directly discriminate against citizens of other States. To nationality requirements the European Court applies a virtual per se rule of prohibition, whilst the American Supreme Court subjects waiting-period requirements to the virtually insurmountable compelling State interest test. Further, the substantial relation test applied under the American Privileges and Immunities Clause, the Commerce Clause as well as the intermediate test adopted under the Equal Protection Clause resemble the test which the Court of Justice applies when reviewing national rules which indirectly discriminate against non-nationals or which merely burden freedom of movement.

Bearing in mind the existing differences as well as the increasing similarities between American constitutional and European Community law, the discussion now proceeds with an examination of the law governing cross-border access to specific public benefits which have been selected for the purposes of this book. 
Chapter 3

MINIMUM SUBSISTENCE BENEFITS 



\section{Introduction}

From the European (Economic) Community's inception, its Member States have objected to a free movement of persons which would enable individuals in need of social assistance benefits to move to and to establish residence in other Member States. Those Member States now located in the geographical heart of the Community especially have always feared that the comparatively high level of their benefits would attract nationals from the "southern" and "poorer" Member States. A large influx of Community citizens moving for the sole purpose of collecting higher benefits, so the arguments runs, could affect the financing of social assistance schemes. Initially, the objections to "social tourism" remained largely hidden. The original EEC Treaty merely prescribed a free movement of (self-)employed persons and it was presumed of such persons that they would provide for themselves and their family members with income earned from full-time work. When from the early 1970s, however, the Court of Justice started to interpret Community provisions on the free movement of workers broadly, and in particular when the first plans for the realisation of a general right of residence for all Community citizens were launched, Member States were quick to express their concerns and objections. The conflict between the goal of realising a free movement of persons, on the one hand, and the need to protect social assistance schemes, on the other hand, ${ }^{1}$ came to the surface.

This chapter explores how Community has sought to settle this conflict by examining the degree to which European Community law gives individuals in need of social assistance(-like) benefits the right to move to other Member States and to claim such benefits there. Section 2 puts the subject in its proper context by $(i)$ describing the main characteristics of the social assistance schemes of the Member States, (ii) the ways in which Member States have traditionally regulated the access of "needy" foreigners to their territory and benefit schemes and (iii) the case law of the Court of Justice on the application of the Community's rules on the co-ordination of social security schemes to social assistance(-like) benefits. The subsequent four sections deal with the free movement and social assistance rights of the economic residents (Section 3), the non-economic residents (Section 4), the non-residents (Section 5) and the third country

\footnotetext{
'On the conflict between the "free movement interest" and the "public benefit interest" see further Chapter 1 Section 2.
} 
nationals (Section 7). ${ }^{2}$ After a brief summary and evaluation (Section 8), the discussion proceeds in Section 9 with an analysis of the law governing the cross-border access to social assistance schemes within the United States. As described in the previous chapter, the American Constitution guarantees a right to travel which, in principle, entitles all persons present, or established, in the United States to move and/or to reside freely among the States. Just as with Member States of the European Community, however, the American States have always resisted a freedom of movement for persons in need of social assistance (or welfare) benefits. Many States have feared that their comparatively high level of benefits would have a magnetic effect on "indigents" from other States and they have claimed the power to put up legal barriers in order to avoid "free-riding indigents" affecting the financial stability of their benefit schemes. Section 9 looks at whether American States are entitled to impose such legal restrictions and how American constitutional law has settled the conflict between the "free movement interest" and the "social assistance interest". In the final section the findings of this chapter will be evaluated. Can, or should, Community law on the free movement of persons and crossborder access to social assistance benefits be adjusted or improved, and what lessons can possibly be learned from the United States?

At the outset, some comments need to be made about terminology. Above, reference has been made to social assistance-like benefits and the title of this chapter refers to minimum subsistence benefits. There are two reasons for this. First, the discussion of European Community law will not only include the traditional social assistance schemes, but also the socalled "mixed" or "hybrid" benefit schemes. The main features of these benefit schemes will be described in the next section, but it should be pointed out that these benefits, like social assistance benefits, are funded out of tax revenues and aimed at giving recipients a minimum means of subsistence. Second, the term "social assistance benefits" is rarely used in the United States. Publicly funded benefits which aim to offer the "poor" a minimum of financial means are usually referred to as "welfare benefits". The "European" sections of this chapter speak of social assistance and mixed benefits and the term welfare benefits will be used in the "American" section. All benefits to be dealt with, however, are funded out

\footnotetext{
${ }^{2}$ For a brief description of the four categories and the main principles governing their legal status under Community law, scc Chapter 2 Scctions 2 to 5 .
} 
of the public purse, aimed at offering beneficiaries minimum means of subsistence and they may therefore all be referred to as minimum subsistence benefits. ${ }^{3}$

\section{Minimum Subsistence Benefit Schemes and the European Community}

\subsection{Minimum Subsistence Benefit Schemes of the Member States}

In each of the Member States governments hold a certain responsibility for the financial well-being of the population. Persons who are, due to unemployment, sickness, old-age or disability no longer able to generate an income from work, should be assured of maintaining (the main) part of their income and every member of society should possess the minimum means for subsistence. ${ }^{4}$ In furtherance of this responsibility, numerous social benefit schemes have been established by the Member States' governments. ${ }^{5}$ Traditionally, a distinction has been made between social security (or insurance) benefit schemes and social assistance schemes. ${ }^{6}$

Social security schemes are State created systems which oblige (or enable) specific categories of persons such as workers to insure themselves against loss of income resulting from unemployment, sickness, invalidity or old-age. Social security schemes place the beneficiaries in a legally defined position which is largely determined by their personal "insurance record". The payment of social charges by workers and their

\footnotetext{
${ }^{3}$ The term is derived from Vonk, De Coördinatie van Bestaansminimumuitkeringen in de Europese Gemeenschap (1991) at pp.40-41.

${ }^{4}$ De Kam et al, Leer van de Social Zekerheid (1989) at pp.18-20.

${ }^{5}$ For an overview of the benefit schemes in the Member States see e.g. Einerhand, Sociale Zekerheid: Een Europese Vergelijking, in: TvA (1997) pp.5-20; Pieters (Ed.), Social Security Law in Fifteen Member States of the European Union (1997); Einerhand, Sociale Zekerheid: Stelsels en Regelingen in Enkele Europese Landen (1995) and Pieters/Schell, Inleiding to het Sociale Zekerheidsrecht van de Landen van de Europese Gemeenschap (1990).

6 Two other types of benefits can be identified. The first consists of benefits for "common risks" which are given regardless of the payment of any contributions. An example of these "universal" benefits are child benefits paid to families irrespective of financial means. The second "other" type concerns social compensation benefits for victims of certain misfortunes for which the State accepts responsibility. These include e.g. vaccination damage payments. See White, EC Social Security Law (1999) at p.6.
} 
employers (to a social insurance fund) entitles workers to benefits when the insured risk occurs. The level of the benefits is fixed and generally does not depend on other possible sources of income. The benefits are granted as of right and in principle funded out of the collectively paid contributions.

Social assistance schemes are different in nature. ${ }^{7}$ The schemes offer minimum financial means to all members of society who are not able to provide for themselves and their dependent family members. Social assistance is subsidiary in nature. Benefits are only granted to persons who have no other financial means be it income from work or social security benefit(s). Social assistance is the last stage of governmental help which, in most Member States, serves as a financial safety net for those in financial need. The schemes take the benefciciaries' financial need, not their insurance record as the starting-point. Usually, the grant of social assistance benefits is preceded by a means-test. Social assistance schemes are non-contributory benefit schemes. They are paid out of tax revenues; payment of taxes is not a prerequisite for individual enjoyment of social assistance benefits. Under the poor relief systems, out of which social assistance systems have grown, ${ }^{8}$ the grant as well as the level of social assistance benefits were dependent upon the discretionary power of the competent administrative body. The benefits were accorded as a privilege; they were seen as a form of governmental charity.

\footnotetext{
${ }^{7}$ On the traditional distinction between social assistance and security see e.g. Forde, Social Assistance and the EEC's Regulations, in: LIEI (1978) pp.9-28 and Perrin, Les Prestations non contributive et la Sécurité sociale, in: DS (1961) pp.179-188. The organisation of social assistance schemes differs considerably. For an overview of social assistance schemes in various European countries see e.g. Einerhand, Bijstand een Internationale Vergelijking, in: SMA (1997) pp.207-220, Eardley et al, Social Assistance in OECD Countries: Synthesis Report (1996) and Council of Europe, Social Assistance Benefits in Cash and in Kind in the Council of Europe Member States and Finland (1982).

${ }^{8}$ On the origin of social assistance schemes see e.g. Vonk (1991) supra footnote 3 , at pp.30-35; Hepple, Welfare legislation and Wage Labour, in: Hepple (Ed.), The Making of Labour Law in Europe - A Comparative Study of Nine Countries up to 1945 (1986) pp.115153; Schulte/Trenk Hinterberger, Sozialhilfe, eine Einführung (1986) pp.37-46 (Germany); and van der Valk, Van Pauperszorg tot Bestaanszekerheid - Een Onderzoek naar de Ontwikkeling van Armenzorg in Nederland tegen de Achtergrond van de Overgang naar de Algcmenc Bijstandswet 1912-1965 (1986) (the Netherlands).
} 
Over the years the traditional distinction between social security and social assistance has become blurred. ' Today, social assistance benefits are also granted as of right, whilst social security schemes often contain features which traditionally characterised social assistance. Insurancebased schemes may contain a means test ${ }^{10}$ they are also often financed by the State and benefits may be granted irrespective of the actual payment of social charges. Often, it is quite difficult, if not impossible, to label benefit systems as either social insurance or social assistance. ${ }^{11}$ Many benefit schemes aim to provide specific categories such as the disabled or the elderly with minimum means of subsistence. Such categorical benefit schemes resemble social assistance in that they are financed out of the public budget, not dependent on the payment of taxes, subsidiary to social security benefits and preceded by a (limited) means test. Such minimum subsistance benefit systems, however, are also insurancelike because they are only made available for specific categories of persons and administered by social security funds. A typical example concerns the Netherlands Law on the Provision of Income for Unemployed Workers who are Elderly or Suffering from Partial Incapacity to Work (the so-called "IOAW"). The benefits offered under the IOAW are funded out of the public purse, provided and administered by the same bodies which are responsible for social assistance benefits in the Netherlands and eligibility for the benefits is subject to a means test. Yet, the IOAW benefits cannot be regarded as classic social assistance benefits. The means test is limited (test of partner's income, no test concerning property) and the benefits are only granted to specific categories of unemployed persons. Benefits such as the ones offered under the IOAW contain a mixture of social security and social assistance features. They are recognised as a separate category of social benefits which can be

\footnotetext{
'van der Mei, De Rechtmatigheid van Woonplaatsvereisten voor Bestaansminimumuitkeringen onder het EG-Recht, in: SMA (1999) pp.451-459; van der Mei, Het Vrij Verkeer van Personen binnen de Europese Gemeenschap en de (Niet-)Exporteerbaarheid van 'Gemengde' Bestaansminimumuitkeringen, in: USZ (1997) pp.895-902 and Laske, The Impact of the Single European Market on Social Protection for Migrant Workers, in: CMLRev (1993) pp.515-540, at p.528.

${ }^{10}$ Schell/Pieters, De Middelentoets in Rechtsvergelijkend Perspectief (1989) at p.174.

1 On this development see in particular the opinion of Advocate General Mayras in Case 1/72 Frilli [1972] ECR 457 at pp.468-475.
} 
situated anywhere in between social security and social assistance. They may be referred to as "mixed", "non-contributory" or "hybrid" benefit schemes. $^{12}$

\subsection{Conditions of Access}

The minimum subsistence benefit schemes of the Member States have traditionally been based on the principle of territoriality. Eligibility for benefits has been limited to residents; non-residents have been excluded. The application of residence requirements does not only imply that residents of other States cannot acquire the right to obtain minimum subsistence benefits. Territoriality also implies that residents lose their right to enjoy such benefits when they decide to move to other States. On the basis of national law, minimum subsistence benefits are not exportable.

The territorial limitation of benefit schemes, and social assistance systems in particular, has been defended on various grounds. A first, rather concrete, one is that the application of a proper means-test to persons living outside the territory of the State would raise technical and administrative difficulties. ${ }^{13}$ A second reason as to why minimum subsistence benefits would not be payable to those residing outside the State borders would be that the level of benefits is calculated on the basis of the cost of living in the national territory. Non-residents would otherwise

\footnotetext{
12 See e.g. van der Mei (1999) supra footnote 9, at p.452 and Vonk (1990) supra footnote 3, at pp.37-38. The assimilation of social insurance and social assistance is in particular a characteristic of the benefit schemes in the original Member States. In these States two guaranteed minimum income benefit schemes can, roughly speaking, be distinguished: general social assistance schemes which grant subsistence benefits to all members of society irrespective of the cause of their need and mixed benefit schemes which apply to specific categories of persons. Both types of benefits are granted as of right and are generally paid out of the public budget. In southern Member States the picture is often different. The general schemes in existence in these States resemble the traditional poor relief systems. A basic right for all "members of society" to minimum means of subsistence does not exist. See e.g. Adler, The 'Habitual Residence Test' in the UK, in: Eichenhofer (Ed.), Social Security of Migrants in the European Union of Tomorrow (1997) pp.53-59, at p.57. Next to these charitable systems several regulations for specific and small groups of persons like the blind, disabled, victims of earthquakes, etc. exist. Vonk (1990) supra footnote 3, at p.34. For brief descriptions of these schemes see the relevant chapters in Schell/Pieters (1990) supra footnote 10 and Council of Europe (1982) supra footnote 7.

${ }^{13}$ See e.g. the observations from the European Commission in Case 24/74 Biason [1974] ECR 999.
} 
be entitled to benefits which are either "too high" or "too low". ${ }^{14} \mathrm{~A}$ third, more theoretical, ground is that the welfare responsibility of governments only applies to residents and not to non-residents. Only residents are part of the solidarity of shared welfare. The most important argument for the principle of territoriality, however, has always been, and still is, financial in nature. If States were (obliged) to grant social assistance and mixed benefits to residents and non-residents alike, the financing of these schemes would be affected. Since minimum subsistence benefits are funded out of revenue from taxes paid mainly by residents, States have limited eligibility for benefits to residents only.

The above is not to say that States merely regulate access to their social assistance schemes through residence requirements. The picture is more complicated. States, and in particular the ones with comparatively high benefit levels, have always recognised that social assistance systems could have a magnetic effect on nationals of other States. Immigration policy has traditionally been used in order to safeguard the funding of social assistance schemes. Whether or not non-nationals are able to provide for themselves and their family members is one of the most important factors States have considered when deciding on admission for residence. Generally, non-nationals in need of social assistance have been refused admission. Under the guest-worker system, as it existed in the 1950 s and 1960 s, non-nationals were required to contribute to the funding of social assistance schemes by paying taxes, but once they became in need of social assistance they would lose their right to residence. From the perspective of social assistance schemes, guest-workers were supposed to be contributors to the welfare state and social assistance schemes. They were not supposed to become a burden on these schemes. Today, being in need of social assistance is usually still a ground for refusing non-nationals residence, but the right to reside is no longer automatically lost the moment a foreigner becomes in need of social benefits. After a minimum period of employment or residence (in most Member States around five years $)^{15}$ non-nationals may become eligible for social assistance benefits.

\footnotetext{
${ }^{14}$ Schulte, Pflegeleistungen zwischen Sozialer Sicherheit und Sozialer Hilfe - Aspekte der Europarechtlichen Abgrenzung, in: Sieveking (Hrsg.), Soziale Sicherung bei Pflegebedürftigkeit in der Europäischen Union (1998) pp.143-159, at p.154.

${ }^{15}$ Vonk (1990) supra footnote 3, at p.194. See for instance the European Convention on Social and Medical Assistance. Article 1 of this Convention provides that the State parties to the Convention shall ensure that nationals of other State parties who are legally residing in their territory are treated equally as regards social (and medical) assistance. Article 6 further states that States shall not repatriate nationals of other contracting parties solely on the ground that they are in need of assistance. The latter Article seems to eliminate the power to end the residence of non-nationals in need of social assistance, but $\Lambda$ rticle 7 makes some
} 
Up until the expiration of the minimum period of residence or employment, however, the being in need of social assistance may still lead to the loss of the right to reside. ${ }^{16}$

Being in need of minimum subsistence benefits may thus affect the residence status of non-nationals. The reverse also holds true. The residence status of non-nationals is relevant for entitlement to minimum subsistence benefits. First, the right to claim benefits has traditionally been linked to legal residence in the State territory. As a rule, non-nationals who are illegally residing in the national territory have been excluded. Non-nationals can only obtain benefits upon presentation of a valid residence permit or residence entitlement. Second, the right to receive minimum subsistence benefits has often been made conditional upon the fulfillment of minimum periods of residence. Generally, such durational residence requirements apply to non-nationals only. ${ }^{17}$ Nationals only have to fulfill the "simple" residence requirement. ${ }^{18}$

The practical result of national immigration laws and rules governing minimum subsistence benefits is that (many) persons in need of such

significant exceptions to this rule. Such persons may be repatriated if they have not resided in the State territory for a period of five years (or ten years for persons who were older than 55 years on the moment of entering the State), are in a fit state of health to be transported and have no close ties to the State of residence. The Convention does not seem to confer upon individuals strong legally enforcable rights. It only imposes on the contracting party State the duty to show restraint in repatriating non-nationals. See further Vonk (1991) supra footnote 3, at pp.204-214

${ }^{16}$ See in general Vonk (1990) supra footnote 3, at p.195-201. For the Netherlands see Swart, De Toelating and Uitzetting van Vreemdelingen (1978) at pp.241-252 and as regards Germany Schuler, Das Internationale Sozialrecht der Bundesrepublik Deutschland (1988) at pp.775-779.

${ }^{7}$ Compare von Maydell, Treatment of Third-Country Nationals in the Member States of the European Union and the European Economic Area in Terms of Social Law - General report, in: Commission of the European Communities/Departemento de Relações Internaçiõnais e Convençoes de Segurança Social, Social Security in Europe - Equality between Nationals and Non-Nationals (1995) pp.139-154, at pp.148-151.

${ }^{18}$ There are more situations in which non-nationals are, or have been, treated less favourably than nationals of the host State. Even if non-nationals have resided in the host State for the required minimum period they may be confronted with other conditions which can only or more easily be met by nationals. For instance, mixed benefits which are granted as a supplement to another social security benefit are often only awarded as a supplement to other social security benefits provided by the host State. Often migrants only receive social security benefits from the State of their origin and are thus in a less favourable position than persons who have never lived or worked in another member State. Furthermore, in applying the means test Member States often leave certain income sources or assests out of consideration. In many cases, however, this exclusion only applies to income or assets in the host Statc. 
benefits cannot move to other (Member) States. Because benefits are exportable, beneficiaries often will not be able to demonstrate that they can provide for themselves in the State where they wish to live. The combined application of immigration laws and the territoriality principle enshrined in the laws and regulations governing minimum subistence benefits, prevents the "needy" from moving to other States.

\subsection{Application of Regulation No $1408 / 71$ to Minimum Subsistence Benefits}

For the purposes of this chapter it is important to establish whether minimum subsistence benefits are covered by social security Regulations No 1408/71 and No 574/72. ${ }^{19}$ Application of these regulations may have legal effects which do not necessarily follow from the general provisions on freedom of movement and non-discrimination such as the exportability of benefits and the application of aggregation rules. ${ }^{20}$

According to Article 4(1), Regulation No 1408/71 applies to sickness and maternity benefits, invalidity benefits, old age benefits, survivors' benefits, benefits in respect of accidents at work and occupational diseases, death grants, unemployment benefits and family benefits. The list of Article 4(1) is exhaustive. ${ }^{21}$ Article 4(4) specifically excludes "social and medical assistance, benefits schemes for victims of war or its consequences" from the scope of application. ${ }^{22}$ The classic social assistance benefits are thus not covered. Difficult questions have arisen as regards the application of the Regulations to mixed benefit schemes. From

\footnotetext{
${ }^{19}$ For a brief introduction to the regulations see Chapter 2 Section 6.

${ }^{20}$ Lyon-Caen, Social Security and the Principle of Equal Treatment in the EC Treaty and Regulation No.1408/71, in: Commission of the European Communities/Departemento de Relações Internaçionais e Convenções de Segurança Social (1995) pp.45-73, at p.52.

${ }^{21}$ See e.g. Case C-66/92 Acciardi [1993] ECR I-4567 and Case 122/84 Scrivner [1985] ECR 1029 at 19.

${ }^{22}$ The reasons behind the exclusion of social assistance are not entirely clear. It has been suggested that the exclusion relates to the fact that at the time the original Regulation 3/58 was adopted, most Member States were bound by the European Convention on Social and Medical Assistance (1953). See Bender, Die Sozialhilfe im System Ausländerrechts, in: Demokratie und Recht (1974) pp.36-42, at p.37. Also, it might be that there was no rational motive for excluding social assistance and that the drafters of Regulation No $3 / 58$ simply continued to apply the principles of the European Interim Agreements of the Council of Europe which did not apply to social asisstance benefits. Vonk (1991) supra footnote 3, at pp.249-250 and Schulte, Pensions and Social Security, in: Carlier/Verwilghen, Thirty Years of Free Movement of Workers in Europe (2000) pp.143-158, at p.145.
} 
the early 1970s, the Court of Justice has in various cases been asked to determine whether or not such benefits are covered by Regulation No $1408 / 71 .^{23}$ The fact that mixed benefits are non-contributory could be no reason for excluding these benefits from the scope of application. Article 4(2) provides that Regulation No 1408/71 applies to all general and special social security schemes, whether contributory or non-contributory. ${ }^{24}$ Further, it was clear that the national classification of benefits as social assistance or social security could not be a relevant factor. If it were, Member States could unilaterally exclude certain benefits from the Regulation. ${ }^{25}$ In the light of the enormous diversity of such benefits, it was in fact impossible for the Court to give a general rule on the application of the Regulation. The only proper method was to assess each benefit scheme individually on the basis of thepurpose and specific features of the benefit schemes. ${ }^{26}$ The Court has therefore consistently held that the dis-

\footnotetext{
${ }^{23}$ See Case 1/72 Frilli [1972] ECR 457; Case 187/73 Callemeyn [1974] ECR 553; Case 24/74 Biason [1974] ECR 999; Case 39/74 Costa [1974] ECR 1251; Case 7/75 Mr and Mrs F. [1975] ECR 679; Case 39/76 Mouthaan [1975] ECR 1901; Case 63/76 Inzirillo [1976] ECR 2057; Case 139/82 Piscitello [1983] ECR 1471; Case 261/83 Castelli [1984] ECR 3199; Case 249/83 Hoeckx [1985] ECR 982; Case 122/84 Scrivner [1985] ECR 1029; Joined Cases 379-381/85 and 93/86 Giletti and others [1987] ECR 955; Case 147/87 Zaoui [1987] ECR 551; Case 236/88 Commission v France [1990] ECR I-3163; Case 356/89 Newton [1991] ECR I-3017; Case C-66/92 Acciardi [1993] I-4567 and Case C-78/91 Hughes [1992] ECR I-4839. For descriptions of the case law see van der Mei (1999) supra footnote 9; van der Mei (1997) supra footnote 9; Schulte (1998) supra footnote 14; Verschueren, Libre Circulation des Personnes et Protection Sociale Minimale, in: RMUE (1996) at pp.83-105; Verschueren, Les Prestation spéciales à Caractère non contributif et le Règlement Communautaire, in: DS (1995) pp.921-930; Pennings, "Bijstandsuitkeringen" en het Recht op Vrij Verkeer van Werknemers, in: MR (1992) pp.146-155; Vonk (1990) supra footnote 3, at pp.318-336 and Watson, Minimum Income Benefits: Social Security or Social Assistance, in: ELRev (1985) pp.335-343.

${ }^{24}$ Taking the financing method as a distinguishing criterion would be rather "artificial" since many benefit schemes are financed from different sources. They are often both contributory and non-contributory in nature. See Advocate General Roemer in his Opinion in Case 28/68 Torrekens [1969] ECR 125 at p.140.

${ }^{25}$ See e.g. Case $79 / 76$ Fossi [1977] ECR 667 . Article 5 of the Regulation provides that every Member State has to notify the President of the Council of the legislation which comes under the scope of the Regulation to. Such notifications, however, do not define the scope of the Regulation. Benefit schemes which have been notified are covered by the Regulation, but the fact that certain schemes are not notified does not necessarily mean that they fall outside the field of application of the Regulation. Case 35/77 Beerens [1977] ECR 2249 at 9 and Case C-85/99 Offermans [2001] ECR I-0000 at 26.

${ }^{26}$ In the assessment of individual benefit schemes the Court usually followed a similar approach. In most rulings the Court started with the general statement that although "it may seem desirable, from the point of view of applying the regulation, to establish a clear distinction between legislative schemes which come within social security and those which
} 
tinction between benefits which are excluded from the field of application of Regulation No 1408/71 and benefits which come within it "rests entirely on the factors relating to each benefit, in particular its purpose and the conditions for its grant". ${ }^{27}$ Even though the Court has not always been consistent, one may conclude from the case law that the following criteria had to be met in order for a benefit to be covered by the Regulation: $(i)$ the legislation under which the benefit is granted must place claimants in a legally defined position as a result of which they have an absolute right to benefit ${ }^{28}$ and (ii) the benefit must cover one of the risks enumerated in Article 4(1). ${ }^{29}$ When a benefit scheme satifies these two criteria, it is to be regarded as a social security benefit falling within the ambit of Regulation No 1408/71. In Acciardi (1993), for instance, the Court concluded that the Netherlands IOAW, mentioned in Section 2.1, fell within the scope of the Regulation. The benefit in question was partly dependent on the income of the applicant and/or the spouse, but this did not imply that it was to be classed as a social assistance benefit. In the

come within assistance, it is possible that certain laws, because of the classes of persons to which they apply, their objectives, and the detailed rules for their application, may simultaneously contain elements belonging to both categories mentioned and thus defy any general classification". Case 1/72 Frilli [1972] ECR 457 at 13; Case 39/74 Costa [1974] ECR 125 at 6 and Case C-356/89 Newton [1991] ECR I-3017 at 12. Usually, this statement was followed by some observation on the specific features of the mixed benefit scheme under consideration. In most cases the Court concluded that such benefit schemes consist "on the one hand in guaranteeing a subsistence level to persons wholly outside the social security system, and on the other hand in providing an income supplement for persons in receipt of inadequate social security benefits". Case 1/72 Frilli [1972] ECR 457 at 15 and Case 24/74 Biason [1974] ECR 999 at 16. After these more general observations the Court continued with the actual individual assessment of the benefit under consideration and determined which factors of the benefit schemes were decisive for the (non-)application of Regulation No $1408 / 71$ to the benefit under consideration.

${ }^{27}$ Case 9/78 Gillard [1978] ECR 1661 at 12 and Case 139/82 Piscitello [1983] ECR 1471 at 10 .

${ }^{28}$ Case 1/72 Frilli [1972] ECR 457 at 18 and Case 139/82 Piscitello [1983] ECR 1471 at 11 .

${ }^{29}$ Case 249/83 Hoeckx [1985] ECR 982 at 12 and Case 122/84 Scrivner [1985] ECR 1029 at 19. It was not relevant whether a mixed benefit was granted as a supplement to another social security benefit or whether it was the sole source of income of the recipient Case 139/82 Piscitello [1983] ECR 1471 at 13. In Newton (1991) the Court seemed to add a third criterion which implied that a benefit only falls within the scope of the Regulation when the recipient has been subject to the social security system of the State under whose legislation the benefit is made available. Case C-356/89 Newton [1991] ECR I-3017 at 19. In most other cases, however, the Court did not apply this criterion. More recently, this requirement seems to have lost its meaning altogether. See Case C-20/96 Snares [1997] ECR I-6057 at 50 and footnote 33 below. 
Court's view, the Dutch law in question provided a legally defined criterion which gave entitlement to the benefit without the competent authority being able to take other personal circumstances into consideration. The grant of the IOAW benefit did not depend on an individual assesment of the claimant's personal needs and since the benefit was directly related to the risk of unemployment, it was classed as an unemployment benefit for purposes of the Regulation. ${ }^{30}$ The case law of the Court has now largely ${ }^{31}$ been codified. In $1992^{32}$ a new Article $4(2) \mathrm{a}^{33}$ was inserted which explicitly states that mixed or non-contributory benefits fall within the scope of the Regulation. In sum, mixed benefits fall within the Regulation, ${ }^{34}$ but the classic social assistance benefits are still excluded by virtue of Article 4(4).

\section{Economic Residents}

Having put the subject of this chapter in its proper context, the discussion can now proceed with an analysis of the Community rules and principles governing the cross-border access to minimum subsistence benefit schemes. For purposes of this book four categories have been identified: economic residents, non-economic residents, non-residents and third country nationals. ${ }^{35}$ This third section discusses the category of the economic residents, and the Community workers and their family members in particular. $^{36}$

\footnotetext{
${ }^{30}$ Case C-66/92 Acciardi [1993] ECR I-4567 at 15-19.

${ }^{31}$ The requirement laid down in Newton (1993) that the recipient must have been subject to the social security system of the State concerned (see footnote 26 above) has not been taken up by the Community legislator when it adopted Regulation No 1247/92. See Verschueren (1996) supra footnote 23, at p.99.

${ }^{32}$ Regulation No 1247/92. OJ 1992 No L 136. On the background of this Regulation see Section 5 of the present Chapter.

${ }^{33}$ The provision states that the Regulation applies to "special non-contributory benefits which are provided under legislation other than that covered by paragraph 1 , where such benefits: a) function as supplements or as substitutes upon the materialisation of any of the risks covered by branches of social security referred to in paragraph 1 ..; or b) are intended solely for the protection of the disabled".

${ }^{34}$ Lyon-Caen (1995) supra footnote 20, at p.54.

${ }^{35}$ See Chapter 2 Sections 2 up to 5.

${ }^{36}$ The category of economic residents also covers the self-employed beneficiaries of the right of establishment and their family members. The rights of beneficiaries of Article $43 \mathrm{EC}$ concerning movement to and eligibility for minimum subsistence benefits in other Member Statcs will not be discussed separately. The basic assumption is that the sclf-cmployed and
} 


\subsection{Community Workers}

When the Community institutions realised the free movement of workers during the 1960s, they had not considered granting workers a right to claim minimum subsistence benefits in the State of employment. In their view, workers were supposed to provide for themselves with the income earned from full-time employment. National rules governing minimum wages would guarantee that workers did not fall below the minimum subsistence level in the host State and in case they were unable to work due to illness, incapacity or retirement, the Community's social security rules would entitle workers to a wage-replacing social security benefit. Rights concerning minimum subsistence benefits were not provided for. Regulation No 1612/68 does not contain any provision specifically dealing with social assistance and other minimum subsistence benefits and, as noted, Article 4(4) of the Regulation No 1408/71 explicitly excludes social assistance benefits from the scope of this regulation. From the early 1970 s, however, the Court of Justice has braodly interpreted the provisions on the free movement of workers. The Court has extended the scope of the right to equal treatment and it has recognised that Article 39 EC can also be relied upon by work-seekers, part-time workers and other "flexible" workers whose income may fall below the minimum subsistence level. Are such "needy" Community citizens entitled to claim social assistance or mixed benefits in the Member State where they (seek) work?

\subsubsection{Right to Reside}

Before considering whether Community citizens have the right to claim minimum subsistence benefits in the State of employment, it is necessary to determine whether being in need of such benefits affects their right to establish residence in that State. ${ }^{37}$ Can Community citizens who have

their family members enjoy the same rights as workers and their family members do. See further Chapter 2 Section 2.4.

${ }^{37}$ The right to enter the territory of another Member State is not affected by being in need of minimum subsistence benefits. This right is only subject to the public policy proviso and it is settled case law that Member States cannot rely on this proviso for economic ends. See further Chapter 2 Section 7.2. In Case 36/85 Bonincontro the Court was asked whether being in need of social assistance benefits could possibly be regarded as a threat to public policy and thus be a reason to refuse residence or to expel a national of another Member State on the basis of Article 39(3). See OJ 1985 C 59. The case, however, was withdrawn. 
found and taken up employment but whose remuneration falls below the minimum subsistence level, acquire the status of worker and the right to reside in the State of employment? The issue arose in Levin (1982). ${ }^{38}$ The case concerned a British national who wished to reside with her South African husband in the Netherlands. The application for a residence permit was rejected on the ground that Ms Levin was not engaged in gainful occupation in the Netherlands. She appealed the decision. During the course of the proceedings she accepted a 20 hour-a-week job as a cleaning lady. The income she derived from this job fell below the minimum subsistence level. Ms Levin claimed that this could be no reason to withhold the requested residence card because she and her husband had property and income enough to support themselves. Before the Court of Justice, the Dutch government argued that persons such as Ms Levin who only work for a limited number of hours, who earn less than the host State's mimimum subsistence level and who move to other States lacking the primary intent of working, cannot claim to be Community workers and acquire the right to reside. The Court rejected the arguments of the Dutch government. The concept of Community worker should not be determined by reference to national rules on mimimum working hours, wages or subsistence levels. Rather, the concept should be clarified within the Community legal order. ${ }^{39}$ The Court held that parttime work can be an effective means to improve a person's living conditions. The concept of worker may therefore also apply to "persons who

Most probably, the Court would have answered the question in the negative. See Verschueren, Internationale Arbeidsmigratie (1990) at p.393, footnote 86 and Hailbronner, Aufenthaltbeschränkungen gegenüber EG-Angehörigen und neuere Entwicklungen im EG-Aufenthaltsrecht, in: ZAR (1985) pp.108-116, at pp.112-113. On this point see further Schulz, Freizügigkeit für Unionsbürger (1997) at pp.305-307.

Further, the right to stay of Community citizens who wish to seek work in other Member States cannot be refused or ended on the ground that beneficiaries are not able to provide for themselves. In 1968 the Member States included in the minutes of the meeting at which Regulation No 1612 was adopted a declaration which stipulated that in case Community citizens should "be taken charge of by national assistance (social welfare)" in the State where they seek work, they could "be invited to leave the territory of this ... State". See Chapter 2 Section 2.2.1. In Antonissen (1991), however, the Court held that the declaration had no legal significance. Case C-292/89 Antonissen [1991] ECR I-745 at 18. Hence, the declaration does not entitle the host States to end the stay of work-seekers on the ground that that they are in need of minimum subsistence benefits. There also does not seem to be any sound reason for limiting the right to stay of work-seekers on the ground that they lack sufficient financial means. Work-seekers can be denied minimum subsistence benefits in the State where they seek work. See supra footnote 163.

${ }^{38}$ Case 53/81 Levin [1982] ECR 1035.

39. Ibid, at 11 
pursue or wish to pursue an activity as an employed person on a part-time basis only and who, by virtue of that fact obtain or would obtain only remuneration lower than the minimum wage guaranteed in the sector under consideration". ${ }^{40}$ The income can be supplemented by private resources or by the earnings of an accompanying family member ${ }^{41}$. The purpose of the movement to another Member State was considered to be immaterial. $^{42}$

From a social assistance perspective, Levin was not yet so controversial. Apparently, the Levins had sufficient financial means; they did not ask for, and were not likely to become in need of, social assistance. However, the judgment did raise the question whether the right to reside of a Community worker could also be obtained by part-time workers who have no other sources of income and who are in need of social assistance benefits. The question was put to the Court in $\operatorname{Kempf}(1985) .^{43}$ The case involved a German music teacher who for twelve hours a week taught guitar lessons in the Netherlands. His application for a residence card was rejected on the ground that he had obtained supplementary social assistance(-like) benefits. Was the refusal to grant him the residence card compatible with Article 39 EC? The Court concluded that the fact that social asisstance benefits are enjoyed can be no reason for denying the status of Community worker because it "is irrelevant whether .. supplementary means of subsistence are derived from property or from the employment of a member of his family .. or whether .. they are obtained from financial assistance drawn from .. public funds" of the host State. ${ }^{44}$

\subsubsection{Right to Claim Minimum Subsistence Benefits}

Thus, being in need of social assistance or other minimum subsistence benefits does not affect the right to establish residence as a Community worker in the State of employment. Neither in Levin nor in Kempf,

\footnotetext{
${ }^{40}$ Ibid, at 16 .

Ibid.

${ }^{42}$ The immigration rights of Article $39 \mathrm{EC}$ are granted in order to facilitate the right to work in other Member States. Following some suggestions that had been made in the literature (e.g. Hartley, EEC Immigration Law (1978) at pp.4-5), Advocate General Slynn concluded that the rights to enter and reside in another Member States are conditional on it being shown that the work in another Member State is the genuine and substantial purpose of Community citizens exercising these rights. The Court, however, rejected this view. Case 53/81 Levin [1982] ECR 1035 at 22.

${ }^{43}$ Case 139/85 Kempf [1986] ECR 1741.

${ }^{44}$ Ibid, at 14.
} 
however, did the Court go into the question whether workers who have established residence in the State of employment ${ }^{45}$ can also claim minimum subsistence benefits there. A few months before the judgment in Kempf, however, the Court had already addressed the issue in Hoeckx (1985). ${ }^{46}$ Ms Hoeckx was a Dutch national who had claimed a minimum subsistence allowance in Belgium. The allowance (the so-called minimex) was refused because Ms Hoeckx had not lived in Belgium for five years prior to her application. The first question the Court of Justice had to answer was whether the minimex fell within the scope of Regulation No 1408/71. An affirmative answer would have implied that Ms Hoeckx could have invoked Article 3 of the Regulation in order to challenge the durational residence requirement. The Court held, however, that the benefit was not covered by the Regulation. The law governing the minimex did confer upon recipients of the allowance a legally defined position, but the benefit was in the view of the Court not linked to one of the risks mentioned in Article 4(1) of the Regulation. ${ }^{47}$ In other words, the minimex was regarded as a general social assistance benefit which by virtue of Article 4(4) is excluded from Regulation No 1408/71. ${ }^{48}$ This conclusion, however, did not mean that Ms Hoeckx lost her case. The Court held that she could invoke Article 7(2) of Regulation No 1612/68 which provides for a right to equal treatment as regards "social advantages". The Court reiterated that social advantages are all those advantages or benefits "which, whether or not linked to a contract of employment, are generally granted to national workers primarily because of their objective status of workers or by virtue of the mere fact of their residence on the national territory". The Court concluded that benefits guaranteeing a minimum means of subsistence "in a general manner" constitute social advantages for purposes of Article 7(2) of Regulation No 1612/68. ${ }^{49}$

Thus, Community workers who wish to claim access to general

\footnotetext{
${ }^{45}$ On the question whether workers who have decided not to establish residence in the State of employment can claim minimum subsistence benefits there, see Section 5 .

${ }^{46}$ Case 249/83 Hoeckx [1985] ECR 982.

${ }^{47}$ Ibid, at 13-15.

${ }^{48}$ Only mixed minimum subistence benefits which are linked to one of the risks referred to in Article 4(1) can fall under Regulation No 1408/71. See e.g. Case 1/72 Frilli [1972] ECR 457 (guaranteed income for old people) and Case 187/73 Callemeyn [1974] ECR 553 (benefits for disabled persons).

${ }^{49}$ Case 249/83 Hoeckx [1985] ECR 982 at 20-22. For a similar conclusion see Case 122/84 Scrivner [1985] ECR 1029 at 26. See further also the judgment in Reina where the Court held that the concept of "social advantages" covers "not only benefits granted as of right" but also rights offered "on a discretionary basis". Case 65/81 Reina [1982] ECR 33 at 17.
} 
social assistance schemes may rely on Article 7(2) of Regulation No $1612 / 68$ and they can as regards mixed benefits, alongside this provision, ${ }^{50}$ invoke Article 3 of Regulation No 1408/71. The mere fact that "needy" Community workers can invoke these provisions does not automatically imply that they will actually receive minimum subsistance benefits. The two Articles provide for a right to equal treatment which implies that Community workers must in principle meet the same eligibility requirements as the nationals of the host State. Thus, in order to receive a benefit Community workers must be available for (full-time) work, lack other sources of income, etc. As a rule, such eligibility criteria do not violate the non-discrimination principle. Yet, does the same hold true for national rules which make the enjoyment of benefits conditional upon a minimum period of residence in the State of employment? Read together, Kempf and Hoeckx would seem to have increased the magnetic effect of the benefit schemes of the "richer" Member States and it has been argued that (such) Member States should be entitled to apply durational residence requirements in order to protect themselves against "social tourism". ${ }^{51}$ The Court, however, has not accepted the validity of such requirements. As noted, in Hoeckx the Court had to answer whether a five year residence requirement for the Belgian minimex which only applied to non-nationals was compatible with Article 7(2) of Regulation No 1612/68. The Court concluded that such a requirement implies "an additional condition imposed on workers who are nationals of a Member State" which constitutes a direct discrimination on the basis of the nationality of the workers. ${ }^{52}$ In response to the judgment in Hoeckx, ${ }^{53}$ the Belgian legislator decided to delete the nationality requirement and to impose the rule that all persons regardless of their nationality had to meet the five year residency requirement. In the view of the European Commission the Belgian rules were still contrary to Article 7(2) and the Commission subsequently started an infringement procedure (Article 169 (now 226) of the Treaty). In Commission v Belgium (1992) the Court

\footnotetext{
${ }^{50}$ The social security benefits covered by the Regulation can in principle also be classed as "social advantages" for purposes of Article 7(2) of Regulation No 1612/68. See further Chapter 2 Section 6 (footnote 219).

${ }^{11}$ Compare e.g. Steiner, The Right to Welfare: Equality and Equity under Community Law, in: ELRev (1987) pp.477 et seq, at p.41 and Hailbronner, Die neuere Rechtsprechung zum EG-Freizügigkeitsrecht, in: ZAR (1988) pp.3-13, at p.6.

${ }_{52}$ Case 249/83 Hoeckx [1985] ECR 982 at 23-24.

${ }^{53}$ See Van den Bogaert, The Consequences of the Gaygusuz Judgement for Belgian Social Security, in: Van den Bogaert (Ed.), Social Security, Non-Discrimination and Property (1997) pp.123-148, at p.141.
} 
concluded that the waiting-period requirement worked to the disadvantage of nationals from other Member States. The requirement constituted an indirect discrimination on grounds of nationality and held to be at odds with both Article 7(2) of Regulation No 1612/68 and Article 3 of Regulation No $1408 / 71 .^{54}$ Thus, Member States are not entitled to make eligibility for minimum subsistence benefits conditional upon the fulfillment of durational residence or employment requirements. ${ }^{55}$

\subsection{3 "Effective and Genuine Work"}

Community workers who earn less than the minimum subsistence level in the State of employment are entitled to establish residence there and, from the moment they actually do so, they are entitled to supplement their income with minimum subistence benefits under the same conditions as the nationals of the host State. This does not imply, however, that the Court has disregarded Member States' concerns regarding "social tourism". On the contrary, due regard has been given to these concerns. The Court has not done so by accepting the legality of durational residence requirements for entitlement to minimum subsistence benefits, by entitling Member States to refuse needy workers residence on public policy grounds $^{56}$ or by allowing the States to deny benefits to workers whose primary intent for moving is to obtain comparatively high benefits. ${ }^{57}$ Rather, the Court has given regard to the host States' interests in its interpretation of the concept of Community worker. As noted in Section 3.1.1, in Levin and Kempf the Court was willing to give quite a broad interpretation to the concept by accepting that part-time workers who might be in need of minimum subsistence benefits can also obtain the status of Community worker. However, not all part-time workers can do so. In Levin the Court held that a minimum amount of work must be performed. The work must be "effective and genuine". Activities which are on such a small scale that they have to be regarded as purely "marginal and ancillary" do not suffice. ${ }^{58}$ The Court has never indicated how many hours must be worked, but from the case law the conclusion could be drawn that a Community citizen must work approximately half of the number of

\footnotetext{
${ }^{54}$ Case C-326/90 Commission v Belgium [1992] ECR I-5517 at 2-3.

${ }^{55}$ This is not to say that the length of residence in the State is in all circumstances an irrelevant factor. See further Section 6 .

${ }^{56}$ See footnote 37 above.

${ }^{57}$ Case 53/81 Levin [1982] ECR 1035 at 21

${ }^{58}$ See Casc 53/81 Levin [1982] ECR 1035 at 17.
} 
normal working hours in a given sector in order to obtain the status of worker and the connected right to equal treatment as regards minimum subsistence benefits. ${ }^{59}$ One cannot be certain of the Court's true motives ${ }^{60}$ but by introducing the criterion of "effective and genuine work" the Court did establish a threshold for Community citizens who through the pursuit of a very small number of hours, would try to obtain the status of Community worker, the right to reside and the right to claim social advantages under Article 7(2) of Regulation No 1612/68.

\subsubsection{Loss of Employment}

So far the Court has never indicated whether Member States must also grant minimum subsistence benefits to nationals of other Member States who have acquired the status of Community worker but later lost their job. ${ }^{61}$ If unemployed workers could indeed claim such benefits, ${ }^{62}$ the status of Community worker could possibly be open to abuse. Community citizens who wish to obtain social assistance benefits in another Member State could take up employment there, then give up their job and subsequently, as Community workers, claim the desired benefits under Article

\footnotetext{
${ }^{59}$ See Jørgensen, Union Citizens - Free Movement and Non-Discrimination (1996) at p.31 and Chapter 2 Section 2.2.4.

${ }^{60}$ It would seem, however, that the Court has indeed deliberately chosen to give regard to the Member States' welfare state interests through the interpretation of the notion of worker. The concept of worker may not be defined by reference to national law (Case 53/81 Levin [1982] ECR 1035 at 11), but the three requirements of work, remuneration and subordination which the Court has laid down (Case 66/85 Lawrie Blum [1986] ECR I-2121 at 17 - see Chapter 2 Section 2.2.4) do indicate that the Court itself has been inspired by national definitions of the concept of worker. The requirement that the work must also be "effective and genuine", at least to the knowledge of the present author, cannot be found in the labour laws of any of the Member States. The work performed by Community citizens whose jobs are according to the Court to be considered as "marginal and ancillary" may often very well be classed as economic activities and indeed part-time workers are, as a rule, seen and treated as workers under national labour laws. The new and unique requirement that work must be "effective and genuine" for the purposes of Article $39 \mathrm{EC}$ has been introduced by the Court itself; it is hard to find any other explanation than that this was done in defence of the welfare state interests of the Member States.

${ }^{61}$ The same question could be raised as regards Community citizens who have accepted an "effective and genuine" job but whose working hours later decrease to reach a level at which work must be regarded as "marginal and ancillary".

${ }^{62}$ Unemployed workers may become entitled to unemployment benefit, but this is not necessarily the case. Workers may not have worked long enough to become eligible for unemployment benefits or they may, after temporary enjoyment of such benefits, become in nced of minimum subsistence benefits.
} 
7(2). From existing case law, it does not become entirely clear whether, and if so, under which conditions unemployed workers can obtain, or retain, minimum subsistence benefits. In Martinez Sala (1998) the Court held that once "the employment relationship has ended, the person concerned as a rule loses his status of worker", and this would seem to imply that the right to invoke Article 7(2) of Regulation No 1612/68 ceases to exist. ${ }^{63}$ However, the Court rather cryptically added that the status of worker "may produce effects after the relationship has ended". ${ }^{64}$ The Court has never fully explained what these effects entail, but the afore cited phrase could best be interpreted to mean that the status of worker and the right to invoke Article 7(2) can be kept as long as the person concerned still holds the right to reside in the host State as guaranteed by Article 39 EC. $^{65}$ Article 7(1) of Directive No 68/360 indicates that voluntary unemployment leads to the loss of the right to reside and, arguably, the right to equal treatment as regards social advantages. ${ }^{66}$ The

${ }^{63}$ To be sure, this may be different for workers who acquire the so-called right to remain. See Article 7 of Regulation No 1251/70 and Chapter 2 Section 2.2.4.

${ }^{64}$ Case C-85/96 Martinez Sala [1998] ECR I-2691 at 32.

${ }^{65}$ See Chapter 2 Section 2.2 .

${ }^{66}$ See Article 7 of Directive No 68/360 and Chapter 2 Section 2.2. To be sure, this does not necessarily imply that the voluntarily unemployed can never claim minimum subsistence benefits. They may be able to do so in their capacity as "non-economic resident". See further Section 4. The legal situation may be different for those who voluntarily give up their job in order to commence studying. Such student-workers can retain the status of worker, and thus rely on Article 7(2) of Regulation No 1612/68, if there is "some continuity between the previous occupational activity and the course of the study; there must be a relationship between the purpose of the study and the previous occuptional activity". Case 39/86 Lair [1988] ECR 3161 at 37. See further Chapter 5 Section 3.2.3. Consider, however, Grzelczyk, a case currently still pending before the Court. The case concerns a French student who was studying sports at the University of Louvain, Belgium. During the first three years of his studies Mr Grzelczyk was able to provide for himself by the income earned from various small jobs. In the fourth and final year, however, he was no longer able to combine his studies and employment. Since his parents were not able to maintain him, Mr Grzelczyk applied for a social assistance benefit in Belgium. His application was rejected on the ground that social assistance benefits could only be awarded to Belgian nationals and Community citizens falling within the ambit of Regulation No 1612/68. The national court which has to decide the case asked the Court of Justice, inter alia, whether denying Mr Grzelczyk the requested benefit is compatible with Articles 12 and 18 EC. In his Opinion of 28 September 2000 Advocate General Alber took the view, however, that it was necessary to consider whether a student such as Mr Grzelczyk could (still) be classed as a worker in the sense of Article 39 EC. The Advocate General did not have much difficulty in concluding that $\mathrm{Mr}$ Grzelczyk had obtained the status of worker and the accompanying right to reside by the work he had performed during the first three years of his studies. Case C-184/99 Grzelczyk (http://www.curia.eu.int/jurisp) at 65-75. Yet, can Mr Grzelczyk still be regarded as a worker now that he has voluntarily given up employment? Albcr statcs that the loss of employment 
danger of abuse of the status of worker thus seems minimal. Involuntary unemployment does not lead to the loss of the right to reside. This right continues for as long as the period for which the residence card was issued has not expired. ${ }^{67}$ Arguably, during this period the involuntarily unemployed retain the status of Community worker and the right to claim equal treatment as regards minimum subsistence benefits under Article 7(2) of Regulation No 1612/68. ${ }^{68}$

\subsection{Family Members}

The drafters of Regulation No 1612/68 recognised that a free movement of workers that os practical and relevant could not be realised without giving workers the right to be joined by their family members. Article 10 of the regulation entitles the workers' spouse, (grand)children who are under the age of 21 years or dependent and the dependent (grand)parents to install themselves with the worker in the host State. ${ }^{69}$ The question whether these family members could possibly claim minimum subsistence benefits in the host State did not seem to arise. Workers were supposed to be full-time workers who would provide for themselves and their families. Family members were assumed to be dependent on the worker, not on the

in principle leads to the loss of the status of worker, but (under reference to Martínez Sala Case C-85/96 [1998] ECR I-2691 at 32) he concluded that the status of worker may produce some effects after the employment relationship has ended. One of these effects is that the status of worker and the right to invoke Article 7(2) of Regulation No 1612/68 can be retained when a worker gives up employment in order to commence study which is substantially related to the nature of the last performed work. From the information given by the national court it did not become clear whether Mr Grzelczyk satisfies this requirement of a link between his work and his studies. Advocate General Alber, however, did not deem this to be decisive. Lair concerned a Community citizen who first worked and subsequently embarked on a study. As regards such students a link between the work and the studies is to be established in order to avoid students claiming rights which are reserved for workers. The case of Mr Grzelczyk, however, was different because he had been working and studying at the same time. Alber did not consider it necessary to insist on a link between studies and work in such a case. Case C-184/99 Grzelczyk (http://www.curia.eu.int/jurisp) at 98-101.

${ }^{67}$ See Chapter 2 Section 2.2.4.

${ }^{68}$ Even if one were to assume that such involuntarily unemployed persons are no longer to be regarded as Community workers, they would still be entitled to equality of treatment as regards minimum subsistence benefits. Such unemployed persons would still be "nationals of the Member States legally residing in another Member State" who are, as follows from the judgment in Martinez Sala, entitled to claim access to minimum subsistence benefit schemes under Article 12 EC. See further Chapter 2 Section 3 and Section 4 of this chapter.

${ }^{69}$ For further details see Chapter 2 Scction 2.3 . 
host State. Yet, over the years the Court has strengthened the legal status of family members of Community workers. In doing so, the Court has been inspired by the preamble of Regulation No 1612/68 according to which the free movement of workers requires the abolition of all obstacles to the integration of the worker's family into the host State's society. Does this imply that family members in need of minimum subsistence benefits have the right to claim such benefits in that State?

\subsubsection{Right to Reside}

As in the case of Community workers themselves, it is first to be established whether being in need of minimum subsistence benefits possibly affects the right of family members to reside in the host State. As regards the spouse and (grand)children below the age of 21 years no problems arise. Article 10 of Regulation No 1612/68 makes the right to reside in the host State only conditional upon the availability of adequate housing. ${ }^{70}$ As regards (grand)children of 21 years or older and (grand)parents, the situation is less clear. Article 10 does not contain a financial means requirement comparable to those contained in the three 1990 residence directives applying to non-economic residents, ${ }^{71}$ but the provision does require that the family members concerned are dependent on the worker. What does this imply? Do family members who have been working in the State of origin but are still living with the worker not have the right to join the worker into the State of employment? Do children who have already left their parents' house and obtained social assistance(like) benefits in the State of origin, have the right to join the worker? Do children who (as a minor) have acquired the right to reside, loose this right when they apply after their 21 st birthday for social assistance(-like) benefits? Can the requirement of being dependent on the worker be met by family members who are dependent on minimum subsistence benefits?

In order to answer such questions Lebon $(1987)^{72}$ is to be considered. Ms Lebon was a 24 year old French woman who had lived almost her entire life in Belgium and who claimed equality of treatment as regards eligibility for social assistance benefits (the so-called minimex) as

\footnotetext{
${ }^{70}$ See Article 10(3) of Regulation No 1612/68.

${ }^{71}$ See Chapter 2 Sections 3.1 and 3.2.

${ }^{72}$ Case 316/85 Lebon [1987] ECR 2811
} 
a family member of a Community worker ${ }^{73}$. Her claim was refused and Ms Lebon subsequently appealed that decision. At first glance, Ms Lebon seemed to have a strong case. In earlier judgments the Court had already concluded that minimum subsistence benefits constitute "social advantages" for the purposes of Article 7(2) of Regulation No 1612/68 ${ }^{74}$ and that family members may also rely on this provision. ${ }^{75}$ For instance, in Castelli (1984) the Court had had no difficulty in concluding that the mother of an Italian worker in Belgium could rely on Article 7(2) in order to claim a non-contributory income benefit intended to provide old people with the minimum means for subsistence. ${ }^{76}$ In the proceedings before the Court in Lebon, however, the Dutch government had argued that family members of workers who have reached the age of majority and who are not dependent on the worker do not have the right to reside in the State of employment under Article 10 of Regulation No 1612/68. For this reason they would not be entitled to claim benefits under Article $7(2)$ either. The Court did not agree. If this line of reasoning were accepted, family members in need of social assistance could loose their status of family member and even their right to reside. In practice it would be impossible for such family members to claim social assistance benefits and this would seriously undermine the right to equal treatment granted to Community workers. The status of dependent family members is to be considered independently of the claim for or the grant of benefits such as the minimex. ${ }^{77}$ That status, the Court stated, is held by family members who are factually supported by the worker. ${ }^{78}$

\footnotetext{
${ }^{73}$ Ms Lebon's parents had exercised their right to remain in accordance with Article 39(3)d EC and Regulation No 1251/70. The legal status of the beneficiaries of this right to remain in the host State is identical to that of Community workers and their family members and for the purposes of this study these beneficiaries are treated as though they were still holding the status of Community worker or family member of Community worker. See further Chapter 2 Sections 2.2. and 2.3.

${ }^{74}$ Case 249/83 Hoeckx [1985] ECR 982 at 20-22.

${ }^{75}$ See e.g. Case 261/83 Castelli [1984] ECR 3199 at 9-10 and Case 94/84 Deak [1985] ECR 1873 at 26.

${ }^{76}$ Case 261/83 Castelli [1984] ECR 3199 at 9-10.

${ }^{77}$ Case 316/85 Lebon [1987] ECR 2811 at 20.

${ }^{78}$ The Court rejected the view that family members can only be regarded as dependants in cases where national law confers upon family members a right to maintenance on the part of the worker. If that were the case "the composition of the family would depend on national legislation, which varies from one State to another", and that "would lead to the application of Community law in a manner that is not uniform". The status of dependent family member of a worker is the result of a factual situation and applies to family members who are supported by the worker without there being a need to determine the reasons for recourse to the worker's support or to raise the question whether the person concerned is able to support
} 


\subsubsection{Right to Claim Minimum Subsistence Benefits}

The fact that being in need of minimum subsistence benefits cannot affect the right to reside does not necessarily imply that family members can also claim such benefits in the host State. The above mentioned argument of the Netherlands government in Lebon was financially motivated. If all family members who have acquired the right to reside in the State of employment could rely on Article 7(2) of Regulation No 1612/68, the pressure on the budget out of which minimum subsistence benefits are funded would increase. The German government had even warned of situations in which workers, by temporarily giving financial support, would enable family members to obtain the right to reside in the host State and to claim upon arrival social assistance under Article 7(2). The status of family member could possibly be open to abuse if family members could rely on both Article 10 and Article 7(2) of the Regulation. The Court appeared sensitive to these concerns. In Lebon the Court confirmed that family members may rely on Article $7(2)$, but it now specified earlier judgments such as Castelli in ruling that family members can only indirectly benefit from this provision. Benefits only qualify as "social advantages" if, and in as far as, they may be regarded as social advantages for the worker himself. This implied, according to the Court, that family members such as Ms Lebon who are 21 years or older and who are no longer dependent on the Community worker, cannot claim equal treatment as regards social assistance benefits under Article 7(2). As regards such family members, the benefits do not constitute a social advantage in the sense of Article 7(2) for the worker. ${ }^{79}$

Lebon implied a compromise. On the one hand, the Court promoted freedom of movement by holding that dependence on minimum subsistence benefits cannot in itself affect the right of family members to reside in the host State. On the other hand, the Court had regard to the financial interests of the host States by stipulating that reliance on Article $7(2)$ is preserved for family members who are dependent on, i.e. actually supported by, ${ }^{80}$ the worker. As a result, family members do not seem to

\footnotetext{
himself by taking up employment. Case 316/85 Lebon [1987] ECR 2811 at 21-22.

${ }^{79}$ Case 316/85 Lebon [1987] ECR 2811 at 13. See also Case C-185/96 Commission v Greece [1998] ECR I-1095 at 21.

${ }^{80}$ The Court did not clarify what the workers' support should consist of. It would seem, however, that this support has to be valuable in financial terms. Otherwise, and if for instance "moral support" would suffice, the requirement of dependence in terms of Article $7(2)$ would have little practical significance. Compare also Bernini where the Court held that benefits can only be regarded as social advantages for workers when they continue to
} 
have a right to claim minimum subsistence benefits in their own right. Independent family members have no right to equal treatment under Article $7(2)$. Dependent family members can rely on this provision, but as members of the workers' family they will often be unable to claim benefits in their own right under national law. What the Court implicitly seems to have said is that family members can reside in the State of employment, but that they either have to provide for themselves or have to be taken care of by the workers. ${ }^{81}$

Lebon, and the exclusion of independent family members from Article $7(2)$ in particular, was problematic however. Safeguarding the financial stability of minimum subsistence benefit schemes is a legitimate interest which deserves protection under Community law, but the requirement of being dependent on the worker seems unnecessarily strict. Why would a child who was born in the host State and has separated from the parent-worker, be denied the right to claim social assistance benefits under the same conditions as nationals of the host State? Why should family members who have lived in the host State for a long period of time and who have socially and culturally integrated in the host State, have to remain dependent on the worker? Denial of the right to rely on this provision is hard to compare with the objectives of promoting freedom of movement and the integration of the workers' family in the host State. From the perspective of avoiding abuse, the requirement was overly inclusive. The recent judgment in Martinez Sala (1998) suggests

support the family member. Case C-3/90 Bernini [1992] ECR I-1071 at 25.

${ }^{81}$ The possibility for dependent family members of relying on Article 7(2) of Regulation No 1612/68 was until recently particularly relevant as regards social security benefits. In Kermaschek the Court had ruled that family members enjoy only derived rights (i.e. rights which are under national law specifically offered to, or for, family members such as family allowances and co-insurance for health care) under Regulation No 1408/71 to the exclusion of "personal rights" (i.e. rights which are granted to beneficiaries in their capacity as workers, residents or nationals). The latter were under the regime of Regulation No 1408/71 preserved for the (self-)employed. Case 40/76 Kermaschek [1976] ECR 1669 at 7. In Schmid (1993), for instance, the Court held that a German national could not rely on Article 3 in Belgium in order to claim a disability benefit on behalf of his dependent daughter because the benefit did not constitute a derived right. The Court ruled, however, that Article 7(2) could be relied upon. Case C-310/91 Schmid [1993] ECR 1-3011 at 12-14. More recently, however, the Kermascheck-rule has been limited in Cabanis-Issarte (Case C-87/94 [1996] ECR I-2097 - see Chapter 2 Section 6). The judgment suggests that independent family members can now claim equal treatment as regards mixed minimum subsistence benefits with the exception of those which are linked to the risk of unemployment, industrial accident and occupational diseases. Compare Peers, Equality, Free Movement and Social Security, in: ELRcv (1997) pp.342-351, at p.347. 
that the Court ${ }^{82}$ has recognised the point and that it has, or is willing to, move away from Lebon. The case will be discussed in further detail in the next section, but it may be already be pointed out that the Court ruled in Martínez Sala that $(i)$ all rights or benefits falling within the scope of Regulation No 1408/71 and Article 7(2) of Regulation No 1612/68 "indisputably" fall within the material scope of Article $12 \mathrm{EC}^{83}$ and (ii) that nationals of the Member States lawfully residing in the territory of another Member State can, as persons falling within the personal scope of the Treaty, rely on this provision. ${ }^{84}$ No certainty exists, but Martinez Sala does suggest that independent family members who hold the nationality of a Member State ${ }^{85}$ and who have installed themselves with the worker in the State of employment, are entitled to rely on Article 12(1) $\mathrm{EC}$ in order to claim access to minimum subsistence benefits under the same conditions as the nationals of the host State.

The mere fact that dependent family members enjoy the right to equal treatment as regards all minimum subsistence benefits does not yet imply that they will actually be able to receive minimum subsistence benefits. Family members must in principle meet the same conditions as the nationals ${ }^{86}$ of the host State in order to become entitled to obtain

${ }^{82}$ The Commission has already taken the initiative to repair Lebon by proposing to confer upon all family members an independent right to equal treatment as regards social advantages. The proposed new Article 10(3) of Regulation No 1612/68 reads: "Members of the family entitled to live in a Member State under the terms of paragraphs 1 and 2 shall be entitled to all financial, tax, social, cultural or other advantages available to nationals". COM(1998) 394 def.

${ }^{83}$ Case C-85/96 Martínez Sala [1998] ECR I-2691 at 57.

${ }^{84}$ Ibid., at 60-61. Compare Fries/Shaw, Citizenship of the Union: First Steps in the European Court of Justice, in: EPL (1998) pp.533-559, at p.536 as well as pp.550-554.

${ }^{85}$ It is not certain whether independent family members who lack the nationality of one of the Member States can rely on Article 12(1) EC. Compare More, The Principle of Equal Treatment: From Market Unifier to Fundamental Right?, in: Craig/de Búrca (Eds), The Evolution of EU Law (1999) pp.517-551, at p.540. It is submitted, however, that family members that have been admitted for residence by virtue of Article 10(1) of Regulation No 1612/68 can rely on Article 12(1) EC. In Martínez Sala the Court only spoke of Union citizens lawfully residing in the territory of another Member State, but it seems indisputable that third country family members who have made use of the right to reside guaranteed by Article 10(1) fall within the personal scope of Community law and, thus, Article 12(1) EC. It still seems doubtful, however, whether family members who have been admitted in the State of the workers' employment by virtue of Article 10(2) of Regulation No 1612/68 can, in their own right, claim equal treatment under Article 12(1).

${ }^{86}$ The question has arisen, however, whether family members are to be treated equally as the host State nationals or as the family members of the latter. Consider Taghavi (1992). The case concerned the Iranian wife of an Italian worker in Belgium who had applied for an invalidity allowance. The benefit was a mixed benefit which was awarded only to Belgian 
minimum subsistence benefits. However, as in the case of Community workers, the right of family members to claim such benefits cannot be made conditional upon a minimum period of residence in the State. In $\mathrm{Mr}$ and Mrs F. (1975) the Court was asked to determine whether the right to a benefit for disabled children could be preserved for nationals of the host

nationals residing in Belgium. On this ground, the application of Mrs Taghavi was rejected and she subsequently appealed the decision. The Belgian court asked the Court to determine whether the refusal to grant the allowance was compatible with Article 3 of Regulation No 1408/71. The Court concluded that Mrs Taghavi could not rely on this non-discrimination provision because the allowance could not be classed as a derived right. Case C-243/91 Taghavi [1992] ECR I-4401 at 8-9. The European Commission had argued, however, that persons as Mrs Taghavi could claim the benefits on the basis of Article 7(2) of Regulation No 1612/68. Invalidity benefits such as the one Mrs Taghavi can in principle be regarded as "social advantages" and Mrs Taghavi was dependent on her husband. The problem, however, was that the family members of Belgian nationals were under the Belgian law in question neither entitled to claim the invalidity benefits. The Court thus had to determine whether the third country family members should be treated equally with the nationals of the host State or with the third country family members of such nationals. In case it would accept that Mrs Taghavi would have to be treated equally with Belgian nationals, a reverse discrimination would occur. If the Court would deny persons as Mrs Taghavi the right to invoke Article $7(2)$ in such cases, it would accept a rule which may induce workers not to remain in the host State and which thus hampers the free movement of workers. Compare the Opinion of Advocate General van Gerven in Case C-243/91 Taghavi [1992] ECR I-4401, at p.4414. In Taghavi the Court chose for the former solution. Since the family members of Belgian nationals could not claim the allowance in question, there was no "social advantage" for nationals workers and Article 7(2) could therefore not apply. Case C-243/91 Taghavi [1992] ECR I-4401 at 11. On Taghavi see Verschueren, Het Arrest Taghavi en de Tegemoetkoming aan niet-EG-familieleden van EG-werknemers, in: MR (1993) pp.74-75.

Less than a year later, however, the Court seems to have come back from Taghavi in Schmid. The case concerned the refusal by Belgian authorities to grant a disability benefit to the daughter of a German national on the ground that she had never worked in Belgium and did not possess Belgian nationality. Under the Belgian law, also the non-Belgian family members of Belgian nationals could not claim the benefits in question. Ignoring Taghavi, the Court concluded in Schmid that any provision which makes entitlement to a social advantage conditional upon nationality is compatible with Article 7(2), even if it also applies to family members of national workers. Since such a criterion would be more easily fulfilled by the family members of national workers than by family members of workers from other Member States, the Court concluded that the refusal to grant the disability benefit was incompatible with Article 7(2). Case C-310/91 Schmid [1993] ECR I-3011 at 24-25.

The two judgments (which were delivered by different chambers of the Court) are at odds with each other and could could certainly need more clarification from the (full) Court. Compare Pennings, Introduction to European Social Security Law (1998) at pp.106107. Until the Court does so, it may be assumed that Schmid has "overruled" Taghavi and that the Court has sacrificed the objections against reverse discrimination for the goal of promoting a genuine free movement of workers. Compare the Opinion of Advocate General van Gerven in case C-243/91 Taghavi [1992] ECR I-4401 at 15-16 and Martin/Guild, Free Movement of Pcrsons (1996) at pp.139-140. 
State and non-nationals who have resided in the territory of that State for a minimum period of fifteen years. The Court answered the question within the terms of Regulation No 1408/71. It concluded, in rather general terms, that as regards such invalidity benefits neither the worker himself nor the members of his family may, as compared with the host State's nationals, be placed in a less favourable position simply because they do not posses the nationality of the State. ${ }^{87}$ The judgment in Mr and Mrs F. still leaves room for the conclusion that durational residence requirements for eligibility for minimum subsistence benefits which apply to nationals and non-nationals alike could survive judicial scrutiny, but by analogy with the judgment in Commission v Belgium (1992), discussed above in Section 3.1.3, one may assume that such requirements are alos invalid. Thus, family members have equal access to benefit schemes from the moment they establish residence in the host State. ${ }^{88}$

\footnotetext{
${ }^{87}$ Case 7/75 Mr and Mrs F. [1975] ECR 679 at 17.

${ }^{88}$ The rights discussed in this Section are conditional upon the status of family member of a Community citizen who has exercised his rights under Article $39 \mathrm{EC}$. Therefore, loss of the status of family member leads, in principle, to the loss of the right to reside and the right to claim minimum subsistence benefits. Two situations may be distinguished.

First, the family relationship itself may end. In practice, this will most often occur as a result of divorce. Where the marriage is dissolved by the competent authorities (see Case 267/83 Diatta [1985] ECR 567 at 20), the former spouse of the worker will have to place him- or herself in another category in order to retain residence and possibly claim minimum subsistence benefits. For spouses who hold the nationality of a Member State, this implies that they will have to obtain residence as (self-)employed person (Articles 39 and 43 EC) or as a "non-economic resident" (1990 residence directives). For spouses who merely hold the nationality of a third State, a divorce may have harsher implications. They have no right to claim residence in their own right. The Commission has recognised this and proposed to offer third country divorcees basically the same rights as Community citizens. Family members of workers who fall within the scope of Article 10(1) of Regulation No $1612 / 68$ but lack the nationality of a Member State, are proposed to be given the right to retain the right of residence if the marriage is dissolved on condition that they have lived in that country for a period of three consecutive years. In the proposed new Article 11 it is further stated that such family members retain the right to work when they have lived in the host State for a period of at least five consecutive years. See COM(1998) 394(01). The wording of the proposed provisions suggests that third country nationals whose marriage has been dissolved after more than three but less than five years of residence have no, or even loose the, right to work as an (self-)employed person. This, however, is not the case. In its proposal for amending Directive No 68/360 the Commission has included a new Article $4 \mathrm{a}$ which provides that in the event of dissolution of the marriage, Member States shall recognise the right of residence of family members who do not hold the nationality of one of the Member States, but who have lived in a Member States for three years and who are still pursuing economic activities on presentation of a contract or certificate of employment or a declaration of self-employment. See the proposed Article $4 \mathrm{a}(3)$ of Directive No $68 / 360$ (COM(1998) 394((02). Third country nationals who are not economically active must
} 


\subsection{Conclusions}

On the basis of the foregoing, one must conclude that Community law on cross-border access to minimum subsistence benefits has undergone significant changes since the 1950s and 1960s. In the view of the drafters of Article 39 EC and Regulation No 1612/68, Community citizens who were in need of social assistance(-like) benefits would not have a right to reside in other States and they would not enjoy equality of treatment as regards such benefits. Today, however, "needy" Community workers and their dependent family members have the right to reside in the State of employment. Moreover, from the moment they indeed establish residence in the State of employment, they are entitled to receive minimum subsistence benefits under the same conditions as the nationals of that State. Family members who are not dependent on the worker cannot claim a right to establish residence in the State where the worker is employed, but Martinez Sala suggests that when, and for as long as, they do lawfully reside there, they are entitled to claim equal access to minimum subsistence benefit schemes. The progress which has been made can be attributed to the Court of Justice which has sought to promote freedom of movement by broadly interpreting the concept of worker, Article 7(2) of Regulation No 1612/68 and Article 12 EC. The Court has not, however,

provide evidence that they have sufficient financial resources for themselves and their dependants and that they have health insurance cover. The provisions of Directive No 90/364 apply mutatius mutandis. See the proposed Article 4a(2) of Directive No 68/360 (COM(1998) 394((02). See also Sewandono, Het Commissievoorstel tot Wijziging van Verordening (EEG) nr.1612/68: Meer Bescherming van Familie- en Gezinsleven en Meer Gelijke Behandeling, in: SEW (1999) pp.284-290.

Second, family members may loose their privileged status when the working parent, spouse or child gives up their status of Community worker. Family members of workers who return to the State of origin are supposed to join the worker. Where they wish to remain in the host State, family members will have to obtain new residence rights as a (self-)employed person or as a "non-economic resident". The above mentioned Commission proposal does not seem to cover cases where the worker returns to the State of origin. Third country nationals will have to join the returning worker. In some cases, however, family members are entitled to stay. Echternach (1989), for instance, indicates that family members of workers who have returned to the State of origin can retain the status of family member in the host State for the period they need to finalise their education in cases where it is not possible to complete the studies in the State of origin. Joined Cases 389 and 390/87 Echternach [1989] ECR 723. See further Chapter 5 Section 3.3.3. Further, in Fahmi the Court has rejected the view advocated by Advocate General Alber that the right to claim equal treatment as a Community worker or a family member of a worker under Article $7(2)$ of Regulation No 1612/68 can be retained in case the worker has returned home but receives a pension from, and which is taxable in, the (former) host State. Case C-33/99 Fahmi [2001] ECR I-0000 at 47. 
sacrificed the "social assistance interest" for this purpose. Workers' right to reside and their right to claim minimum subsistence benefits in the State of employment, is conditional upon the pursuit of "effective and genuine" work. This requirement constitutes a considerable barrier to Community citizens (and their family members) who consider moving to other Member States for the sole purpose of collecting benefits. For the host States, the requirement serves as a safeguard against "social tourism".

\section{$4 \quad$ Non-Economic Residents}

\subsection{Introduction}

From the early 1970s, Community institutions have worked on a general right of residence which would no longer be linked to, or conditional on, the pursuit of economic activities, but be granted as an independent right which nationals of the Member States would enjoy merely in their capacity as European citizen. ${ }^{89}$ From the beginning, it was undisputed that this anticipated right should not affect the funding of Member States' minimum subsistence benefit schemes. At all costs, social tourism was to be avoided. $^{90}$ Thus, when in 1979 the European Commission sent its first proposal for a directive on a general right of residence to the Council ${ }^{91}$, it included a provision which allowed Member States to require from nationals of other Member States "to provide proof of sufficient resources for their own needs and the dependent members of their family"12. The inclusion of this financial means requirement did not allay the concerns

\footnotetext{
${ }^{89}$ See Chapter 2 Section 4.1 .

${ }^{90}$ Compare Fries/Shaw (1998) supra footnote 88 , at p.536.

${ }^{91}$ OJ 1979 C 204; COM(79) 215 final.

${ }^{92}$ Article $4(2)$ of the 1979 draft directive. The Commission observed that the financial means requirements would discourage "population movements being undertaken with the sole aim of obtaining the most favourable social benefits". COM(80) 358 final at p.3. The draft directive did not define what was to be understood by "sufficient means". It merely provided that "Member States may not require the resources to be greater than the minimum subsistence level defined under their own law" which basically implied that the resources should at least be as great as to avoid that beneficiaries and their family members becoming a charge on the public purse of the host State.
} 
and objections of the Member States. The Council negotiations ${ }^{93}$ proved difficult. It was only following the Court's judgment in Gravier (1985), ${ }^{94}$ in which the Court laid down the legal foundations for free movement of students, and the subsequent replacement of the original 1979 proposal by three new Commission proposals, that Member States reached agreement on Directives Nos 90/366 (as replaced by Directive No 93/96), 90/365 and 90/364 which offered a right of residence to students, pensioners and "other" Community citizens respectively. ${ }^{95}$

\subsection{Right to Reside}

The preambles to the three directives stress that beneficiaries must not become an unreasonable burden on the public finances of the host Member State. This financial safeguard for the Member States is set out in Article 1 of each of the directives. Pensioners shall be granted the right of residence when they receive invalidity, early retirement or other pensions or old age benefits which are of an amount sufficient to avoid becoming a burden on the social security system of the host State. The residual class of "other Community citizens" must have sufficient means to provide for themselves and their family members. ${ }^{96}$ The pensions and resources of the two categories are deemed sufficient where they are higher than the level of resources below which Member States may grant social assistance benefits to its own nationals. ${ }^{97}$ The financial means requirement to be

\footnotetext{
${ }^{93}$ The Member States had considerable difficulty in agreeing on which family members would be given the right to join the principal beneficiary and whether students would have to demonstrate that they possess enough financial means. See further Chapter 2 Section 4.1. On the Council negotiations on the 1979 draft directive see O'Leary, The Evolving Concept of Community Citizenship - From the Free Movement of Persons to Union Citizenship (1996) at pp.109-118; Bolly, Droit d'entrée et de Sejour des Ressortissant communautaire: Développements récents, in: ActduDr (1990) pp.735-748; Taschner, Free Movement of Students, Retired Persons and other European Citizens - A Difficult Legislative Process, in: Schermers et al (Eds), Free Movement of Persons in Europe (1993) pp.427-436 and van Nuffel, Een Bijna Algemeen Verblijfsrecht in de Europese Gemeenschap - Commentaar op de Verblijfsrecht-Richtlijnen van 28 juni 1990, in: SEW (1990) pp.887-903.

${ }^{94}$ Case 293/83 Gravier [1985] ECR 593. See further Chapter 4 Section 4.

${ }^{95}$ See further Chapter 2 Section 4.1 .

${ }^{96}$ Next to the financial means requirement, beneficiaries must satisfy a requirement of sickness insurance. For further details on this requirement see Chapter 4 Section 3.3.3.

${ }_{97}$ Where this requirement cannot be applied in a Member State, the resources are deemed sufficient if they are higher than the level of the minimum social security pension paid by the host Member State. See Article 1(1), third paragraph of Directives No 90/364 and No 90/365.
} 
met by students is less strict. Students only have to assure the relevant national authorities that they have enough resources in order to avoid becoming a "public burden". 98 The financial means requirements must be met throughout the period of residence in the host State. ${ }^{99}$ Those who have obtained the right to reside, but later cease to meet the financial means requirement, may lose the right to reside and be subjected to deportation procedures. ${ }^{100}$

In the view of the European Commission, Directives Nos 90/364 and 90/365 are not correctly transposed by national measures which arbitrarily limit the types of resources that can be taken into account or impose excessive demands with regard to the types of supporting documentation accepted. European Commission, Report to the Parliament and the Council on the Implementation of Directives 90/364, 90/365 and 93/96 (1998) at p.10.

The pensioners directive requires that the pension or the benefit which is received must be "sufficient". This could imply that Community citizens who receive pensions which are relatively low and fall below the minimum subsistence level in other Member States, cannot rely on Directive No 90/365. Such pensioners, however, may possess other financial resources which together with the pension would be "sufficient". In such cases pensioners may rely on Directive 90/364. See Martin/Guild, Free Movement of Persons (1996) at p.220.

${ }^{98}$ See further Chapter 4 Section 4.4.3. The difference between the other two categories may be explained by the fact that the students' right to reside is limited to the duration of the studies, whilst the right of pensioners and the "other" Community citizens is in principle of unlimited duration. Students are less likely to become a burden on the public purse of the host State. Compare Case C-424/98 Commission v Italy [2000] ECR I-0000 at 40. Another reason could possibly be that the legislator wished to avoid introducing an additional requirement for the residence rights of students. See Opinion of Advocate General Alber in Case C184/99 Grzelczyk (http://www.curia.eu.int/jurisp) at 86.

Article 3 of Directives No 90/364, No 90/365 and No 93/96. The question could be raised, however, whether the same holds true for mixed benefits. Directive No 90/364 requires that beneficiaries have sufficient financial means to avoid becoming a burden on the social assistance system of the host State. Does this imply that Community citizens who have acquired the right to reside but who later become in need of, and who are according to national law, eligible for a mixed benefit can loose the right to reside? Such benefits are in the view of the Court and according to Article 4(2a) of Regulation No 1408/71 not to be classed as social assistance benefits in principle, but as social security benefits. Do these terms have the same meaning as under Regulation No 1408/71? If so, then one could on a literal reading of Article 1 of the directives, claim that the right to reside will not be lost. Further, the preamble to the Directive states that beneficiaries should not become an "unreasonable burden" on the public purse of the host Member State. Recipients of mixed benefits do become a burden on the public purse, but does this imply that the burden is "unreasonable"?

${ }^{100}$ The right to reside is also granted to the spouse and the dependent (grand)children and (grant)parents of pensioners and "other Community citizens". In Commission v Italy [2000] the Court held that in applying the financial means requirements Member States have a certain discretion and that they therefore do not have to apply identical criteria in relation to the family members of beneficiaries of Directive No 90/364 and Directive No 90/365. Case C-424/98 Commission v Italy [2000] ECR I-0000 at 26. Students are only entitled to bring their spouse and their dependent children. Article 1 Dircetive No 93/96. 


\subsection{Right to Claim Minimum Subsistence Benefits}

The drafters of the directives did not intend to grant beneficiaries of the three directives a right to equal treatment as regards social assistance or other minimum subsistence benefits. In their view, being in need would lead to the loss of the right to reside. The judgment in Martinez Sala (1998), however, strongly suggests that non-economic residents do have a right to equal treatment as regards enjoyment of minimum subsistence benefits. The case concerned a Spanish national, Ms María Martínez Sala, who had lived in Germany since 1968. Between 1976 and 1989 she had had various jobs, but since 1989 Ms Martínez Sala received a social assistance benefit (Sozialhilfe) by virtue of German law. Due to Article 6 of the 1953 Convention on Social and Medical Assistance, to which both Germany and Spain are contracting parties and which provides that nationals of the contracting parties shall not be repatriated on the sole ground that they are in need of assistance, Ms Martínez Sala could not be expelled. In 1993 she applied for a child-raising allowance for her newborn child. At the time of application, Ms Martínez Sala did not have a residence permit. She only possessed a document certifying that she had applied for a residence permit. Her application for the allowance was denied on the ground that she did not possess a valid residence permit. Ms Martínez Sala appealed the decision.

The main question the Court of Justice had to answer was whether a Member State like Germany is entitled to make the right to social security benefits subject to the presentation of a residence permit. The Court had no difficulty in concluding that the German child-raising allowance fell within the scope of both Regulation No $1408 / 71^{101}$ and Article $7(2)$ of Regulation No $1612 / 68^{102}$ and that the duty to present a residence permit constitutes a discrimination on grounds of nationality when no comparable duty is imposed on nationals of the host State. ${ }^{103}$ Thus, the German rules were incompatible with Article 3 of Regulation

${ }^{101}$ In an earlier judgment the Court had already concluded that the child-raising allowance which Mrs Martínez had applied for, falls within the scope of Regulation No 1408/71. Joined Cases C-245/94 and C-312/94 Hoever [1996] ECR I-4895. The German Government had argued that the Court should reconsider that judgment, but the Court saw no reasons for doing so. Case C-85/96 Martínez Sala [1998] ECR I-2691 at 24.

${ }_{102}$ Case C-85/96 Martinez Sala [1998] ECR I-2691 at 26.

${ }^{10.3}$ In Royer the Court had already held that for the purposes of the right of residence, a residence permit can only have declaratory and probative force. Case 48/75 Royer [1976] ECR 497. In Martínez Sala the Court concluded that the same must apply for purposes of the grant of social security benefits. Case C-85/96 Martinez Sala [1998] ECR I-2691 at 5354. 
No 1408/71 and Article 7(2) of Regulation No 1612/68. It was not certain, however, if Ms Martínez Sala could invoke these provisions. The referring German court had not submitted enough information to the Court of Justice in order to determine whether Ms Martínez Sala could indeed be regarded as a worker for purposes of the two Regulations. The question therefore arose whether Ms Martínez Sala, in case the national court were to conclude that she was not a worker, could invoke Article 12 EC in order to challenge the German rules. The German Government had argued that Ms Martínez Sala could not do so because the benefit in question would fall outside the material scope of Article 12(1) EC and Ms Martínez Sala herself would not fall within the personal scope of the Treaty. The Court did not agree. As regards the material scope of Article $12 \mathrm{EC}$, the Court held that the child-raising allowance in question falls within the scope of both Regulation No 1408/71 and Article 7(2) of Regulation No 1612/68 and this implied, according to the Court, that the allowance "indisputably" fell within the scope of Community law. ${ }^{104}$ As to the personal scope of Article 12, the European Commission had argued that, in case Ms Martínez Sala could indeed not be regarded as worker, she would have a right to reside under Article 18 of the Treaty and thus fall within the scope of the Treaty. The Court did not address the possible importance of Article $18 \mathrm{EC}$ in detail. In the view of the Court, it was not necessary to examine whether a person like Ms Martínez Sala can rely on Article 18 in order to obtain recognition of a new right to reside in the territory of the host State Germany since she had already been authorised to reside there. As a national of a Member State who is lawfully residing in the territory of another Member State, Ms Martínez Sala came, according to the Court, within the personal scope of the Treaty provisions on European Citizenship. Article 17(2) attaches to the status of citizen of the Union the rights and duties laid down by the Treaty, including the right laid down in Article 12 not to suffer discrimination on grounds of nationality within the material scope of the Treaty. Consequently, citizens of the Union who are lawfully resident in the territory of another Member State can rely on Article 12 of the Treaty in "all situations which fall within the scope ratione materiae of Community law". ${ }^{105}$

Like the child-raising allowances Ms Martínez Sala had applied for, minimum subsistence benefits are covered by Regulation No 1408/71 and/or Article 7(2) of Regulation No 1612/68 and, as follows from Martinez Sala, they thus also fall within the scope of Article 12(1) EC.

\footnotetext{
${ }^{104}$ Case C-85/96 Martínez Sala [1998] ECR I-2691 at 57.

${ }^{105} \mathrm{Ibid}$, at $60-65$.
} 
As a result, non-economic residents seem entitled to claim equal treatment as regards minimum subsistence benefits when, and for as long as, their residence in the host State is lawful.

\subsection{Lawful Residence}

When lawful residence in the territory of another Member State gives entitlement to equality of treatment as regards minimum subsistanace benefits, it is important to establish when, or under what conditions, economically inactive Community citizens who are not able to provide for themselves are to be regarded as lawful residents. Martinez Sala itself was a rather unique case because Ms Martínez Sala was entitled to live in Germany on the basis of the Convention on Social and Medical Assistance. If, however, Ms Martínez Sala had not had a residence right on the basis of international or German law, would the German authorities have been entitled to withdraw the decision to grant her Sozialhilfe? Can Community citizens such as Ms Martínez Sala claim a right of residence on the basis of Community law? The answer to the question depends on the source of the non-economic right. More specifically, it depends on the answer to the question whether the right to reside directly derives from Article 18(1) EC or whether it is (still) to be regarded as a right granted by Member States in accordance with the criteria laid down in Directive No 90/364. In the proceedings before the Court in Martinez Sala the German government had argued that the right to reside is not based on the Treaty. Article 18(1) EC stipulates that the rights to move and reside are subject to "limitations and conditions" laid down by the Treaty and secondary legislation. In the German view, these limitations and conditions concerned the existence of the right to freedom of movement itself. Community citizens who do not, or no longer, meet the financial means requirement would only be entitled to claim residence rights under national law, not under Community law. Such Community citizens would fall outside the personal scope of Community law and, thus, Article 12(1) EC. ${ }^{106}$ The German view was contested by the European Commission which, as noted earlier on, had argued that the rights to move and reside freely do follow directly from Article 18(1) EC. The limitations and conditions this provision refers to would merely concern the exercise of

\footnotetext{
${ }^{106}$ Opinion of Advocate General La Pergola in Case C-85/96 Martínez Sala [1998] I2691 at 15. Compare further Tomuschat, Annotation Martinez Sala, in: CMLRev (2000) pp.449-457, at pp.452-453.
} 
the rights. For as long as Member States do not make use of their power to limit the exercise of the right of "needy" nationals of other Member States, persons such as Ms Martínez Sala would be entitled to rely on Article 12(1) EC as lawful residents.

In its judgment in Martinez Sala the Court did not deem it necessary to establish the source of Ms Martínez Sala's residence right. ${ }^{107}$ As a national of a Member State who had been authorised to reside in the territory of another Member State, Ms Martínez Sala fell within the personal scope of the Treaty provisions on European citizenship and she could therefore claim equality of treatment under Article 12 EC. The observations of the Court were short but they do indicate that the Court did not support the view advocated by the German government. Union citizens who are not able to provide for themselves may not be covered by Directive No 90/364, but Martínez Sala indicates that they do fall within the scope of Treaty provisions on European citizenship when they lawfully reside in another Member State. This does not necessarily imply that the Court endorsed the view of the European Commission in Martinez Sala. The judgment could still be interpreted as implying that "needy" and non-economically active Union citizens can only claim equality of treatment in another State under Article 12 when they are residing there on the basis of international or national law. ${ }^{108}$ The more recent ruling in Elsen (2000), however, strongly suggests that Article 18(1) EC indeed constitutes the source of the right to reside. The case involved a German national who was living with her husband and son in France. Ms Elsen, who had worked in Germany but never in France, requested the German social security institutions to take into consideration the periods she had spent rearing her son as insurance periods for purposes of her old-age pension. The German institutions refused on the ground that the applica-

\footnotetext{
${ }^{107}$ In previous cases the Court has also never expressly gone into the question whether the general right of residence is now based on Article 18(1) EC. In cases such as Skanavi (1996) and Stöber and Pereira (1997) the question did arise, but the Court did not (have to) consider the provision because the cases under consideration could be decided on the basis of Article 43 EC. Case C-193/94 Skanavi [1996] ECR I-929 and Joined Cases C-4/95 and C5/95 Stöber and Pereira [1997] ECR I-511. Furthermore, in Wijsenbeek (1999), in which the Court was asked whether a duty to present a passport on entry into a Member State is compatible with Article $18 \mathrm{EC}$, the Court did not address the issue. Even if under Article 17 or Article $18 \mathrm{EC}$ "nationals of the Member States did have an unconditional right to move freely within the territory of the Member States", Member States still have the right to impose on all persons wishing to enter their territory the duty to establish that they are nationals of the Member States. Case C-378/97 Wijsenbeek [1999] ECR I-0000 at 42-43.

${ }^{108}$ Compare Fries/Shaw (1998) supra footnote 88, at p.547 and Moore (1999) supra footnote 89 , at p. 540
} 
ble German rules only allowed them to do so when the child-rearing has taken place in Germany. The Court concluded that the German rules were disadvantageous to Community citizens who wish to exercise their noneconomic free movement rights and that, by not taking into account the periods devoted to child-rearing completed in France, the German social security institution had acted contrary to Article 18 EC. ${ }^{109}$

Elsen thus indicates Article 18 may have legal force. No certainty exists, but the ruling suggests that the right to reside has acquired "constitutional status". Arguably, this is also the most, if not the only, logical interpretation of the provision. In the words of Advocate General La Pergola:

"now that Article 8a (now 18: APvdm) of the Treaty has entered into force, the right of residence can no longer be considered to have been created by the directive .. That legislation was adopted by the Council to cover situations in which citizens did not enjoy a right of residence under other provisions of Community law. Now, however, we have Article $8 \mathrm{a}$ of the Treaty. The right to move and reside freely throughout the whole Union is enshrined in an act of primary law and does not exist or cease to exist depending on whether or not it has been made subject to limitations under other provisions of Community law, including secondary legislation. The limitations provided for in Article $8 \mathrm{a}$ itself concern the actual exercise but not the existence of the right". ${ }^{110}$

\footnotetext{
${ }^{109}$ Case C-135/99 Elsen [2000] ECR I-0000 at 34-36.

${ }^{110}$ Opinion of Advocate General La Pergola in Case C-85/96 Martinez Sala [1998] ECR
} I-2691 at 18. See also the Opinion of Advocate General Cosmas in Case C-378/98 Wijsenbeek [1999] ECR I-0000 at 79-87, the Opinion of Advocate General Alber in Case C-184/99 Grzelczyk (http:www.curia.eu.int/jurisp) at 120 and Report of the High Level Panel on the Free Movement of Persons (1998) at p.17. Textual support for this conclusion can also be found in the second paragraph of Article $18 \mathrm{EC}$ which empowers the Council to adopt measures with a view to facilitating the exercise of the free movement rights referred to in the Article's first paragraph. If the drafters of the Treaty had actually intended to say that freedom of movement is not a Treaty based right, then they should have empowered the Council to extend free movement rights.

If Article 18(1) EC constitutes the legal base of the right to reside, one may safely assume that the right is directly enforcable in court. The fact that the exercise of free movement rights may be subjected to certain "limitations and conditions" does not alter the clear and conditional nature of the rights themselves. The limitations and conditions which Member States may impose can be subjected to judicial control. In the literature various authors have commented on the point and they have all concluded that Article 18(1) is indeed directly applicable. See e.g. Martin/Guild (1996) supra footnote 100, at p.97; O'Leary (1996) supra footnote 96, at pp.141-142; Koenig/Pechstein, Die Europäische Union (1995) at p.178; Wouters, European Citizenship and the Case-law of the Court of Justice of the European Communities on the Free Movement of Persons, in: Marias (Ed.), European Citizenship (1994) pp.25 et seq, at p.49 and Douglas-Scott/Kimbell, The Adams Exclusion Order Case: New Enforcable Civil Rights in the post-Maastricht European Union?, in: Public Law (1995) pp.516-525, at pp.520-521. 
Read together, Martínez Sala and Elsen suggest that the Court has accepted the Commission's interpretation of Article 18(1) EC. If correct, the conclusion can be drawn that Member States are still entitled to deny residence in the national to economically inactive nationals of other Member States who are unable to provide for themselves erritory and to end the lawful residence status of those who are in need of social assistance benefits. However, where they do not make use of these powers, Member States are obliged to treat the Community citizens concerned equally as regards access to minimum subsistence benefits schemes. Put differently, Union citizens who are actually residing in the territory of another Member State are, as lawful residents, entitled to be treated equally as regards minimum subsistence benefits until the moment that the host State executes measures to end their lawful residence status. ${ }^{11}$

111 This conclusion raises a series of new questions. What should the measures taken by the Member States consist of? From which moment on does lawful residence become unlawful residence? O'Leary has argued that Community citizens are to be regarded as lawful residents until they are subject to formal proceedings to effect deportation. O'Leary, The Principle of Equal Treatment on Grounds of Nationality in Article 6 EC - A Lucrative Source for Member State Nationals?, in: O'Leary/Tiilikainen (Eds), Citizenship and Nationality Status in the New Europe (1998) pp.105-136, at p.134. Yet, what does this imply? Are Community citizens unlawful residents from the moment they are informed by the immigration authorities that they have to leave the host State's territory? In the light of Article 1 of Protocol 7 to the European Convention on Human Rights (procedural safeguards as regards the expulsion of aliens) and by analogy with Articles 8 and 9 of Directive No $64 / 221$ (on the co-ordination of special measures concerning the free movement rights which are justified on grounds of public policy, public security or public health - OJ 1963/1964 (Spec. English Ed.) 117 - see further Chapter 2 Section 7.1), it would seem that Community citizens have a right to appeal expulsion decisions. By analogy with the case law on Directive No 64/221, it could be argued that such Community citizens retain the status of lawful resident, and thus the right to equal treatment as regards minimum subsistence benefits, until they have been able to to complete the formalities to avail themselves of that remedy and the competent authority has reached a decision. Compare Case 48/75 Royer [1976] ECR 497 and Case C-175/94 Gallagher [1996] ECR I-4253. If Community citizens who are challenging decisions of immigration authorities are indeed to be regarded as lawful residents until the moment a decision on appeal has been made, can the institutions responsible for payment of social assistance benefits require the presentation of a document stating that they have actually started the procedure or are they obliged to grant benefits to those who can prove to be actual residents until they have received the decision of the appeal body? Does a negative decision on appeal itself end lawful residence or does such a decision merely imply an authorisation for the immigration authorities to end lawful residence? In answering such questions, is any distinction to be made between Community citizens who apply for a residence card for the first time and Community citizens who have acquired such a card but later cease to meet the financial means requirement? Can Community citizens who know in advance that they are unable to meet the financial means requirement in another Member State but nonetheless move there, claim lawful residence status and social assistance benefits for the duration of the appeal procedure? 


\subsection{Conclusions}

One may object to the above and claim that one cannot, and should not, read so much in the Martinez Sala judgment which did not concern minimum subsistence benefits, might be confined to the rather unique facts of the case, ${ }^{112}$ is not extensively reasoned, which seems to run counter to the intentions of the Treaty drafters and which has not been free from criticism. ${ }^{113}$ More specifically, it could be argued that noneconomic residents cannot have a right to equal treatment as regards to social assistance benefits because, as Advocate General Alber has opined has in Grzelczyk, the being in need of such benefits, may constitute a ground for ending lawful residence. ${ }^{114}$ Yet, what are the true objections? The crux of problem, and the critique which has been expressed, concerns the possible burden on the social welfare systems. States may have to grant benefits which have not been anticipated for and which "have not been earned by the claimant on account of his or her her participation in the collective work process of a given society". ${ }^{115}$ The category of noneconomic residents, however, consists of persons who have demonstrated to be able to provide for themselves and who can be required to pay taxes and/or premiums. Member States still hold the power to end the lawful residence status of non-economic residents who after some time cease to meet the financial means requirement (and who do not enjoy a residence right under international law). Martínez Sala has not limited that power. Exceptions to the free movement and equal treatment rights of Union citizens are to be interpreted restrictively. Why, then, should Member States have both the power to deny them social assistance benefits and the power to expel them? ${ }^{116}$

\footnotetext{
112 O'Leary, Putting Flesh on the Bones of European Union Citizenship, in: ELRev (1999) pp.6879, at p.77; Bulterman, Annotation to Bickel, in: CMLRev (1999) pp.13251334, at p.1329 and Fries/Shaw (1998) supra footnote 84, at p.558.

113 See e.g. Becker, Freizügigkeit in der EU - Auf dem Weg vom Begleitrecht zur Bürgerfreiheit, in: EuR (1999) pp.522-533 and, in particular, Tomuschat (2000) supra footnote 41 .

114 Opinion of Advocate General Alber in Case C-184/99 Grzelczyk (http://www.curia.eu.int/jurisp) at 125 .

${ }^{115}$ Tomuschat (2000) supra footnote 106 , at p.455.

116 The answer that Member States may already have given up the power to expel by becoming a party to international agreements (such as the European Convention on Social and Medical Assistance) and that, if they had known about the obligations following from Martinez Sala, they might never decided to become a State party to these agreements, does not persuade. The obligation not to expel nationals of other State parties on the ground that they are in need of social assistance applies, as a rule, only applies to persons who have resided on the national territory for a minimum period of time (see e.g. Article 7 of the afore
} 


\section{$5 \quad$ Non-Residents}

Member States' laws and rules on minimum subsistence benefits are all based on the principle of territoriality. ${ }^{117}$ The benefits have traditionally been preserved for residents; non-residents have been excluded. At first glance, the legality of residence seems beyond doubt. If Member States were obliged to grant minimum subsistence benefits to residents and nonresidents under the same conditions, the funding of their benefits schemes would be jeopardised. ${ }^{118}$ The validity of residence requirements, however, is not entirely obvious as regards certain categories of non-residents who have certain "economic ties" with the State concerned because they work and/or pay taxes there or have done so in the past. Why would frontier workers be denied a right to claim minimum subsistence benefits in the State where they are employed and (may) pay taxes? Why would Community citizens who have lived and worked their entire life in a given Member State have to lose entitlement to minimum subsistence benefits the moment they decide to live in another Member State? Recipients of such benefits may be discouraged from working or moving elsewhere if they cannot export their benefit. Due to the financial means requirements contained in the 1990 residence directives, it might even be impossible for them to take up residence in other Member States. The case law demonstrates that the validity of residence requirements for, and the non-exportability of, minimum subsistence benefits has indeed been quite controversial. A distinction is to be made between mixed or hybrid benefits and the classic social assistance benefits.

mentioned Convention - period of five or ten years) and who during these years often will have worked and made their contributions to the "common wheal". Martínez Sala obliges States to offer non-economic residents benefits they had not envisaged, but as long as States hold the power to end the residence of the "needy" (during at least the initial years of their stay) arguments concerning financial implications for the host State are not persuasive enough to reject the suggested conclusions from the Martinez Sala ruling.

${ }^{117}$ See Section 2.2 .

${ }^{118}$ van der Mei (1999) supra footnote 9, at p.451. 


\subsection{Mixed Benefits}

\subsubsection{Article 10 of Regulation No 1408/71}

Questions concerning the validity of residence requirements have played a central role in the Court's case law on the application of Regulation No $1408 / 71$ to mixed benefits. ${ }^{119}$ Article 10 of Regulation No $1408 / 71$ allows for the exportability of benefits. ${ }^{120}$ On a literal reading of the provision $^{121}$ one might conclude that once it is decided that a mixed benefit is covered by the Regulation, it is also exportable. Nonetheless, this conclusion appears not as obvious as it may seem. Consider Biason (1971). The case concerned an Italian woman who received a supplementary allowance in France in addition to an invalidity pension. This tax-funded allowance, which was only granted to persons in receipt of invalidity pensions, was withdrawn the moment Ms Biason moved to Italy. She claimed that the withdrawal was inconsistent with Article 10 of Regulation No 3/58, the predecessor of the current Article 10 of Regulation No 1408/71. In the proceedings before the Court of Justice, the European Commission strongly argued against the exportability of mixed benefits. Article 10 would only apply to social insurance-like benefits. Such benefits may be regarded as "deferred income" and "must of necessity" $^{122}$ be exportable. Mixed benefits, however, are usually financed out

\footnotetext{
${ }^{119}$ See Section 2.3 above.

${ }^{120}$ The aim of the provision is "to promote freedom of movement for workers and members of members of their family by protecting them against any adverse consequences which might arise as a result of the transfer of their residence from one Member State to another. The provision therefore seeks to ensure that such persons retain their rights to benefits, pensions and allowances to which they are entitled under the legislation of one or more Member States if they reside in the territory of a Member State other than that in which the institution responsible for payment is situated". Case 139/82 Piscitello [1983] ECR 1427 at 15. See also Joined cases 379-381/85 and 93/86 Giletti and others [1987] ECR 955 at 14 .

${ }^{121}$ Article 10 reads: "Save as otherwise provided in this regulation, invalidity, old-age or survivors' cash benefits, pensions for accidents at work or occupational diseases and death grants acquired under the legislation of one or more Member States shall not be subject to any reduction, modification, suspension, withdrawal or confiscation by reason of the fact that the recipient resides in the territory of a Member State other than that in which the institution responsible for payment is situated". Article 10 may be regarded as the general export provision of the Regulation No 1408/71. For certain benefits specific export provisions exist. See e.g. Article 69 for unemployent benefits.

${ }^{122}$ See the observations of the Commission in Case 24/74 Biason [10974] ECR 999 at p. 1004.
} 
of the public budget and generally regarded as an expression of the welfare solidarity between the residents of a State. Persons who wish to export such mixed benefits are no longer residents and thus no longer part of the shared welfare solidarity. Furthermore, the Commission claimed that the assessment of financial resources in the context of the means test would be largely impossible when such benefits are exported to other States.

In Biason the Court first had to determine whether the supplementary allowance Ms Biason received fell within the scope of Regulation No 3/58. The Court held that the French legislation conferred upon recipients a legally defined position and that the allowance was linked to the risk of invalidity mentioned in Article 4(1)b of Regulation No 1408/71. So far as Ms Biason was concerned, the allowance was therefore a social security benefit within the meaning of the Regulation. ${ }^{123}$ In the view of the Court, the allowance was also exportable. Article 10(2) of Regulation No 3/58 entitled Member States to exclude certain non-contributory benefits from the export provision in Article 10(1) by including benefits in an annex to the Regulation for "benefits not payable abroad". The French supplementary allowance was not set out in the annex and the Court therefore simply concluded that a person such as Ms Biason could continue to receive the benefit while staying in another Member State. $^{124}$

The line of reasoning followed by the Court in Biason was rather formal. Basically, the Court reasoned that if France had wished to limit the export of the benefit in question, it should have included it in the annex. As France had not done so, Ms Biason could "simply" export her benefit. The possibility of excluding certain benefits from the export provision was abolished, however, when Regulation No 1408/71 was adopted. At first glance, this would seem to have increased the possibility of exporting mixed benefits. France, however, held to the view that mixed benefits could not be exported. The European Commission, acting in response to a number of complaints it had received from recipients of French supplementary benefits whose benefits were stopped on the moment they moved to another Member State, commenced in 1980 an infringement procedure under Article 226 (formerly 169) E(E)C. France subsequently submitted to the Council a communication in which it referred to the specific problems regarding the exportability of noncontributory minimum subsistence benefits. France proposed to bring

\footnotetext{
${ }^{123}$ Case 24/74 Biason [1974] ECR 999 at 15-16.

${ }^{124} \mathrm{Ibid}$, at $17-22$.
} 
these mixed benefit schemes under Regulation No 1612/68 and to insert into this regulation a special provision which would limit the export of such benefits. In response, the Commission postponed the infringement procedure without, however, directly sending a legislative proposal to the Council. The Commission only did so following the Court's decision in Piscitello (1983). ${ }^{125}$

Ms Piscitello was an Italian national who was living and receiving a social aid pension in Italy. The benefit was granted to all persons of 65 years and older whose income fell below the minimum income fixed by law. The benefit was Ms Piscitello's only source of income. When she transferred her residence to Belgium, the Italian authorities withdrew the pension on the ground that she was no longer resident in Italy. Ms Piscitello challenged the withdrawal in an Italian court which initiated a procedure under Article 177 (now 234) E(E)C in order ask the Court of Justice whether the benefit at issue was covered by the Regulation and, if so, whether it could be exported. The Italian and British governments had argued that the conclusions drawn in Biason could not be extended to this case. The former case concerned the exportability of an allowance which was granted as a supplement to another social security benefit. Ms Piscitello's benefit, however, constituted her only source of income. It was a benefit financed solely out of public funds which served for Ms Piscitello, in fact, as a social assistance benefit. No Community machinery existed for assessing the income which might be received in other Member States or for sharing the costs involved amongst the Member States. The exportability of benefits would cause disruption to the national systems. ${ }^{126}$ The Court was not persuaded by these arguments. It had no difficulty in concluding that the benefit scheme fell within the Regulati$o^{127}$ and that the benefit Ms Piscitello received was amongst the benefits referred to by Article 10. Since Regulation No 1408/71 did not contain any specific provisions applying to such a pension, the Court "simply" ruled "that the waiver of residence clauses provided for in Article 10(1) of that regulation applies to the benefit in question". ${ }^{128}$

Piscitello implied that all benefits covered by the Regulation were, in principle, also exportable. ${ }^{129}$ This seemed to have far-reaching conse-

\footnotetext{
${ }^{125}$ Case 139/82 Piscitello [1983] ECR 1427.

${ }^{126} \mathrm{Ibid}$, at p. 1434

${ }^{127} \mathrm{Ibid}$, at $8-13$.

${ }^{128} \mathrm{Ibid}$, at 16 .

${ }^{129}$ In Giletti (1987) the Court further held that Article 10 of Regulation No 1408/71 not only implies that beneficiaries may retain the right to receive benefits after they have moved to another Member Statc, but also that bencficiaries may not be prevented from acquiring the
} 
quences. Also the conclusion that minimum subsistence benefits which are not granted as a supplement to other social security benefits can be exported, implied that also persons who have never paid social security premiums or contributions could export benefits. More generally, Piscitello raised the fundamental issue whether Member States had been forced to extend their welfare responsibility to (certain) non-residents. It should be noted, however, that the Court concluded that mixed benefits are only exportable because the Regulation did not contain any specific provision for such benefits. The Court had left open the possibility for the Community legislator to amend the Regulation and to include in it specific provisions which would entitle Member States to limit the export of mixed minimum subsistence benefits. Two years after the judgment in Piscitello the Commission responded to the Court's implicit call by submitting a proposal to the Council to amend Regulation No 1408/7$1{ }^{130}$ In brief, the proposal suggested that mixed benefits would be brought under the material scope of Regulation No 1408/71 and that a new Article 10a would be introduced which would entitle the Member States to limit the right to receive mixed benefits to Community citizens residing within their territory.

The Commission's proposal was not directly adopted by the Council. Faced with a lack of progress in the Council negotiations, the Commission decided in 1988 to carry on the infringement procedure against France. This Member State still held the view that mixed benefits should not be exportable; it even refused to implement the ruling in Piscitello. ${ }^{131}$ In the proceedings before the Court, the French government referred to the Commission's proposal suggesting that it could be relieved from the obligation to allow beneficiaries to export the benefits at issue. In Commission v France (1990), however, the Court stated that "the fact that a proposal which could terminate an infringement is submitted to the Council cannot relieve the member State responsible for that infringement of its obligation to comply with the provisions of Community law in force". ${ }^{132}$ It was not for the Court to anticipate any amendments which

right to such benefits on the ground that they do not reside in the State concerned. Joined Cases 379-381/85 and 93/86 Giletti [1987] ECR 955 at 15 .

${ }^{130} \mathrm{COM}(85) 396$ final.

131 It has been suggested that France did so in order to constraint the other Member States to adopt the Commission's proposal. Lyon-Caen (1995) supra footnote 20, at p.52 (footnote 20).

${ }^{132}$ Case C-236/88 Commision v France [1990] ECR I-3163 at 19. 
might be made by the Community legislature. ${ }^{133}$ The French government had further argued that the level of mixed benefits is fixed by each Member State having regard to a specific economic and social environment. The level of the French benefit was designed to guarantee a minimum means of subsistence at the level fixed in France. The possibility of exporting such benefits would, in the French view, carry the risk of social regression as a result of the differences in national laws and the disparity in standards of living. The Court did not accept the argument. The fact that a mixed benefit "is linked to a specified economic and social environment cannot, under Community law as it now stands, constitute a ground for" excluding the application of Article 10 to mixed benefits. ${ }^{134}$

\subsubsection{Article 10a}

The Court thus put pressure on the Council to take legislative action to co-ordinate mixed benefit schemes. Two years after Commission $v$ France, the Council did indeed do so by adopting Regulation No 1247$192^{135}$ which inserted a specific co-ordination mechanism for mixed

\footnotetext{
133 Opinion of Advocate General in Case C-236/88 Commission v France [1990] ECR I3162 at p.3175.

${ }^{134}$ Case C-236/88 Commision v France [1990] ECR I-3163 at 13. The French government had further claimed that the export of mixed benefits would raise serious problems of management, coordination and substance which can only be resolved by Community legislation. The Court responded that such practical difficulties must not prejudice the rights which individuals derive from Community law. Ibid, at 17.

${ }_{135}$ OJ 1992 No L 136. The regulation was adopted on 1 May 1992 and came into force on 1 June 1992. Prior to this amendment, the Court was once more confronted with an "export-case". In Newton (1991) a British national, who was working as a self-employed person in France, became the victim of a car accident as a result of which he became paralysed. He returned to the United Kingdom where he applied for, and was awarded, a so-called mobility allowance. This was a minimum income benefit granted to persons who, due to physical disability were unable to walk. The national law required inter alia that the beneficiaries were "ordinarily present" on the territory of the United Kingdom. Thus, when Newton decided to move back to France the competent administrative authorities withdrew the mobility allowance. In order to be able to export his allowance it had to be established that the mobility allowance was covered by Regulation No 1408/71. Mr Newton had never worked in the United Kingdom and had never been subject to the social security system of the United Kingdom. In the proceedings before the Court, the Commission therefore argued that $\mathrm{Mr}$ Newton could not export his allowance because if he could, therewould be a danger that persons who have never worked and lived in a certain State could nonetheless claim certain mixed benefit schemes. Unlike Advocate General Darmon, the Court accepted the Commission's argument. In the Court's view, the benefits could not be regarded as being covered by Rcgulation No $1408 / 71$ in the case of persons who have only becn subject to the lcgislation
} 
benefits into Regulation No 1408/71. As stated in Section 2.3, a new Article 4(2a) was included which has brought mixed benefit schemes within the ambit of the Regulation. As follows from the preamble to the Regulation, the benefits are regarded as social security benefits. In addition, a new Article 10a was inserted which, in its first paragraph, provides that by way of derogation of Article 10, the mixed benefits falling within the ambit of Article 4(2a) shall be granted exclusively in the territory of the Member State in which beneficiaries reside. The main justification for this rule is that mixed benefits are intended to provide recipients with financial means at minimum subsistence level. This level is to be determined by the cost of living and the social and economic environment in the State of residence. ${ }^{136}$ The benefits are granted by, and at the expense of, the institution of this State in accordance with the legislation applicable there. In order to be entitled to refuse the export of mixed benefits, however, Member States must list the benefits in the newly created Annex IIa. ${ }^{137}$ Benefits which have not been listed in the Annex do not fall under Article $10 \mathrm{a}(1)^{138}$ but under the general provision of Article 10 which implies that they can be exported. By adopting Regulation No 1247/92 the Community legislator thus introduced a mechanism for the (non-)exportability of mixed benefits comparable to the one which existed under the original Regulation No 3/58. ${ }^{139}$ Member States may deny the exportability of mixed benefits by including benefits in an Annex to the regulation. If they do not do so, residence requirements for mixed benefits cannot be applied.

of States other than the one whose legislation is invoked. Case C-356/89 Newton [1991] ECR I-3017 at 15-16. The Court recognised the financial concerns of the Member States. Any other conclusion would affect the "stability" of the system instituted by the national legislation. The co-ordination system set up by the two social security regulations is aimed at promoting free movement of persons, but the provisions of the regulations cannot be interpreted in such a way as to upset national systems. Case C-356/89 Newton [1991] ECR $1991 \mathrm{I}-3017$ at $17-19$.

136 Verschueren (1996) supra footnote 23, at p.100.

137 This Annex now contains more than fifty types of national benefits which usually concern financial support benefit for handicapped persons, retired persons or family benefits. Verschueren (1996) supra footnote 23, at p.97.

${ }^{138}$ Article 10a cannot result in the withdrawal of rights obtained prior to the entry into force of Regulation No 1247/92. See Article 2 of Regulation No 1247/92.

139 Article 10a basically concerns a specific rule determining the applicable legislation which deviates from, and takes precedence over, the general conflict rules laid down in Articles 13 et seq of the Regulation. Thus, Community citizens working in one Member State but residing in another, are in principle assigned to the social security legislation of the State of employment. Yet, in as far as mixed benefits are concerned, they are subject to the legislation of the Member States in whosc territory they reside. 
In addition, Article 10a contains a number of provisions which partly compensate for the Member States' right to limit the export of mixed minimum subsistence benefits. In order to secure that beneficiaries will actually be able to receive mixed benefits in the State of residence, Article $10 \mathrm{a}(2)$ states that the institution which is to grant mixed benefits shall, where necessary, regard periods of employment, residence or insurance completed in other Member States as though they had been fulfilled in its own territory. Article 10a(3) further provides that a Member State whose legislation makes the grant of a supplementary benefit subject to the prior award of a particular social security benefit under its own legislation, is to treat a corresponding benefit awarded under the legislation of another Member State, as if it were awarded under its own legislation. The supplementary benefit is then added to that foreign corresponding benefit. ${ }^{140}$

\subsubsection{Snares: The Validity of Article 10a}

Since the coming into force of Regulation No 1247/92, the debates and controversies regarding the exportability of mixed benefits seemed to have come to an end. In the beginning of 1996, however, the discussion seemed to start all over again when the Snares case was put to the Court. Mr Snares was a British national who had been working and been subject to the British social security system for more than 25 years. In April 1993 he became the victim of a serious accident. Mr Snares applied for and was awarded a disability living allowance. This allowance was noncontributory, linked to incapacity for work, not subject to a means test and granted, inter alia, to persons whose walking ability was impaired. On 1 November 1993 Mr Snares informed the competent institution that he wished to establish himself permanently in Tenerife (Spain) so that his family members who lived there, could take care of him. The relevant institution informed $\mathrm{Mr}$ Snares that from the date of his departure to Spain he could no longer receive the mobility allowance since the British

${ }^{140}$ See $\operatorname{COM}(85) 396$ final. Article $10 a(4)$ provides that where the legislation of a Member State makes entitlement to a mixed benefit for disability or invalidity subject to the condition that the disability or invalidity should be diagnosed for the first time in the territory of that Member State, this condition shall be deemed to be fulfilled where such diagnosis is made for the first time in the territory of another Member State. See further Article 2a of Regulation No 574/72 (as inserted by Regulation No 1945/93 - OJ 1993 L 181) and Decisions Nos 151 and 152 of the Administrative Commission on the implementation of Article 10a (OJ 1994 L 244). 
legislation provides that the benefits can only be granted to persons who are "ordinarily resident" in Great Britain. Mr Snares appealed the decision and the national court referred the case to the Court of Justice for a preliminary ruling.

The main ${ }^{141}$ question the Court had to answer was whether Regulation No 1247/92 was valid in the light of Articles 51 (now 42) and 235 (now 308) of the Treaty in so far as that regulation makes the right to receive mixed benefits subject to residence clauses. In other words, was the Community legislator empowered to adopt a rule authorising the States to restrict the exportability of mixed benefits? The Court recalled some of its previous case law and stated that on numerous occasions it had pointed out that the principle of the exportability of social security benefits applies so long as no derogating provisions have been adopted by the Community legislator. The Court further reiterated the ruling in $\mathrm{Le}$ noir (1988) ${ }^{142}$ in which it had held that the grant of benefits closely linked with the social environment may be made subject to a condition of residence in the competent State. The fact that a person such as $\mathrm{Mr}$ Snares did not satisfy the conditions applied by his new State of residence to the award of an invalidity benefit, could not invalidate Article 10a of Regulation No 1408/71. The system introduced by Regulation No $1247 / 92$ contains rules whose very purpose is to protect the interests of migrant workers. The Court referred in this regard to the second, third and fourth paragraphs of Article 10a which strengthen the right to equal treatment in the State of residence as regards mixed benefits. ${ }^{143}$ Article $10 \mathrm{a}$, the Court concluded, is valid. ${ }^{144}$

This conclusion fitted well in the case law which the Court has developed under Regulation No 1408/71 since the early 1970s. In various cases the Court had accepted the exportability of mixed benefits on the basis of Article 10 of the regulation, but it had always indicated that the Community legislator was empowered to amend the regulation on this point. By adopting Regulation No $1247 / 92$ the legislator responded to this implicit call and in Snares the Court therefore did not have much difficul-

${ }^{141}$ The first question to be answered was whether the position of persons like Mr Snares, who, after the entry into force of Regulation No 1247/92, satisfy the conditions for the award of mixed benefits, is governed exclusively by the coordination rules established by Article 10a. The Court answered the question in the affirmative. Mr Snares did fall within in the personal scope of the Regulation, the allowance was covered by Article 4(2a) and the disability allowance was mentioned in Annex Ila of the Regulation. Case C-20/96 Snares [1997] ECR I-6057 at 30-39.

${ }^{142}$ Case 313/86 Lenoir [1988] ECR 5391 at 16.

${ }^{143}$ Case C-20/96 Snares [1997] ECR I-6057 at 51

144 Ibid, at $52-54$ 
ty in concluding that the legislator was entitled to limit the exportability of mixed benefits. ${ }^{145}$

\subsection{Social Assistance Benefits}

The judgment in Snares now seems to have definitively ended the discussions and controversies regarding the exportability of mixed minimum subsistence benefits. Residence requirements for mixed benefits are valid when the laws governing the benefits have been included in Annex IIa. The question arises whether Member States can apply residence requirements for classic social assistance benefits. Regulation No 1408/71 does not apply to such benefits and Regulation No 1612/68 does not contain an export provision comparable to Article 10 of the social security regulation. ${ }^{146}$ The case law of the Court on Regulation No $1612 / 68$, however, raises the question whether residence requirements for social assistance benefits are compatible with Article 7(2) of this regulation. As the Court ruled in Hoeckx $(1985)^{147}$, social assistance benefits are to be regarded as "social advantages" and this implies that Community workers and their dependent family members enjoy equality of treatment as regards such benefits. Yet, can they be required to establish, or keep their, residence in the State of employment?

145 The validity of Article 10a has been confirmed by the Court in Case C-297/96 Partridge [1998] ECR I-3467, Case C-90/97 Swaddling [1999] ECR I-1075 and Case C215/99 Jauch [2001] ECR I-0000. In the latter judgment the Court indicated that Article 10a, as a provision derogating from the principle of exportability, is to be interpreted strictly. More concretely, this implies that Article 10a can apply only to benefits which satisfy the conditions laid down in Article 4(2)a of Regulation No 1408/71 and which are listed in Annex IIa. Member States are not entitled to limit the exportability of any benefit by "simply" listing it in the mentioned annex. They can only do so as regards benefits which are special and non-contributory. Case C-215/99 Jauch [2001] ECR I-0000 at 20-22. On this point see also the Opinion of Advocate General Jacobs in Case C-43/99 Deaconescu (http://www.curia.eu.int/jurisp) at 59-76 and Pennings, Het Einde van de Exporteerbaarheid van Wajong-Uitkeringen?, in: MR (2000) pp.71-74. Remarkably, in the Commission's 1998 proposal (COM (1998) 779 final) for a simplication of the social security co-ordination rules one no longer finds a specific regime for mixed benefits. This would seem to suggest that the Commission has proposed re-introducing the exportability of mixed benefits again. Compare Pennings (2000) supra, at p.73.

${ }^{146}$ Altmaier, Europäisches koordinierendes Sozialrecht - Ende des Territorialitätsprinzip?, in: Eichenhofer/Zuleeg (Hrsg.), Die Rechtsprechung des Europäischen Gerichtshof zum Arbeits- und Sozialrecht im Streit (1995) pp.71-91, at p.81

${ }^{147}$ Casc 249/83 Hoeckx [1985] ECR 982 at 20-22. 
A first case to be discussed in this context is Meints (1998). ${ }^{148}$ The case concerned a German frontier worker who was working on a farm in the Netherlands and residing in Germany. Following set-aside measures taken by his employer, Mr Meints lost his job. He applied for a benefit which was made available to workers whose contract of employment has been terminated as a result of the setting aside of land by their former employer. Under the Netherlands legislation enjoyment of this special benefit was conditional upon the receipt of "normal" unemployment benefits. Since Mr Meints was wholly unemployed and not residing in the Netherlands, he could not claim the latter benefits in the Netherlands, ${ }^{149}$ and his application for the special benefit was therefore denied. Appealing that decision, Mr Meints claimed, inter alia, that the residence requirement was contrary to Article 7(2) of Regulation No 1612/68. The French and the Netherlands governments argued that residence requirements for benefits which can be classified as social advantages were valid because Article 7(2) would not provide for the possibility of exporting such advantages. The Court rejected this argument by referring to the fourth recital of the preamble to of Regulation No 1612/68 which states that the right of free movement must be enjoyed "without discrimination by permanent, seasonal and frontier workers". Frontier workers thus can invoke Article 7(2). ${ }^{150}$ The Court further held that the residence requirement in question could be more easily met by nationals than by nationals of other Member States. The requirement constituted an indirect discrimination by reason of nationality.

Hoeckx and Meints, however, do not necessarily imply that residence requirements for social assistance benefits are indeed prohibited by Article 7(2) of Regulation No 1612/68. It is settled case law that the concept of social advantages covers all advantages which are granted to "national workers because of their objective status as workers" or by "virtue of the mere fact of their residence on the national territory". Meints concerned benefits which beneficiaries enjoyed in their capacity as (former) workers and the judgment could therefore still be read so as to imply that residence requirements for benefits which are offered by virtue of residence, such as social assistance, do not violate Article 7(2). ${ }^{151}$

\footnotetext{
${ }^{148}$ Case C-57/96 Meints [1997] ECR I-6689

${ }^{149}$ See Article 71(1)(a)(ii) of Regulation No 1408/71.

${ }^{150}$ Case C-57/96 Meints [1998] ECR I-6689 at 50-51.

${ }^{151}$ Compare the Opinion of Advocate General Jacobs in Case C-43/99 Leclere (http://www.curia.eu.int/jurisp) at 98; the Opinion of Advocate General Alber in Case C-255/99 Humer (http://www.curia.eu.int/jurisp) at 86 and Sewandono, Werknemersverkeer en Gezinslcven (1998) at pp.225-226.
} 
This interpretation of the ruling in Meints, however, seems at odds with the more recent ruling in Meeusen (1999). ${ }^{152}$ The case, which will be discussed in further detail in Chapter 5, concerned a Belgian child of a Belgian frontier worker who was working in the Netherlands. Ms Meeusen, who was residing in Belgium, claimed student financial aid in the Netherlands for her studies in Antwerp. The Netherlands government argued that a person such as Ms Meeusen cannot rely on Article 7(2) because this provision is intended to promote the integration of the worker and his family in the host State. Frontier workers, however, have chosen not to establish residence in, and to become a member of the society of, the State of employment. The Court, however, reasoned that such an interpretation disregarded the wording of Regulation No 1612/68. Under reference to Meints, the Court stated that frontier workers may enjoy rights under Article 7(2) and it concluded that:

"in a situation where national legislation .. does not impose any residence requirement on the children of national workers for financing of their studies, such a requirement must be regarded as discriminatory if it is imposed on the children of workers who are nationals of other Member States". ${ }^{153}$

As with study grants, social assistance benefits can be regarded as benefits which are not granted to beneficiaries in their capacity as worker, but rather because of their residence in the national territory. A combined reading of Hoeckx, Meints and Meeusen would thus seem to lead to the conclusion that frontier workers and other workers not residing in the State of employment can rely on Article 7(2) of Regulation No 1612/68 in order to claim social assistance benefits under the same conditions as nationals of the host State. The practical significance of this conclusion, however, seems minimal. It would indeed imply that national rules which deny non-nationals social assistance benefits on the ground that they do not possess the nationality of the State in question, but the mere fact that frontier workers can rely on Article 7(2) does not necessarily imply that residence requirements equally applied to nationals and non-nationals violate this provision. Such requirements mainly affect non-nationals but they can be saved when necessary for, and proportional to, the protection of a legitimate public interest. ${ }^{154}$ Residence requirements for social assistance benefits may be regarded as a prerequisite for safeguarding the funding and organisation of social assistance schemes. Any other conclusi-

\footnotetext{
${ }^{152}$ Case C-337/97 Meeusen [1999] ECR I-0000.

153 Ibid., at 23.

${ }^{154}$ Case C-237/94 O'Flynn [1996] ECR I-2617 at 17 and 20.
} 
on is hard to compare with the Court's conclusions in Snares that benefits which are linked with the social environment can be made subject to the condition of residence in the competent State. ${ }^{155}$ The social assistance schemes of Member States are territorial systems based on a form of "membership" which has always been, and still is, defined in terms of residence on the State territory. Community law does not order any changes in this regard. Member States do not have to accept welfare responsibility for persons living outside their territory. Such persons fall within the responsibility of the State where they reside. Community citizens can claim social assistance benefits in one Member State only and the criterion of "lawful" residence determines which Member State is responsible for persons in need of such benefits. The non-exportability of minimum subsistence benefits may impinge on the right to freedom of movement, but this, as the Court held in Snares, is indeed only the result of the differences between the national social systems.

\section{Residence}

When "lawful residence" serves as the criterion assigning the State where the "needy" should obtain minimum subsistence benefits, it is of the utmost importance to establish what this notion implies. Lawful residence comprises two elements. The first concerns the legality of residence and has already been addressed. The second element involves the notion of residence itself. What does it take to establish residence in another Member State? Community law does not provide a crystal clear definition. Regulation No 1408/71 defines "residence" as "habitual residence" which is to be distinguished from "stay" which means "temporary residence" ${ }^{156}$ whilst the Court has not stated much more than that residence is the place or State where a person "habitually resides" or where the

\footnotetext{
${ }^{155}$ On this point compare the Report of the High Level Panel on the Free Movement of Persons (1998) at p.50. Further, in the recent ruling in Fahmi (2001) the Court, with reference to the preamble to Regulation No 1612/68, stressed that Article 7(2) aims to promote the free movement of workers by eliminating obstacles to the mobility of workers, in particular as regards the integration of the worker's family in the host State. The Court concluded that Article $7(2)$ cannot, as a general rule and except in special circumstances (such as e.g. in the case of Meints), be extended to workers who, after ceasing to exercise their occupational activity in the host State, have decided to return to their Member State of origin. Case C33/99 Fahmi [2001] ECR I-0000 at 47. On Fhami see further Chapter 5 Sections 3.3 .2 and 9.3.2.

${ }^{156}$ Scc Article 1(h) and (i) of Regulation No 1408/71.
} 
"habitual centre of their interests is found". ${ }^{57}$ Vague as they may be, these descriptions do reveal that residence entails more than just the place or State where an individual effectively lives. For the purposes of minimum subsistence benefits, the term residence cannot have the meaning commonly given to it. Individuals may very well live in more than one place or State, but they can claim social assistance or mixed benefits in one State only. As regards persons who live in or have ties with more than one State, a choice has to be made. "Habitual residence" may be equated with "domicile". The concept is equally elusive and whilst it often coincides with residence, it does not have an identical meaning. In legal terms, domicile is the place where a person has his principal establishment which serves to link a given act or fact to a specific legal order. ${ }^{158}$ In layterms, it is the place or State with which a person is most closely connected. ${ }^{159}$

Application of the notion of "habitual residence" is often far from easy. Consider Swaddling (1999). The case concerned the social security legislation of the United Kingdom under which eligibility for income support benefits was made conditional upon "habitual residence" in the country. The requirement was introduced in order to tackle social security abuses by Community citizens ${ }^{100}$ and to exclude in particular workseekers from such benefit schemes. Under the United Kingdom legislation, "habitual residence" implies that a claimant has a "settled purpose of establishing residence" in the country and has resided there for "an appreciable period". This definition of "habitual residence" was applied to a $\mathrm{Mr}$ Swaddling, a British national who, after having worked in France, returned to the United Kingdom in January 1995. Mr Swaddling was granted the income benefit but only from the beginning of March. For January and February the benefit was denied because during these months $\mathrm{Mr}$ Swaddling had not yet resided in the United Kingdom for an "appreciable period". The benefit Mr Swaddling had applied for was listed as a mixed benefit in Annex IIa to Regulation No 1408/71 and was thus covered by Article 10a. This implied that the United Kingdom was entitled to preserve eligibility to the benefits for residents. Yet, was Mr Swaddling to be regarded as a resident? The Court held that the phrase "the Member State

\footnotetext{
${ }^{157}$ Case C-90/97 Swaddling [1999] ECR I-0000 at 29-30.

158 See Garot, A New Basis for European Citizenship: Residence?, in: La Torre, European Citizenship: An Institutional Challenge (1998) pp.229-248, at pp.236-239.

${ }_{59}$ Reese/Green, That Elusive Word, "Residence", in: VdBiltLRev ((1953) pp.561-580, at p.562. To be sure, under national law one may often find wholly different definitions of the two terms. The descriptions given above only have significance for this Chapter.

${ }^{160}$ O'Lcary (1998) supra footnote 111 , at p.134.
} 
in which they reside" in Article 10a of the regulation refers to the State in which the persons concerned "habitually reside" or where the "habitual centre of their interests is found". In this context, account should be taken in particular of the person's family situation, the reasons which have led him to move, the length and continuity of his residence, the fact that a person is in "stable employment" and his "intention as it appears from all the circumstances". ${ }^{161}$ The Court held that the length of a person's residence could no, be regarded as an "intrinsic element" of the concept of residence. The mere fact that a person like Mr Swaddling had not resided in the country for "an appreciable period" could in itself be no reason for classing him as a non-resident and denying him the claimed benefit.

The concept of habitual residence, as Swaddling demonstrates, does not have a fixed meaning. ${ }^{162}$ It is a concept which Member States and their courts have to apply on a case-by-case basis in accordance with a number of qualitative (e.g. family situation, place of stable employment etc.) and quantative (e.g. duration of envisaged or actual residence) factors which in themselves are never decisive and which, depending on the facts of a given case, may have to be given different weight. Outcomes of individual cases are hard to predict and it is quite difficult to draw more general conclusions from the case law. Swaddling would seem to imply that work-seekers are not to be regarded as habitual residents of the host State for the purposes of social assistance laws. Until the moment they find employment, work-seekers indeed seem to have the closest ties with the State which they moved from. ${ }^{163}$ Yet, does this imply that Community citizens who have worked and live in another Member State and who, after having become unemployed, seek a new job in the host State can be classed as residents for social assistance laws? Further, in cases

${ }^{161}$ Case C-90/97 Swaddling [1999] ECR I-0000 at 30.

${ }^{162}$ Although the Court merely referred to Article 10a of Regulation No 1408/71, it may be assumed that the given definition of residence can be applied to social assistance as well

16.3 In Lebon (1987) the Court held that only workers can claim equal treatment as regards social advantages under Article 7(2) of Regulation No 1612/68. Case 316/85 Lebon [1987] ECR 2811 at 26. Recently, the Court seems to have partly come back from Lebon in Martinez Sala (1998) where it concluded that "persons genuinely seeking work must ... be classed as a worker". Case C-85/96 Martínez Sala [1998] ECR I-2691 at 32. Work-seekers now seem entitled to invoke Article 7(2) (compare O'Leary, Putting Flesh on the Bones of European Union Citizenship, in: ELRev (1999) pp.68-79, at p.76), but that conclusion merely implies that work-seekers can no longer be denied equal treatment as regards "social advantages" on grounds of their nationality (van der Steen, De Europese Burger Krijgt Handen en Voeten, in: NTER (1998) pp.163-166, at p.165). Martinez Sala does not prohibit Member States from denying work-seekers minimum subsistence benefits on the ground that they lack residence status. 
such as Reibold (1990) ${ }^{164}$ and Knoch (1992) ${ }^{165}$ the Court suggested that teachers or professors who participate in exchange programmes are not to be regarded as residents of the host State for the purposes of unemployment benefits. Without establishing a general rule, the Court seemed to have indicated that such providers of education are still to be seen, and treated, as residents of the home State because the length of employment is normally limited at the outset and the work performed is often interrupted by long holiday periods which may be spent in the State of origin. Similar arguments could be made as regards Community students. In fact, students often spend most of their time in the host State, but given the limited duration of their studies and the fact that many students spend holidays "at home", the State of origin would seem their "habitual residence". As a rule, therefore, Community students do not seem entitled to claim minimum subsistence benefits in the State of their studies. In some cases, however, this may be possible. For instance, in Grzelczyk, a case currently still pending before the Court, Advocate General Alber concluded that a French student who had earned an income as a worker during the first three years of his studies in Belgium, but ceased to do so in the last year, can claim a social assistance benefit in Belgium merely in his capacity as Community student for as long the Belgian authorities do not make use of their power to end his lawful residence. ${ }^{166}$

The determination of a Community citizen's "habitual residence" entails an assessment of facts which may vary from case to case. For this reason, it is quite understandable that the Court has refrained from giving a detailed general definition and chosen merely to enumerate a number of factors which Member States and national courts have to apply in individual cases. The result, however, is that Member States enjoy a wide margin of discretion in interpreting the notion of "habitual residence". In practice, the notion may be given quite different meanings and the danger exists that Community citizens might be denied minimum subsistence because of overly restrictive and "self-serving" interpretations of the notion of "domicile". In "the spirit of juridical justice", ${ }^{167}$ it would be desirable if the Court, when given the opportunity, were to provide further clarification and guidance.

\footnotetext{
${ }^{164}$ Case C-216/89 Reibold [1990] ECR I-4163.

${ }^{165}$ Case C-102/91 Knoch [1992] ECR I-4341.

106 Case C-184/99 Grzelczyk (http://www.curia.eu.int/jurisp) at 125. A student as Grzelczyk may, however, still hold the status of Community worker. See footnote 66 .

${ }^{167}$ Garot (1998) supra footnotc 158, at p.239.
} 


\section{$7 \quad$ Third Country Nationals}

Community provisions on the free movement of persons and the coordination of social security schemes apply in principle only to Community citizens. ${ }^{168}$ Third country nationals can only claim minimum subsistence benefits under these provisions when they can be classed as a family member of a Community citizen who has established residence in another Member State. The exclusion from the free movement and social security regime does not imply, however, that Community law has nothing to offer "needy" nationals of third countries. Third country nationals enjoy social rights under various agreements which the Community and its Member States have concluded with third States. This section explores whether, and if so, the conditions under which, third country nationals can claim minimum subsistence benefits under the Agreement on the European Economic Area (EEA), the EC-Turkey Association Agreement and the agreements which have been concluded with the Maghreb countries (Morocco, Algeria and Tunisia). ${ }^{169}$

\subsection{EEA Nationals}

The EEA Agreement aims to promote a continuous and balanced strengthening of trade and economic relations between (Member States of) the

\footnotetext{
${ }^{168}$ See Chapter 2 Sections 5 and 6. The Commission, however, has proposed to bring third country nationals within the ambit of the Regulation No 1408/71. COM(97) 561 final and $\operatorname{COM}(1998) 779$ final.

169 For (brief) descriptions of these agreements and the relevant free movement and/or equal treatment provisions, see Chapter 2 Section 5. This Section does not discuss the possible implications for minimum subsistence benefits of the judgment of the European Court of Human Rights in Gaygusuz (Judgement of 16 September 1996, Case No 39/1995/545/631). In this case Austria was condemned for rejecting the application of a Turkish national for emergency assistance for unemployed persons on the ground of his nationality. In brief, the Strassbourg court concluded that the Austrian rejection was in breach of Article 14 of the European Convention (non-discrimination principle) read in conjunction with Article 1 of the first Protocol to the Convention (the right to property). Fundamental rights such as those contained in the European Convention are, as general principles of law, also protected by Community law (see Chapter 2 footnote 237), but so far there are no indications that Gaygusuz has any (indirect) implications for Community rules governing freedom of movement and entitlement to non-contributory benefits such as minimum subsistence benefits. On Gaygusuz see Verschueren, EC Social Security Coordination Excluding Third Country Nationals: Still in Line with Fundamental Rights after the Gaygusuz Judgment?, in: CMLRev (1997) pp.991-1017 and the various contributions in Van den Bogaert (Ed.), Social Security, Non-Discrimination and Property (1997).
} 
European Community, on the one hand, and Norway, Iceland and Liechtenstein, on the other hand. ${ }^{170}$ In order to achieve these objectives, the Agreement has extended the scope of the common market freedoms to the nationals and the territories of the three countries concerned. Article 28 of the Agreement applies to the free movement of workers and is phrased similarly to Article 39 of the EC Treaty. The secondary legislation adopted under Article 40 of the Treaty, including Regulation No 1612/68, has been integrated into the EEA Agreement. Further, Article 29 EEA largely reproduces Article 42 EC and Regulations No 1408/71 and No $574 / 72$ have been made applicable to EEA nationals. ${ }^{171}$ In as far as the free movement of workers is concerned, the legal status of the nationals of the three States and their family members under the EEA Agreement is in principle identical to the status of the category of the economic residents discussed in Section 3. Thus, when the work they perform in another EEA State is classed as "effective and genuine", EEA workers and their dependent family members are eligible for minimum subsistence benefits under the same conditions as the nationals of the host State from the moment they take up residence in that State. It is not certain whether the same conclusion can be drawn as regards economically inactive EEA nationals ${ }^{172}$ who have established residence in another EEA State. The three residence directives of 1990 for students, pensioners and "other" Community citizens have been extended to EEA nationals and Article 4(1) EEA contains a non-discrimination clause phrased similarly to Article 12(1) EC. It could be argued that "needy" EEA nationals who are lawfully residing in another EEA State can invoke Article 4(1) EEA in order to claim equal access to minimum subsistance benefits in the host State. Uncertainty exists, however, because the EEA agreement does not provide for an equivalent of European Union citizenship. The reasoning followed by the Court in Martinez Sala, and the conclusions drawn in Section 4, cannot be automatically transposed to EEA nationals.

\subsection{Maghreb Nationals}

Neither the 1978 Maghreb agreements nor the more recent Euro-Mediterranean agreements which the Community and its Member States have

\footnotetext{
${ }^{170}$ Article 1 EEA.

${ }^{171}$ OJ 1994 L 1. See further Sakslin, The Agreements on the European Economic Area, in: Jorens/Schulte (Eds), European Social Security Law and Third Country Nationals (1998) pp.399-417.

${ }^{172}$ The same holds true for the independent family members of EEA workcrs.
} 
concluded with Tunisia and Morocco confer upon Maghreb nationals a right to freedom of movement. However, the various agreements do contain a number of provisions on social security. ${ }^{173}$ The first paragraph of Article 65 of the Euro-Mediterranean agreement with Morocco, which replaced Article 41(1) of the original co-operation agreement, offers Moroccan nationals who are residing in one of the EC Member States a right to equal treatment in the field of social security. The subsequent three paragraphs grant Moroccan nationals a right to aggregation of insurance, employment or residence periods for various social security benefits, a right to family allowances for family members residing within the Community and a right to transfer old-age pensions to Morocco. Article 42 states that the Cooperation Council shall adopt measures implementing the principles set out in Article 41. Virtually identical provisions are found in Articles 39 and 40 of the Agreement with Algeria and Articles 65 and 67 of the Euro-mediterranean agreement with Tunisia. What do the above provisions entail for Maghreb nationals who wish to obtain social security benefits, and minimum subsistence benefits in particular, in the Member State in whose territory they reside? For quite some time it seemed that Maghreb nationals could not enjoy any rights under the social security provisions. The Co-operation Councils established by the respective agreements have not taken any implementing measures. ${ }^{174}$ The social security provisions seemed nothing but "dormant provisions" lacking legal and practical significance. Since the early 1990s, however, the Court of Justice has breathed life into these provisions in cases such as Kziber ${ }^{175}$ (1991), Yousfi ${ }^{176}$ (1994) and Krid ${ }^{177}$ (1995).

Kziber concerned a Moroccan national who lived in Belgium with her Moroccan parents and who, for reasons of her nationality, had been refused an unemployment benefit for young workers who have just completed their studies. In order to determine whether the refusal was compatible with Article 41(1) of the Morocco co-operation agreement, the Court first had to determine whether this provision has direct effect. The Court ruled that this Article can indeed be directly relied upon. It held

\footnotetext{
${ }^{173}$ For a brief overview see Chapter 2 Section 5.3 and Section 6.

174 Recently, however, proposals for social security measures have been made in the context of the Euro-Mediterranenan agreements with Morocco (http://europa.eu.int/eur-lex) and Tunisia (COM(2000) 216 def).

${ }^{175}$ Case C-18/90 Kziber [1991] ECR I-199. On this judgment see e.g. Vonk, Het HvJEG-arrest in de zaak Kziber - Een Levenskus voor de Slapende Paragrafen in de EGSamenwerkingsovereenkomsten, in: MR (1991) pp.149-151.

${ }^{176}$ Case C-103/93 Yousfi [1994] ECR I-1353.

${ }^{177}$ Case C-103/94 Krid [1995] ECR 1-719.
} 
that Article 41(1) lays down a clear, precise and unconditional prohibition of discrimination on grounds of nationality and that the direct applicability of this provision cannot be made conditional for the sole reason that Article 42 envisages implementing measures to be adopted by the Cooperation Council. ${ }^{178}$

The second question the Court had to answer in Kziber concerned the precise meaning of the term "social security". The Court held that this term "must be understood by means of analogy with the identical concept in Regulation No 1408/71". Since Article 4(1) of this Regulation includes unemployment benefits in the scope of the Regulation, the Court held that the benefits Ms Kziber had applied for were also covered by Article 41(1) of the Morocco agreement. ${ }^{179}$ In Yousfi (1994) the Court was confronted with the question whether mixed minimum subsistence benefits are also covered by Article 41(1). The case concerned the Moroccan son of a Moroccan worker living Belgium who after an accident at work applied for a disability allowance. This mixed benefit was denied on the ground of Yousfi's nationality. Disability allowances were initially not mentioned in Article 4(1) of Regulation No 1408/71, but, as described earlier in this chapter, the Court had already concluded that benefits can be regarded as being covered by the Regulation when the legislation under which they are granted places claimants in a legally defined position as a result of which they have an absolute right to benefit and the benefits cover one of the risks enumerated in Article 4(1). ${ }^{180}$ The disability allowance $\mathrm{Mr}$ Yousfi had applied for met these conditions and, following the rule established in Kziber, the Court therefore concluded that such benefits therefore fell within the scope of Article 41(1) of the Morocco agreement. ${ }^{181}$ In Krid the Court concluded that a widow of an Algerian wor-

178 Ibid, at 16-23. The Court confirmed this conclusion in Case C-58/93 Yousfi [1994] ECR I-1353 at 19. The identically phrased provision contained in Article 39 of the Algeria agreement is, as the the Court held in Krid (Case C-103/94 [1995] ECR I-719 at 23-24) also directly applicable. One may safely assume that the same holds true for provision in in the Euro-Mediterranean Agreements with Morocco and Tunisia.

${ }^{179}$ Case C-18/90 Kziber [1991] ECR I-199 at 25-26. In the proceedings before the Court it had been argued that unemployment benefits would not be covered by Article 41(1) because Article 41(2) (aggregation rule) does not apply to unemployment benefits and no unemployment insurance scheme exists in Morocco. The Court, however, reasoned that the fact that Article 41(2) does not mention unemployment benefits is merely relevant for the application of the aggregation rule; it cannot warrant the conclusion that such benefits are excluded from the term "social security" in Article 41(1) of the Agreement. Case C-18/90 Kziber [1991] ECR I-199 at 26.

${ }_{180}$ See Section 2.3 above.

${ }^{181}$ Casc C-103/93 Yousfi [1994] ECR I-1353 at 28. 
ker in Belgium could be denied a supplementary allowance which was, inter alia, granted to recipients of old-age pensions or invalidity benefits who lack sufficient means of subsistence on grounds of her nationality. The allowance was a mixed benefit in the sense of Article 4(2)a of Regulation No $1408 / 71$, as inserted by Regulation No 1247/92. The latter regulation had already came into force at the time Ms Krid applied for the allowance. Therefore, the Court did not have much difficulty in concluding that the allowance was also to be considered as a social security benefit for purposes of Article 39(1) of the agreement with Algeria. ${ }^{182}$

The non-discrimination provisions enshrined in the social security provisions of the cooperation agreements may thus be directly relied upon in court and the material scope of these provisions coincides with the scope of Article 3 of Regulation No 1408/71. This did not imply, however, that the applicants in the three cases could indeed invoke the provisions. The social security provisions apply to workers of Moroccan, Algerian or Tunisian nationality and family members living with them. In Yousfi the Court held that the term "workers" encompasses "both active workers and those who have left the labour market after reaching the age required for receipt of an old-age pension or after becoming victims of the materialisation of one of the risks creating entitlement to allowances falling under other branches of social security". ${ }^{183} \mathrm{Mr}$ Yousfi, who had become incapable of working after an accident at work, could be classed as a worker for the purposes of Article 41(1). ${ }^{184}$ The claimants in Kziber and Krid, however, were not workers but family members of workers. In both cases it was argued by governments represented in the proceedings before the Court that, by analogy with the "Kermaschek-rule" adopted by the Court under Regulation No 1408/71, the applicants could only enjoy derived rights as family members. The unemployment benefits for young workers in Kziber and the supplementary allowance for old people in Krid would have to be classified as "personal rights" which could be denied to applicants. In his Opinion in Kziber Advocate General van Gerven agreed with this line of reasoning. In his view it could not be accepted that family members of Moroccan workers could possibly enjoy more extensive rights than family members of Community workers residing in other Member States. ${ }^{185}$ The Court, however, took another view. In Kziber it simply held that family members of Moroccan workers who fulfil the

\footnotetext{
${ }^{182}$ Case C-103/94 Krid [1995] ECR I-719 at 37.

${ }^{183}$ Case C-58/93 Yousfi [1994] ECR I-1319 at 21.

184 Ibid, at 23.

${ }^{185}$ Opinion of Advocate General van Gerven in Case C-18/90 Kziber [1991] ECR I-199
} at 18 . 
requirements for entitlement to (unemployment) benefits may not be refused such benefits on the ground of their nationality. ${ }^{186}$ In Krid the Court reached a similar conclusion and, after referring to the text of Article 39(1) of the Algeria agreement, it stated that the personal scope of this provision is not the same as the scope of Regulation No 1408/71. Therefore, the Kermaschek case law "distinguishing between derived rights and the personal rights of members of the migrant workers' families .. cannot be applied in the context of the Agreement". ${ }^{187}$

Workers who hold the nationality of one of the three Maghreb countries and members of the family who are living with them, ${ }^{188}$ thus enjoy a right to claim minimum subsistence benefits which are covered by Regulation No 1408/71 under the same conditions as the nationals of the host State. ${ }^{189}$ This is not to say that nationals of the Maghreb countries are in an equally privileged position with Community citizens. ${ }^{190}$ First,

\footnotetext{
${ }^{186}$ Case C-18/90 Kziber [1991] ECR I-199 at 28.

187 Case C-103/94 Krid [1995] ECR I-719 at 39. See also Case C-126/95 Hallouzi-Choho
} [1996] ECR I-4807 at 30 and Case C-113/97 Babahenini [1998] ECR I-183 at 24. In Kziber and Krid the Court thus accepted that family members of Maghreb workers may indeed enjoy more extensive rights than family members of workers holding the nationality of a Member State. This could already be seen as a sign that the Court was "preparing" itself for the conclusion in Cabanis-Issarte (1996 - see Chapter 2 Section 6) that the distinction between derived rights and personal rights should no longer or at least be less relevant for the legal status of family members of European workers under Regulation No 1408/71. Compare Jorens, De Rechtspositie van Niet-EU-Onderdanen in het Europees Socialezekerheidsrecht (1996) at pp.326-327.

${ }_{188}$ Article 41(1) of the Morocco agreement and the equivalent provisions of other Maghreb agreements do not define the term "family members living with them". The Court has held, however, that the term not only covers spouses and children but also relatives in the ascending line who are living with the worker in the host State. Case C-179/98 Mesbah [1999] ECR I-0000 at 43-48. Family members who have installed themselves with the worker in the host State after the latter has acquired the nationality of the host State, however, are not entitled to benefit from Article 41(1). This conclusion does not differ where the worker still possesses a Maghreb nationality. Ibid, at 41 .

189 So far the Court has not explicitly determined whether the prohibition enshrined in the non-discrimination provisions also covers indirect discrimination by reason of nationality. Kziber and subsequent cases suggest, however, that the Court draws inspiration from the Community provisions on freedom of movement, and equality of treatment in particular, while interpreting the Maghreb provisions. It could thus be argued that durational residence or employment requirements for mixed benefits are also at odds with provisions in the Maghreb agreements.

${ }^{190}$ In one respect, however, Maghreb nationals are in a more priveliged position than Community citizens. It is settled case law that Regulation No 1408/71 replaces social security conventions previously concluded by the Member States, even where these conventions are more favourable for beneficiaries than Regulation No 1408/71. See Chapter 2 footnote 208. The Maghreb agreements, however, cannot affect rights enjoyed under agree- 
Maghreb nationals do not seem to enjoy equality of treatment as regards the classic social assistance benefits. Such benefits are excluded from Regulation No 1408/71 and, thus, the social security provisions of the Maghreb agreements. The latter agreements do not contain clauses comparable to those contained in Article 7(2) of Regulation No $1612 / 68^{191}$ or Article 12 of the EC Treaty, into which a right to equal treatment as regards social assistance benefits could possibly have been read. Second, the agreements do not confer upon Maghreb nationals a right to reside in the State of employment. ${ }^{122}$ Being in need of minimum subsistence benefits can be a reason for refusing Maghreb nationals a work and residence permit or withdrawing such permits. ${ }^{193}$

\subsection{Turkish Nationals}

Article 12 of the 1963 Association Agreement between the European Community and Turkey provides that the Contracting Parties agree to be guided by Articles 39 (formerly 48) et seq of the EC Treaty for the purpose of progressively realising a free movement of workers between them. So far, however, the EC-Turkey Association Council has not yet adopted all necessary measures. Up until today, it is for the Member States to decide whether Turkish nationals are admitted to their labour market and territory. ${ }^{194}$ Once admitted to a national labour market, however, Turkish workers enjoy various rights. Decision No $1 / 80$ of the Association Council grants Turkish workers (Article 6) and their family members (Article 7) employment rights which enable them to gradually

ments Member States have concluded with Maghreb countries. See e.g. Article 68 of the Euro-Mediterranean Agreement with Morocco and Jorens, Non-European Union Nationals and the Co-ordination of European Social Security Law: The International Agreements Concluded by the European Union with Third Countries and Conflict Rules in European Social Security Law, in: Jorens/Schulte (Eds), European Social Security Law and Third Country Nationals (1998) pp.1-110, at pp.12-13.

191 Compare the Opinion of Advocate General van Gerven in Case C-18/90 Kziber [1991] ECR I-199 at 19.

${ }^{192}$ See e.g. Case C-416/96 El-Yassini (1999) ECR I-0000. See further Chapter 2 footnote 204.

193 The situation might be different where a Member State has voluntarily granted a Maghreb national a work permit the duration of which exceeds the accompanying residence permit. In such a situation a Maghreb national can claim a right to reside until the expiration of the period for which the work permit is granted (Case C-416/96 El-Yassini (1999) ECR I0000 at 64-66) and, during this period, probably also a right to claim equality of treatment as regards mixed benefits.

${ }^{194}$ Chapter 2 Section 5.3 . 
integrate in the labour market of the host State and which encompass rights of residence. ${ }^{195}$ In addition, Turkish nationals enjoy rights in the field of social security. In furtherance of Article 39 of the Additional Protocol of 1970, in 1980 the Association Council adopted Decision No $3 / 80$ on the application of social security schemes to the benefit of Turkish workers moving between the Member States of the Community. By analogy with the provisions of Regulation No 1408/71, Decision No $3 / 80$ aims to avoid Turkish workers losing certain social security rights when they decide to move to another Member State. ${ }^{196}$ The Decision provides for a right to equal treatment in social security matters (Article 3 ), a right to export certain benefits (Article 6) and it extends the application of most rules determining the applicable legislation contained in Articles 13 et seq of Regulation No 1408/71 to Turkish workers (Article 9). For the most part, the provisions of Decision No $3 / 80$ refer to provisions of Regulation No $1408 / 71$ and, less frequently, to Regulation No 574/72.

Until recently, however, Decision No $3 / 80$ did not have any practical significance for Turkish workers who wished to claim minimum subsistence benefits or other social security rights in the host State. In order to be implemented, decisions of the Association Council require a unanimous decision of the Councilon the part of the Community. In 1983 the European Commission had submitted a proposal for such a decision to the Council, but this proposal has not been adopted. ${ }^{197}$ Two quite recent judgments of the Court demonstrate, however, that Decision No 3/80 does have legal effect. The first was the one in the Taflan-Met (1996) ca$\mathrm{se}^{198}$. Ms Taflan-Met and two other Turkish widows had applied for widows pensions in the Netherlands where their former husbands had worked. The Dutch social security system is based on risk which implies that insured persons or their survivors are only entitled to receive benefits when the insured risk materialises at a time when the insured is covered

195 See e.g. Case C-171/95 Tetik [1997] ECR I-329 at 24; Case C-237/91 Kus [1992] ECR I-6781 at 27-36 and Case C-355/93 Eroglu [1994] ECR I-5113 at 20 and 23.

${ }^{196}$ For more extensive descriptions of the Decision see e.g. Centel, The Social Security of the Turkish Workers in Europe within the Framework of the Association Agreement, in: Jorens/Schulte (Eds), European Social Security Law and Third Country Nationals (1998) pp.281-297 and Hänlein, Problems Concerning Decision No 3/80 of the Council of Association - A Point of View from a EU Perspective, in: Jorens/Schulte (Eds), European Social Security Law and Third Country Nationals (1998) pp.299-322.

${ }^{197}$ The reason for this is that Greece, which became a Member State a few weeks after the adoption of Decision No 3/80, was not willing to agree to any decision in favour of Turkey. See Hänlein (1998) supra previous footnote, at p.305.

${ }^{198}$ Casc C-277/94 Taflan-Met [1996] ECR I-4085. 
by the Netherlands legislation. The husbands of the three widows, however, had died in Turkey and the pensions were therefore denied. The Court of Justice was asked to determine whether the refusal to grant the pensions was compatible with a number of provisions of Decision No $3 / 80$. It ruled that the binding effect of the decision of the Association Council could not depend on any implementing measures. In the absence of a provision on the date of the coming into force of the Decision, the Court held that Decision No 3/80 was supposed to have come into force on the day the decision was adopted, i.e. 19 September $1980 .{ }^{199}$ This conclusion, however, did not help the Turkish widows very much. The Court concluded that the specific provisions they had relied upon were not directly effective. In reaching this conclusion the Court drew a comparison with Regulation No 1408/71 and its implementing Regulation No $574 / 72$. The Court held that the main principles set out in the former Regulation could only have been given practical effect because of the procedures and formalities contained in the latter Regulation. The coming into force of Regulation No 574/72 was thus a prerequisite for the enforcement of the rights enshrined in Regulation No 1408/71. The Commission's proposal of 1983 does contain implementing measures comparable to ones contained in Regulation No 574/72, but for as long as this proposal has not been adopted, the provisions of Decision No 3/80 could not, according to the Court, be enforced in court. ${ }^{200}$

After Taflan-Met Decision No $3 / 80$ seemed a "walking corp$\mathrm{se}^{\prime \prime}{ }^{201}$ the decision had come into force but in the absence of any implementing measure its provisions could not be applied. The reasoning $^{202}$ and the conclusion of the Court in Taflan-Met, however, was not persuasive. As regards certain rights which require the co-operation of social security institutions, such as rights concerning the aggregation of insurance periods, implementing measures may be necessary for their enforcability. This does not seem to be the case, however, for other rights

\footnotetext{
199 Ibid, at 21.

$200 \mathrm{Ibid}$, at 31-37. On Taflan-Met see e.g. Bulterman, Annotation Taflan-Met, in: CMLRev (1997) pp.1497-1507; Peers, Equality, Free Movement and Social Security, in: ELRev 91997) pp.342 et seq; Verschueren, Na het Arrest Taflan-Met: Is er Leven na de Dood? - Besluit 3/80 (Sociale Zekerheid) van de Associatieraad EEG-Turkije Bestudeerd, in: MR (1997) pp.29-34, at p.30 and Zuleeg, Das Urteil Taflan-Met des Europäischen Gerichtshofs, in: ZIAS (1997) pp.170 et seq.

${ }^{201}$ Verschueren (1997) supra previous footnote, at p.33.

${ }^{202}$ Hänlein has criticised the Court's reasoning on the ground that Decision No $3 / 80$ itself refers to the most relevant implementing provisions of Regulation No 574/72. Hänlein, Fehlende unmittelbare Wirkung der Bestimmungen des Assoziationsratsbeschlusses EWGTürkei über 'Invalidität' und Renten bei 'Alter und Tot', in: EASr (1997) pp.21-23.
} 
guaranteed by Decision No $3 / 80$ such as, in particular, the right to equal treatment. Article 3 contains a non-discrimination provision which is phrased in similar terms to Article 3 of Regulation No 1408/71. Why would Turkish nationals be denied the right to invoke this non-discrimination provision in court? This question was addressed by the Court in Sürül (1999). ${ }^{203}$ The case concerned a Turkish women who had been authorised to reside in Germany with her Turkish husband who was studying and working there. After the birth of their child, Mrs Sürül was given family allowances as well as a supplementary allowance for persons with a low income. The competent social security institution, however, terminated payment of the family allowances on the ground that Mrs Sürül could no longer produce a residence entitlement or permit. Mrs Sürül, who only possessed an "accessory residence authorisation", challenged that decision in court. The German court referred the case to the Court of Justice asking whether the refusal to grant family allowances was compatible with Article 3 of the Decision. The Court held that the reasoning followed in Taflan-Met merely applied to provisions of Decision No $3 / 80$ which actually require additional measures for their application in practice. The application of the non-discrimination principle embodied in Article 3(1) of the Decision, however, does not raise problems of a technical nature as is the case with the rules concerning aggregation of insurance periods or the rules for determining the applicable legislation. ${ }^{204}$ The Court held that Article 3 of Decision No $3 / 80$ is a precise and unconditional provision which does not require any additional measures in order to be directly relied upon in national courts. ${ }^{205}$ As to Mrs Sürül's substantive claim, the Court held that if she could be classed as a worker or a family member of a worker for the purposes of Decision No $3 / 80$, as a Turkish national who has been authorised to reside, and actually resides, in the host Member State she could not be denied social security benefits such as family allowances on the ground that she only held a conditional residence authorisation. A national rule which makes eligibility for social security benefits subject to the possession of a residence permit covers, by its very nature, only non-nationals and is thus caught by the non-discrimination provision of Article 3(1) of Decision No

\footnotetext{
${ }^{203}$ Case C-262/96 Sürül [1999] ECR I-0000. On this judgment see e.g. Peers, Social Security Equality for Turkish Nationals, in: ELRev (1999) pp.627-637; Pennings, Het Arrest Sürül: Een Arrest dat Knaagt aan de Koppelingswet, in: SMA (1999) pp.442-450 and Verschueren, The Sürül Judgment: Equal Treatment for Turkish Workers in Matters of Social Security, in: EJML (1999) pp.371 et seq.

${ }^{204}$ Case C-262/96 Sürül [1999] ECR I-0000 at 54-57.

${ }^{205} \mathrm{Ibid}$, at 74
} 
$3 / 80 .^{206}$

It follows that Article 3(1) of Decision No 3/80 produces direct effect. Although the Court did not set out a general rule for interpreting (the scope of the) Decision, it would seem that, since the date of the Sürül judgment, ${ }^{207}$ Turkish nationals who are lawfully residing in the territory of a Member State and as workers or family members of workers covered by Decision No $3 / 80$, are entitled to claim equal access to all benefit schemes falling within the scope of Regulation No 1408/71 including mixed benefit schemes. Sürül, however, leaves a number of questions unanswered. For instance, are Turkish nationals entitled to equality of treatment as regards the classic social assistance benefits? Such benefits are not covered by Regulation No 1408/71 and, thus, Decision No 3/80. Article 9 of the 1963 Association Agreement, however, contains a general non-discrimination clause which prohibits discrimination on grounds of nationality "in accordance with the principle laid own in Article 7 of the EEC Treaty" (now Article 12 EC). Even though no "Turkish equivalent" of Article 7(2) of Regulation No 1612/68 exists, the possibility cannot be excluded that the afore mentioned Article 9 might cover "social advantages". ${ }^{208}$ Further, does the being in need, or enjoyment, of minimum subsistence benefits affect the right of Turkish nationals to reside in the host State? The Court has never answered this question, but on the basis of existing case law one could conclude that Member States are entitled to deny "needy" Turkish nationals the right to establish residence in their territory, but that those who have been admitted are entitled to retain their residence right when, and for as long as, they continue to satisfy the conditions laid down in Articles 6 or 7 of Decision No 1/80. These provisions directly confer precise and unconditional rights upon Turkish nationals which cannot be made conditional upon additional requirements imposed by the host State. ${ }^{209}$

${ }^{206} \mathrm{Ibid}$, at 101-105.

${ }^{207}$ The Court time-limited the effect of its judgment. In principle, Article 3(1) of Decision No $3 / 80$ can only be relied upon in support of claims relating to benefits in respect of periods prior to the date of the judgment (i.e. 4 May 1999). Case C-262/96 Sürül [1999] ECR I-0000 at 106-113.

${ }^{208}$ See Peers (1999) supra footnote 200, at p.635.

${ }^{209}$ Compare Casc C-36/96 Günaydin [1997]I-5143 at 39 and 40. 


\section{Conclusions}

In Section 1 the goal was set to establish the degree to which Community law entitles individuals who are not able to provide for themselves to move to, and to obtain minimum subsistence benefits in, other Member States. This chapter has demonstrated that the legal status of the "needy" has been strengthened in the last three decades. At the end of the 1960s it was still wholly up to the Member States to decide whether "needy" nationals of other States would be admitted for residence in their territory and, if so, whether they would be offered minimum subsistence benefits. Today, the legal status of "needy" nationals of third countries is fragmented and in many respects still not very well developed, but nationals of Member States have acquired a right to equal to treatment as regards eligibility for minimum subsistence benefits when, and for as long as, they are lawfully domiciled in another Member State. The Court of Justice, which has largely been responsible for this progress, however, has not ignored the financial interests of Member States. It has accepted the validity of rules which limit entitlement to minimum subsistence benefits to Community citizens residing (or domiciled) within their borders and, in brief, it has allowed Member States to deny residence/domicile in their territory to nationals of other Member States who do not perform "effective and genuine" work and who are unable to provide for themselves and their families.

The fact that the Court has had regard to the financial concerns of the Member States may be understandable, but, as it stands today, Community law in the field under examination is not free from criticism. Article 18(1) EC confers upon all citizens of the European Union the fundamental non-economic right to establish residence in any Member State. For many Union citizens who are in need of minimum subsistence benefits, however, this right lacks practical relevance. Union citizenship is a political rather than an economic concept which only has limited meaning for as long as some citizens are denied the right to freedom of movement because of their economic status. ${ }^{210}$ The question arises whether, and if so, how, the legal status of "needy" Union citizens could possibly be improved. Is it possible to realise, or to move closer to, a general right of residence without seriously undermining the funding of minimum subsistence benefit schemes? Before attempting to answer the question, it is useful to first take a look at American constitutional law. As noted in the introductory section, the United States Constitution

${ }^{210}$ Comparc O'Lcary (1996) supra footnote 93, at p.99. 
guarantees a right to travel which includes both a right to cross the interState boundaries and a right to reside freely in any of the States. Does this right also apply to those who are in need of welfare benefits, and if so, does it also include a right to claim such benefits in other States? How has American Constitutional law settled the conflict between the "free movement interest" and the "welfare interest"? What lessons are there to be learned for the European Community?

\section{$9 \quad$ The United States}

\subsection{The American Welfare System: A Brief Introduction}

American constitutional law on cross-border access to welfare is to be placed against the background of the history and the structure of the American welfare system. The roots of the system can be traced back to the Elizabethan Poor Laws adopted in the early 1600s in England. ${ }^{211}$ Like the Poor Law system, the original American welfare system was essentially local in character. Not the Federal government, but State and local governments bore the responsibility for handling the problem of poverty. In fact, "the" welfare system consisted of a large number of seperate and independent welfare systems. These were not social systems in the sense that they reflected a solidarity of the "rich" with the "poor". The poor were regarded as a "moral pestilence"; welfare was merely offered in order to protect the elite from beggary, crime and other problems the poor were associated with.

The Great Depression of the 1930s demonstrated the inadequacies of the local structure of the welfare system. Tax revenues decreased whilst the number of people in need of public assistance increased. About four million people, most of them indigents, ${ }^{212}$ "tried to seek their luck"

\footnotetext{
211 On the English origins of the American welfare system see e.g. Camissa, From Rhetoric to Reform? - Welfare Policy in American Politics (1998) Chapter 2; Trattner, From Poor Law to Welfare State: History of Social Welfare Law in America (1989); tenBroek, California's Dual System of Family Law: Its Origin, Development and Present Status, in: StanfLRev (1964) pp.257 et seq; Mandelker, The Settlement Requirement in General Assistance, in: WashULQ (1955) pp.355-377 and Riesenfeld, The Formative Era of American Public Assistance Law, in: CalLRev (1955) pp.175 et seq.

${ }^{212}$ Adams, State Control of Interstate Migration of Indigents, in: MichLRev (1942) pp.711-733, at p.713.
} 
in other States. This enormous flow of indigents across the inter-state borders constituted visible proof for the view that poverty was no longer a problem which State and local governments could solve individually. It had become a national problem which called for a national solution. Furthermore, it was recognised that the poor could no longer be regarded as a "moral pestilence"; they were rather seen as victims of the economic recession who lacked financial means due to circumstances beyond their control. Federal participation was required to guarantee that every person had an income sufficient for at least the essential needs of life. These new perceptions on poverty and welfare were expressed in the New Deal politics and ultimately resulted in the Social Security Act of $1935 .{ }^{213}$ The Act's title on Public Assistance introduced welfare programmes for four categories of indigents: the aged, the blind, the disabled and dependent children. Indigents not falling within one of these "categorical" assistance programmes were left to the traditional general welfare programmes which remained wholly within the responsibility of the States. The Social Security Act did not federalise welfare in the sense that the programmes were organised, administered and financed by Federal authorities. The States remained the central governmental entities in the field. The Act also did not oblige States to develop or to improve welfare programmes. Its purpose was to encourage the States to provide new and enhanced welfare programmes by making available federal financial aid for States participating in the program. Federal funding, which itself was financed by a tax introduced by the Social Security Act and made available in the form of matching grants (i.e. subsidies that are contigent upon the amount States have decided to spend on welfare), was made subject to detailed requirements. In brief, the Federal authorities determined which categories of people were to be eligible for public assistance; the States set the level of the benefits. ${ }^{214}$ The programmes were "major experiments in "cooperative federalism", .. combining state and federal participation to solve the problems of the depression". 215

The complex system of cooperative federalism introduced by the Social Security Act was partially simplified in 1973 by the Supplemental

${ }^{213}$ Social Security Act, 49 Stat. 620 (1935). The power to adopt the Act derived from Article I Section 8 of the Constitution which grants Congress the power to provide for the "general Welfare" of the United States. For a discussion of the structure and administrative operation of the social security system see e.g. Wedemeyer/Moore, The American Welfare System, in: tenBroek, The Law of the Poor (1966) pp.2-33 and LaFrance, Welfare Law: Structure and Entitlement (1979).

${ }^{214}$ Dandridge v Williams, 397 US 471 (1970).

${ }^{215}$ Shapiro v Thompson, 394 US 618 (1969) at 645 (Chief Justice Warren, dissenting). 
Security Income Program (SSI) adopted by Congress. SSI federalised three of the four categorical programmes; the most important, Aid for Families with Dependent Children (AFDC), was excluded. The administration and funding of the three programmes were brought under the sole responsibility of the Federal authorities. The SSI program introduced a nation-wide uniform benefit level for the aged, blind and disabled. ${ }^{216}$ States no longer played a role in the provision, administration and financing of these three programmes. Further, in response to the growing concerns about the (federal) financing of the welfare system, the welfare system was significantly altered in 1996 by the Personal Responsibility and Work Opportunity Act (PRWORA). The Act has replaced the AFDC program by the Temporary Assistance for Needy Families (TANF) which has eliminated the federal entitlement to welfare benefits, replaced the original matching grants for the States by block grants (i.e. lump sum payments) and limited the receipt of benefits to a maximum duration of two years. TANF implies a decentralisation of the welfare system. Much more then under the AFDC program, State are free to determine whether, and if so, under which conditions benefits are made available. ${ }^{217}$

The current American welfare system provides for three different types of welfare programmes. The first, SSI, is administered and financed by the Federal authorities. It guarantees the aged, the blind and the disabled a universal annual income. The second type, TANF (the former AFDC), is partly financed by the Federal government but falls under the responsibility of the States. The third concerns the general assistance programmes (or "Home Relief"). These programmes serve as a safety net for all those indigents who are not eligible for benefits under one of the other programmes. They are purely local in character, the Federal authorities do not administer or fund these programmes. This section examines constitutional law with regard to cross-border access to TANF- (and AFDC-)benefits as well as general social welfare benefits. ${ }^{218}$ The SSI-

\footnotetext{
${ }^{216}$ LaFrance (1979) supra footnote 213, at p.22.

${ }^{217}$ See Camissa (1998) supra footnote 211, at pp.117-122.

218 The level of welfare benefits is by comparison with many of the European systems relatively low. For instance, the average AFDC benefit for a family with three children in 1988 was $\$ 501$. This amounted to 63 per cent of the poverty line. For further figures see Peterson/Rom, Welfare Magnets (1990). The variation between benefit levels in the different States has historically been wide. Taking into consideration the differences in living costs, the benefit level in the most generous States was approximately five times as high as in the least generous States. Center on Social Policy and Law, Living at the Bottom: An Analysis of AFDC Benefit Levels (1993) at p.25 and Peterson/Rom (1991) supra at pp.6-10. In addition to the social welfare benefits, indigents may enjoy a number of "in-kind" benefits such as medical care (see further Chapter 4 Section 5.1), public housing and Food Stamps.
} 
benefits are not included in the discussion as the conflict between the "free movement interest" and the "public facilities interest" does not arise under this federal program.

\subsection{Conditions of Access}

The States' policies regarding cross-border access to their welfare programmes have always been aimed at preserving benefits for the States' own citizens. ${ }^{219}$ Non-residents have been denied welfare; residence in the State is a prerequisite for eligibility for welfare benefits. In addition, States have always attempted to prevent or discourage indigents from other States establishing residence in their territory. ${ }^{220}$ Initially, States did so in order to protect public order. By using their police or "immigration" power States prohibited indigents from establishing residence in the State and indigents who were "found" within State borders could be sent back to the State they came from. ${ }^{221}$ The main motive for "keeping indigents out", however, has always been financial in nature. States, and in particular the more generous ones, have always feared that their welfare systems would attract indigents moving to the State for the sole purpose of collecting benefits. A large influx of indigents could affect the States' ability to maintain their benefit schemes. States have therefore always, and in particular when their economies experienced a downturn $^{222}$, attempted to decrease the magnetic effect of welfare systems. The typical legal instrument used for this purpose is the durational residence requirement. By denying indigents welfare during an initial period of time, States have aimed to discourage indigents or persons likely to become public charges, from coming to the State. The last legal

\footnotetext{
See further LaFrance (1978) supra footnote 211, at pp.155-193.

${ }^{219}$ Compare Loffredo, If You Ain't Got the Do, Re, Mi" The Commerce Clause and State Residence Restrictions on Welfare, in: YaleLPR (1993) pp.147-202, at p.154.

${ }^{220}$ See further Trattner (1984) supra footnote 211.

${ }^{221}$ Mandelker, Exclusion and Removal Legislation, in: WisLRev (1956) pp.57 et seq, at p.57. It is hard to discover the extent to which States actually used this power. A comprehensive and effective border control system has never existed but during the Depression of the 1930s some States appear to have installed border patrols to bar the entry of the poor. It is not unlikely that many States have made use of their police power by removing indigents from their territory and sending them back to their home States. See Rosberg, Free Movement of Persons in the United States, in: Sandalow/Stein (Eds), Courts and Free Markets Perspectives from the United States and Europe (1982) pp.273-384, at 288-289.

${ }^{222}$ Davis, The Evolving Right to Travel: Saenz v Roe, in: Publius (1999) pp.95-110, at p. 100 .
} 
instrument by means of which States have tried to protect their welfare systems is the alienage classification. By denying aliens welfare or by making their eligibility for welfare subject to a long period of residence within the (United) State(s), States attempted to reduce the pressure on their welfare budgets. Often, States claimed to have a "special public interest" in favouring United States citizen in granting welfare. Aliens were not perceived as "equal members of society" but rather as guests who might be granted the privilege of welfare benefits but who had no right to such assistance.

The next sub-sections explore the degree to which indigents are entitled to move to and to collect welfare benefits in other States by discussing the constitutionality of the four legal instruments by means of which States have traditionally attempted to regulate cross-border access to welfare programmes by using four legal instruments: the police or immigration power, the durational residence requirement, the residence requirement and the requirement of United States citizenship.

\subsection{Edwards: Recognition of a Freedom of Movement for Persons in} Need of Welfare Benefits

The power of States to deny indigents entrance and residence is at odds with the constitutional right to travel. ${ }^{223}$ This right is as old as the Constitution itself, but up until the middle of the twentieth century constitutional law did not object to the use of the police or "immigration power". Indigents did not enjoy the right to travel. ${ }^{224}$ Illustrative is the Supreme Court decision in Mayor of the City of New York v. Miln (1837). ${ }^{225}$ The case involved a New York statute which required the master of any ship to report to the mayor on the names and origins of the passengers. A

\footnotetext{
${ }^{223}$ See Chapter 2 Sections 8.1 and 8.2.

${ }^{224}$ In support of this view reference was often made to Article IV of the Articles of Confederation which stated that "the free inhabitants of each of these States, paupers, vagabonds and fugitives from justice excepted, shall be entitled to all priviliges and immunities of free citizens in the several States; and the people of each State shall have free ingress and egress to and from any State .." (ital: APvdM). When the clause was incorporated in Article IV of the Constitution the explicit exclusion of paupers and vagabonds was, like the terms "free ingress and egress" (see Chapter 2 Section 8.1), dropped. Article IV, however, was considered to be based on the same principles of the fourth article of the Articles of Confederation. It was therefore generally assumed that paupers or indigents were not entitled to the privileges and immunities of citizenship, including the right to travel. Rosberg (1982) supra footnote 221 , at p.288.

${ }^{225}$ Mayor of the City of New York v. Miln, 36 US 102 (1837).
} 
person who was deemed "liable to become chargeable on the City" could be removed "to the place of his last settlement". The Supreme Court sustained the statute. The Court spoke of the "danger" of a State's citizens being subjected to a heavy charge in the maintenance of indigents and stated that it is "as competent and as necessary for a State to provide precautionary measures against the moral pestilence of paupers, vagabonds, and possibly convicts". The Court even held it the duty of the State to protects its citizens from this "evil". ${ }^{226}$ The power to exclude indigents, which "undeniably existed at the formation of the Constitution", was not taken away from the States.

In 1941, six years after the coming into force of the Social Security Act, the Court moved away from Miln in Edwards $v$ Californi$a^{227}$ The case concerned a California statute which made it a misdemeanor to bring or assist "in bringing into the state any indigent person who is not a resident of the State knowing him to be an indigent person". A California resident brought an unemployed relative to California to help him to have a new start in life and was sentenced to six months' imprisonment for doing so. Before the Supreme Court, the State of California attempted to justify the statute by referring to the huge influx of migrants into California which had resulted in problems of health, morals, and especially finance, the proportions of which were staggering. The Supreme Court recognised the seriousness of California's concern, but, nonetheless, it held the statute to be unconstitutional. The Court stated that:

"none is more certain than the prohibition against attempts on the part of any single state to isolate itself from difficulties common to all of them by restraining the transportation of persons and property across its borders. It is frequently the case that a State might gain a momentary respite from the pressure of events by the simple expedient of shutting its gates to the outside world. But in the words of Mr. Justice Cardozo: "The Constitution was framed under the dominion of a political philosophy less parochial in range. It was framed upon the theory that the peoples of the several States must sink or swim together, and in the long run prosperity and salvation are in union and not division". 228

\footnotetext{
226 Ibid, 36 US 102 (1837) at 142-143. See e.g. also Smith $v$ Turner (The Passenger Cases), 48 US 283 (1849); Railroad Co. v Husen, 95 US 465 (1877) (a State may use its police power "to exclude from its limits convicts, paupers, idiots, and lunatics, and persons likely to become a public charge ..") and Plumley v Massachusetts, 155 US 461 (1894).

${ }^{227}$ Edwards v California, 314 US 160 (1941).

${ }^{228}$ Ibid, at $173-174$
} 
The Court explained that:

"recent years, and in particular the past decade, have been marked by a growing recognition that in an industrial society the task of providing assistance to the needy has ceased to be local in character. The duty to share the burden, if not wholly to assume it, has been recognized not only by State governments, but by the Federal government as well. The changed attitude is reflected in the Social Security laws under which the Federal and State governments cooperate for the care of the aged, the blind and dependent children"229.

Before the Court reached a conclusion it explicitly considered the contention that the limitation of this State power would be subject to an exception for "paupers". The Court admitted that support for this contention could be found in earlier decisions of the Court such as New York $v$ Miln. Yet, the Court found itself no longer bound by those observations:

"New York $\mathrm{v}$ Miln was decided in 1837. Whatever may have been the notion then prevailing, we do not think that it will now be seriously contended that because a person is without employment and without funds he constitutes a "moral pestilence". Poverty and immorality are not synonimous". 230

The Court concluded that States no longer held the power to interfere with the cross-border movement of persons, including indigents. Implicitly, then, the Court recognised that indigents enjoyed the right to travel including both the right to cross the inter-state boundaries and the right to choose the State of residence.

Edwards may be regarded as a response of the Supreme Court to the transformation of the welfare system. The Social Security Act of 1935 had established a single welfare union in which not only the States but also the Federal government held a responsibility for guaranteeing every individual a "minimum income" sufficient for at least the "essential needs of life". In this newly created welfare union there was, in the view of the Court, no longer room for "any single State to isolate itself from difficulties common to all" by "shutting its gates" for indigents. ${ }^{231}$ Indigents were no longer seen as "second-class" citizens. Rather, they were regarded as "equally deserving" United States citizens who, like other citizens of the Union, should have the right to move to and to pursue their interests

\footnotetext{
$229 \mathrm{Ibid}$, at 175

${ }^{230} \mathrm{Ibid}$, at 177 .
}

${ }^{231}$ Ibid, at 173-174. 
in the State of their choice. ${ }^{232}$ A "man's mere property status", as the concurring Justice Jackson put it, could no longer, "be used by a state to test, qualify, or limit his rights as a citizens of the United States". ${ }^{233}$ The right to travel may always have been "inherent in the nature of the Union", ${ }^{234}$ but the right was only granted to indigents after the establishment of the "welfare Union".

\section{$9.4 \quad$ Residents}

\subsubsection{Post-Edwards Debates}

Edwards did not yet guarantee that indigents also enjoyed in practice a greater freedom of movement. Virtually all States made eligibility for welfare benefits conditional upon the fulfillment of durational residence requirements. States had always imposed such requirements and they continued to do so after "1935". ${ }^{235}$ The Social Security Act had not

232 "It is a privilege of citizenship of the United States, protected from State abridgment, to enter any state of the Union, either for temporary sojourn or for the establishment of permanent residence therein and for gaining resultant citizenship thereof. If national citizenship means less than this, it means nothing". Edwards $v$ California 314 US 160 (1941) at 183-184 (Justice Jackson, concurring). The concurring Justice Douglas held that to deny indigents freedom of movement would "introduce a caste system utterly incompatible with the spirit of our system of government. It would permit those who were stigmatized by a State as indigents, paupers, or vagabonds to be relegated to an inferior class of citizenship. It would prevent a citizen, because he was poor, from seeking new horizons in other States. It might thus withhold from large segments of our people that mobility which is basic to any guarantee of freedom of opportunity. The result would be a substantial dilution of the right of national citizenship, a serious impairment of the principles of equality". Edwards $v$ California 314 US 160 (1941) at 181 (Justice Jackson, concurring). The majority in Edwards did not speak in "right-to-travel-terms" because it considered the transportation of persons to be "commerce" and dealt with the case under the Commerce Clause.

${ }^{233}$ Edwards v California 314 US 160 (1941) at 183-184 (Justice Jackson, concurring).

${ }^{234}$ See Chapter 2 Section 8.1 .

${ }^{235}$ During the 1940s and 1950s, a number of States concluded compacts with other States in which the parties agreed to waive durational residence requirements for their mutual citizens. See Shapiro v Thompson, 394 US 618 (1969) at 635-636 (footnotes 15 and 16). Some States reduced the duration of the residence period required for welfare eligibility even unilaterally, but only a few abolished waiting-periods entirely. Many States even increased the duration of residence required for eligibility for general assistance programmes. Altmeyer, People on the Move: Effect of Residence Requirements for Public Assistance, in: SocSccBull (1946) pp.4 et seq, at p.4 and National Travcllcrs Aid Ass'n, Onc Manncr of 
established a uniform welfare benefit level nor had it provided for a system under which States were reimbursed for the costs of the benefits offered to recently arrived indigents. In the States' view, they still needed to protect themselves against "welfare migration". The States found support for their view in the Social Security Act itself which explicitly allowed them to impose, within certain limits, ${ }^{236}$ waiting-period requirements. The practical significance of Edwards' right to travel was still minimal. Indigents who moved to another State risked a temporary loss of their "basic income". In the years after Edwards, however, welfare waiting-periods became the subject of often heated debates. ${ }^{237}$ In the literature it was increasingly argued that the temporary denial of welfare to migrating indigents was at odds not only with Edwards' right to travel but also with the basic philosophy of the Social Security Act that every person should have a "basic income" sufficient for the "essential needs of life". ${ }^{238}$ Furthermore, the justifications offered by States for waitingperiods were said to have no basis in fact. The administrative costs of enforcing the requirements would exceed the probable costs of granting welfare to "newcomers"; data were presented which would indicate that indigents would not move to other States for the purpose of obtaining

\footnotetext{
Law - A Handbook on Residence Requirements in Public Assistance (1961).

${ }^{236}$ During the debates on the Social Security Act in Congress in the 1930s, welfare durational residence requirements had been subject of heated discussions. Advocates of lengthy waiting-period requirements had emphasised the "danger" of a high influx of persons seeking higher welfare benefits, whilst the opponents of such requirements had stressed the unfairness of the requirements to those who were forced by the Depression to seek work in other States. Advocates and opponents reached a compromise implying that Federal funding would be made subject to durational residence requirements not exceeding a maximum -one year for AFDC- to be set by Congress. See dissenting opinion of Chief Justice Warren in Shapiro v Thompson, 394 US 618 (1969) at 646 and Rosenheim, Shapiro v Thompson 'The Beggars are Coming to Town', in: SCRev (1969) pp.303-346, at p.313.

See e.g. LoGatto, Residence Laws - A Step Forward or Backward?, in: CathLaw (1961) pp.101 et seq; Note, Residence Requirements in State Public Welfare Statutes-I, in: IowaLRev (1966) pp.1080-1095; Note, Residence Requirement for Public Relief: An Arbitrary Preriquisite, in: ColJLSP (1966) pp.133-143 and Harvith, The Constitutionality of Residence Tests for General and Categorical Assistance Programs, in: tenBroek, The Law of the Poor (1966) pp.243-317.

${ }^{238}$ The unconstitutionality of welfare waiting-periods was also claimed to be implied in Edwards. This conclusion was not only based on the "sink-or-swim-together-rationale" of the decision but also on a dictum in Edwards in which the Court had said that the nature and extent of a State's obligation "to afford relief to newcomers is not here involved. We do, however, suggest that the theory of the Elizabethan poor laws no longer fits the facts". Edwards v California, 314 US 160 (1941) at 174.
} 
welfare benefits. ${ }^{239}$ In the absence of a "need" for the requirements, waiting-periods would have to be held unconstitutional as unnecessary burdens on the right to travel and/or arbitrary denials of the equal protection of the laws. ${ }^{240}$

\subsubsection{Shapiro $v$ Thompson}

It was not until 1969, however, that the issue of the constitutionality of welfare waiting-period requirements was brought before the Supreme Court. In Shapiro $v$ Thompson ${ }^{241}$ the Court was asked to rule upon the constitutionality of the statutes of two States and the District of Columbia which all made eligibility for AFDC-benefits conditional upon one year of residence in the State. Each of the applicants met all the requirements for the benefits except this one. The Court opened the decision by defining the constitutional problems raised by the waiting-periods as problems of equal protection:

"There is no dispute that the effect of the waiting-period requirement .. is to create two classes of needy resident families indistinguishable from each other except that one is composed of residents who have resided a year or more, and the second of residents who have resided less than a year. in the jurisdiction. On the basis of this sole difference the first class is granted and the second class is denied welfare aid upon which may depend the ability of the families to obtain the very means to subsist- food, shelter and other necessities of life". 242

The main question to be answered by the Court was whether the discrimination against "new" indigent residents could be justified. The primary justification put forward by the States concerned the preservation of the "fiscal integrity" of welfare programmes. The States contended that if indigents could be deterred from entering the State by denying them welfare benefits during the first year, state programmes to assist long-term residents would not be impaired by a substantial influx of newcomers. The Court did not doubt that a one-year waiting-period "was well suited to discourage the influx" of indigents but it held that the purpose of deter-

\footnotetext{
${ }^{239}$ For an overview of research and literature on "welfare migration" before 1969 see e.g. Peterson/Rom (1991) supra footnote 218, at pp.151-152 and Long, Poverty States and Receipt of of Welfare Among Migrants and Nonmigrants in Large Cities, in: ASRev (1974) pp.46-56.

${ }^{240}$ See in particular Harvith (1966) supra footnote 237.

${ }^{241}$ Shapiro v Thompson, 394 US 618.

${ }^{242} \mathrm{Ibid}$, at 627.
} 
ring in-migration could not serve as justification for the classification created by the waiting-period requirement. It confirmed the constitutional status of the right to travel and stated that if a law has "no other purpose .. than to chill the assertion of constitutional rights by penalizing those who chose to exercise them, then it is patently unconstitutional". ${ }^{243}$

The States had argued, however, that even if it were forbidden to deter the entry of all indigents, the waiting-period could be justified as an attempt to discourage those indigents from entering the State who might come for the sole purpose of obtaining higher welfare benefits. The Court responded negatively to this "free-rider argument". The requirements were "all-inclusive". They did not only result in a denial of welfare to persons who came to the States for the sole purpose of collecting higher welfare benefits, but they also withheld benefits from the great majority who came to the State for other purposes. More fundamentally, however, the Court held that

"a State may no more try to fence out those indigents who seek higher welfare benefits than it may try to fence out indigents generally. Implicit in any such distinction is the notion that indigents who enter a State with the hope of securing higher welfare benefits are somehow less deserving than indigents who do not take this consideration into account. But we do not perceive why a mother who is seeking to make a new life for herself and her children should be regarded as less deserving because she considers, among others, the level of a State's public assistance. Surely such a mother is no less deserving than a mother who moves into a particular State in order to take advantage of its better educational opportunities". ${ }^{244}$

The States further presented a "past-contributions-argument" which suggested that welfare waiting-periods could be sustained as an attempt to distinguish between new and old residents on the basis of the contributions made to the community through the payment of taxes. The Court rejected this argument too. A State may legitimately attempt to limit its expenditure but a State may not seek to achieve such a purpose by invidious distinctions between classes of its citizens. ${ }^{245}$ Accepting the past-contributions argument would permit States to bar new residents from schools, parks, and libraries or deprive them from police and fire protection. It would even permit States to apportion all benefits and services according to the past contributions of citizens. The Equal Protection Clause, the Court said, prohibits such an apportionment of state services. $^{246}$

\footnotetext{
${ }^{243} \mathrm{Ibid}$, at 631

${ }^{244}$ Ibid, at 631-632.

${ }^{245}$ Ibid, at 633

${ }^{246}$ Ibid.
} 
In rejecting the free-rider and the past-contributions arguments the Court did not (have to) decide which of the equal protection tests ${ }^{247}$ was to be applied. Both arguments were held to be constitutionally unacceptable; they simply could not justify the welfare waiting-periods. The States, however, had offered a number of additional justifications which were accepted by the Court as legitimate. The Court held that strict scrutiny was to be applied since "in moving from State to State .. appellees were exercising" the fundamental right to travel and "any classification which serves to penalise the exercise of that right, unless shown to be necessary to promote a compelling State interest, is unconstitutional". ${ }^{248}$ In Shapiro the defending States could not demonstrate that the requirements were necessary for a compelling State interest. They had claimed that durational residence requirements could be sustained as objective tests of bona fide residence and as a safeguard against the fraudulent receipt of welfare payments. One year of residence would, in other words, ensure that an applicant was actually a resident of the State and not, in fact, a non-resident faking residence for the purpose of obtaining welfare in another State in addition to the benefits received in the State where the indigent actually resides. The Court, however, did not consider a one-year waitingperiod a necessary means for determining bona fide residence and avoiding double payments. Less drastic means were thought to be available for determining bona fide residency. ${ }^{249}$ The Court concluded the States did

\footnotetext{
${ }^{247}$ On the equal protection clause and the various tests which may have to be applied, see Chapter 2 Section 8.4

Shapiro $v$ Thompson, 394 US 618 (1969) at 634. The fundamental right which triggers strict scrutiny was the right to travel, not a right to welfare. In Dandridge $v$ Williams (1970) the Supreme Court concluded that the constitution does not guarantee a right to welfare payments. The administration of welfare, the Court reasoned, raises "intractable economic, social and even philosophical problems" that are not "the business of the Court". Dandridge v Williams, 397 US 471 (1970) at 485-487. Under the Equal Protection Clause wealth criteria are merely subject to rational relation review. See further Bork, The Impossibility of Finding Welfare Rights in the Constitution, in: WashULRev (1979) pp.695 et seq; Loffredo, Poverty, Democracy and Constitutional Law, in: UPennLREv (1993) pp.1277 et seq and Hershkoff, Positive Rights and State Constitutions: The Limits of Federal Rationality Review, in: HarvLRev (1999) pp.1131-1196.

249 Before granting welfare, the responsible authorities investigate the applicant's employment, housing and family situation and in the course of the inquiry necessarily learn whether or not the applicant is a resident or not. The hazard of double payments could in the view of the Court simply be prevented by a call or letter from the authorities to the welfare authorities of the State an applicant came from. Shapiro $v$ Thompson, 394 US 618 (1969) at 636-637. Nor did the Court accept the argument that a one-year waiting-period could be justified as a means of encouraging "newcomers" to join the labour market promptly. The Court simply held that this logic would also require a similar waiting-period for long-term
} 
not use, and had no need to use, one-year waiting-periods for the purposes suggested. Even under the rational relation test of the Equal Protection Clause the requirements would have been unconstitutional.

Before the Court could reach a final conclusion, it had to deal with what may, at first, have seemed the strongest argument of the defending States. Shapiro concerned categorical assistance programmes (AFDC) for which Congress had authorised the States to impose durational residency requirements not exceeding a maximum of one year. The States argued that they had not exceeded this maximum and that they were therefore justified in imposing the requirements. In the view of the States the real issue was not whether, acting on their own, they were permitted to impose (minimal) durational residence requirements, but rather whether Congress could authorise States to impose such requirements. ${ }^{250}$ The Court rejected this argument by stating that regardless of the possible approval by Congress, it was the State legislation which infringes the constitutional rights of freedom of travel and equal protection of the laws. In the view of the Court, the constitutional questions were posed by State legislations, not by any federal statute. The Court added, however, that even if it could be argued that Shapiro involved the constitutionality of a federal statute, the waiting-periods at issue would be unconstitutional. Congress is prohibited from denying public assistance to otherwise eligible poor persons solely on the ground that they have not been residents of a State for one year prior to their application for welfare. "Congress", the Court said, "may not authorise the States to violate the Equal Protection Clause". ${ }^{251}$

From a welfare perspective, ${ }^{252}$ Shapiro did not come as a real surprise. Prior to the decision calls had already been made for welfare waiting-periods to be held unconstitutional. By rejecting the "free-rider-" and the "past-contributions-argument" and by holding that the requirements are to be reviewed under the strict scrutiny test, the Court made it patently clear that there was no longer room for welfare waiting-periods. Shapiro largely built on the "sink-or-swim-together" rationale of Edwards. States were no longer permitted to shift the burden of the poor to other

\footnotetext{
residents of the State. Shapiro v Thompson, 394 US 618 (1969) at 637-638.

${ }^{250}$ On this argument see in particular Chief Justice Warren, dissenting in Shapiro. Shapiro $v$ Thompson, 394 US 618 (1969) at 647-648.

${ }^{251}$ Shapiro v Thompson, 394 US 618 (1969) at 641.

${ }^{252}$ To be sure, Shapiro did cause a stir in the legal doctrine. Most of the confusion and criticism, however, concerned the implications of the Court's conclusion that any classification which serves to penalise the exercise of that right is subject to strict scrutiny, for waiting-period requirements in arcas other than welfare. See further Chapter 2 Section 8.5.
} 
States. In a single welfare Union, in which the task of "taking care of the needy" is shared by the States and the Federal authorities, States were not only prohibited from "isolating" themselves from the poverty problem by shutting the gates to their State territory but also from closing the gates to their welfare systems. Shapiro made Edwards' right to freedom of movement a practical reality for indigents. In the single welfare Union indigents can, as "equally deserving" United States citizens, move to the State where they think they can pursue their interests best without being discouraged by a temporary loss of their "basic income" even if the sole motive for moving to another State is to collect higher welfare benefits there. From the moment indigents establish residence in a State, they can, as "equally deserving" State citizens, apply for welfare.

Shapiro, however, was also more than the logical follow-up from Edwards. It was only in Shapiro that the Court was confronted with the "welfare magnet problem". Unlike Congress and the dissenting Chief Justice Warren, ${ }^{253}$ the majority of the Justices in Shapiro did not consider this problem serious enough to uphold the waiting-period requirements. Why? The answer is not to be found in the Federal funding made available under the Social Security Act. Five years after Shapiro, the Court held in Maricopa County v Memorial Hospital (1973) that whether or not a program is federally funded is irrelevant to the applicability of Shapiro's penalty-analysis. ${ }^{254}$ It is hard to know whether, or to what extent, the welfare magnet problem played a role in the deliberations within the Court, ${ }^{255}$ but the conclusions drawn, and the reasoning followed, in Shapiro do suggest that the majority did not see a need for the challenged requirements. It does not seem very likely that the Court would have rejected the free-rider and past-contributions arguments in

${ }^{25.3}$ Chief Justice Warren was of the view that "Congress quite clearly believed that total elimination of durational requirements would be self-defeating because the prospect of a sudden influx of new residents might deter the States from significantly increasing categorical assistance benefits", and that these legislative realities could not be ignored in assessing the validity of the congressional decisions to authorize" durational residence requirements for welfare benefits. Schwartz, Super Chief - Earl Warren and his Supreme Court - A Judicial Bibliography (1983) at p.726 (quoting fromo a draft $\mathrm{f}$ the opinion in Shapiro).

${ }^{254}$ Memorial Hospital v Maricopa County, 415 US 250 (1973) at 261. This conclusion was already implicit in the Shapiro-decision. The decision implied that waiting-periods for general purely State-funded assistance programmes were in principle also unconstitutional. Furthermore, Shapiro itself only involved categorical welfare programmes, but the Court spoke in general terms of "welfare" and "public assistance" and did not in anyway indicate that an exception for general welfare programmes was to be made.

255 On the discussions within the Court in Shapiro see Schwartz (1983) supra footnote 253 at pp. $725-732$. 
such strong terms if it had expected that the abolition of welfare waitingperiods would incite large numbers of indigents to move to other States. Further, the Court subjected welfare waiting-periods to strict scrutiny under the equal protection test. It explicitly, however, added that even under the traditional equal protection tests a classification of welfare applicants according to whether they have lived in the State for one year would seem "irrational"256 and unconstitutional. It is hard to understand, however, why waiting-periods are "irrational" or "arbitrary", where their invalidation could possibly result in a large influx of indigents and increase in welfare costs. As undesirable and objectionable a limitation of indigents' right to travel and equal protection may be thought to be, waiting-periods do for that reason seem not to be "without any reasonable basis". Thus, even though it is hard to prove, Shapiro suggested that the Court did not refrain from invalidating durational residence requirements for welfare benefits because it did not expect that welfare-induced migration would occur.

\subsubsection{From Shapiro to Saenz}

In Shapiro the Supreme Court ordered the States to abolish welfare waiting-period requirements. In subsequent years, the States indeed did so. No claims of welfare migration were made. It seemed that Shapiro had definitively settled the earlier controversies regarding the need for, and the validity of, welfare waiting-period requirements. Since the late $1980 \mathrm{~s},{ }^{257}$ however, the welfare migration issue has returned to the political agenda of many States and the Federal institutions. States such as Wisconsin, ${ }^{258}$ Minnesota and California claimed that they were confronted with an increased influx of indigents from other States. In order to protect the financing of their welfare benefit schemes these States decided to re-introduce waiting-periods. In order to avoid conflicts with Shapiro, Wisconsin imposed a durational residence requirement of merely sixty days -instead of one year- and exempted persons who were born in the State, had previously lived there for one year, came to Wisconsin to join family members or to accept a job offer, from the denial of welfare benefits during the

\footnotetext{
${ }^{256}$ Shapiro v Thompson, 394 US 618 (1969) at 638.

${ }^{257}$ For some first comments about the expected impact of Shapiro see e.g. Chambers, Residence Requirements for Welfare Benefits: The Consequences of their Unconstitutionality, in: SW (1969) pp.29-37.

${ }^{258}$ On Wisconsin's welfare magnet problem see Peterson/Rom (1990) supra footnote 218, Chapter 2.
} 
first sixty days of residence. The purpose was thus to deter only "freeriding indigents" from coming. Minnesota and California responded to claimed increases in the number of welfare recipients by applying two-tier benefit schedules. In Minnesota newcomers were only granted $60 \%$ of the basic welfare benefits during the first six months, whilst in California newcomers were only offered welfare up to the level of the State they came from provided this benefit was lower than the benefit level in California during the first twelve months of residence. ${ }^{259}$ The Federal authorities seemed to support a re-introduction of waiting-periods for AFDC-benefits. Prior to the coming into force in 1996 of the PRWORA, they allowed (i.e. by not refusing Federal funding) a number of States to experminent with various types of relatively short waiting-periods, ${ }^{260}$ and PRWORA itself explicitly allowed the States to apply "the rules (including benefit amounts) of the program .. of another State if the family has moved to the State from the other State and has resided in the State for less than 12 months". ${ }^{261}$

${ }^{259}$ Both the Minnesota and California waiting-periods have been invalidated in court. For Minnesota, see Mitchell $v$ Steffen, Minn SupCt, No.C3-92-239, 8/6/93 (as published in the USLWeek of 8 August 1993, 62 LW 2111). For California see Green v Anderson, N.9315306 9th Cir., 29 April 1994 (as published in United States Law Week 61 LW 2475). The courts in question basically followed Shapiro and concluded that the challenged statutes penalised the right to travel. The States could not demonstrate a compelling State interest for which the welfare waiting-periods were necessary. The Wisconsin Statute, however, has been upheld by the Supreme Court of that State. This Court concluded that a sixty-day waitingperiod "was substantially less onerous" than the one-year period in Shapiro and that the Wisconsin waiting-period did not penalise the right to travel. The Court referred to the State's "legitimate" interests in "preserving the public fisc" and "conserving scarce taxpayers' funds". Jones v Milwaukee County, 485 NW2d 21 (as published in USLWeek 61 LW 2027 (1992)). See further Poppe, Defining the Scope of the Equal Protection Clause with Respect to Welfare Waiting-Periods, in: ChicLRev (1994) pp.291-323, at pp.300-303. The decision of the Wisconsin Supreme Court was hard to compare with Shapiro. The very purpose of the waiting-period was to discourage free-riding indigents from coming and to deny newcomers welfare for the sole purpose of saving money. Compare Loffredo (1993) supra footnote 219, at p.167.

${ }^{260}$ See Schram/Kruger, 'Welfare Magnets' and Benefit Decline: Symbolic Problems and Substantive Consequences, in: Publius (1994) pp.61-82, p.80-81 (referring in footnote 72 to a review of the federal waiver process to Wiseman, Welfare Reform in the States) and Bennet/Sullivan, Disentitling the Poor: Waivers and Welfare "Reform", in: UMJLR (1993) pp.741-784.

${ }^{261} 42$ U.S.C.A. $\$ 604$ (c) (Supp.1997). Since 1996 the number of States which decided to re-introduce durational residence requirements increased to fifteen. Allard, Revisiting Shapiro: Welfare Magnets and State Residency Requirements in the 1990s, in: Publius (1998) pp.45-66, at p.55. It may be recalled that PRWORA replaced the AFDC programme with the TANF programme. The original matching grants were replaced by block grants, the new States were given much more freedom as to how they wished to organise welfare. 
The introduction of waiting-period requirements fully re-opened the welfare magnet debate in which two separate, but closely intertwined, issues played a role. The first concerned the question whether there was actually a need for the newly introduced requirements. Was the fear of "welfare migration" justified? Views differed. Several empirical studies on the mobility of welfare recipients were conducted and these reached different and conflicting conclusions. Some scholars ${ }^{262}$ claimed to have demonstrated that States like Wisconsin, Minnesota and California were faced with welfare migration and that there was indeed a need to take measures in order to safeguard these States' welfare systems. These scholars did not claim that "large numbers of poor people rush from one state to another with every modest adjustment in state benefit levels", but they did suggest that "as people make major decisions about whether they should move or remain where they are, they take into acount the level of welfare a state provides and the extent to which that level is increasing". The poor would do this "roughly to the same extent that they respond to differences in wage opportunities in other state". ${ }^{263}$ Other scholars, however, questioned the validity of this "evidence" and argued that there was no or hardly any welfare migration. ${ }^{264}$ This group of scholars did not doubt that some States may have been faced with a larger number of "new" indigents from other States, but they did deny that the poor would move to other States for the sole purpose of obtaining higher welfare benefits. Like others, the poor would primarily move to the places or States where jobs are available. If there was any welfare migration, it would be a secondary factor and it would not take such drastic forms as to force States either to raise taxes or to lower welfare benefit levels. The welfare magnet issue was, in their view, largely symbolic. State policymakers would use the symbol of the welfare magnet in order to defend

PRWORA decentralized the welfare systems and increased the danger of a "welfare race to the bottom".

${ }^{262}$ Clark, Does Welfare Affect Migration? (1990); Peterson/Rom (1990) supra footnote 218; Peterson/Rom, American Federalism, Welfare Policy, and Residential Choices, in: APSRev (1989) pp.711-728 and Gramlich/Laren, Migration and Income Redistribution Responsibilities, in: JHR (1984) pp.489-511.

${ }^{263}$ Peterson/Rom (1990) supra footnote 218 , at p.83.

${ }^{264}$ See e.g. Dye, The Policy Consequences of Intergovernmental Competition, in: CatoJ (1990) pp.59-73 and Schram/Krueger (1994) supra footnote 260, at pp.74-79 (referring to other inter alia Hanson/Hartman, Do Welfare Magnets Attract? (1994) and Walker, Migration Among Low-Income Households: Helping the Witch Doctors Reach Consensus (1994)). 
refusals to raise welfare benefits. ${ }^{265}$

The second issue in the welfare magnet debates was a legal one. It concerned the constitutionality of the waiting-period requirements. At first glance, the durational requirements that were introduced seemed unconstitutional. Shapiro did not exclude the possibility that relatively short waiting-period requirements for welfare could be upheld when they are applied as tests of bona fide residence, but the newly introduced waitingperiods did not serve this goal. They seemed aimed at deterring freeriding indigents from the "poorer" States from coming and protecting the funding of benefit schemes by denying recently arrived State citizens welfare. Both objectives were declared unconstitutional in Shapiro. The fact that PRWORA authorises States to apply the said requirements did not seem to alter that conclusion since Shapiro indicated that Congress does not have the power to permit the States to violate the Equal Protection Clause. ${ }^{260}$ However, advocates of welfare waiting-period requirements increasingly made calls upon the Supreme Court to move away from Shapiro. The alleged existence of welfare migration would compel the Court to recognise that States are, in certain circumstances, entitled to discourage indigents from migrating in order to protect their welfare

\footnotetext{
${ }^{265}$ Schram/Krueger (1994) supra footnote 260, at p.82. Compare further Allard/Danziger, Welfare Magnets: Myth or Reality?, in: JoP (2000) pp.350-368.

${ }^{266}$ One could of course have tried to "read" into Shapiro a possibility that welfare waiting-periods were nonetheless constitutional. Some such attempts were indeed made. In Shapiro the Court accepted as legitimate a number of State interests which could possibly justify waiting-periods provided they could be demonstrated to be necessary for the promotion of a compelling State interest test. In particular, Shapiro left room for the suggestion that the requirements could possibly be sustained if they serve as tests of bona fide residency. In Shapiro the Court merely held that a one-year waiting-period could not be upheld on this ground, but the decision did not exclude the possibility that shorter waiting-periods (of one or two months) might be constitutional where they function as tests of bona fide residence. In the field of voting, the Court had similarly shot down one-year waiting periods (Dunn $v$ Blumstein, 405 US 330 (1972), but it had accepted durational residence residence requirements of up to 50 days in as far as they serve as reasonable tests of bona fide residence. Martson v Lewis, 410 US 679 (1973) and Burns v Fortson, 410 US 686 (1973). See further also LaFrance (1979) supra footnote 213, at p.253; Rosberg (1982) supra footnote 221, at p.312. Furthermore, it had been argued that welfare waiting-periods could possibly be upheld in as far as they are used as a means to encourage indigents to join the labour force as soon as possiblc. Poppe (1994) supra footnote 259, at pp.317-323.
} 
programmes, to abandon penalty-on-the-right-to-travel-analysis and to develop an alternative legal framework under which (welfare) waitingperiods are to be reviewed. ${ }^{267}$

\subsubsection{Saenz v Roe}

In the light of post-Shapiro developments and debates, it was inevitable that the question of the constitutionality of welfare waiting-period requirements would be brought before the Supreme Court again. This indeed happened in Saenz $v$ Roe (1999). ${ }^{268}$ The case concerned the previously mentioned California statute which limited the amount of welfare benefits payable to families that had resided in the State for less than twelve months to the amount payable by the State of the family's prior residence. The relevant provisions of the 1992 California statute were challenged by three women who had all recently moved from other States to California to live with relatives in order to escape abusive family circumstances. Since the benefit levels in the States which the women had moved from were lower than the Californian benefits, their benefits were limited to the benefit level in those other States. In support of the durational residence

${ }^{267}$ It had been suggested that the Court should ground the right to travel or migrate in, and review welfare waiting-period requirements under, the citizenship clause of the Fourteenth Amendment which provides that United States citizens are citizens of the State wherein they reside. See Cohen, Discrimination Against New State Citizens: An Update, in: Constitutional Commentary (1994) pp.74 et seq and Zubler, The Right to Migrate and Welfare Reform: Time for Shapiro $v$ Thompson to Take a Hike, in: ValpULRev (1997) pp.893-950. On the face of it, this clause would not seem to leave any room for durational residence requirements. However, it was argued that the Clause does allow the Federal government to authorize the States to treat "new" State citizens differently than other residents. Under the Citizenship Clause "any State discrimination against newcomers would be per se unconstitutional unless Congress specifically authorized it". Zubler (1997) supra at p.946. Other suggested means for subjecting durational residence requirements to an intermediate level of judicial scrutiny involved an ad hoc balancing test, review under the Priviliges and Immunities Clause of Article IV $\S 2$ of the Constitution and classing "new" residents as a semi-suspect class. See further Chapter 2 Section 8.6.

${ }^{268}$ In 1995 the question on the validity of durational residence requirements had already been brought before the Supreme Court in Anderson v Green (USLWeek 7 February 1995 63 LW 3581). The Court, however, did not decide upon the case because it was not "ripe" (United States Law Week 21 February 1995 63LW 4162-4163). The challenged California statute in this case would only take effect upon receipt of a waiver of the Federal government. Initially, such a waiver was granted but later the waiver was vacated. In the absence of a waiver California simply granted welfare to new residents upon arrival in the State under the same conditions as "old" residents. Since PRWORA took effect in 1996, no specific approval of waiting-periods was requircd. 
requirements for its welfare benefits, the State of California had advanced only fiscal justifications. In brief, the statute would save some 10.9 million dollars in annual welfare costs. Under the compelling State interest test of the Equal Protection Clause this argument could not stand, but California claimed that the requirements would merely have to satisfy the much more lenient rational relation test. Since the California statute did not wholly deprive recently arrived residents from welfare payments, it would not constitute a penalty on the right to travel.

In response to debates about the appropriate standard of review to be applied to (welfare) residency requirements, the Court reconsidered in Saenz the rules and provisions governing the right to travel. As described earlier on in this book ${ }^{269}$, the Court moved away from Shapiro's penalty-on-the-right-travel-analysis: it indicated that State statutes which discriminate against State citizens on the ground that they have not lived long enough in the State are to be reviewed under the Privileges or Immunities of the Fourteenth Amendment which provides that "No State shall make or enforce any law which shall abridge the privileges or immunities of citizens of the United States". This change in the Court's approach towards durational residence requirements, however, did not in any way affect its view on welfare waiting-period requirements. The Court condemned the requirements in terms which were as clear and unequivocal as the ones it had used in Shapiro.

Firstly, the fact that the Privileges or Immunities Clause rather than the Equal Protection Clause was to be applied did not imply a relaxation of the level of judicial scrutiny. Neither mere rationality nor some intermediate standard of review should be used in order to judge the validity of rules such as durational residence requirements which discriminate against a State's own citizens. The appropriate standard, the Court held, may be "more categorical than that articulated in Shapiro .. but it surely is no less strict"270. Secondly, even though California had disavowed that its waiting period requirements were introduced to deter indigent residents of other States from coming to California, the Court expressly rejected the "free rider argument". The Court recognised that even though it may be:

"reasonable to assume that some persons may be motivated to move for the purpose of obtaining higher benefits, the empirical evidence .. indicates that the number of such persons is quite small - surely not large enough to justify a burden on those who had no such motive".

\footnotetext{
${ }^{269}$ See Chapter 2 Section 8.5 .

${ }^{270}$ Saenz $v$ Roe, 119 S.Ct.1518 (1999).
} 
Repeating Shapiro, the Court held the purpose of discouraging indigents from moving to be "unequivocally impermissible". Thirdly, the Court did not accept the fiscal justification raised up by California. The Court calculated that the State could just as well save the envisaged 10.9 million if it were to decrease the benefits of all welfare recipients by a mere 72 cents per month. The Court explicitly held, however, that its rejection of the fiscal argument did not rest on the weakness of California's claim. Rather, it rests on the fact that the Citizenship Clause of the Fourteenth Amendment, which expressly equates citizenship with residence and does not "allow for .. degrees of citizenship based on length of residence". The length of residence in California and the identity of the prior States of residence do not have any relevance to the need of applicants for welfare benefits nor do those factors, according to the Court, bear any relationship to the State's interest in making an equitable allocation of funds to be distrubuted among needy State citizens. Citing Shapiro the Court held that States are not entitled "to apportion all benefits and services according to the past contributions of its citizens" and it concluded that the "State's legitimate purpose in saving money provides no justification for its decision to discriminate among equally eligible citizens".

Fourthly, and lastly, the Court rejected the view that the durational residence requirements under consideration could be upheld on the ground that Congress had given its approval to the requirements when it adopted PRWORA. Because the TANF program gives States much broader discretion in setting benefit levels and eligibility criteria than AFDC did, it was argued before the Court that the 1997 program would provide new incentives for welfare recipients to change their residences and incite States to engage in a "race to the bottom" in setting benefit levels. The Court, however, was not persuaded. It could not see why the disparities among the States' benefit systems would be any greater under TANF than under AFDC; and it held that the savings which could possibly result from the discriminatory Californian statute could just as well be achieved by non-discriminatory means which would have only a miniscule impact on benefit levels. Where in Shapiro the Court had concluded that Congress is not empowered to authorise States to violate the Equal Protection Clause, the Court now held in Saenz that the same holds true for all Clauses of the Fourteenth Amendment. The protection afforded by the Citizenship Clause implies a limitation on the powers of the National Government as well as the States. In conclusion, the Court held the California statute to be unconstitutional.

In Saenz $v$ Roe the Supreme Court may have altered the legal framework for reviewing durational residence requirements, but this does not imply that the Court has also altered its view on the legality of 
welfare waiting-periods. Such requirements are unconstitutional. ${ }^{271}$ In fact, from a welfare perspective, Saenz is quite similar to Shapiro: under the Privileges or Immunities Clause welfare waiting periods are subject to a standard of review which is at least equally strict as the compelling State interest test of the Equal Protection Clause, both Clauses of the Fourteenth Amendment do not allow Congress to authorise discriminatory State measures in the field of welfare and the Court confirmed that the free-rider and past-contribution arguments are constitutionally unsound. Thus, all United States citizens regardless of their economic status, enjoy the constitutional privilege of acquiring citizenship of the State of their choice and of being treated as citizens from the moment they establish residence in that State. The main difference between the two decisions is that Saenz is more explicit in the rejection of the financial arguments of the State. In brief, the Court does not see a practical need for durational residence requirements because it does not expect that applicants for welfare benefits will, if at all, move in such great numbers to other States as to serously affect the funding of the States' welfare systems.

\section{$9.5 \quad$ Non-Residents}

In Edwards, Shapiro and Saenz the Court has thus removed from the States two legal instruments by means of which they have traditionally regulated cross-border access to their welfare programmes: the police or "immigration" power and the durational residence requirement. Shapiro indicated, however, that the Court does approve of the use of the third instrument originating from the Elizabethan Poor Laws: the residence requirement. The Court said that the "residence requirement and the oneyear waiting-period are distinct and independent prerequisites" for welfare

\footnotetext{
${ }^{271}$ To be sure, Saenz still leaves room for the conclusion that (relatively short) welfare waiting-period requirements might survive judicial scrutiny when they are applied in order to establish bona fide residence. Compare supra footnote 259. In Saenz it was undisputed that respondents were bona fide residents and the Court therefore saw no need to consider what weight is to be given to a citizen's length of residence in cases where State citizenship is questioned. Compare in this regard also the ruling of the European Court of Justice in Swaddling in which it was held that the length of a person's residence cannot be regarded as "intrinsic element" of the concept of residence. Case C-90/97 Swaddling [1999] ECR I-0000 as discussed in Section 6.
} 
under any program. ${ }^{272}$ In Shapiro the Court granted indigents the right to establish residence in the State of their choice and to claim welfare benefits as "equally deserving" State citizens. The Court merely prohibited discrimination among State citizens, not discriminations between State citizens and citizens of other States. ${ }^{273}$

Indigents who have not yet established residence in a State are thus not eligible for welfare. Does this also imply, then, that indigents who have moved to another State and have given up residence/citizenship, can no longer claim welfare benefits? In other words, are welfare benefits exportable $?^{274}$ The issue came before the Court in Califano $v$ Torres (1978), ${ }^{275}$ a case which involved a section of the Social Security Act which denied SSI-benefits to persons living in Puerto Rico. The District Court there held that the Constitution requires that a person who moves to Puerto Rico must be given benefits "superior to those enjoyed by other residents of Puerto Rico if the newcomer enjoyed those in the State from which he came". ${ }^{276}$ The Supreme Court disagreed by stating that this

"Court has never held that the constitutional right to travel embraces any such doctrine, and we decline to do so now. (..) Such a doctrine would apply with equal force to any benefits a State might provide for its residents, and would require a State to continue to pay those benefits indefinitely to any person who had once resided there. And the broader implications of such a doctrine in other areas of substantive law would bid fair to destroy the independent power of each State under our Constitution to enact laws uniformly applicable to all of its residents". 277

Indigents who move to, and establish residence in, another State are

${ }^{272}$ Shapiro v Thompson, 394 US 618 (1969) at 636. Shapiro's analysis only applies to the right to migrate and thus only to durational residence requirements. Memorial Hospital $v$ Maricopa County, 415 US 250 (1973) at 255. See further Chapter 2 Section 8.5.

${ }^{273}$ Under the Equal Protection Clause residence requirements are only subject to the flexible rational relation test. The Court has never reviewed welfare residence requirements under the Privileges and Immunities Clause. See Chapter 2 Section 8.6.1. It can safely be assumed, however, that the Court would uphold the requirements under this Clause. The requirements are subject to the "substantial relation test" of this Clause - welfare is obviously "fundamental"- but it seems beyond doubt that welfare residence requirements are "substantially" related to the legitimate objective of maintaining welfare programmes. In the absence of residence requirements the "benefits" of the welfare system would "spill over" to other States and States would not be able to financially maintain their welfmeare programs.

${ }^{274}$ Prior to Shapiro, some States allowed their former residents to export welfare benefits for the period they could not yet claim welfare in the "new" State. Shapiro v Thompson, 394 US 618 (1969) at 637.

${ }^{275}$ Califano v Torres, 435 US 1 (1978).

${ }^{276}$ Ibid, at 4.

${ }^{277}$ Ibid, at 4-5. 
eligible for welfare in the "new" home State, but can no longer claim welfare in the "old" home State. Welfare benefits are in principle not exportable. The movement to another State does not lead to a loss of the right to claim welfare, but it may imply a loss of income where the indigent moves to a State where welfare benefits are lower. Migrating indigents do not have a constitutional right to retain a certain minimum income nor can they "double their income" by moving to another State. The Social Security Act did not demand an invalidation of welfare residence requirements. The Act did not transform welfare system(s) into a unitary system under which the Federal authorities were fully responsible for the provision, financing and administration of welfare. The constitutionality of residence requirements merely reflects the fact that the single welfare Union is based on a federal system of government in which States are still the primary responsible governmental entities.

\subsection{Aliens}

A third category of individuals which has often been denied welfare is that of aliens. Up until the 1970s, it seemed beyond doubt that States were entitled to exclude aliens from their welfare systems. The Supreme Court recognised that States had a "special public interest" in favouring United States citizens over foreigners in the distribution of welfare. Illustrative are the following words of Justice Cardozo in People v Crane (1915):

"To disqualify aliens is discriminatory indeed, but not arbitrary discrimination, for the principle of exclusion is the restriction of the resources of the state to the advancement and profit of the members of the state. Ungenerous and unwise such discrimination may be. It is not for that reason unlawful. .. The state in determining what use shall be made of its own moneys, may legitimately consult the welfare of its own citizens rather than that of aliens. .. In its war against poverty, the state is not required to dedicate its own resources to citizens and aliens alike." 278

Welfare alienage classifications were merely scrutinised under the rational relation test of the Equal Protection Clause and were, thus, generally

\footnotetext{
${ }^{278}$ People v Crane, 214 NY 154, 108 NE 427 (1915) at 429-430 (as quoted in Graham v Richardson, 403 US 365 (1971) at 373).
} 
upheld. Two years after Shapiro, however, the Court considerably strengthened the legal status of "needy" aliens, and in particular residents aliens, in Graham v Richardson ${ }^{279}$ (1971).

\subsubsection{Permanent Residents}

In Graham the Court was asked to rule upon the constitutionality of an Arizona statute which made eligibility for categorical welfare benefits for aliens dependent upon fifteen years of residence within the United States and a Pennsylvania statute which wholly excluded aliens from general welfare programmes. Both Arizona and Pennsylvania argued that they had a "public interest" in favouring citizens over aliens in the distribution of welfare benefits. The Court rejected the States' argument. It held that alienage classifications were "inherently suspect" and therefore subject to strict judicial scrutiny. ${ }^{280}$ Citing Shapiro, the Court stated that a

"State has a valid interest in preserving the fiscal integrity of its programs. It may legitimately attempt to limit its expenditures .. for public assistance.. But a State may not accomplish such a purpose by invidious distinctions between classes of its citizens. .. The saving of welfare costs cannot justify an other wise invidious classification". ${ }^{281}$

The Court concluded that "a concern for fiscal integrity is no more compelling a justification" for the requirement of United States citizenship than it was for the waiting-period requirement. The justification of limiting welfare expenses was particularly inappropriate and unreasonable when the class which was discriminated against consists of resident aliens. Like citizens, aliens pay taxes and they contribute to the economic growth of a State. There can be no "special public interest" in tax revenues to which aliens have contributed on an equal basis with residents". ${ }^{282}$ An additional reason why the classifications in question could not be upheld, emerged from what the Court called "federal-state relations". ${ }^{283}$ Graham concerned permanent residents. Such aliens enjoy the rights to reside and to be treated equally in any State $^{284}$ and Congress had explicitly declared that when resident aliens become "public charges for causes arising

\footnotetext{
${ }^{279}$ Graham v Richardson, 403 US 365 (1971).

${ }^{280}$ See Chapter 2 Section 8.7.

${ }^{281}$ Graham v Richardson, 403 US 365 (1971) at 374-375.

${ }^{282}$ Ibid, at 376

${ }^{28.3} \mathrm{Ibid}$, at 377

${ }^{284}$ Ibid, at 378 (citing Takahashiv Fish, 334 US 410 (1948) at 420).
} 
after their entry, they .. are entitled to the full and equal benefit of all state laws for the security of persons and property". ${ }^{285}$ The statutes in question conflicted with this Federal policy: an "alien, becoming indigent and unable to work, will be unable to live, where .. he cannot secure the necessities of life, including food, clothing and shelter". ${ }^{286}$ Finally, the Court rejected Arizona's argument that its fifteen year residence requirement for aliens would be authorised by Federal law and could thus be upheld. The Court admitted that Congress has broad powers to determine the conditions under which aliens are admitted to the United States, but it held, citing Shapiro again, that Congress does not have the power to authorise individual States to violate the Equal Protection Clause. ${ }^{287}$ In conclusion, the Court held the challenged statutes unconstitutional.

Graham implied that aliens whose right to reside in the United States is not conditional upon their not becoming a public charge, can move to and claim welfare in the State of their choice. Graham extended the "sink-or-swim" rationale of Edwards and Shapiro to aliens. States cannot shift the poverty problem to other States by denying welfare to those aliens who have been allowed by the Federal authorities to stay or remain in the United States even if they become in need of welfare. States have to treat such aliens equally with United States citizens, they are prohibited to "keep indigent permanent resident aliens out".

\subsubsection{Undocumented Aliens}

Graham and its conclusion that aliens constitute a suspect class did not imply that all aliens can claim State welfare benefits under the same conditions as United States citizens. The question whether aliens are likely to become dependent upon social welfare is one of the most important the Federal immigration authorities consider. Without discussing Federal immigration policy in detail, it can be said, albeit somewhat oversim-

\footnotetext{
$285 \mathrm{Ibid}$, at 378 .

${ }^{286} \mathrm{Ibid}$, at $379-380$

${ }^{287} \mathrm{Ibid}$, at 382 . See also Guendelsberger, Equal Protection and Resident Aliens Access to Public Benefits in France and the United States, in: TulLRev (1993) pp.631-676, at pp.720721. Section 402 of PRWORA gives States the option to deny TANF benefits to aliens lawfully residing in the United States. Because of Graham it would seem, however, that such denials are incompatible with the Equal Protection Clause. See Chang, Immigrants under the New Welfare Law: A Call for Uniformity, a Call for Justice, in: UCLA LRev (1997) pp.205-280, at p.266 and Note, Welfare Reform: Treatment of Legal Immigrants, in: HarvLRev (1997) pp.1191 et seq.
} 
plified, that aliens likely to become a burden on the public purse are, in principle, not admitted and that the right to reside of aliens who are admitted is made conditional upon their not becoming a public charge. ${ }^{288}$ With the exception of permanent resident aliens, aliens lose, in principle, their right to reside in the country when they become in need of social welfare after admission. They are subject to deportation. Aliens who are deported do not, needless to say, have a right to claim welfare.

The only question left, then, is whether States can deny welfare to aliens who have lost their right to reside but who have not (yet) been deported. In other words, do undocumented or illegal aliens have a constitutional right to claim social welfare benefits? At the present state of the law, they probably do not have such a right. In Plyler $v$ Doe (1982) the Court held that illegal aliens do enjoy equal protection from the law, but that their illegal presence does prevent them from being considered a suspect class. ${ }^{289}$ Undocumented aliens only enjoy the minimal protection of the rational relation test. A denial of social welfare to aliens who have entered or remained in the country illegally does not seem to be wholly invidious or arbitrary ${ }^{290}$ and one may thus assume that States are under no constitutional obligation to grant illegal aliens social welfare. The main reason, however, that undeported illegal aliens cannot claim welfare seems to lie in Federal-State relations. In Plyler, Chief Justice Burger held that "a state has no power to prevent unlawful immigration, and no power to deport illegal aliens .. If the Federal Government, properly chargeable with deporting illegal aliens, fails to do so, it should bear the burdens of their presence here". ${ }^{291}$ Basically, the legal status of illegal aliens, and their eventual welfare rights, are the responsibility of the Federal government, not the States. ${ }^{292}$

\footnotetext{
${ }^{288}$ The Federal immigration law bars the admission of any alien "who in the opinion of the consular officer at the time of application for a visa, or in the opinion of the Attorney General at the time of application for admission or adjustment of status" is likely to become a public charge. Immigration and Nationality Act $\$ 212(a)(4), 8$ USC $\S 1182(a)(4)$ (Supp.II 1990). Additionaly, an alien who "within five years after the date of entry .. has become a public charge from causes not affirmatively shown to have arisen since entry is deportable". INA $\S 241$ (a)(5), 8USC $\S 1252$ (a)(5).

${ }^{289}$ Plyler $v$ Doe, 457 US $202(1982)$ at 215 and 223

${ }^{290}$ Compare Legomsky, Immigration, Federalism and the Welfare State, in: UCLALRev (1995) pp.1453-1474, at p.1468.

${ }^{291} \mathrm{Ibid}$, at 242 (Burger, C.J., dissenting).

${ }^{292}$ The issue of the social welfare rights of illegal aliens became the subject of heated debates atn the end of 1994 when California voters approved Proposition 187. This Proposition was designed to make illegal aliens ineligible for most social welfare benefits, health care facilities and education. See e.g. Schuler, Equal Protection and the Undocumented Immigrant: California's Proposition 187, in: Boston CTWLJ (1996) pp.275-312; Abricl,
} 
Constitutional law on aliens' access to welfare demonstrates that the United States also constitutes towards "the outside world" a single welfare Union. A single decision, made by the Federal immigration authorities, determines whether or not an alien is entitled to be eligible for welfare. Aliens who have been allowed by the Federal authorities to stay in the United States when in need of welfare, can move to and are entitled claim welfare in the State of their choice. All other aliens do not have a constitutional right to claim welfare in either one of the States.

\subsection{Summary and Conclusions}

American constitutional law on cross-border access to social welfare benefit schemes has undergone drastic changes over the years. Prior to the transformation of the welfare system in the 1930s it was virtually impossible for indigents to establish residence and obtain welfare benefits in other States. The States' responsibility for the poverty problem was limited to their territory and the indigents living therein. The "immigration" of indigents from other States was perceived as a threat to both public order and the States' ability to maintain adequate welfare programmes. The local structure of "the" welfare system, required indigents to stay where they were and States were permitted to refuse migrating indigents residence in the State and to deny them welfare during the first months or years of residence in the State. The Social Security Act of 1935, however, opened the door for a strengthening of the rights of indigents. The Act

Rethinking Preemption for Purposes of Aliens and Public Benefits, in: UCLALRev (1995) pp.1597-1630; Neuman, Aliens as Outlaws: Government Services, Proposition 187, and the Structure of Equal Protection Doctrine, in: UCLA LRev (1995) pp.1425-1452 and X, Unenforced Boundaries: Illegal Immigration and the Limits of Judicial Federalism, in: HarvLRev (1995). It may come as no surprise that it is the State of California in which debates regarding welfare rights of illegal aliens have been so heated. $40 \%$ of all illegal aliens present in the United States (have) settle(d) in California. Another $40 \%$ have settled in only six other States (Arizona, Florida, Illinois, New Jersey, New York and Texas). The main problem regarding illegal aliens' welfare rights lies in the Federal-State relations and in particular which government should bear the financial responsibility for illegal aliens. In general, the costs of granting illegal aliens welfare, education or other governmental benefits are, roughly speaking, equal to the taxes generated from these aliens. Yet, the costs are for the biggest part borne by the (six or seven) States which host most illegal aliens, whilst the biggest part of the tax revenues goes to the Federal government. The latter does not seem willing, however, to compensate the States which in practice bear the burden of offering illegal aliens governmental benefits. The Federal government does not reimburse the States for the AFDC-expenditures made on behalf of illegal aliens. X, Unenforced Boundaries (1995) supra at p.1656 and Legomsky (1995) supra footnote 290, at pp.1470-1473. 
embodied the notion that every person should have a right to an income sufficient for at least the "essential needs of life" and recognised that poverty and welfare had become matters of common concern which the States and the Federal government had to handle together. The Supreme Court responded by holding that in the newly established welfare union there was no longer room to deny indigents the fundamental right to travel (Edwards) and to allow States to deny welfare benefits to new, recently arrived, indigent residents (Shapiro, Saenz) and permanent resident aliens (Graham). In sum, all indigents lawfully residing in the United States now enjoy the freedom to choose in which State they wish to live and claim welfare.

When one compares American constitutional law and European Community law on cross-border access to welfare or minimum subsistence benefit schemes, one must conclude that the conflict between the "free movement interest", on the one hand, and the "minimum subsistence interest", on the other hand, has been settled differently. On both sides of the Atlantic, States are entitled to make eligibility for minimum subsistence benefits subject to the requirement of residence in the State territory, but the degree to which individuals in need of such benefits may move freely between States differs. In the European Community, this right is limited to Community (and EEA) workers and their family members. Member States are protected against the feared social tourism by the threshold requirements of "effective and genuine work" (Article $39 \mathrm{EC}$ status of Community worker), the possession of sufficient financial means (1990 residence directives) as well as by the power to regulate the immigration of virtually all third country nationals. In the United States, however, all persons entitled to reside in the country can choose in which States they wish to live and to claim welfare benefits on the same basis as residents already living there. The individual States lack powers to protect themselves against a possible influx of "free-riding" welfare applicants and recipients. In the United States the conflict between the two interests referred to above has basically been settled to the benefit of the "free movement interest", whilst in the European Community the "minimum subsistence interest" has so far proven to be of greater weight.

What explains the differences between American constitutional law and European Community law? Why has it been possible to realise a general freedom of movement in the United States, whilst in the European Community it has not? Given the different historical, political and legal backgrounds against which the law governing freedom of movement of persons has developed, it is far from easy, if not impossible, to give a single or definite answer to these questions. Nonetheless, several factors may explain the differences. 
The first one concerns the constitutional position of the Supreme Court and the European Court of Justice, and the "legal tools" the two courts have (had) at their disposal. From the very beginning it has never been questioned that all Americans enjoy, as citizens of the Union, the right to move and reside freely among the States ${ }^{293}$ and since 1867 they enjoy constitutional protection under the Equal Protection Clause, Privileges or Immunities Clause and/or the Citizenship Clause of the Fourteenth Amendment. The right to travel and the various constitutional Clauses have provided the Supreme Court with tools which it could use to invalidate welfare waiting-perods requirements and to conclude that all United States citizens (as well as the permanent resident foreigners) have the right to claim equal access to welfare from the moment they establish residence in the State of their choice. Until recently, however, the European Court of Justice did not seem to possess comparable tools which it could use in order to make a contribution to the realisation of a right of residence for all European citizens. It is only since 1993 that the notion of a European citizenship and a general right to freedom of movement for all citizens are enshrined in the Treaty itself and the free movement rights are, according to the wording of Article $18 \mathrm{EC}$, still conditional upon certain limitations. In Martínez Sala the Court did seem to be inspired by the provisions on European Union citizenship, but so far the Court has never been directly asked whether non-economically active European citizens in need of minimum subsistence benefits can rely on the Treaty in order to claim a right to establish residence and minimum subsistence benefits in other Member States. ${ }^{294}$

A second factor concerns the structure of the American and European "welfare systems". The reasoning of the Supreme Court in Edwards, Shapiro and Saenz was largely based on the "sink-or-swimtogether-rationale" reflected in the Social Security Act. Poverty and the problems caused by the "migrating" poor have since 1935 been perceived as common problems for which not only individual States but also the Federal government hold a responsibility. Federal funding did not constitute the direct basis for the invalidation of welfare waiting-periods but the common welfare responsibility has inspired the Court to conclude that States were no longer entitled to shift the responsibility for these common problems by "closing the gates" to their territory. In the European Community, however, the notion is still predominant that the responsibility for citizens who do not contribute to but rather seem to burden economic

\footnotetext{
${ }^{293}$ See also Chapter 2 Section 8.1

${ }^{294}$ See Section 10 below.
} 
development is to be borne not by the Community, but by the individual States. It may perhaps not be correct to speak of "the" American welfare state, but there is no doubt that the United States has evolved much further than the European Community towards a "welfare Union". 295

A third factor which may help to explain the differences in the law governing freedom of movement of the "poor" concerns the fear for welfare migration or social tourism. In Shapiro the Supreme Court did not confirm Edwards' right to travel, and it did not confer upon the "migrating poor" a right to equal treatment as regards welfare benefits, because the Federal funding made available under the Social Security Act safeguarded the financial stability of welfare systems. At least in theory, the welfare magnet problem still existed and it still does so today. As Saenz expressly indicates, the Court has recognised a "genuine" right to freedom of movement for the "poor" simply because it did not, and does not, expect that welfare recipients would move to other States in such large numbers as to seriously affect welfare benefit schemes. In the European Community, however, the fear of becoming a "welfare magnet" is still very strong among the Member States. This is reflected in the financial means requirements contained in the 1990 residence directives, Article 18(1) EC, which states that the right to freedom of movement is subject to the conditions and limitations laid down in the Treaty and secondary legislation as well as the requirement of "effective and genuine work" for obtaining the status of Community worker.

10 Towards a General Right of Residence in the European Community

\subsection{Introduction}

Turning back to the European Community, it may be recalled that the legal status of persons in need of minimum subsistence benefits has been strengthened in the course of the last three decades. Four decades ago, Community law had virtually nothing to offer to "needy" persons who

\footnotetext{
${ }^{295}$ Compare Garth, Migrant Workers and Rights of Mobility in the European Community and the United States: A Study of Law, Community and Citizenship in the Welfare State, in: Cappelletti et al, Integration Through Law - Europe and the American Federal Experience (1986) pp.85-163 (1986) at p.115.
} 
wished to establish residence, and claim minimum subsistence benefits, in other Member States. Today, all nationals of the Member States enjoy, in their capacity as citizens of the European Union, the right to move to and reside in other Member States (Article $18 \mathrm{EC}$ ) and to claim equal treatment as regards access to minimum subsistence benefit schemes (Article $12 \mathrm{EC}$ ) when, and for as long as, they are lawfully residing in the territory of another Member State. For many Community citizens who are in need of minimum subsistence benefits, however, the progress which has been made does not seem to have had much practical significance. Article 18(1) EC stipulates that free movement rights are subject to "limitations and conditions" laid down in the Treaty and secondary legislation. Community citizens who wish to establish residence in another member State can still be required to demonstrate that they have obtained "effective and genuine" employment (Article $39 \mathrm{EC}$ - Levin) or that they possess sufficient finances to support themselves and their family members (Article 1 of Directive No 90/364). In addition, economically inactive Community citizens can still lose their right to reside when they become in need of public financial assistance (Article 3 of Directive No 90/364). As argued in Section 8, from the perspective of Union Citizenship the financial means requirements for obtaining and retaining the right to reside are problematic. Union citizenship is a political rather than an economic concept which is deprived of much of its meaning as long as some citizens are, because of their economic status, denied the "fundamental and personal right ${ }^{1296}$ to freedom of movement. ${ }^{297}$

This final section addresses the question whether and, if so, how, one could move closer to, or possibly even realise, a general right of residence for all Union citizens including all those who are dependent on minimum subsistence benefits. Is it possible to realise a general right of residence which is not subject to a financial means requirement and, for all beneficiaries, encompasses a right to obtain minimum subsistence benefits in the State in which they have chosen to live? Can this goal be achieved without threatening the financial integrity of the national benefit systems? What lessons can possibly be learned in this regard from the United States? In an attempt to answer such questions, this section considers both legislative and judicial options. The number of issues involved is too large, and the subject is too politically loaded, however, to come up with a single solution which would be acceptable for all (Member States).

\footnotetext{
${ }^{296}$ COM (97) 230 at 4.1.

${ }^{297}$ Compare O'Leary (1996) supra footnote 93, at p.99.
} 
The observations below merely intend to give impetus to the discussion about how a general right of residence could possibly be realised. ${ }^{298}$

\subsection{Freedom of Movement versus the Financial Stability of Social Assistance Schemes}

In order to see how a general right of residence could possibly be realised, one should ignore for a moment the historical factors which have influenced the development of the free movement of persons. This allows us to take a step from the specific legal issues involved and to approach the conflict between the desire to realise a general freedom of movement and the need to maintain social assistance schemes, from a more theoretical perspective. Some elements of the economic theories on fiscal federalism may be of help in this regard. ${ }^{299}$ The theories start from the presumption that a general right to freedom of movement exists; they may contribute to a better understanding of the impact which inter-State mobility of persons may have on the organisation and funding of social assistance schemes in multi-tiered governmental entitities such as the United States and the European Community in which the task of establishing and financing social assistance schemes is carried out at (Member) State level.

\subsubsection{Race to the Bottom Hypothesis}

In fiscal federalism literature various advantages of the provision of public benefits at State or decentralised level are pointed out. One of these is that it enables individuals to move to the States (or other local jurisdictions) where the collective choices as regards public benefits and taxes best suit personal interests or preferences. Individuals may "vote by

\footnotetext{
${ }^{298}$ For the sake of convenience, the discussion in this Section is limited to Community citizens who are in need of social assistance benefits. The specific issues which may arise as regards mixed or hybrid benefits will not be dealt with seperately.

${ }^{299}$ On these theories on the economy of federalism (or fiscal federalism) see e.g. Rosen, Public Finance (1985) Chapter 19; Due/Friedländer, Government Finance (1977) pp.456 et seq; Musgrave/Musgrave, Public Finance in Theory and Practice (1976) and Oates, Fiscal Fcdcralism (1972).
} 
their feet". ${ }^{300}$ Persons who prefer public benefits of a comparatively high quality, and who are willing to contribute to the financing of such benefits by paying comparatively high taxes, may move to the States where such a pattern of public services has been chosen. Individuals with other preferences may move to States where other choices are made. In as far as social assistance benefit schemes are concerned, however, the relevance of this Tiebout-hypothesis is limited. ${ }^{301}$ In the theory behind it, there is a nexus between between the benefits which may be received and the taxes which must be paid. To put it simply, taxes may be regarded as the price which an individual is willing to pay for the benefits. In the case of social assistance benefits, however, this link between "price" and "product" is often largely absent. Often the recipients of these benefits do not, or hardly, contribute to the funding of the benefits by paying (direct) taxes. Fiscal federalism theories teach that public benefits can only be efficiently provided if the group of the (tax-paying) contributors (largely) coincides with the group of beneficiaries. ${ }^{302}$ In the case of redistributional programmes such as social assistance schemes this "double identity" often does not exist.

In a federal setting where social assistance benefits schemes are provided at State or decentralised level, freedom of movement may affect the funding of the individual States' schemes. Potentially, the free movement of persons in need of such benefits might even be a threat to social assistance schemes throughout the entire federal entity. Consider the following (oversimplified) model. State $\mathrm{A}$ is grouped together with several other States in federal entity X. State A has to decide on the level of its benefits. If it opts for comparatively high benefits, and thus for comparatively high taxes, State A will encounter the problem that it may attract persons from other States who are in need of such benefits. The higher the level at which benefits are set, the greater the magnetic effect

${ }^{300}$ Tiebout, A Pure Theory of Local Expenditures, in: JPolEc (1956) pp.416 et seq and Calabresi, "A Government of Limited and Enumerated Powers": In Defense of United States v. Lopez, in: MichLRev (1995) pp.752-831, at pp.775-776. Compare further Barnard, Regulating Competitive Federalism in the European Union? - The Case of EU Social Policy, in: Shaw (Ed.), Social Law and Policy in an Evolving European Union (2000) pp.49-69 and Barnard, Social Dumping and Race to the Bottom: Some Lessons for the EU from Delaware?, in: ELRev (2000) pp.57 et seq.

${ }^{301}$ Note, Devolving Welfare Programs to the States: A Public Choice Perspective, in: HarvLRev (1996) pp.1984-2001, at p.1987.

${ }^{302}$ Compare Bertola et al, EU Welfare Systems and Labor Markets: Diverse in the Past, Integrated in the Future, in: Bertola et al, Welfare and Employment in Europe (2000) pp.23122, at p.90 and Scholsem, A Propos de la Circulation des Etudiants: Vers un Federalisme Financier Européen?, in: CDE (1989) pp.306-323, at p.309-310. 
on "needy" individuals from other States. The more "free-riding" benefit recipients that come from other States, the greater the pressure on the funding of the benefit scheme. Should the inflow of non-contributing benefit recipients become quite considerable, State A might have to choose either to lower benefit levels or to raise tax-rates. If State A were to choose the latter option, the danger exists that tax-paying citizens would move to other States which might again lead to a reduction in tax revenues. In the end, State A might be forced to lower its benefits anyway. At the outset, State A might therefore decide to set the level of its benefits lower than the benefit level in neighbouring State B in the hope that "free-riders" from other States would move to B. If State A were indeed to make that choice, it would indirectly increase the magnetic effect of States B's benefit scheme. This State would be faced with the same problems that State A had initially encountered and State B might therefore to decide to decrease its benefits to a level lower than in State C in the hope that "free-riders" would now go to that State. C might respond similarly and try to shift the burden to State D. A domino-effect could occur. The fear of becoming a welfare magnet might trigger competition between States each lowering their benefits in the hope that other States would "take of the poor". This competition might result in "a race to the bottom" which could lead to a reduction in welfare benefit levels throughout the entire federal entity X.

\subsubsection{A Race to the Bottom in the European Community?}

The above is a theoretical model. The introduction of a general right to freedom of movement in a federal-like entitity such as the European Community would not necesarily result in a "race to the bottom". The model is based on a number of assumptions which would not necessarily materialise in practice. This particularly holds true for the assumption that the "poor" are mobile. If they were given the right, would the economically inactive European Union citizens be likely to move to other States in order to collect higher benefits? Member States with the comparatively high benefit levels would answer the question in the affirmative, but there are reasons to believe that the number of "free-riders" would not be so great as to seriously affect the funding of the benefit schemes. In the late $1950 \mathrm{~s}$, Member States also feared that the introduction of a free movement of workers would trigger considerable labour movement. Experience, however, has demonstrated that this movement has never been 
considerable. $^{303}$ Social, cultural and linguistic obstacles (have) preven$\mathrm{t}(\mathrm{ed})$ many Community citizens from working in other Member States and it does not seem unrealistic to assume that the same would hold true for the future beneficiaries of a general right of residence. Furthermore, if in the United States, a country where citizens are generally more mobile than in the European Community, no conclusive evidence has been put forward as to the existence of social tourism, then one is inclined to conclude that the possible introduction of a general right of residence in the European would not lead to an excessive inter-State flow of freeriding social assistance recipients. Furthermore, one may assume that in deciding whether or not to move to other Member States, European Union citizens in need of social assistance benefits would consider the geographical distance to States with higher benefits. In the United States the differences between welfare benefit levels in neighbouring States is often quite considerable, but in the European Community the differences between neighbouring States appear comparatively small. For instance, it does not seem very likely that the differences in benefit levels in the Benelux countries will trigger social tourism. Significant differences exist between the northern and the southern Member States. Social tourism is largely a "north-south" problem and one doubts whether many of the "southern citizens of the Union" would be willing to move "all the way to the north".

It could be, and it indeed has been, ${ }^{304}$ argued that there are no strong (financial) objections to a general right of residence and that such a right could "simply" be recognised without there being a need to take any protective measures for the benefit of the more generous Member States. However, there are reasons why one should be careful and not wholly ignore the objections to the introduction of a general right of residence. First, even it could be proved that European Union citizens are not likely to become "free-riders", the funding of Member States' social assistance schemes might be put under pressure. The funding of the schemes is not affected because a Community citizen has the intention of obtaining benefits, but because a State may have to grant benefits to a larger number of

${ }^{303}$ See e.g. Muus, A Study on the Expected Effects of Free Movement for Legally Residing Workers from Third Countries within the European Community, in: Curtin et al, Free Movement for non-EC-Workers within the European Community (1997) pp.5-28; Penninx/Muus, No Limits for Migration after 1992? - The Lessons of the Past and a Reconnaisance of the Future, in: IM (1989) pp.373-388 and Werner, Post-war Migration in Western Europe, in: IM (1986) pp.543-557.

${ }^{304}$ See von Wilmowsky, Zugang zu öffentlichen Leistungen anderer Mitgliedstaaten, in: ZfaöR (1992) pp.231-276, at p.259 and Schulz (1997) supra footnote 37, at p.339. 
persons. Also "needy" Community citizens who primarily move to other Member States in order to look for employment, to live closer to family members or friends, or who wish to live in a better climate, may increase the pressure on social assistance schemes. Many of the objections against a general right of residence would probably not exist if it could be shown that the migration of Community citizens in need of such benefits was more or less in balance. Yet, this does not seem very likely. For various reasons, and the level of social assistance benefits is only one, some Member States will be more attractive than others and the former are likely to bear a heavier burden than the latter. Second, the race to the bottom theory is not based on the assumption that social tourism actually occurs, but on the mere fear that it might occur. ${ }^{305}$ In the model described in the previous sub-section, States not only lower their benefit levels once they have actually been confronted with an influx of "freeriders" from other States. They lower benefit levels in advance in an attempt to discourage free-riders from coming. The lowering of benefits in the "race to the bottom" is often a preventive act on the part of States trying to be on the safe side. Finally, even if it could be established that Member States would not lower benefit levels in order to deter free-riders from coming or tax-payers from leaving, one cannot exclude the possibility that fear of movement may prevent Member States from increasing benefits. The possible introduction of a general right of residence might not be likely to trigger a total "race to the bottom", but it might hamper a "race to the top".

It may not be very likely that the "poor", if given the right, will move in such great numbers as to upset social assistance schemes, but the possibility cannot be wholly ruled that the introduction of a general right of residence may have implications for the (funding of the) social assistance schemes of (some) Member States. At least in considering the legislative options for realising a general right of residence, it is to be assumed that progress can probably only be made when some protective measures are taken to the benefit of the more generous States.

\footnotetext{
${ }^{305}$ Bennet, The Threat of the Wandering Poor: Welfare Parochialism and its Impact on the Use of Housing Mobility as an Anti-Poverty Strategy, in: FordLJ (1995) pp.1207 et seq, at pp.1216-1217.
} 


\subsection{Legislative Options}

If the Community legislator were to study whether, and if so, how, a general right of residence could possibly be realised, it might consider several alternatives. As regards some of these one can be rather brief. For instance, one could explore the possibilities of setting up a common social assistance benefit scheme. ${ }^{306}$ No doubt, such a scheme could pave the way for a general right of residence but any attempt to develop such a scheme is probably fruitless. One can assume that Member States are not willing to transfer the powers and financial resources necessary for establishing such a common scheme to the Community institutions. ${ }^{307}$

306 Fiscal federalism theories teach that redistributional programmes such as social assistance or welfare schemes cannot be efficiently organised at local or State level. For as as long as freedom of movement exists, local governmental entities may serve as welfare magnets and a "race to the bottom" may occur. Redistributional programmes should therefore be put in place at Federal or central level. See e.g. Grewal, Economic Criteria for the Assignment of Functions in a Federal System, in: Advisory Council for Inter-Governmental Relations - Towards Adaptive Federalism (1981) at p.27 and Buchanan, Who Should Distribute What in a Federal System, in: Hochman/Peterson, Redistribution Through Public Choice (1974).

In setting up a common scheme, several alternatives could be considered. A benefit scheme could be established for which the Community is wholly responsible and which would either wholly subsititute or supplement the current national benefit schemes. One could also study the possibility of establishing a programme comparable to the American TANF programme (the former AFDC) under which the Community would incite the Member States to develop new, or to improve existing, benefit schemes by making available grants which would cover a large part of the expenditure. Furthermore, one can imagine common benefit scheme which would only apply to the "needy" Europeans who wish to, or have decided to, establish residence in another Member State and draw inspiration from Professor Pieters' proposals to develop a so-called "thirteenth country social security system" for migrant workers. See Pieters, Sociale Zekerheid na 1992: Eén over Twaalf (1989) and Pieters/Vansteenkiste, The Thirteenth State - Towards a European Community Social Insurance Scheme for Intra-Community Migrants (1993)

${ }^{307}$ Compare Poiares Maduro, Europe's Social Shelf: "The Sickness Unto Death", in: Shaw (Ed.), Social Law and Policy in an Evolving European Union (2000) pp.325-349, at p.339. The Community has taken some initiatives to encourage Member States which do not yet have a social assistance scheme to develop such a scheme. See Council Recommendation on Common Criteria concerning Sufficient Resources and Social Assistance Protection Systems (Recommendation 92/441, OJ 1991 C 163). See further Coussins, The EC Recommendations on Social Protection: A Case Study in EC Social Policy, in: SPA (1993) pp. 286 et seq. No financial resources are made available, however, for the Member States concerned; the Recommendation mentioned does not confer enforcable rights upon individuals Mention may further be made of the idea of introducing something like a 'European Social Snake' aimed at avoiding radical (downward) changes in social security schemes. See Busquin, De Sociale Slang en het Europees Programma ter Bestrijding van Armoede, in: BTSZ (1990) pp.557 et seq. 
Another alternative which is probably not feasible would be to reduce the differences between benefit levels in the various Member States or to even harmonise benefit levels. ${ }^{308}$ This option would tackle the problem of social tourism at its core, but current benefit levels (in the northern and southern Member States) simply differ too much. Member States with comparatively high benefit levels will not be willing to lower their benefits to a level which would be acceptable to States with lower benefits. $^{309}$ Realistically, therefore, it can be assumed that a possible general right of residence is to be realised in a Community where the task of establishing social assistance benefit schemes is carried out at Member State level and where benefit levels differ considerably.

In order to overcome the various objections of Member States, one could consider the possibility of setting up some kind of system whereby States which receive a comparatively high number of "needy" persons from other Member States are compensated for the benefits they grant to such persons. ${ }^{310}$ Two options seem to be available. The first entails a system where the host State would be reimbursed by the State from which the migrant had moved. Such a compensation mechanism would have regard to the fact that the flow of "needy" Community citizens in different directions is unlikely to be in balance and that the financial burden would ultimately be borne by States which are most likely to have received taxes from the persons concerned and which benefit from the reduction in the number of persons to whom they have to pay social assistance benefits. ${ }^{311}$ The main $^{312}$ problem, however, with such a "pay-

${ }^{308}$ See e.g. Bertola et al (2000) supra footnote 302, at pp.105-108; and Atkinson, Poverty in Europe (1998) and Bean et al, Social Europe: One for All? (1998).

${ }^{309}$ Peterson and Rom have proposed a common welfare standard for the United States. Peterson/Rom (1990) supra footnote 218, Chapter 5. The feasibility of their proposal seems slim though.

${ }^{310}$ See also Vonk (1990) supra footnote 3, at p.473.

${ }^{311}$ The introduction of such a reimbursement mechanism has been considered in the past. When the European Commission submitted to the Council in 1989 a proposal for a directive on the right of residence for students, it proposed to grant to students the right to receive social security benefits in the host State on condition that the State of origin reimbursed the host State upon the latter's request. See Article 1(3) of the proposal for a Council directive on the right of residence for students. OJ $1989 \mathrm{C} 191$. On this proposal see further Taschner (1993) supra footnote 93, at p.433. Due to some Member States' fears that the costs would not be paid back by the State of origin, this proposal has never been accepted by the Council. O'Leary (1996) supra footnote 93, at p.120. Furthermore, in a memorandum which was presented by the Spanish government during the 1990-1991 Intergovernmental Conference it was proposed to grant Community citizens an unlimited right to move and reside freely and to adopt legislation that would lay down "provisions to ensure a fair distribution of the resulting burden on the Member States, particularly in the area of social protection". Scc the 
ing back system" is that it might in the end work out unfavourably for Member States with comparatively low benefit levels. They would be forced to bear the costs of benefits which are higher than the ones made available "at home". The funding of their minimum subsistence benefit schemes could be affected. Politically, compensation mechanisms under which the State of origin has to reimburse the "new" host State do not seem feasible. ${ }^{313}$ In the alternative, one could consider setting up a mechanism under which the "net-importers" of persons in need of minimum subsistence benefits would be reimbursed by the Community. A special Community fund could be set up for this purpose. ${ }^{314}$ The problem, however, is that such a common "pay-back-system" does not eliminate the problem of social tourism. Persons in need of benefits would still have an incentive to move to States where benefits are relatively high. The total costs of benefits granted within the Community are likely to increase. Who will bear these costs? The main beneficiaries of such a Community reimbursement scheme would be the States with comparatively high benefits and ultimately such a scheme would require the "netexporting" States with the lower benefits levels to bear the extra financial burden. The latter are likely to resist. They may prefer to invest in their own benefits chemes instead of compensating other States. Ultimately, the problems concerning a Community reimbursement scheme are comparable to those relating to schemes under which the State of origin would have to pay the bill.

The above mentioned options would allow for a general right of residence which would encompass a right to claim social assistance

Spanish Memorandum on European Citizenship as published in e.g. Cornett, The Treaty of Maastricht (1993) at p.156.

${ }^{312}$ Another problem as regards such "paying-back schemes" concerns the duration of the duty to reimburse the host State. A duty which is limited to a rather short period of time of for instance three months might possibly be acceptable to Member States, but the same does not hold true for longer periods of reimbursement. Furthermore, to whom should the duty to refund the host State apply? Should this duty only exist as regards Member States' own nationals who have moved elsewhere? Or should residence be taken as the starting-point and, if so, can a Member State also be obliged to refund the host State if the persons concerned holds the nationality of that State? Should the duration of the period during which the persons concerned have lived and paid taxes in the State which has to reimburse, be considered as a relevant factor?

${ }^{313}$ Vonk (1990) supra footnote 3, at p.469.

${ }^{314}$ In the United States plans for introducing a federal "charge back" were considered in the 1950s. The Federal government would reimburse the States for the expenses of welfare granted to newcomers during the first year. After that year, States would be fully financially responsible for welfare. The plan, however, has never become law. Mandelker (1955) supra footnote 211 , at pp.364-365. 
benefits from the moment beneficiaries establish residence in another Member State. The chances of realising such a "full" right of residence through legislative means seem slim. Realistically, efforts need to be focussed on some less far-reaching solutions. A first option might consist of reconsidering the exportability of minimum subsistence benefits. This option would not guarantee that in all cases "needy" Community citizens are able to meet the financial means requirements and to establish residence in other Member States, but it would promote freedom of movement. By comparison with a reimbursement scheme where the State of origin has to bear the costs, the exportability of benefit schemes has the advantage that States with comparatively low benefits would not be obliged to pay more than they would if beneficiaries had stayed at home. Various obstacles would have to be overcome though. A first one concerns the duration of the right to export benefits. Under Article 10 of Regulation No 1408/71 no time-limit exists. The duration of the exportability basically coincides with the duration for which national laws guarantee entitlement to benefits. In order to increase the chances of having a proposal for the exportability social assistance adopted, one might therefore consider a right to export social assistance benefits for a limited period of time. ${ }^{315}$ Further questions arise as regards the level of the benefit and the cost of living in other Member States. These costs may very well be lower than in the State which would have to pay benefits. In Lenoir and Snares the Court explicitly stated that eligibility for "benefits closely linked with the social environment" of Member States may be made conditional upon a residence requirement. Yet, in order to avoid Member States being obliged to pay social recipients "more than they would need", Member States could be allowed to limit the amount of benefits to the level applied in the State to which a Community

\footnotetext{
${ }^{315}$ One could consider a solution comparable to the one which exists for unemployment benefits. Article 69 of Regulation No 1408/71 allows for the export of unemployment benefits for a period of three months. See e.g. Case 139/78 Coccioli [1979] ECR 991 and Joined Cases 41/79, 121/79 and 796/79 Testa [1980] ECR 1979. The Commission has proposed to the Council to extend the duration of the exportability of unemployment benefits. See COM(95) 734 def, COM(98) 779 final and Pennings, Introduction to European Social Security Law (1998) at pp.190-191. In fact, it may be considered rather "odd" that a person who has been unemployed for a relatively short period of time may seek work in another Member State and continue to receive unemployment benefit, whilst a person who has been unemployed for a much longer period of time, has lost entitlement to unemployment benefit and become dependent on social assistance benefits, does not have any right to export his benefit.
} 
citizen has moved or to the cost of living there. ${ }^{316}$ Obstacles to a limited right to export social assistance benefits need not be insurmountable, but in the light of the saga surrounding the export of mixed minimum subsistence benefits, ${ }^{317}$ one may question the feasibility of introducing such a right.

The legislator could further consider the option of replacing the financial requirements now contained in the 1990 residence directives by a single provision which would allow Member States to make eligibility for social assistance benefits conditional upon the fulfillment of minimum periods of residence. Various alternatives seem to be available. During the time that such durational residence requirements might be applied by Member States, Community citizens could be denied a right to claim benefits in the host State. As described in Section 8, this option applied in the United States in the period between the judgments in Edwards (1941) and Shapiro (1969). The main disadvantage is that "needy" Community citizens would still be deterred from moving elsewhere. In order to partly overcome this obstacle, one could consider a relatively short durational residence requirement of, for instance, only two or three months. Also, one could choose the "two-tier-benefit-policies" comparable to those which some of the American States have applied in recent years. Thus, during the waiting-period a right to a benefit could be granted which only consists of a certain percentage of the benefits in the host State or the benefit could be limited to the level of benefits received in the State from which they have moved. ${ }^{318}$ The above options seem to strike a fair bal-

${ }^{316}$ Compare Case C-237/94 O'Flynn [1996] ECR I-2617 at 28-29 (payment for costs of funerals abroad); Case C-158/95 Kohll [1998] ECR I-1931 at 26 (reimbursement of costs of medical care received in other Member States) and the Opinion of Advocate General Alber in Case C-33/99 Fahmi (http://www.curia.eu.int/jurisp) at 83 (export of study grants).

317 See Section 5.

${ }^{318}$ Possibly, the "waiting-period option" could be combined with one of the alternatives discussed before. Thus, for the duration of the waiting-period in the new host State, the State from which the person concerned had moved could be obliged to allow the export of benefits. Alternatively, "needy" persons who have moved from one State to another could be given a right to obtain benefits but during an initial period the State of origin would be obliged to reimburse the host State. As a less far-reaching alternative, one could further think of removing the financial means requirement without conferring upon beneficiaries any entitlement to minimum subsistence benefits. The main reason why Member States have always insisted on the requirements concerning financial means relates to the fear of an increase in expenditure. Yet, if no obligation to grant such benefits exists, the main objections would no longer seem to exist. The abolition of the requirements contained in the 1990 residence directives would reduce the administrative burden caused by the duty of Community citizens to prove that they possess sufficient financial means. The disadvantages of this option are also clear however. Community citizens who receive minimum subsistencc 
ance between the aim of promoting freedom of movement for Community citizens and the need to safeguard the funding of minimum subsistence schemes. The waiting-period options would take away hurdles for the non-economically active Community citizens who wish to establish residence in other States, whilst providing the Member States with a means of protecting themselves against social tourism. Yet, the feasibility of the "waiting-period option" also seems minimal. The fact that the right to reside would not include a right to obtain social assistance benefits seems to be at odds with the policies and responsibilities of most Member States to guarantee all residents, where necessary, minimums means for subsistence. Furthermore, waiting-period requirements are at odds with the obligations which many Member States have accepted under international agreements and treaties. For instance, Article 1 of the European Convention of Social and Medical Assistance stipulates that the Contracting Parties must ensure that nationals of the other State parties who are lawfully residing within their territory and who are without sufficient resources, shall be entitled to social assistance under the same conditions as the States' own nationals.

If the Community legislator were seriously to consider how a general right of residence might possibly be realised or worked on, it might consider one of the above alternatives. Yet, the purport of the discussion may be clear. Due to the fear of social tourism, and constant concerns about the financing of social security and assistance schemes, Member States do not some eager to make any progress. They pay lipservice to but do not seem willing to take definite steps towards realising a genuine right of residence for all Union citizens. ${ }^{319}$ The issue does not rank high on the agenda of the political Community institutions. In fact, it is not even on the agenda. If the first initiatives are to be taken by the political Community institutions, one should not expect that much pro-

benefits are unlikely to move to other States if they were not entitled to export their benefits and lack a right to benefits in the host State. In practice, this option does not seem to bring free movement for Community citizens any closer.

${ }^{319}$ Illustrative are the results of the recent summit in Nice. Member States were willing to adopt a Charter of Fundamental Rights including a right for Union citizens to move and reside freely within the Community which, unlike Article 18(1) EC, is not subject to any limitation or condition. The Charter, however, is not a legally binding document which contains directly enforcable rights. Further, in the provisional text of the Treaty of Nice Article $18 \mathrm{EC}$ is proposed to be altered. The current Article 18(2) will be amended in that the provisions necessary for facilitating the rights to move and reside freely mentioned in Article 18(1) EC shall no longer be adopted by Council by unanimity. In the proposed new Article 18(3), however, it is expressly stated that Article 18(2) EC shall not apply to provisions on inter alia social sccurity or social protection. 
gress will be made in the near future. Therefore, if one wishes to move towards a genuine freedom of movement, it might be better to consider judicial options. ${ }^{320}$

\subsection{Judicial Options}

Prior to the cominginto force of the Treaty on European Union, the Court of Justice did not seem to dispose of legal tools which it could have used to make a contribution to the realisation of a general non-economic right of residence for Community citizens. The EC Treaty only provided for functional residence rights intended to facilitate the right to work in other Member States (Article 39) and the right of establishment (Article 43). ${ }^{321}$ The adoption of Directive No 90/364 on a general right of residence was not required by any Treaty provision. It was a voluntary act; nothing prevented the Community legislator from making the right of residence subject to a financial means requirement. The Treaty on European Union, however, has put the general right of residence in a new and different perspective. A European citizenship has formally been established (Article $17 \mathrm{EC}$ ) and it is in this capacity that nationals of Member States now enjoy "the right to move and reside freely within the territory of the Member States" (Article 18(1) EC). Articles 17 and 18 EC are not merely symbolic provisions. Martinez Sala and Elsen demonstrate that the provisions may have legal force. The two rulings would seem to indicate that $(i)$ the general right to reside is now a Treaty-based right; (ii) that Article 18(1) EC may be relied upon by Union citizens in order to challenge national rules which hamper the right to establish residence in other Member States and (iii) that Union citizens lawfully reisiding in the territory of other Member States are entitled, as persons falling within the personal scope of the Treaty provisions on Union citizenship, to claim under Article 12(1) EC social benefits, including minimum subsistence benefits, under the same conditions as the nationals of the host State. Martinez Sala and Elsen show that the Court is indeed willing to use Article(s 17 and) 18 as tools for strengthening the status of Union citizens. This, however, does not imply that the financial means requirement

\footnotetext{
${ }^{320}$ Compare O'Leary (1996) supra footnote 93, at pp.144-145.

${ }^{321}$ The introduction of the requirement of "effective and genuine work" for obtaining the status of Community worker (see Section 3.1.3) suggests that the Court has indeed rejected the view that Article $39 \mathrm{EC}$ can serve as the legal basis for a general non-economic right of residence. See van der Mei, The Elusive and Exclusive Concept of Union Citizenship, A Review Essay, in: MJ (1998) pp.391-402, at p.397.
} 
for taking up residence in other Member States is no longer valid. The drafters of the Treaty on European Union carefully wished to avoid such a conclusion by inserting in Article 18(1) the phrase that the free movement rights are subject to "limitations and conditions laid down in this Treaty and the measures adopted to give it effect". The financial means requirements mentioned in Directive No 90/364 amount to such limitations or conditions. ${ }^{322}$ The wording of Article 18(1) EC may warrant judicial restraint, but if the provision now constitutes the source of the right to reside, the legality of the application of the financial means requirement laid down in national $\operatorname{law}^{323}$ is no longer wholly self-evident. The rights guaranteed by Article 18(1) EC are fundamental rights which, having been put on "on a par with other rights central to Community law", ${ }^{324}$ are to be construed broadly and which can only be subjected to limitations and conditions which do not affect the core of the right. $^{325}$

National rules which make the right to reside conditional upon the possession of sufficient financial means are intended to protect the financial stability of social assistance schemes. This is a legitimate and compelling Member State interest which deserves protection under Community law. Yet, is it really necessary to deny needy Community citizens the right to establish residence in another Member State in order to protect the States' financial interests? The examination of American

${ }^{322}$ In the drafters' view, any progress was to be made by the Community legislature. Article 18(2) EC provides that the Council, acting unanimously and in accordance with the co-decision procedure, may adopt provisions aimed at facilitating the exercise of free movement rights. The provisional text of the Treaty of Nice approved by the Intergovernmental Conference proposes to alter Article 18(2). The new Article 18(2) states that if "action by the Community should prove necessary to attain this objective" and "the Treaty has not provided the necessary powers", the Council may adopt measures in accordance with the co-decision procedure. The Council will no longer have to act unanimously. Article 18(2) EC, however, does not apply to provisions "on passports, indentity cards, residence permits or any other such document or to provisions on social security or social protection" (Article 18(3)).

${ }^{32.3}$ To be sure, Article 1 of Directive No 90/364 itself cannot be considered as being incompatible with Article 18(1) EC. The Article is drafted in positive terms; it states that Member States shall grant the right to reside to nationals of Member States who have sufficient financial resources (and are insured for medical care). The Article does not oblige Member States to refuse residence to persons are not able to provide for themselves. The power to deny residence to such persons derives from national law, not Community law. The question to be adressed therefore is whether national rules or measures which make residence conditional upon the possession of sufficient resources are compatible with Article 18(1) EC.

${ }^{324}$ Report from the Commission on Citizenship of the Union. COM(93) 702 final at p.5.

${ }^{325}$ Opinion of Advocate General Cosmas in Case C-378/97 Wijsenbeek [1999] ECR I0000 at 97. 
constitutional law on cross-border access to welfare benefit schemes has demonstrated that there are alternative ways in which States' interests can be safeguarded. In particular, the financing of benefit schemes could be protected by rules which make eligibility conditional upon a minimum period of residence in the State. The case law of the Court of Justice does not wholly exclude the possibility that waiting-period requirements might be upheld under Article 12(1) EC. Martínez Sala indicates that all Union citizens who are lawfully residing in another Member States can invoke Article 12(1) in order to claim social assistance benefits under the same conditions as the nationals of the host State. Waiting-period requirements that are only imposed on nationals of other States constitute direct discrimination on grounds of nationality and would be prohibited. Waiting-periods applied to both nationals and non-nationals, however, could possibly escape the classification of a prohibited indirect discrimination for reasons of nationality where it can be demonstrated that they are necessary to safeguard the financial stability of social assistance schemes. ${ }^{326}$

Nonetheless, waiting-period requirements do not seem a serious alternative to the current financial means requirement. First, such requirements sit uneasily with the case law of the Court. In the context of the free movement of workers the Court has given due regard to the social assistance interests of the Member States. The Court has not done so by allowing States to discriminate against workers and their family members who have established residence in their territory, but rather by entitling States to refuse residence to workers who do not perform "effective and genuine work". More generally, the case law suggests that Member States can no longer protect their welfare state interests by making distinctions between lawful residents. These interests are to be protected by using (the remaining) immigration powers. Translated to non-economic residents, this would imply that the social assistance interests of Member States are

\footnotetext{
${ }^{326}$ To be sure, in its case law on the free movement of workers the Court has consistently held that durational residence or employment requirements are contrary to Article $39 \mathrm{EC}$ and Article 7(2) of Regulation No 1612/68. See Sections 3.1.3 and 3.2.3. This does not necessarily mean that the same requirements applied to non-economic residents also run counter to Article 12(1). In the context of the free movement of workers the Court has had regard to the financial interests of the host States by making the status of worker and, thus the right of residence and the right to equal treatment under Article 7(2) of Regulation No $1612 / 68$, conditional upon the requirement of "effective and genuine" work. In the field of the free movement of workers there was no need to uphold waiting-period requirements. The requirement of "effective and genuine" work, however, cannot be applied to non-economic residents and it could thus be argued that host States do need waiting-period conditions in order to sccure their financial interests.
} 
to be secured by limitations on the right to reside rather than by exceptions to the right to equal treatment. Second, international instruments such as the previously mentioned European Convention of Social and Medical Assistance do not seem to allow Member States to apply such durational residence requirements. Article 1 of the Convention expressly provides that the Contracting Parties must ensure that nationals of the other State parties who are lawfully residing within their territory and who are without sufficient resources, are entitled to social assistance under the same conditions as the States' own nationals. The principles enshrined in international instruments such as the European Convention are to be regarded as general principles of Community law which are protected by Community law. ${ }^{327}$ The precise contours of the Court's "human rights review" of Member State actions are still quite unclear, ${ }^{328}$ but it would be rather "odd" if the Court were to condemn the financial means requirement for the right to reside on the ground that they can secure their financial interests by a "prohibited" alternative.

If waiting-periods and, as one may assume, the exportability of social assistance benefits, ${ }^{329}$ are not serious alternatives, then there only seems one judicial option left for extending the free movement rights of "needy" Community citizens: the "simple" invalidation of the financial means requirement. Against the conclusion that the requirements are incompatible with Article 18(1) EC two basic objections could be made.

\footnotetext{
${ }^{327}$ See Chapter 2 Section 7 (footnote 237).

${ }^{328}$ Craig/de Búrca, EU Law - Text, Cases \& Materials (1998) at p.318.

${ }^{329}$ At first glance, the recent judgment in Elsen leaves some room for the suggestion that national rules which deny the export of minimum subsistence benefits run counter to Article 18(1) EC. Case C-135/99 Elsen [2000] ECR I-0000 at 34. Snares (1997), however, suggests that the Court has already rejected this option. It may be recalled (see Section 5.1.3) that the Court was asked in this case whether the Community legislator had exceeded its powers in the field of the free movement of workers by inserting Article 10a in Regulation No 1408/71, which offers Member States the possibility of limiting the export of mixed benefits. The Court answered in the negative. Some additional observations suggest that the Court would have ruled similarly if the national court had asked whether Article 10a is compatible with Article 18 EC. In Snares the Court recognised that Community citizens could be refused a right of residence in another Member State if they, contrary to the requirements laid down Article 1 of Directive 90/365 on a right to residence for pensioners, did not receive a pension. The non-exportability of mixed benefits could have the effect of diminishing the financial means of persons like Mr Snares. According to the Court, however, this was only the result of the differences between the national social security systems. Snares concerned a Community provision applying to mixed benefits only, but the encore given in Snares suggests that the Court does not consider national rules limiting the export of social assistance benefits to be incompatible with Article $18 \mathrm{EC}$. This Article does not require the exportability of mixed benefits. Compare also O'Leary (1996) supra footnotc 93, at p.131.
} 
The first is that it is too "risky" to grant the "poor" a right of residence without giving the Member States some kind of legal tool for protecting themselves against "social tourism". On the basis of the discussion of the American jurisprudence on the freedom of movement for persons in need of welfare benefits in Section 9, one could question whether there is any real risk. In Saenz v Roe (1999) the Court concluded that welfare waitingperiod requirements are unconstitutional. This conclusion formally rested on the Citizenship Clause of the Fourteenth Amendment which does not "allow for .. degrees of citizenship based on the length of residence", but in its ruling the Court clearly indicated that it also saw no "economic need" for the requirements. As argued in Section 10.2.2, there are reasons to believe that European citizens are not so likely to move in large numbers to other States and that, even if they did appear more mobile than expected, it could be questioned whether the funding of the "netimporters" of "needy" Union citizens would be seriously affected. If, as the Supreme Court calculated in Saenz, an among "needy" Americans a quite popular State as California could secure the funding of its benefit systems by reducing benefits by 72 cents per month, then it does not seem wholly unrealistic to conclude that a possible invalidation of the financial means requirements in the European Community would not disrupt the financing of the benefit schemes of the more generous European Member States. Certainly, the possibility cannot be excluded that some States will lower, or refuse to increase, benefits because they fear an influx of free-riding social assistance recipients. Yet, is a mere fear a good enough reason for denying the less well-off Union citizens the fundamental right to move to other Member States? Furthermore, even if one were to hold the view that the financial means requirement for obtaining recognition of the right to reside (Article 1 of Directive No 90/364) is a prerequisite for the protection of the funding of benefit sytems, does the same hold true for the requirement that the non-economic residents must also meet the requirement in order to retain the right (Article 3 of Directive No 90/364)? Are the financial concerns of the host State serious enough in order to end residence of nationals of other Member States who have become in need of social assistance benefits but who may have lived and paid taxes there for a number of years? Furthermore, if social tourism were actually to occur and if States were indeed to respond by increasing taxes, tax-payers might decide to move elsewhere and this may again be a reason for States to choose the option of lowering benefit levels. Yet, would this not be a reason to impose limits on the free movement rights of these tax-payers rather than on the right of those in 
need of social assistance benefits? ${ }^{330}$ Ultimately, the problem is that there is no guarantee in advance that social tourism will indeed not occur and the recognition of an unconditional right to reside for all Union citizens may therefore indeed be somewhat risky. Yet, in the light of the American and previous European experiences, it would seem that the problems concerning welfare migration or social tourism are more symbolic than real.

A second objection to the conclusion that the financial means requirements are inconsistent with Article 18(1) EC, is that it ignores the intentions of the drafters of the Treaty. ${ }^{331}$ By expressly stating that the free movement rights are "subject to the limitations and conditions laid down in this Treaty and by the measures adopted to give it effect", the drafters had made it patently clear that Article 18(1) EC was not inserted in the Treaty with a view to bringing about substantive changes in the free movement regime. So far the question of the compatibility of the financial means requirements with Article 18(1) EC has never been addressed by the Community judiciary, but recent judgments suggest that the will of the drafters indeed constitutes a serious, and perhaps insurmountable, obstacle. The Court of First Instance, for example, has already accepted the validity of the health insurance requirement mentioned in Directive No 90/364. In response to a claim by the former wife of Member State national employed by the European Community that the impossibility of obtaining sickness insurance in a Member State constitutes a restriction on her right to move freely, the Court held in Kuchlenz-Winter (1997) that Article 18 EC expressly provides that the right to reside is subject to the conditions and limitations laid down in secondary legislation. From Directives No 90/364 and No 90/365 it would clearly follow that persons who are not in active employment must have sickness insurance in order to claim a residence right. ${ }^{332}$ The recent judgment in Kaba (2000) suggests that the Court of Justice holds a similar view. In this case the Court was asked to determine whether Article 7(2) of Regulation No 1612/68 objected to a United Kingdom rule according to which spouses of United Kingdom nationals and persons who are "settled" in the country, could apply for indefinite leave to remain under more

\footnotetext{
${ }^{330}$ On this point compare Fox Piven, The Race Among the States in Welfare Benefits: A Comment, in: Publius (1998) pp.39-43.

${ }^{331}$ See e.g. Kovar-Simon, La Citoyenneté européenne, in: CDE (1993) pp.284 et seq, at pp.295-300; Dollat, Libre Circulation des Persones et Citoyenneté européenne: Enjeux et Perspectives (1998) at p.133 and the Opinion of Advocate General La Pergola in Case C356/98 Kaba [2000] ECR I-0000 at 51-64.

${ }^{332}$ Case T-66/95 Kuchlenz-Winter [1997] ECR II-637 at 47.
} 
favourable conditions than EEA nationals who have been issued a residence permit valid for five years. The Court answered that Member States are entitled to rely on any objective difference there may be between their own nationals and those of other Member States when they lay down the conditions under which leave to remain is to be granted to spouses of such persons. The Court reached this conclusion because, as Community law stands at present:

"the right of nationals of a Member State to reside in another Member State is not unconditional. That situation derives ... from .. Article $8 \mathrm{a}$ of the EC Treaty (now, after amendment, Article $18 \mathrm{EC}$ ) which, whilst granting citizens of the Union the right to move and reside freely within the Member States, expressly refers to the limitations and conditions laid down in the Treaty and by the measures adopted to give it effect". 333

The issue was not directly addressed by the Court, but the above observations do suggest that, at least in the near future, the Court is not likely to overrule the intentions of the drafters ${ }^{334}$ by holding that financial means requirements, especially where they are applied as a condition for establishing residence in another Member State, are incompatible with Article 18 EC.

${ }^{333}$ Case C-356/98 Kaba [2000] ECR I-0000 at 30. On Kaba see Peers, Dazed and Confused: Family Members' Residence Rights and the Court of Justice, in: ELRev (2001) pp.76-83.

${ }^{334}$ Compare further Baglieri (1993) in which the Court was asked to interpret Article 14 which provides for the adoption of measures aimed at progressively establishing the internal market by 31 December 1992. In a Declaration annexed to the Final Act adopting the Single European Act it is expressly stated that the date of 31 December 1992 "does not create an automatic legal effect". In answering the question whether Article 14 EC imposes on Member States from that date onward an obligation to admit persons who have been subject to compulsory insurance in another Member State to voluntary affiliation to their social security schemes, the Court held that such an obligation presupposes the harmonisation of social security legislation within the Community. Case C-297/92 Baglieri [1993] ECR I-5211 at 16-17. Even though the Court did not refer to the Declaration, it would seem that the Court, just like Advocate General Jacobs (Opinion of Advocate General Jacobs in Case C297/92 Baglieri [1993] ECR I-5211 at 12), did not wish to interpret Article 14 EC in a way which runs directly counter to the intentions of the drafters.

Furthermore, in Wijsenbeek the Court was asked whether Articles 14 and 18 EC preclude national legislation which requires persons entering national territory to present a passport. The Court held that even if Community citizens were to enjoy a right to freedom of movement under Article 14 or Article $18 \mathrm{EC}$, they do not have a right to move freely and unconditionally within the Community. For as long as national immigration, visa and asylum policies have not been harmonised, Member States remain free to carry out identity checks at the internal frontiers of the Community in order to establish whether a person is a Community citizen having the right to move freely. Case C-378/97 Wijsenbeek [1999] ECR I-0000 at $42-43$. 


\subsubsection{Conclusions}

The conclusion to be drawn at the end of this section, and chapter, is one of disappointment. The financial means requirements contained in the 1990 residence directives for the non-economically active who are not able to provide for themselves imply a de facto denial of the right to reside in other Member States. From the perspective of Union citizenship such a denial is problematic, but chances that the situation will improve in the near future seem slim. The Community legislator is not likely to work on the issue at all and judgments such as Kaba cast doubt as to whether the Court is willing to make a contribution. In the light of the wording of Article $18 \mathrm{EC}$, and the intentions of its drafters, it would not be incomprehensible, but it would be somewhat disappointing if the Court were to remain passive. In Edwards, Shapiro and Saenz the American Supreme Court assumed responsibility for strengthening the notion of United States citizenship, the right to freedom of movement and the legal status of the "poor" by obliging the States to admit "the free-riding poor" for residence and to grant them, upon arrival, welfare benefits. By doing so the Supreme Court expressly overruled Congress which had allowed States to deny "newcomers" welfare benefits during an initial period of time because it was not persuaded that welfare waiting-periods were really necessary for protecting States' welfare interests. The legal and political settings in which the subject of freedom of movement for the "poor" is to be placed may differ, but from an economic-political perspective the issues concerning the "wandering poor" on both sides of the Atlantic are in essence quite similar. ${ }^{335}$ The problems of welfare migration and social tourism are not as serious as they are often presented and, for this reason, one might question whether there is a need to fully respect the intentions of the drafters of the Treaty on European Union on this point. The realisation of a general freedom which would also enable the "poor" to reside in the Member State of their choice indeed may not be a task for the Court, and it is no doubt safer to configure Community law on

\footnotetext{
${ }^{335}$ It has been argued that the "sink or swim together" adagio in the United States does not hold true for the European Community. The realisation of a general right of residence for all Union citizens would first require the adoption of legislative measures concerning social security at Community level. Schrauwen, Annotation Martínez Sala, in: SEW (1999) pp.426-430, at p.430. In Baglieri (1993) (see footnote 329 above) the Court indeed drew such a conclusion in relation to social insurance benefits (and Article 14 EC), but given the unlikelihood of excessive social tourism, one could question whether there is a need for such mcasurcs as regards social assistance benefits (and Article 18(1) EC).
} 
freedom of movement as if the "poor" were wholly mobile, ${ }^{336}$ but it would be quite embarrassing if the Community as a whole, which claims to pursue social objectives and has formally introduced a common citizenship, is not able to solve a problem which seems more symbolic than real. When taken seriously, Union citizenship ought to be developed in such a way that the rights that come with it can be enjoyed by both the "rich" and the "poor".

\footnotetext{
${ }^{336}$ Compare Bertola et al (2000) supra footnote 302, at p.105.
} 

Chapter 4

HEALTH CARE 

The European Community's goal of realising a free movement of persons inevitably raises questions about the degree to, and the conditions under, which beneficiaries can obtain medical care in other Member States.

On the one hand, one might expect Community law to provide for quite extensive cross-border health care rights. The risk of becoming sick or a victim of an accident can occur at any moment and at any place, and health care is of such tremendous importance for health and life, that Community citizens might be deterred from exercising their free movement rights if these did not encompass a right to obtain the necessary medical facilities. Indeed, access to medical care in other Member States would seem to be a prerequisite for a free movement of persons which is practical and relevant. In reverse, freedom of movement might also be crucial for medical reasons. By going to other States patients placed on waiting lists may be able to obtain the care they need "on time", residents of border regions could obtain treatment at a place closer to their home and the "medical movement" abroad might enable patients to obtain types of treatment which are not available "at home" but essential for their medical conditition. Further, the cost of medical services or medic(in)al products are often so high that free movement and cross-border health care rights would lack practical meaning if Community citizens were required to bear all the cost themselves. In brief, from the patients' perspective it would be "ideal" if they could move to and claim medical benefits in any other Member State at the expense of the sickness fund or health institution they are affilliated to.

On the other hand, however, some limitations on cross-border care may be expected and required. Within the European Community, it is up to Member States to organise, finance and administer health care and insurance. If patients were wholly free to choose in which State they wish to obtain medical treatment, Member States may not be able to keep up their health systems. Member States which receive large numbers of foreign patients may be confronted with financial problems if they are not compensated in any way for the cost involved and they may face capacity problems such as waiting lists if they have to admit all foreign patients unconditionally. Further, if patients were free to shop around for medical services throughout the Community, and if Member States were obliged to bear all cost, health expenditure could increase and problems of underutilisation of health facilities "at home" could occur.

Thus, the Community's goal of promoting freedom of movement may clash with the Member States' ability to maintain financially sound and adequate health care systems. The aim of this Chapter is to explore 
how Community law has settled this conflict. To what extent, and under which conditions, are Community citizens and third country nationals who are publicly ${ }^{1}$ insured in one of the Member States entitled to obtain medical benefits in other Member States? To what extent are the Member States entitled to protect their health care systems by imposing restrictions on cross-border care?

The chapter is structured as follows. Section 2 puts the subject of cross-border access to medical care in its proper context by describing ( $i$ ) the main features of the Member States' public health care and insurance systems, (ii) the way States have traditionally regulated cross-border access to these systems, (iii) the various ways in which the European Community is involved, or touches upon, health care (related) issues and (iv) the main principles on which the health care provisions of EC Regulations No 1408/71 and No 574/72 are based. The subsequent section discusses the cross-border health care rights which economic residents (3.1), non-residents (3.2), non-economic residents (3.3) and third country nationals (3.4) enjoy under the afore mentioned regulations and, in as far as third country nationals are concerned, the social security provisions of the agreements which the Community (and its Member States) have concluded with third countries. Section 4 addresses the question whether, and to what extent, beneficiaries of the free movement of persons can claim additional health care rights under the Treaty's common market provisions. The fourth section is mainly devoted to the 1998 judgments of the Court of Justice in Decker and Kohll which have provoked so much debate and criticism in health care and insurance circles. The background to the cases, the judgments themselves as well as their possible implications are examined. Section 5 discusses the degree to which American constitutional law entitles individuals covered by public health care or insurance systems to acquire in other States medical treatment at the expense of the public insurer. Can the European Community learn some lessons from the United States as to how cross-border access to medical care is best regulated? The chapter will end with some concluding and evaluating observations (Section 6)

1. The present study does not discuss cross-border health care rights of patients who are privately insured for health care. It is estimated, however, that approximately $95 \%$ of the European Union population is covered by a public health (insurance) system. See Hermessc/Lewalle, L'Accès aux Soins en Europe - Quelle Mobilité du patient? (1993). 


\subsection{Health Care Systems of the Member States}

In economic terms medical care and products may be regarded as commodities which could be supplied by private actors operating in a purely commercial market. Not one of the Member States, however, has chosen to fully entrust the supply of medical care to the market and its principles of laissez-faire and free competition. Governments regulate and subsidise the health care sector, many of them have made insurance for medical care mandatory by law and in many Member States health care facilities are provided by State institutions. Apart from the fact that the private provision of medical care is not necessarily (the most) cost-efficient, ${ }^{2}$ public intervention has been considered necessary for reasons of "social justice". ${ }^{3}$ First, governments have taken measures in order to ensure that medical benefits meet minimum "quality" requirements. Medic(in)al products can be marketed only when they meet health, safety and efficacy standards. Admission to health professions is made conditional upon the possession of diplomas which often can only be obtained after rather

2. See e.g. Hyman, Public Finance - A Contemporary Application of Theory to Policy (1999) Chapter 9 and Barr, The Economics of the Welfare State (1998) Chapter 12.

3. Governments in all Member States have taken responsibility for ensuring that all "members of society", regardless of their place of residence or economic status, have access to adequate health care. This responsibility has found legal recognition in a right to health care which is setforth in the constitutions and/or legislations of most Member States (Leenen et al. Trends in Health Legislation in Europe (1986) at pp.5-7) as well as international human rights instruments (see e.g. Article 25 of the Universal Declaration of Human Rights, Article 12 of the International Covenant on Economic, Social and Cultural Rights and Article 11 of the European Social Charter; see further Toebes, The Right to Health as a Human Right in International Law (1999) and Roscam Abbing, International Organizations in Europe and the Right to Health Care (1979)). See also Hermans, Patients' Rights in the European Union - Cross-Border Care as an Example of the Right to Health Care, in: EJPH (1997) pp.11-17. A number of specific policy objectives derive from this right to health care: 1. Adequacy and equity in access - all citizens should have access to at least a basic minimum of health care; "equal treatment for equal need" is to be the starting-point as regards publicly funded health services. 2 . Income protection - patients should be protected from health care payments which could form a catastrophic threat to their income or wealth; health care payment should be related to the individuals' ability to pay. 3. Macro-economic efficiency - health expenditures should consume an appropriate fraction of the gross domestic product. 4. Micro-economic efficiency - considering the macro-economic limits, health outcome and consumer satisfaction should be as high as possible. 5. Freedom to choose health care providers. 6. Appropriate autonomy for health care providers. See further Hurst, Reforming Health Care in Seven European Nations, in: H^ (1991) pp.1-10, at pp.8-9. 
lengthy training and education and in pursuing their professions, doctors, pharmacists nurses etc. are bound to observe rules of professional conduct. Second, governments have intervened in the market in order to ensure that all persons, including those living in the least populated regions, have access to doctors and hospitals at a place not too far from their home (geographic accessibility). For this purpose, comprehensive establishment and capacity policies have been developed in each of the Member States. Third, medical care should be available for all persons regardless of their economic status (financial accessibility). Governments in each of the Member States have established public (or collective) health (insurance) systems to which the vast majority of the population is compulsorily affiliated. The systems of the Member States differ considerably, ${ }^{4}$ but a distinction can be made between "social insurance systems" and "national health services".

Social health insurance schemes can be found in the "old" Member States now located in the geographical centre of the Community (the Benelux countries, Germany and France). In these countries the law determines the categories of persons who are compulsorily insured, the insurance premiums to be paid, the benefit package and the rules governing the administration of the systems. Often the whole population is compulsorily insured (e.g. Belgium, France, the Netherlands for exceptional medical cost), but in some States (e.g. Germany, the Netherlands for normal medical cost) only (albeit large) parts of the population are covered by the insurance schemes. The level of the premiums is usually income-related and calculated on the basis of the total yearly expenditure. The administration of the insurance systems is often integrated into the

4. In spite of the numerous differences, however, there is a clear tendency towards convergence of the systems. Palm et al, Implications de la Jurisprudence récente Concernant la Coordination des Systèmes de Protection contre Le Risque de Maladie (2000) at p.19 and Recommendation No $92 / 442$ of the European Council on the convergence of the objectives of social protection policies (OJ 1992 L 245). For more detailed descriptions of the systems of the Member States see e.g. Jacobs/Goddard, Social Health Insurance Systems in European Countries - The Role of the Insurer in the Health Care System: A Comparative Study of Four European Countries (2000); Palm et al (2000) supra, at pp.14-24; Jakubowski/Busse, Health Care Systems in the EU - A Comparative Study (1998); van Kemenade, Health Care in Europe 1997 (1997); Hermans et al, Health Care in Europe after 1992 (1992); De Klein/Collaris, The Choices in Care: A European Problem? (1991); Casparie et al, Competitive Health Care in Europe (1990) Vreugdenhil/De Bruine, Gezondheidszorg in Europa Structuur en Financiering van de Gezondheidszorg in enkele Europese Landen (1990); Schneider et al, Gesundheitssysteme im internationalen Vergleich (1989); De Klein/ Collaris, Sociale Ziektenkostenverzekeringen in Europees Perspectief (1987) and AbelSmith/Maynard, De Organisatie, Financiering en Kosten van de Gezondheidszorg in de Europese Gemeenschap (1978). 
general social security system and entrusted to local (semi-)public bodies such as sickness funds. Among the social health insurances a further distinction can be made between systems based on the principle of reimbursement and systems based on the benefits-in-kind principle. In States where the former principle is applied (e.g. Belgium, Luxembourg), health insurance laws state that patients are entitled to the payment of the cost of medical care. Patients have to pay the doctor, therapist, etc. themselves and, upon presentation of a receipt, they are afterwards reimbursed by their sickness fund. In Member States which have opted for the principle of benefits-in-kind (e.g. the Austria, Germany, the Netherlands) beneficiaries are entitled to obtain medical benefits from health practitioners who are directly paid by the competent health (insurance) institutions. Apart from possible co-payments, patients are not confronted with a "medical bill".

The national health services, which exist in e.g. the United Kingdom, Ireland and most of the southern Member States, are not based on an insurance model in the technical meaning of the term. They are characterised by funding out of the public purse and public delivery of care in accordance with the principle of benefits-in-kind. Usually, the funding of national health services has a closed-end character. The oldest system is the British National Health Service which is indeed largely funded out of tax-revenues and offers medical services to almost the entire population. The systems of the other countries are based on comparable concepts but they are often less universal in the sense that the benefit packages differ for various categories of beneficiaries. Generally, national health systems are more centralised than social insurance systems.

In all States, regardless of the specific form of their health care system, governments have regulated the prices of medical treatment and products and limited the benefits which the insured can obtain at the expense of the sickness fund or the health institution they are affiliated to. The basic, and from a medical perspective necessary, types of treatment are included in the insurance packages, whilst more "luxurious" types of treatment (e.g. cosmetic plastic surgery, dentistry, physiotherapy) are, depending on cost or price, often excluded. As regards medic(in)al products, some States use "positive" lists mentioning the products which can be received at the expense of the insurer. In other States "negative lists" exist which state the products the cost of which is not to be reimbursed.

Generally, patients are free to choose the doctor they wish to be treated by. In some cases, however, this choice has been limited. In the Netherlands, for instance, the insured can only choose among the health providers with whom their sickness fund has concluded a contract. If patients wish to obtain care from a non-contracted health provider, they 
must ask their sickness fund for a prior authorisation. Further, in some Member States general practitioners are subject to quota regulations which imply that they can only register and treat a defined number of patients. General practitioners who have reached their quota, must refer new patients to other general practitioners. Furthermore, in some Member States such as the Netherlands and the United Kingdom patients can only obtain medical treatment from specialists (established in hospitals) upon referal by a general practitioner. In such States, general practioners serve as gatekeepers who steer patients to the appropriate specialists and prevent trivial complaints being dealt with by specialists. ${ }^{5}$

In all Member States health care is in principle a public affair, but in recent years "private elements" have become increasingly important. First, private health insurers have entered the market offering persons not covered by social insurance systems (e.g. self-employed persons, employees with a high income or certain categories of civil servants) the possibility of insuring themselves for health care or enabling patients to obtain insurance for health services which are not covered by the basic packages (e.g. dental care). Private insurance differs from social insurance in that private insurers operate on a commercial basis in mutual competition with each other. In addition, governments intervene less in the private insurance sector. Premiums are not always fixed by law, they may be related to the individual risk of the insured and private insurers may be entitled to refuse to accept certain persons. Second, in many Member States there is an increase in the number of private institutions which offer (usually rather specialised) health services which are not made available under the national public health care systems. Such institutions often operate wholly outside public health care systems. Third, in recent years "private elements" have increasingly been introduced within public health (insurance) systems themselves. Health care systems are characterised by a rapid growth in cost. ${ }^{6}$ In order to maintain health care systems, reforms are constantly under consideration by all Member States. The (proposed) reforms differ from State to State and have to be viewed in the context of

5. Barr (1993) supra footnote 2, at p.311 (as regards the United Kingdom).

6. There are many reasons for this. Among the most important ones are the ageing of the population (i.e. the older people get the more vulnerable they become to chronic diseases such as cancer, heart disease, rheumatism, etc), developments in medical technology (which increase the number of health services to be provided as well as the price of the services) and the growing number of unemployed and disabled people (see De Klein/Collaris (1986) supra footnote 4, at pp.93-109). 
the existing systems, ${ }^{7}$ but a distinction can be made between "macroeconomic" and "micro-economic" reform plans. ${ }^{8}$ The former concern the more general measures aimed at controlling the total expenditure of health care systems, whilst the latter involve efforts to improve quality of care and efficiency, to shift part of the cost onto patients and to introduce competition and free-market elements into the systems. Through competition providers and insurers should be encouraged to work more efficiently. The proposed reforms do not intend to achieve full competition but merely a form of what is called "managed competition". Competition should increase but only within limits set by governments. ${ }^{9}$ Providers and insurers may have to work with fixed or limited budgets, but governments retain the task of controlling the price of health services, to ensure the quality of the facilities and to safeguard the (equal) accessibility of health care.

\subsection{Conditions of Access}

Member States' health care and insurance systems are based on the principle of territoriality. Two premises follow from this principle. First, health care is only accessible to (lawful) residents regardless of nationality. ${ }^{10}$ In principle, non-residents are excluded. This premise is not fully effectuated in all cases. For instance, persons who have not resided in the State territory for a minimum period of time may be denied access to certain (usually rather expensive) types of treatment, ${ }^{11}$ whilst visitors

7. For an overview of the current reforms in the various Member States see e.g. KirkmanLiff, Stelselwijzigingen in Enkele Andere Landen, in: Elsinga/van Kemenade, Van Revolutie naar Evolutie (1997) Chapter 7 and Langer, Probleme der Koordinierung beim Public/PrivatMix von Gesundheitsleistungen, in: ZSR (1999) pp.716-734.

8. van Kemenade (1997) supra footnote 4, at pp.170-171.

9. Compare Palm et al (2000) supra footnote 4, at pp.23-24.

10. Compare von Maydell, Treatment of Third Country Nationals in the Member States of the European Union and the European Economic Area in Terms of Social Law, in: Commission of the European Communities/ Departemento de Relações Internaçionais e Convenções de Segurança Social, Social Security in Europe - Equality Between Nationals and NonNationals (1995) pp.139-154, at pp.148-149.

11. In the United Kingdom, for instance, access to health care is based on residency, but only persons who have resided in the United Kingdom for more than a year are regarded as residents under the laws and regulations governing the National Health Service. The Netherlands has applied comparable rules. Persons who have established residence in the Netherlands have during the first twelve months no right to various expensive types of intramural care in case they were already receiving, or could have foreseen that they would be in need of, such forms of treatment the moment they establish residence in the Netherlands. See 
who become ill or are the victim of an accident on the national territory are offered the care necessary to protect their health or life. The second premise entails that residents should obtain medical care from providers established on the national territory. In principle, the cost of medical care received abroad are to be paid by the patients themselves. As a rule, sickness funds and health institutions only pay the "foreign medical bill" (i) in cases of medical emergencies occuring abroad, ${ }^{12}$ (ii) when an agreement to this effect has been concluded with the State (or the health institution) in question or (iii) when they (or other institutions) have given patients prior authorisation for obtaining treatment abroad. In principle, no right to obtain such a permission for treatment abroad exists. States are free to pursue their own "authorisation policies" and, although differences exist, ${ }^{13}$ such policies are generally very restrictive. Authorisation for treatment abroad is a rarely given privilege.

For the purposes of the subject of this chapter, it is significant to establish why Member States apply the territoriality principle and, in particular, why they are reluctant to bear the cost of medical treatment which their "own" patients have obtained abroad. At the risk of oversimplification, three reasons can be given. First, the territorial limitation of the right to obtain medical benefits is seen as a guarantee of "quality". Each Member State has established its own minimum requirements as to the education of doctors, nurses, pharmacists, etc; hospitals can only operate when they meet certain quality criteria and medic(in)al products must satisfy health, safety and efficacy standards before they can be marketed. Member States would not be able to guarantee the quality of medical care if patients were free to obtain medical care and/or products in other States where different standards are applied. Second, if patients could freely decide in which State they wish to obtain medical care and

\footnotetext{
further Jorens, De Rechtspositie van niet-EU-onderdanen in het Europese Socialezekerheidsrecht (1997) at pp.242-243.

12. Such cases of medical emergency are often regulated in bi- or multilateral agreements which impose on the host State an obligation to give the necessary care and on the State of residence or insurance a duty to reimburse the expenses incurred. See e.g. Article 21(1) of the 1972 European Convention on Social Security and Article 4(1) of the 1980 European Agreement concerning the Provision of Medical Care during Temporary Residence. On the latter agreement see e.g. Creutz, The European Agreement Concerning the Provision of Medical Care during Temporary Residence, in: ISSRev (1985) pp.38-45 and Schreiber, Europese Overeenkomst betreffende het Verlenen van Geneeskundige Verzorging bij Tijdelijk Verblijf, in: Info RIZIV (1981) pp.199-203.

13. For an overview see e.g. Palm et al (2000) supra footnote 4, at pp.46-65 and Kesteloot et al, The Reimbursement of the Expenses for Medical treatment Received by 'Transnational' Patients in EU-countries, in: HP (1995) pp.43 et seq.
} 
products, many of them might wish to obtain care and products which they cannot obtain at home, which are not covered by their insurance package or which are far more expensive than the benefits available "at home". If the insured were to have the right, they might shop around for the most expensive types of care and products. The Member States' autonomy in deciding the types of treatment and products the cost of which they wish to bear could be affected and, because of higher costs of foreign medical care and products, ${ }^{14}$ sickness funds may be unable to pay the medical bills out of the health contributions they receive. Lastly, medical care must be obtained "at home" in order to protect the infrastructure of health care systems. Member States not only determine which types of treatment should be available in the national territory. They also decide how many of the various facilities must be present. For each number of inhabitants, a certain number of general practioners must be available and in order to offer adequate care, a specific number of hospital beds must be present. The number of facilities must be adequate. Undercapacity, as reflected in waiting lists, must be avoided. At the same time, there should not be too many facilities. Overcapacity implies an unnecessary waste of financial and human resources. In order to determine over a longer period of time how many facilities are to be made available, States need to know how many patients will make use of their care systems. If patients were free to choose treatment in other Member States, adequate capacity planning "at home" would be virtually impossible.

\subsection{Health Care and the Common Market}

Within the European Community it is up to the Member States to organise, finance and administer health care and health insurance. ${ }^{15}$ Community institutions do hold certain powers in the field of public

14. The prices of medical products and services in the various Member States differ considerably. See e.g. Euzeby, Le Financement de la Protection sociale dans les pays de la CEE: Problèmes et Perspectives, in: X, Quel Avenir pour l'Europe sociale: 1992 et Après (1990) pp.133 et seq and Euzeby, Financement de la Protection sociale, Efficacité économique et Justice sociale, in: RMC (1997) pp.253 et seq.

15. Compare Case C-158/96 Kohll [1998] ECR I-1931 at 17-18 and Case C-70/95 Sodemare [1996] ECR I-3422 at 27. See also the Resolution of the Council and the Ministers for Health, meeting within the Council of 11 November 1991 concerning fundamental health policy choices (91/C 304/05 - OJ 1991 C 304) in which it is emphasised that "it is a matter for the Member States to determine the organisation and funding of health-care systems and to make fundamental health policy choices". 
health ${ }^{16}$ but these do not entitle them to intervene in the internal organisation of the national health care and insurance systems. Article 152(5) $\mathrm{EC}$, as inserted by the Amsterdam Treaty, explicitly provides that Community action in the field of public health shall fully respect the responsibilities of the Member States with regard to the organisation and delivery of health services and medical care. ${ }^{17}$ This is not to say that health care

16. Public health policy is primarily concerned with preventive measures aimed at improving the health of the population or avoiding sickness and illness. For a discussion on the meaning of the term public health and related concepts see in particular Berg, Gesundheitsschutz als Aufgabe der EU (1997) at pp.40-77. Prior to "Maastricht", the EEC Treaty did not provide for specific Community powers in the field of public health. Issues concerning public health did arise, however, in various substantive policy areas such as environmental policy and social policy. See further e.g. van der Mei/Waddington, Public Health and the Treaty of Amsterdam, in: EJPH (1998) pp.129-154 and Berg (1997) supra. Since the mid1970s, and especially the mid-1980s, the Council and the "Ministers of Health Meeting within the Council" have also taken measures solely and directly aimed at promoting or protecting public health. Typical examples are the action programmes "Europe against Aids" (OJ 1991 L 175) and "Europe against Cancer" (OJ 1992 C 289). See further Berg (1997) supra and Massart-Pierard, Vers une Politique Commune de la Sante?, in: Massart-Pierard (Hrsg.), L'Europe de la Santé. Hasard et/ou Nécessité? (1988) at pp.27 et seq. The various initiatives have ultimately led to an amendment of the Treaty. The Treaty on European Union added the raising of "the quality of life" to the list of Community objectives in Article 2 EC, it included in Article 3 EC the phrase that the activities of the Community "shall include ... a contribution to the attainment of a high level of health protection" (sub o) and it inserted an Article 129 which empowered the Community institutions to develop a common public health policy. The common measures and activities were aimed at supporting and coordinating the national public health policies and they oblige the Community institutions, within their own "spheres of influence", to consider public health requirements and issues. On Article 129 EC see Verwers, Towards a New EC Health Policy?, in: European Public Health Association, Uniting Public Health in Europe (1992) pp.11-14. In response to the BSE crisis and other food related issues such as the concerns about the sale of genetically modified soya and American beef treated by hormones, the Treaty of Amsterdam has reformulated public health provision (renumbered as Article 152) entirely. The aims of the Community in the field have been defined more broadly and powers have been extended, even though Article $152 \mathrm{EC}$ is still embued with the notion of subsidiarity. On the implications of "Amsterdam" for public health policy see Barents, Het Verdrag van Amsterdam in Werking (1999) pp.203-210; van der Mei/Waddington (1998) supra and Roscam Abbing, Volksgezondheid in het Verdrag van Amsterdam - Een Beknopte Analyse, in: NTGR (1998) pp.75-80. On the European Union's role in the field of public health see further also Belcher, The Role of the European Union in Healthcare (1999) pp.16-46 and Closon et al, Public Health Policy in the European Community, in: Holland/Mossialos (Eds), Public Health Policies in the European Union (1999) pp.49-67.

17. Further, Article 152(4) EC expressly excludes the power to harmonise the laws and regulation of the Member States with a view to pursuing public health objectives. See Case C-376/98 Germany v Parliament and Council [2000] ECR I-0000 at 77. On this case, in which the Court annulled Council Directice No $98 / 43$ on the approximation, regulations and administrative provisions of the Member States relating to advertising and sponsorship of 
and health insurance are free from Community involvement. The mere fact that health care and insurance have not been brought within the ambit of the Treaty does not free the national rules in these areas from the limits imposed by Community law, and common market rules in particular. The territoriality of health care and insurance schemes may conflict with the free movement and competition provisions of the EC Treaty. Indeed, virtually all "actors" in the health sector (insurance organisations, providers of care, governments, pharmaceutical companies, patients, etc.) may benefit from, or have to consider the limits imposed by, the law governing the common market. ${ }^{18}$

First, medicines, ${ }^{19}$ medical equipment and medical products ${ }^{20}$ constitute goods for the purposes of Articles 28 (formerly 30) EC. Consequently, once they have been lawfully marketed in one of the Member States, medic(in)al products ought to be freely saleable throughout the Community. The free trade objective, however, is not absolute. National rules which make the marketing of medical products subject to quality, safety and efficacy requirements can be justified on the basis of Article 30 (formerly 36) EC when, and in as far as, necessary for protecting the health and life of humans and for as long as no harmonisation measures have been adopted at Community level. ${ }^{21}$ Furthermore, Article

tobacco products, and the question to what extent Article $95 \mathrm{EC}$ can be used for harmonisation measures aimed at protecting public health, see e.g. Hervey, Up in Smoke? Community (Anti-)Tobacco Law and Policy, in: ELRev (2001) pp.101-125; Mortelmans/Ooik, Het Europese Verbod op Tabaksreclame: Verbetering van de Interne Markt of Bescherming van de Volksgezondheid?, in: AA (2001) pp.114-130 and Barents, De Tabaksrichtlijn in Rook Opgegaan, in: NTER (2000) pp.327-331.

18. A comprehensive overview of the impact of the common market rules in the health care and insurance fields would go far beyond the scope of this Section. For more detailed discussions as to where common market rules and health care may "meet" see e.g. Hollmann, Der Einfluss der EG auf das Gesundheitswesen der Mitgliedstaaten, in: ZIAS (1998) pp.180214; Dommers, An Introduction to European Union Health Law, in: EJHL (1997) at pp.1941; ter Kuile, Onzekerheden over de Invloed van Gemeenschapsrecht op de Nationale Gezondheidszorg (1997); Hermans, Europese Unie en de Gezondheidszorg - De Gevolgen van de Eenwording voor de Nederlandse Gezondheidszorg (1994); Roscam Abbing, Patiënt en Gezondheidszorg in het Recht van de Europese Gemeenschap (1993); du Pré/Sevinga, De Gemeenschap en de Gezondheidszorg: een Terreinverkenning, in: SEW (1990) at pp.350-378 and ter Kuile, Nationale Gezondheidszorg en Gemeenschapsrecht, in: TvG (1989) at pp.275291.

19. See e.g. Case 238/82 Duphar [1984] ECR 523; Case 215/87 Schumacker [1989] ECR 617 and Case C-320/93 Ortscheit [1994] ECR I-5243.

20. Case C-120/95 Decker [1998] ECR I-1831.

21. In particular for medicinal products, a whole set of harmonisation measures has been adopted. In order to ensure the twin goals of protecting public health and bringing about freedom of movement for medical products Community institutions have, since the mid- 
$30 \mathrm{EC}$ in principle ${ }^{22}$ does not object to the application of national health insurance rules which determine which products will (not) be reimbursed by public insurers. In Duphar (1984) the Court accepted that Member States may adopt rules intended to govern "the consumption of pharmaceutical products in order to promote the financial stability of their health care insurance schemes" and that States "may, in order to limit cost, prepare limitative lists excluding certain medical products from the reimbursement scheme in their sickness laws". ${ }^{23}$

1960s adopted various harmonisation measures. See Directive No 65/65 (OJ Engl.Spec.Ed. 1965-1966 at p.20 - harmonisation of national rules concerning authorisation for medical products); Directive No 75/318 (OJ 1975 L 147 - harmonising national requirements for supporting documents to be included with an application for authorisation); Directive 75/319 (OJ 1975 L 147 - mutual recognition of authorisation decisions; the so-called multi-state and consultation procedures); Directive No 83/570 (OJ 1983 L 332 - European standard summary of product characteristics) and Directive 87/21 (OJ $1987 \mathrm{~L} 15$ - procedure for abridged application). In 1995 the multi-state and consultation procedures were replaced by a decentralised (Directive No 93/93, OJ 1993 L 214 - obligation to grant authorisation unless there is a risk to public health) and a centralised procedure (Directive No 2309/93, OJ 1993 L 214 - common authorisation granted by the European Agency for the Evaluation of Medicinal Products). See further Gardner, The European Agency for the Evaluation of Medicines and European Regulation of Pharmaceuticals, in: ELJ (1996) pp.48-82 and Broekmans et al, Europees Geneesmiddelenbeleid in Ontwikkeling, in: Roscam Abbing/van Berkestijn, Gezondheidsbeleid in Europa (1995) pp.109-127. On the free movement of medicines see further also Geddes, Free Movement of Pharmaceuticals within the Community: The Remaining Barriers, in: ELRev (1991) pp.295 et seq; Hancher, The European Pharmaceutical Market: Problems of Harmonisation, in: ELRev (1990) pp.9 et seq and Hancher, Creating the Internal Market for Pharmaceutical Medicines - An Echternach Jumping Procession, in: CMLRev (1991) pp. 821 et seq.

22. See, however, Section 4.7 .

23. Case 238/82 Duphar [1984] ECR 523 at 16. See also Case C-249/88 Commission v Belgium [1989] ECR I-1275 at 31. No harmonisation measures have been adopted for such reimbursement rules. The same holds true for national rules on the pricing of medical products. The absence of harmonisation of these rules has triggered the phenomenon of "parallel imports". On parallel imports (and the rights of trade-mark holders to prevent marketing by others of medicinal products) see e.g. Case C-201/94 Ex Parte: Smith and Nephew Pharmaceuticals Ltd [1996] ECR I-5819; Case 215/87 Schumacker [1989] ECR 617; Case C-347/89 Eurim-Pharm [1991] ECR I-1747; Case C-320/93 Ortscheit [1994] ECR I-5243; Joined Cases C-427/93, C-429/93 and C-436/93 Bristol-Myers Squibb [1996] ECR I3457 and Casc C-379/97 Upjohn [1999] ECR I-(0)00. 
Further, health care providers such as doctors, nurses and pharmacists can benefit from provisions on the free movement of persons and services. These professionals are entitled to take up employment, to establish themselves as self-employed persons and to provide medical services in other Member States. ${ }^{24}$ The medical professions are subject to often detailed professional rules and strict educational requirements which vary from State to State and, thus, may act as a brake on the exercise of free movement rights by medical professionals. ${ }^{25}$ Many of these barriers, however, have been surmounted by various directives on the mutual recognition of diplomas. ${ }^{26}$ Private hospitals, clinics and private (health)

24. See e.g. Case 246/80 Broekmeulen [1981] ECR 2311; Case 96/85 Commission v France [1986] ECR 1475 and Case 131/85 Gül [1986] ECR 1573. See further Oosterman-Meulenbeld, Quality Regulation on Professional Health Care Practitioners in the European Community, in: LIEI (1993) pp.61 et seq.

25. See e.g. the recent ruling in Mac Quen (2001) in which the Court held that Member States are under Article 43 EC entitled in principle to protect public health by reserving the right to carry out eyesight-examinations to professionals holding specific qualifications, such as ophtalmologists, to the exclusion of opticians who are not qualified as medical doctors. Case C-108/96 Mac Quen [2001] ECR I-0000.

26. From the early Community years, it has been recognised that the existence of different national educational systems, each issuing their own diplomas and qualifications, constituted an obstacle to the free movement of persons. The Community legislator has therefore taken various initiatives aimed at the mutual recognition of diplomas. Initially, Community institutions followed a "vertical approach" which implied that separate mutual recognition directives were developed for separate professions. Among the first professions for which measures were adopted were doctors (the original Directives No $75 / 362$ and 75/363 - OJ L 167 (see further Wägenbauer, La libre Circulation des Médicins dans la Communauté européenne - Problèmes actuels, in: CDE (1976) pp.707-735) - and the current Directive 93/16 - OJ 1993 L 165), nurses (Directives No 77/452 and 77/453 - OJ 1977 L 176), dentists (Directives No 78/686 and 78/687 - OJ 1978 L 233), veterinarians (Directives No 78/1027 and 78/1028 - OJ 1978 L 362 - see Wägenbauer, L'Europe des Vétérinaires, in: RTDE (1979) pp.653-663), midwives (Directives No 80/154 and 80/155 - OJ 1980 L 33) and pharmacists (Directives No 85/432 and 85/433 - OJ 1985 L 253 - see e.g. Kraus, Niederlassungsfreiheit der freien Berufe in der Europäischen Gemeinschaft unter besonderer Berücksichtigung der Apotheker (1989)). The adoption of these directives, however, proved to be a slow and time-consuming process partly because Member States insisted on first harmonising the educational systems before agreeing to the mutual recognition of diplomas. In the wake of the Community's initiatives to create the Internal Market by the end of 1992, another approach to the mutual recognition of diplomas was adopted. The goal of the mutual recognition of diplomas was no longer pursued on a sector-by-sector basis. Directive 89/48 established a general system for the recognition of diplomas (OJ 1989 L 19) and Directive $92 / 51$ introduced a second general system for the recognition of professional education and training to supplement Directive 89/48 (OJ 1992 L 209). These "horizontal" directives are based on the starting-point that higher education diplomas awarded on the completion of professional education and training of at least three years' duration should in principle be recognised in another Member State when the holder wishes to obtain access to a certain 
insurance companies can in principle benefit from Articles 43 and 49 EC. Member States, however, are entitled to impose certain conditions on the exercise of such companies' activities. In principle, national licence systems for the establishment of health care institutions are consistent with Community law provided they are applied without distinctions based directly or indirectly on nationality ${ }^{27}$ and, as the Court held in Sodemare

profession in that Member State. On the Community measures on the mutual recognition of diplomas with special reference to health professionals see e.g. Roscam Abbing, Quality of Medical Practice and Professional Misconduct in the European Union, in: EJHL (1997) pp.273-278; Roscam Abbing, The Right of the Patient to Quality of Medical Practice and the Position of Migrant Doctors within the EU, EJHL (1997) pp.347-360; du Pré, Public and Private Harmonisation of Vocational Training Qualifications in the EC: The Case of Denturists, EJHL (1996) pp.273-293; Schneider, Die Anerkennung von Diplomen in der Europäischen Gemeinschaft (1995), in particular pp.99-160; Oosterman-Meulenbeld (1993) supra footnote 24; Hurwitz, The Free Circulation of Physicians within the European Communities (1990) and van der Mijn, Kansen en Bedreigingen voor Beroepsbeoefenaren bij een Vrije Europese markt, in: TvG (1989) pp.305-315.

In addition, the afore mentioned obstacles have been partly surmounted by the Court of Justice which has given a broad interpretation of the prohibitions contained in the Articles 39 (formerly 48), 43 (formerly) 52 and 49 (formerly 59) E(E)C. See e.g. Case C340/89 Vlassopoulou [1991] ECR I-2357; Case C-319/92 Haim I [1994] ECR I-425; Case C234/97 Fernández de Bobadilla [1999] ECR I-4773 and Case C-238/98 Hocsman [2000] ECR I-()OO(). In these cases the Court recognised that individual Member States are in principle entitled to prescribe the knowledge and qualifications needed in order to pursue a certain occupation or to obtain access to further education, and that they, for this purpose, may require the possession of certain qualifications. The Court has added, however, that the authorities of Member States to whom an application has been made by a Community national for authorisation to practice a profession must take into consideration all diplomas, certificates and other evidence of formal qualifications of the person concerned and his relevant experience by comparing the specialised knowledge and abilities so certified and that experience with the knowledge and qualifications required by national rules.

27. Harmonisation directives have not been adopted. It has to be pointed out, however, that the transnational establishment of health institutions and the provision of medical services in other Member States has so far been relatively rare. Ter Kuile (1989) supra footnote 18, at p.284. Private health insurers have to observe the three non-life insurance directives. Directive No 73/239 (OJ 1973 L 228); Directive No 88/357 (OJ 1988 L 172) and Directive $92 / 49$ (OJ 1992 L 228). These directives regulate technical insurance matters like solvability and liquidity requirements, competition, the possibility of operating an insurance company in other Member States, the protection of consumers, etc. Article 54 of Directive No 92/49 provides that Member States in which private health insurance serves as a partial or complete alternative to health cover provided by the statutory social security system may require that those insurances comply with the specific legal provisions adopted by that State to protect the "general good". See further Hamilton, Interne Markt en (Aanvullende) Ziektekostenverzekeringen, in: NTGR (2001) pp.37-48 and Withers, The Concept of General Good in European Jurisprudence, in: Alliance Nationale des Mutualités Chrétiennes/Association Internationale de la Mutualité, Competition and Solidarity - Can They Co-exist in Europe's Health Care Systems? (1997) pp.91-97. 
(1997), Member States are entitled to make the admission of private companies in "social welfare systems of a health care nature" subject to the condition that they are non-profit making. ${ }^{28}$

Further, by virtue of Articles 39(3), 46 (formerly 56) and 55 (formerly 66) EC Member States are entitled to limit the exercise of free movement rights on grounds of inter alia public health. According to Article 4 of Directive No $64 / 221,{ }^{29}$ restrictions on entry to or residence in the territory of another Member State can only be justified on public health grounds as regards (contagious) diseases or disabilities which are listed in an Annex to Directive No 64/221. ${ }^{30}$ The exception, however, cannot be relied upon on for economic ends ${ }^{31}$ or to exclude the public health sector from the free movement regime. ${ }^{32}$

Health professionals, hospitals and health insurers ${ }^{33}$ may further

28. Case C-70/95 Sodemare [1997] ECR I-3395 at 32.

29. OJ 1963/1964 (SpecEd), at p.117.

30. If, however, a disease or disability manifests itself after a first residence permit has been granted it cannot justify expulsion or a refusal to renew the said permit. Article 4(2) of Directive No 64/221. The diseases are listed under two headings. The first concerns the contagious diseases which are listed in International Health Regulation No. 2 of the World Health Organization as being subject to quarantine (tuberculosis of the respiratory system in an active state or showing a tendency to develop; syphilis; other infectious diseases or contagious parasitic diseases if they are the subject of provisions for the protection of nationals of the host country). The second category contains diseases and disabilities which can justify exclusion or expulsion on the grounds of public policy or public security (drug addiction, profound mental disturbance; manifest conditions of psychotic disturbance with agitation, delirium, hallucinations or confusion). In the literature it has been debated whether Member States are entitled to restrict the free movement rights of persons infected by the HIV-virus or suffering from AIDS. See e.g. Carlier/Schiffino, The Free Movement of Persons with HIV/AIDS (2000) at pp.32-48; Hendriks, The Right to Freedom of Movement and the Unlawfulness of AIDS/HIV Specific Travel Restrictions from a European Perspective, in: NJIL (1990) pp.86 et seq; Pais Maçedo van Overbeek, AIDS/HIV Infection and the Free Movement of Persons within the European Community, in: CMLRev (1990) pp.791824 and Dworkin/Steyger, Aids Victims in the European Community and the United States: Are They Protected from Unjustified Discrimination?, in: TexILJ (1989) pp.295-329.

31. Article 2 of Directive No 64/221. The mere fact, however, that besides objective reasons based on public security or public health economic objectives are strived for, does not necessarily exclude the possibility of relying on the exception. Compare Case 72/83 Campus Oil [1984] ECR 2727 at 36 and Case C-158/96 Kohll [1998] ECR I-1931 at 50-51. See further Section 4 of this Chapter.

32. Case 131/85 Gül [1986] ECR 1573 at 17 and Case C-158/96 Kohll [1998] ECR I-1931 at 46 .

33. Articles 81 and $82 \mathrm{EC}$ are concerned with the conduct of undertakings, not with the laws and regulations of the Member States. However, the two Articles, read in conjunction with Article $10 \mathrm{EC}$, require Member States to refrain from introducing or maintaining in force measures which may render ineffective the competition rules applicable to undertakings. Sec 
be subject to limitations imposed by the competition rules contained in Articles 81 (formerly 85) and 82 (formerly 86) EC when, or in as far as, they can be classed as undertakings for the purposes of these Treaty provisions. The case law of the Court of Justice, and the judgment in Poucet and Pistre (1993) in particular, indicate that health care actors are to be regarded as undertakings when they perform economic activities rather than activities embodying a notion of "solidarity". ${ }^{34}$ Generally, health care providers and insurers do perform economic activities and this implies that they are in principle prohibited from concluding agreements $^{35}$ or, where they hold a dominant position in the market, from

Case C-70/95 Sodemare [1997] ECR I-3395 at 41.

34. See Joined Cases C-159/91 and C-160/91 Poucet and Pistre [1993] ECR I-637. See further Hermans et al, Zorgverzekeraars en Uitvoeringsorganen Sociale Zekerheid: Ondernemingen in het Licht van het EG-Recht, in: SMA (1996) pp.227-238.

35 . It is only in recent years that the implications of the competition rules for the health care sector have become apparent. See e.g. the recent ruling in van der Woude. The case concerned an employee of a health care institution whose employment contract was governed by a collective labour agreement relating to medical treatment for the hospital sector. By virtue of this agreement Mr van der Woude was affilliated to a specific supplementary health insurance scheme, but he wished to be insured under another scheme which provided for lower insurance premiums and a broader insurance package. Mr van der Woude claimed that his employer should also contribute to the cost of supplementary insurance if he switched to the other scheme. The national court which had to decide the case was of the view that the employer could only be required to make such contributions when the relevant provisions of the collective labour agreement were void and asked the Court of Justice whether these provisions were compatible with Articles 81 and 82 EC. The Court (applying and largely following its conclusions in Case C-67/96 Albany [1999] ECR I-0000 - see further Gyselen, Annotation Albany, in: CMLRev (200()) pp.425-448 and Loozen, CAO's, Bedrijfspensioenen en het EG-Mededingingsrecht, in: NTER (1999) pp.274-284) concluded that an agreement by employers to make fixed financial contributions to the cost of supplementary health insurances are not in principle covered and prohibited by Article 81(1) EC. See Case C222/98 van der Woude [2000] ECR I-0000 at 32. See further also Joined Cases C-180/98 to C-184/98 Pavlov [2000] ECR I-0000 and Loozen, Mededinging - Pavlov en van der Woude: Meer dan een Pavlov-Reactie, in: NTER (2000) pp.301-307.

Another case in which the Court was asked how competition rules are to be applied in the health care sector was Ferlini $(2000)$. The case involved a civil servant of the European Commission who was working in Luxembourg and affiliated to the common health insurance scheme for European civil servants (RCAM). For the delivery of his wife in a Luxembourg hospital Mr Ferlini was charged an amount which was higher than the tariff which is applied to persons covered by the Luxembourg public health insurance scheme. The tariffs for persons falling under the Luxembourg system were based on collective conventions concluded between the Luxembourg hospitals and insurance institutions. The national court had asked the Court of Justice to determine whether the decision of a hospital association which fixes scales of fees for hospital care for persons who are not affiliated to the national social security scheme, which are higher than those applied to residents who are affiliated to the national scheme, is prohibited by Article 80(1) EC. The Court decided the 
abusing that position when this could affect trade between the Member States and distort competition. ${ }^{36}$

2.4 Regulations No 1408/71 and No 574/72: Objectives and Basic Principles of the Rules on the Co-ordination of Health Insurance Schemes

Just like the other "actors" in the health care and insurance sectors, patients may enjoy certain rights under the common market rules or the general provisions on freedom of movement and equal treatment. For instance, in Luisi and Carbone (1984) the Court held that Articles 59 (now Articles 49) et seq EC encompass a right to move to other Member States in order to receive services and the Court explicitly added that "persons receiving medical treatment" are to be regarded as recipients of

case solely under the heading of Article 12(1) EC, but in his Opinion in Ferlini Advocate General Cosmas did address the competition provisions. He answered the preliminary question in the affirmative provided the national court could establish that the decision of the hospital association could affect intra-Community trade significantly. Opinion Advocate General Cosmas of 21 September 1999 in Case C-411/98 Ferlini [2000] ECR I-0000 at 105135. On Ferlini see e.g. van der Steen, Horizontale Werking van de Vier Vrijheden en van het Discriminatieverbod van Artikel 12 EG. in: NTER (2001) pp.4-9.

On the importance of the competition rules for the health care sector see further e.g. Bosco, Are National Social Protection Systems under Threat? Observations on the Recent Case Law of the Court of Justice (2000); Hervey, Social Solidarity: A Buttress Against Internal Market Law?, in: Shaw (Ed.), Social Law and Policy in an Evolving European Union (2000) pp.31-47; Pieters, De Nederlandse Zorgverzekering in het Licht van het Recht van de EG - Onderzoek naar de Verenigbaarheid van het Nederlandse Zorgstelsel met het Recht op Vrij Dienstenverkeer en het Europese Mededingingsrecht (1999); Ballon/Pieters, Het Europese Kartelrecht en de Ziekenfondsen (1997); Pieters/van den Bogaert, The Consequences of European Competition Law for National Health Policies (1997) and du Pré, Klein Duimpje en de Nederlandse Ziektekostenverzekeringen, in: SR (1993) pp.138-141. 36. Furthermore, also Directive No $89 / 665$ on the co-ordination of laws, regulations and administrative provisions relating to the application of review procedures to the award of public supply and public works contracts may have implications for the health care and insurance sectors. See e.g. Case C-76/97 Tögel [1998] ECR I-5357; van der Bend, Aanbestedingsrecht in de Gezondheidszorgsector - Verdient het Aanbestedingsrecht in de Gezondheidszorgsector meer Zorg?, in: NTG (1999) pp.359-369; Hermans/Buijsen, Aanbesteden van Medisch-Specialistische Zorg, in: SR (2000) pp.286-292 and Scheiffers, Openbare Aanbesteding van Zorgcontrcaten, in: Essers/Scheiffers (Reds), Grensoverschrijdende Zorg - Marktwerking vs. National Zorgbewaking (2000) pp.33-38. For an application of (the exemption of Article 13 concerning exemptions for activities in the public interest of) the Sixth Directive No 77/388 on the harmonisation of the laws of Member States relating to turnover taxes to natural persons active in the health sector see e.g. Case C-216/97 Gregg and Gregg [1999] ECR I-0000 
services. ${ }^{37}$ Further, in Cowan (1989) the Court held that when "Community law guarantees a natural person the freedom to go to another Member State the protection of that person from harm in the Member State in question, on the same basis as the nationals and persons residing there, is a corollary of that freedom of movement". ${ }^{38}$ This observation, it could be argued, ${ }^{39}$ implies a right to obtain emergency treatment for "Community travellers". More recently, the Court concluded in Ferlini (2000) that the application to Community citizens who are not affilliated to a national insurance scheme of scales of fees for medical and hospital care which are higher than those applied to persons who are affilated to such a scheme, is in breach of Article 12(1) EC..$^{40}$

Until recently, ${ }^{41}$ however, the general provisions on the free movement of persons, services and non-discrimination did not seem to have much practical significance for patients. From the early Community years, Community institutions had recognised that a genuine freedom of

37. Joined Cases 286/82 and 26/83 Luisi and Carbone [1984] ECR 377 at 10 and 16. Compare also the ruling in $G B-I N N O-B M$ (1990) in which the Court held that a "free movement of goods requires, particularly in frontier areas, that consumers resident in one Member State may travel freely to the territory of another Member State to buy goods" (and thus medic(in)al products: APvdM) "under the same conditions as the local population". Case C-362/88 GB-INNO-BM [1990] ECR I-667 at 8.

38. Case 186/87 Cowan [1989] ECR 195 at 17.

39. Compare O'Leary, The Principle of Equal Treatment on Grounds of Nationality in Article 6 EC - A Lucrative Source for Member State Nationals?, in: O'Leary/Tiilikainen (Eds), Citizenship and Nationality Status in the New Europe (1998) pp.105-136, at p.112.

40. Case C-411/98 Ferlini [2000] ECR I-0000) at 62. Ferlini concerned a Community worker who was working for the European Commission in Luxembourg. Mr Ferlini challenged the legality of the fees for the care given at his wife's confinement and for her stay in a maternity unit of a Luxembourg hospital. One might have expected that the Court, following the suggestion of the Advocate General (at 59), would have decided the case under Article $7(2)$ of Regulation No 1612/68. This provision grants equality of treatment as regards "social advantages" which, according to settled case-law (see Chapter 2 Section 2.2.3), cover all rights and benefits granted to workers by virtue of their employment of residence in the territory of the State concerned. Access to care would seem a "social advantage" (compare Case C-185/96 Commission v Greece [1998] ECR I-1095 at 15 and 21), but the Court held that Mr Ferlini was not claiming entitlement to a social advantage which consisted of a payment of a flat rate. The Court answered the question under the heading of Article 12(1) EC. Case C-411/98 Ferlini [2000] ECR I-0000 at 62. See further van der Steen (2001) supra footnote 35. See also Case C-302/98 Sehrer in which the Court held that Member States which, in determining health insurance contributions to be paid by pensioners, do not take into consideration the contributions which the persons concerned may pay or have paid in other States may violate Articles 12 and 39 EC. Case C-302/98 Sehrer [2000] ECR I-0000 at 36.

41. See further Section 4. 
movement not only requires that Community citizens who become in need of medical treatment during a temporary or more permanent stay in another Member State are entitled to obtain the required care. Such persons should also have the right to have the "medical bill" paid by the health (insurance) institution they are affiliated to. A mere right to equal treatment in other Member States did not seem to impose on the State where an individual is insured an obligation to pay "foreign" medical bills. Special measures were deemed necessary in order to ensure that Community citizens retain insurance cover when moving to other Member States. For this purpose, the Community legislator adopted Regulations No 3 and No 4 as far as back as in 1958 which contained rules intended to co-ordinate the national health insurance schemes. ${ }^{42}$ In the early 1970s, the regulations of 1958 were replaced by the currently still ${ }^{43}$ applicable Regulations No $1408 / 71$ and No $574 / 72$.

In order to guarantee that beneficiaries of the free movement of persons are entitled to gain access to medical care at the expense of their health institution in other Member States, the Regulations contain two sets of rules. The first consists of the rules laid down in Articles 13 et seq of Regulation No 1408/71 which determine the State in which beneficiaries are insured. The so-called competent State is in principle the State where beneficiaries are employed. It is in the competent State that health contributions are to be paid and it is the legislation of this State which determines which persons are insured, and the conditions under which they are insured. The second set of rules is contained in Articles 18-36 of Regulation No 1408/71 (Title III - Chapter 1: "Sickness and Maternity Benefits") and the accompanying provisions of Regulation No 574/72. The former regulation sets out the cross-border health care rights which beneficiaries enjoy, whilst the latter regulation contains the administrative rules governing co-operation between the health institutions of the competent State and the "providing" State.

The regulations' health care provisions are quite difficult to read, but they are based on two relatively simple principles. First, in all cases

42. On the health care and insurance provisions of the original 1958 regulations see e.g. Troclet, Europees Sociaal Recht - Institutioneel Kader, Rechtsinstrumenten, Sociale Problemen en hun Oplossing (1971) pp.293-298.

43. See, however, Section 3.7. On the two regulations in general see e.g. Pennings, Introduction to EC Social Security Law (2000); White, EC Social Security Law (1999); Voogsgeerd, Vrij Verkeer en Sociale Zekerheid (1999); van Raepenbusch, Le Sécurité sociale des Personnes qui Circulent à l'Intérieur de la Communauté économique européenne (1991); Jorens, Wegwijs in het Europees Sociale Zekerheidsrecht (1992) and, briefly, Chapter 2 Section 6 of this book. 
in which Regulation No $1408 / 71$ provides for a right to obtain "benefits in kind" (medical treatment, nursing, medicines, etc.) ${ }^{44}$ in other Member

44. In Articles 18-36 of Regulation No 1408/71 medical care and medical products are referred to as "benefits in kind". In addition, the Articles apply to "cash benefits". Neither one of the terms is defined in the Regulation, but the case law provides for some clarification. In Jordens-Voster (1980) the Court indicated that it is of no relevance under what type of legislation the benefits are offered. Rights to medical care offered under national legislation relating to invalidity benefits are to be regarded as "benefits in kind" for the purposes of Articles 18-36 of Regulation No 1408/71. Case 69/79 Jordens-Voster [1980] ECR 75 at 8 . Further, the term "benefits in kind" may also consist of direct payments or the reimbursement of costs for medical treatment, medicines, etc; "cash benefits" are designed to compensate for a worker's loss of earnings through illness. Case 61/65 Vaassen [1966] ECR 257 at p.278. Payments which are intended as a contribution to the financing of insurance, however, do not fall within the meaning of the term "benefits in kind". Case 103/75 Aulich [1976] ECR 697 at 7 and Case C-73/99 Movrin [2000] ECR I-0000 at 41. There is an "inherent contradiction between the concept of contribution and that of benefit. The first is a condition precedent to the creation of a right, the second presupposes the existence of a right". Opinion of Advocate General Gand in Case 33/65 Dekker [1965] ECR 901, at p.909.

More recently, the Court was asked in Molenaar (1998) whether certain benefits made available under the German Care Insurance Law (Pflegeversicherungsgesetz) were to be regarded as cash benefits or as benefits in kind. The law was introduced to cover the costs of care needed by persons who are dependent on assistance from other persons in the performance of their daily routine. The benefits provided under the law could be provided, at the choice of the recipient, either in the form of care dispensed by authorised bodies or in the form of a monthly allowance (the so-called Pflegegeld) which enables recipients to choose the form of aid they consider most appropriate to their condition. It was argued that the care allowance was aimed at allowing recipients to cover the payment of medical expenses and that it constituted a "surrogate" of benefits in kind. Compare Bokeloh, Export von Pflegeleistungen innerhalb der Europäischen Union, in: Zentrum für Europäischen Wirtschaftsrecht, Die Krankenversicherung in der Europäischen Union (1997) pp.115-162, at pp.135-137. The Court did not agree. After it had referred to the fact that the Pflegegeld was granted periodically, that it was fixed independently of the actual costs incurred and that recipients enjoyed freedom in using the allowance, the Court concluded that the "care allowance .. takes the form of financial aid which enables the standard of living of persons requiring care to be improved as a whole, so as to compensate for the additional expense brought about by their condition". The Pflegegeld was thus to be regarded as a cash benefit. Case C-160/96 Molenaar [1998] ECR I-1545 at 34-36. On Molenaar see further de Gans, Comment on Molenaar, in: RZA (1999) pp.252-260; Gassner, Pflegeversicherung und Arbeitnehmerfreizügigkeit, in: NZS (1998) pp.313-318; Koch, Die Entscheidung des EuGH zum Leistungsexport des Pflegegeldes vom 5. März 1998 (Rs C-160/96), in: ZFSH (1998) pp.451-454 and van der Mei, Het Arrest Molenaar: Export van het Persoonsgebonden Budget?, in: USZ (1998) pp.407-412. In response to the Molenaar judgment the Administrative Commission has adopted Decision No 175 (23 June 1999 (OJ 2000 L 47) replacing Decision No 109 of 18 November 1977 (OJ 1978 C 125)) in which the term "benefits in kind" was defined more precisely. Benefits such as the Pflegegeld do not necessarily have to be classed as sickness benefits. In cases where such benefits are linked to e.g. old-age pensions they might have to be classed as old-age pensions. See Opinion of Advocate General Alber in Case C-215/99 Jauch [2001] ECR I-(0000) at 104. Disagreeing with its 
States, the cost are to be paid by the institution to which beneficiaries have paid health premiums. ${ }^{45}$ As a rule, this is the so-called competent institution. The institution of the "providing State" is, as follows from Article $36(1)$ of Regulation No 1408/71, entitled to be fully refunded ${ }^{46}$ by the competent institution. ${ }^{47}$ Second, medical care is in all cases to be provided in accordance with the legislation of the State where the benefits are provided. ${ }^{48}$ In the light of the first principle, one might possibly have

Advocate General, however, the Court concluded in Jauch that the Austrian equivalent of the German Pflegegeld was also to regarded as a sickness benefit. Case C-215/99 Jauch [2001] ECR I-0000) at 35 .

45. Compare Stiemer, Sickness Insurance - Viewpoint of the EU-Member States, in: Jorens/Schulte, Coordination of Social Security Schemes in Connection with the Accession of Central and Eastern European States (1999) pp.225-253, at p.228.

46. Article 36 forms part of a Section headed "Reimbursement between Institutions". The purpose of the provision is to make clear the financial consequences that flow from the fact that benefits in kind have been provided by the institution of one Member State on behalf of the institution of another Member State, so far as the relations between the institutions are concerned. Case C-389/99 Rundgren [2001] ECR I-0000 at 60-62. Article 36(2) of Regulation No $1408 / 71$ provides that settlement takes place on the basis of production of proof of actual expenditure or lump sum payments. The specifics concerning reimbursement are worked out in further detail in Articles 93-95 of Regulation No 574/72. The starting-point is that the competent organ has to pay the actual costs of the care that is provided (i.e. the tariffs applied by the providing institution) which are determined on the basis of the accounting of the institution which has provided the benefits. If the costs of the individual benefits do not follow from the accounting, reimbursement takes place on a lump sum basis The lump sum is determined on the basis of all available information. The Administrative Commission assesses the grounds used to calculate lumps sums and fixes their amount. See Decision $\mathrm{Nr} 109$ of 18 November 1977 (OJ 1978 C 125). For a more detailed description of the reimbursement rules see Stiemer (1999) supra footnote 45, at pp.240-241. Finally, Article 36(3) authorises two or more Member States to waive reimbursement between their institutions, with teh result that the repayment obligation is not enforced. The mere fact, however, that States have made use of Article 36(3) is of no consequence for purposes of interpreting Articles 18-36. Case C-389/99 Rundgren [2001] ECR I-(00)00 at 64.

47. Where several institutions of the same Member State can be regarded as the competent institution, it is for national law to determine how reimbursement will be provided. Compare Case 818/79 Allgemeine Ortskrankenkasse Mittelfranken [1980] ECR 2729 at 10.

48. This second principle only applies to "benefits in kind". Cash benefits are to be provided in accordance with the legislation of the competent institution and are thus exportable. In the Molenaar and Jauch cases (see above footnote 48), which both concerned workers residing outside the competent State, this (would have) implied that the workers could enjoy the care allowances. See further van der Mei (1998) supra footnote 44, pp.407-412.

One of the most controversial issues as regards cash benefits concerns the medical examination of beneficiaries who (temporarily) reside outside the competent State. According to Article 18 of Regulation No $574 / 72$ it is in principle the institution of the State of (temporary) residence which is responsible for the investigation. The results are to be sent to the competent institution which has the right to have the persons concerned re-examined by a doctor of that institution's choice. If the competent institution does not make use of this 
expected that benefits in kind would also be provided in accordance with the legislation administered by the competent institution. However, such a rule would imply that the institution of the providing State has to apply the legislation of other Member States with which it is not likely to be familiar. For practical reasons the drafters of the Regulations have opted for the rule that medical care is to be delivered in accordance with the legislation of the providing State. ${ }^{49}$

As a result of the two rules, movement to other Member States may work out favourably or unfavourably for the insured. ${ }^{50}$ In cases where medical benefits are obtained in a Member State other than the competent State, it is of no relevance whether or not a given type of treatment or medic(in)al product is covered by the insurance package of the competent State. The competent institution has to pay for all benefits included in the package of the "providing State". For instance, frontier workers who are living in State A where dental care is covered by the applicable legislation, are entitled ${ }^{51}$ to have the dental bill paid by the insurance institution in State B even if dental care is not covered by the legislation of State B. Frontier workers, however, who are insured in that same State A and who reside in the competent State B, are not entitled to have the bill paid even though they are in fact paying health contributions for dental care. Furthermore, it is of no relevance whether the price of medical benefits in other States is higher or lower than the prices in the competent State. In all cases, the competent institution is obliged to pay the institution of the "providing State" fully. Thus, frontier workers who have received in the State of residence medical care which is far more expensive than the care offered in the competent State, are entitled to

right, it is bound in fact and in law by the findings of the institution of the place where the persons concerned reside as regards the commencement and the duration of the incapacity to work. Case 22/86 Rindone [1987] ECR 1339 at 15. The person concerned cannot be required to return to the competent State to undergo examination there. Ibid, at 22. Article 18 is also applicable where the sickness benefits are to be paid by the employer. See Case C-45/90 Paletta $I$ [1992] ECR I-3423 at 23. The competent institution, however, is not bound by the findings of an institution in another Member State where it can prove that Article 18 has been abused. Case C-206/94 Paletta II [1996] ECR I-2357 at 28. See further van der Steen, Controle bij Ziekte in het Buitenland, in: NTER (1996) pp.176-178 and Neumann-Duesberg, Krankenversicherung, in: Schulte/Zacher, Wechselwirkungen zwischen dem europäischen Sozialrecht und dem Sozialrecht der Bundesrepublik Deutschland (1991) pp.83-109, at pp.96-102.

49. See the Opinion of Advocate General Jacobs in Case C-451/93 Delavant [1993] ECR I1545.

50. Bokeloh (1997) supra footnote 44 , at p. 156

51. Sec Section 3.1.2. 
have the entire bill paid by their insurance body. ${ }^{52}$

The various rights to obtain medical benefits in Member States other than the competent State at the expense of the competent institution are conditional upon fulfillment of administrative formalities. ${ }^{53}$ These formalities differ but generally consist of an obligation upon beneficiaries to request a certified statement (one of the so-called E-forms) ${ }^{54}$ from the competent institution which indicates that they are indeed insured for medical care, the period during which medical benefits may be obtained

52. In reverse, the movement of insured patients to other Member States may also work out favourably or unfavourably for the competent institution. In cases where beneficiaries are entitled to receive benefits in kind where the costs of medical care are higher or where more or other types of treatment are included in the insurance package, health expenditures could, especially where expensive types of treatment delivered in hospitals are concerned, be considerably higher than if treatment is, or would have been, obtained "at home". The drafters of the Regulations recognised this. Article 17(6) of Regulation No 574/72 obliges the institution of the providing State, in the event of hospitalisation, to notify within three days, the competent institution of the date of entry to the hospital, the probable duration of the hospitalisation and the date of leaving the hospital. The same institution also has to notify the competent institution in advance of any decision relating to the grant of certain expensive types of treatment. The Administrative Commission has stated that the competent institution must be notified in the case of enlisted types of treatment (e.g. surgical appliances, dental prostheses, accomodation and treatment in sanatoria .. etc.) and for types of treatment from which the costs are expected to exceed a certain fixed amount. Decision Nr.135 of 1 July 1987 (OJ 1987 C 281) as amended by Decision No 171 of 9 December 1998 (OJ 1999 L 143). In cases of medical urgency the institution of the place of residence has to inform the competent institution immediately. In order to enable the competent institution to exercise some control over its expenditure, this institution is given the right to make a reasoned objection within fifteen days. Article 17(7) Regulation No 574/72. The competent institution cannot object on the sole ground that a certain type of treatment is not covered by its own insurance package. See Decision No 121 of the Administrative Commission of 21 April 1983 (OJ 1983 C 193).

53. See, however, Article 34 of Regulation No 574/72 which provides for a number of cases in which reimbursement can take place when the required formalities have not been fulfilled. 54. In order to effectuate social security and cross-border health care rights different E-forms are to be used. The aim of the various certificates differs and it is therefore quite difficult to draw any definite conclusions about the legal value of the various forms. Compare Opinion of Advocate General Lenz in Case C-425/93 Calle Grenzshop Andresen [1995] ECR I-269 at 56-57. The Court has indicated, though, that the legal value of the E-forms is to be determined in the light of Article 39-42 EC. Case 93/81 Knoeller [1982] ECR 951 at 9. In the light of the "good faith provision" contained in Article $10 \mathrm{EC}$, it could be argued that the health insurance institutions of the State to which a Community worker or citizen has moved to must presume the correctness of the information and data stated on the certificates. However, the institutions concerned remain free to verify the content of the certificates. The E-forms do not provide irrebuttable proof. Compare Case C-202/97 Fitzwilliam [2000] ECR I-0000 at 46-59 (concerning premium duties in the case of the posting of workers) and Case C-102/91 Knoch [1992] ECR I 4341 at 50-54 (unemployment benefits). 
in other Member States and/or the types of benefits for which the institutions is willing to pay the cost. The statement must be submitted to the competent health institution in the host Member State which then possesses the information necessary for reimbursement by the competent institution. ${ }^{53}$

Cross-Border Access to Health Care under the Community Rules on the Co-ordination of Health Insurance Schemes

Having put the subject of this chapter in its proper context, the discussion can now proceed with an examination of the cross-border health care rights of the various categories of beneficiaries of the free movement of persons. This section examines the cross-border health care rights which the beneficiaries of the free movement of persons enjoy under the Community's rules on the co-ordination of health insurance schemes. For Community citizens, the most important co-ordination rules are contained in EC Regulations No $1408 / 71$ and No $574 / 72 .{ }^{56}$ Most third country nationals will have to rely on the social security rules contained in the agreements the Community has concluded with the countries of which they hold the nationality.

\subsection{Economic Residents}

For the purposes of this book, the category of economic residents has been defined as consisting of all Community citizens and their family members who (are entitled to) stay or reside in other Member States by virtue of Articles 39 (formerly 48) or 43 (formerly 52) E(E)C. ${ }^{57}$ The discussion below is confined to the beneficiaries of the free movement of workers under Regulations No 1408/71 and No 574/72, the basic assump-

55. For details of the reimbursement procedures and formalities see Stiemer (1999) supra footnote 45 .

56. For other descriptions of the Regulations' health care provisions see e.g. Stiemer (1999) supra footnote 45 and Schoukens, Coördinatiebepalingen inzake Gezondheidszorg: het Communautaire Recht (1994).

57. On the category of "economic residents" see further Chapter 2 Section 2. 
tion being that the self-employed falling within the ambit of Article 43 EC enjoy the same cross-border health care rights. ${ }^{58}$

\subsubsection{Work-Seekers}

Article 39 EC confers upon all Community citizens the right to move to, and to stay for "a reasonable period of time" in the territory of, other Member States in order to seek employment. ${ }^{59}$ During this period, workseekers can rely on Article 25(1) of Regulation No 1408/71 in order to claim medical benefits in accordance with the legislation of the host State at the expense of the institution they are insured with. The conditions to be met for obtaining medical care are quite strict. This right is only granted to wholly unemployed persons who are entitled to unemployment benefits in the competent State and who have made use of the right to export such benefits as guaranteed by Article 69 of Regulation No $1408 / 71$. The exportability of unemployment benefits, and thus the right to obtain medical care, is limited to a maximum period of three months. ${ }^{60}$ Community citizens who are only partially unemployed, who

58. For the purposes of clarity and convenience the discussion in this section is further based on the assumption that all categories to be dealt with fall within the personal scope of Regulation No $1408 / 71$.

59. Case C-292/89 Antonissen [1991] ECR I-745 at 21 and Case C-271/91 Tsiotras [1993] ECR I-2925 at 13-14.

60. In order to become entitled to export unemployment benefits wholly unemployed workers must $(i)$ before their departure have been registered in the competent State as persons seeking work for at least four weeks and (ii) register as persons seeking work in the State where they go to. See further Article 69 of Regulation No 1408/71 and, for the administrative details, Article 83 of Regulation No 574/72. In order to effectuate the right to medical care, unemployed work-seekers must submit to the health institution in the State where they are looking for work form E 119 which, upon their request, has been issued by the competent institution. See further Article 26 of Regulation No 574/72. If the persons concerned do not return to the competent State before the expiry of the period of three months, they shall lose "all entitlement" to unemployment benefits (see e.g. Joined Cases $41 / 79,121 / 79$ and $796 / 79$ Testa [1980] ECR 1979) and thus the right to obtain medical benefits in the State concerned. In cases of force majeur, the three month period may be extended by the competent institution (Article 25(4) of Regulation No 1408/71), even when the request for doing so is made after the afore mentioned period (Case 139/78 Coccioli [1979] ECR 991). The sickness fund of the Member State where the persons concerned are looking for work must inform the competent institution that it considers it necessary to extend the three month period. On the basis of, inter alia, a report from the examining doctor, the competent institution can then make a decision as to the extension of the three month period. See Article 26(6) of Regulation No 574/72. The Commission has proposed to extend this period up to six months. See Section 3.6.2. 
have not become or are no longer entitled to unemployments benefits, who do not satisfy the formalities for exporting such benefits or who continue to seek work after the three month period has expired, cannot benefit from Article 25. ${ }^{61}$ Such work-seeking Community citizens can only claim medical benefits in the State concerned as "non-residents". ${ }^{62}$

\subsubsection{Employed Workers}

Community citizens who have been successful in their search for employment obtain the right to establish residence in the host State when the work they have found is "effective and genuine". ${ }^{63}$ By virtue of Article 13 of Regulation No 1408/71 such workers are in principle insured in the State of employment and in case they do decide to establish residence in that State, they can, where necessary, invoke the non-discrimination provision contained in Article 3 in order to claim access to health care in, and under the same conditions as the nationals of, the host State. Article 18 obliges the institution in the State of residence whose legislation makes the acquisition, retention or recovery of entitlement to benefits conditional upon the completion of insurance or employment periods, to take into account the periods which have been completed under the legislation of another Member State. For the rest, Articles 18-36 do not contain any other provision applying to such workers. From the perspective of the coordination mechanism, this standard situation is largely an internal affair. No co-operation between health insurance institutions in different Member States is necessary to guarantee such workers access to health care in the Member State of residence. ${ }^{64}$

61. Article 25 is not applicable to wholly unemployed persons who resume a part-time professional or trade activity. Such persons are considered as employed persons for purposes of Articles 18-36 of Regulation No 1408/71. Decision No 156 of 7 April 1995 (OJ 1995 L 249).

62. See Section 3.2 .

63. Case 53/81 Levin [1983] ECR 1035. See Chapter 2 Section 2.2.

64. To be sure, co-operation is necessary in order to implement the aggregation rule of Article 18. In order to benefit from this rule, workers must submit a form E 104 to the competent institution which specifies the periods of insurance completed under the legislation to which they were last subject. At the request of the workers, the form is issued by the institution to whose legislation they were last subject. If no form is submitted, the competent institution must obtain it from the "other" institution. Article 16 of Regulation No 574/72. Waiting periods are usually rather short and form E 104 therefore only has to relate to the most recent completed periods of insurance. See European Commission, Compendium of Community Provisions on Social Security (1995) at p.430. For an application of Article 18 see e.g. Tessier (1978). The case concerned a French national who had been an au pair in 
Such cooperation between health insurance institutions is necessary in order to ensure that workers who reside in a Member State other than the one in which they are employed, can obtain medical benefits in the State of residence. Article 19 of Regulation No 1408/71 provides that such workers are entitled to obtain medical care in the State of residence as though they were insured there. The care is provided in accordance with the legislation of the State of residence; the cost are borne by the competent institution. ${ }^{65}$ Workers residing in a Member State other than the competent State can also claim medical benefits in the latter State. Frontier workers, i.e. workers who return as a rule daily or at least once a week to the country of residence, ${ }^{66}$ enjoy this right under Article $20 .{ }^{67}$ Other non-resident workers ${ }^{68}$ can rely on Article $21 .{ }^{69}$ Read together,

the United Kingdom and who had received treatment during her stay under the National Health Service. On her return to France, she again received medical treatment. Her sickness fund refused to bear the costs on the ground that she had not been employed and insured for the minimum period required by French law. The Court ruled that if Ms Tessier could be classed as a worker (i.e. if it could be established that she had been paying social security contributions in the United Kingdom) she could rely on Article 18 of Regulation No $1408 / 71$ in order to have the periods of insurance in the United Kingdom taken into account by the French institution. Case 84/77 Tessier [1978] ECR 7. In Klaus the Court further ruled that periods of insurance fulfilled in other Member States must also be taken into account in cases where the competent institutions, on the basis of national law, are entitled to refuse sickness benefits to persons whose illness or disability already existed at the commencement of the insurance. Case C-482/93 Klaus [1995] ECR I-3551. On Article 18 see further Case 150/82 Coppola [1983] ECR 43 and Case C-111/91 Commission v Luxembourg [1993] ECR I-817.

65. In order to become entitled to medical benefits in the State of residence, workers must request a form E 106 from the competent organ which testifies that they are insured and submit this form for registration to the health institution in the State of residence. See Article 17(1) of Regulation No 574/72

66. See Article 1(b) of Regulation No 1408/71

67. This provision aims to avoid unnecessarily long work-stoppages. Schoukens (1992) supra footnote 56 , at p. 22 .

68. Examples are: commercial travellers, persons working in more than one Member State, workers in embassies and consulates who have opted for the legislation of the country of origin and workers in frontier undertakings subject to the legislation of the country where the undertaking has its registered office, but residing and working in the neighbouring State. See European Commission (1995) supra footnote 64, at p.430.

69. This right is guaranteed even if the worker has already received medical care for the same sickness in the State of residence. Article 21(1), second sentence of Regulation No 1408/71. Article 21(4) states that workers who reside outside the competent State and who wish to transfer their residence to this State, can receive medical benefits there even if, before the transfer of residence, they have already obtained medical benefits chargeable to the competent institutions. 
Articles 19, 20 and 21 thus guarantee both categories of workers a right to choose in which of the two States they wish to obtain medical care. ${ }^{70}$

\subsubsection{Unemployed Workers}

Community citizens who have found but later lose employment may retain the right to reside in the host State.$^{71}$ For as long as they indeed continue living there, they retain the right to obtain medical care. As workers, the partially, intermittently or wholly unemployed remain covered by Regulation No $1408 / 71 .^{72}$ They continue to be insured for medical care ${ }^{73}$ and can rely on Article 3 or Article 19 in order to claim medical benefits in the State of residence at the expense of the competent institution. ${ }^{74}$ The loss of employment, however, may have implications for workers who, during their employment, were residing outside the competent State. By virtue of Article 25(2) of Regulation No 1408/71, wholly unemployed frontier workers as well as wholly unemployed nonfrontier workers who were residing in a Member State other than the competent State and who have decided to search for (new) employment in the State of residence, remain entitled to medical benefits in the State of residence as though they had been insured there during their last employment; ${ }^{75}$ the two categories no longer have the right, however, to claim

70. For frontier workers one exception exists. Such workers do have the right to receive medical care in both the State of residence and insurance, but they can, according to Article 19 of Regulation No 574/72, only obtain medic(in)al products in the State where they have "chosen to go to the doctor" and where the products have been prescribed. Further, Article $22(1) \mathrm{b}$ provides that workers who have become entitled to benefits chargeable to the competent institution and who are authorised by that institution to transfer their residence to another Member State, are entitled to claim benefits in the latter State. In such cases, authorisation may be refused only if it is established that the movement of the persons concerned would be prejudicial to their health or the receipt of treatment. Article 22(2), first sentence.

71. See further Chapter 2 Section 2.2.2.

72. See Article 1(a) juncto Article 2 of Regulation No 1408/71.

73. The partially unemployed remain insured in the State of employment. The wholly unemployed, however, are by virtue of Article 13(2)f (as interpreted by the Court in Case C275/96 Kuusijärvi [1998] ECR I-3443) subject to the legislation of the State in whose territory they reside.

74. Compare Schoukens (1994) supra footnote 56, at pp.29-30.

75. However, wholly unemployed non-frontier workers who were residing in a Member State other than the competent State and who have decided to seek (new) employment in the State of residence, cannot benefit from Article 25(2) when they have already become entitled to unemployment benefits in the competent State. In such circumstances the persons concerned can only claim medical benefits as work-seekers (Article 25(1) - see Section 
medical benefits in the State in which they used to be employed. ${ }^{76}$

\subsubsection{Pensioners}

Community citizens who have definitively ended their working career because of old-age or permanent incapacity for work, lose their right to reside as a worker in the host State and they can no longer benefit from the health care provisions of Regulations No 1408/71 and No 574/72 as described so far. ${ }^{77}$ Community law, however, does not leave retired workers empty handed. They may continue to live in the State of (former) employment by virtue of the so-called right to remain ${ }^{78}$ and Articles 2634 of Regulation No 1401/71 contain a detailed set of rules governing the

3.1.1). See Article 25(2) juncto Article 71(1)(b)(ii) of Regulation No 1408/71.

76. Article $25(2)$ of Regulation No $1408 / 71$ refers to Article $71(1)$ (a)(ii) which stipulates that wholly unemployed frontier workers shall receive unemployment benefits in the State of residence. Article 71(1)(a)(ii) has exclusive effect. Case 1/85 Miethe [1986] ECR 1837 at 1012. For as long as wholly unemployed frontier workers do not (return to or) establish residence in the State in which they used to work, the State of residence acts as though it were the competent State (Case C-131/95 Huijbregts [1996] ECR I-1409 at 24) and it is only in this State that they can claim unemployment benefits. Since Article 25(2) explicitly refers to Article 71(1)(a)(ii), it may be assumed that the same holds true for medical benefits. Nonfrontier workers who were residing in a Member State other than the State of employment can choose (by making themselves available to the employment services in one of these States) in which of the two States they wish to claim unemployment benefits when they become wholly unemployed. The State they have chosen is to be regarded as the competent State. The wholly unemployed who choose the State of former employment to retain the right to claim medical benefits in the State of residence (Article 19 of Regulation No 1408/71) and the competent State (Article 21), but those who make themselves available to the employment services in the State of residence are subject to the legislation of, and can only claim medical benefits, in that State (under Article 25(2) of Regulation No 1408/71). 77. Persons who cease all activity do not necessarily lose their status of employed persons under Regulation No 1408/71. Yet, for the purposes of the health care provisions they do lose that status. Under these provisions the term "employed persons" has a more restrictive meaning than the definition given in the general provision of Article 1 of the Regulation. See Stiemer, Ziekte en Moederschap - Arbeidsongevallen en Beroepsziekten, in: Pieters, Europees Sociale Zekerheidsrecht - Commentaar (1989) pp.69-88, at p.75 and Stiemer (1999) supra footnote 45, at p.230. See, however, Article 34(2) which provides that where pensioners are also, or still, receiving health benefits by virtue of the pursuit of vocational activities, they will be regarded as workers. Article 34(2), however, does not apply to pensioners who are entitled to health benefits by virtue of the receipt of unemployment benefits. Decision No 156 of the Administrative Commission (OJ 1995 L 249)

78. Sec Chapter 2 Section 2.2.2. 
health care and insurance rights of pensioners. ${ }^{79}$ These rules have a double purpose. They intend to ensure that pensioners $(i)$ retain their right to medical care in the State of residence ${ }^{80}$ and (ii) cannot be obliged to pay health contributions in more than one Member State. ${ }^{81}$

In many Member States, health insurance for pensioners is linked to the receipt of a pension. In practice quite some time may pass between the application for and the actual grant of a pension ${ }^{82}$ and this could bring about the result that pension claimants who have ceased to be insured in the last competent State, would not be entitled to medical care at all. Article 26 of Regulation No 1408/71 therefore provides that during the period of application, applicants are entitled to health care in the Member States of residence provided they are entitled to such benefits under the legislation of the State of residence or by virtue of the legislation of another Member State if they were residing there. During this period, the costs of the health services are borne by the institution of the Member State which has received health insurance contributions or, in the absence of such an institution, the institution of the State of residence. Ultimately, however, the cost will have to be borne by the institution, which after the pension is awarded, will receive the health contributions. $^{83}$

79. The rules concerning invalidity, old age and death pensions contained in Articles 37-51 of Regulation No 1408/71 do not contain provisions for medical benefits "in kind". Coordination problems concerning such benefits are to be dealt with under Article 18-36 of Regulation No $1408 / 71$ and the accompanying provisions of Regulation No 574/72. Case 69/79 Jordens-Voster [1980] ECR 75 at 7. Articles 52-63 of Regulation No 1408/71 concerning workers who have become the victim of accidents at work or suffer from occupational diseases do contain provisions for medical "benefits in kind". These are, however, virtually identical to the rules contained in Articles 18-36 and, for this reason, they will not be discussed seperately in this Chapter. For a brief description see Schoukens (1992) supra footnote 56 , at pp. $45-46$

80. Cornelissen, The Principle of Territoriality and the Community Regulations on Social Security (Regulations 1408/71 and 574/72), in: CMLRev (1996) pp.439 et seq, at p.463.

81. Compare Stiemer (1989) supra footnote 77, at p.84. See also Rundgren (2001) where the Court held that the purpose of Articles 27,28 and $28 \mathrm{a}$ is to identify (i) the institution responsible for providing pensioners with sickness benefits and (ii) the institution responsible for bearing the costs. Case C-389/99 Rundgren [2001] ECR I-0000) at 44.

82. This is particularly true when a right to a pension exists in more than one Member State. De Groot, De Wettelijke Verzekering van Geneeskundige Verzorging en Ziekengeld binnen het Kader van de EEG-Verordeningen, in: Boot et al, Europees Sociaal Verzekeringsrecht (1978) pp.91-110, at p.101.

83. If necessary, financial settlement takes place. See further Article 26(2) and (3) Regulation No 1408/71. In order to receive medical care pension claimants must have registered themselves with the institution of the State of residence by use of form E 120 which is issued by the Member State responsible for the medical benefits. 
As regards retired workers who are entitled to one or more pensions ${ }^{84}$ under the legislation of a single Member State, and who have actually been granted the pension(s), two situations are to be distinguished. The first concerns pensioners who are residing in the territory of the State concerned. Articles 26-34 of Regulation No 1408/71 do not contain any specific provisions for this situation. The pensioners in question are subject to the legislation of that State and they can "simply" rely on the general non-discrimination provision of Article 3 of Regulation No $1408 / 71$ in order to claim medical benefits under the same conditions as the nationals of the State concerned at the expense of the institution of that State. ${ }^{85}$ The second situation concerns pensioners who receive a pension from one Member State but who reside in another where they are not entitled to medical benefits. Article 28 of Regulation No 1408/71 provides that such pensioners are entitled to obtain medical benefits in the State of residence as though they were residing in the State offering the pension. ${ }^{86}$ The costs are borne by the institution of the "pension State" ${ }^{87}$ Article 28 fulfils the same role as Article $19 .{ }^{88}$ Both Articles

84. Where pensioners receive two pensions under the legislation of a single Member State, they will be treated as though they were only receiving one pension in that State. See Article 34(1) of Regulation No 1408/71.

85. Where necessary, such pensioners may also rely on Article 18 in order to have periods of insurance, employment or residence taken into account by the competent institution.

86. Article 28(1)a of Regulation No 1408/71.

87. Article 28(2)a of Regulation No $1408 / 71$. Pensioners who receive a pension from only one Member State but who are residing in a State where health insurance is based on residence are entitled to claim medical benefits in the latter State. Article 28a of the regulation indicates, however, that where the pensioner resides in the territory of a Member State under whose legislation the right to receive benefits in kind is not subject to conditions of insurance or employment, nor is any pension payable, the costs are borne by the State responsible for the pension provided the pensioners would have been entitled to benefits in that State if they were residing there. In Rundgren (2001) the Court was asked to clarify the meaning of the expression "nor is any pension payable". The case concerned a Swedish national who received a Swedish pension, who lived in Finland and who was required to pay in the latter State contributions for the national State pension and sickness insurance. $\mathrm{Mr}$ Rundgren submitted that he could not be required to pay contributions since he only received a Swedish pension and had not applied for a pension in Finland. The Finnish government argued that the expression "pension payable" refers to a theoretical entitlement to a pension, given by the national legislation of the Member State concerned, even if the person concerned has not applied for the pension. The Court did not agree. Article 28a aims to ensure that Member States whose legislation confers a right to benefits in kind merely by virtue of residence in the State territory without imposing conditions of insurance or employment, are not penalised for doing so. Under the system established by Articles 27, 28 and 28a the institution which has to bear the costs of medical benefits in kind will always be an institution of a Member State competent in respect of pensions. The connection thus established between the competence to provide pensions and the obligation to bear the costs 
grant persons who reside in a Member State other than the one in which they pay health premiums a right to gain access access to medical care in the State of residence. Frontier workers, for instance, are during their working-career entitled to health care in the State of residence on the basis of Article 19; after their career they enjoy this right under Article $28 .^{89}$

Also as regards retired workers who have worked in various Member States as a result of which they have become entitled to pensions under the legislation of more than one Member State, ${ }^{90}$ two situations are to be distinguished. The first involves pensioners who receive pensions from the institutions of more than one State, one of which is the State of residence and who are entitled to medical benefits in that State. In the absence of any co-ordination rules, such pensioners might be obliged to pay health contributions in more than one State and the institution of more than State might be obliged to bear the cost of medical care. Article 27 provides that such pensioners can claim health care benefits in the State of residence as though they were solely receiving a pension in that State. ${ }^{91}$ The second situation concerns pensioners who

of benefits in kind, so the Court held, leads to the conclusion that that obligation is incidental to an actual competence in respect of pensions. Therefore, the costs of benefits in kind cannot be borne by the institution of a Member State which has only a hypothetical competence in respect of pensions. That interpretation is borne out of Article 33(1) which provides that the institution responsible for payment of a pension is authorised to make deductions from the pension actually paid by it in order to cover the costs of inter alia medical benefits. See supra footnote 93. Thus, because the Finnish authorities were not responsible for bearing the costs of benefits in kind of $\mathrm{Mr}$ Rundgren, they could not impose any duty to make contributions on him. Case C-389/99 Rundgren [2001] ECR I-0000 at 4557.

88. Case 69/79 Jordens-Voster [1980] ECR 75 at 12.

89. Pensioners who wish to claim benefits under Article 28 or $28 \mathrm{a}$ must register with the institution of the State of residence by submitting form E 121. See further Article 29 of Regulation No $574 / 72$.

90. For most types of benefits the two EC regulations apply the so-called integration method. Under this method beneficiaries who have worked in, or have become entitled to benefits under the legislation of, more than one Member State, will receive a benefit in or at the expense of only one State. For long-term benefits such as invalidity or old-age pensions this method could have far-reaching financial implications, and in order to avoid these, the regulations prescribe (in most cases) the partial pension method which implies that pensions are awarded to beneficiaries on the basis of the rules of more than one Member State. See further the literature referred to in footnote 43 .

91. The main purpose of Article 27 is to prevent the competent institution of the State of residence, which is compelled to pay sickness benefits, from relieving itself from that obligation on the ground that the person concerned is entitled to a benefit under the legislation of another Member State. Case 103/75 Aulich [1976] ECR 697 at 5. 
receive pensions from two or more States other than the State of residence. Where they have no claim to medical benefits under the legislation of the State of residence, Article 28(1) guarantees that pensioners can claim medical benefits in the State of residence. The cost are borne by the institution of the State where the pensioners have been insured for the longest time ${ }^{92}$ provided the pensioners would be entitled to medical benefits if they were residing there. ${ }^{93}$ Community citizens who remain

92. See Article 28(2) Regulation No 1408/71 which further indicates that where pensioners have been subject to the legislation of different Member States for equal periods of time, the Member State to whose legislation they were last subject is to bear the costs. Pensioners who receive pensions from two or more States and who reside in a State where health insurance is based on residence, can claim medical benefits there, but, as follows from Article 28a, the costs are in this situation borne by the institution of the "pension State" where the pensioners have been insured for the longest time.

93. In cases where Member States are obliged to pay the costs of medical benefits in kind on the basis of one of the pensioner provisions discussed above, they are entitled to deduct health insurance contributions from pensions. See Article 33(1) of Regulation No 1408/71. If no such obligation exists, no contributions can be deducted. Case 275/83 Commission $v$ Belgium [1985] ECR 1097. Article 33 constitutes the "application of a more general principle according to which a pensioner cannot be required, because he resides in the territory, to pay compulsory insurance contributions to cover benefits payable by an institution of another Member State". Case C-140/88 Noij [1991] ECR I-387 at 14; Case C389/99 Rundgren [2001] ECR I-(0000) at 53 and Opinion of Advocate General Alber in Case C-347/98 Commission v Belgium [2001] ECR I-0000 at 63. The prohibition following from Article 33 only applies to statutory pensions, not to supplementary pensions established by industrial or collective agreements. See Case 275/83 Commission v Belgium [1985] ECR 1097; Case C-57/90 Commission v France [1992] ECR I-75; Case C-253/90 Commission v Belgium [1992] ECR I-531 and Case C-302/98 Sehrer [2000] ECR I-0000 at 26.

The judgment in Sehrer (2000) demonstrates that the legal status of pensioners is not exhaustively governed by Articles 26 to 28 a of Regulation No 1408/71. The case concerned a German national who lived in Germany and used to work there as a miner. Since reaching the age of 60 , he had received a statutory retirement pension in Germany as well as a supplementary retirement pension from an association for miners. Because $\mathrm{Mr}$ Sehrer had also worked as a miner in France, he received in addition a supplementary pension which was based on a French collective labour agreement. When the competent German authority learnt of Mr Sehrer's French supplementary pension, it demanded payment of arrears of sickness insurance contributions from him on the basis of the gross amount of the French pension. In doing so, however, the German authority did not take into account the fact that sickness insurance contributions had already been deducted in France. In determining whether the law applied by the German authority was compatible with Community law, not one of Regulation No 1408/71's health care provisions for pensioners could be applied. From Article 1(j) of the regulation it follows that benefits granted by industrial agreements do not fall within the scope of the Regulation with the result that Mr Sehrer, for the purposes of the regulation, was deemed to draw a retirement pension under the legislation of a single Member State (i.e. Germany) only. The regulation's health care provisions for pensioners, however, only cover situations where pensioners draw pensions under the legislation of two or more Member States or situations where they draw a pension under the 
living in the State of employment after retirement thus retain insurance cover and the right to claim medical benefits in that State. Retired workers who live in a Member State other than the one in which they were most recently employed no longer have a right to claim medical benefits in that State as though they were still working there. The health care and insurance rights of pensioners are exclusively governed by Article 26-34 and these Articles do not contain any provision comparable to Articles 20 and 21 of Regulation No 1408/71. ${ }^{94}$ The right to choose between the competent State and the State of residence that such persons enjoyed when they were in employment is lost. ${ }^{95}$

\subsubsection{Family Members}

Community citizens who make use of the free movement rights guaranteed by Article $39 \mathrm{EC}$ are entitled to be accompanied by their spouse, their (grand)children who are under the age of 21 years or dependent and their dependent (grand)parents. ${ }^{96}$ A genuine free movement of workers which is relevant and practical requires that these family members are also entitled to medical care in the Member State in which they stay or reside. Family members ${ }^{97}$ staying or residing in the competent

legislation of a single Member State but are not entitled to medical benefits in the country of residence. Case C-302/98 Sehrer [2000] ECR I-0000 at 25-27. This did not imply, however, that challenged German rules in question were compatible with Community law. The Court concluded that Germany, by not taking into account the fact that sickness insurance contributions had been deducted in France, had applied a rule which hampers the exercise of free movement rights and violated Article 39 EC. Ibid, at 33-36.

94. The Commission, however, has proposed to grant retired frontier workers a right to obtain medical care in the State in which they used to work. See further Section 3.6.2.

95. In practice, however, this does not have very serious implications for retired frontier and other non-residents workers. Article 31 of Regulation No 1408/71 grants pensioners during a (temporary) stay in a Member State other than the one in which they reside the right to obtain medical benefits in accordance with the legislation applicable there. See further Section 3.2.1. Further, pensioners can benefit from Article 22(1)b which states that workers who have become entitled to benefits chargeable to the competent institution and who are authorised by that institution to transfer their residence to another Member State, are entitled to claim benefits in the latter State. Stiemer (1999) supra footnote 45, at p.232.

96. See Chapter 2 Section 2.3 .

97. For the purposes of Regulation No 1408/71, family members are defined as the persons who are defined or recognised as family members or designated as a member of the household by the legislation where benefits are provided for. Article 1(f) of Regulation No $1408 / 71$. Where, however, the legislation in question regards as members of the family or members of the household only persons living under the same roof as the principal beneficiary, this condition is considered satisfied if the persons concerned are mainly dependent on 
State can rely, where necessary, on Article 3 of Regulation No 1408/71 in order to claim care under the same conditions as the nationals of the host State. For family members staying or residing in Member States other than the competent State Regulation No 1408/71 contains several specific provisions. Article 19(2) of Regulation No 1408/71 grants family members of frontier workers and other workers residing outside the competent State, the right to obtain medical care in that State. ${ }^{98}$ Article $25(3)$ of

that person. Where the legislation of a Member State does not enable members of a family to be distinguished from other persons to whom it applies (i.e. in Member States where the right to benefits is based on residence - Stiemer (1999) supra footnote 45, at p.229), the term "member of the family" has the meaning given to it in Annex I(A) to Regulation No 1408/71.

98. The right is only granted to family members who have no right to medical benefits under the legislation of the State where they reside. The second sentence of Article 19(2) indicates that this requirement does not apply to family members who reside in a Member State where the right to obtain medical care is only conditional upon residence (e.g. Finland, Denmark). If, however, the spouse (or the person looking after the children) pursues a professional or trade activity in that State, the requirement does apply. The second sentence of Article 19(2) reflects the basic principle underlying the Regulations that the Member State which receives the health contributions must also pay the "medical bill". See European Commission (1995) supra footnote 64 , at p.430.

It had always been assumed that family members could only benefit from Article 19(2) when they were also defined or recognised as family members by the legislation of the State of residence. Stiemer (1999) supra footnote 45 , at p.229. The ruling in Delavant (1995) indicates that this view is no longer correct. Delavant concerned a French national who was employed in France and lived with her husband and two children in Germany. Mrs Delavant requested a declaration from the German sickness fund that her children would be entitled to medical care at the expense of the sickness fund. This request was refused. The sickness fund referred to Article 1(f) of Regulation No $1408 / 71$ which defines family members as persons who are defined as family members under the legislation under which benefits are provided for. The fund subsequently applied the German law under which children could only be co-insured (free of charge) in cases where the income of the spouse of the insured person does not exceed a fixed maximum. Mr Delavant's income exceeded that maximum. This practice of the German sickness fund basically meant that family members of frontier workers such as Mrs Delavant must qualify as family members under the legislation of both the competent State (in casu France) and the residence State (in casu Germany) in order to benefit from Article 19 of the regulation. The Court, however, concluded that Article 1(f) of Regulation No 1408/71 does not deal with conditions for insurance and that the question whether or not family members meet requirements for health insurance cover are to be determined by the legislation of the competent State alone. Case C-431/93 Delavant [1995] ECR I-1545 at 18-19. On Delavant see van der Steen, Medische Zorg voor Gezinsleden van Grensarbeiders, in: NTER (1995) pp.121-122. The European Commission intends to correct Delavant. It has proposed that the Regulation is to be amended in order to define family members, for the purposes of sickness and maternity benefits, as persons with derived rights and who are defined or recognised as family members or designated as members of the household by the legislation of the State of residence. See Article 7(e) of the proposal to simplify Regulation No 1408/71. COM(1998) 779 final. 
Regulation No $1408 / 71$ provides for similar rights for family members of work-seekers, wholly unemployed frontier workers and the wholly unemployed non-frontier workers who were residing in a Member State other than the competent State and who have decided to seek (new) employment in the State of residence. ${ }^{99}$ Furthermore, Articles 26, 27, 28 and $28 \mathrm{a},{ }^{100}$ all of which intend to ensure that pension claimants and pensioners are subject to the health insurance of one Member State only and can claim access to medical care in the State of residence, apply equally to their family members. ${ }^{101}$

Most family members who are residing in a Member State other than the competent State only have a limited possibility of obtaining benefits in the competent State. Family members of workers residing outside the competent State and who do not return daily or weekly to this State, can also claim medical benefits in the competent State during a stay there. ${ }^{102}$ Family members of frontier workers, however, have, according to the second sentence of Article 20 of Regulation No 1408/71, only such a right $(i)$ in "urgent" cases, ${ }^{103}$ (ii) when the Member States concerned, or the competent institutions of these States, have reached an agreement

99. These rights are granted provided the employed persons themselves meet the conditions for entitlement to medical benefits in the State responsible for the cost of the unemployment benefits. Article 25(3) of Regulation No 1408/71.

100. Article 29 further contains a special provision for the family members of pensioners who do not reside in the same Member State as the pensioners. Such family members can claim medical benefits in the State in which they reside. The costs are borne by the institution of the State in which the pensioner resides or when the pensioner has been insured for the longest time. See Article 29(1)a (as amended by Regulation No 1223/98 - OJ 1998 L 168) which further adds that where the family members reside in the competent State, the costs are borne by the competent institution. Family members who decide to move to the State where the pensioner resides can claim medical benefits even if they have already received benefits for the same case of sickness before transferring residence. Article 29(2)a of Regulation No 1408/71.

101. In order to implement the cross-border health care rights of family members several administrative formalities have to be fulfilled. Generally, the duty to request the certified statements from the competent institution and to use these for registration with the institution where the family members reside is imposed on the worker. When family members do not reside in the same State as the worker, it is up to them to fulfil the formalities. See e.g. Article 30 of Regulation No 574/72

102. Article 21(2) of Regulation No $1408 / 71$. Where these family members reside in the territory of a Member State other than the one in whose territory the worker resides, medical benefits obtained in the competent State are to be paid by the health institution of the State where they reside. Article 21(2), second sentence.

103. The Administrative Commission has stated that urgent cases are present whenever medical treatment cannot be postponed without endangering the life or health of the person concerned. Decision No 116 (OJ 1983 C 193) 
to this effect ${ }^{104}$ or, in the absence of such an agreement, (iii) when the competent institution has given prior authorisation. ${ }^{105}$

\subsection{Non-Residents/Travellers}

All Community citizens enjoy the right to cross intra-Community borders and to stay for a limited period of time in the territory of other Member States. ${ }^{106}$ Regulations No $1408 / 71$ and No $574 / 72$ contain several provisions which confer upon such "Community travellers" cross-border health care rights. A distinction is to be made ${ }^{107}$ between beneficiaries who become in need of medical treatment and/or medic(in)al products during a stay in another Member State and beneficiaries who move to other Member States for the purpose of obtaining medical benefits.

\subsubsection{Emergency Treatment}

Article 22(1)a (juncto Article 22a) ${ }^{108}$ of Regulation No $1408 / 71$ confers

104. France and Belgium have concluded such an agreement which entitles families of frontier workers to gain access to health care in the State of insurance. This agreement is (still) quite unique though. See Hermesse/Lawalle (1991) supra footnote 1, in the Section on Belgium.

105. For the family members of pensioners see Article 31 of Regulation No 1408/71. The Commission has proposed, however, to grant family members of frontier workers as well as family members of pensioners the same choice that frontier workers enjoy. See Section 3.6 .2

106. See Chapter 2 Section 4

107. See, however, footnote 130 .

108. Initially, Article 22(1)a was merely intended to apply to workers from the southern Member States working in one of the northern Member States and who became in need of medical care during a vacation in their State of origin. Creutz, Accord européen Concernant l'Octroi des Soins médicaux aux Personnes en Séjour temporaire, in: RISS (1985) pp.42-49. In practice, however, the application of Article 22(1)a has never been restricted to the State of origin and the provision had often already been applied to all persons covered by a public health (insurance) scheme. Article 22(1) of Regulation No 1408/71 merely speaks of (self)employed persons, but in 1996 Article 22a was inserted which has extended the scope of Article 22(1)a (and c - see Section 3.2 .2 below) to all persons holding the nationality of a Member State who are insured under the legislation of a Member State. See further Decision No 174 of the Administrative Commission of 20 April 1999 (OJ 1999 L 047).

Family members also enjoy the right offered by Articles 22(1)a (see Article 22(3)) and Article 22(a). For the purposes of Article 22(1) the term "family members" is defined by the State of residence. Sec Article 1(f) of Regulation No 1408/71. For the purpose of 
upon all Community citizens "whose medical condition necessitates immediate benefits during a stay in the territory of another Member State" the right to obtain medical benefits. Also in these E 111 cases $^{109}$ the benefits are provided in accordance with the legislation of the visited State and the costs are borne by the competent institution. ${ }^{110}$ Article 22(1)a can only be relied upon in cases of "emergency", i.e. cases in which, in the view of the doctor in the State of the visit, ${ }^{111}$ treatment

applying Article 22(1)a to family members referred to in Article 19(2) who reside in the territory of a Member State other than the one in whose territory the worker resides, "benefits in kind" are to be provided by the institution in the visited place on behalf of the institution of the Member State in whose territory the family members are residing. See Article 22(3), second sentence, under a.

109. In order to receive benefits in kind under Article 22(1)a beneficiaries must before departure to another Member State request from their insurance institution form $\mathrm{E} 111$ which states that they are entitled to obtain "emergency care"and the duration for which they may do so. Upon arrival in the visited State, form E 111 must be submitted to the insurance institution of the State concerned which may then issue a national document for use in that country. If no E 111 form is submitted, the institution of the visited State shall obtain it from the competent institution. See Article 21 of Regulation 574/72 and Decision No 74 of the Administrative Commission (OJ 1973 C 75). In case the E 111-formalities are not fulfilled, the expenses shall, upon beneficiaries' application, be refunded by the competent institution in accordance with the rates administered by the institution of the visited place which shall supply the competent institution with the necessary information about such rates. Article 34(1) and (2) of Regulation No 574/72. The competent institution may effect reimbursement of expenses incurred in accordance with the rates it administers provided that it $(i)$ is possible to make a refund in accordance with these rates, (ii) the expenses do not exceed a level set by the Adminstrative Commission (500 Euro - Decision No 161 - OJ 1996 L 083) and (iii) beneficiaries agree to this. The amount of reimbursement shall never exceed the amount of the expenses actually incurred. Article 34(4) of Regulation No 574/72. In practice, the administrative formalities often lead to difficulties. See e.g. Hermans, Access to Health Care and Health Services in the European Union: Regulation 1408/71 and the E 111 Process, in: Leidl (Ed.), Health Care and its Financing in the Single European Market (1998) pp.324-343 and Hermans, Gezondheidszorg bij Tijdelijk Verblijf over de Grens: Toepassing Verordening 1408/71 (E111) in de Europese Praktijk, in: SR (1996) pp.343-348. Discussions have been held about the possible introduction of a European health care card which would minimise the cumbersome and inefficient administrative current procedures. See e.g. Hermans (1996) supra, at p.347; Neumann-Duesberg (1991) supra footnote 48 at pp.94-95 and Bloch, Auswirkungen des Europäischen Binnenmarktes aud die gesetzliche Krankenversicherung, in: BB (1989) pp.2405-2410, at pp.2408-2409.

110. This institution also determines the duration of the period during which medical benefits can be obtained.

111. Jorens (1992) supra footnote 43, at pp.96-97 and Hermans (1998) supra footnote 109 , at p.337. The duty of the institution of the providing State to notify the competent institution in cases of hospitalisation or the grant of certain expensive types of treatment and the possibility for the competent institution to make a reasoned objection (see supra footnote 53) must in emergency cases during a temporary stay abroad be done immediately. See Article 21(2) of Regulation No $574 / 72$. 
cannot be postponed without endangering the life or health of the Community citizen concerned. ${ }^{112}$ Once the medical urgency is over, the providing State is entitled to send the patient ${ }^{113}$ back to the State of residence for further treatment. ${ }^{114}$

\subsubsection{Authorised Treatment}

Article 22(1)c (juncto Article 22a) ${ }^{115}$ of Regulation No 1408/71 grants all publicly insured Community citizens who have been authorised by the competent institution to go to the territory of another Member State in order to receive medical treatment, the right to obtain medical care. ${ }^{116}$

112. Decision No 135 of the Administrative Commission (contained in European Commission (1995) supra footnote 65, at pp.293-295) at points 4 and 5. See also Neumann-Duesberg, Defizite, Probleme und Perspektiven bei der Umsetzung des Europäischen koordinierenden Sozialrechts - Verordnungen Nr. 1408/71 und Nr.574/72 - Leistungen bei Krankheit und Pflegebedürftigkeit, in: Schulte/Barwig, Freizügigkeit und Soziale Sicherheit - Die Durchführung der Verordnung Nr.1408/71 über die soziale Sicherheit der Wanderarbeitnehmer in Deutschland (1999) pp.89-108, at p.96. Article 22(1)a requires "confirmation of a pressing medical need" for benefits which encompass "benefits in kind needed fortwith". Case C206/94 Paletta [1996] ECR I-2357 at 20.

113. Some beneficiaries can obtain medical care more easily. Beneficiaries who are staying in another Member State for a relatively long period of time but who have not established residence in that State (e.g. posted workers), can, according to Article 22c, obtain medical benefits whenever their medical condition so requires. Article 31 further holds that pensioners are entitled to treatment during a stay in a State other than the one in which they reside, when treatment becomes necessary. See also Hermans (1998) supra footnote 109, at p. 337 .

114. For instance, beneficiaries who are suffering from sudden dental pain during a temporary stay in another Member State are entitled to the necessary treatment. This treatment may consist of the grant of painkillers or the removal of teeth, but not dental protheses. See Langer (1999) supra footnote 7, at p. 720.

115. See footnote 108 above.

116. Article 22(1)c is intended "to allow an insured person, authorised by the competent institution to go to another Member State to receive there treatment appropriate to his condition, to receive sickness benefits in kind, on account of the competent institution but in accordance with the provisions of the legislation of the State in which the services are provided, in particular where the need for the transfer arises because of the state of health of the person concerned, without that person incurring additional expenditure". Case C-120/95 Decker [1998] ECR I1831 at 28 and Case C-158/96 Kohll [1998] ECR I-1931 at 26. Authorisation can be granted to individual insured persons as well as to a group of persons. Ncumann-Duesberg (1999) supra footnote 112, at p.97. 
The bill is to be paid by the competent institution. ${ }^{117}$ The prior authorisa-

117. According to Article 36(1) of Regulation No 1408/71, the institution of the "providing" State is entitled to be fully reimbursed for the costs incurred by the competent institution to which the insured are affiliated. As regards the insured who have gone to other Member States for the sole purpose of obtaining medical treatment, this would seem to imply that the costs will in all cases be reimbursed in accordance with the rates or tariffs applied by or in the State where they (have) obtain(ed) medical treatment. Vanbraekel, a case currently still pending before the Court, demonstrates that this is not necessarily the case. The case involves a Belgian national, Ms Descamps, who in 1990 had gone to a Paris hospital in order to obtain surgical treatment. The sickness fund refused to pay the costs. According to the relevant Belgian rules medical care provided in foreign hospitals is only refundable when the treatment concerned has an additional medical value which has been established by a doctor or physician with academic credentials. Ms Descamps challenged the refusal of the sickness fund in court. During the proceedings it was ultimately established that the treatment did indeed have an additional medical value, but this did not end the dispute between Ms Descamps and the sickness fund. The two parties could not agree on the basis of which tariffs the costs of Ms Descamps treatment in Paris were to be reimbursed. Ms Descamps claimed she was entitled to be reimbursed in accordance with the tariffs applicable in Belgium which were higher than the ones applied in France. The sickness fund only wanted to reimburse on the basis of the French tariffs. In the course of the proceedings Ms Descamps passed away and the proceedings were continued by her husband, Mr Vanbraekel, and their six children. The Belgian court which is to decide upon the case has asked the Court of Justice whether in cases in which the medical need for treatment abroad has been recognised but in which no prior authorisation has been granted in accordance with Article 22(1)c of Regulation No 1408/71, reimbursement is to take place in accordance with the rules applicable in the competent State of insurance or the rules of the State where the treatment is provided. A preliminary issue which arises is whether a person such as Ms Descamps can be said to have obtained authorisation in the sense of Article 22(1)c of the regulation. In his Opinion in Vanbraekel Advocate General Saggio considered the issue of little significance. The referring court had indicated that Ms Descamps was, on the basis of Belgian law, entitled to reimbursement of the costs she had incurred in France. Article 22 requires an authorisation, but Regulation No 1408/71 cannot be interpreted so as to deprive an insured person of a right to reimbursement which she has acquired under national law. Moreover, in the view of the Advocate General, a retroactively granted authorisation is fully in line with the regulation's goal of promoting freedom of movement and may in principle be put on a par with a prior authorisation. Opinion of Advocate General Saggio in Case C368/98 Vanbraekel (http://www.curia.eu.int/juris) at 12. At first glance, this conclusion would seem to imply that, on the basis of Article 36 of Regulation No 1408/71, the costs incurred by Ms Descamps are to be reimbursed in accordance with the French tariffs. The Advocate General concludes, however, that this provision is not applicable in the case of Ms Descamps. Article 36 only applies to the relationship between the social security institutions of the different Member States. The beneficiary of Article 36 is the institution of the State where the care is provided. It is this institution, and not the patient, which is entitled to be "fully reimbursed". The Advocate General, however, concluded that there is no specific provision in the regulation that indicates which tariffs are to be applied in the cases such as the ones at issue in Vanbraekel. On the basis of the general principles underlying Regulation No 1408/71, such as non-discrimination and the retention of rights acquired under national law, the Advocate General concluded that, on the one hand, beneficiaries are entitled to full 
tion for treatment in another Member State is given by means of form $\mathrm{E}$ $112^{118}$ which states that the person ${ }^{119}$ concerned is authorised to receive a given type of medical treatment and the period for which he is so entitled. The form has to be submitted to the institution in the visited State which, as the Court ruled in Pierik II (1979), is upon presentation of the form under the duty to provide the health services concerned. ${ }^{120}$

Member States are free to authorise any type of treatment considered to be effective for the sickness or the disease the persons concerned suffer from. It is of no relevance whether or not the medical benefits are covered by the legislation administered by the competent institution. ${ }^{121}$ Of much greater importance is the question when authorisation is to be given. In other words, in which cases does the Regulation give insured persons the right to go to another Member State in order to obtain medical treatment at the expense of of their insurance institution? The answer is found in Article 22(2) of Regulation No 1408/71. This provision states that authorisation for treatment in other Member States may not be refused where the treatment in question $(i)$ is among the benefits provided for by the legislation of the Member State on whose territory the person concerned resides, and (ii) where the patient, taking account of his current state of health and the probable course of the disease, cannot be given the treatment in question within the time normally necessary for

reimbursement of the costs of "foreign" medical care and, on the other hand, that this reimbursement must be equal to the amount for which medical care obtained "at home" is refundable. The legislation of the competent State is to be applied and, in cases where authorisation is granted, the institutions applying this legislation are not to make a distinction between patients receiving treatment "at home" and those obtaining treatment "abroad". Ibid, at 25-26.

118. In each State a request for treatment abroad has to be made by the specialist or the hospital treating the patient. The next step involving the actual grant of the authorisation, however, differs considerably. See further Palm et al (2000) supra footnote 4, at pp.46-65 and Kesteloot et al (1995) supra footnote 13, at pp.48-49.

119. Family members also enjoy the right afforded by Articles 22(1)c (see Article 22(3)) and Article 22(a). For the purposes of Article 22(1)c the term "family members" is defined by the State of residence. See Article 1(f) of Regulation No 1408/71. For the purpose of applying Article 22(1)c to family members referred to in Article 19(2) (i.e. family members residing outside the competent State) who reside in the territory of a Member State other than the one in whose territory the worker resides, the required authorisation shall be issued by the institution of the Member State in the State of residence. See Article 22(3), second sentence, under (b).

120. This is so even if, under the legislation which it administers, the institution does not have a duty but merely a power to grant the services. Case 182/78 Pierik [1979] ECR 1977 at $15-16$.

121. Case $117 / 77$ Pierik [1978] ECR 825 at 15-16. 
obtaining this treatment in the Member State of residence.

The current Article 22(2) was inserted by the Community legislator in 1981 in response to the judgments of the Court of Justice in the two Pierik cases. The cases concerned a Dutch national who worked, lived and was insured in the Netherlands and who had gone to Germany in order to receive hydrotherapy treatment. Upon her return to the Netherlands, Mrs Pierik asked for the costs she had incurred to be refunded. The insurance institution refused reimbursement on the ground that hydrotherapy treatment was not among the types of treatment covered by the Dutch health insurance. Mrs Pierik started legal proceedings. The Dutch court which had to decide upon the case in last resort, referred several questions to the Court of Justice relating to Article 22(2) of Regulation No 1408/71. At the time, this provision stipulated that authorisation for treatment abroad could not be refused "where the treatment in question cannot be provided for the person concerned within the territory of the Member State in which he resides". In Pierik I (1978) the Court held that the:

"duty laid down in the second subparagraph of Article 22(2) to grant authorisation required in Article 22(1)(c) covers both cases where the treatment provided in another Member State is more effective than that which the person concerned can receive in the Member State where he resides and those in which the treatment in question cannot be provided on the territory of the latter State". ${ }^{122}$

The Court's interpretation of Article 22(2) seemed to imply that patients would also have the right to obtain authorisation for types of treatment which are deliberately excluded from the national insurance package on medical, medical-ethical or financial grounds. In Pierik II (1979) the Court confirmed that this was indeed the case:

"it emerges from the provisions and the essential aims of Article 22 that it was the intention of the regulation to give medical requirements a decisive rôle in the decision of the competent institution to grant or refuse the aforesaid authorisation by providing generally and unreservedly in the second subparaph of Article 22(2) that authorisation may not be refused 'where the treatment in question cannot be provided for the person concerned within the territory of the Member State in which he resides'. .. Thus .. when the competent institution acknowledges that the treatment in question constitutes a necessary and effective treatment of sickness or disease from which the person concerned suffers, the conditions for the application of the second subparagraph of Article 22(2) of Regulation No 1408/71 are fulfilled and the competent institution may not in that case refuse the authorisation referred to by that provision and required under Article $22(1)(\mathrm{c}){ }^{\prime \prime}{ }^{123}$

122. Ibid, at 22 .

123. Case 182/78 Pierik II [1979] ECR 1977 at 12-13. 
From the patients' perspective, the two Pierik judgments were to be welcomed. The Court had come close to recognising a free movement of patients. In principle, patients could still be required to seek and obtain medical treatment in their State of residence, but in cases where other types of treatment or better treatment would be available in other Member States, patients were entitled to obtain authorisation for and thus to receive, at the expense of the competent institution, such types of treatment. Medical requirements were said to be decisive for this right. From the Member States' perspective, however, the two judgments were problematic. Patients were granted the right to obtain forms of treatment not included in their "own" insurance package as well as "foreign" types of treatment which might have been far more expensive than offered "at home". The competent institutions, as the Court explicitly held in Pierik I, were obliged to pay the "foreign medical bill" in full. ${ }^{124}$ The Member States' autonomy in deciding which types of treatment are eligible for reimbursement and their ability to keep health expenditure under control seemed to have been affected. In addition, the judgments might have triggered an uncontrollable and unpredictable inter-State flow of patients which could cause capacity problems both in the providing and the competent State.

In the Member States' view, the Court had not given sufficient regard to their health care and insurance interests. They decided to alter the regulation. In 1981 the initial Article 22(2) was replaced by the current Article 22(2). ${ }^{125}$ The "legislative correction" of the Pierik judgments was drastic. The wording of Article 22(2) is cumbersome but does make clear that patients do not have the right to obtain authorisation for types of treatment which are not included in their own insurance package. Further, patients do not seem entitled to rely on Article 22(2) with a view to circumventing waiting lists in the State of residence. ${ }^{126}$ They may only have a right to obtain authorisation in cases where postponement of

124. Case $117 / 77$ Pierik I [1978] ECR 825 at 26.

125. OJ 1981 L 275.

126. Bieback, Krankheit und Mutterschaft, in: Eichenhofer (Ed.), Reform des Europäischen koordinierendes Sozialrechts (1993) pp.55-73, at p.64. 
treatment would be "medically unacceptable". ${ }^{127}$ In all other cases authorisation may be refused. ${ }^{128}$ In practice, it generally is refused; authorisation is only given in exceptional cases. ${ }^{129}$ By replacing Article 22(2) the Member States made it patently clear that the decision whether a patient can move abroad in order to obtain care, at the expense of the sickness fund, is made by them and not by the patients themselves. ${ }^{130}$

127. Kesteloot (1995) supra footnote 13, at p.46.

128. Cornelissen (1996) supra footnote 80, at p.464

129. The "authorisation policies" of Member States differ. See Palm et al (2000) supra footnote 4, at pp.46-64 and Kesteloot et al (1995) supra footnote 13, at p.47. Some Member States, such as the United Kingdom, only meet their basic obligations under Article 22(2) of Regulation No $1408 / 71$. Authorisation for treatment is granted where waiting-periods appear to be "too long", but authorisation is in principle refused in all other cases. A number of other Member States make more use of their freedom to send patients abroad. A Member State like Luxembourg gives authorisation for hospital treatment in other Member States relatively often. Other Member States such as Denmark, Germany, Greece, Ireland, the Netherlands and Portugal grant authorisation for types of treatment not available in their own country. This often concerns "new" types of treatment the effectiveness of which is recognised, but which have not yet been developed or been made available in these countries. In some (of these) countries, however, authorisation is granted only for such types of treatment. Apparently, then, not all Member States comply with Article 22(2). For persons living in border regions, some countries grant authorisation more easily. Belgium, for instance, has allowed residents of frontier regions to obtain medical care within a radius of up to 25 kilometers provided that there is no similar establishment in Belgium which is closer. $\operatorname{COM}(90) 561$ at p.11 and De Buyser, Grensoverschrijdende Gezondheidszorg, in: Jorens, Grensarbeid - Sociaalrechtelijke and Fiscaalrechtelijke Aspecten (1997) pp.129-160, at pp. 145-146.

130. In the view of the drafters of the Regulation Article 22(1)a was supposed to cover cases where the need for treatment occurred abroad and was not, or could not have been, foreseen at the moment the persons concerned decided to travel to another Member State. Article $22(1) \mathrm{c}$ was intended to apply to cases in which the need for medical treatment was or could be foreseen. It concerns cases where patients are sent abroad in order to receive medical care. This distinction, however, is not entirely reflected in the text of Article 22. Article 22(1)a stipulates that beneficiaries are entitled to obtain treatment when their "condition necessitates immediate treatment" during a stay in the territory of another member State. The wording of Article 22(1)a leaves room for the view that it can also be relied upon by persons who know in advance that they will come to need medical treatment. This may be at odds with the objective of and the intentions of the drafters of Article 22(1)a, but at least in some cases one has to assume that patients can indeed rely on that provision if they know in advance that they will come to need treatment. An overly restrictive interpretation of Article 22(1)a "would cause a significant obstacle to the free movement of persons whose conditions necessitates continuous and regular medical treatment such that they will be likely to require immediate benefits in the event of a stay in the territory of another State". Decision No 163 of the Administrative Commission (OJ 1996 L 241). The Administrative Commission has stated that patients in need of kidney dialysis (Decision No.123 - OJ 1984 C 203) and oxygen therapy (Decision No 163 - OJ 1996 L 241) can rely on Article 22(1)a in other Member States, and it could be argued that the same holds true for patients in need of 
treatment during pregnancy (see e.g. Neumann-Duesberg (1999) supra footnote 112, at p.98) and those suffering from other chronicle diseases and needing other forms of treatment.

In other cases, one might be more hesitant to accept that patients who know in advance that they will be in need of treatment can invoke Article 22(1)a of the Regulation. Article 22(1)a could possibly be abused. Consider the following example, taken from a Dutch newspaper article (NRC Handelsblad, 25 September 1993). A German woman living in a small German village close to the Dutch border was suffering from a worn-out hip. Surgery was necessary. The woman wished to be operated on in Winterswijk, a Dutch village just across the German-Dutch border, in order to enable her family members to visit her regularly in hospital. Unfortunately, the Krankenkasse, the German sickness fund, was not willing to finance the surgery in the Netherlands. Nevertheless, the woman agreed with the Dutch hospital that she would be admitted on a Saturday in order to be operated on two days later. On the Saturday concerned the woman had herself driven to the market in Winterswijk where she laid down in the market square and called for help. With a fictitious accident she was transported to the Dutch hospital. Two days later she was given a new hip. The Krankenkasse had to pay the costs of the surgery. In case of accidents abroad "the EC regulation" would oblige the sickness fund to pay the costs of the received treatment". The newspaper message provides an example of a case which should have been dealt with as an Article 22(1)c case but which was handled as an Article 22(1)a case. Yet, the conclusion was correct that the Krankenkasse had to reimburse the health care provider in the Netherlands. Even though the Regulation itself is silent on the issue, it is to be assumed that it is in principle up to health care providers to decide whether or not a particular case is an emergency. Jorens (1992) supra footnote 43, at pp.96-97. Similar "tricks" could possibly be played with Article 25. The unemployed who wish to obtain a certain type of treatment which is either not covered by their insurance or who wish to avoid waiting-lists could register with an employment office in another member State, export their unemployment benefit and claim medical benefits in the State concerned as though they were insured in that Member State. It is hard to establish how often Articles 22(1)a and 25 are used in the way described above, but given the fact that doctors and other health care providers are often self-employed and thus often likely to be interested in increasing their income by accepting more patients, the possibility cannot be excluded that it happens quite often.

The question could be raised whether the competent institutions must in all such cases bear the costs. Neither Regulation No 1408/71 nor Regulation No 574/72 contains a provision which could free the competent institution from the obligation to pay the bill and in the light of the Community's goal of promoting freedom of movement, the basic assumption must be that institutions must presume the correctness of the views of health care providers in other Member States. By analogy with the case-law of the Court on determination of sickness for the purposes of the grant or payment of cash benefits (Paletta cases - see footnote 46 above) or the medical examinations of applicants or recipients of invalidity (Articles 40 and 51 of Regulation No 574/72 - see e.g. Case C-279/97 Voeten [1998] ECR I8293), however, one cannot exclude the possibility that the competent institutions can refuse payment in cases where they can prove that Article 22(1)a has been "abused".

Difficulties concerning the demarcation of "emergency cases" and "authorisation cases" have also arisen in Agnello, a Luxembourg case. The case concerns a French frontier worker in Luxembourg. After an accident, he transported his spouse to a Belgian hospital for emergency treatment. Afterwards he asked for the E 111 form. The form was refused on the ground that the accident had not taken place in Belgium. Mr Agnello started legal proceedings and called upon the Luxembourg court to refer the case to the Court of Justice. The 


\subsection{Non-Economic Residents}

The third category of beneficiaries of the Community provisions on the free movement of persons which has been identified for the purposes of this book consists of so-called non-economic residents. It concerns Community students, pensioners and the residual category of "other" Community citizens whose right to reside in other Member States is (probably) ${ }^{131}$ based on Article 18(1) EC and set out in further detail in Directives No 93/96, No 90/365 or No 90/364. ${ }^{132}$ As regards the crossborder health care and insurance rights of these categories, a distinction is to be made between pensioners and "other" Community citizens, on the one hand, and students, on the other hand.

\subsubsection{Pensioners and "other" Community Citizens}

Regulations No $1408 / 71$ and No $574 / 72$ have never been drafted with the category of non-economic residents in mind. At the time of drafting, Community law merely provided for a free movement of workers and self-employed persons. The category of non-economic residents did not yet "exist". Until recently, ${ }^{133}$ Article 2 of Regulation No 1408/71 defined the personal scope to include employed or self-employed persons "who are or have been subject to the legislation of one or more Member States" and "who hold the nationality of one of the Member States". This did not, and does not, imply, however, that non-economic residents are necessarily excluded from the scope of the regulations' application. In fact, in many cases they will be able to benefit from the provisions contained in Regulation No 1408/71.

The definitions of the term worker differ for the purposes of Article 39 EC and the social security regulations. Article 1(a) of Regulation No 1408/71 defines employed persons as persons who are "insured, compulsorily or on an optional continued basis" by one of the branches of a social security scheme for employed persons as well as persons who are compulsorily insured under a social security scheme for all residents or for the whole population if such persons can be identified as employed

court refused to do so, however, on the ground that the E 111 form could be issued retroactively. The sickness fund in question has appealed that decision in Luxembourg. See Palm et al (2000) supra footnote 4, at p.82.

131. See in particular Chapter 3 Section 4.3.

132. See Chapter 2 Section 3.

133. See further Section 3.3.2. 
persons by virtue of the manner in which a social security scheme is administered or financed. This definition is much broader than the definition of worker for the purposes of Article $39 \mathrm{EC}$ which requires in particular that Community citizens meet the threshold requirement of "effective and genuine work". ${ }^{34}$ Many part-time workers will not be able to meet this requirement. As regards the right of residence they will have to rely on Directive No 90/364. The requirement of "effective and genuine work", however, does not apply under Regulation No 1408/71. Part-timers who perform merely "marginal and ancillary" activities can be classed as workers for the purposes of the social security regulation. ${ }^{135}$ By virtue of Article 13 et seq they will be insured in the State concerned and be entitled to claim medical care there under the same conditions as the nationals of the host State. Moreover, many Community citizens who would like to establish residence in other Member States without taking up employment there will be covered by the social security regulations because as workers they are subject to the legislation in the State of origin (or another Member State). A change of private residence does not lead to the loss of the status of worker in the State of employment under Regulation No 1408/71 and such non-economic residents can rely on Article 19 of Regulation No 1408/71 in order to claim medical benefits in the State of residence. Furthermore, pensioners covered by residence Directive No 90/365 will also be regarded as pensioners for the purposes of Article 2634 of Regulation No 1408/71. As a result, they are entitled to obtain medical benefits in the State of residence. In sum, the vast majority of the pensioners, the residual category of "other" Community citizens as well their family members is publicly insured in one of the Member States and this entitles them to all rights and benefits discussed in section 3.1 and Section 3.2 .

\subsubsection{Students}

Much of what has been said above could also apply to the specific category of Community students, i.e. Community citizens who have made use of the opportunity guaranteed by Articles 12, 126 and $127 \mathrm{EC}$ to study in other Member States. ${ }^{136}$ By performing part-time jobs in the evenings or at weekends students may acquire the status of worker for the

\footnotetext{
134. Case 53/81 Levin [1982] ECR 1035 at 17. See further Chapter 2 Section 2.2.4

135. Compare e.g. Case 2/89 Kits van Heijningen [1990] ECR I-1755.

136. See Chapter 2 Section 3 and, more extensively, Chapter 5 Section 4
} 
purposes of Regulation No 1408/71 and, in this capacity, they may benefit from the various health care provisions of the two social security regulations. The Community legislator has recognised, however, that the coordination rules for workers and their family members do not in all circumstances provide students and their family members with sufficient health insurance cover. For instance, many students could merely benefit from the health care provisions of Regulations No 1408/71 and No 574/72 in their capacity as family members. This meant that students who participate in the Socrates/Erasmus programme ${ }^{137}$ and who do not establish residence, i.e. the place where they have the permanent or normal centre of their interests, ${ }^{138}$ in the State of their studies could only rely on Article 22(1)a of Regulation No 1408/71 in order to claim treatment in cases of medical emergency. Otherwise, they could, at least in theory, be required to return to their country of origin in order to obtain treatment. Furthermore, in a number of Member States specific health insurance schemes for students exist. Sometimes such schemes merely provide insurance for students studying at a national educational institution with the result that students following courses or training in other Member States could be without insurance cover or be forced to insure themselves with "quite expensive" private insurers. ${ }^{139}$ Also, such schemes may apply compulsorily to foreign students which could imply that such students might have to pay health insurance contributions in more than one State.

With a view to promoting the free movement of students, the Community legislator inserted Article 22c into Regulation No 1408/71 in 1997 which entitled students to rely on Article 22(1)a "for any condition necessitating benefits during the stay in the territory" of the State where they are studying. ${ }^{140}$ Further, in 1999 the legislator adopted Regulation No 307/1999 which has extended the personal scope of Regulation No $1408 / 71$ in its entirety to students ${ }^{141}$ and has inserted new provisions

\footnotetext{
137. See Chapter 5 Section 4.9

138. Compare Case C-90/97 Swaddling [1999] ECR I-1073 at 29-30.

139. In a recent proposal for a Recommendation of the European Parliament and of the Council, the European Commission has included a provision (numbered as 2(c)) which calls upon Member States to take appropriate measures so that students who have private health insurance can transfer the advantages of this insurance to the host coutry. COM(1999) 708 final.

140. The Article was inserted by Regulation No 1290/97 (OJ 1997 L 176).

141. Article 2 of Regulation No 1408/71 has been amended and now provides that besides (self-)employed persons, students who are or have been subject to the legislation of one or more Member States also fall within the scope of the Regulation. The newly inserted Article 1(ca) of Regulation No $1408 / 71$ defines a student as "any person other than an employed or
} 
specifically governing the cross-border health care rights of students Article $34 \mathrm{a}$ provides that some of the provisions applying to (self)employed persons (and their family members), and which have been discussed in Section 3.2 and Section 3.3, are to be applied by analogy to students and their family members. ${ }^{142}$ Article $34 \mathrm{~b}$ has replaced the afore mentioned Article 22c.

The new health care and insurance provisions for students are quite difficult to fathom mainly because Regulation No 307/1999 has not introduced rules for determining the State in which students are insured. ${ }^{143}$ Community students can be insured in the State of origin and/or the State of the studies. Students who are (only) insured in the State of origin and who have kept their residence there can, where necessary, rely on Article 3 of Regulation No 1408/71 in order to claim medical benefits under the same conditions of the nationals of that State. ${ }^{144}$ According to Article $34 \mathrm{~b}$, such students have the right to rely on Article 22(1)a in the State where they study for any condition necessitating benefits during their stay. The right to medical treatment is thus not limited emergency situations. All medical products or services which may be medically required are included. De facto, students who are insured and residing in the State of origin can choose in which of the two States they wish to "go to the doctor". Students who are insured in the State of

self-employed person or a member of his family or survivor within the meaning of this regulation who studies or receives vocational training leading to a qualification officially recognised by the authorities of a Member State, and is insured under a general social security scheme or a special social security scheme applicable to students".

142. Besides the provisions which will be discussed below these concern Articles 23 (calculation of cash benefits), Article 24 (special rules for substantial benefits in kind), Article 35 (not discussed in this Chapter) and Article 36 (reimbursement by the competent institution)

143. The new health care and insurance provisions for students do not prevent double health insurance. In the preamble to Regulation No $307 / 1999$ it is stated that it "is desirable, as far as possible, to prevent" students "from being subject to a double levy of contributions, or acquiring dual rights to benefits", but, due to "the specific nature of the situation relating to students" no agreements could be reached on specific conflict rules. See the eighth recital of the preamble to Regulation No 307/1999. The Member States represented in the Council have not been able to agree on rules determining the applicable legislation. The additional rights which the two new provisions confer upon students and their family members have only been guaranteed since 1 May 1999. See (the new) Article 95d(1). This does not apply to the rights guaranteed by Article 18 of Regulation No 1408/71 (see Article 95d(2)) and illnesses which already existed on the said date (Article 95d(3)).

144. In addition, such students can benefit from Article 18 of Regulation No 1408/71 (which by virtue of Article 34a applies by analogy to students) in order to have their periods of insurance or residence fulfilled in other States taken into account where the legislation of the State concerned makes entitlement to benefits conditional upon fulfilment of such periods. 
origin but who have decided to establish residence in the State of their studies do not seem to have such a choice. In the State where they study and reside, they can claim "full access" to medical care under Article 19 which, as Articles 34a states, applies by analogy to students. Article 34a, however, does not refer to Articles 20 and 21 and this would seem to imply that students cannot claim under Regulation No 1408/71 medical benefits in the competent State during a stay. On the basis of national law such students may possibly claim medical benefits in the competent State, but Regulation No 1408/71 does not seem to entitle them to challenge national rules which preserve medical benefits for insured students who are studying at a national educational institution. ${ }^{145}$ Students who are only insured in the State where they study can benefit from Article 3 of Regulation No 1408/71 when they wish to claim medical care in that State. ${ }^{146}$ Students who do not reside in the State where they are insured and study, can benefit from Article 19 of Regulation No 1408/71 in order to get medical care and products in the State of residence. ${ }^{147}$

\subsubsection{The Right to Reside and the Health Insurance Requirement}

The right of residence of pensioners, students and "other" Community citizens as well as the family members of these categories, is conditional upon the requirement that the persons concerned are "covered by sickness insurance in respect of all risks in the host Member State". ${ }^{148}$ This requirement has been introduced in order to avoid non-economic residents becoming a burden on the public purse of the host State. Neither the

\footnotetext{
145. Article 34a states that Articles 22(1)a and c (as well as the provisions contained in Article 22(3) (family members) and Article 22(2) (right to authorisation)) apply by analogy to students and their family members. These provisions, however, can only be relied upon in order to claim emergency treatment or authorised treatment in a Member State other than the State of insurance. Remarkably, then, students can rely on the afore mentioned provisions in "third" Member States, but not in the State where they are insured. Possibly, however, students can challenge national rules which preserve medical benefits for insured students who are studying at a national educational institution under Articles 12 and/or $18 \mathrm{EC}$. 146. Where necessary, Article 18 of Regulation No 1408/71 can be relied upon.

147. There is no specific health care provision which entitles students who are insured, but who have decided not to establish residence, in the State where they study, to claim medical care in that State. Neither Articles 20 and 21 nor Article $34 \mathrm{~b}$ of the Regulation, which only applies in State other than the competent State, can be relied upon. It would seem, however, that such non-resident students can invoke Article 3 in order to challenge possible residence requirements contained in the State of insurance.

148. Sec Articles 1(1) of the Directives Nos 93/96, 90/365, 90/364.
} 
directive itself nor any of the prepatory documents ${ }^{149}$ clarify the precise meaning of the requirement, but it seems very unlikely that many Community citizens will encounter serious difficulties in meeting this requirement. The majority of the beneficiaries of the three 1990 directives is publicly insured for medical care and covered by Regulations No 1408/71 and No 574/72. As workers, pensioners, students or family members, they will be able to benefit from Articles 3, 13 and/or the health care provisions in order to claim medical benefits in the State of residence. Further, the principle that all beneficiaries, regardless of the State where they are insured, have the right to obtain medical benefits in the State of residence in accordance with the applicable legislation, guarantees that non-economic residents are insured "in respect of all risks in the host Member State". ${ }^{150}$ Furthermore, the two regulations ensure that the cost of medical care are (to be) fully reimbursed by the institution to which beneficiaries have paid their health contributions and this would seem to guaran-

149. The Commission's proposal of 1979 for a general right of residence (see Chapter 2 Section 3.1) did not contain a condition as regards health insurance. In the negotiations on the 1979 proposal the issue of health insurance does not seem to have come up. The condition appears for the first time in the Adonnino Report of 1985. See EC Bull.Suppl.7/85 at p.14. The report indicates that the health insurance requirement was introduced in order to avoid beneficiaries becoming an unreasonable burden on the public purse of the host State, but nowhere does it explain the precise meaning of the requirement. In its proposals for the three Directives on the right of residence the Commission has followed the recommendations of the Adonnino-report, but the precise contours of the insurance condition are again not elucidated in the proposals (or the text of the adopted directives).

150. Taken literally, the requirement that beneficiaries must be insured for "all risks in the host State" could be interpreted to imply that the persons concerned must be insured for all risks including e.g. dental care, cosmetic plastic surgery and co-payments even in cases where such types of benefits and payments are excluded from the legislation in the host State. The mere fact, however, that certain types of medical benefits are to be wholly or partially paid by patients already guarantees that patients receiving such benefits, regardless of their nationality, will not become a burden on the public purse. The literal interpretation of the requirement of insurance for "all risks" runs counter to the purpose of the health insurance requirement. Therefore, it would seem more logical to read the requirement to imply that non-economic residents must, in principle, be insured for the same risks as the nationals of the host State in a comparable situation. See van Nuffel, Een Bijna Algemeen Verblijfsrecht in de Europese Gemeenschap, in: SEW (1990) pp.887-993, at p.900. This interpretation of the insurance requirement also seems to be consistent with the definition of the financial means requirement contained in particular in Directive No 90/364 which sets the level of resources below which Member States grant social assistance benefits to their own nationals as the criterion to be applied in determining whether or not nationals of other Member States possess sufficient financial resources. 
tee that the persons concerned will not become a burden on the host State's public purse. ${ }^{151}$

\subsection{Third Country Nationals}

Third country nationals do not enjoy the right to freedom of movement within the Community ${ }^{152}$ and they are (therefore also) excluded from the personal scope of Regulations No $1408 / 71$ and No 574/72. ${ }^{153}$ In principle, nationals of third countries can only claim the cross-border health care rights which the social security regulations confer upon family members. This does not imply, however, that Community law has nothing to offer third country nationals who wish to claim medical benefits in one of the Member States. They may possibly enjoy certain rights under the co-operation or association agreements which the Community and its Member States have concluded with third States. For the purposes of this book three (sets of) agreements have been selected: the Agreement creating the European Economic Area (hereafter: the EEA Agreement), the Maghreb agreements (concluded with Morocco, Algeria and Tunesia) and the Association Agreement with Turkey.

151. This is not to say that problems regarding the health insurance requirement cannot arise. For instance, students who are covered by a special scheme applicable to students which does not allow them to obtain medical benefits outside the State of origin may still be forced to enrol in a rather expensive private insurance scheme in order to acquire the right to reside in the State of the studies. See also Martin/Guild, Free Movement of Persons (1996) at p.211. Furthermore, the requirement may pose problems for Community citizens falling outside the scope of Regulation No 1408/71 such as the privately insured. Such Community citizens will have to ensure that their insurance in the State of origin covers treatment for "all risks" in the State where they intend to reside or, when this is not the case, insure themselves (additionally) in the State of their planned residence. The Directives do not specify what type of insurance is required and it may thus be assumed that both private and public health insurance may suffice for satisfying the requirement. Compare Report from the Commission to the Parliament and Council on the Implementation of Directives 90/364, 90/365 and 93/96 - Right of Residence (1998) at p.11. Neither do the directives indicate where a person must be insured. The only condition is that Community citizens and their family members must be insured for all risks which may occur on the territory of the State of residence. As regards private insurance it may thus be assumed that an insurance contract with any private insurer established in one of the Member States suffices as long as all risks in the Member State of residence are covered. See further also Langer (1999) supra footnote 7 , at pp. $721-722$.

152. Case C-378/97 Wijsenbeek [1999] ECR I-0000) at 43.

153. See Article 2 of Regulation No $1408 / 71$ 


\subsubsection{EEA Nationals}

In order to promote a continuous and balanced strengthening of trade and economic relations between the European Community and its Member States, on the one hand, and Norway, Iceland and Liechtenstein, on the other hand, the EEA Agreement has extended the scope of the four common market freedoms to the nationals (and territories) of the three EEA countries mentioned. As a result, EEA nationals can benefit from the provisions on the free movement of (self-)employed persons and they enjoy, under the services provisions, the right to travel freely throughout the EEA. ${ }^{154}$ In addition, the application of the three non-economic residence directives of 1990 has been extended to EEA nationals. ${ }^{155}$

As to cross-border health care rights, one can be relatively brief. Article 29 EEA largely reproduces Article 42 (formerly 51) EC and by virtue of Annex VI to the Agreement, Regulations No 1408/71 and No 574/72 are also applicable in the European Economic Area. Basically, the EEA Agreement has extended the scope of the right to equal treatment in social security matters, the rules for determining the applicable legislation as well as the health care provisions contained in Article 18-36 of Regulation No 1408/71 and the corresponding provisions of Regulation No $574 / 72$ to all EEA nationals. As a result, the nationals of Norway, Iceland and Liechtenstein enjoy in all eightteen States the rights which have been discussed in Section 3.2 and Section 3.3 of this chapter. ${ }^{156}$

154. See Chapter 2 Section 4

155. See further Chapter 2 Section 3.

156. See Sakslin, The Agreements on the European Economic Area, in: Jorens/Schulte (Eds), European Social Security Law and Third Country Nationals (1998) pp.399-417, at 410-411. To be sure, in Opinion $1 / 91$ the Court of Justice held that the fact that two international instruments are identically worded does not necessarily mean that they have the same legal effect. The context of a rule determines its legal effect. Opinion 1/91 [1991] ECR I-6079. On this point see Zuleeg, International Instruments on Equal treatment in Social Security Matters, in: Commission of the European Communities/Departemento de Relações Internaçionais e Convenções de Segurança Social, Social Security in Europe - Equality between Nationals and Non-Nationals (1995) pp.89-101, at pp.93-94. It seems very unlikely, however, that any of the provisions governing the cross-border health care rights are to be interpreted more restrictively as regards EEA nationals. 


\subsubsection{Turkish Nationals}

The 1963 EEC-Turkey Association Agreement, the Additional Protocol of 1970 and the various decisions adopted by the EEC-Turkey Association Council do not confer upon Turkish workers a right to freedom of movement within the Community or between Turkey and the Community. ${ }^{157}$ Access by Turkish nationals to the labour market and territory of Member States is in principle governed by national immigration laws. ${ }^{158}$ However, Turkish workers and their families who have been admitted by one of the Member States do enjoy certain social security rights under Decision No 3/80 of the EEC-Turkey Association Council. This Decision on the application of social security schemes to the benefit of Turkish workers provides for a right to equal treatment in social security matters (Article 3) and a right to export certain benefits (Article 6). It also extends the application of most rules determining the applicable legislation contained in Articles 13 et seq of Regulation No 1408/71 to Turkish workers (Article 9) and the Decision states that virtually all health care provisions contained in Regulation No 1408/71 apply by analogy to Turkish workers. ${ }^{159}$

At first glance, it would thus seem that Turkish workers enjoy quite extensive health insurance protection in the Member State that they have been admitted to. Nonetheless, significant limitations exist. It may be recalled $^{160}$ that the Court was asked in Taflan-Met $(1996)^{161}$ to determine $(i)$ whether, and if so, when, Decision No $3 / 80$ had come into force and (ii) whether the provisions of the Decision could be relied upon by Turkish workers in court. Uncertainty as to the binding force existed because the decision did not contain any provision on its coming into force and the Commission's proposal for a regulation implementing Decision No $3 / 80$ within the Community has never been adopted by the

157. See Chapter 2 Section 5.3.

158. Case C-210/97 Akman [1998] ECR I-7519 at 50.

159. By virtue of Articles 10 and 11 of Decision No 3/80, Articles 18-36 of Regulation No 1408/71 apply by analogy to Turkish workers (and their families). Article 25(1) (right of work-seekers to obtain medical benefits in the State where they seek employment - Section 3.1.1) and Article 25(2) (which states that wholly unemployed frontier workers as well as the wholly unemployed non-frontier workers who were residing in a Member State other than the competent State and who have decided to seek (new) employment in the State of residence, shall receive medical benefits in the State of residence as though they had been insured there during their last employment - Section 3.1.3) of Regulation No 1408/71 do not apply to Turkish workers.

160. See Chapter 3 Section 7.3.

161. Case C-277/94 Taflan-Met [1996] ECR I-4085. 
Council. The Court concluded that the decision was supposed to have come into force on the day the decision was adopted, i.e. 19 September $1980{ }^{162}$ In the Court's view, however, the provisions of Decision No $3 / 80$ could not be relied upon in court. In reaching this conclusion the Court drew a comparison with Regulation No 1408/71 and its implementing Regulation No 574/72. The main principles set forth in the former Regulation could only have been given practical effect because of the procedures and formalities contained in the latter Regulation. The coming into force of Regulation No 574/72 was seen as a prerequisite for the enforcement of the rights enshrined in Regulation No 1408/71. Decision No $3 / 80$, however, is not yet accompanied by an implementing legislative measure comparable to Regulation No 574/72. As long as such a measure has not been adopted, the Court held that the provisions of Decision No 3/80 could not have direct effect. ${ }^{163}$ In Sürül (1999), however, the Court has nuanced the conclusions drawn in Taflan-Met. The Court held that the reasoning which had led it to conclude in Taflan-Met that the provisions of Decision No 3/80 do not have direct effect, must apply by analogy to all other provisions which require additional measures for their application in practice. The Court ruled, however, that technical or administrative problems do not arise in relation to the non-discrimination provision of Article $3(1)$ of the decision. This Article can be directly invoked in national courts. ${ }^{164}$

Translated to the provisions relevant for access to medical benefits, Taflan-Met and Sürül seem to imply that Turkish workers can only benefit from those provisions which are not dependent for their practical application on any implementing measures or the fulfilment of administrative formalities. As a rule, Turkish workers (and their family members) will live in the State of employment and insurance. There they can, where necessary, rely on Article 3 of Decision No 3/80 in order to claim access to health care under the same conditions as the host State's nationals. Turkish workers do not have the right to have periods of insurance, residence or employment they might have fulfilled in other Member States taken into account by the competent institution. Article 18 of Regulation No $1408 / 71$ is to be applied to Turkish workers but is conditional upon fulfillment of various administrative formalities for its imple-

\author{
162. Ibid, at 21 \\ 163. Ibid, at 31-37. \\ 164. Casc C-262/99 Sürül [1999] ECR I-0000 at 58-74.
}


mentation. ${ }^{165}$ Turkish workers also do not seem to have any right to claim medical benefits in Member States other than the State of residence or insurance. Article 25(1), which confers upon work-seekers the right to obtain medical care in the Member State where they seek work, is excluded from the health provisions which are according to Article 11 of Decision No $3 / 80$, to be applied by analogy to Turkish workers. The rights of non-residents to emergency and authorised treatment (Article 22(1)a and c) are for all practical effects dependent on the exchange of one of the E-forms.

\subsubsection{Maghreb Nationals}

The (co-operation and/or Euro-mediterranean) agreements which the European Community and its Member States have concluded with Morocco, Algeria and Tunesia do not provide for a free movement of workers between the Community and these countries or a freedom of movement for Maghreb nationals between the Member States. ${ }^{166}$ However, the Agreements do contain a number of provisions which confer upon Maghreb nationals rights in the field of labour and social security law. Article 41(1) of the co-operation agreement with Morocco, as now replaced by Article 65 of the Euro-Mediterranean Agreement of 2000, confers upon Moroccan nationals the right to equal treatment in the field of social security. The second paragraph grants Moroccan nationals the right to aggregation of insurance, employment or residence periods for various social security benefits among which rights to obtain health care. Article 42 of the co-operation agreement (now Article 67 of Euro-Mediterranean Agreement) states that the Cooperation Council shall adopt measures to implement the principles set out in Article 41. A decision equivalent to Decision No 3/80 of the EEC-Turkey Association Council,

\footnotetext{
165. As regards the relatively small group of Turkish workers who are residing in a Member State other than the one of insurance, Taflan-Met and Sürül seem to lead to a "quite odd" result. The workers seem able to benefit from Articles 20 and 21 of Regulation No 1408/71, which apply by analogy with Article 11 of Decision No $3 / 80$ to Turkish workers and which do not make the right to claim medical benefits in the competent State conditional upon any formalities, in order to gain access in the State where they are insured. Yet, they do not seem entitled to claim medical care in the State of residence. Implementation of Article 19 of Regulation, which has been held to apply by analogy to Turkish workers, is conditional upon fulfilment of a co-operation between health insurance institutions. 166. Sec Chapter 2 Section 5.3
} 
however, has not been adopted. ${ }^{167}$ Similarly phrased provisions are contained in Articles 39 and 40 of the 1978 Co-operation agreement with Algeria and Articles 65 and 67 of the 1998 Euro-mediterranean agreement with Tunisia.

From the judgments in Kziber (1991) ${ }^{168}$ and Krid (1995), ${ }^{169}$ as discussed in Chapter $3,{ }^{170}$ it follows that the provisions guaranteeing equality of treatment in the field of social security produce direct effect and that the term social security in these provisions must be understood "by means of analogy with the identical concept in Regulation No 1408/$71 "$. In the State where they are employed, insured and residing Maghreb nationals thus have the right to be treated equally as regards health insurance and access to medical care just as the nationals of the host State. Apart from the right to equal treatment, the three agreements do not offer Maghreb nationals any other rights in the fields of health care and insurance. In the absence of any implementing decisions, and by analogy with the Sürül judgment, it may be assumed that Maghreb nationals cannot benefit from aggregation rules and the provisions guaranteeing health care rights to persons staying or residing in a Member State other than the State of insurance.

\subsection{Patient Mobility}

For a proper understanding of the Community rules on the co-ordination of health insurance schemes it is useful to see how they are applied in practice and how much use is actually made of the cross-border health care rights. For this purpose, a study conducted by the Association Internationale de la Mutualité (AIM) is of particular interest. ${ }^{171}$

The AIM-study first of all demonstrates that the cost of crossborder health care constitute only a very small percentage of the total health care expenditure of Member States. The percentage is on the

167. Recently, however, a proposal for social security measures have been made in the context of the Euro-Mediterranenan agreements with Morocco (http://europa.eu.int/eur-lex). 168. Case C-18/90 Kziber [1991] ECR I-199. On this judgement see e.g. Vonk, Het HvJEGarrest in de zaak Kziber - Een Levenskus voor de Slapende Paragrafen in de EG-samenwerkingsovereenkomsten, in: MR (1991) pp.149-151.

169. Case C-103/94 Krid [1995] ECR I-719 at 23-24.

170. See Chapter 3 Section 7.2 .

171. Hermesse/Lawalle (1991) supra footnote 1. For updates of the study see Hermesse/Lewalle/Palm, Patient Mobility within the European Union, in: EJPH (1997) pp.4-10 and Palm et al (2000) supra footnote 4 , at pp.38-44. 
average between $0.3 \%$ and $0.5 \% .{ }^{172}$ Furthermore, virtually all crossborder health care takes place among the original six Member States. The study makes a calculation of the global claims and debts of each Member State, ${ }^{173}$ and it appears that about $90 \%$ of the total claims cost of crossborder health care within the Community is in the hands of Belgium, France, Germany, and Italy. These four are the main providers of crossborder health care. Together with Luxembourg and the Netherlands, these countries are also responsible for $90 \%$ of the total debts of care provided under Regulations No $1408 / 71$ and No 574/72. The health care system of France appears to be the most popular. It takes on $49 \%$ of the total claims. Italy, being responsible for about $36 \%$ of the total debts, is the main debtor. The concentration ofmovement between the "old" six may, as the authors of the study explain, not come as a real surprise. Belgium, France, Germany, Luxembourg and the Netherlands are all located in the geographical heart of the Community and these Member States have more experience in applying the co-ordination mechanism set up by Regulations No 1408/71 and No 574/72 than the "newer" Member States in the "outerring" of the Community. The authors of the study further suggest that the fact that the "old" Member States have an insurance-based health care system rather than national health services may be a reason for their greater involvement in cross-border care.

Of the three main cross-border health care situations (emergency treatment, authorised treatment and "frontier workers") authorised treatment abroad is responsible for the largest percentage (about 60\%) of the cost of cross-border health care. This is explained by the fact that authorisation for treatment abroad is usually given for specific diseases. It usually concerns rather specialised and expensive types of treatment. Because of these cost, the number of authorised treatments is, by comparison with other forms of cross-border health care, relatively low. France is by far the most popular Member State to which patients of other Member States are sent. The reasons why France attracts so many patients from other Member States could be geographical in nature, but those conducting the study state that it is more likely that the high quality of

172. Only Luxembourg spends a relatively high percentage $(5 \%)$ of its health care expenditures on care abroad. Due to the low number of inhabitants and tax-payers, and the therefore limited finances available for health care, Luxembourg seems to have opted for allowing its residents to be treated in other Member States instead of developing a comprehensive health care system within the country itself.

173. The claims relate to the costs of care given by each Member State to persons insured in another country, whilst the debts concern the costs for health care enjoyed by their "own" insured in another Member State. 
the French health care system (in particular with respect to kidney, heart and liver transplants) constitutes the main reason. The quality of the French system is probably also one of the reasons why the French authorities hardly give any authorisations to French patients for treatment abroad. Italy and Luxembourg appear to be the Member States which are the least strict in granting authorisation for treatment abroad. This attitude probably results from the limitations of the health care systems in the two countries. In general, it might have been expected that countries with a less developed health care system would give authorisation for treatment abroad rather frequently. This, however, does not appear to be true. Apparently, these countries choose to invest in the development of their national health care system rather than to send their patients abroad. ${ }^{174}$

As regards health care provided in emergency cases during a temporary stay abroad, it is noticable that tourist countries like Spain, Portugal, Italy and Greece are only responsible for a low proportion of the total claims for "emergency care". Tourists appear reluctant to take advantage of the health care systems in these countries. Emergency treatment on the basis of Article 22(1)a of Regulation No 1408/71 is above all provided by Member States, and in particular France, in the geographical centre of the Community. This conclusion may, in as far as France is concerned, not come as a surprise since it is one of the most popular touristic countries within the Community. With respect to the Netherlands, Belgium and Germany, however, the conclusion surprise somewhat. The authors of the AIM-study explain the high percentage of the cost of emergency care of Article 22(1)a by referring to the comparatively high quality and cost of the health care systems in these Member States and the fact that these States absorb quite high numbers of work-related movements.

Cross-border treatment of persons living in frontier regions is the most frequent but also the cheapest. The cost of health care granted to frontier workers in the Member States of their residence constitute a small percentage of the total expenditure. The treatment concerned mostly consists of regular and relatively cheap types of treatment. Most of the health care provided under Article 19 of Regulation 1408/71 takes place between the Member States in the geographical centre of the Community.

174. See further supra footnote 129. 
Germany and Luxembourg appear to be the countries that have to pay the most for health care of frontier workers in the State of residence. ${ }^{175}$

\subsection{Initiatives to Extend Cross-Border Health Care Rights}

\subsubsection{The Call for an Extension of Cross-Border Health Care Rights}

The rules and principles governing cross-border access to health care that have been described in the this section are virtually as old as the Community itself. Regulations No 1408/71 and No 574/72 have only been in existence since the early 1970s but their health care provisions are based on the same principles as their equivalents in the original Regulations No $3 / 58$ and No $4 / 58$. On the one hand, it has always been recognised that Community citizens who become in need of medical care while staying or residing in another Member State should have the right to obtain the

175. The study also shows that the formalities and procedures are in practice not always (fully) applied. Member States and the competent health institutions often consider the procedures to be too cumbersome, too complicated and/or too expensive. This particularly holds true for the E 111 formalities for emergency treatment. Due to the frequency and relatively low cost of emergency treatment many Member States do not require (all) the formalities to be fulfilled. Emergency treatment is simply given and financial settlement often takes place on the basis of a flat rate payment. Many Member States even waive the recovery of the costs of emergency treatment. They may do this unilaterally, but flat rate payment and the waiving of the claims for the cost, are more often based on bi- or multilateral conventions or agreements with other Member States or health care institutions. Other forms of financial settlement or the waiving of claims, are also common as regards the cost of treatment given to beneficiaries living in frontier regions. In many Member States (e.g. Belgium, the United Kingdom and Spain) the E 111 formalities are not considered to be of much practical value and it has been suggested that the E 111 formalities should be abolished altogether. In other Member States, however, the formalities are deemed necessary for bureaucratic reasons. Furthermore, due to a lack of information, language problems, the immediacy of the medical treatment or the fact that the institution to which form $\mathrm{E} 111$ has to be submitted is often too far away, many insured persons do not fullfil the required formalities. In order to avoid the administrative formalities many Community citizens even appear to take out private travel insurance when travelling abroad. Rambags, Samenloop Ziekenfondsverzekering (EG-verordeningen 1408/71 en 574/72) en Reisverzekering, in: De Beursbengel (1988) p.448 et seq. On (the practice of) the E 111 formalities see further the references in footnote 109 . With respect to authorised treatment, however, the formalities are fully applied and recovery takes place on the basis of actual expenditures. This is explained by the fact that $\mathrm{E} 112$ treatment usually concerns rather specialised and expensive types of medical treatment. Moreover, the number of times authorisation is given is, at least in comparison to emergency treatment and "frontier treatment", rather low. 
required treatment and to have the bill paid by their insurance institution. On the other hand, however, from the beginning it has been equally undisputed that Community citizens should not have a right to travel to other Member States for the sole purpose of obtaining medical treatment at the expense of the institution they are insured with. In essence, access to medical care has traditionally been seen as a territorially limited right; those who wish to benefit from the medical services available in other States have to bear the cost themselves. The only time that the Court of Justice did touch upon the basic principles governing the cross-border access to health care (Pierik cases), the Member States repaired the situation quickly (by amending Article 22(2) of Regulation No 1408/71). ${ }^{176}$

Since the late 1980s, early 1990s, however, the territorial limitation of the right to obtain medical care has increasingly been debated and criticised. The health care provisions of Regulations No 1408/71 and No 574/72 have been classed as being "too restrictive" and no "longer appropriate to today's requirements". ${ }^{177}$ The criticism has been threefold. ${ }^{178}$ First, the territorial limitation of the right to gain access to medical care has been said to give insufficient regard to the interests of patients. For instance, residents of frontier regions often have to go to hospitals which are relatively far away from their homes, whilst, if it were not for the existing legal obstacles, they could be treated in hospitals "just across the border". Furthermore, because of waiting lists, many beneficiaries have to wait for quite some time before they can get treatment, whilst, if given the right, they could be treated immediately or much sooner in another Member State. Second, the rules on cross-border access to health care have been claimed to obstruct an efficient use of the health care facilities in the Union. In some Member States there is a shortage of various types of treatment, whilst in other States surplusses of the same or comparable types of treatment exist. An increased cross-border use of health care facilities could possibly bring these shortages and surplusses more into balance. This would stimulate a more efficient use of the existing medical facilities and prevent, at least partly, an unnecessary waste of resources. Third, the exclusion of third country nationals from Regulations No 1408/71 and No 574/72 has increasingly been felt as an omission. Even though they fall outside the Community's free movement regime, third country nationals do in practice move from one State to

176. See Section 3.3.2.

177. COM(94) 333 at IV.12

178. van der Mei, Cross-border Access to Medical Care Within the European Union: Some Reflections on the Judgments in Decker and Kohll, in: MJ (1998) pp.277-297, at pp.278-279. 
another and since, as a rule, they pay health contributions under the same conditions as the nationals of the host State in whose territory they reside, it has increasingly been felt unjustified to deny them the benefits of the co-ordination rules and the provisions on cross-border access to health care in particular. ${ }^{179}$

In response to the above criticism and desires, several intitiatives have been taken in order to promote the cross-border access to, and use of, health care facilities. Two strategies have been followed. The first is the "legislative strategy" which consists of extending health care rights by amending the provisions of Regulation No 1408/71. The second method consists of a "contractual strategy" under which cross-border care is promoted through the conclusion of agreements between insurers and providers in different States.

\subsubsection{Legislative Strategy}

The Commission has submitted to the Council several proposals for amending the health care provisions of Regulations No 1408/71 and No $574 / 72$. Most useful for purposes of this discussion is the Commission's 1998 proposal for the simplification of the two social security regulations. ${ }^{180}$ In this proposal various earlier and more specific proposals for amending health care provisions have been clustered.

For a proper understanding of the proposed changes to medical "benefits in kind", it is to be pointed out that the Commission has proposed to extend the personal scope of the Regulation considerably. In the envisaged new Article 1 it is stated that the regulation shall apply to "persons who are or have been subject to the social security legislation of one or more Member States, as well as the members of their family and to their survivors". The term "persons" indicates that the personal scope will be extended as to include ( $i$ ) not only (self-)employed persons and students but also all insured persons including those who are no longer, or

179. See e.g. the Explanatory Memorandum of the Commission for its proposal to amend Regulation No $1408 / 71$ with a view to extending the personal scope of the regulation to third country nationals. $\operatorname{COM}(97) 561$ final.

180. COM(1998) 779 final. On this proposal see Pennings/Essers. Het Voorstel van de Europese Commissie tot Vereenvoudiging van Verordening 1408/71, in: SMA $(2000)$ pp.512-525 and Eichenhofer, How to Simplify the Co-ordination of Social Security, in: EJSS (2000) pp.229 et seq. 
have never been, economically active and (ii) third country nationals. ${ }^{181}$

The proposed chapter on "Sickness and Maternity" consists of thirteen Articles numbered as Articles 14-26. They are based on the same principles as the current Articles 18-36. ${ }^{182}$ Thus, $(i)$ medical benefits are in all cases provided in accordance with the legislation where they are provided and (ii) the cost are to be borne by the institution of the State where beneficiaries have paid health contributions. ${ }^{183}$ The proposed new Article 14 provides that "persons" who are insured for medical care and who reside in the territory of a Member State other than the competent State shall receive medical benefits "in kind" in the State of residence as though they were insured there. The wording of Article 14 largely coincides with the wording of the current Article 19. The main difference is that third country nationals are also offered the right in question. The

181. To be sure, the proposal does not intend to confer any free movement rights upon third country nationals. It merely intends to offer nationals of third countries who have acquired the right to stay or reside in a(nother) Member State under (inter)national law, the social security protection guaranteed by the regulation. On this point, the 1998 proposal is largely based on an earlier Commission proposal of 1997. See COM(1997) 561 final. On the background of the proposal(s) to include third country nationals in the scope of the social security regulations see Verschueren, The Commission's Proposal to Extend Regulation (EEC) No $1408 / 71$ to Third Country Nationals, in: Jorens/Schulte (Eds), European Social Security Law and Third Country Nationals (1998) pp.187-208; Jorens, De Rechtspositie van Niet-EU-Onderdanen in het Europees Socialezekerheidsrecht (1997) Chapter VI; Verschueren, EC Social Security Coordination Excluding Third Country Nationals: Still in Line with Fundamental Rights after the Gaygusuz Judgment?, in: CMLRev (1997) pp.991-1017 and Altmaier/Verschueren, The Extension of the Scope of Regulation 1408/71 to Nationals of Non-member Countries, in: Commission of the European Communities/Departemento de Relações Internaçionais e Convenções de Segurança Social, Social Security in Europe Equality Between Nationals and Non-Nationals (1995) pp.245-261.

A second proposed amendment to the general provisions relevant to cross-border access to health care concerns the simplification of the rules for determining the applicable legislation. In the proposed new Article 8 it is explicitly stated that persons are subject to the legislation of one Member State only. Persons who are pursuing a professional activity in a Member State are subject to the legislation of that State, whilst beneficiaries not pursuing such an activity are assigned to the legislation of the State where they reside. The latter category, however, only covers persons who have ceased all activity. Those who are only temporarily inactive, and who have become entitled to social security benefits (sickness or unemployment) by virtue of a professional activity are treated as though they were still active.

182. The proposed chapter no longer contains a specific aggregation rule for health benefits as is the one now contained in Article 18 (see Section 3.1.2). Article 4 of the proposed regulation provides for a general aggregation rule to be applied to all benefits covered by the regulation.

183. As with the current Article 36 of Regulation No 1408/71, the proposed Article 26 lays down the rule that the cost of medical benefits in kind provided by the institution of one Member State on behalf of another shall give rise to "full reimbursement". 
envisaged new Article 15 provides that all persons residing outside the competent State can also obtain benefits in the competent State. All persons who, for whatever reason, are staying in the competent State will be granted an automatic right to medical benefits there. ${ }^{184}$ The substantive differences with the current provisions are $(i)$ that frontier workers and other workers residing outside the competent State will retain the right to choose in which of the two States (i.e. State of residence or the competent State) they wish to obtain medical benefits when they become wholly unemployed or retire and (ii) that the family members of all "persons" residing outside the competent State will be given such a choice. ${ }^{185}$

Articles 16 and 17 contain provisions applying to persons who are temporarily present in Member States other than the competent State. Article 16 replaces the current Articles 22(1)a and 22a and provides for the general rule that insured persons visiting other Member States "shall receive immediately necessary benefits in kind". The main difference with the current provisions is that third country nationals travelling within the Community will also be able to benefit from the right to emergency treatment. Article 17 contains special rules for various groups of persons who are staying temporarily in other Member States for a specific purpose. Persons pursuing (self-)employed activities outside the competent State (e.g. seconded workers), students and work-seekers are entitled to claim medical benefits in the State concerned as though they were residing there. Article 17 does not seem to grant the categories concerned more extensive rights than they enjoy under the current provisions. The main difference is that they no longer have to fulfill the E 111-formalities but rather the formalities for persons residing outside the competent State. As regards the work-seekers, it is to be noted that the duration of the right to export unemployment benefits, and the accompanying right to claim medical benefits, is extended to a period of six months in principle. ${ }^{186}$

184. See Explanatory Memorandum of the Commission, COM(1998) 779 final, at p. 8. 185. In addition, this choice is proposed to be granted to recipients of "pre-retirement benefits" (and their family members). These benefits are proposed to be included in the material scope of the regulation. See Articles 2(i) and 7(s) of the proposal. The inclusion of these benefits builds on earlier proposals of the Commission (OJ 1980 C 169 and COM(95) $735 \mathrm{def}$ ) in which it was proposed to bring early retirement pensions within the scope of Regulation No 1408/71 and to offer recipients of such benefits a right to claim medical benefits in kind in the State of residence and, where applicable, the competent State.

186. See Article 17(3). This provision refers to Article 50 which grants work-seekers the right to export their unemployment for a maximum period of six months in principle. The Commission's proposal of 1998 builds as regards work-seekers on earlier proposals of 1980 (COM(80) 312 final) and 1996 (COM(95) 734 def.). 
Furthermore, the proposed new Article 18 provides that persons who have been authorised by the competent institution to go to the territory of another Member State to receive the treatment appropriate to their condition shall receive the benefits in kind there. Apart from the extension to third country nationals no significant changes are envisaged. The second sentence of Article 18, which states the situations in which authorisation must be accorded, is phrased differently but does not seem to be broader scope than the second sentence of the current Article 22(2). Finally, the pensioner provisions will be simplified considerably. The central health care provision for pensioners is contained in Article 20 of the proposal which provides that recipients ${ }^{187}$ of one or more pensions and members of their families shall receive medical benefits in kind in the State where they reside. ${ }^{188}$

As to the chances that the "legislative strategy" will soon lead to changes, one cannot be too optimistic. ${ }^{189}$ The regulations can only be amended when all Member States agree to this. ${ }^{190}$ The entire redrafting and simplification of the regulations ${ }^{191}$ will probably the be subject of difficult and lengthy discussions in the Council. Experiences with previous Commission proposals aimed at extending health care rights ${ }^{192}$

187. Article 22 states that Article 20 shall apply mutatis mutandis to pension claimants.

188. The main substantive difference with the current provisions concerns the question who is to bear the costs in cases where pensioners receive pensions from more than one Member State. The current rule that the cost is borne by the institution of the Member State where pensioners have been insured for the longest time, is proposed to be replaced by the rule that the costs shall be divided among the Member States paying a pension proportional to the period completed in each State (Article 20(2))

189. Compare Pennings/Essers (2000) supra footnote 180, at p.524

190. See Article 42 EC.

191. Article 72 of the proposal states that the regulation shall come into force upon the adoption and coming into force of a regulation which will lay down the procedures for implementing the regulation. The 1998 proposal does not include a proposal for an equivalent of Regulation No 574/72 nor has a seperate proposal for an implementing regulation been submitted to the Council

192. In 1995, for instance, the Commission had already submitted to the Council a proposal which was aimed at $(i)$ granting family members of frontier workers, former frontier workers and family members of the latter the right to receive treatment in the competent State and (ii) extending the personal scope of Articles 22(1)a and $\mathrm{c}$ to all persons who are publicly insured in one of the Member States regardless of their nationality. The proposal did not seem to have far-reaching implications. The experiences with frontier workers, who already have a right to gain access to care "on both sides of the border", suggest that granting the three categories mentioned a right to choose a doctor across the border would hardly, if at all, affect health care funding and capacity planning. Compare Hermesse/Lewalle (1993) supra footnote 1. Further, in practice virtually all Member States already apply the rules concerning emergency and authorised treatment in other Member States to all persons 
suggest that the Member States are not "too eager" to accept significant changes. ${ }^{193}$

insured under their system regardless of their nationality. Nonetheless, the Commission's proposal was largely rejected. The Council was willing to extend the scope of Article 22(1)a and $\mathrm{c}$ but it explicitly preserved the rights to emergency and authorised treatment to "persons who are nationals of the member States" so as to exclude third country nationals. The formal argument for rejecting the proposal concerned an alleged lack of powers on the part of Community. This argument was not persuasive however. Compare Pieters, Enquiry into the Legal Foundations of a Possible Extension of Community Provisions on Social Security to Third Country Nationals Legally Residing and/or Working in the EU, in: Commission of the European Communities/Departemento de Relações Internaçionais e Convenções de Segurança Social, Social Security in Europe - Equality Between Nationals and Non-Nationals (1995) pp.189-243. The proposal to grant family members of frontier workers, former frontier workers and their family members the right to obtain care on "both sides of the border" was wholly rejected.

193. For this reason it is understandable that the Commission has never sent a specific proposal for altering Article 22(1)c and/or Article 22(2) of the Regulation to the Council and that Article 18, second sentence, as proposed in the 1998 proposal is basically identical as the current Article 22(2). The feasibility of any such amendment simply seemed, and still seems, minimal.

In the literature some authors have discussed the possiblity of extending the scope of Article 22(2) or partially abolishing prior authorisation rules. Neumann-Duesberg, for instance, has considered whether the requirement of prior authorisation might not be abolished entirely. An abolition could have positive aspects. In particular, increased crossborder use of health care facilities could guarantee a more efficient use of facilities in States where overcapacity exists. In the view of this author, the main obstacle to the abolition of the requirement is that the competent institutions are obliged to fully reimburse the costs of treatment obtained in other States. The cost of medical facilities differs widely in the various States and an increased inter-State flow of patients would lead to considerable financial problems. The "poorer" Member States especially could have difficulties in maintaining their systems financially if they were obliged to bear the full cost of treatment the insured receive in the "richer" States. In order to stimulate cross-border use of medical care, one would therefore have to consider a limitation of the prior authorisation requirement for some specific types of treatment which should be carefully checked in order to avoid medical tourism. Neumann-Duesberg (1991) supra footnote 48, at pp.92-93.

Bieback has claimed that a distinction is to be made between forms of treatment which are included in the insurance package of the competent State and forms of care which are not. As to the latter, he argued that prior authorisation rules should be maintained in order to avoid social tourism. Bieback, Soziale Sicherung für den Fall der Krankheit und Mutterschaft, in: Europäisches Sozialrecht - Bundestagung des Deutschen Sozialrechtsverbandes e.V. 9.bis11.Oktober 1991 (1992) pp.51-69, at p.60. With respect to the "included" forms of treatment, however, Bieback considered the second requirement contained in Article 22(2) superfluous because it would hardly leave any room for the patients' right to receive medical services in other States (Luisi and Carbone). In his view, the condition should be deleted or replaced by a provision which would oblige the competent institution to grant authorisation for "included products" in all cases unless this would be detrimental to the health of the patient concerned. Bieback (1993) supra footnote 126, at p.64. Bieback recognises, however, that the competent institution should have the right to refuse authoris- 


\subsubsection{Contractual Strategy}

In addition to these legislative initiatives, attempts have been made to extend cross-border access to, and use of, medical facilities by concluding, or promoting the conclusion of, agreements between health care providers and health insurance institutions in different Member States. Some agreements have already been concluded. One of the most wellknown examples concerns a 1978 agreement between Dutch and Belgian health institutions. The number of medical facilities in the Dutch regions of Zeeland Flanders and West-Brabant is insufficient and other facilities in the Netherlands are difficult to reach due to geographical obstacles. Under the 1978 agreement residents of these Dutch regions are given the right to obtain treatment in a number of Belgian hospitals. ${ }^{194}$ Further, in recent years some projects have been started which are aimed at extending the cross-border health care rights of patients living in border regions by promoting the conclusion of more cross-border agreements. ${ }^{195}$ The strat-

ation in cases where the grant of such authorisation would lead to a disproportional increase in health expenditure. A second best solution would, in his view, therefore be to request the Administrative Commission to draw up lists (comparable to the lists referred to in e.g. Article 17(7) of Regulation 574/72) mentioning the types of treatment for which authorisation must be given.

Furthermore, at an AIM-seminar held in Bruges in 1991 it was proposed to abolish the requirement of prior authorisation for the cost of medical treatment except the cost of hospitalisation and that a list could be drawn up which would contain types of treatment which could be subject to a financial ceiling. See Hermesse et al, Gezondheidsbescherming in de Europese Gemeenschap (1991) at p.36

194. On the case of Zeeuws-Vlaanderen see in particular Rombouts, Grensoverschrijdende Gezondheidszorg? Een Onderzoek naar de Huidige en Toekomstige Mogelijkheden en Knelpunten van Grensoverschrijdende Gezondheidszorg (1990); Van Tits/Gemmel, Een Grensoverschrijdende Verkenning van Belangen. Ziekenhuiszorg in Zeeuwsch-Vlaanderen en Belgisch Vlaanderen (1995); Van Tits/Gemmel, Haalbaarheidsonderzoek Samenwerkingsnetwerk Ziekenhuizen in de Euregio Scheldemond (1995) and De Buijser (1996) supra footnote 129, at pp.135-136. Further, there is a border agreement between Dutch health insurance institutions and a German hospital in Aachen under which victims of car-accidents can be sent directly to the Aachen hospital. Besides a French-Belgian agreement which entitles all members of frontier workers' families access to health care on either side of the border, there is an agreement between a French health institution and a Belgian hospital which allows pregnant women resident in Halluin to obtain treatment in the maternity section of the Mennin hospital in Belgium. Similar arrangements are made for the use of a Belgian child guidance centre. Further, a bilateral agreement has been concluded between the United Kingdom and Ireland which regulates the financing of cross-border care between the two countries and extends rights to gain access to care across the border for certain categories of persons. See Palm et al (2000) supra footnote 4, at p.66.

195. Most projects concern specialised medical practices such as cardiology, traumatology, pacdiatrics, radiotherapy, etc. Palm et al (2000) supra footnote 4 , at p.67. 
egy followed in the context of these projects, which have mainly been carried out by health institutions and Member States in the geographical heart of the Union, ${ }^{196}$ is comparable. The first step involves the exchange of information regarding the types of treatment for which shortages and surplus exist on the both sides of the border. Communication between health institutions across the border is to be intensified before the second step is taken which involves the drafting of lists of types of treatment for which agreements can be concluded. Upon agreement of the list and conclusion of the contract, patients can then be referred to health care providers across the border.

The projects aim to explore the possibility of promoting crossborder health care within the current legal framework. The EC Regulations' provisions and the principles on which these are based are not proposed to be altered. Thus, medical care is in all cases to be delivered in accordance with the legislation of the "providing State" and the institution of the State of insurance has to fully reimburse the health institution of the providing State. It is not planned to adjust national laws and regulations either. In fact, the initiatives are merely aimed at promoting more flexible authorisation policies. For a limited period of time form E 112 will be given more easily or automatically.

196. Quite a few projects have been carried out in border-regions between the Netherlands, Belgium and Germany. See e.g. Grunwald/Smit, Grensoverschrijdende Zorg - Zorg op Maat in de Euregio Maas-Rijn; Evaluatie van een Experiment (1999); Hofmann/Kocks, Freier Zugang zu Gesundheitsleistungen im Grenzgebieten - Grenzüberschreitendes Projekt in der Euregio Maas/Rhein, in: ZFSH/SGB (1998) pp.306 et seq; Godry, Krankenbehandlung ohne Grenzen - Anmerkungen zu einem Modellprojekt im niederländischen-deutschen Grenzgebiet, in: ZFSH/SGB (1997) pp.416 et seq; Ros/van der Zee, Grensoverschrijdende Zorg Vooronderzoek naar de Haalbaarheid van een Experiment in een Grensgebied betreffende Verruiming van Mogelijkheden voor Grensoverschrijdend Zorgverkeer - Uitgevoerd door het NIVEL in opdracht van de Ziekenfondsraad (1996) and Bijzondere Euregionale Commissie Grensoverschrijdende Zorg, Zorg Dichtbij oòk over de grens - Advies over Grensoverschrijdende Zorg in de Euregio Maas-Rijn (1994). See also the project in the Euregion Rhine/Meuse which involves cooperation between German sickness funds and a hospital in Nijmegen (the Netherlands) regarding the opportunities for persons insured in Germany to obtain specialized types of treatment such as heart surgery and radiotherapy. See Lottman/van der Wilt, Eindrapportage Project Grensoverschrijdende Zorg in de EU-Region Rijn/Waal (1999) and Nationaal Ziekenhuisinstituut/Deutsche Krankenhausinstitut, Grensoverschrijdende Gezondheidszorg - Duits-Nederlandse Samenwerking in de Gezondheidszorg in de Euregio Rijn-Waal (1995). See further Hermans/den Exter, Cross-Border Alliances in Health Care: International Co-operation between Health Insurers and Providers in the Euregio Meuse-Rhine, available on: http://www.mefst.hr/cmj/1999/4002/400219.htm and Palm et al (2000) supra footnote 4, at pp.67-70. 
There have been some successes, ${ }^{197}$ but it seems unlikely that the contractual method will lead to a significant extension of cross-border health care rights throughout the Community. The initiatives are taken in a few border regions only and the approach followed in these regions is characterised by caution. Member States only allow their sickness funds or providers to conclude cross-border agreements when there is a guarantee that health expenditure will not increase and that the accessibility and infrastructure of their national care systems is not in any way affected. Just like the legislative method, the contractual method for extending cross-border access to health care is ultimately based on an assumption of the voluntary co-operation of the Member States (or their health institutions) and experience so far suggests that Member States are only willing to co-operate when inter-State patient flow can be kept fully under control.

\subsection{Conclusions}

The goal of Regulations No $1408 / 71$ and No $574 / 72$ is to co-ordinate national health care and insurance schemes in such a way that Community citizens who travel to, or establish residence in, other Member States retain health insurance cover. On the basis of the discussion in this section, the conclusion can be drawn that the regulations largely meet this objective. The vast majority of Community citizens falls within the personal scope of Regulations No 1408/71 and No 574/72 which guarantee a right to emergency treatment in any Member State beneficiaries may visit, a right to obtain care in the State where they (seek) work and, above all, a right to claim access to medical care in the Member State in whose territory they reside. Apart from possible co-payments, beneficiaries are entitled to have the medical bill paid by the institution they are insured with or affiliated to.

This section has also demonstrated, however, that Regulations No $1408 / 71$ and No $574 / 72$ do not meet the specific objective in all respects. Basically, the regulations only grant cross-border rights to persons who become in need of medical care during a temporary or more permanent stay in another Member State. The possibility of travelling to other States

197. For a brief overview of the first experiences and results of the various projects see e.g. Brouwer, Het Nederlandse Gezondheidszorgstelsel in Europa - Een Economische Verkenning (1999) at pp.53-66. 
in order to obtain medical benefits are limited. As interpreted by the Court in Luisi and Carbone, Article 49 EC does entitle Community citizens to travel to other Member States for the purpose of obtaining medical treatment, but a right to have the cost reimbursed only exists when sickness funds have given prior authorisation. Apart from the few cases mentioned in Article 22(2), Regulation No 1408/71 does not provide for a right to obatin such authorisation. Formally a free movement of patients may thus exist, but because of the limited scope of Article 22(2) and the rather restrictive national authorisation policies, this freedom of movement does not seem to have much practical relevance for most Community citizens

For a long time, it was undisputed that it should be for Member States (or their sickness funds) to decide whether patients were entitled to move to other Member States for medical purposes. In order to protect the funding of health insurance schemes and to protect the infrastructure of medical care systems, Member States claim they need to control or regulate the inter-State flow of patients. In principle, this view is still held today, but in recent years the territorial limitation upon the right to gain access to health care has been criticised and questioned. Among Member States as well as in health care and health insurance circles, there is a growing awareness that cross-border access to health care may promote the accessibility of medical care in border regions and, albeit to a much lesser extent, that an extension of cross-border rights may help to solve waiting lists and other capacity problems. Yet, the legislative and contractual attempts to overcome the current territorial obstacles have so far not been very successful. The health care provisions of Regulation No $1408 / 71$ are not likely to be fundamentally amended in the near future and the method of promoting cross-border access to medical care by concluding cross-border agreements between health insurers and health care providers seems too cumbersome and too time-consuming to expect a significant extension of cross-border health care rights throughout the Community in the short term. Both the legislative and the contractual method require the voluntary co-operation of Member States and, used as they are to the principle of territoriality and as much as they fear medical tourism, the Member States only seem willing to co-operate on condition that expenditure does not increase and that the infrastructure of their care systems is wholly safeguarded. 


\subsection{Introduction}

Until the mid-1990s Member States regarded the health care provisions of Regulations No 1408/71 and No 574/72 as a self-contained regime which, free from any other obligations imposed by Community law, exclusively governed the degree to which, and the conditions under which, Community citizens are to be granted cross-border health care rights. ${ }^{198}$ The fact that national health insurance rules could possibly be contrary to, or that Community citizens could possibly derive additional cross-border health care rights from, the Treaty rules on the free movement of goods, services and/or persons was either denied or simply not recognised. ${ }^{199}$ On the one hand, this was not wholly incomprehensible. From the early Community years, cross-border access to health care had been strictly regulated and the implications of the application of private rules governing the common market to the (still) predominantly public health sector seems "risky". On the other hand, however, the above view of the two social security regulations was surprising. Even a brief survey of the jurisprudence of the Court of Justice demonstrates that health care and health insurance rules are not wholly immune to the limitations imposed by the Treaty's common market rules and that obedience to secondary legislation does not guarantee compliance with the Treaty itself. ${ }^{200}$ In particular, prior authorisation rules seem hard to compare with the rules and principles governing the free movement of goods and services. As stated in Sections 2.3 and 2.4, Articles 28 and 49 EC entitle Community citizens to move to other Member States in order to obtain medical goods ${ }^{201}$ and

198. See e.g. Neumann-Duesberg (1999) supra footnote 112 , at p.92 and the observations of various Member States' governments in the Decker and Kohll proceedings.

199. Leibfried/Pierson, Halbsouveräne Wohlfahrtsstaaten - Soziale Sicherung in der europäischen Mehrebenen-Politik, in: BDIP (1997) at p.45.

200. Compare e.g. Leingärtner, Diskussionsbeitrag zur Kritik and der Rechtsprechung des EuGH in den Rechtsachen C-160/96, C-120/95, C-158/96, Molenaar, Decker u. Kohll aus der Sicht der Lesitungsberechtigten, in: Schulte/Barwig, Freizügigkeit und Soziale Sicherheit - Die Durchführung der Verordnung Nr.1408/71 über die soziale Sicherheit der Wanderarbeitnehmer in Deutschland (1999) pp.117-121, at p.118.

201. Medic(in)al products constitute "goods" for purposes of Article $28 \mathrm{EC}$ (formerly $30 \mathrm{EC}$ - Case 238/82 Duphar [1984] ECR 523 and Case 215/87 Schumacker [1989] ECR 617) and the "free movement of goods requires, particularly in frontier areas, that consumers resident in one Member State may travel freely to the territory of another Member State" to buy 
services $^{202}$ and it is settled case law that national rules which hamper freedom of movement are, in the absence of justification, incompatible with the free movement rules. ${ }^{203}$ Further, the prohibitions of Articles 28 and $49 \mathrm{EC}$ are not absolute. National rules which burden freedom of movement may possibly be justified under (the public health derogations contained in) Articles 30 (formerly 36) and 46 (formerly 56) EC or the so-called "rule of reason". The Court of Justice may promote freedom of movement but this is not to say that it does not keep an eye on the Member States' health care interests. In fact, in the light of existing case law, and suggestions made in the literature, ${ }^{204}$ it was quite remarkable that until the mid-1990s no questions had been submitted to the Court on the compatability of prior authorisation rules with the Community rules on the free movement of goods and services. ${ }^{205}$ This only occured in 1995 and 1996 when the Decker and Kohll cases were referred to the Court.

(medical) goods "under the same conditions as the local population" (Case C-362/88 GBINNO-BM [1990] ECR I-667 at 8).

202. Medical care is to be classed as a service in the sense of Article 50 EC (Case C-159/90 Grogan [1991] ECR I-4685) and Article 49 entitles "persons receiving medical treatment", as recipients of services, to move to other Member States in order to receive medical services (Case 286/82 Luisi and Carbone [1984] ECR 377 at 16).

203. See Chapter 2 Section 7.3.

204. These suggestions were especially made in the German literature. See e.g. Steindorff, Dienstleistungsfreiheit im EG-Recht, in: RIW (1983) pp.831-839 and von Maydell, Erbringung von Sozialleistungen (insbesondere im Gesundheitswesen) und Marktfreiheit, in: von Maydell/ Schnapp (Eds), Die Auswirkungen des EG-Rechts auf das Arbeits- und Sozialrecht der Bundesrepublik - Unter besonderer Berücksichtigung der neuen Bundesländer (1992) pp.25-43. See further van der Mei, Patients' Access to Cross-Border Care and Insurance Cover, in: Alliance Nationale des Mutualités Chrétiennes/Association Internationale de la Mutualité, Competition and Solidarity - Can They Co-exist in Europe's Health Care Systems? (1997) pp.68-75 and Mavridis, Le Citoyen européen Peut-il se Faire Soigner dans l'Etat de son Choix?, in: DS (1996) pp.1086-1093.

205. van der Mei, The European Court of Justice and the Co-ordination of Health Insurance Schemes, in: Association Internationale de la Mutualité/ European Institute of Social Security, Health Care without Frontiers within the European Union - Free Movement of Goods and Services in the Health Care Sector (1999) at pp.18-25, at p.18 (citing Jorens) 


\subsection{Decker and Kohll}

\subsubsection{Facts}

Both Decker and Kohll were Luxembourg cases. Except in cases of emergency treatment in the event of an accident or illness occurring abroad, insured persons could under the Luxembourg health insurance rules only obtain treatment abroad with the prior consent of their sickness fund. Authorisation could only be given for medical benefits which were covered by the Luxembourg rules and was granted only after a medical assessment and on production of a written request from a doctor established in Luxembourg indicating in particular that the treatment in question could not be carried out in Luxembourg. The legality of these prior authorisation rules was challenged in Decker by a Luxembourg national and resident who had purchased a pair of spectacles with corrective lenses from an optician in Arlon (Belgium). Mr Decker's request to be reimbursed for the cost was rejected by the Luxembourg sickness fund on the ground that he had not asked for prior authorisation. Mr Decker challenged that decision in a Luxembourg court which referred the case to the Court of Justice asking whether the prior authorisation rules were compatible with the Treaty provisions on the free movement of goods. ${ }^{206}$ Kohll concerned a Luxembourg resident who had requested authorisation for the treatment of his daughther by an orthodontist in Trier (Germany). The request was rejected on the ground that the treatment in question was not urgent and could have been obtained in Luxembourg itself. Mr Kohll appealed that decision and the competent court submitted a preliminary question to the Court concerning the validity of the Luxembourg prior authorisation rules under the provisions of the EC Treaty on the free movement of services. ${ }^{207}$

206. In Decker the Luxembourg Court submitted the following question to the Court: "Is Article 60 of the Luxembourg Social Insurance Code, under which a social security institution of Member State A refuses to refund to an insured person, who is a national of Member State A, the cost of spectacles with corrective lenses, prescribed by a doctor established in member State A but purchased from an optician in Member State B, on the ground that all medical treatment outside Member State A must be authorised in advance by the above social security institution, compatible with Articles 30 and 36 of the EC Treaty in so far as it penalises in general the importation by private individuals of medicaments or, as in this case, spectacles from other Member States?"

207. In Kohll the preliminary questions were as follows: "1. Are Articles 59 and 60 of the Treaty establishing the EEC to be interpreted as precluding rules under which reimbursement of the cost of benefits is subject to authorisation from the insured person's social security 
4.2.2 Can Prior Authorisation Rules be Reviewed under Articles 28 and $49 \mathrm{EC}$ ?

Before the Court could examine whether prior authorisation rules burden freedom of movement, and if so, whether, they could be justified, it had to ascertain itself that such rules can be reviewed under Articles 28 and 49 EC. Various governments represented in the proceedings before the Court had denied this. The rules would fall wholly outside the scope of the free movement provisions. The first reason for this would be that the contested rules concerned social security. Reference was made to case law in which the Court had ruled that it for Member States, and not the Community, to organise social security systems ${ }^{208}$ and to lay down rules governing the access to the systems. ${ }^{209}$ The argument was not persuasive. It is established case law that in areas which have not been brought within the ambit of the Treaty, Member States must also observe the limitations imposed by the fundamental freedoms for goods, services and persons. ${ }^{210}$ Social security, as Advocate General Tesauro put it in his Opinion in Decker and Kohll, does not constitute "an island beyond the reach of Community law". ${ }^{211}$ In both judgments the Court confirmed that Community law does not detract from the Member States' powers to

\footnotetext{
institution if the benefits are provided in a Member State other than the State in which that person resides? 2. Is the answer to the first question different if the aim of the rules is to maintain a balanced medical and hospital service accessible to everybody in a given region?".

208. See e.g. Case C-70/95 Sodemare [1996] ECR I-3422 at 27 and Case 238/82 Duphar [1984] ECR 523 at 6.

209. See e.g. Case 110/79 Coonan [1980] ECR 1445 at 12 and Case C-349/87 Paraschi [1991] ECR I-4501 at 5.

210. In fact, there is not a single policy area or area of law in which Member States and their institutions can ignore the principles of non-discrimination and freedom of movement See e.g. Case C-279/93 Schumacker [1995] ECR I-225 (tax law) and Case C-226/97 Lemmens [1998] ECR I-3711 (criminal law). Some governments had also referred to the judgment in Poucet and Pistre in which the Court had indicated that social security institutions may fall outside the scope of the Treaty's competition rules (Articles 80 and 81 EC) in as far as they pursue non-economic activities in furtherance of a public task. Joined Cases C-159/91 and C-160/91 Poucet and Pistre [1993 ECR I-637. Compare also Case C244/94 Federation Francaise des Societes d'Assurance [1995] ECR I-4013. The Court did not even see a need to respond to the argument. The fact that health insurance institutions may possibly be partly exempt from the competitition rules does not imply that the legislation and rules applying to them are free from the obligations resulting from the Treaty provisions on the free movement of goods and services.

211. Opinion of Advocate General Tesauro in Case C-120/95 Decker and Case C-158/96 Kohll [1998] ECR I-1831 at 17.
} 
lay down the conditions of insurance and entitlement to benefits, but that in exercising these powers, Member States must comply with Community law, and Articles 28 and 49 EC in particular. ${ }^{212}$

A second reason as to why the contested Luxembourg rules would not be caught by Articles 28 and $49 \mathrm{EC}$ was that these rules would be fully consistent with Article 22 of Regulation No 1408/71. By challenging national prior authorisation rules the validity of this Community provision would indirectly be called into question. The Luxembourg rules were indeed fully consistent with Article 22 of the Regulation, but as could have been expected, this argument was also not accepted by the Court. Article 22(1) applies to situations in which insured persons have received prior authorisation from the competent institution, but the provision does not regulate situations where such authorisation is not granted. Both in Decker and Kohll the Court concluded that mere compliance with a provision of secondary Community law does not remove national rules from the obligations resulting from provisions of primary Community law. ${ }^{213}$

\subsubsection{Do Prior Authorisation Rules Hamper the Free Movement of} Goods and Services?

Having established that the Luxembourg rules could be reviewed under the free movement provisions, the Court proceeded with the question whether the rules hampered the free movement of goods and services. In Decker some Member States had argued that the Luxembourg authorisation rules do not have the purpose or effect of restricting the free movement of goods. The rules did not prohibit the import of spectacles, they did not influence the possibility of purchasing them outside the national territory and they did not prohibit Luxembourg opticians from importing spectacles and corrective lenses from other Member States. The authorisation rules would merely lay down the conditions for the reimbursement of medical expenses. In Kohll similar arguments were expressed as regards the freedom to provide and receive medical services. The Court

212. Case C-120/95 Decker [1998] ECR I-1831 at 25 and Case C-158/96 Kohll [1998] ECR I-1931 at 21. On this point see in particular the Opinion of Advocate General Fennelly in Case C-70/95 Sodemare [1997] ECR I-3398 at points 23-30.

213. Case C-120/95 Decker [1998] ECR I-1831 at 30 and Case C-158/96 Kohll [1998] ECR I-1931 at 28. In fact, provisions of secondary law themselves must be in conformity with the Treaty itself and, in case they are not, they may be invalidated by the Court of Justice. See c.g. Casc 41/84 Pinna I [1986] ECR 1. 
rejected the arguments. In Decker it observed that the rules at issue encouraged persons insured under the Luxembourg social security scheme to purchase their spectacles from opticians established in Luxembourg rather than in other Member States. While the national rules at issue in the main proceedings did not deprive insured persons of the possibility of purchasing medical products in another Member State, they did make reimbursement of the cost incurred in that Member State subject to prior authorisation, and denied such reimbursement to insured persons who have not obtained that authorisation. Such rules are to be categorised as a barrier to the free movement of goods since they encouraged insured persons to purchase those products in Luxembourg rather than in other Member States. The rules were liable to curb the import of spectacles assembled in those States. ${ }^{214}$ In Kohll the Court stated that while the Luxembourg rules did not deprive insured persons of the possibility of approaching a provider of services established in another Member State, they did deter insured persons from approaching providers of medical services established in another Member State and they did constitute, for them and their patients, a barrier to freedom to provide services. ${ }^{215}$

\subsubsection{Justification of the Prior Authorisation Rules}

The most difficult questions the Court had to answer concerned the possible justification of the prior authorisation rules. In defense of the rules, three grounds were considered by the Court.

\section{Quality of Medical Benefits}

A first suggested justification concerned the protection of public health. The "protection of health and life of humans" is mentioned in Article 30 (formerly 36) EC as a ground on which national rules which burden the free movement of goods could possibly be justified. Article 46 (formerly 56) EC allows Member States to lay down rules for the special treatment of foreign nationals on grounds of "public policy, public security or public health". Luxembourg had argued that medical products must be supplied by professionals such as pharmacists and opticians who are

214. Case C-120/95 Decker [1998] ECR I-1831 at 34-36. 215. Case C-158/96 Kohll [1998] ECR I-1931 at 34. 
authorised by law to pursue their profession and who, due to their rather lengthy training, guarantee that the products and services provided are of sufficient quality. If medical products such as spectacles are supplied in another Member State, supervision to ensure that this has been carried out properly would be called into question or even impossible. Similarly, the quality of medical services provided by doctors in other Member States could only be ascertained at the time a request for treatment abroad is made.

The Court was not persuaded. In Decker it observed that the conditions for taking up and pursuing regulated professions have been the subject of Community legislation ${ }^{216}$. As a result, the purchase of a pair of spectacles from an optician established in another Member State provided guarantees equivalent to those afforded on the sale of a pair of spectacles by an optician established in the national territory. ${ }^{217}$ In Kohll the Court held that Article 46 does not permit Member States to exclude the public health sector, as a sector of economic activity and from the point of view of freedom to provide services, from the application of the fundamental principle of freedom of movement. After referring to several directives which co-ordinate or harmonise the conditions for taking up and pursuing the profession of doctor and dentist, the Court concluded that "doctors and dentists established in other Member States must be afforded all guarantees equivalent to those accorded to doctors and dentists established on national territory, for the purposes of freedom to provide services"218. In both cases the Court concluded that prior authorisation rules such as the ones applicable in Luxembourg could not be justified on grounds of public health in order to ensure the quality of medical products and services supplied in other Member States.

\section{Financial Stability of Health Insurance Schemes}

A second suggested justification for prior authorisation rules concerned the control of health expenditure. As stated in Section 2.2, the price of medicines, medical products and medical care differ considerably in the various Member States. If the Member States and/or their sickness funds were obliged to reimburse the cost of all medical benefits obtained in other member States, they might be confronted with higher expenditure

216. For the relevant directives see supra footnote 26.

217. Case C-120/95 Decker [1998] ECR I-1831 at 42-43.

218. Case C-158/95 Kohll [1998] ECR I-1931 al 46-48. 
and this could possibly affect the financial stability of their health insurance schemes. The requirement of prior authorisation was claimed to be the only effective and the least restrictive means for controlling expenditure on health and balancing the budget of health insurance systems.

At first glance, this suggested justification seemed to pose a quite delicate problem for the Court. The need to preserve the financial stability of health insurance schemes is an interest which is worthy of protection by Community law. In Duphar (1984) the Court had already recognised that "Community law does not detract from the powers of the Member States .. to adopt .. provisions intended to govern the consumption of pharmaceutical products in order to promote the financial stability of their health care insurance schemes". ${ }^{219}$ In Duphar, however, the Court had recognised the preservation of the financial stability of health insurance schemes as a general interest for purposes of the so-called rule of reason. ${ }^{220}$ It is settled case law that this judicially created exception can only be relied upon in order to justify non-discriminatory rules. Prior authorisation rules, however, seem to be discriminatory. Articles 30 or 46 EC did not seem to leave room for prior authorisation rules either. These Treaty provisions do allow for the application of discriminatory rules which are necessary on public health grounds, but the Court has consistently held that the provisions can only be invoked in defence of noneconomic aims. ${ }^{221}$

Nonetheless, the problem was not as difficult as it seemed. In fact, the solution to solve the problem was presented to the Court by Decker and Kohll themselves. The former had referred to the fact that as regards spectacles the Luxembourg rules provided, at the material time, for a flat-rate reimbursement which was fixed independently of the cost actually incurred. The mere fact that spectacles were purchased in another Member State would thus not lead to an increase in expenditure. For dental care the Luxembourg rules did not provide for a flat-rate reimbursement, but Mr Kohll claimed that expenditure would not increase, and that the financial stability of the Luxembourg insurance scheme would not be affected, when he, as requested, were reimbursed in accordance with the rates applicable in Luxembourg.

219. Case 238/82 Duphar [1984] ECR 523 at 16.

220. See Chapter 2 Section 7.3

221. As regards goods see e.g. Case 238/82 Duphar [1984] ECR 523 at 23 and Case 7/61 Commission v Belgium [1961] ECR 317 at p.329. As regards services, see Joined Cases 62 and 63/81 Seco SA [1982] ECR 223 at 236-237 and Case C-17/92 Fedicine [1993] ECR I2239 at 16 and 21. 
The Court approved of the line of reasoning followed by Mr Decker and Mr Kohll. It accepted that the maintenance of the financial stability of health insurance schemes may be a justification ground for purposes of the so-called rule of reason. Aims "of a purely economic nature" cannot justify a barrier to the fundamental principle of the free movement of goods and services", but it "cannot be excluded that the risk of seriously undermining the financial balance of the social security system may constitute an overriding reason in the general interest capable of justifying a barrier of that kind". ${ }^{222}$ The Luxembourg rules could not pass the test. In Decker the Court concluded that "reimbursement at a flat rate of the cost of spectacles and corrective lenses purchased in other Member States has no effect on the financing or balance of the social security system". ${ }^{223}$ In Kohll the Court held that "reimbursement of the cost of dental treatment provided in other Member States in accordance with the tariff of the State of insurance has no significant effect on the financing of the social security system". 224

The fact that Article 22(1) of Regulation No 1408/71 prescribes that medical benefits are to be provided in accordance with the social insurance rules of the "other" Member States, and that Article 36(1) obliges the competent institution to pay the "medical bill" fully, could not alter this conclusion. Article 22(1) of Regulation No 1408/71, the Court ruled, is intended

"to allow an insured person, authorised by the competent institution to go to another Member State to receive there treatment appropriate to his condition, to receive sickness benefits in kind, on account of the competent institution but in accordance with the provisions of the legislation of the State in which the services are provided, in particular where the need for the transfer arises because of the state of health of the person concerned, without that person incurring additional expenditure". 225

The Article, however, is not intended to "regulate and hence does not in any way prevent the reimbursement by Member States, at the tariffs in force in the competent State, of the cost of medical products purchased in another Member State", in cases where no prior authorisation has been given. $^{226}$

222. Case C-120/95 Decker [1998] ECR I-1831 at 39 and Case C-158/96 Kohll [1998] ECR I-1931 at 41.

223. Case C-120/95 Decker [1998] ECR I-1831 at 40.

224. Case C-158/96 Kohll [1998] ECR I-1931 at 42

225. Case C-120/95 Decker [1998] ECR I-1831 at 28 and Case C-158/96 Kohll [1998] ECR

I-1931 at 26.

226. Ibid, at 29 and 27 respectively. 
In Decker the Court finally concluded that the Treaty provisions on the free movement of goods preclude the application of national rules under which social security institutions refuse to reimburse to an insured person on a flat-rate basis the cost of a pair of spectacles with corrective lenses purchased from an optician established in another Member State, on the ground that prior authorisation is required for the purchase of any medical product abroad. ${ }^{227}$ In Kohll, however, the Court had to consider an additional argument which was raised in defence of the prior authorisation rules in question. According to the various governments represented in the proceedings before the Court, prior authorisation rules would be necessary to protect the infrastructure of health care systems. In order to provide adequate care, Member States must ensure that there are enough doctors, medical facilities and hospital beds available on their territory. Waiting lists and other problems of undercapacity imply a limitation on the accessibility of the health care system and are to be avoided. At the same time, the number of available doctors, facilities and beds should not be too large. Overcapacity implies an unnecessary waste of human and financial resources. Capacity planning, so it was argued, would be virtually impossible if patients were free to choose in which State they wished to obtain medical treatment. Member States would need the power to control, to a certain extent, where patients can obtain medical care and prior authorisation rules would be the only effective means for protecting the infrastructure of their health care systems. ${ }^{228}$

Especially in as far as intramural care is concerned this argument seemed to have force. In fact, the Court seemed to have no other choice than to accept that the protection of the infrastructure of health care systems could be a ground on which certain national rules could be justified. The Court indeed did so, but it was forced to be creative. In order to protect the infrastructure of their health care systems, Member States need to make a distinction between patients consulting health providers abroad and patients going to providers established in the national territory. Discriminatory measures are required to avoid possible problems of over- or undercapacity. Therefore, the rule of reason did not seem an option. The same seemed to hold true for Article 56 (now 46) EC. This provision does not necessarily exclude discriminatory rules, but can only be relied upon in defence of non-economic ends. The Court

227. Case C-120/95 Decker [1998] ECR I-1831 at 46.

228. Compare Hermesse/Lewalle (1993) supra footnote 1. 
found the following solution. Although the objective of "maintaining a balanced medical and hospital service open to all" is intrinsically linked to the method of funding the social security system, the Court held that it may

"fall within the derogations on grounds of public health under Article 56 of the Treaty, in so far as it contributes to the attainment of a high level of health protection. [ ] Article 56 of the Treaty permits Member States to restrict the freedom to provide medical and hospital services in so far as the maintenance of a treatment facility or medical service on national territory is essential for the public health and even the survival of the population". ${ }^{229}$

The fact that Member States may under certain conditions restrict the freedom to provide and receive medical services did not imply that the Luxembourg prior authorisation rules could be justified. Neither one of the parties in the proceedings before the Court had shown that the rules at issue were necessary to provide a balanced medical and hospital service accessible to all or that the rules were indispensable for the maintenance of an essential treatment facility or medical service on national territory. ${ }^{230}$ In conclusion, the Court held that the Treaty provisions on the free movement of services preclude national rules which make the reimbursement, in accordance with the scales of the State of insurance, of the cost of dental treatment provided by an orthodontist established in another Member State, conditional upon the prior authorisation of a social security institution. ${ }^{231}$

\subsubsection{Conclusion}

From the perspective of Community law, Decker and Kohll may be regarded as the "normal" evolution of the Court's jurisprudence on the free movement of goods and services. ${ }^{232}$ It may not have been possible

229. Case C-158/96 Kohll [1998] ECR I-1931 at 50-51.

230. Ibid, at 52 .

231. Ibid, at 54

232. For first comments on, and analyses of, the two judgments in the literature see e.g. Becker, Brillen aus Luxemburg und Zahnbehandlung in Brüssel - Die Gesetzliche Krankenversicherung im europäischen Binnenmarkt, in: NZS (1998) pp.359-364; Hamilton, Annotatie Decker-Kohll, in: TvG (1998) pp.394-397; Hermans et al, Zorg in het Buitenland: Gevolgen voor Patiënten en Zorgverzekeraars, in: Staatscourant (1998) p.5; Jorens, Annotatie Decker-Kohll, in: RZA (1998) pp.303-309; van der Mei, Grensoverschrijdende Toegang tot de Gezondheidszorg in de Europese Gemeenschap, in: USZ (1998) pp.462-471; van der Mei, Decker and Kohll: Op Weg Naar een Vrij Verkeer voor Patiënten in de Europese Gcmcenschap?, in: SR (1998) pp.187-196; van der Mei (1998) supra footnote 178; von 
to predict the outcome of the rulings with mathematical precision, but virtually all conclusions drawn by the Court do derive from, and are based on, principles developed in earlier case law. ${ }^{233}$ From a health care and insurance perspective, it would, at least at first glance, seem more appropriate to class the two rulings as a "revolution". ${ }^{234}$ Under the regime of Regulations Nos 1408/71 and 574/72 Member States are largely

Maydell, Wenn Schutzzäune fallen .. Das Kohll-Decker-Urteil des Europäischen Gerichtshofes (EuGH) hat Fragen Aufgeworfen: Gefährdet die Grenzöffnung die Deutschen Krankenversicherung? Oder verheisst der Richterspruch mehr Markt im Gesundheitswesen?, in: GuG p.3; Neumann-Duesberg, Kohll-Decker-Urteile "Die EuGH-Position ist Angreifbar", in: GuG (1998) pp.22-27; Novak, EG-Grundfreiheiten und Europäisches Sozialrecht, in: EuZW (1998) pp.366-369; du Pré, Het EG-Verdrag door een Ziekenfondsbrilletje, in: SMA (1998) pp.364-376; van Raepenbusch, La libre Choix par les Citoyens européens des Produits médicaux et des Prestataires de Soins, Conséquence sociale de Marché interieur, in: CDE (1998) pp.683-697; Schulz-Weidner, Rechtliche Entwicklungen bei Krankenkassenleistungen im Ausland, in: KrV (1998) pp.241-245; Sendler, Europäisches Gesundheitswesen Offensiv Gestalten, in: KrV (1998) pp.285-290; Spiegel, Der EuGH Als (Wiederentdecktes) Feindbild, in: SS (1998) pp.665-668; van der Steen, Vergoeding van Medische Zorg over de Grens: Alleen bij Toestemming Vooraf?, in: NTER (1998) pp.159-163; Tomscheid, EG-Binnenmarkt rüttelt an den nationalen Sozialversicherungssystemen, in: KrV (1998) pp.246-250; Wismar/Busse, Freedom of Movement Challenges European Health Care Scenery, in: Eurohealth (1998) pp.13-15; Brouwer (1999) supra foonote 197; Cabral, Cross-border Medical Care in the European Union - Bringing Down a First Wall, in: ELRev (1999) pp.387-395; Cath, Vuurwerk of Veenbrand? Decker en Kohll Spoken door Europa (1), in: MC (1999) pp.466-467; Cath, Blijft het Tobben of Onstaat er Iets Moois? Decker en Kohll Spoken door Europa (2), in: MC (1999) pp.468-471; Kanavos, Cross Border Health Care in Europe - European Court Rulings Have Made Governments Worried, in: BMJ (1999) pp.1157-1158; Mavridis, Une Libéralisation des Soins de Santé - Un premier Diagnostic après les arrêts CJCE Kohll et Decker, in: DS (1999) pp.172-175; Nourissat, Quand Panacée Rejoint Europe ou Comment la Cour de Justice Consacre la Liberté des Soins dans la Communauté, in: SJ (1999) 10002; Pieters, De Nederlandse Zorgverzekering in het Licht van het Recht van de Europese Gemeenschap (1999); Roscam Abbing, Editorial: Public Health Insurance and Freedom of Movement within the European Union (Cases Kohll and Decker), in: EJHL (1999) pp.1-6; Steinmeyer, Der Zugang zu Leistungen der Kranken- und Pflegeversicherung der EU-Bürger - Veränderte rechtliche Dimensionen (Vertragsfreiheiten), in: ZSR (1999) pp.735 et seq; Stuyck, Annotatie Decker and Kohll, in: SEW (1999) pp.259262; Callens, De Arresten Kohll en Decker: Implicaties voor Grensoverschrijdende Zorg, : in: Essers/Scheiffers (Reds), Grensoverschrijdende Zorg - Marktwerking vs. National Zorgbewaking (2000) pp.11-13 en Linders, De Arresten Kohll en Decker: Impact op de Tariefstelling in de Gezondheidszorg, in: Essers/Scheiffers (Reds), Grensoverschrijdende Zorg - Marktwerking vs. National Zorgbewaking (2000) pp.14-18.

233. La "jurisprudence d'hier sur les articles 30 et 59-60 contenait déjà celle d'aujourd'hui. Les arrêts Kohll et Decker ne sont donc ni big bang, ni révolution, ni explosion, ni autre catastrophe naturelle. Ils étaient tout simplement annoncés depuis longtemps". Mavridis (1998) supra footnote 232, at p.195.

234. van der Mei (1999) supra footnote 205, at p.18 and van der Mei, The Kohll and Decker Rulings: Revolution or Evolution?, in: Eurohealth (1999) pp.14-16. 
free to decide whether patients who wish to go to other Member States in order to obtain medical products or care, will be reimbursed by their sickness fund. Apart from the few cases covered by Article 22(2) of Regulation No 1408/71, State (or sickness funds) are under no obligation to grant the required authorisation. Decker and Kohll, however, indicate that prior authorisation rules are at odds with the Treaty provisions on the free movement of goods and services. In principle, publicly insured Community citizens no longer need the prior authorisation in order to have the cost of foreign care (wholly or partly) reimbursed. Decker and Kohll imply a reversal of the basic premises on which Community law governing cross-border access to medical care is based. Reimbursement of the cost of "foreign" medical products and services is no longer a privilege voluntarily given by the sickness funds. It is now a judicially enforcable Treaty-based right which can only in some cases be limited or partially limited.

As significant as this conclusion may be, Decker and Kohll do not necessarily mean that patients are now entitled to freely choose in which of the Member States they wish to receive medical benefits. First, much more than in the Pierik judgments ${ }^{235}$, the Court has had regard to the interests of Member States. The Luxembourg authorisation rules could not withstand judicial scrutiny, but the Court did accept that Member States are entitled to impose restrictions on the free movement of medical benefits when, and in as far as, such restrictions are necessary for securing the financial stability of health insurance schemes and/or "maintaining a balanced medical and hospital service open to all". Second, the scope of the Decker and Kohll rulings is far from clear. The conclusions drawn by the Court seem partially linked to the facts of the case and the specific features of the Luxembourg health insurance system. The systems of other Member States differ from the Luxembourg one in various respects and because of this, many Member States have interpreted the rulings as having only minimal implications for their systems. ${ }^{236}$

235. See Section 3.3.2.

236. For an overview of the views of the Member States and the various actors in the health care scene see in particular Palm et al (2000) supra footnote 4, at pp.82-107. See further Gobrecht, National Reactions to Kohll and Decker, in: Eurohealth (1998) pp.16-17. Ministerie van Volksgezondheid, Welzijn en Sport, De Gevolgen van de Arresten Kohll en Decker voor het Nederlandse Stelsel van Ziektekostenverzekeringen (1998); Union des caisses de Maladie, Avis officiel aux Assurés des Caisses de Maladie (1998); Standpoint of the Executive Committee of the Association of Dutch Health Insurers (..) Following the Decisions of the Court of Justice of the European Communities in the Decker and Kohll Cases (1998) and Ziekenfondsraad, Grensoverschrijdende Zorg: Arresten Decker en Kohll (1998). 
Decker and Kohll raise more questions than they answer. The remaining part of this section examines the scope and implications of the two rulings. ${ }^{237}$ The discussion includes a number of questions which have already been submitted to the Court of Justice as well as some questions which have not yet been but are likely to be referred to "Luxembourg" in the (near) future.

\subsection{Benefits-in-Kind Systems: Geraets-Smits and Peerbooms}

\subsubsection{Introduction}

A first question which has been raised in the "post-Decker/Kohll debates" is whether, or to what extent, the two rulings also have implications for health insurance schemes which are based on the principle of benefits-inkind. Under such systems the insured are not, as in the case of reimbursement schemes, entitled to be reimbursed for the medical bills they themselves have paid to providers. Benefits-in-kind systems entitle the insured to obtain medical benefits directly from providers. Doctors, hospitals, etc. are paid by the insurance institution. Apart from possible co-payments, the insured are not confronted with a medical bill. The Luxembourg system is a reimbursement system and in Decker and Kohll the Court did not make any specific comments on benefit-in-kind-systems. ${ }^{238}$ For this reason it has been argued that the Treaty provisions on the free movement of (goods and) services do not prevent the application of prior authorisation rules by sickness funds operating in a benefits-in-kind system. ${ }^{239}$ In as far as these arguments are used in support of the view that prior authorisation requirements for treatment abroad are valid on the sole ground that the States applying them have chosen a benefits-in-kind

237. The discussion below is limited to publicly insured patients. For comment on the implications of Decker and Kohll for private health insurances (in the Netherlands) see e.g. Ingelse, Verplichting tot Vergoeding van in andere Lid-Staten gemaakte Ziektekosten: Decker en Kohll in Nederland, in: SMA (2000) pp.208-211.

238. Compare Hirsch, Europäische Sozialunion durch Richterrecht?, in: FAZ (1998) at p.18. 239. This argument has been made in Germany especially where legislation is indeed (largely) based on the principle of benefits in kind (Sachleistungsprinzip). See e.g. Gobrecht (1998) supra footnote 236, at p.16 and Neumann-Duesberg, Grenzüberschreitenden Behandlungsleistungen - Die Praxis der gesetzlichen Krankenversicherung, in: Zentrum für Europäisches Wirtschaftsrecht, Grenzüberschreitende Behandleistungen im Binnenmarkt (1998) pp.21-38. 
scheme rather than a reimbursement scheme, are not persuasive. ${ }^{240}$ Community law, as the Court recognised in Decker and in Kohll, does not take away from the Member States the power to organise their health care and insurance systems in the way they deem appropriate. ${ }^{241}$ Yet, the judgments equally indicate that the choices Member States may have made internally do not automatically free them from the obligation to comply with Community law and its free movement rules. This does not imply that arguments made in defence of prior authorisation rules applied by sickness funds operating in a benefits-in-kind system are without ground. Implementation of such a system requires measures regulating the relationship between sickness funds and health care providers. The efficacy of these measures may possibly be a ground for justifying and upholding prior authorisation rules. The point is clarified by the Dutch prior authorisation rules, the legality of which has been challenged in Geraets-Smits and Peerbooms.

\subsubsection{Facts}

With a view to effectuating the principle of benefits-in-kind, sickness funds in the Netherlands are required to conclude contracts with health care providers which have been recognised by the Minister of Health. ${ }^{242}$ In these agreements the contracting parties must agree on the number of treatments which hospitals or doctors will provide for the sickness funds' patients, the quality of the care that is offered and the payments which the providers will receive. The freedom of sickness funds to conclude contracts is considerable but there are restrictions upon it. Sickness funds $(i)$ must conclude contracts with institutions based in the area the funds operate in and they (ii) can only contract with providers who are entitled to provide care and care institutions which have obtained approval from the Health Care Insurance Board. In order to keep expenditure under control and to secure an efficient use of contracted facilities, the insured

240. Compare Eichenhofer, Dienstleistungsfreiheit und Freier Warenverkehr als Rechtsgrundlagen für Grenzüberschreitenden Behandlungsleistungen, in: Zentrum für Europäisches Wirtschaftsrecht, Grenzüberschreitenden Behandlungsleistungen im Binnenmarkt (1998) pp.1-20, at pp.15-19 and du Pré (1998) supra footnote 232, at pp.371-373.

241. Compare Marhold, European Economic Law and its Impact on Health Services, in: Association Internationale de la Mutualité/ European Institute of Social Security, Health Care without Frontiers within the European Union - Free Movement of Goods and Services in the Health Care Sector (1999) at pp.43-48, at p.47.

242. For a more detailed description of the Netherlands public health insurance rules see Pieters (1999) supra footnote 35 , at pp.31-58 
must obtain medical benefits from one of the providers with whom their sickness fund has concluded a contract. In principle, the sickness funds are under no obligation to pay the cost of medical benefits provided by non-contracted providers. Non-contracted care is to be paid by the patients themselves. This is different only in cases where the sickness funds, upon the request of the patients (or their doctors), have given their prior authorisation. Authorisation for non-contracted medical benefits can be given when two conditions are met. First, the types of treatment for which authorisation is requested must be recognised in the Netherlands legislation as "benefits in kind". These include a number of specifically enlisted medical benefits as well as benefits which are considered "common practice in the profession". Second, authorisation can only be given in cases where this is considered necessary for the medical treatment of the insured. Formally, this criterion is applied equally to non-contracted providers established in the Netherlands and non-contracted foreign providers, but Dutch case law demonstrates that in determining the necessity for treatment abroad the medical facilities available in the Netherlands are (to be) taken into consideration. ${ }^{243}$

The validity of these prior authorisation rules has been challenged in Geraets-Smits and Peerbooms by two patients. The first case concerns a patients with Parkinsons who asked for the reimbursement of the cost of treatment in a clinic in Kassel (Germany). Ms Geraets-Smit was refused authorisation because the "Parkinson-treatment" she received was neither enlisted nor considered "common practice in the profession" and the facility in Germany was claimed not to have additional medical value by comparison with the facilities available in the Netherlands. The second case involves a Dutch patient who after a traffic accident had lapsed into a coma. The doctor treating the patient requested the sickness fund to send the patient to a university clinic in Innsbruck (Austria) where a special type of therapy is used which in the Netherlands is only offered on a experimental basis. In the Netherlands Peerbooms could only be treated in a health centre where the treatment in question was not available. The patient was in fact treated in Innsbruck where he indeed regained consciousness, but the sickness fund refused to bear the cost on the ground that the coma treatment in Austria was not a "benefit in kind" for the purposes of the Dutch health insurance legislation. Even if the treatment were to be regarded as "common practice in the profession", the sickness fund claimed that the treatment, in relation to the facilities offered in the Netherlands, would have no additional medical value. There 
was no medical need to grant authorisation for treatment in Austria.

In order to be able to make a decision in the two cases before it, the competent Dutch court asked the Court of Justice whether national rules which make the reimbursement of the cost of medical care provided by a "foreign" doctor or hospital with whom the sickness fund has not concluded an agreement subject to prior authorisation burden the free movement of services as guaranteed by Articles 49 and 50 EC. If so, can such rules be justified by the objectives which benefits-in-kind systems aim to achieve. ${ }^{244}$

\subsubsection{Opinion of Advocate-General Ruiz-Jarabo Colomer}

The cases are still pending before the Court, but on 18 May 2000 Advocate-General Ruiz-Jarabo Colomer delivered his Opinion in Geraets-Smits and Peerbooms. The questions of the referring Dutch Court are based on the assumption that the medical treatment which the patients GeraetsSmits and Peerbooms obtained in Germany and Austria constitutes services for the purposes of Community law. The Advocate General did not dispute this, but he did not consider the classification of the treatments in Germany and Austria decisive for the answer to the preliminary questions. Since the two patients rely on Article $50 \mathrm{EC}$ in order to have the cost of treatment paid by their sickness fund, the Advocate General rather considered whether the legal relationship of the insured with their sickness funds can be defined in terms of the provision of services in the

244. Similar questions have been raised and referred to the Court of Justice in Case C385/99 Müller-Fauré and van der Riet. Like Geraets-Smits and Peerbooms, this case concerns two patients who challenged the Dutch prior authorisation rules for non-contracted care. The first patient was in need of quite extensive dental treatment. Being dissatisfied with the treatment given by Dutch dentists, Ms Müller-Fauré decided to seek the required dental treatment in Germany whilst on holiday there. Her request for reimbursement of the costs was rejected on the ground that the Dutch legislation is based on the principle of benefits-inkind and that a right to be reimbursed for the costs can only be given in exceptional cases. No emergency situation in the sense of Article 22(1)a of Regulation No 1408/71 existed and there was in the view of the sickness fund "no need" for Ms Müller-Fauré to be treated by a provider with whom the fund has not concluded an agreement. Ms van der Riet is patient who had requested authorisation for an arthroscopy in a Belgian hospital because such an operation could be performed much sooner than in the Netherlands. Ms van der Riet was refused authorisation on the ground that sufficient facilities were available in the Netherlands and that the waiting period was not considered unacceptably long. The questions submitted to the Court by the Central Raad van Beroep largely overlap with those raised in GeraetsSmits and Peerbooms and for this reason the case will not be discussed seperately in this Section. 
sense of Article 50. He concludes that no such classification can be made In the Netherlands general practitioners are not paid for the individual treatments or consultations of patients registered with them. They are paid a fixed amount for every patient regardless of whether or not patients actually make use of the practioners' services. ${ }^{245}$ Contracted hospitals are paid on a treatment-by-treatment basis, but the payments by sickness funds do not necessarily cover the actual cost of medical benefits. On the basis of the specific way in which tariffs for hospital care are calculated, the Advocate General held that these are to be seen as a means of fixing hospitals' yearly budgets. The payments which sickness funds make to health care providers cannot be regarded as remuneration for the purposes of Article $50 \mathrm{EC}$ and, hence, that the authorisation rules in question do not run counter to Article 49 EC. $^{246}$

In case the Court were not to agree with this conclusion, the Advocate General proceeded to consider the restrictive effects of prior authorisation rules and their possible justification. The Advocate-General did not have much difficulty in concluding that the Dutch prior authorisation rules may deter insured persons from approaching providers of medical services established in other Member States and that they therefore burden the right to receive services in other Member States. ${ }^{247}$ In defence of the prior authorisation rules, several grounds of justification were brought forward all of which related to the need to maintain the

245. See also Langer (1999) supra footnote 7, at p.538.

246. Opinion of Advocate General Ruiz-Jarabo Colomer in Case C-157/99 Geraets-Smits and Peerbooms (http://www.curia.eu.int/jurisp) at 41-49.

247. Ibid, at 53-54. In addressing this issue the Advocate General did not consider whether the Dutch rules were to be classed as discriminatory or non-discriminatory. In as far as the free movement of services is concerned there does not seem to be a need for doing so. In the context of the free movement of goods the Court has made a distinction between imports and exports. The prohibition contained in Article 28 (formerly 30) EC may also apply to non-discriminatory rules burdening import (e.g. Case 120/78 Rewe-Zentral [1979] ECR 649), but Article 29 (formerly 34) EC concerning export merely covers discriminatory rules or measures (Case 15/79 Groenveld [1979] 3409). In Alpine Investments, however, the Court refused to make such a distinction in the context of the free movement of services. Case C394/93 Alpine Investments [1995] ECR I-1141. See further Hatzopoulos, Recent Developments of the Case Law of the ECJ in the Field of Services, in: CMLRev (2000) pp.43-82, at pp.69-70. Alpine Investments concerned rules applying to providers of services, but given the goal of Article $49 \mathrm{EC}$ of realising a free movement of services, it could be argued that nondiscriminatory rules burdening the right to receive services in other Member States, in the absence of a justification, may also caught by Article $49 \mathrm{EC}$. In the light of the above, the argument could still be made that prior authorisation rules for non-contracted pharmacists and other product providers which are applied without any distinction as to the State of origin or establishment of the providers do not run counter to Community law. 
financial stability of the health insurance scheme and to protect the infrastructure of the health care system. ${ }^{248}$ Before going into the substance of the claims for justification, the Advocate-General sought to establish whether the prior authorisation rules being challenged were discriminatory or non-discriminatory in nature. The referring Dutch court expressed doubts about the non-discriminatory nature of the Dutch prior authorisation rules. The first reason for this is that Dutch sickness funds have concluded contracts with the vast majority of health care providers established on Dutch territory, whilst only a few "foreign" providers have been contracted. As a result, prior authorisation rules for non-contracted care are likely to work to the detriment of "foreign" providers. The AdvocateGeneral did not consider this a reason for considering the rules in question as discriminatory. There are no legal obstacles to the conclusion of cross-border agreements and, in his view, it would be "quite another thing" for sickness funds, in order to provide better care for their insured, to try to reach agreements with providers based in the vicinity of patients. A second point which made the Dutch court question the non-discriminatory nature of the prior authorisation rules concerned the criteria for granting authorisations. In order to determine whether a given type of treatment is considered "common practice in the profession", and thus whether it is to be regarded as a benefit covered by the health insurance rules, sickness funds mainly, if not exclusively, consider the views of doctors, professionals and hospitals established on Dutch territory. According to the Advocate-General, however, this does not imply that the criterion of "common practice in the profession" is discriminatory because the views of the "national" health professionals are largely influenced by the views expressed by foreign medical specialists in the literature and at international congresses. Also the second criterion, i.e. that medical benefits must be necessary for the treatment of the insured, does not render the authorisation rules discriminatory in the view of the AdvocateGeneral. This conclusion is not affected by the fact that treatment abroad is, under Dutch law, only considered "medically necessary" when the treatment concerned cannot be provided in time by providers on the Dutch territory, because the criterion is applied to all insured persons who wish to move abroad for medical purposes. By merely making a distinction between contracted and non-contracted providers regardless of the State of their establishment, the rules would make no distinction among

248. See the observations of the Netherlands government in Geraets-Smits (Report of the Hearing at points 134-149) and X, Zaken Smits en Peerbooms - Nederlandse Regering: Contractenstelsel niet Strijdig met Europees Recht, in: Zorgverzekeraars Internationaal (1999) pp.6-7. 
the insured on the basis of the origin of medical benefit. ${ }^{249}$

Having established that the authorisation rules in question are formally non-discriminatory, the Advocate-General considered whether the rules could be justified in order to maintain the financial stability of health insurance schemes. Under health insurance schemes such as the one existing in the Netherlands, sickness funds manage their budget by concluding contracts with health professionals and hospitals in which agreements are made as to which medical benefits will be provided and how much sickness funds will pay the providers. In this way, the funding of the care needed by the insured in a given year is fixed in advance so that sickness funds are under no obligation to make any additional payments. Under such a system, prior authorisation rules are, in the view of the Advocate-General, the only means for keeping health expenditure under control. In addition, in a system where capacity planning is regulated in advance through the conclusion of contracts between sickness funds and health providers, he deemed the prior authorisation rules for non-contracted care necessary for maintaining a balanced medical and hospital service and for the maintenance of medical facilities or services which are essential for the public health of the population "so that sickness funds know for which extra help there is a need in order to correct established inequalities". In conclusion, the Advocate-General accepted that sickness funds are entitled to refuse patients authorisation for treatment abroad on the ground that the treatment can be provided by contracted providers established on the national territory.

\subsubsection{Comment}

By holding that the Dutch prior authorisation rules do not violate Article 49 EC, Advocate-General Ruiz-Jarabo Colomer reached the same conclusion as all twelve governments that were represented in the proceedings before the Court in Geraets-Smits and Peerbooms. The conclusions of the Advocate General may not therefore come as a real surprise. His views, however, result from a quite, and arguably too, restrictive interpretation of Kohll and they are not wholly clear on all points.

The latter holds true, for instance, for the Advocate General's conclusion that the challenged prior authorisation rules do not infringe upon Article 49 EC because the medical benefits offered to the insured under

249. Opinion of Advocate General Ruiz-Jarabo Colomer in Case C-157/99 Geraets-Smits and Peerbooms (http://www.curia.eu.int/jurisp) at 55-63. 
the Dutch health insurance rules cannot be classed as "services". Basically, the Advocate General seems to reason that the medical benefits offered by contracted providers are not covered by Article 50 EC because these benefits are not remunerated either by the patients themselves or their sickness funds. Even if one were to agree that payments made by Dutch sickness funds to contracted health care providers cannot be regarded as remuneration, ${ }^{250}$ it is hard to understand why for this reason the care offered by non-contracted providers cannot be classed as a service. The Advocate General's analysis of, and his conclusions as regards, the calculation and the function of tariffs do not apply to non-contracted care providers who are under the Dutch rules in principle paid by the patients themselves in accordance with the reimbursement principle. A possible duty for sickness funds to pay non-contracted providers could possibly undermine the social objectives of benefits-in-kind systems and these may possibly be a ground for justifying prior authorisation rules, but this does not compel the conclusion that the relationship which patients have with foreign care providers operating outside such a system lacks economic character. ${ }^{251}$ The Advocate General stated that he did not have enough information to answer the question whether the services provided by the

250. It may indeed be questioned whether this conclusion is correct. See Section 4.4

251. Also compare in this regard Ferlini $(2000)$ in which the Court was asked to determine whether the application to an EC official by a group of health care providers of scales of fees for care which are higher than those applicable to persons insured under the national insurance scheme, is compatible with Article 12(1) EC and/or Article 81(1) EC. See Section 2.3 (footnote 35 ). The Court merely addressed the compatability of the rules being challenged with Article 12(1), but Advocate General Cosmas did discuss Article 81 EC too. He concluded that the services which the hospitals offer to persons not subjected to the Luxembourg health insurance scheme can be classed as economic activities when a remuneration is paid. The relationship between (public or private) hospitals and persons not affiliated to the national health insurance scheme does not fall within the framework of the national social security system. Such a relationship can be classed as economic in nature without there being a need to consider whether the activities performed within the context of social security systems can be said to be based on the principle of solidarity (e.g. Joined Cases C-159/91 and C-160/91 Poucet and Pistre [1993] ECR I-637). The definition of the term "economic activity" for the purposes of Article $81 \mathrm{EC}$ and the concept of "services" in the sense of Article 50 EC do not necessarily coincide (see e.g. van Gerven et al, Kartelrecht - Europese Gemeenschap (1997) at pp.72-73) and the applicants in Geraets-Smits and Peerbooms were affiliated to the public health insurance rules in the Netherlands. It would seem, however, that also in cases where the person or institution providing the benefits is not subjected to the social health insurance scheme an economic activity may be presumed to be present. Compare also on this point Pieters (1999) supra footnote 35, at pp.94-95. The Dutch health insurance scheme, and its contract model in particular, may on a number of point possibly also be incompatible with the Treaty's competition rules. See further Pieters (1999) supra footnote 35 , at pp.85-112. 
non-contracted German and Austrian doctors or hospitals could be viewed as services for the purposes of Community law, but he did not deem this to be decisive. It would seem, however, that this is the only question which may be relevant.

Furthermore, the Advocate's conclusion that the prior authorisation rules being challenged are to be regarded as non-discriminatory is open to dispute. In the field of the free movement of services, it is often far from easy to establish whether a national rule is discriminatory or non-discriminatory, ${ }^{252}$ but it would seem that the discriminatory effect of formally indistinctly applicable rules cannot be (wholly) ignored. In cases where the discriminatory effect is all "too obvious"253 or clearly protectionist, the rule in question may be classed as distinctly applicable. The Dutch rules have such protectionist effect. A duty to contract care institutions only exists as regards institutions based on national territory and, even where no such duty (would) exist(s), the number of contracted national providers is likely to, and in practice does indeed, exceed the number for contracted foreign providers. For as long as this is the case, preferential treatment of contracted providers de facto discriminates against foreign providers and care. ${ }^{254}$ The protectionist effect of the Dutch rules is even more apparent when one considers the conditions under which Dutch sickness funds may grant authorisation for obtaining medical services from non-contracted providers. ${ }^{255}$ The first criterion, i.e. that benefits must be considered "common practice in the profession", may indeed, as the Advocate General concludes, be indistinctly applicable, but the same cannot be said for the second criterion. Under Dutch law treatment by a non-contracted "foreign" doctor or hospital is only considered necessary for the treatment of the insured when it has been established that the

252. In some cases the Court has held that national rules or measures which do not formally lay down different rules for providers of services established "at home" and providers based "abroad" are to be regarded as indistinctly applicable (see e.g. Case C-204/90 Bachmann [1990] ECR I-249), whilst in other cases it has held that discriminatory rules include those which indirectly give rise to unequal treatment of providers based in other Member States (Case C-484/93 Svensson and Gustavsson [1995] ECR I-3955). On this point see also the Opinion of Advocate General Tesauro in Case C-120/95 Decker and Case C-158/96 Kohll [1998] ECR I-1831 at 44-50.

253. See Opinion of Advocate General Tesauro in Case C-120/95 Decker and Case C-158/96 Kohll [1998] ECR I-1831 at 50.

254. Compare Case C-411/98 Ferlini [2000] ECR I-0000) at 58

255. Initially, the conditions for granting authorisation for non-contracted care "at home" and abroad were not wholly equal, but in response to Decker and Kohll, the Dutch government decided to prepare an amendment to its legislation aimed at equalizing the conditions under which foreign and national providers can conclude agreements with Dutch sickness funds. See Report of the Hearing in Geraets-Smits and Peerbooms at point 127 and 130. 
treatment in question cannot be offered by a non-contracted provider "at home". If not formally discriminatory, this criterion would at the least be de facto discriminatory. ${ }^{256}$ The Dutch and the Luxembourg health insurance rules may differ in many respects, but the combined application of contracts and prior authorisation rules in the Netherlands seals off the national health care market in a similar way to the Luxembourg prior authorisation rules for foreign care. Under both systems preferential treatment is given to providers on the national territory and for publicly insured Dutch patients it would seem equally difficult to cross the border for medical reasons as it is for the insured in Luxembourg.

Presumably, however, the Advocate General wished to avoid classing the rules in question as discriminatory because he is sympathetic, and wishes to have regard, to the financial concerns of the Dutch government. By classing the rules as non-discriminatory, the Advocate General opens the possibility of justifying the rules on grounds of securing the financial stability of the health insurance scheme (rule of reason) without there being a need to demonstrate that the rules are necessary to protect the infrastructure of health care systems (Article 46 EC). The Advocate General stated that in under a health insurance system under which the financing of medical care is fixed in advance through the conclusion of contracts with providers, prior authorisation rules are needed in order to protect sickness funds against unexpected additional expenditure. This may no doubt hold true, but it is to be noted that the Court did not rule in Kohll that the protection of the budgets of individual sickness funds constitutes a public interest for the purposes of the rule of reason. The Court held that "the risk of seriously undermining the financial balance of the social security system" constitutes such an interest for the Member State concerned. ${ }^{257}$ Prior authorisation rules for non-contracted care may be the only way in which individual sickness funds can secure the funding of their budgets, but for the Member State in this case, the Netherlands there might very well be alternative solutions for handling the possible financial consequences of cross-border care. In this respect, States where benefits-in-kind systems exist are in no way unique. Sickness funds operating under reimbursement schemes often also have to work with budgets which are fixed in advance in accordance with the expected expenditure; such funds may be faced with the additional cost of cross-

256. On this point see in particular the views expressed by the European Commission in the proceedings before the Court in Geraets-Smits and Peerbooms (Report of the Hearing at points 110-121).

257. Case C-158/96 Kohll [1998] ECR I-1931 at 41. 
border care. Sickness funds acting under a reimbursement scheme cannot, as Kohll would seem to indicate, apply prior authorisation rules in order to avoid increases in expenditure. The extra cost of cross-border care which cannot be financed out of the budgets of individual sickness funds, in one way or another, will have to be paid out of the general health care budget. In times when the financing of medical care is increasingly put under pressure one cannot ignore the cost of cross-border care, but the Advocate General did not explain why a distinction was to be made in this regard between benefits-in-kind systems and reimbursement systems. If Member States with reimbursement schemes can be required to solve the financial problems caused by cross-border care internally, why should individual sickness funds acting under benefits-in-kind systems be entitled to refuse payment for any medicall bill issued by a (non-contracted) foreign provider?

Comparable comments can be made about the Advocate General's response to the Dutch argument that prior authorisation rules are necessary for "maintaining a balanced medical and hospital service open to all". In a system where capacity planning is regulated in advance through the conclusion of contracts between sickness funds and health providers, he considered prior authorisation rules for non-contracted care justified "so that sickness funds know for which extra help there is a need in order to correct established inequalities". Albeit far from clear, this observation seems based on an interpretation of Article $46 \mathrm{EC}$ which is far more flexible than the Court itself suggested in Kohll. In that judgment the Court held that Article $46 \mathrm{EC}$ only leaves room for national rules which are necessary for "the maintenance of a treatment facility or medical service on national territory" which "is essential for the public health and even the survival of the population". 258 Also these observations need further clarification, but, at the least, they do indicate that the Court requires Member States to demonstrate that the infrastructure of their care system would in some way, or to some extent, be affected if they could not apply prior authorisation rules. In his Opinion in Geraets-Smits and Peerbooms Advocate General Ruiz-Jacabo Colomer did not seem to require any proof from a Member State such as the Netherlands. All Member States including those which have opted for a reimbursement system and where no contract model exist, have to calculate in advance how many hospital beds, doctors and facilities are required. The Netherlands may have chosen to entrust part of its capacity planning policies to individual sickness funds and it may very well be that the ability of these 
funds to perform their task properly could be affected, but it is hard to see why, for this reason, a Member State as the Netherlands is to be given so much more leeway than a State such as Luxembourg.

On the basis of the reasoning followed by the Court in Kohll one could very well reach another conclusion than reached by the Advocate General $^{259}$ and question whether Member States with benefits-in-kind systems require prior authorisation rules any more than States reimbursements systems do. ${ }^{260}$ The Opinion of Ruiz-Jacabo Colomer could be read, however, as a critique of the judgment in Kohll and as an implicit call to the Court to show more restraint in applying the common market rules to, and to give more regard to the specific concerns and interests of the Member States in, the health care and insurance sectors. In the light of the Member States' concerns about the implications of Kohll and the application of the private rules governing the common market in the public health sector, one cannot exclude the possibility that the Court might give in. It is submitted that the Court should not give in, but if in Geraets-Smits and Peerbooms it were nonetheless to do so, it is at least to be hoped that the Court will provide clearer and more persuasive reasons than the Advocate General has done. ${ }^{261}$

259. See e.g. Raad voor de Volksgezondheid, Europa en de Gezondheidszorg (1999) at p.45 (concluding that the Dutch prior authorization are outlawed by Decker and Kohll).

260. See e.g. Marhold (1999) supra footnote 241, at pp.43-48 (holding -in relation to Germany- that, given the small number of migratory patients, benefits-in-kind systems are not in the least threatened by Decker and Kohll).

261. If the Court were to reach the opposite conclusion and oblige sickness funds in principle to reimburse the costs of non-contracted care too, the question would arise which tariffs are to be applied. The prices that sickness funds have agreed upon with the various contracted providers may differ. Arguably, sickness funds would have to apply the highest of all contracted prices. Internally, the insured are entitled to choose among all contracted providers. The price sickness funds and care providers have agreed upon is of no relevance in this regard. Application of one of the lower prices in cross-border cases would have a discriminatory effect with the result that sickness funds (or Member States) cannot claim that this would affect the financial stability of health insurance schemes. This interest was accepted in Decker and Kohll as a possible ground for justification under the rule of reason which does not allow for discriminatory rules. The administrative or practical problems which States may face in reimbursing foreign non-contracted providers in accordance with "contract prices" does not seem a good enough reason for justification. In Terhoeve (1999) the Court held that "considerations of an administrative nature cannot justify derogations by a Member State from the rules of Community law" and this principle "applies with even greater force where the derogation in question amounts to preventing or restricting the exercise of one of the fundamental freedoms of Community law". Case C-18/95 Terhoeve [1999] ECR I-345 at 45 . 
A further question which has been raised is whether the ruling in Kohll also has implications for intramural (or hospital) care. ${ }^{262}$ Kohll itself concerned medical care provided by a dentist operating outside a hospital infrastructure and the Court seemed to have limited its conclusions to such forms of extramural care. ${ }^{263}$ The question of the validity of prior authorisation rules for obtaining hospital care in other Member States is thus still open. ${ }^{264}$

In his opinion in Decker and Kohll Advocate General Tesauro took the view that prior authorisation rules for hospital care are in all circumstances justified. In considering whether the Luxembourg prior authorisation rules could be justified as being necessary for maintaining "a balanced medical and hospital service open to all", the Advocate General made a clear distinction between extramural and intramural care. As regards the former, Tesauro recognised that in the absence of prior authorisation rules patient mobility could increase especially in borderregions. He did not expect, however, that the accessibility of medical services in border regions would be affected. Patient movement was not likely to be "one-way" and the possibility of applying their own reimbursement rates would enable States to secure the funding of medical services. According to the Advocate General this would be quite different as regards the hospital infrastructure. The location and the number of hospitals is determined by forward-planning and the cost of one person's stay in a hospital cannot be separated from the cost of a hospital as a whole. If large numbers of patients were to move across borders to avail themselves of hospital services, hospitals in the State from which they

\footnotetext{
262. See e.g. Schutyser, "Round Table: Positions and Reactions of the Private Actors", in: in: Association Intemationale de la Mutualité/ European Institute of Social Security, Health Care without Frontiers within the European Union - Free Movement of Goods and Services in the Health Care Sector (1999) pp.63-65, at p.64 and Union des Caisses de Maladie (1998) supra footnote 237.

263. The preliminary question the Luxembourg court sent to the Court of Justice was drafted in general terms of benefits and medical services. See footnote 206 above. The Court, however, delimited the issue under consideration by holding that the dispute before the national court concerned treatment provided by an orthodontist established in another Member State, outside "any hospital infrastructure" (Case C-158/96 Kohll [1998] ECR I1931 at 29) and in its final conclusion the Court held that the provisions on free movement of services preclude national rules which make the reimbursement of the cost of dental treatment provided by an orthodontist conditional upon the prior authorisation of sickness fund (Ibid, at 54).

264. Compare Belcher (1999) supra footnote 16, at pp.70-71
} 
moved could be underutilised. Tesauro did not fear that the freedom to choose one's doctor and hospital, would lead to an "uncontrolled and uncontrollable flow of patients", but he did consider prior authorisation rules for intramural care essential for upholding adequate hospital services. ${ }^{265}$

In his Opinion in Vanbraekel Advocate General Saggio also concluded that intramural care is not affected by Kohll. The reasons offered by Saggio differ, however, from the ones given by Tesauro. In Vanbraekel $^{266}$ the Court has been asked whether, in cases in which the medical need for treatment in a foreign hospital has been recognised but in which no prior authorisation has been granted by the competent sickness fund in accordance with Article 22(1)c of Regulation No 1408/71 , reimbursement is to take place in accordance with the rules applicable in the competent State of insurance or the rules in the State where the treatment is provided. The Belgian court which is to decide in the case wondered whether, or the extent to which, the rulings in Decker and Kohll were relevant to the answer to the preliminary question. Advocate General Saggio did not deem these rulings relevant because hospital care would fall outside the scope of Articles 49 and 50 EC. In reaching this conclusion Saggio mainly relied on Humbel (1988). ${ }^{267}$ This case concerned a French national who was working and residing in Luxembourg and who had sent his son to a public secondary school in Belgium. Admission to the school was made conditional upon the payment of a school fee which was not imposed on Belgian nationals residing outside Belgium. The Belgian court which was to decide upon the case asked the Court of Justice whether courses taught at a public secondary school were to be regarded as a service for the purposes of Articles 49 et seq EC and, if so, whether the school fee was consistent with these provisions. The Court answered in the negative. Article $50 \mathrm{EC}$ requires that services are "normally provided for remuneration". The essential characteristic of the remuneration lies, according to the Court, in the fact that "it constitutes consideration for the service in question, and is normally agreed upon between the provider and the recipient of the service". That characteristic was considered to be absent in the case of courses provided under national educational systems which, as a rule, are funded from the public purse. In establishing or maintaining national educational systems States do not seek to be engaged in gainful activity. Rather, by doing so, States are

265. Opinion of Advocate General Tesauro in Cases C-120/95 Decker and C-158/96 Kohll [1998] ECR I-1831 at 58-60.

266. See Section 3.3 footnote 117 .

267. Case 263/86 Ilumbel [1988] ECR 5365. 
fulfilling their duties towards their own population in the "social, cultural and educational fields". ${ }^{268}$ Transposing the ruling in Humbel to the field of health care, Advocate General Saggio concluded that the Treaty provisions on the free movement of services do not apply to benefits which, on the one hand, constitute an integral part of public health systems in as far as these are established and organised by the State and, on the other hand, are financed out of the public purse. ${ }^{269}$

Both Advocates General thus argued that prior authorisation rules for intramural care are in all cases compatible with the Community provisions on the free movement of services. Their views are open to dispute, however. The conclusions drawn in Humbel cannot be automatically transposed to the health care and insurance sector. At least in Member States where social health insurance schemes exist, public hospitals and public schools are funded differently. The latter are largely funded from tax-revenues. School and enrolment fees constitute only a relatively small part of their budgets. Public education is offered largely free of charge and the relationship between public educational institutions and their pupils and students would indeed seem to be non-economic in nature. ${ }^{270}$ This is not as obvious as regards the relationship between public hospitals and patients. Hospitals operating under social health insurance schemes may also receive considerable public subsidies for their basic infrastructure and general running cost, but the main part of their budgets is often funded by payments from sickness funds (principle of benefits-in-kind) or the patients themselves (reimbursement principle). Whenever this is the case, the payments made by sickness funds and/or patients would seem to constitute remuneration in the sense of Article 50

268. Ibid, at 17-19. The fact that pupils or their parents must sometimes pay teaching or enrolment fees was not considered to be of any relevance in this regard. See further the Opinions of Advocate General Slynn in Case 293/83 Gravier [1985] ECR 1425 at pp.602604 and Case 263/86 Humbel [1988] ECR 5365 at pp.5377-5380.

269. Opinion of Advocate General Saggio in Case C-368/98 Vanbraekel (http://www.curia.eu.int.juris) at 19-22.

270. Furthermore, the mere fact that the State, in fulfilling its "welfare duty" vis-à-vis its population, assumes responsibility for establishing and running hospitals does not in itself seem a sufficient reason for excluding hospital care from Articles 49 and 50 EC. A few years after Humbel the Court ruled in Wirth (1993) that "courses given in an establishment of higher education which is financially essentially out of public funds do not constitute services" within the meaning of Article 50 EC. Case C-109/92 Wirth [1993] ECR I-6447 at 19. The Court did not pay any attention to the States' motives or reasons for establishing and organising public schools and it made the answer to the question whether or not a service exists solely dependent on the public or private nature of the funds out of which education is predominantly funded. Ibid, at 19. See further Chapter 5 Section 4.8 . 
EC. Kohll indicates that the fact that medical care is paid by a third party such as sickness funds does not prevent the relationship between the provider and the patients from being defined in terms of the provision of services. ${ }^{271}$ It is not clear, as Advocate General Ruiz-Jacabo Colomer suggests in his Opinion in Geraets-Smits and Peerbooms, ${ }^{272}$ why the payments made by sickness funds cannot be classed as remuneration because they may serve as a means for fixing the yearly budgets of hospitals or because they do not reflect the total cost of intramural care. Also the rates or tariffs charged by private hospitals do not necessarily reflect all the cost of individual treatments and the payments they receive from (private or public) insurers form the main source of their income. It seems beyond doubt, however, that private hospitals may be regarded as providers of services for purposes of Articles 49 and 50 EC. The concept of services may not be interpreted restrictively. ${ }^{273}$ Arguably, neither Humbel nor any other Court judgment compels the conclusion that intramural care wholly falls outside the scope of Articles 49 and 50 EC. ${ }^{274}$

Furthermore, the conclusion of Advocate General Tesauro that prior authorisation rules can in all cases be justified as being necessary for maintaining a "balanced medical and hospital service to all" is open to dispute. In fact, the judgment in Kohll already suggests that the Court does not support this conclusion. In Kohll the Court did recognise that prior authorisation rules may play a significant role as regards the protection of hospital infrastructures, but it did not adopt the reasoning suggested by Advocate General Tesauro. The Court held that Article 46 EC allows Member States to restrict the freedom to provide medical and hospital services in so far as the maintenance of a treatment facility or medical service on national territory is essential to public health. ${ }^{275}$ No distinction was made between intramural and extramural care and the explicit reference to hospital services suggests that prior authorisation rules for intramural care are not automatically lawful.

271. See also Case C-352/85 Bond van Adverteerders [1988] ECR 2085 at 16; Joined Cases C-51/96 and C-191/97 Deliege [2000] ECR I-0000 at 56 and the Opinion of Advocate General Tesauro in Cases C-120/95 Decker and C-158/96 Kohll [1998] ECR I-1831 at 41 . . 272. See Section 4.3.3.

273. Joined Cases C-51/96 and C-191/97 Deliège [2000] ECR I-0000 at 52.

274. Although not decisive, it may be noted in this regard that hospitals, be they public or private, are generally also seen as providers of economic activities for purposes of the competitition rules of Articles 81 and 82 EC. See e.g. Pieters/van den Bogaert (1997) supra footnote 35, at p.16 and Opinion of Advocate General Cosmas in Case C-411/98 Ferlini [2000] ECR I-0000) at 111 .

275. Case C-158/96 Kohll [1998] ECR I-1931 at 50-51. 
Cross-border access to medical care may indeed have more and further reaching implications for intramural care than for extramural care. The case law, however, does not seem to leave much room for an "institutional approach" under which prior authorisation rules for intramural care are automatically valid either because the medical services provided by hospitals can never be classed as a service for the purposes of Article 50 or because the rules are, in all circumstances, considered necessary for protecting hospital infrastructures. The case law, and Kohll in particular, would rather seem to suggest that a "functional approach" is to be followed under which the legality of prior authorisation rules is to be judged on a case-by-case basis. Such an approach also seems preferable. Not only could problems of definition as to what precisely constitutes intramural and extramural care be avoided, ${ }^{276}$ but there also seems no need to exclude intramural care altogether. Cross-border access to intramural care does not necessarily have to affect the funding and hospital infrastructure. It could also help to solve problems of overcapacity and undercapacity (e.g. waiting lists) in the various Member States by bringing shortages and surplusses in intramural facilities into balance.

\subsection{Waiting Lists}

If Kohll were indeed also apply to intramural care, the question arises whether publicly insured patients are now also entitled to circumvent waiting lists by seeking the necessary in hospitals or clinics in other Member States. ${ }^{277}$ Kohll did not concern waiting lists, but the Court's judgment suggests that patients have such a right. The application of prior authorisation rules to "foreign" types of treatment for which "at home" waiting lists exist, hampers freedom of movement. Following the reasoning of the Court in Kohll, this would seem to imply that prior authorisation rules can only be upheld when the Member State concerned can demonstrate that non-payment for treatment in other Member States is

276. Indeed, if intramural care were wholly excluded from the implications of Kohll, some interpretation problems as to what constitutes intramural care and extramural care would arise. See e.g. Pieters (1999) supra footnote 35, at p.85. For instance, should vaccinations for foreign travels given by doctors in a hospital be classed as intramural care? Do patients actually have to be hospitalised in order for their treatment to be classed as hospital care or is out-patient care also covered? Are the services offered in nursing homes to be classed as intramural care?

277. See e.g. Palm et al (2000) supra footnote 4, at p.110 and Cath, Europa en Vrij Verkeer - Consequenties voor de Zorgsector, in: PhW (1999) pp.1779-1780. 
necessary to protect the financial stability of health insurance schemes or the maintenance of a balanced medical and hospital service. The "burden of proof" on Member States seems heavy. The possibly higher cost of treatment in other Member States do not seem a sufficiently good reason for justifying prior authorisation rules. By reimbursing medical services obtained in other Member States in accordance with the national tariffs, sickness funds would seem able to keep health expenditure under control. Admittedly, the cross-border movement of patients circumventing waiting lists could lead to an increase in the number of treatments and thus to additional expenditure. Yet, increases in expenditure seem unable to justify prior authorisation rules or other measures which would exclusively limit the reimbursement of "foreign" medical benefits. The Court has accepted the financial stability of insurance schemes as a possible ground of justification under the rule of reason. As a result, only non-discriminatory measures can be applied in furtherance of this interest. $^{278}$

If correct, refusals to pay for the "foreign" treatment received by patients who are on a waiting list only seem justifiable under Article 46 EC. More specifically, it would seem that Member States will have to demonstrate that non-reimbursement is necessary for maintaining "a treatment facility or medical service on national territory" which is "essential for the public health .. of the population". ${ }^{279}$ It seems virtually impossible to deliver such proof. After all, how does one explain that certain medical services or facilities for which waiting lists exist cannot be maintained when patients seek treatment abroad? Waiting lists are likely to become shorter and the accessibility of the health care system "at home" would be likely to improve. Indeed, cross-border movement of patients may be a means to solve waiting lists problems. Of course, if many patients were to decide "not to wait" and to seek treatment abroad, problems of undercapacity as reflected in waiting lists could turn into problems of undercapacity. In the long run, excessive cross-border patient mobility could endanger the maintenance of certain facilities. Hospitals might have to limit their services, some departments or clinics may even have to be closed down. At present, however, this does not seem an

278. Further, even if one were to agree that the prior authorisation rules of some Member States (such as the Netherlands - compare the Opinion of Advocate General Ruiz-Jacabo Colomer in Geraets-Smits and Peerbooms as discussed in Section 4.3.2) are non-discriminatory, one could doubt whether such rules can be justified on the ground that they are necessary for maintaining the financial stability of health insurance schemes. Costs may increase, but not any increase in costs will have to affect the financing of insurance schemes. 279. Case C-158/96 Kohll [1998] ECR I-1931 at 50-51. 
adequate reason for justifications under Article 46 EC. Patient mobility is still not excessive. Moreover, Kohll suggests that even the mere disappearance or elimination of a given treatment facility or medical service does not suffice for the successful reliance on Article 46 EC. This provision only allows for restrictions on the free movement of services as regards the maintenance of facilities or services which are essential for the public health of the population. The judgment does not precisely indicate what is meant by this, but it could even be reasoned that the maintenance of a given facility or service on the national territory cannot be regarded as "essential" for public health when patients can, at a place not too far from their residence, obtain treatment for a certain disease in another Member State. ${ }^{280}$ Kohll did not concern waiting lists and the possibility cannot be excluded that the Court in a future case would be willing to relax the conditions for invoking Article $46 \mathrm{EC}$, but the wording of the judgment suggests that patients are in principle entitled to circumvent waiting lists by seeking treatment in other Member States and to have the bill (partially or wholly) paid by their sickness fund.

Indeed if patients have this right, and if many of them were to decide to make use of it, questions would arise about the implications of patient mobility for the States to which the patients move. The "patientimporting" States may be confronted with capacity problems. In these States waiting lists might occur or might become longer. The accessibility of the health care system for the population of the host States might be affected. Can these States impose restrictions on the rights of "foreign" patients? Can they give preferential treatment to their "own" resident patients? If the Court's observations in Kohll are taken literally, the questions are to be answered in the negative. After all, the "maintenance" of essential medical services or facilities is only endangered in cases of overcapacity, whilst waiting lists are rather reflections of undercapacity. The maintenance of the medical services in question is not threatened. Rather, there is a demand for more facilities. It should be recognised, however, that Kohll did not deal with the problems faced by the States to which the patients move. The observations of the Court on Article 46 EC were drafted with the "sending" States in mind. As regards these States, it is quite understandable that the conditions for relying on Article $46 \mathrm{EC}$ are quite strict. When patient mobility increases, the "sending" States may possibly face budgetary problems and one cannot exclude the possibility that, over a longer period of time, these may lead to certain capacity problems. In principle, however, for these States the cross-border move-

280. Compare Brouwer (1999) supra footnote 197, at p.24. 
ment of patients on waiting lists would seem to promote rather than undermine the accessibility of their care systems. The "receiving" States are in a fundamentally different position. Kohll may have the positive effect that medical facilities or services for which a surplus exists may be used more efficiently, but for the receiving States patient mobility is more likely to affect the accessibility of medical services. When capacity or waiting-list problems occur, these States are in fact penalised for the fact that other States have not invested sufficiently in health care to avoid waiting lists. Kohll's interpretation of Article 46 does not give any regard to the interests of, and is arguably not to be literally applied to, the receiving States. As significant as the right of patients to move to and to obtain medical services in other States may be, it does not seem desirable to interpret the right so broadly as to have the practical effect of limiting the right of the residents of the State concerned to obtain medical care. It is submitted that in cases where waiting lists exist, and in particular where these are de facto caused by cross-border patient mobility, some form of preferential treatment of residents over non-residents ought to be justified under Article 46 EC.

\subsection{National Health Services}

In the post-Decker/Kohll debates questions have also been raised about the implications of the judgments for national health services. ${ }^{281}$ On the basis of the ruling in Humbel, in which the Court concluded that education cannot be classed as a service in the sense of Article $50 \mathrm{EC}$ when it is mainly funded out of the public purse, ${ }^{282}$ one might be tempted to conclude that Kohll only has minimal implications for national health services which are for the main part financed from tax-revenues. Such a conclusion, however, may be too premature. As noted in Section 4.4, the conclusions drawn in Humbel cannot be automatically transposed to the health care sector. In the field of public education, the State usually acts both as the provider and the funder of the benefits offered. The State does not receive any substantial payment or compensation for the cost incurred

281. See e.g. Baeyens, Free Movement of Goods and Services in Health Care: A Comment on the Cases Decker and Kohll from a Belgian Point of View, in: EJHL (1999) pp.373-383, at p.379; Mc. Conn, "Round Table: Positions and Reactions of the Public Actors", in: Association Internationale de la Mutualité/ European Institute of Social Security, Health Care without Frontiers within the European Union - Free Movement of Goods and Services in the Health Care Sector (1999) pp.39-4) and Langer (1999) supra footnote 7, at p.538.

282. See the previous Section. 
by students, their parents or another "actor". Public education is provided largely free of charge. The relationship between public educational institutions and their students indeed seems to lack the necessary economic character. That relationship, however, may very well be economic in nature when the courses offered to students by public schools or universities are mainly funded from sources other than tax-revenues ${ }^{283}$ or, possibly, when students attend courses at independently operating private schools which are subsidised by the State. ${ }^{284}$ In general, in the case of bi-partite provider-recipient relationships under which the State itself acts as the provider, the "public/private funding distinction"285 may indeed constitute the main, and perhaps the decisive, criterion for determining the economic character of activities performed. However, neither Humbel nor any other judgment compels the conclusion that the same also holds true when the State provides benefits which are paid by a third party or when it funds benefits which are provided by third parties.

If this interpretation of Humbel were correct and were transposed to national health services, then one could first of all conclude that Kohll might also have implications for the prior authorisation rules which national health service institutions apply themselves. The relationship between patients affiliated to e.g. the national health service of the United Kingdom and providers established in another Member State may very well be defined in terms of the provision of services. The fact that the medical benefits which British patients obtain in other Member States are ultimately (to be) funded out of taxes rather than insurance premiums does not in itself seem a good enough reason for classing the relationship of patients with foreign providers as non-economic in nature. ${ }^{286} \mathrm{In}$ principle, there do not seem to be persuasive reasons why patients covered by national health services should be wholly excluded from Kohll. ${ }^{287}$

283. For instance, the post-graduate courses or facilities which public universities offer are usually funded out of tuition fees or alternative private funds. The possibility cannot be excluded that such courses may constitute services in the sense of Article 50 EC.

284. Compare Schulz, Freizügigkeit für Unionsbürger (1996) at pp.159-160.

285. O'Leary, The Evolving Concept of Community Citizenship - From the Free Movement of Persons to Union Citizenship (1996) at p. 75.

286. Compare Case 344/87 Bettray [1989] ECR 1621 at 15 (holding that the status of Community worker for the purposes of Article $39 \mathrm{EC}$ can also be acquired when the remuneration is largely provided by subsidies from public funds).

287. Possibly, prior authorisation rules for foreign care applied by national health service institutions could be saved if the Court were to rule in Geraets-Smits and Peerbooms that the Dutch authorisation rules, which are formally based on a distinction between contracted and non-contracted providers, do not infringe Article 49 EC. 
Furthermore, medical care offered in States where national health services exist, does not necessarily have to fall outside the scope of Article $50 \mathrm{EC}$. Under most national health services medical care was initially both Stateprovided and State-funded, but reforms in recent years have largely seperated the provision and the funding of medical care. Usually, medical treatment is still ultimately paid for out of the public purse, but the care itself is increasingly provided by hospitals and general practitioners operating on an independent and (semi-)commercial basis. ${ }^{288}$ The relationship between national health service institutions and "their" patients may not necessarily be classifiable in terms of the provision of services, but the relationship between private health care provider and their patients in a Member State such as the United Kingdom, be they established in the United Kingdom or another Member State, would seem to be economic in nature. ${ }^{289}$

Further, Humbel does not necessarily imply that Community law has no implications for medical benefits offered by or in national health service institutions. The judgment suggests but does not wholly exclude the possibility that such medical benefits can be defined as services. The medical benefits which these providers offer to their "national" patients are largely funded out of the public purse and, hence, do not seem to constitute services. However, when the benefits are offered to foreign patients this conclusion is not entirely obvious. In this regard, education and health care differ. At present, no Community rule or mechanism exists which imposes on the State from which students move a duty to bear the true economic cost of the education which students receive in other States. The relationship between public universities and foreign students seems to lack an economic character because there is no third party which can be required to pay the cost or, in terms of Article $50 \mathrm{EC}$, the remuneration. In the area of health care, however, such compensation or reimbursement mechanisms do exist. All Member States can be required to pay the cost of the care which "their" patients have obtained in other Member States under the regime of Regulation No 1408/71 and

288. For instance, the District Health Authorities in the United Kingdom were initially supposed to provide medical care themselves, but today they are above all entrusted with the task of purchasing for their residents medical care from the most efficient hospitals. See Barr (1998) supra footnote 2 (Chapter 12).

289. Compare Eichenhofer (1998) supra footnote 240, at pp.14-15 and Hervey (2000) supra footnote 35 , at p. 42 . 
all States have developed their own authorisation policies. ${ }^{290}$ In crossborder situations, medical benefits offered by national health services do seem "normally provided for remuneration" and it could be argued that sickness funds burden the free movement of services whenever they refuse to pay for the cost of care offered by national health services in other Member States.

Furthermore, even if medical benefits offered by national health services do not fall within Articles 49 et seq, they are not necessarily excluded from Community law in general. In Humbel the Court may have ruled that students cannot rely on Articles 49 and $50 \mathrm{EC}$ in order to claim admission to public universities or schools in other States, but in Gravier (1985) and subsequent judgments the Court concluded that students do have such a right under Articles 12 juncto Articles 149 and 150 EC. ${ }^{291}$ Read together, Gravier and Humbel suggest that access to education is covered by the Treaty and that the Court has merely chosen to deal with questions concerning the cross-border access to public and private education under different legal headings. ${ }^{292}$ When these conclusions from the educational case law are transposed to the health care sector, it could be argued that Article $12 \mathrm{EC}$ entitles Community citizens to gain access to health care in other Member States in cases where Article 49 cannot be relied upon. ${ }^{293}$ If so, patients could possibly further claim that a refusal to bear the cost of care obtained from national health service institutions hampers the right to obtain health care in other States

The Court's case law in the field of education does not compel the above conclusions regarding the health sector, and national health services in particular. Contrary to arguments occasionally made, ${ }^{294}$ however,

290. One could object and claim that in cases where the patients' sickness funds refuse to grant authorisation and to pay the medical bill issued by national health service institutions or doctors, the latter cannot be seen as a "remunerated" providers of services and that for this reason prior authorisation rules cannot be said to violate Article $49 \mathrm{EC}$. Yet, if this were correct, Member States could unilaterally define the Community concept of services by "simply" granting or refusing a right to reimbursement.

291. Case 293/83 Gravier [1985] ECR 593. See further Chapter 5 Section 4.

292. See van der Mei, The Elusive and Exclusive Concept of Union Citizenship, A Review Essay, in: MJ (1998) pp.391-402, at p.396.

293. Compare Case C-411/98 Ferlini [2000] ECR I-0000 at 62. Access to health care can be classed as a social advantage in the sense of Article 7(2) of Regulation No 1612/68 (see Chapter 2 Section 2.3, supra footnote 40 and the Opinion of Advocate General Cosmas in Case C-411/98 Ferlini [2000] ECR I-(0)O()) and, as follows from the judgment in Martinez Sala, hence, falls within the scope of Community law and Article 12 EC. Case C-85/96 Martinez Sala [1998] ECR I-2691 at 57.

294. See the Opinion of Advocate General Saggio in Case C-368/98 Vanbraekel (http://Www.curia.eu.int/juris) at 21 . 
Humbel neither compels the conclusion that (prior authorisation rules for) publicly funded medical care systems such as national health services are exempt from the limitations imposed by Community law.

\subsection{Medical Benefits not Covered by Insurance Packages}

Another issue to be adressed is whether publicly insured patients can now also rely on Articles 28 and 49 EC in order to claim reimbursement for the cost of "foreign" medical products or services which are not available in the State where they live and/or are not covered by the legislation under which they are insured. The importance of the issue can hardly be underestimated. If prior authorisation rules for excluded medical benefits were compatible with Community law, Decker and Kohll would be deprived of much practical significance. For the vast majority of patients who do not live in border regions and who are not placed on waiting lists, the rulings would have little significance if they only entitled them to benefits they can also obtain "at home". ${ }^{295}$ If, however, prior authorisation rules for non-covered benefits were in principle also prohibited, Decker and Kohll would offer publicly insured patients a much broader range of medical benefits to choose from. They would be entitled to

295. This may particularly hold true for medic(in)al products. Pharmaceutical companies often "split up" the common market by distributing the same or comparable products in the different States under different names, with different trade-marks or in different packagings. Compare e.g. Case C-379/97 Upjohn [1999] ECR I-0000. As a result, patients who upon their doctor's prescription have bought medicines in other Member States which are formally not included in their insurance package, but which qua substance or therapeutical effects are (virtually) identical and which might have been included if they could be purchased for the same price in other States, can be refused reimbursement for such products.

To be sure, if Decker does not entitle publicly insured patients to obtain "other" or in their view "better" medic(in)al products, the judgement may still have indirect implications for the southern States in particular. When prices for medicines (or the co-payments) in other Member States are lower than "at home", the insured may move to and buy medicines in these States. Patients could import cheaper medicines and, if they were to do so on a large scale, the sales of medicines in the home State could be affected. Pharmaceutical companies might be tempted to combat such a development of parallel imports by developing a European price policy. For many States, and in particular the southern States where prices are now comparatively low, this may lead to a price increase for medicines which may again be a reason for limiting insurance cover. See Hermesse, Opening Up the National Borders to Patients - The Economic Consequences, in: Association Internationale de la Mutualité/ European Institute of Social Security, Health Care without Frontiers within the European Union - Free Movement of Goods and Services in the Health Care Sector (1999) pp.49-58, at p.55. 
obtain in other Member States new and other types of benefits which are not (yet) available "at home" but which may be essential for their health.

The most commonly expressed view is that patients are not entitled to be reimbursed for "foreign" medical benefits which are not covered by the legislation under which they are insured. ${ }^{296}$ In GeraetsSmits and Peerbooms Advocate General Ruiz-Jacabo Colomer shares this view. In his opinion, a non-covered medical benefit cannot be classed as a "covered benefit" solely because it has been obtained in another Member State. For as long as insurance packages have not been harmonised at Community level, Member States cannot be required to include in their legislation all medical benefits which other Member States have included in their legislation. ${ }^{297}$ The possibility certainly cannot be ruled out that the Court will draw a similar conclusion, but the issue is not as simple or obvious as Ruiz-Jacabo Colomer suggests. Existing case law does not provide much, if any, support for the argument that the absence of harmonisation measures is in itself a good enough reason for upholding national rules. On the contrary, the case law demonstrates that for as long as harmonisation has not taken place, national rules hampering freedom of movement are in principle prohibited. The rules can only be validy applied when they are necessary for, and proportional to, a legitimate public interest. ${ }^{298}$ The mere power to lay down rules for entitlement to social security benefits has never been recognised as such an interest. Consider Duphar (1984). The Court was asked in this case to determine whether Member States, with a view of making savings, can exclude certain medicinal preparations from their reimbursement scheme without violating the Treaty provisions on the free movement of goods. The exclusion of medicinal products from reimbursement schemes may affect free trade among Member States, but the Court ruled that Community law does not take away from the Member States the power to organise their social security systems and to adopt "provisions intended to .. promote the financial stability of their health care insurance schemes". According to the Court, it was not incompatible with Community law for Member States "to prepare limitative lists excluding certain products from the reimbursement scheme" which are "drawn up in accordance with objective criteria, without any reference to the origin of the products" and which

296. See e.g. the views expressed by the various governments in Geraets-Smits and Peerbooms and Langer (1999) supra footnote 7, at p.540.

297. Opinion of Advocate General Ruiz-Jacabo Colomer in Case C-157/99 Geraets-Smits and Peerbooms (http://www.curia.eu.int/juris) at 59-60.

298. See Chapter 2 Section 7.3 
"are verifiable by any importer". ${ }^{299}$ The rules challenged in Duphar could be upheld, but the judgment demonstrates that medical products which are not, or have not yet been, included in the reimbursement scheme are also to be regarded as goods for the purposes of Community law and that national rules or measures burdening freedom of movement can only be saved when proven necessary for the protection of a public interest. The Court did not state that the States' autonomy in the fields of health care and insurance constitutes such an interest. The accepted ground for justification concerned the financial stability of the insurance schemes. Ultimately, therefore, the Court did not seem to have said much more than that Member States are entitled to keep health expenditure under control by excluding "too expensive" medical products or services from their reimbursement scheme.

National rules denying reimbursement for "foreign" benefits not included in the national insurance package would seem to need a more substantive and specific ground for justification than the mere power to define insurance packages. If correct, patients' rights would be significantly extended. It would seem virtually impossible to justify prior authorisation rules on financial grounds. The financial stability of insurance schemes does not have to be affected because of price differences among Member States. The price or the cost of medical benefits which patients have obtained in other Member States may very well be lower than the benefits available at home. Further, since Decker and Kohll it would seem possible to safeguard the funding of health insurance schemes by limiting the reimbursement of more expensive "foreign" benefits in accordance with the tariffs applied to the "equivalent" benefits which have been included in the national insurance legislation as regards the treatment of a given illness or disease. ${ }^{300}$

299. Case 238/82 Duphar [1984] ECR 523 at 16-21.

300. Admittedly, price regulations for medic(in)al products and benefits are often far from transparent and it may be quite difficult to determine which national medical products or services are to be regarded as the equivalent of foreign benefits. Compare also Brouwer (1999) supra footnote 197, at p.23. Yet, the Court's observations in Terhoeve that "considerations of an administrative nature cannot justify derogations by a Member State from the rules of Community law" and that this principle "applies with even greater force where the derogation in question amounts to preventing or restricting the exercise of one of the fundamental freedoms of Community law" (Case C-18/95 Terhoeve [1999] ECR I-345 at 45) cast doubt as to whether difficulties in determining the "foreign" equivalents of medical benefits for a given disease can justify refusals for payment.

As regards illnesses or diseases for which no benefits have been included in the insurance schemes, or for which no "equivalents" exist, an obligation to pay the costs could cause budgetary problems for sickness funds. Yet, the number of disedses for which no 
Difficult questions arise as regards the possible justification of prior authorisation rules for non-covered benefits on grounds of public health. At first glance, Decker and Kohll do not seem to leave any room for justification on this ground. The Court rejected Luxembourg's claim that prior authorisation rules were necessary in order to enable it to supervise the quality of medical benefits which the insured obtain in other Member States. Under reference to various directives on the mutual recognition of diplomas for (the medical) professions, the Court held in Kohll that for the purposes of the free movement of goods and services health care providers "established in other Member States must be afforded all guarantees equivalent to those accorded to" providers established on national territory. As a result, the Luxembourg rules in question could not be justified on grounds of public health. ${ }^{301}$ As such, the conclusions of the Court were understandable. If the Court had accepted the Luxembourg argument, it would have given Member States an almost blanket permission to refuse reimbursement for the cost of any "foreign" medical benefit. A simple reference to differences in national legislations would have sufficed. However, the Court's observation that foreign providers must be afforded all guarantees equivalent to those accorded to national health providers, is not entirely clear. First, the rules concerning the recognition of diplomas and admission to medical professions may have been subject to harmonisation measures, but the same does not hold true for rules concerning licenses for the establishment of hospitals and health care institutions. Does this imply that foreign hospitals do not have to be accorded the guarantees accorded to national hospitals for the purposes of the reimbursement of the cost of intramural care? Second, even if one were to accept that doctors, pharmacists, etc. possess qualifications and skills of an equal quality, it is to be recognised that medical codes of conduct may differ and that some Member States invest far more in medical research and technology than others. Doctors and other providers make use of quite different tools and/or facilities with the result that the quality of the medical products or services received by patients may differ in practice. In cases where it can be established that the quality of foreign care is at least equal to the quality of care provided "at home" arguments about refusing reimbursement on public health grounds are not persuasive. Yet, what is the situation where, on objective grounds, it can be established that "foreign" benefits do not meet quality standards laid down in

medical treatments or medicines are included in the insurance packages of the Member States does not seem so large that a duty to pay for such benefits will seriously affect the financial stability of health insurance systems.

301. Case C-158/95 Kohll [1998] ECR I-1931 at 46-48. 
the regulations applied by sickness funds? Are States or sickness funds entitled to refuse payment for, in their view, "inferior" medical benefits? Under national law, governments have the task of securing the quality of the medical services offered to the insured, and one might therefore be inclined to conclude that sickness funds are indeed entitled to refuse payment for "inferior" benefits. One cannot be certain, however. In the context of Regulation No 1408/71, Member States have accepted the rule that medical benefits in kind are to be provided in accordance with the legislation of the State where the benefits are provided. Arguments concerning the protection of public health have never been made. So, why should a different rule now be applied as regards patients "who have made use of Decker and Kohll"? Further, the quality of medical care is not determined by reimbursement rules. It is determined by rules concerning medical education, codes of conduct and regulations on health, safety and the efficacy of medical benefits. How does one explain that a denial of reimbursement of the cost of foreign medical services performed in accordance with the legislation and rules applicable in the State concerned, undermines the ability of the State of insurance to protect public health?

More questions ${ }^{302}$ could be raised; answers are not always read-

302. Comparable questions could be raised as regards abortions, gender re-assignment surgeries or medical treatments in the form of artificial insemination whereby the sperms of deceased persons is used (see e.g. the British case R. v Human Fertilisation and Embryology Authority, ex parte DB [1997] CMLRep 591) and other types of treatment which have deliberately been excluded on the ground that they are considered contrary to public morality and/or medical ethics. The mere fact that medical products or types of treatment are considered immoral or illegal in the State of insurance does not prevent them from being classed as goods (see e.g. Case 294/82 Einberger [1984] ECR 1177 - illegal drugs) or services (see e.g. Case C-159/90 Grogan [1991] ECR I-4685 at 20-21 - abortions) for purposes of Community law. The protection of public morality on the national territory does not seem a good enough reason for preventing patients from obtaining such benefits in other States (compare Opinion of Advocate General van Gerven in Case C-159/90) Grogan [1991] ECR I-4685 at 29 ), but it would seem that sickness funds are under no obligation to pay the cost of "immoral" benefits. The notion of public morality is to be defined by individual Member States and their definition are not be replaced by definitions of or views in other Member States. On Grogan see further e.g. O'Leary, The Court of Justice as a Reluctant Constitutional Adjudicator: an Examination of the Abortion Information Case, in: ELRev (1992) pp. 138-157.

Further, if patients were entitled to have the costs of foreign medical benefits which are not covered by their own insurance package paid by their sickness fund, patient mobility might increase. The State where these benefits are provided may be confronted with an increased influx of foreign patients and possibly face capacity problems. Compare Hervey (2000) supra footnote 35 , at p.42. Is, and if so under which conditions is, this State entitled to preserve the benefits in question for its "own" patients? 
ily available. The Court could avoid difficult questions by simply confirming the view of Advocate General Ruiz-Jacabo Colomer that prior authorisation rules for non-covered benefits are justified because Member States are free to define their own insurance packages. Such a conclusion, however, does not necessarily follow from existing case law and would imply a significant limitation of the rights of patients. Due regard is to be given to the States' interests in the health care and insurance sectors; some limits on patients' rights may be required. It is submitted, however, that there is no need for national rules which deny the insured reimbursement for medical benefits simply on the ground that they are not included in "their" insurance package.

\subsection{Third Country Nationals}

A first glance, Decker and Kohll do not seem to have any implications for persons who do not hold the nationality of one of the Member States. Community law, as it stands at present, does not confer upon third country nationals the right to travel to other Member States. ${ }^{303}$ This is not to say, however, that the rulings have no significance for them. ${ }^{304}$ Two points can be made.

Firstly, in order to establish "an area of freedom, security and justice", Article 61 EC confers upon the Council the task of adopting the measures necessary for the abolition of border controls. Once these measures are adopted, third country nationals will fall within the scope of Community law and enjoy the right to travel freely within the Community. This will not automatically entitle third country nationals to take up employment, to establish a company or to provide services in other Member States. The relevant Community provisions expressly preserve these rights for Community citizens. ${ }^{305}$ Article 49 EC, however, does not contain a nationality requirement for service recipients and it could thus be argued that, in the (near) future, third country nationals will be

303. See Chapter 2 Section 5 .

304. Compare also Nickless, Kohll and Decker: A New Hope for Third Country Nationals, in: Eurohealth (1999) pp.20-22.

305. See Article $39 \mathrm{EC}$ juncto Article 7(1) of Regulation No 1612/68 (right to take up employment, Article $43 \mathrm{EC}$ (right of establishment) and Article 49 (right to provide services) EC. 
able to benefit from Decker and Kohll under the same conditions as Community citizens can. ${ }^{306}$

Secondly, the fact that Community law does not confer upon third country nationals a right to travel across intra-Community borders does not necessarily mean that third country nationals who have acquired a right to enter other Member States under national or international law cannot benefit from the Decker and Kohll rulings. Reference may be made to the 1998 judgment of the Court in Martinez Sala. It may be recalled $^{307}$ that Ms Martínez Sala was a Spanish national who lived in Germany and who claimed a right to equal treatment as regards childraising allowances under Article 12 EC. Ms Martínez Sala did not seem to fall within the scope of the Treaty provisions on the free movement of workers and, as a recipient of a social assistance benefit, she did not meet the financial means requirement laid down in Directive No 90/364. Ms Martínez Sala resided in Germany by virtue of an international agreement to which both Germany and Spain were parties. The German government argued that she could not rely on Article 12 EC because she would fall outside the personal scope of Community law. The Court disagreed. As a Community national lawfully residing in the territory of another Member State, she fell within the Treaty provisions on European citizenship and this, so the Court ruled, sufficed for reliance on Article $12 \mathrm{EC}$ as regards all benefits falling within the material scope of Community law. ${ }^{308}$ Admittedly, Martínez Sala concerned a Community citizen residing in another Member State; the case did not concern, and the Court did not make any comments on, third country nationals who are merely travelling to other Member States. Yet, the judgment does indicate that Community law not only protects the legal status of persons who are staying or residing in other Member States by virtue of Community law itself. It could be argued that in deciding on the legality of prior authorisation rules applied to third country nationals, national courts must include in their considerations the fact that such persons may have acquired the right to enter a Member State on the basis of national law or international agreements. A duty to consider this "acquis non-communautaire" could possibly imply that national courts cannot deny third country nationals the right to rely on Article $49 \mathrm{EC}$ on the ground that they have no right to

306. Compare Guild, European Community Law From a Migrant's Perspective (2000) at pp.41-42.

307. See in particular Chapter 2 Section 4 and Chapter 3 Section 4.3.

308. Case C-85/96 Martínez Sala [1998] ECR I-2691 at 61-62. 
enter other Member States. ${ }^{309}$ Martinez Sala certainly does not compel such a particularly, and perhaps indeed overly, broad interpretation of Article 49 EC, but from a health care perspective much can be said for it. The reasons why third country nationals still do not enjoy a right to travel freely within the Community are different from, and do not seem in any way related to, the motives for applying prior authorisation rules. The right to travel is denied in order to protect the immigration and related policies of the host States, whilst prior authorisation rules are applied in order to protect the health care and insurance interests of the State where patients are insured. For the latter State it does not seem in any way relevant whether patients are admitted to other States by virtue of Community law, national law or international law. Why would third country nationals who are insured, and pay premiums, under the same conditions as the nationals of the State of insurance and which have lawfully entered, and obtained medical benefits in, other Member States be denied reimbursement of the cost incurred? $?^{310}$

309. On a possible duty of national courts to use this "acquis non-communautaire" see e.g. also the Opinion of Advocate General Cosmas in Case C-378/97 Wijsenbeek [1999] ECR I0000 at $107-116$

310. One could even go one step further and claim that all third country nationals established in the Community are at present already entitled to rely on Article $49 \mathrm{EC}$ in order to claim the right to move to and receive medical services in other Member States. Compare e.g. Hatzopoulos (2000) supra footnote 247, at pp.58-59; Kapteyn/Verloren van Themaat, Introduction to the Law of the European Communities (1998) at p.751 and Hatzopoulos, Annotation Svensson, in: CMLRev (1996) pp.569-588, at p.575. Some, although not conclusive, support for this view seems to have been given in Svensson where the Court held that Luxembourg had violated Article 49 EC by making the grant of an interest rate subsidy in respect of housing subject to the condition that the loan had been obtained from credit institutions established in Luxembourg. The Court did not attach any importance to the fact that the plaintiffs were third country nationals. Unlike Advocate General Elmer, the Court was of the view that the plaintiifs did have standing under Community law. Case C-484/93 Svensson [1995] ECR I-3955. In the absence of a nationality requirement in Article 49 EC and any compelling economic objections, why should equally insured third country nationals not be entitled to benefit from Decker and Kohll? It is doubtful, however, whether the argument has much chance of being accepted in the near future. The wording of Article $49 \mathrm{EC}$ may not exclude the possibility that third country nationals residing within the Community can be classed as recipients of (medical) services, but Article 1 of Directive No 73/148 (OJ 1973 L 172) does state that Member States are merely obliged to abolish restrictions on the free movement rights of "nationals of the Member States wishing to go to another Member State as recipients of services". No similar provision for third country nationals exists and the Court has never held that a similar obligation vis-à-vis third country nationals can be read in Article 49 EC. In fact, in Wijsenbeek (1999) the Court seems to have rejected such an obligation where it held that Member States are at present still entitled to require from persons who wish to cross their borders to present a valid passport as provided for by inter alia Directive No $73 / 148$ in order to establish whether the person concerned is a Community 


\subsection{Conclusions}

The judgments in Decker and Kohll have made it patently clear that the initial, and long-held, assumption that cross-border access to health care would fall into a legal "vacuum, hermetically sealed from the impact of the European Single Market" ${ }^{\prime 11}$ no longer stands. Patients can claim cross-border health care rights not only under Regulations No 1408/71 and No 574/72, but also under the Treaty provisions on the free movement of goods and services. This section has demonstrated, however, that it is at present still far from clear how far the impact of the common market rules reaches. ${ }^{312}$ Afraid as they are that the common market rules and its private principles of free competition and laissez-faire will affect their public health care systems and undermine the solidarity on which these systems are based, ${ }^{313}$ Member States have generally interpreted Decker and Kohll very restrictively. ${ }^{314}$ The judgments would have no implications, or if any, only minor, for benefits-in-kind systems, national health services, intramural care and medical benefits which have not been included in the national health insurance packages. If all Member States' interpretations of Decker and Kohll were accepted, the rulings would lack much practical significance. The rulings would not entail much more than a right for Community citizens who are insured under a social health insurance system based on the principle of reimbursement of obtaining medical benefits from a general practioner or other health professional operating outside a hospital which they can also obtain "at home". Advocates General Saggio and Ruiz-Jacabo Colomer seem to support a restrictive interpretation of Decker and Kohll. In their opinions in Vanbraekel and Geraets-Smits and Peerbooms, they both seem to call upon the Court to show restraint in applying the common market rules in the health care and insurance sectors. Cross-border care, so they seem to

citizen having the right to move freely among the Member States or a third country national not having that right. Case C-378/97 Wijsenbeek [1999] ECR I-0000) at 43.

311. Belcher (1999) supra footnote 16, at p.116.

312. See e.g. the Opinion of Advocate General Saggio in Case C-368/98 Vanbraekel (http://www.curia.ei.int/juris) at 17-18.

313. See e.g. the views expressed by Seehofer, in: Der Spiegel of 4 May 1998.

314. For an overview of the Member States' reactions see Palm et al (2000) supra footnote

4 , at pp.82-92 
argue, should not be legally enforced but be promoted by the Member States acting on a voluntary basis. ${ }^{315}$

As such, Member States' concerns about the implications of crossborder care are justified. One must be careful in applying private rules governing the common market to a traditionally, and still predominantly, publicly organised sector in which financial limitations make it increasingly difficult for governments to satisfy the growing demands for adequate and sufficient medical care. The more specific arguments submitted by Member States, however, are not always persuasive. This particularly holds true for Member States who claim that their system differs from the Luxembourg system and that for this reason the conclusions drawn in Decker and Kohll cannot be applied, or transposed, to their system. Certainly, the way Member States have internally organised, and regulated access to, their systems differs. Yet, viewed from the perspective of cross-border care, and looking through the formal structures and rules of the systems, ${ }^{316}$ the similarities among the systems seem far more pertinent than the differences. All public health care and insurance systems are territorial in nature. They are all based on the notion that the insured must in principle obtain medical care from providers operating under their systems and/or based on national territory. Prior authorisation rules, however they may be phrased, all intend to, or at least have the effect, of "keeping patients at home" and in all Member States authorisation rules are claimed to be necessary in order to safeguard the financial stability and infrastructure of the systems. Precisely these two interests, however, have been recognised by the Court as grounds for a possible justification of national rules governing the crossborder access to medical services. In some respects the rulings in Decker and Kohll may be tied to the facts of the cases and the specific features of the Luxembourg system, but the two exception grounds have been drafted in such general terms that they entitle all Member States to impose limits on cross-border care whenever, and in as far as, this is necessary for the main social objectives which they all, in their own way, aim to achieve in the field of health care. Decker and Kohll suggest that the Court has opted

315. See e.g. the Opinion of Advocate General Ruiz-Jacabo Colomer in Case C-157/99 Geraets-Smits and Peerbooms (http://www.curia.eu.int/juris) at 75-80 where he calls upon Member States to pursue more flexible prior authorisation policies. See further also Stiemer who states that the degree to which Decker and Kohll "will have any impact upon Member States with a benefits in kind system will largely depend on whether, and to what extent, these Member States feel they are under any obligation to these judgements". Stiemer (1999) supra footnote 45 , at pp.233-234.

316. Compare du Pré (1998) supra footnote 232, at pp.371-372. 
for a substantive approach under which the need for prior authorisation rules and other rules governing cross-border access to care is to be judged on a case-by-case basis. The judgments do not seem to leave much room for more formal arguments according to which certain types of medical care or certain types of systems are wholly exempt.

The considerable criticism and the numerous concerns which have been expressed in the "post-Decker/Kohll" debates may of course alarm the Court and warrant some restraint in applying free movement rules in the health sector. It is submitted, however, that the Court should not give in to the suggested formal arguments according to which benefits-in-kind systems, national health services and intramural care would be wholly immune from the limits imposed by Community law. In order to have due regard for the Member States' interests there is no need to categorically deprive patients of rights which may be crucial for their health. The functional approach the Court seems to have followed in Decker and Kohll enables it to promote the interests of patients and, where necessary, to have regard to the Member States' interests. In order to remove many of the current concerns about the implications of the rulings, it would be desirable if the Court, in future cases, would define the precise contours of the grounds of justification in Decker and Kohll more clearly and possibly somewhat more flexibly. A mere increase in expentitures does not seem to suffice, but when can Member States claim that there is a risk that the financial stability of their systems is seriously undermined? What does the observation actually mean that Member States are permitted "to restrict the freedom to provide medical and hospital services in so far as the maintenance of a treatment facility or medical service on national territory is essential for the public health and even the survival of the population"?

The main aim of this book is to examine the degree to which European Community law entitles individuals to move to and to claim access to public services in other Member States. The Community, however, is still a relatively young and inexperienced organisation which can learn from other "federal-like" entities in determining how cross-border access to public benefits can be best regulated. For this purpose, the book also investigates how American constitutional (and, where relevant, federal) law has sought to reconcile the constitutional guarantees of freedom of movement and equality of treatment with the need to safeguard the 
quality of public services. ${ }^{317}$ This section examines the United States' rules and principles governing the degree to which individuals can seek access to medical care in other States.

\subsection{The American Health Care System}

The United States has a vast and complex health care system which differs in many respects from, and is far more costly ${ }^{318}$ than, the European systems. ${ }^{319}$ The American health care system is highly fragmented; it consists of numerous sub-systems which serve different categories of persons and in which various public and private "actors" play a role in the delivery, funding and organisation of medical care. Its complexity and the differences between it and the European countries are caused, and explained, by the fact that the American system is esentially a private system based on the market model. In the United States health care has always been, and still is, seen as the prime responsibility of the individual rather than the State or society. ${ }^{320}$ In the European Community approximately $95 \%$ of the population is covered by a public health care or

317. See Chapter 1 Section 3.3.

318. The American health care system is the most expensive in the world. In 1995 about $13 \%$ of the gross domestic product (GDP) was spent on health care, whilst the European Community's Member States spent on average approximately $8-9 \%$ of their GDP on health care. See Shi/Singh, Delivering Health Services in America - A Systems Approach (1998) at p. 449 .

319. For more extensive descriptions of the United States health care system(s) see e.g. Verbelen, The United States' Health Care System. Invisible Hand, Visible Effects (1995); Furrows et al, Health Law - Cases, Materials and Problems (1991); Committee for the Study of the Future of Public Health, The Future of Public Health (1988); Neipp, Das Gesundheitswesen der USA: Ein Vorbild für die Gesetzliche Krankenversicherung? (1988) and Williams/Torrens, Introduction to Health Services (1984).

320. The Federal Constitution does not confer upon Congress or the States an obligation to provide health care facilities, to pay for individuals expenses or to protect health. Maher $v$ Roe, 432 US 464 (1977) at 469-470. See further e.g. Capron, United States of America, in: $\mathrm{X}$, The Right to Health in the Americas (1989) pp.498-520. If an individual has no access to care because a State has not provided medical benefits, that problem stems, according to the Supreme Court, from his own indigence and not from any failure on the part of the State. Parmet, Regulation and Federalism: Legal Impediments to State Health Care Reform, in: AJLM (1993) pp.121-144, at p.124. See also Parmet/O'Connell, Rehnquist's Road to Serfdom: The Ominious Message from Rust $v$ Sullivan, in: AP (1992) at pp.94 et seq. State Constitutions or statutes may contain a right to health care or some kind of duty for States to provide medical care for the poor, but such rights or duties are not truly enforceable. See Dowell, State and Local Government Responsibilities to Provide Medical Care for the Poor, in: JLII (1988-89) pp.1-45. 
insurance scheme. ${ }^{321}$ In the United States this holds true for only $25 \%$ of the population. About $60 \%$ is privately insured ${ }^{322}$, whilst $15 \%$ of the American population is without (sufficient) health insurance cover. ${ }^{323}$

In the United States, governments have only taken "health care responsibility" for indigents, the elderly and other people with no ties to the employment market who are not able to get access to adequate care. For this purpose, governments have subsidised and established hospitals and developed public health insurance schemes. Most important are the Medicare and Medicaid programs which Congress established in 1965. Medicare is governed by Title XVIII of the Social Security Act. It is a Federal programme which finances medical care for persons of 65 and over as well as disabled persons who are receiving insurance benefits under other titles of the Social Security Act. The programme provides for hospital insurance (Part A) and supplementary insurance (Part B). Part A,

321. Supra footnote 1 .

322. Private health insurance is usually connected to employment, but can take quite different forms. Many employers insure their employees with Health Maintenance Organizations (HMOs) which act both as providers and insurers of medical care. The basic idea is that payments made by the employer (and/or employees) entitle the insured to a comprehensive range of services which must be obtained from one of the providers participating in the $\mathrm{HMO}$ and which include in particular many preventive services such as check-ups which help the insured to maintain their health (hence, the name "health maintenance" organisation). Preferred Providers Organizations (PPOs) are quite similar to HMOs. PPOs are arrangements in which a group of care providers offers care to the insured employees who are encouraged but not obliged to use preferred providers.

323. See e.g. Bovbjerg/Kopit, Coverage and Care for the Medically Indigent: Public and Private Opitions, in: IndLRev (1986) pp.857 et seq and Davis/Rowland, Uninsured and Undeserved: Inequities in Health Care in the United States, in: MMF Quart (1983) pp.157 et seq. The group of the uninsured comprises about 35 million people and mainly consists of (young) part-timers who are working for relatively small firms and whose income is too high for Medicaid eligibility but too low for the payment of private insurance premiums. The uninsured are likely to become a burden on the public purse. Non-profit making hospitals often do provide the uninsured with (emergency) care and recoup the costs by increasing the fees the insured have to pay, whilst the uninsured who have been forced to pay high medical bills themselves may be faced with financial problems so serious that they become eligible for Medicaid. In addition to continuously rising health care costs, this large group of uninsured persons has been the main reason why in the last two decades various health care reform plans have been proposed and debated. On the various proposals see e.g. White, Competing Solutions - American Health Care Proposals and International Experience (1995) and Marmor, Understanding Health Care Reform (1994). The most well-known proposal is the one which President Clinton introduced to Congress in 1993 ("Health Security Act") which aimed at guaranteeing universal access and controlling expenditure. On this proposal see White (1995) supra, Chapter 9 and Verbelen (1994) supra footnote 319, at pp.60-62. So far these plans have not led to structural changes which secure universal coverage for all United States citizens and legal residents. 
which is mainly financed by a tax on employees' income, offers protection against the cost of hospital care and home care for a defined period of time. Part B provides insurance for physician and non-hospital care which is subject to payment of monthly premiums. This insurance is optional but virtually all beneficiaries covered by Part A have chosen to enroll in Part B. Medicare is administered by the Federal government, is based on rules and criteria which in principle apply universally throughout the country and it entitles beneficiaries to obtain care from any provider participating in the programme.

Medicaid was established, and is governed, by Title XIX of the Social Security Act. The programme provides for federal grants which are intended to encourage States to offer medical care to indigents and other low-income individuals. Today, all States operate Medicaid programmes. By law, the Federal Medical Assistance Percentage cannot be more than $83 \%$ and not less than $50 \%$ of the total amount States spend. The remaining part is paid by States themselves. Within quite broad federal guidelines, States are free to lay down their own eligibility standards, to define their "own" insurance packages and to set the rates of payments made to health care providers. In order to receive federal funding, however, States are required to include certain individuals in their programmes such as recipients of the Federal welfare program TANF (the former AFDC) and SSI. ${ }^{324}$ States have the option of providing Medicaid coverage to other groups such as e.g. the "medically needy", i.e. persons whose income exceeds the "normal" eligibility standards for Medicaid but who might be confronted with medical bills so high that that the amount of money they can spend on the normal cost of living would de facto fall below the stated Medicaid standards. Title XIX of the Social Security Act requires that States offer a number of basic facilities to beneficiaries such as hospital care, nurses and midwives services and labaratory facilities. States can also obtain federal funding for certain optional services such as prescribed drugs and dental care. In principle, beneficiaries are entitled to obtain the services from any provider which has chosen to participate in Medicaid and has concluded a contract with the State for this purpose. States are free to set the reimbursement rates but, in doing so, they must

324. See further Chapter 3 Section 9.1. Under the original Medicaid rules individuals who received AFDC benefits were automatically eligible for Medicaid. The Personal Responsibility and Work Opportunities Act (PRWORA) of 1996 has eliminated the AFDC programme and replaced it by the Temporary Assistance for Needy Families (TANF) program. However, families who met the original AFDC eligibility criteria have remained eligible for Medicaid. On the impact of PRWORA on the Medicaid see further e.g. Schneider, The Impact of Welfare Reform on Medicaid, in: Publius (1998) pp.161-174. 
ensure that a sufficient number of providers joins the programme so that the "needy" are entitled to medical care to an extent comparable to other residents of the States. The differences among the Medicaid programmes of the several States are considerable. The quality and number of the services offered, the groups of beneficiaries covered and the income eligibility levels vary from State to State. ${ }^{325}$ In addition to a Medicaid programme, most States have established medical programmes for indigents who do not qualify for Medicaid. Such State programmes are not funded by the Federal government and wholly governed by State law.

The American health care system differs in so many respects from the European systems that a comparative analysis of the degree to which American constitutional law and European Community law entitle individuals to gain access to public medical care must necessarily be limited in scope. The private health care and insurance sectors fall outside the scope of this chapter and the federally funded and administered Medicare programme is of no relevance. The conflict between the "free movement interest" and the "health care and insurance interests" of individual States only truly arises as regards public health care programmes which States make available for the "poor". The discussion below will therefore be confined to Medicaid programmes and other public health care programmes which States have chosen to put in place.

\section{$5.2 \quad$ Residents}

The diversity among States' Medicaid and other public health care systems may provide an incentive for the poor to move to States with comparatively generous and well-developed systems. ${ }^{326}$ Some States have been aware of this and attempted to decrease the magnetic effect of their systems by making eligibility for public medical care programmes conditional upon fulfilment of durational residence requirements. The constitutionality of waiting-period requirements for public health care

\footnotetext{
325. For a more extensive description of the Medicaid programme see e.g. Coughlin/Holahan, Medicaid since 1990: Costs, Coverage and the Shifting Alliance between the Federal Government and the States (1994).

326. Stone, Why States Can't Solve the Health Care Crisis, in: AP (1992) pp.51 et seq, at p.51 and Bobinski, Unhealthy Federalism: Barriers to Increasing Health Care Access for the Uninsured, in: UCDavisLRev (1990) pp.255-348, at p.271.
} 
schemes not covered by Medicaid ${ }^{327}$ was considered by the American Supreme Court in Memorial Hospital v Maricopa County ${ }^{328}$ (1974). The case involved Henry Evaro, an indigent suffering from a chronic asthmatic and bronchial illness, who had moved from New Mexico to Arizona. One month after his arrival in Arizona. Evaro had a severe respiratory attack and he was sent to Memorial Hospital (a non-profit making private hospital) for treatment. Pursuant to an Arizona statute, the hospital notified the county (Maricopa) that it had in its charge an indigent who might qualify for county care. The hospital requested that Evaro be transferred to the county's public hospital and claimed reimbursement of the costs of the care it had given to Evaro. Maricopa county would probably have responded positively had it not been for an Arizona statute which stated that only those indigents who had resided in the county, and thus within the State, for at least twelve months were eligible for free non-emergency care. ${ }^{329}$

In reviewing the Arizona durational residence requirement the Court first had to establish the appropriate standard of review. ${ }^{330}$ In Shapiro $v$ Thompson (1969) the Court had concluded that one-year waiting-period requirements for welfare benefits are subject to strict scrutiny. Such requirements penalise the constitutional right to travel and any classification which does so is unconstitutional unless shown to be necessary to promote a compelling governmental interest. ${ }^{331}$ It was not certain, however, whether durational residence requirements for nonemergency medical care were to be classed as a penalty on the right to travel. In a footnote in Shapiro the Court had explicitly held that it had not yet expressed its view on the test to be applied to durational residence requirement in fields other than welfare ${ }^{332}$ and the Court had already

327. The requirements were not imposed as regards Medicaid programmes; the Social Security Act does not allow States to apply waiting-period requirements. See 42 USC 1396a(b)3 (prohibiting "any citizenship requirement which excludes any citizen of the United States") and HCFA State Medicaid Manual, Section 3230.3.

328. Memorial Hospital v Maricopa County, 415 US 250 (1974).

329. The fact that the durational residence requirement was imposed by the county rather than the State was not considered a relevant factor: "Appelant Evaro has been effectively penalized for his interstate migration, although this was accomplished under the guise of a county residence requirement. What would be unconstitutional if done directly by the State can no more readily be accomplished by a county at the State's discretion". Memorial Hospital v Maricopa County, 415 US 250 (1974) at 256.

330. See further Chapter 2 Section 8.4 .

331. Shapiro v Thompson, 394 US 618 (1969) at 634. On Shapiro see Chapter 2 Section 8.5 and Chapter 3 Section 9.4

332. Ibid, footnote 21 
accepted that tuition waiting-period requirements in the field of higher education were not subject to strict scrutiny. ${ }^{333}$ In Memorial Hospital the Court decided to class the waiting-periods being challenged as a "penalty":

"Whatever the ultimate parameters of the Shapiro penalty analysis (..), it is at least clear that medical care is as much "a basic necessity of life" to an indigent as welfare assistance. [..] the right of interstate travel must be seen as ensuring new residents the same vital government benefits and privileges in the States to which they migrate as are enjoyed by other residents". 334

Having established that strict scrutiny was to be applied, ${ }^{335}$ the Court considered a number of arguments which the county of Maricopa had raised in defence of the challenged requirements. The first concerned the preservation of the quality and the fiscal integrity of the medical care programme. In the absence of a waiting-period requirement, so the County argued, any indigent sick person could seek admission to it's hospital. The facilities in the hospital were apparently "the newest and most modern" and a large influx of "free-riding" indigents would cause long waitingperiods and put pressure on the funding of the programme. The Court could not agree. To the extent that the waiting-period was intended to "inhibit the immigration of indigents generally, that goals is constitutionally impermissible". In as far as the goal is to "deter only those indigents who take up residence .. solely to utilize .. new and modern public medical facilities, the requirement at issue is clearly overinclusive". ${ }^{336}$ Citing Shapiro the Court held the class of barred newcomers to be all-inclusive, "lumping the great majority who come to the State for other purposes with those who come for the sole purpose of collecting higher benefits". An indigent "who considers the quality of public hospital facilities in entering the State is no less deserving than one who moves into the State in order to take advantage of its better educational facilities". ${ }^{337}$ Maricopa County had further argued that it should be able to

333. See in particular Vlandis $v$ Kline, 412 US 441 (1973). See further Chapter 5 Section 8.4

334. Memorial Hospital v Maricopa County, 415 US 250 (1974), at 259-261.

335. The fact that Arizona had not participated in the Medicaid could not alter this conclusion. Memorial Hospital v Maricopa County, 415 US 250 (1974) at 261

336. Ibid, at 263-264.

337. Ibid, at 264. The Court added that it is also "useful to look at the other side of the coin- at who will bear the cost of indigents' illnesses if the County does not provide the needed treatment. For those newly arrived residents who do receive at least hospital care, the cost is often borne by private nonprofit hospitals .. many of which are already in precarious financial straits. .. When absorbed by private hospitals, the costs of caring .. must be passed 
protect longtime residents because of their contributions to the community, particularly through the past payment of taxes. The Court rejected the argument simply by quoting Shapiro where it had already held that the Equal Protection Clause prohibits such an apportionment of state services. ${ }^{338}$ In conclusion, the Court held that the County had not met the burden of showing a compelling state interest and that the waitingperiod was in violation of the Equal Protection Clause. ${ }^{339}$

From the moment they establish residence in another State, United States citizens thus have the right to benefit from the public health care programmes and facilities available there under the same conditions as that States' long-term residents. Provided they meet the (financial) eligibility criteria for Medicaid and other public health programmes, and apart from possible co-payments, they are in principle under no obligation to pay the "medical bill".

on to paying patients and "at a rather inconvenient time"- adding to the already astronomical costs of hospitalization which bear so heavily on the resources of most Americans... The financial pressures under which private non-profit hospitals operate have already led many of them to turn away patients who cannot pay or severely limit the number of indigents they will admit. .. And, for those indigents who receive no care, the cost is, of course, borne by their own suffering".

338. Ibid, at 266. The County further defended the waiting-period by arguing that the requirement would be necessary for public support for the development of modern and effective medical facilities. Even if waiting-period did not deter migration, voters would believe that waiting-periods protected them from low income families being attracted to the county hospital. The Court was not persuaded of this: "A State may not employ an invidious discrimination to sustain the political viability of its programs". Ibid, at 266. The arguments that the waiting-period could be justified because they would serve as a test of bona fide residency, would prevent fraud and be necessary for budget predictability were also not, and for reasons similar to thise in Shapiro, accepted by the Court. Ibid, at 267-269.

339. It does not seem very likely that the conclusions drawn by the Court in Memorial Hospital are affected by the more recent decision in Saenz $v$ Roe (1999). It may be recalled that in Saenz the Court abandoned Shapiro's penalty-on-the-right-to-travel analysis and developed a new legal framework under which durational residence requirements are to be reviewed under the Privileges and Immunities Clause of the Fourteenth Amendment. See Chapter 2 Section 8.5.2. The standard of review to be applied under this Clause is more categorical than the one applied in Shapiro, but it is, according to the Court, "surely no less strict". No certainty exists, but in Saenz the Court held to its view that waiting-period requirements for welfare benefits are unconstitutional. There do not seem to be any good reasons for assuming that the Court has moved away from Memorial Hospital or that it is considering doing so. 


\section{$5.3 \quad$ Non-Residents}

The States' Medicaid and other public health care systems for the poor are based on the principle of territoriality. The systems have been developed to serve the "poor" residing within a State's territory, the "non-resident poor" having traditionally been excluded. Further, the Medicaid programme is based on the assumption that beneficiaries are only entitled to claim medical care in the State wherein they reside. ${ }^{340} \mathrm{~A}$ few exceptions appear to exist, however. Residence normally implies physical residence in a State plus an intention to remain there for a certain period of time $^{341}$ For Medicaid purposes, however, mere physical presence or residence in a State may in some cases suffice in order to be classed as a resident. Beneficiaries may choose their "Medicaid-residence". For instance, an individual who resides in one State but seeks employment or temporarily works in another can choose the latter State as his State of residence for Medicaid purposes. ${ }^{342}$ Furthermore, a State can arrange for an individual to be placed in an institution located in another State. The "arranging" State "retains responsibility" for the individual concerned and this includes cases where a State has initiated placement in another State because it lacks a sufficient number of appropriate facilities to provide services to its residents. ${ }^{343}$ Treatment in another State, however, is a privilege, not a right. States can further conclude (written) agreements with other States to resolve cases of disputed residence or for other reasons. Such agreements, which can pertain to one or more individuals, supersede general residency rules. The basic idea is that a State agrees to provide Medicaid services to (an) individual(s) physically residing in their territory but who for Medicaid purposes is (or are) still (a) resident(s) of another State. ${ }^{344}$

The Medicaid rules do not oblige States to give health insurance to non-residents or to pay the cost of treatment which "their" beneficiaries may have obtained outside the State territory. Can the "poor" possibly

\footnotetext{
340. HCFA State Medicaid Manual, Section 3230.

341. Chapter 2 Section 8.3.

342. Also, the spouse of an employed person working in State B who is residing in State A may choose residence in either one of the two States. HCFA State Medicaid manual, Section $3230.3 \mathrm{~B}$.

343. HCFA State Medicaid Manual, Section 3230.3 D.

344. Ibid, Section 3230.4. Finally, in cases where other States are not interested in concluding "interstate agreements", States can allow individuals who are physically present in the State to be classed as residents of the State by having "open agreements". Ibid, Section 3230.5 .
} 
claim certain cross-border medical rights under the Constitution? Are residence requirements for public health care or insurance programmes constitutional? $?^{345}$ More specifically, are such requirements consistent with the Privileges and Immunities Clause of Article IV $\S 2$ of the Constitution which insures a "citizen of State A who ventures into State B the same privileges which the citizens of State B enjoy". ${ }^{346}$ The only case in which the Supreme Court has ever commented on the relevance of the Clause to health care rights is Doe $v$ Bolton $^{347}$ (1973). The case concerned a Georgia Statute which made the right to abortion subject to a number of conditions one of which concerned the residence of the mother in the State. The residence requirement was held to be unconstitutional. The requirement, the Court ruled,

"is not based on any policy of preserving State-supported facilities for Georgia residents, for the bar also applies to private hospitals and to privately retained physicians. There is no intimation, either, that Georgia facilities are utilized to capacity in caring for Georgia residents. Just as the Privileges and Immunities Clause .. protects persons who enter other States to ply their trade, ... so must it protect persons who enter Georgia seeking the medical services that are available there. .. A contrary holding would mean that a State could limit to its own residents the general medical care available within its borders. This we could not approve." ${ }^{1348}$

Doe concerned non-residents using their own financial resources to obtain medical care, not with the denial to non-residents of publicly funded care. Nonetheless, in Doe the Court implicitly seems to have said that medical services are to be regarded as "fundamental" for the purposes of the Privileges and Immunities Clause of Article IV $\$ 2$. If correct, this would imply that residence requirements for public health care are unconstitutional unless a State can demonstrate that they are "substantially related"

345. The Equal Protection Clause does not seem to prohibit such requirements. Shapiro, Memorial Hospital and Saenz merely concerned durational residence requirements, not "simple" residence requirements. Strict scrutiny is only to be applied in cases where States discriminate among State residents "because of the timing of their migration". Attorney General of New York $v$ Soto-Lopez, 476 US 898 (1986) at 904. Discrimination against nonresidents is merely reviewed under the rational relation test. Residence requirements for access to public health care are also not subject to a "heigthened level" of judicial scrutiny because they discriminate on grounds of wealth or because special importance attaches to health care. See Maher v Roe, 432 US 464 (1977) at 469-470 and Mariner, Access to Health Care and Equal Protection of the Law: The Need for a New Heighthened Scrutiny, in: AJLM (1986) pp.345-380

346. Paul v Virginia, 75 US (8 Wall.) 168 (1869) at 180-181.

347. Doe v Bolton, 410 US 179 (1973).

348. Ibid, at 200 . 
to the furtherance of a State interest. ${ }^{349}$ Doe suggests that the preservation of the quality and fiscal integrity of public health care programmes constitute such "substantial" interests and it could very well be argued that States are not obliged to give all non-residents "full" access to their programmes. The "substantial relation test" to be applied under the Privileges and Immunities Clause, however, does not seem to allow States to deny access to care in all circumstances. For instance, a refusal to grant non-residents the emergency care residents are entitled to would seem incompatible with the Clause. ${ }^{350}$ Neither Doe nor any other decision of the Supreme Court, however, provides guidance in determining the precise degree to which States must offer access to care to residents of other States or whether they can be constitutionally obliged to bear the cost of care which beneficiaries have obtained in other States. ${ }^{351}$

\section{$5.4 \quad$ Aliens}

A third category of persons which has often been discriminated against by States in the fields of social policy and health care consists of aliens. Depending on their immigration status, aliens have been denied (equal) access to medical care and often have only been given a right to emergency care. The Court has never ruled on the constitutionality of State rules for public medical care containing alienage classifications. ${ }^{352}$ In order to establish the validity of such rules under the Constitution, the general constitutional rules and principles governing the status of the various categories of aliens (permanent residents, non-immigrants and undocumented aliens) as developed in fields other than public medical care are to be considered.

349. See further Chapter 2 Section 8.6.1.

350. Also, States which deny access to public care programmes which are financed through pay-roll taxes to resident-workers on the ground that they reside in another State might violate the Priviliges and Immunities Clause. See Parmet (1993) supra footnote 320, at pp. 130-131.

351. State rules which deny non-residents access to publicly funded health care programmes or services do not seem to run counter to the Commerce Clause (on this Clause see Chapter 2 Section 8.6.2). In 1945 Congress enacted the McFarran-Ferguson Act which exempts "the business of insurance" from review under the Commerce Clause. Publicly funded care can probably benefit from this exemption. See Parmet (1993) supra footnote 318 , at p.127 who also states that public health care may also be immune to Commerce Clause inquiries by virtue of the market participant doctrine (see Chapter 2 Section 8.6.1)

352. On the differences between alienage classifications and nationality classifications see Chapter 2 footnote 410 . 


\subsubsection{Permanent Residents}

Up until the early 1970s courts subjected State rules which made eligibility for social or public benefits conditional upon United States citizenship to the lenient rational relation test reasoning that States had a "special public interest" in favouring United States citizens over aliens. ${ }^{353}$ As described earlier in this book, however, since the 1971 decision of the Supreme Court in Graham $v$ Richardson, ${ }^{354}$ the Supreme Court has considerably strengthened the legal status of aliens, and in particular those who have acquired permanent resident status. In Graham the Court was asked whether the Equal Protection Clause prevents States from making welfare benefits conditional upon the possession of United States citizenship or, in the case of aliens, residence in the United States for a specified number of years. The Court held that alienage classifications were subject to strict scrutiny. Referring to Shapiro v Thompson, the Court held that since States cannot preserve the fiscal integrity of their welfare programmes by making distinctions between its own State citizens, they may not do so either by treating United States citizens and aliens differently. As citizens, resident aliens pay taxes and they contribute to the economic growth of a State and for this reason there is no "special public interest" in tax revenues to which aliens have contributed on an equal basis with residents. ${ }^{355}$

Memorial Hospital means for medical care what Shapiro means for welfare and eligibility for Medicaid is in most cases conditional upon receipt of welfare benefits. Therefore, the conclusions drawn in Graham as regards welfare benefits can be transposed to the field of health care. As a result, States do not seem entitled to deny aliens access to public health care (programmes) on the ground that they lack United States citizenship or that they have not resided in the United States for a given number of years. This conclusion, however, seems inconsistent with the Federal rules for Medicaid eligibility. Congress allows States to deny aliens full Medicaid coverage for the first five years of their residence in the United States. ${ }^{356}$ Congress itself is entitled to discriminate against aliens when it provides public benefits such as those covered by the

353. See further Chapter 2 Section 8.7.1 and Chapter 3 Section 9.6.1.

354. Graham v Richardson, 404 US 365 (1971).

355. Ibid., at 376

356. HCFA State Medicaid Manual Section 3211.6. This conclusion only applies to aliens who entered the United States on or after 22 August 1996. Aliens who on that date were lawfully residing in the United States and who met the conditions for Medicaid eligibility, continue to be entitled to the benefits. 
Medicare programme. Federal alienage classifications, as the Court ruled in Mathews v Diaz (1976), are merely subject to rational relation review. ${ }^{357}$ Does this imply that States can "hide behind" Congress and, in spite of the limitations imposed by the Equal Protection Clause, deny aliens Medicaid services? Graham strongly suggests that they cannot do so. In this case it was argued by the defendant States that the alienage classifications being challenged for welfare benefits could be upheld because they would be fully compatible with the rules laid down by Congress. The Court rejected the argument. It admitted that Congress has broad powers to determine the conditions under which aliens are admitted to the United States, but it denied that the classifications had actually been authorised by Congress. Moreover, even if this had been the case, Federal rules could not have prevented the discrimination against aliens. Congress, the Court concluded, does not have the power to authorise individual States to violate the Equal Protection Clause. ${ }^{358}$ Consequently, Graham seems to imply that States cannot deny full Medicaid coverage to permanent resident aliens and that the Federal

357. Mathews concerned a number of aliens who had been lawfully admitted to the United States and who attacked federal provisions which made enrollment in the Medicare programme for aliens of 65 years or older conditional upon permanent residence or residence for a minimum period of five years in the United States. The Court did not have much difficulty in upholding the provisions being challenged. Aliens do enjoy a right to equal treatment (under the Due process Clause of the Fifth Amendment - see Chapter 2 footnote 426), but this in no way implies that the Federal government is obliged to treat aliens in all respects equally with United States citizens. Congress, the Court held, may very well decide to deny claims of aliens "to share in the bounty that a conscientious sovereign makes available to its own citizens and some of its guests" and it may make distinctions among aliens according to length of residency. Since the relationship between the United States and aliens has been committed to the political branches of the Federal government and since there is no constitutional duty to provide aliens with welfare or health care, the Court was reluctant to question the decision of Congress. The Court decided to employ mere rational relation scrutiny and in doing so it rejected the view that the five-year residence requirement was not rationally related to the goal of maintaining the fiscal integrity of the Medicare programme because aliens must pay premiums and federal taxes. The Court expressly denied that the decision in Graham would compel another conclusion. That case concerned State rather than Federal statutes and the relationships of aliens with individual States differ from the relations which aliens have with the Federal government. Congress does hold the power to exercise control over travel across the borders of the United States, but the Constitution does inhibit every State's power to restrict travel across State borders. Moreover, a division by a State of the category of persons who are not citizens of that States into subcategories of United States citizens and aliens has no apparent justification, whereas a comparable classification by the Federal government is a routine and normally legitimate part of its business. Mathews $v$ Diaz, 426 US 67 (1976) at 17-20.

358. Graham v Richardson, 404 US 365 (1971) at 382. 
provisions which authorise the States to do so are invalid. ${ }^{359}$ The fact that States granting Medicaid to aliens during the first five years of their residence may not be able to receive Federal funding, and thus may have to bear the financial burden themselves, does not seem to affect this conclusion. Fiscal concerns, as Graham indicates, cannot justify discrimination against resident and tax-paying aliens.

\subsubsection{Non-Immigrants and Undocumented Aliens}

In Graham the Court considered alienage classifications as suspect for the purposes of equal protection analysis and this would seem to suggest that any alienage discrimination is subject to strict scrutiny and, thus, probably unconstitutional. This, however, is not the case. Subsequent case law indicates that the protection offered by the compelling State interest test is largely preserved for permanent resident aliens and that discrimination against non-immigrants and undocumented aliens is subject to a lower level of scrutiny. ${ }^{360}$ This is particularly relevant for medical care. Generally, aliens who are only temporarily present or resident in the United States and undocumented aliens are not eligible for "full" medical care coverage under public programmes. They are only entitled to emergency care. ${ }^{361}$

359. Chang, Immigrants under the New Welfare Law: A Call for Uniformity, A Call for Justice, in: UCLA LRev (1997) pp.205 et seq, at p.266 and X, Welfare Reform: Treatment of Legal Immigrants, in: Harv LRev (1997) pp.1191 et seq, at pp.1193-1994.

360. See Chapter 2 Section 8.7 .

361. For the purposes of Medicaid, an emergency medical condition is defined as a "medical condition (including labour and delivery) manisfesting itself by acute symptoms of sufficient severity (including severe pain) such that the absence of immediate medical attention could reasonably be expected to result in (a) placing the patient's health in serious jeopardy, (b) serious impairment to bodily functions, or (c) serious dysfunction of any bodily organ or part. HCFA State Medicaid Manual, Section 3211.11. States which offer emergency care to undocumented aliens may be eligible for Federal funding under the Balanced Budget Act. See further Schlosberg, Not-Qualified Immigrants' Access to Public Health and Emergency Services After the Welfare Law (available on http:/www.healthlaw.org/pubs/19980112immigrant.html). See further also California's Proposition 187 which excludes undocumented aliens from all medical services except for emergency services ordered by Federal law and which provides for a procedure under which the providers are obliged to notify inter alia the United States immigration authorities of an aliens apparent illegal status. See further Schuler, Equal Protection and the Undocumented Immigrant: California's Proposition 187, in: BCTW LJ (1996) pp.275-312, at p.277 in particular. 
The jurisprudence of the Supreme Court does not provide much guidance as to whether State rules which exclude foreign students, temporary workers, visitors or other aliens covered by the heterogenous group of non-immigrants are constitutional. The decision in Toll v Moreno ${ }^{362}$ (1982) demonstrates that State alienage requirements are unconstitutional in cases where the Federal immigration authorities have explicitly or implicitly indicated that non-immigrant aliens should be treated equally. ${ }^{363}$ However, the decision does not indicate which of the equal protection tests is to be applied as regards rules which discriminate against nonimmigrants in cases where the Federal authorities allow but do not oblige States to grant such aliens public benefits. The same holds true for State rules which deny undocumented aliens full public health care coverage. The leading case on the legal status of this category is Plyler $v$ Doe $e^{364}$ (1982). In reviewing a Texas policy under which undocumented schoolage children were denied access to free public education under the Equal Protection Clause, the Court held that undocumented aliens are entitled to equal protection from the laws, but that their undocumented status does prevent them from being treated as a suspect class. The Court did not limit itself to mere rational relation review because the case involved, on the one hand, undocumented children who could "affect neither their parents' conduct nor their own status" and, on the other hand, concerned education which was not just "some" governmental benefit. The statute in question could only be upheld if Texas could show a "substantial state interest". The Court held that a concern for the preservation of resources was in itself not such a substantial interest. Texas had to have stronger justification grounds. Texas claimed that it was entitled to protect itself from an influx of illegal immigrants who might move to the State for educational purposes alone. The Court did not deny that States, in spite of the exclusive federal control of external borders, had some power to deter the influx of illegal aliens in order to protect the States' economy or other traditional State interests, ${ }^{365}$ but it found no evidence that Texas' interests were actually affected. The dominant incentive for illegal entry was, as the Court said, the availibility of employment. Only few, if any, illegal immigrants would come to Texas or the United States in order to gain access to education. Charging "tuition to undocumented children consti-

362. Toll v Moreno, 458 US 1 (1982)

363. Ibid, at 12-13.

364. Plyler v Doe, 457 US 202 (1982). On Plyler see e.g. Hull, Undocumented Alien Children and Free Public Education: An Analysis of Plyler v. Doe, in: UPittLRev (1983) pp.431 et seq and Chapter 5 Section 8.5.3.

365. Ibid, at 228 and in particular footnote 23 . 
tutes a ludicrously ineffectual attempt to stem the tide of illegal immigration". 366

The value of Plyler as a precedent in terms of medical care is uncertain. ${ }^{367}$ The decision does not indicate which of the equal protection tests is to be applied when reviewing State rules which deny aliens access to all medical care other than emergency services. It would seem, however, that even if an intermediate standard of review were to be applied, States might be able to demonstrate a need for excluding undocumented aliens "full" access to medical care. Illegal immigration may not be induced by the educational opportunities for children, but access to adequate medical care may very well constitute an incentive for such migration. ${ }^{368}$

\subsection{Lessons for the European Community?}

In comparison with the "American" sections in the chapters on minimum subsistence benefits and public education, this section has been relatively short. The reasons are not hard to find. Firstly, unlike the European systems, the American health care system is predominantly private in nature. The comparative analysis of the rules and principles governing cross-border access to public health care in the United States has necessarily been limited to Medicaid and other health care systems States have developed for the poor. Secondly, the degree to which American law confers upon individuals a right to gain access to public medical care in other States is quite limited. The Constitution and the Federal Medicaid rules do not require from the States much more than to grant $(i)$ public health insurance and care to United States citizens and permanent resident aliens residing within their borders and (ii) to give non-residents, nonimmigrant aliens and undocumented aliens emergency care under the same conditions as their American residents. In particular, publicly insured patients do not have the right to move to other States for medical purposes nor to have the medical bill paid by the institution they are insured with or affiliated to. By comparison with European Community law, American law on cross-border access to public health care has not been very well developed. No federal rules co-ordinating the States' public health care systems exist; hardly any case law on cross-border

366. Ibid, at 228

367. Ibid, at 243 (Burger, C.J. dissenting)

368. Compare Schuler (1996) supra footnote 361 , at p.309. 
access to health care exists. Basically, for the European Community there is not much to be learned from the limited American experience. The reverse would rather seem to hold true.

\section{Conclusions}

In the course of the last decades, European Community law on the free movement of persons has proven to be quite dynamic. More and more beneficiaries have been included in the free movement regime and the rights of the various categories have been extended considerably. ${ }^{369}$ This dynamism, as Chapter 3 has demonstrated, has had significant changes for the Member States' rules governing the access to their territories and minimum subsistence benefits schemes. Community law still does not entitle all Union citizens to establish residence in other Member States and to claim minimum subsistence benefits there, but the legal status of the "poor" has been strengthened considerably since the early 1960s. The same can hardly be said for the legal status of the "sick". Community law governing the access to health care in other Member States has proven to be quite static. Until recently, the cross-border access to health care was considered to be exclusively governed by the provisions of Regulations No $1408 / 71$ and No $574 / 72$ and the main principles on which these provisions are based have never been fundamentally altered. In brief, just as three decades ago, the regulations confer upon Community citizens rights to obtain medical care during a temporary or more permanent stay in another Member State, but the regulations do not entitle patients to go to other States in order to obtain medical care. Member States have always claimed that the right to gain access to medical care is, and should remain, a territorially limited right. A free movement of patients has always been seen as a potential threat to the funding and infrastructure of health care systems. Against this background, it is not surprising that early claims about the possible incompatibility of prior authorisation rules with the Treaty's free movement rules ${ }^{370}$ were largely ignored and that, when the Court actually condemned such rules in Decker and Kohll, many Member States attempted to interpret these rulings restrictively. It is not fully understandable, however, why many States and other actors in the health care and insurance sectors have taken such a defensive attitude vis-

369. See Chapter 2 .

370. See Section 4.1. 
$\grave{a}$-vis, in their view presumably, a too dynamic Court. Decker and Kohll may have implications for the organisation and administration of health care and health insurance schemes, but the rulings do not necessarily have to be seen as a threat to the quality of these schemes. The judgments might just as well be viewed as a challenge. Cross-border care may also promote a more efficient use of medical facilities within the Community and it may help to improve the accessibility of medical care. 
Chapter 5

\section{EDUCATION}





\section{$1 \quad$ Introduction}

The 1957 Treaty of Rome did not confer upon Community institutions specific powers for the development of a common educational policy. The Treaty did not mention any educational rights for the employed and selfemployed beneficiaries of the free movement of persons and a free movement of students was not provided for. The word "education" could not even be found in the EEC Treaty. In the view of the drafters, education was, and would remain, a policy area to be governed by Member States. More than four decades later, this premise still stands. Article 149(1) of the current EC Treaty stipulates that the Community shall fully respect "the responsibility of the Member States for the content of teaching and the organisation of education systems and their cultural and linguistic diversity". Article 149(4) EC expressly adds that institutions are not empowered to harmonise the national rules governing educational systems.

The mere fact, however, that the Treaty now contains such protective clauses demonstrates that things have changed over the years. From the early years, the Community institutions have recognised that education and training are closely linked to, and of the utmost importance for, the European integration process. An efficiently functioning common market requires a well-trained and qualified labour force and a genuine free movement of workers can only be realised when Community citizens, both before and during their working-life, have the possibility of acquiring in other Member States the knowledge, skills and qualifications necessary for performing work there. ${ }^{1}$ Since the early 1960s, Community institutions have therefore entered the fields of vocational training and education. Initially, the Community's role was still rather modest, but since the judgments of the Court of Justice in Gravier ${ }^{2}$ (1985) and Commission v Council (Erasmus) ${ }^{3}$ (1989), and subsequent Community practice, the Community's role in the area can no longer be ignored. ${ }^{4}$

1. See e.g. Council Decision of 2 April 1963 laying down general principles for implementing a Common Vocational Training Policy (63/266/EEC), in: Council of the European Communities - General Secretariat, European Educational Statements (1987) at pp.199-202. 2. Case 293/83 Gravier [1985] ECR 593. See further Section 4.1.

3. Case 242/87 Commission v Council (Erasmus) [1989] ECR 1425. See further Section 2.3.

4. Community law and policy on education have attracted considerable attention in the doctrine. See e.g. Shaw, From the Margins to the Centre: Education and Training Law and Policy, in: Craig/De Búrca, The Evolution of EU Law (1999) pp.555-595; van der Ven, De Europese Unie en de Nederlandse Studiefinanciering, in: De Staat van de Studiefinanciering (1999) pp.37-61; Field, European Dimensions - Education, Training and the European Union (1998); Shaw, The Nature and Extent of 'Educational Rights' under EC Law, in: JSWFL 
(1998) pp.203 et seq; Vermeulen/Kuijer, Toegang tot het Onderwijs binnen de Europese Unie - Juridische Aspecten van de Toegang tot Onderwijsvoorzieningen voor Middelbaar en Hoger Onderwijs voor EG-migranten en Derdelanders binnen de Europese Unie in een Drietal Lidstaten (1997); Brouwer, De Europese Gemeenschap en Onderwijs: Geschiedenis van de Samenwerking en het Communautair Beleid op Onderwijsterrein (1996); André de la Porte/Zegveld, Mobiliteit van Studenten binnen de Europese Unie (1996); O'Leary, The Evolving Concept of Community Citizenship - From the Free Movement of Persons to Union Citizenship (1996) Chapter 5; van der Ven, Onderwijsrecht en Onderwijsbeleid in Nederland en de Europese Unie - Ontwikkelingen voor Hoger Onderwijs na Maastricht (1996); Frazier, L'Education et la Communauté européenne (1995); McMahon, Education and Culture in European Community Law (1995); Beckedorf/Henze, Neuere Entwicklungen in der Bildungspolitik der Europäischen Gemeinschaft, in: NVwZ (1993) pp.125-130; De Witte, Higher Education and the Constitution of the European Community, in: Gellert (Ed.), Higher Education in Europe (1993) pp.186-202; Leenknegt, Onderwijs en de Europese Integratie, in: S\&W (1993) pp.50-55; Thiele, Die Rechtssprechung des Gerichtshofs der Europäischen Gemeinschaften zum Recht auf Gleichbehandlung von EG-Ausländern beim Zugang zu Bildungseinrichtungen und auf Studiefinanzierung, in: ZfRV (1993) pp.185-197; Van Gerven/van den Bossche, Freedom of Movement and Equal Treatment for Students in Europe: An Emerging Principle?, in: Schermers et al (Eds), Free Movement of Persons in Europe: Problems and Experiences (1993) pp.405-426; Verbruggen, Toegang tot het Onderwijs en Studiefinanciering, in: TOO (1992-1993) pp.282-290; De Witte, The Influence of European Community Law on National Systems of Higher Education, in: Pertek (Ed.), General Recognition of Diplomas and Free Movement of Professional (1992) pp.73-88; De Witte, Het Europees Onderwijsrecht, in: Europa en het Onderwijs (1992) pp.13-44; Oertzen, Bildung und Berufsausbildung in den Europäischen Gemeinschaften - Eine Analyse der Kompetenzgrundlagen und der subjektiven Rechte im Rahmen des EWG-Vertrages (1992); van der Ven, Naar een Europese Studiefinanciering?, in: NTOR (1992) pp.156-166; Wimmer, Freedom of Movement for Students under Community Law, in: ELSA (1992) pp.53-68; Watson, Wandering Students: Their Rights under Community Law, in: Curtin/O'Keeffe (Eds), Constitutional Adjudication in European Community and National Law (1992) pp.7988; Curall, Bildung und Ausbildung im Recht der Europäischen Gemeinschaft, in: RJB (1991) pp.139-161; De Blois, Europees Gemeenschapsrecht en Onderwijs, in: SEW (1991) pp.513-537; Hartley, Free Movement of Persons, in: Green et al, Legal Foundations of the Single European Market (1991) Chapter 13; Shaw, Vocational Training and Education in the European Community, in: EBLRev (1991) pp.279-282; Schweitzer, Bildungspolitik und EWG-Vertrag - Eine Bestandsaufnahme, in: ZfRV (1991) pp.14-25; Verschueren, De Buitenlandse Student, in: van Hoestenberghe (Red.), Studentenrecht (1991) pp.259-272; von Wittkowski, Die Rechtsprechung des Europäischen Gerichtshofs zur Freizügigkeit und Gleichbehandlung von Angehörigen der EG-Mitgliedstaaten hinsichtlich des Besuchs von Ausbildungsstätten und deren Auswirkung für die Bundesrepublik Deutschland (1991); Curall, Education Rights under the EC Treaty, in: Mobility of People in the European Community (1990) pp.13-32; De Witte, Recht op Onderwijs zonder Grenzen?, in: JF (1990) pp.535-549; Fuchs, Bildung ohne Grenzen, in: DV (1990) pp.245-246; Hennis, Access to Education in the European Communities, in: LJIL (1990) pp.35-44; Lenz, Zuständigkeiten und Initiativen der Europäischen Gemeinschaft im Bereich des Bildungswesen, in: EGForum, Beilage zu IBW-Heft (1990) pp.183-208; Lichtenberg, Freizügigkeit und Bildungswesen in der Europäischen Gemeinschaft an der Schwelle zum Gemeinsamen Binnenmarktes, in: Festschrift für Ernst Steindorff (1990) pp.1269-1286; Sieveking, Bildung im Europäi- 
Today, the Community institutions hold significant powers in the field of education and a common educational policy does now exist. Further, in pursuing national policies regarding admission to their educational systems Member States must observe the limitations imposed by Community law. ${ }^{5}$ In principle, Member States are still entitled to lay down the conditions for access, but in so doing they must respect the rights that Community law confers upon nationals and residents of other (Member) States.

This Chapter examines the degree to which, and the conditions under which, Community law entitles individuals to gain access to

schen Gemeinschaftsrecht, in: KritV (1990) pp.344-373; Waegenbauer, Die Einbeziehung der Hochschulen in den Europäischen Integrationsprozess, in: ER (1990) pp.135-142; Conrad, Die Rechtsprechung des Gerichtshofs der Europäischen Gemeinschaften auf dem Gebiet des Bildungswesen, in: WissR (1989) pp.97-110; Crijns, EG-recht en Onderwijs, in: NTOR (1989) pp.23-41; De Witte (Ed.), European Community Law of Education (1989); Flynn, Vocational Training in Community Law and Practice, in: YEL (1989) pp.59-85; Felmer, Gemeinschaftsrecht und Nationales (Aus-)bildungsrecht, in RJB (1989) pp.175 et seq; Gilliams, Van "Gravier" tot "Erasmus": Over de Bijdrage van het Hof van Justitie tot de Uitbouw van een Europees Onderwijsbeleid, in: RW (1989-1990) pp.494-504; Gould, Equality of Access to Education, in: MLRev (1989) pp. 497 et seq; Hartley, La libre Circulation des Etudiants en Droit communautaire, in: CDE (1989) pp.325 et seq; Isaac, L'Enseignement supérieur et le Champ d'Application du Traité CEE, in: Philip (Ed.), L'Enseignement supérieur et la Dimension européenne (1989) pp.11-18; Lenz, Die Rechtsprechung des Europäischen Gerichtshofs im Bereich des Bildungswesen, in: EA (1989) pp.125-134; Lonbay, Education and Law: The Community Context, in: ELRev (1989) pp.363-387; Maresceau, Komt Toegang tot het Onderwijs ook Binnen de Werkingssfeer van het EEG-Verdrag?, in: Liber Amicorum Van Den Bogaert (1989) pp.165-185; Traversa, L'Interdiction de Discrimination en Raison de la Nationalité en Matière d'Accès à l'Enseignement, in: RTDE (1989) pp.45-69; Avenarius, Zugangsrecht von EG-Ausländern im Bildungswesen der Bundesrepublik Deutschland, in: NZfV (1988) pp.385-393; Drijber, Gelijke Behandeling van Studenten uit de EEG - Zijn er nog Grenzen?, in: NJB (1988) pp.22-29; Meade, Free Movement of Students: Access to Higher Education in another Member State, in: MR (1988) pp.260-263; Hochbaum, Politik and Kompetenzen der Europäischen Gemeinschaften im Bildungswesen, in: BayV (1987) pp.481-490; Sieveking, Europäisierung der Bildungspolitik?, in: ZAR (1987) pp.99-108 and Neave, The Role of Education in European Integration, in: IP (1986) pp.277-284.

5. In Casagrande, for instance, the Court held that "although educational training and policy is not as such included in the spheres which the Treaty has entrusted to the Community institutions, it does not follow that the exercise of powers transferred to the Community is in some way limited if it is of such a nature as to affect the measures taken in the execution of a policy such as that of education and vocational training". Case 9/74 Casagrande [1974] ECR 773 at 12. Also, in Gravier the Court held that "although educational organization and policy are not as such included in the spheres which the Treaty has entrusted to the Community institutions, access to and participation in courses and apprenticeship, in particular vocational training, are not unconnected with Community law". Case 293/83 Gravier [1985] ECR 293 at 19. 
education in other Member States. ${ }^{6}$ Are individuals entitled to gain access to education and, if so, does this also include a right to claim study grants? To what extent can Member States restrict the access of nonnationals and non-residents to their educational institutions with a view to securing the organisation and/or funding of their systems? How has Community law settled the conflict $^{7}$ between the aims of promoting freedom of movement and securing equality of treatment, on the one

6. This Chapter only discusses the cross-border rights which Community law confers upon the recipients of education (pupils, students) to the exclusion of the rights offered to the providers (teachers, professors, schools, etc). Teachers and professors may be classed as workers for the purposes of Article 39 EC. See e.g. Case 44/84 Hurd [1986] ECR 29 (teachers of "European schools"); Case 66/85 Lawrie-Blum [1986] ECR 2121 (trainee teachers); Case 33/88 Allué [1989] ECR 1591 (university lecturers) and Case C-4/91 Bleis [1991] ECR I-5627 (teachers in secondary education). Their employment does not fall within the scope of the public service exception of Article 39(4). See e.g. Case 66/85 Lawrie-Blum [1986] ECR 2121 at 27-28; Case 33/88 Allué [1989] ECR 1591 at 7 and Case C-4/91 Bleis [1991] ECR I-5627 at 7. National rules which impose, in respect of recruitment of teachers in private schools, more stringent conditions on non-nationals (Case C-123/94 Commission v Greece [1995] ECR I-1457 at 6), which contain certain limits on the (duration of) employment contracts of lecturers in foreign languages but not on the contracts of other lecturers (Case 33/88 Allué I [1989] ECR 1591 at 19; Joined Cases C-259/91, C-331/91 and C-332/91 Allué II [1993] ECR I-4309 at 21; Case C-272/92 Spotti [1993] ECR I-5185 21 and Case C90/96 Petrie [1997] ECR I-6527 at 57) or which limit the taking into account of previous periods of work spent in other Member States for purposes of determining the pay of (contractual) teachers (Case C-195/98 Österreichischer Gewerkschaftsbund [2000] ECR I0000 at 51 and 56) may be in breach of Article 39(2) EC. National rules which require that teachers possses a certain level of knowledge of the national language, however, may be compatible with Article 39 EC. See Case 379/87 Groener [1989] ECR 3967 at 15-19. On Groener see further Section 4.7 below. In addition, Community citizens can rely on Articles 43 and $49 \mathrm{EC}$ in order to establish private schools (Case 147/86 Commission v Greece [1988] ECR 1637 - also indicating that the establishment of private schools does not fall under the public authority provision of Article 45 (formerly 55) EC) or to provide in other Member States educational services of a private nature (compare Case 263/86 Humbel [1988] ECR 5365). Further, providers of education can benefit from the social security rules of Regulation No 1408/71. See e.g. Case 33/88 Allué [1989] ECR 1591 (exclusion of lecturers of foreign languages from social security regimes may constitute a discrimination contrary to Article 3 of Regulation No 1408/71); Case C-216/89 Reibold [1990] ECR I-4163 (unemployments benefits for university lecturers participating in exchange programs) and Case C102/91 Knoch [1992] ECR I-4341 (idem). See further Case 44/84 Hurd [1986] ECR 29 (Member States which tax teachers of "European schools" for their income funded out of the Community budget violate the "loyalty provision" contained in Article 5 (now 10) EC) and Case C-407/98 Abrahamsson [2000] ECR I-0000 (compatibility of positive action rules for women in university rules with Article 2(4) of Directive No 76/207 on equal treatment for men and women).

7. On the conflict between the "free movement interest" and the "public benefit interest" in general, see Chapter 1 Section 2. 
hand, and the need to protect the education systems of Member States, on the other hand?

The Chapter is structured as follows. Section 2 puts the subject of cross-border access to education in its proper context by describing $(i)$ the main features of the national educational systems, (ii) the ways in which Member States have traditionally regulated cross-border access to their systems and (iii) the evolution and main principles of the common educational policies. The subsequent four Sections deal with the educational rights of economic residents (3), non-residents (or Community students) (4), non-economic residents (5) and third country nationals (6). ${ }^{8}$ After a brief summary and evaluation (Section 7), the Chapter then continues with an analysis of American constitutional law on cross-border access to education (Section 8). As described in Chapter 2, the American Constitution provides for a general right to freedom of movement which encompasses a right to equal treatment in other States. Does this imply a right to study in other States, and if so, under what conditions are students admitted? The analysis of American law on cross-border access to education partly provides the basis for Section 9 in which Community law will be evaluated and in which the question is addressed whether, and if so, how, Community rules governing cross-border acces to education could possibly be improved or adjusted.

\section{Education and the European Community}

\subsection{The Educational Systems of the Member States}

Within the European Community it is for Member States to organise, administer and finance their educational systems. States are free to do so in accordance with their social, religious and cultural norms and traditions. In spite of the numerous differences among the educational systems, ${ }^{9}$ a number of common characteristics can be detected. A first common

8. See further Chapter 1 Section 3.1 and Chapter 2 Sections 2 up to 5.

9. For more detailed descriptions of the educational systems of the Member States see e.g. European Commission, Strukturen der algemeinen und beruflichen Bildung in den Mitgliedstaaten der Europäischen Gemeinschaft (1991); Müller-Solger, Bildung und Europa - Die EG-Förderungsmassnahmen (1993); Teichler, Europäische Hochschulsysteme - Die Beharrlichkeit vielfältiger Modelle (1990) and Ortelius - The Database on Higher Education in Europe (http://ortelius.unifi.it/index2.html) 
feature is that the educational systems are all largely public in nature. In economic terms, education may be regarded as a commodity or service which could, in principle, be provided by private actors operating in a commercial market. Not one Member State, however, has chosen to fully entrust the provision of education to the market principles of laissez-faire and undistorted competition. The market mechanism is not necessarily the most cost-efficient and it does not guarantee "socially just" results. ${ }^{10}$ In particular, the private market does not guarantee that all "members of society", regardless of their socio-economic status and place of residence, can gain access to adequate education. In order to make education financially and geographically accessible to all members of society, ${ }^{11}$ governments in each of the Member States have intervened in, and largely removed education from, the private market by establishing public ${ }^{12}$ schools and universities. Furthermore, Member States' systems are all divided into pre-training, primary and secondary education and higher education. In secondary education and higher education a distinction is often made between general education and vocational training. The former type of education is aimed at increasing knowledge and cultural awareness or developing "the mind in a general manner", ${ }^{13}$ whilst vocational training is said to be more directly aimed at preparing students for specific professions. The distinction, however, is not clear-cut. General secondary and higher education may also prepare students for specific jobs, whilst vocational training courses also contain many elements which are "general" in nature.

10. See e.g. Barr, The Economics of the Welfare State (1998) Chapter 12 and Le Grand et al, The Economics of Social Problems (1993) Chapter 3.

11. Governments are under an obligation to promote the availibility and accessibililty of education. This obligation has found legal recognition in, and results from, the right to education which is enshrined in various international human rights instruments. See e.g. Article 26 of the Universal Declaration on Human Rights, Article 2 of the First Protocol to European Convention on Human Rights and Fundamental Freedoms and Article 13 of the International Covenant on Economic, Social and Cultural Rights. Next to this "social aspect", the right to education contains an aspect of freedom which entails the right to choose a specific form of education and the right to establish educational institutions. See further Leenknegt, Vrijheid van Onderwijs in Vijf Europese Landen - Een Rechtsvergelijkend Onderzoek naar de Gemeenschappelijke Beginselen op het Gebied van Onderwijs in België, Duitsland, Engeland, Frankrijk en Nederland (1997) and, in particular, Coomans, De Internationale Bescherming van het Recht op Onderwijs (1992).

12. Private education has historically played a relatively modest role, even though the number of private educational organisations which enter the market without any public financial support has increased in recent years.

13. Compare the Opinion of Advocate General Slynn in Case 239/85 Commission v Belgium [1988] ECR 305 at p.337. 
Among the various types of education, higher education is the one on which Member States spend most of their resources. The sums that Member States make available for higher education differ considerably. Member States such as the Netherlands, Germany and Denmark spend significantly more than the southern Member States do. ${ }^{14}$ Noticable is Luxembourg's low spending which is explained by the absence of a university system in the country. Also, the degree to which governmental responsibilities and powers regarding the organisation, funding and administration of higher education are divided between the central government and local government, varies. The degree of decentralisation is relatively high in the United Kingdom and federal States such as Belgium and Germany, whilst in Member States such as the Netherlands and the Scandinavian countries the autonomy and powers of local government entities (municipalities, school districts, etc.) are comparatively limited. In order to make education, and higher education in particular, financially accessible to all members of society, many States have developed student financial aid systems. ${ }^{15}$ These systems intend to provide students with the financial means they need for bearing the cost of the studies (e.g. tuition fees, cost for study materials) and/or maintenance (housing, travel expenses .. etc). The systems in the "southern" Member States are generally not very well developed, but in the Member States in the geographical heart of the Community and the Scandinavian States quite comprehensive support systems exist. A distinction can be made between direct and indirect student financial aid systems. Direct aid mainly consists of grants and loans which are often means-tested. Some Member States (e.g. Austria, Belgium) only provide grants, whilst other countries (e.g. Denmark, Germany) provide both types of direct aid. Indirect student financial aid consists of support which is provided through parents and usually

\footnotetext{
14. For some figures see e.g. Kaiser et al, Public Expenditure on Higher Education - A Comparative Study in the Member States of the European Community (1992). See also O'Leary (1996) supra footnote 4, at pp.166-168.

15. Oosterbeek, An Economic Analysis of Student Financial Aid Schemes, in: EJE (1998) pp.21-29, at pp.21-22. For an overview of the systems see e.g. Vossensteyn, Access: Selection and Affordability - A Comparative Analysis of the Barriers in Higher Education in Nine Western European Countries (1997); van Vught/Vossensteyn, De Toekomst van het Nederlandse Stelsel van Studiefinanciering in Europees Perspectief, in: Cohen et al, Expertbijdragen, Scenario's en Achtergrondinformatic - Een Bundeling Bijdragen ten Behoeve van het College Toekomst Studiefinanciering (1997) pp.31-44; Vossensteyn, Studiefinanciering in Internationaal Perspectief, in: THOM (1996) nr.5; Hulst, Studiefinanciering in Zes Europese Landen (1995); Ulleroe, Le Budget de l'Etudiant et son Financement en Europe (1994) and Oijen et al, International Comparative Study of Financial Assistance to Students in Higher Education (1990).
} 
takes the form of child allowances or tax benefits. In many countries a mix of direct and indirect financial aid is provided. In Member States such as Belgium, Germany and France direct aid is generally rather low. Grants or loans are only available where the income of the students' parents (taking into account various forms of indirect aid) falls below a certain level. In other Member States such as e.g. the Netherlands direct aid is predominant. ${ }^{16}$

\subsection{Conditions of Access}

The power of Member States to organise and administer their educational systems includes the power to lay down the conditions for admission to these systems. ${ }^{17}$ A distinction can be made between "internal" and "external" conditions of access. The former concern conditions which apply to all persons who wish to be admitted to educational institutions. It concerns e.g. requirements that pupils or students have finished preparatory training, have obtained certain diplomas, language and age requirements, duties to pay tuition and enrolment fees, etc. The external conditions of access are those which specifically apply to nationals and/or residents of other (Member) States. Admission policies have traditionally been based on the principle of territoriality. Public education is generally open for all persons who are lawfully ${ }^{18}$ residing in the territory of the State. In principle, the nationality of legal residents is of no relevance to the right to be admitted. This may be different as regards direct student financial aid. Often, non-nationals must have been employed or have resided in the national territory for a minimum period of time before they may become eligible for grants or loans. Also as regards residents from other States and persons who merely wish to come to the host State in order to pursue education, a distinction is often made between nationals and non-nationals. The former are generally admitted as though they were residing in

16. In most countries study grant systems have been expanded in recent years. An exception is the Netherlands which, after the introduction of a rather generous student financial aid system in 1986, has reduced the amounts of grants and imposed on students requirements concerning study progress or results. See e.g. Roorda, Het Vormgeven van de Rust; of: De Teloorgang van de Wet op de Studiefinanciering, in: NTOR (1994) pp.2-16.

17. For more detailed descriptions see e.g. De Jonghe/Dillo, Access to Higher Education (1991); Mohr, Studentenhandboek (1990) and Ortelius, supra footnote 9.

18. In recent years governments in the various Member States have taken initiatives to exclude illegal residents from welfare state services including education. As regards the Netherlands see e.g. Coomans, Recht op Onderwijs, Ook voor 'Illegale' Vreemdelingen, in: MR (1996) pp.57-60 
their "own" State, whilst the latter are often refused admission (and the required residence permit). For the non-resident foreigner admission is not a right but a privilege which often has only been granted to students from former colonies and been made subject to a maximum number of students or a percentage of the total student body. Generally, the non-resident foreigner also has no claim to student financial aid. Further, study grants are generally only made available to students who have been enrolled at public schools and universities established in the territory of the State concerned. On the basis of national law, study grants as a rule are not exportable. $^{19}$

Many of the "educational" cases which have come before the Court of Justice, and which will be discussed in this Chapter, concern Belgium. A good understanding of these cases requires some insight into the rather unique Belgian admission policies. ${ }^{20}$ The uniqueness of these policies lies in the fact that traditionally they have never been aimed at excluding foreign students from their educational institutions. A 1971 law stated that the Belgian State would contribute to the funding of universities in accordance with the number of enrolled students regardless of their State of origin. From the early 1970s, however, the number of foreign students grew considerably and this increased the pressure on the financing of the educational system. The Belgian authorities did not decide to limit access by foreign students by imposing quota regulations. Rather, they did so by imposing on foreign students a duty to pay an additional tuition fee, the so-called Minerval. Neither foreign students nor their parents can be required to contribute to the funding of public education through the payment of (income) taxes and it was therefore felt justified to ask from them to pay part of the cost of their education. Students whose parents lived in Belgium, Luxemburg students and students from countries with which Belgium had concluded certain development agreements were excluded from the duty to pay the additional fee. The level of the Minerval was set at a minimum of $50 \%$ of the fixed cost per student of a given study. Furthermore, it was decided that

19. To be sure, some Member States, either unilaterally or on the basis of bi-lateral agreements, have allowed "their" students to export study grants when they study at certain foreign universities. For the Netherlands see e.g. van der Ven (1999) supra footnote 4, at pp.48-49 and van der Ven (1996) supra footnote 4, at p.45.

20. For more detailed information on the Belgian policies and regulations see e.g. Verbruggen, supra footnote 4 , at pp.39-42. See also van der Mei, Nogmaals: Inschrijvingsgelden voor EG-Studenten, in: NTOR (1995) pp.202-208, at p.202 and Joris/Veny, Bijkomende Inschrijvingsgelden voor Buitenlandse Studenten - Welke Wetgeving is van Toepassing?, in: RW (1988) pp.735-740. 
once the number of foreign students at a given higher education institution exceeded a quota of $2 \%$, all other foreign students would only be taken into account for funding by the Belgian State if they had paid the Minerval. The students which were not taken into account for funding could be refused admission.

\subsection{The Common Educational Policy}

Education may primarily be a matter for Member States, but this is not to say that the Community has no role to play in the field. On the contrary, Articles 149 and $150 \mathrm{EC}$ (prior to the coming into force of the Treaty of Amsterdam: Articles 126 and 127) empower the Community institutions to act in the fields of education and vocational training respectively and significant common policies in these fields have been developed. Before commenting on the two Articles and the nature of the Community's activities in the fields, a brief history is in order. The insertion of Articles 149 and 150 EC by the Treaty on European Union was "no accident", but rather the "natural culmination"21 of a series of events and activities since the early Community years. Some historical knowledge is required for a good understanding of the two Articles and the Community rules on cross-border access to education.

The word "education" may not have been mentioned in the EEC Treaty, but the drafters were aware of the importance of education and training for the Community and the establishment of a common market. They recognised that a free movement of (in particular self-employed) persons could not be realised without adopting measures for the mutual recognition of diploma's and therefore conferred upon the Community institutions the powers necessary for adopting such measures. ${ }^{22}$ More

21. Jones, Humanresourcen, Bildung, Ausbildung, Jugend (1992) - Speech delivered on 20 February 1992 (as quoted in Schink, Kompetenzweiterung im Handlungssystem der Europäischen Gemeinschaft: Eigendynamik und Policy Entrepreneurs (1993) at p.118).

22. See Article $47 \mathrm{EC}$ (formerly $57 \mathrm{E}(\mathrm{E}) \mathrm{C}$ ). The Community legislator has adopted various directives on the mutual recognition of diplomas. Initially, a "vertical approach" was followed which implied that separate mutual recognition directives were developed for specific professions such as doctors (Directives No 75/362 and 75/363 (OJ L 167) as replaced by the current Directive 93/16 (OJ 1993 L 165)), nurses (Directives No 77/452 and 77/453 - OJ 1977 L 176), dentists (Directives No 78/686 and 78/687 - OJ 1978 L 233), veterinarians (Directives No 78/1027 and 78/1028 - OJ 1978 L 362), midwives (Directives No 80/154 and 80/155 - OJ 1980 L 33), pharmacists (Directives No 85/432 and 85/433 - OJ 1985 L 253) and architects (Directive No 85/384 (OJ 1985 L 223) as replaced by Directive No 85/614 (OJ 1985 L 376) and Directive No 8617 (OJ 1986 L 71). For lawycrs scc further 
important for the purposes of this book was Article 128 EEC which empowered the Council to lay down "general principles" for implementing a common vocational training policy. ${ }^{23}$ The Article reflected a lack of ambition on the part of the drafters. ${ }^{24}$ The wording of Article 128, as well as the fact that the general principles could be adopted without consultation of the European Parliament and by a simple majority of votes in the Council, indicated that the common vocational training policy was

Directive No 77/249 (OJ 1977 L 78) and Directive No 98/5 (OJ 1998 L 77). The adoption of these vertical directives proved to be a slow and time-consuming process partly because Member States insisted (in most cases) on first harmonising the educational systems before agreeing on the mutual recognition of diplomas. In the wake of the Community's initiatives to create the Internal Market by the end of 1992, another approach to the mutual recognition of diplomas was adopted. The goal of the mutual recognition of diplomas was no longer pursued on a sector-by-sector basis. Directive $89 / 48$ established a general system for the recognition of diplomas (OJ 1989 L 19) and Directive 92/51 introduced a second general system for the recognition of professional education and training to supplement Directive 89/48 (OJ 1992 L 209). These "horizontal" directives are based on the starting-point that higher education diplomas awarded on the completion of professional education and training of at least three years' duration should in principle be recognised in another Member State when the holder wishes to obtain access to a certain profession in that Member State. Besides the Community legislator, the Court has contributed to decreasing the diploma obstacles to freedom of movement through its interpretation of Articles 39 (formerly 48), 43 (formerly) 52 and 49 (formerly 59) E(E)C. In the absence of harmonisation, individual Member States are entitled to prescribe the knowledge and qualifications needed for admission to a certain occupation or education and, for this purpose, Member States may require the possession of certain qualifications. However, the Court has interpreted the afore mentioned Treaty provisions so as to impose on Member States an obligation to take into consideration all diplomas, certificates, experience obtained or acquired in other Member States, to compare these with the requirements laid down by their national rules and, where equivalence is established, to admit the persons concerned to the profession in question. See e.g. Case C-340/89 Vlassopoulou [1991] ECR I-2357; Case C-319/92 Haim I [1994] ECR I425; Case C-234/97 Fernández de Bobadilla [1999] ECR I-4773 and Case C-238/98 Hocsman [2000] ECR I-0000. On the professional recognition of diplomas see e.g. van Nuffel, Het Algemeen Stelsel van Erkenning van Diploma's, in: SEW (1996) pp.371-380; Schneider, Die Anerkennung von Diplomen in der Europäischen Gemeinschaft (1995) (with numerous references to other literature); Pertek, L'Europe des Diplomes et des Professions (1994); Pertek, Free Movement of Professionals, in: YEL (1992) pp.293-324 and Laslett, The Mutual Recognition of Diplomas, Certificates and other Evidence of Formal Qualifications in the European Community, in: LIEI (1990) pp.1-66.

23. Article 128 EEC Treaty read: "The Council shall, acting on a proposal from the Commission and after consulting the Economic and Social Committee, lay down genera principles for implementing a common vocational training policy capable of contributing to the harmonious development both of the national economies and of the common market".

24. Flynn (1989) supra footnote 4, at p.60. 
not envisaged to be developed by the adoption of legally binding measures. $^{25}$

In 1963 the Council fulfilled its task of formulating the general principles for implementing a common vocational training policy by adopting Decision No 63/266. ${ }^{26}$ In furtherance of the goals set in the Decision, the Council and the "Ministers of Education meeting within the Council" adopted from the early 1970s various legally non-binding conclusions and recommendations. ${ }^{27}$ Legislative measures, which could possibly have been based on the "common market provision" of Article 100 EEC (now 94 EC) and/or the "safety net clause" of Article 235 EEC (now 308 EC), were rarely adopted. Even though the Commission had sought to extend Community powers, ${ }^{28}$ the predominant view during the 1960 s and 1970s was that the common vocational training policy should be limited to providing general orientations or guidelines. ${ }^{29}$ The Commission could not do much more than to promote the voluntary cooperation of the States and educational institutions in vocational training and educational projects by providing financial incentives.

Even though through this "facilitating approach" ${ }^{30}$ some progress was made, a genuine vocational training policy had not been developed by the early 1980s. With the launching of the project of a "Peoples' Europe $^{\prime 31}$ and plans to create an internal market within the Community, however, the absence of a common policy in the field of education was

25. Rather, the "general principles" of Article 128 were probably supposed to function as guidance for the Commission which was entrusted to promote co-operation between the Member States in matters relating inter alia to "basic and advanced vocational training" (Article $118 \mathrm{EEC)}$ ) and which, by administering the European Social Fund (ESF), was to promote the employment opportunities of workers through "vocational training and retraining" (Article $125 \mathrm{EEC}$ ). See also Wohlfarth et al, Die Europäische Wirtschaftsgemeinschaft - Kommentar zum Vertrag (1960) at p.386.

26. Supra footnote 1 .

27. For an overview see Council of the European Communities - General Secretariat, European Educational Policy Statements (1987). The measures did not only concern concern vocational training but also education in general.

28. In its first proposal for the general principles in 1963, for instance, the Commission had stated that it should also have the possibility of acting in the field of general education and that it "needed" the power to adopt legally binding measures. The Council, however, disagreed. See Schink (1993) supra footnote 21, at p.39 and Hochbaum (1987) supra footnote 4 , at p. 485 .

29. Hochbaum, The Federal Structure of Member States as a Limit to Common Educational Policy: The Case of Germany, in: De Witte, European Community Law of Education (1989) pp.145 et seq, at p.154.

30. Neave, The EEC and Education (1984) at p.96.

31. See the second report of the "Adonnino Committee" (EC Bull. Suppl. 7/85) at point 5. 
increasingly felt as an omission. In particular, the European Commission and the European Parliament called for an extension of the Community's powers in the fields of vocational training and education. In 1985 these two institutions received considerable support from the Court of Justice. In Gravier the Court held, after referring to Article 128 and a number of Community "soft-law" measures concerning access to vocational training, that the common vocational training policy referred to in Article 128 was gradually being established and that the conditions for access to vocational training fell within the scope of the Treaty and, consequently, that any discrimination based on nationality was prohibited by Article 7 EEC (now $12 \mathrm{EC}$ ). ${ }^{32}$

In Gravier the Court had laid down the legal foundations for a free movement of students within the Community. More generally, however, the decision seemed to imply that Article 128 was a Treaty provision which, at least through the operation of Article 7 EEC, could have legal force. The Commission was quick to see the potential implications and read Gravier in such a way as to imply that Article 128 EEC could constitute the legal basis for the adoption of legislative measures. It decided to base the proposal for the Erasmus programme solely on Article 128. In its judgment in Commission v Council (Erasmus) (1989) the Court endorsed the Commission's reading of Article 128 EEC and Gravier. In the Court's view, the task of implementing the common vocational training policy was one for the Member States and the Community institutions working in co-operation. From "an interpretation of Article 128 based on that conception", it followed that the Council was indeed "entitled to adopt legal measures providing for Community action in the sphere of vocational training and imposing corresponding obligations of co-operation on the Member States". ${ }^{33}$

For the Commission, the Erasmus judgment opened unique opportunities. In order to have proposals for legislative measures adopted, there was no longer a need to reach the unanimity in the Council as required by

32. Case 293/83 Gravier [1985] ECR 293 at 23-26. See further Section 4.1.

33. Case 242/87 Commission v Council (Erasmus) [1989] ECR 1425 at 11. See also Case 56/88 United Kingdom v Council (Petra) [1989] ECR 1615 and Joined Cases C-51/89, C90/89 and C-94/89 United Kingdom v Council (Comett II) [1991] ECR I-2757. On the Erasmus judgment see e.g. Gilliams (1989) supra footnote 4, at pp.394-504; Classen, Bildungspolitische Förderprogramme der EG - Eine kritische Untersuchung der vertragsrechtlichen Grundlagen, in: EuR (1990) pp.10-19; Schmidt-Räntsch, Erlass von Förderprogrammen durch den Rat der EG aufgrund Art.128 EWGV, in: NJW (1989) pp.3071-3072 and Lenaerts, Erasmus: Legal Basis and Implementation, in: De Witte, European Community Law of Education (1989) pp.113-126 (written before the judgment itself). 
Articles 100 (now 94) and 235 (now 308) of the Treaty. A simple majority would suffice for adopting binding measures on the basis of Article 128. In addition, the Commission could also partly conquer the field of education in general because the Court appeared willing to give a very broad definition of the term "vocational training". Many forms of education which had traditionally been classed as general education were considered to be covered by the term "vocational training". ${ }^{34}$ The Commission did not hesitate to make use of the new opportunities. Within a relatively short period of time a wide range of measures were taken. Various educational programmes were created $^{35}$ which, being governed by the Commission, were intended to encourage the voluntary participation of educational institutions of higher education.

Within a relatively short time a European vocational training policy was established. As significant as the various measures may have been, however, this development did not proceed without debate and criticism. On the one hand, it was claimed that education should no longer be approached from a purely economic perspective. In spite of the broad meaning given to the concept of vocational training, the desire was expressed that the Community should also be involved in general education so that due regard could be given to the personal, social and cultural aspects of education and training. ${ }^{36}$ On the other hand, some Member States (e.g. the United Kingdom and Germany) ${ }^{37}$ feared that their autonomy in the field of education was affected. It had been the Court, a Community institution without democratic legitimation, which, without the Member States' consent, had empowered the Council to adopt legislation by simple majority and without a need to consult the European Parliament. The limits of Community powers were not clearly delimited. The fear of an ever extending Community educational policy which would increasingly affect national education systems was more and more expressed. $^{38}$

Ultimately, these desires and concerns have led to an amendment of the Treaty. The 1992 Treaty on European Union added a new Article

\footnotetext{
34. On the definition of the term "vocational training" see further Section 4.2.

35. Roughly speaking, a distinction could be made between mobility programmes and research and technology programmes. De Witte (1993) supra footnote 4, at p.192. For an overview of the various educational programes see Müller-Solger et al (1993) supra footnote

36. Verbruggen (1991-1992) supra footnote 4, at p.131.

37. Read: the Länder.

38. van der Mei, Vrij Dienstenverkeer in de EG, in: NTOR (1994) pp.102-107, at pp.106-

107 and Verbruggen (1991-1992) supra footnotc 4, at p.138.
} 
3(p) which states that the activities of the Community shall include "a contribution to education and training of quality and to the flowering of the cultures of the Member States". Article 3(p) was worked out in further detail by Articles 126 and 127 EC (now 149 and 150 EC) which replaced the old Article 128 of the EEC Treaty. ${ }^{39}$ The Articles provide for a more defined balance of powers governing co-operation between Member States and the Community in the fields of education and vocational training. They are based on the principle that Member States hold the primary responsibility of establishing, organising and governing educational systems. The Community's role is merely complementary and supplementary in nature. Its activities should bring about a "European added value". ${ }^{40}$

Article 149 deals with general education; Article 150 concerns vocational training. In the field of general education the Community shall contribute to the development of quality education and, if necessary, support and supplement Member States' action by the adoption (in accordance with the co-decision procedure) of "incentive measures" and recommendations. The Community shall encourage mobility of students and teachers, promote co-operation between educational establishments, encourage the development of distance learning, etc. In the field of vocational training the Community is entitled to develop a vocational training policy which shall support and supplement the actions of Member States. More specifically, under Article 150 Community action shall aim

39. For more detailed descriptions of Articles 126 and 127 EC see e.g. Lenaerts, Education in European Community Law, in: CMLRev (1994) pp.7-41; van der Ven, Europees Onderwijsrecht na Maastricht, in: NTOR (1994) pp.140-152; Lenaerts, Het Onderwijs in het Europees Recht na "Maastricht", in: TOO (1992-1993) pp.264-281; Bergreen, Das Bildungswesen nach Maastricht - Auswirkungen der Beschlüsse von Maastricht auf den Bildungsföderalismus, in: RJB (1992) pp.436 et seq; Dittmann/Fehrenbacher, Die Bildungdrechtliche Harmonisierungsverbote (Art.126 Abs.4 EGV, Art.127 Abs.4 EGV) und ihre Bedeutung für die nationale Bildungshoheit, in: RJB (1992) pp.478 et seq; Dohms, Die Kompetenz der EG im Bildungsbereich der algemeinen Bildung nach Artikel 126 EGV, in: RJB (1992) pp.451 et seq and Lane, New Community Competences under the Maastricht Treaty, in: CMLRev (1993) pp.939-979.

40. In exercising their powers, the Community institutions have to act in accordance with the principle of subsidiarity laid down in Article 5 (formerly 3b) EC. The second sentence of this Articles reads: "In areas which do not fall within its exclusive competence, the Community shall take action, in accordance with the principle of subsidiarity, only if and in so far as the objectives of the proposed action cannot be sufficiently achieved by the Member States and can therefore, by reason of the scale or effects of the proposed action, be better achieved by the Community". On the importance of the subsidiarity principle for the fields of education and vocational training see further, De Groof/Friess, Opportunities for a European Educational Policy, in: EJELP (1997) pp.9-17 and Leenknegt, Europees Onderwijsrecht en Subsidiariteit, in: Bekkers et al (Eds), Subsidiariteit en Europese Integratie Ecn Oude Wijshcid in cen Nicuwc Contcxt (1995) pp.93 et seq. 
to facilitate adaptation to industrial changes, improve vocational training in order to facilitate vocational (re)integration into the labour market, etc. Community action, which includes legislative measures, is aimed at an intermediary function between education, industrial life and the labour market. ${ }^{41}$ In both fields the Community in principle is not entitled to meddle in the substance of education. ${ }^{42}$ Paragraphs 4 of Articles 149 and 150 EC emphasise the protection of the national autonomy in the field of education by stating that the Community shall take "incentive measures" excluding any harmonisation of the laws and regulations of the Member States. Community action will continue to take the form of providing financial incentives for educational institutions which are invited to participate in the co-operation prescribed or proposed by the Community. ${ }^{43}$

In response to the insertion of Articles 149 and 150, the Council re-arranged the various educational programmes. These are now clustered under two general programmes: Socrates and Leonardo da Vinci. ${ }^{44}$ The former covers all programmes which are intended to implement Article

41. Cohen, Europa en het Onderwijs(recht), in: Postma (Red.), Europa en het Onderwijs (1992) pp.21-42, at p.36.

42. See however Article 149(2) EC which states that the Community shall aim at developing a European dimension in education. According to the third paragraph of Articles 149 and 150 the "Community and the Member States shall foster cooperation with third countries and the competent international organizations". See further Gori, External Relations in Community Education and Vocational Training Policies", in: MJ (1998) pp.25-51.

43. Leanerts (1993) supra footnote 39, at p.279.

44. Mention may further be made of the Youth for Europe Programme (Decision No 818/95 - OJ 1995 L 87) which aims to contribute to the educational progress of young people by facilitating exchanges, encouraging youth action at local level and facilitating the access of disadvantaged young people into the programme's activities as well as the European Voluntary Service for Young People which offers young people the opportunity of spending a period of time in another country and of getting involved in local projects as volunteers so that they "broaden their horizons, .. familiarise themselves with a different social and cultural environment and develop self-confidence" (European Commission, European Voluntary Scrvicc - availablc on http/: curopa.cu.int/comm/education/volunt/index.html). 
149; the latter programme implements Article 150. ${ }^{45}$ Even though the line of demarcation between Articles 149 and 150 is not crystal clear, ${ }^{46}$ the Community powers are defined more clearly since the coming into force of the Treaty of Maastricht and much of the initial criticism has faded away. It may not therefore come as a surprise that the Treaties of Amsterdam and Nice have not introduced significant substantive changes. Apart from the renumbering of Articles 126 and 127 as Articles 149 and $150 \mathrm{EC}$, "Amsterdam" has only added a new phrase in the preamble to the EC Treaty which provides that the contracting parties are "determined to promote the development of the highest possible level of knowledge for their peoples through a wide access to education and through its continuous updating". ${ }^{47}$ The Treaty of Nice, which is still waiting for ratification, has not altered the Treaty rules relevant to education. The Charter of Fundamental Rights of the European Union, which was adopted at the Nice summit, provides in Article 14 for a right to education and to have access to vocational and continuing training which includes the possibility of receiving free compulsory education. In the near future, however, this right to education is unlikely to bring about significant changes. The Charter does not establish new, nor does it modify the

45. Socrates covers Erasmus and Lingua as well as the new programme Comenius which deals with Community action in the areas of primary and secondary education. Leonardo concerns Article 150 and covers inter alia Comett and Petra. See further Hermans, The Socrates Programme: From Negotiation to Implementation, in: EJELP (1997) pp.19-39 and van der Mei, EG-Recht en Onderwijs, in: JBOO (1993-1994) pp.17-26. On the future of the common educational policy and recent initiatives see e.g. Mitchell, EU Cooperation in Higher Education and Training: New Challenges and Recent Progress, in: EJVT (1996) pp.43-54; van der Mei, EG-Recht en Onderwijs, in: JBOO (1995-1996) pp.17-25 and Education, Training and Youth - A New Generation of Programmes (2000-2006) (available on http://europa.eu.int.comm/education/newprogr/index.html).

46. Articles 149 and $150 \mathrm{EC}$ do not define the terms "education" and "vocational training". This is as such remarkable since the powers of the various Community institutions in the two fields differ. The definition the Court has given to the term "vocational training" in the "old" Article 128 cannot be used to demarcate the scope of Articles 149 and 150. University training was covered by the Court's definition of "vocational training", but it is now (also) covered by Article 149 EC. Difficult questions regarding the proper legal basis may therefore arise. Lenaerts (1993) supra footnote 39, at pp.273-275. Ultimately, it will be for the Court to draw the proper borderline between Articles 149 and $150 \mathrm{EC}$, but, with Lenaerts, it can be argued that Article 149 is the basic provision on which Community action is in principle to be based and that Article 150 complements Article 126 whenever specific vocational training aspects are involved. Article 149 is the lex generalis, Article 150 the lex specialis. Lenaerts (1993) supra footnote 39 , at p. 273.

47. The proposal to add this observation was made by the British Prime Minister Blair and relates to the reformulated Article 136 (the former Article 117) of the EC Treaty on social policy. Scc Barcnts, Het Verdrag van Amstcrdam (1997) at p.37. 
current, powers and tasks of the Union ${ }^{48}$ and its legal status still needs to be determined.

\section{Economic Residents}

3.1 The Community's Power to Grant Educational Rights to Workers and their Family Members

The drafters of the original EEC Treaty did not pay much, if any, attention to the question whether Community law should confer upon wor$\mathrm{kers}^{49}$ a right to gain access to education in the Member State of employment. $^{50}$ Education was, and would remain, a national affair. ${ }^{51}$ In the drafters' view, it would be entirely up to the Member States to determine whether beneficiaries of Article 48 EEC (now $39 \mathrm{EC}$ ) would be admitted to their educational institutions, and if so, the conditions under which, they would be admitted. The Community institutions which had had to realise the free movement of workers during the 1960s, however, recognised that a genuine free movement of workers could not be realised without granting workers and their family members educational rights. ${ }^{52}$

48. Article 51 of the Charter.

49. For the purposes of this book the category of economic residents has been defined so as to consist of all Community citizens and their family members who stay or reside in another Member State on the basis of Article 39 or Article 43 EC. See Chapter 2 Section 2. The self-employed beneficiaries of Article $43 \mathrm{EC}$ will not be dealt with seperately. As noted in Chapter 2 Section 2.4, this book is based on the assumption that, at least in as far as crossborder access to public benefits is concerned, the self-employed and their family members enjoy the same rights as workers and their family members do. Compare Case C-337/97 Meeusen [1999] ECR I-0000 at 26-30.

50. In the so-called Val Duchesse documents (see Chapter 2 footnote 12) this author did not find any document which indicates, or even suggests, that the Member State delegations paid attention to educational rights for workers.

51. Hartley (1991) supra footnote 4, at p.175.

52. For instance, the European Commission and Parliament had expressed concern about the low level of training of, at the time in particular Italian, migrant workers. In order to increase employment opportunities, migrant workers should have the right to gain access to vocational training schools in both the State of origin and the State of employment. See e.g. Verslag namens de Sociale Commissie nopens de Resultaten van de Studiereizen in de Landen van de Gemeenschap ter Bestudering van Bijzondere Vraagstukken in Verband met het Vrije Verkeer van Werknemers, Europees Parlement Zittingsdocumenten 1963-1964, Document 118, January 1964 and Boni, Freizügigkeit und Integration - Struktur und integrationspolitike Bedeutung der Arbeitsmarktverflechtung zwischen den Mitgliedstaaten 
Article 7(3) was included in Regulation No 1612/68 which states that Community workers shall "by virtue of the same right and under the same conditions as the national workers, have access to training in vocational schools and retraining centres". As regards family members, it was stipulated in the preamble to Regulation No 1612/68 that all obstacles to the integration of the worker's family in the host State's society had to be eliminated. Such an integration requires children of Community workers to go to school. Article 12 was included in the Regulation which provides that the:

"children of a national of a Member State who is or has been employed in the territory of another Member State shall be admitted to that State's general educational, apprenticeship and vocational training courses under the same conditions as the nationals of that State, if such children are residing in its territory. Member States shall encourage all efforts to enable such children to attend these courses under the best possible conditions".

Politically, the inclusion of Article 7(3) and Article 12 did not raise many problems during the Council negotiations in the 1960s. Legally, however, the inclusion of the two provisions was not wholly uncontroversial. The policy area of education had not been brought within the ambit of the Treaty. The question had been raised whether the Council was at all empowered to grant educational rights upon Community workers and their family members. ${ }^{53}$ In 1974 the German government raised this point in the proceedings before the Court in Casagrande in support of its view that it could not be obliged to make study graants available to children of Community workers. The Court did not accept the argument:

"Although educational and training policy is not as such included in the spheres which the Treaty has entrusted to the Community institutions, it does not follow that the exercise of powers transferred to the Community is in some way limited if it is not of such a nature as to affect the measures taken in execution of a policy such as that of education and training". 54

The Community institutions had thus not overstepped the limits of their powers by including in Regulation No $1612 / 68$ provisions granting educational rights. Casagrande indicates that the Community is entitled to grant educational rights in as far as this is necessary for the realisation of the free movement of workers. In order to grant these rights no substanti-

der Europäischen Wirtschaftsgemeinschaft (1976) pp.133-134.

53. See e.g. Knolle, Freizügigkeit der Arbeitnehmer - Zur Verordnung Nr.15 der Europäischen Wirtschaftgemeinschaft, in: BArbBl (1961) pp.674-679, at p.677.

54. Case 9/74 Casagrande [1974] ECR 773 at 12. 
ve educational powers are required; the functional power to take measures with a view to realising the free movement of workers suffices. ${ }^{55}$

\subsection{Community Workers}

\subsubsection{Admission to Education}

The drafters of Regulation No 1612/68 regarded education primarily as a form of training for improving the labour skills of workers. This explains why Article 7(3) of the regulation merely speaks of a right to attend vocational schools and retraining centres. The Court has interpreted Article 7(3) accordingly. In Lair (1988) the Court held that an educational institution cannot be regarded as a vocational school in the sense of Article 7(3) just because some vocational training is provided. The concept of vocational school "is a more limited one and refers exclusively to institutions which provide only instruction either alternating with or closely linked to an occupational activity, particularly during apprenticeship". ${ }^{56}$ Generally, universities do not fulfill this condition.

The rather limited scope of Article 7(3) does not imply, however, that Community workers are not entitled to have access to universities and other types of "general" education. Workers do have such a right under Article 7(2) of Regulation No 1612/68 which provides for a right to be treated equally with the host State's nationals as regards "social advantages". In the view of its drafters, Article 7(2) would not cover educational rights, ${ }^{57}$ but in Lair the Court held that this provision entitles a Community worker "in the same way as national workers to all advantages available to such workers for improving their professional qualifications

55. See De Witte, The Scope of Community Powers in Education and Culture in the Light of Subsequent Practice, in: Bieber/Ress (Eds), The Dynamics of EC-Law (1987) pp.261-281. Casagrande is a typical example of a case which indicates that in determining the material scope of the right to equal treatment of workers the functional criterion of promoting freedom of movement (and integration in the host State) is to be applied. See further Chapter 2 Section 2.2.3

56. Case 39/86 Lair [1988] 3161 at 23.

57. See De Witte (1989-1990) supra footnote 4, at p.539 and O'Keeffe, Equal Rights for Migrants: the Concept of Social Advantages in Article 7(2), Regulation 1612/68, in: YEL (1986) pp.93-123, at p.95. 
and promoting their social advancement." ${ }^{58}$ Access to any form of education may improve workers' qualifications and contribute to the integration of workers into the host State's society. Even though the Court has never said so explicitly, it may be assumed that all ${ }^{59}$ forms of education not covered by Article 7(3) can be regarded as "social advantages" in the sense of Article 7(2) of the Regulation. ${ }^{60}$

\subsubsection{Study Grants}

Community workers' right to gain access to education under the same conditions as the nationals of the host State logically implies that workers must be treated equally as regards the payment of tuition fees, the recognition of diplomas and the application of numerus clausus regulations. These are all issues directly linked to access to education. This link is less obvious as regards study grants, especially in as far as these cover the cost of maintenance. Grants may facilitate access, but they are not in all cases, or for all persons, a prerequisite for attending courses. The question whether Community workers can claim study grants was submitted to the Court in the afore mentioned case of Lair (1988). Ms Lair was a French national who claimed equality of treatment as regards study grants in Germany under Article 7(2) of Regulation No 1612/68. The German authorities had refused Ms Lair a grant on the ground that she had not resided and been employed in Germany for a minimum period of five years as required by German law. The Court reiterated that the concept of social advantages in Article 7(2) covers all benefits which "whether or not linked to a contract of employment" are "granted to national workers

58. Case 39/86 Lair [1988] 3161 at 22. See also Case 235/87 Matteucci [1988] ECR 5589 at 11.

59. Possibly, an exception can be made for those forms of education which are directly related to, and intended to prepare individuals for, certain posts in the public services which are covered by Article 39(4) EC. On the public service exception see Chapter 2 Section 7.1. 60. See also Van Gerven/van den Bossche (1993) supra footnote 4, at p.410. As regards the access to education, Article 7(2) thus fulfils a safety-net role vis-à-vis Article 7(3). Compare the Opinion of Advocate General in Case 39/86 Lair [1988] ECR 3161 at pp.3187-3188. In a proposal for amending Regulation No 1612/68 the Commission has included a new Article 7(3) which reads: "A worker who is a national of a Member State shall, by virtue of the same right and under the same conditions as nationals workers, have access to all levels of education and university or other vocational training and to vocational rehabilitation, retraining and further training". OJ 1998 C 344 at p.9; COM(98) 394 final. The text of the proposed Article 7(3) indicates that the Commission intends to make this provision the one and only education clause for Community workers. The proposed Article 7(3) is to be seen as a codification of the case law. 
primarily because of their status as workers or by virtue of the mere fact of their residence on the national territory". It follows, the Court held, that Community workers are entitled "in the same way as national workers to all the advantages available to such workers for improving their professional qualifications and promoting their social advancement". ${ }^{61}$ Study grants were classed as a social advantage and the durational residence and employment requirement in question was held to be incompatible with Article 7(2). ${ }^{62}$ The Court concluded that Member States cannot "unilaterally make the grant of social advantages in Article 7(2) conditional upon the completion of a given period of occupational activity". ${ }^{63}$ Thus, from the moment they take up employment and establish residence in another Member State, Community workers can gain admission to education and claim study grants under the same conditions as the nationals of that State. ${ }^{64}$

The Court has never been directly confronted with the question whether workers who have decided not to establish residence in the State of their employment can claim educational grants there. At first glance, one might think that frontier workers cannot claim educational rights under these provisions. In interpreting Article 7(2) the Court has been guided by the goal of promoting the integration of the workers (and their family) in the host State. As regards frontier workers, it could be argued that they have chosen not to establish residence in, and to become a member of the society of, the State of employment. Nonetheless, non-resi-

61. Case 39/86 Lair [1988] ECR 3161 at 21-22.

62 . It could be argued that Community workers who have started studying at a vocational training school covered by Article 7(3) of Regulation No 1612/68 can claim equal treatment as regards study grants under this provision. If one of the conditions under which national workers can attend a vocational training course is that they obtain a study grant, then such a grant can be regarded as one of the conditions Article 7(3) refers to. See e.g. Opinion of Advocate General Slynn in Case 39/86 Lair [1988] 3161 at pp.3185-3186. The Advocate General made reference to the Casagrande judgment in which the Court had held that the similar phrase "under the same conditions" in Article 12 of Regulation No 1612/68 also applied to study grants. Case 9/74 Casagrande [1974] ECR 773 at 8 . See also Van Gerven/van den Bossche (1993) supra footnote 4, at p.411.

63. Case 39/86 Lair [1988] ECR 3161 at 42.

64. The durational residence and employment requirement at issue in Lair only applied to non-Germans. The requirement thus constituted direct discrimination on grounds of nationality. By analogy with the Court's case law on the validity of durational residence requirements for social security and social assistance benefits (see e.g. Case C-326/90 Commission v Belgium [1992] ECR I-5517, Case C-111/91 Commission v Luxembourg [1993] ECR I-817 and Chapter 3 Section 3.1.2), it may be assumed that durational residence or employment requirements which are to be satisfied by both nationals and non-nationals are prohibited as indirect discrimination on grounds of nationality. 
dent workers can rely on Articles 7(2) of Regulation No 1612/68) in order to claim study grants in the State of employment. In Meints (1997), ${ }^{65}$ for instance, the Court was asked whether frontier workers can invoke Article 7(2) against the State of employment in order to claim certain unemployment benefits. The Court concluded that such workers do indeed have this right. It rejected the argument concerning integration into the host State's society by referring to a phrase in the preamble to Regulation No $1612 / 68$ according to which the right to freedom of movement must be enjoyed "without discrimination by permanent, seasonal and frontier workers". Article 7(2), the Court concluded, provides without any reservation for equality of treatment as regards social advantages, and thus can be relied upon by workers who have not taken up residence in the State of employment. ${ }^{66}$

The drafters of Regulation No 1612/68 had primarily been concerned with the legal status of workers in the State of employment. They certainly had not considered giving workers a right to claim study grants for studies outside that State. Nonetheless, workers may have such a right.

65. Case C-57/96 Meints [1997] ECR I-6689.

66. Ibid, at 21. To be sure, Meints alone does not guarantee that non-resident workers can also claim educational rights in the State of employment. First, the concept of social advantages in Article 7(2) has been defined by the Court as to apply to benefits which are granted to national workers in their capacity as workers or by virtue of their residence in the host State. See Chapter 2 Section 2.2.3. Unlike unemployment benefits, general education and study grants would seem to be benefits which are granted to beneficiaries by virtue of residence rather than employment. It could thus be argued that study grants do not constitute social advantages for non-resident Community workers. Compare Sewandono, Werknemersverkeer en Gezinsleven (1998) at p.226; van der Mei, De Rechtmatigheid van Woonplaatsvereisten voor Bestaansminimumuitkeringen onder het EG-Recht, in: SMA (1999) pp.451459, at p.458; Lhernould, Avantages sociaux et Egalité de Traitement - Une nouvelle Etape dans la Jurisprudence de la CJCE, in: DS (1999) pp.938-939 and Advocate General Jacobs in his Opinion in Case C-43/99 Leclere (http://www.curia.eu.int/jurisp) at 98. Meeusen (1999), however, suggests that this distinction is of no relevance. In the judgment, which will be discussed further in Section 3.3.2, the Court accepted that a child that had not established residence in the State where the parent-worker was employed, could rely on Article $7(2)$ in order to claim study grants. The Court did not seem to attach importance to the distinction between benefits related to employment and benefits granted by virtue of residence. Read together, Meints and Meeusen would seem to imply that frontier workers can claim access to all forms of education and student financial aid schemes in the State of employment under the same conditions as the nationals of that State.

Second, the mere fact that frontier workers can invoke Article 7(2) of Regulation No 1612/68 does not necessarily imply that residence requirements are invalid. Such requirements may escape the classification of a prohibited indirect discrimination on grounds of nationality when they can be objectively justified. It would seem, however, that no persuasive justification exists for residence requirements for study grants. 
In Matteucci $(1988)^{67}$ the Court was faced with the case of an Italian national who was residing and teaching rhythmics in Belgium. Ms Matteucci applied for a scholarship in order to take a specialist course in singing and voice-training in Berlin. The scholarship was refused on the ground that Ms Matteucci lacked Belgian nationality. In light of the aim of Regulation No 1612/68 to promote the integration of the worker (and his family) into the host State, it was argued before the Court that the refusal to offer the grant was not contrary to Article 7(2). The Court, however, held that the provision had been violated. Article 7(2) lays down a general rule:

"which imposes responsibility in the social sphere on each Member State with regard to every worker who is a national of another Member State and established in its territory as far as equality of treatment with nationals is concerned. Consequently, where a Member State gives its nationals the opportunity of pursuing training provided for in another member State, that opportunity must be extended to Community workers established in its territory". 68

Ms Matteucci was a worker who had already established residence in the State of employment at the time she applied for the study grant. The judgment merely implied that actual residence outside the State of employment for the duration of the studies cannot affect the right to claim grants in that State. From Matteucci the conclusion could not yet be drawn that workers who have decided not to establish domicile in the State of employment, can claim study grants there for studies outside that State. Meeusen (1999), ${ }^{69}$ however, strongly suggests that frontier workers do have such a right. In this case the Court accepted that a child of a frontier worker who had not established residence in the territory of the State where the parent-worker was employed, could invoke Article 7(2) in that State in order to claim study grants. The fact that Ms Meeusen did not study in the State of employment but in the State where she had kept her residence did not alter this conclusion. A combined reading of Mat-

67. Case 235/87 Matteucci [1988] ECR 5589.

68. Ibid, at 16. The scholarship Ms Matteucci had applied for was awarded under a bilateral cultural agreement between Germany and Belgium which had established a system of scholarships to promote cultural exchanges. In the proceedings before the Court the French government had argued that such agreements fall within the cultural sphere to which the Treaty would not apply. The Court rejected this argument by ruling that the refusal to grant such a benefit may jeopardise the Community right to equal treatment and that the "application of Community law cannot be precluded on the ground that it would affect the implementation of a cultural agreement between two Member States". Case 235/87 Matteucci [1988] ECR 5589 at 14.

69. Case C-337/97 Meeusen [1999] ECR I-0000. 
teucci and Meeusen does not seem to leave room for any conclusion other than that non-resident workers are entitled to claim study grants in the State of employment for studies in that State as well studies elsewhere in all cases where, and under the same conditions as, the nationals of the State of employment are given such a right.

\subsubsection{Status of Community Worker}

Community provisions on the free movement of workers provide for equal treatment rights in virtually all educational matters. Enjoyment of these rights, however, is conditional upon the possession of the status of Community worker.

The Court has given quite a broad interpretation of the concept of Community worker. The mere fact that Community citizens have moved to another State for educational purposes does not imply that they cannot be classed as Community workers. ${ }^{70}$ Further, the Court has given due regard to the emergence of new "flexible" forms of labour. The status of worker can be obtained by students who work part-time during evenings or weekends. The fact that work is performed on the basis of "on-call contracts" $^{171}$ or through temporary employment agencies, is no obstacle. Even trainees and interns, who usually work for educational purposes, may be classed as Community workers. ${ }^{72}$ In addition, the Court has accepted that Community workers can retain their privileged status when they have ceased working and commenced studying. In Lair the Court held that Community workers who have voluntarily given up their employment in order to study can retain their worker status on condition that there is "some continuity between the previous occupational activity and the course of the study; there must be a relationship between the

70. Compare Case 53/81 Levin [1983] ECR 1035 at 21.

71. Case C-357/89 Raulin [1992] I-1027 at 10

72. Case 66/85 Lawrie-Blum [1986] ECR 2121 at 19 and Case C-3/90 Bernini [1992] ECR I-1071. The fact that internships are part of students' education and that they are often regarded as preparation for the actual pursuit of an occupation, does not exclude the possibility of interns attaining the status of Community worker. Trainees can obtain this status despite the fact that their productivity is often rather low, that they work only a few hours a week and that they receive a relatively low remuneration. Case 66/85 Lawrie-Blum [1986] ECR 2121 at 15 and 19-20. The Commission has proposed to codify this case-law by including stagiaires in Articles 1 of Regulation No 1612/68 and Directive No 68/360. See COM (1998) 394 def (Explanatory Memorandum, at p.10). 
purpose of the study and the previous occuptional activity" ${ }^{173}$. The defini-

73. Case 39/86 Lair [1988] ECR 3161 at 37. In subsequent case law the Court has confirmed this conclusion. See e.g. Case 197/86 Brown [1988] ECR 3205 at 26; Case C-357/89 Raulin [1992] ECR I-1027 at 21 and Case C-3/90 Bernini [1992] ECR I-1071 at 19. In Bernini the Court specified that in assessing the link between the previous occupational activity and the subject of the study, national courts have to consider the "various factors which are useful in that assessment, such as the nature and the diversity of the activities pursued and the duration of the period between the end of those activities and the commencement of the studies". Case C-3/90 Bernini [1992] ECR I-1071 at 19. In his Opinion in Raulin Advocate General Van Gerven proposed interpreting the requirement of continuity broadly. Studies which improve the position of workers in the "sector of activity" in which they are employed, would provide proof of sufficient continuity, even if, as a result of such studies. workers are able to gain access to higher or more specialised posts in that sector. The continuity, however, should not be interpreted too broadly. Opinion Advocate General in Case C-357/89 Raulin [1992] ECR I-1027 at p.1047. On this point see also Van den Bossche, Elders Gaan Studeren op Andermans Kosten?, in: NJB (1992) pp.792-797, at p.795.

The Court does not require studies to commence immediately following the ending of the occupational activity. A "certain period of time" may have elapsed. Case C-3/90 Bernini [1992] ECR I-1071 at 21.

As regards workers who have become involuntarily unemployed, the Court stated in Lair that such continuity or relationship may not be required if the person concerned is "obliged by conditions in the job market to undertake occupational training in another field of activity". Case 39/86 Lair [1988] ECR 3161 at 37. This observation of the Court is not free from criticism. Firstly, as argued Chapter 2 Section 2.4, Community workers who become involuntarily unemployed do not necessarily lose their right to reside as a worker in the host State; arguably, they retain the right to equal treatment under Article 39 and Regulation No 1612/68. Secondly, the observation of the Court that workers who have become unemployed against their will and who are not forced by conditions in the labour market to undertake training in another field of activity, suggests that such workers loose entitlement to "social advantages". As regards workers who are still lawfully residing in the host State, however, this conclusion seems no longer correct. In Martinez Sala (1998) the Court held that all Community citizens who lawfully reside in the territory of another Member State enjoy under Article 12 a right to equal treatment which covers inter alia all benefits which can be classed as social advantages in the sense of Article 7(2) of Regulation No 1612/68. See Case C-85/96 Martínez Sala [1998] ECR I-2691. See further Chapter 2 Section 3 .

Community citizens who loose the status of worker and subsequently return to, or continue to reside in, another Member State, are (still) entitled to rely on Article 7(2) of Regulation No 1612/68 in order to claim benefits which are intrinsically linked to the objective status of worker (Case C-57/96 Meints [1997] ECR I-6689 - special unemployment benefits and Case C-349/97 Paraschi [1998] ECR I-4501 - incapacity for work benefits). Such workers cannot, however, claim rights or benefits granted by virtue of residence in the (former) host State. See Case C-33/99 Fahmi [2001] ECR I-0000 at 47 (study grants). In Fahmi the Court seems to have rejected the argument of Advocate General Alber who had concluded that (children of) former workers who have returned to their State of origin remain entitled to tax-funded benefits (such as study grants) where the persons concerned ( $i$ ) receive a pension from the State of employment and (ii) pay taxes in respect of such a 
tion of the term Community worker, however, is not infinitely broad. The case law suggests that the Court has wished to avoid that Article 39 EC could de facto serve as the legal basis for a free movement of students. ${ }^{74}$ For the purposes of Article $39 \mathrm{EC}$, studies do not constitute economic activities. ${ }^{75}$ Further, in order to acquire the status of Community worker and the rights linked to it, students must perform work that can be regarded "effective and genuine". The Court has never specified how many hours must be worked, but it could be argued that a Community citizen must work approximately $50 \%$ of "normal" working hours. ${ }^{76}$ In practice, it may be quite difficult for full-time students to meet this threshold requirement for obtaining the status of worker and the rights linked to it. $^{77}$ Further, the possibility of retaining the status of worker having given up employment for educational purposes, was merely accepted by the Court in Lair because this would correspond with current developments in labour markets. The Court said that continious careers are no longer so common and occupational activities are frequently interrupted

pension in that State. Opinion of in Case C-33/99 Fahmi and Esmoris Cerdeiro-Pinedo Amado [2001] ECR I-0000 at 79.

74. See also van der Mei, The Elusive and Exclusive Concept of Union Citizenship, A Review Essay, in: MJ (1998) pp.391-402, at pp.397-398.

75. See e.g. Case 66/77 Kuyken [1978] ECR 2311 and Case 238/83 Meade [1984] ECR 2631. Kuyken concerned a Belgian national who had followed a course of study in the Netherlands. On completion of his studies, Mr Kuyken returned to Belgium where he applied for a special unemployment benefit for young workers who have just completed their studies. The benefit was denied on the ground that Kuyken had not studied in school recognised by the Belgian State. The national court which was to rule upon the case asked the Court of Justice whether the refusal to grant the benefit was compatible with Community law on the free movement of workers. The Court concluded that neither Article 48 (now 39) E(E)C nor Regulation No $1408 / 71$ prohibit such a denial because students who have never been employed fall outside the personal scope of the relevant provisions. Case 66/77 Kuyken [1978] ECR 2311 at 23.

76. Jørgensen, Union Citizens - Free Movement and Non-Discrimination (1996) at p.31.

77. The Bernini judgment indicates that it will often be quite difficult for trainees to satisfy the criterion of "effective and genuine" work. The Court held that in assessing whether or not interns perform such work, one does not have to take into account the number of hours during which trainees still have to familiarise themselves with the work. Case C-3/90 Bernini [1992] ECR I-1071 at 16. In Bernini Advocate General Van Gerven suggested that the ten weeks which an intern from a technical school worked at a furniture factory was too short. Opinion of Advocate General Van Gerven in Case C-3/90 Bernini [1992] ECR I-1071 at 11 12. In Brown, however, the Court held that a student who had entered a "pre-university industrial training"-relationship with an employer of eight months, which consisted of a three-month introduction course and five months of employment, could be classed as a Community worker. Case 197/86 Brown [1988] ECR 3205 at 23. 
by periods of training or retraining. ${ }^{78}$ The possibility of retaining the status of Community worker was not recognised in order to enable "real students" to obtain the status of worker through relatively short jobs, to give up this work once the studies begin and to claim as a Community worker study grants under Article 7(2) of Regulation No 1612/68. ${ }^{79}$ In Brown the Court concluded that in "such circumstances, the employment relationship, which is the only basis for the rights deriving from Regulation $1612 / 68$, is merely ancillary to the studies to be financed by the grant". ${ }^{80}$ Community law does not cover "abuses" of the status of Community worker. ${ }^{81}$

78. Case 39/86 Lair [1988] ECR 3161 at 38 .

79. Consider, however, Grzelczyk, a case currently still pending before the Court. The case concerns a French student who was studying sports at the University of Louvain, Belgium. During the first three years of his studies Mr Grzelczyk was able to provide for himself with the income earned from various small jobs. In the fourth and final year, however, he was no longer able to combine his studies with employment. Since his parents were unable to bear the cost of his maintenance, Mr Grzelczyk applied for a social assistance benefit in Belgium. His application was rejected on the ground that social assistance benefits could only be awarded to Belgian nationals and Community citizens falling within the ambit of Regulation No 1612/68. The national court which is to decide the case has asked the court inter alia whether the refuseal to grant Mr Grzelczyk the requested benefit is compatible with Articles 12 and $18 \mathrm{EC}$. In his Opinion of 28 September 2000 Advocate General Alber has taken the view, however, that it is necessary to consider whether a student like Mr Grzelczyk can (still) be classed as a worker in the sense of Article 39 EC. The Advocate General has not had much difficulty in concluding that Mr Grzelczyk obtained the status of worker and the accompanying right to reside as a result of the work he performed during the first three years of his studies. Case C-184/99 Grzelczyk (http://www.curia.eu.int/jurisp) at 65-75. Yet, can $\mathrm{Mr}$ Grzelczyk still be regarded as worker now that he has voluntarily given up employment? Alber states that the loss of employment in principle leads to the loss of the status of worker, but (under reference to Martinez Sala - Case C-85/96 [1998] ECR I-2691 at 32) he concludes that the status of worker may have some continuing effects once the employment relationship has ended. One of these effects is that the status of worker and the right to invoke Article $7(2)$ of Regulation No 1612/68 can be retained when a worker gives up employment in order to commence study which is substantially related to the nature of the work that he was last engaged in. From the information given by the national court it is not clear whether Mr Grzelczyk satisfies the requirement of a link between his work and his studies. Advocate General Alber, however, does not deem this to be decisive. Previous cases such as Lair, Brown and Bernini all concerned Community citizens who had first worked and subsequently embarked on study. In such cases a link between the work and the studies needs to be established in order to avoid "real students" claiming study grants. The case of Mr Grzelczyk, however, would be different because he had been working and studying at the same time. Alber does not consider it necessary to insist on a link between studies and work in such a case. Case C-184/99 Grzelczyk (http://www.curia.eu.int/jurisp) at 98-101.

80. Case 197/86 Brown [1988] ECR 3205 at 27.

81. Case 39/86 Lair [1988] ECR 3161 at 37-38. 


\subsection{Children of Community Workers}

\subsubsection{Admission to Education}

Article 12 of Regulation No 1612/68 confers upon the children of Community workers who are residing in the territory of the host State the right to gain access to "general educational, apprenticeship and vocational training courses" under the same conditions as nationals of the host State. The Court has interpreted this provision to apply to the admission ${ }^{82}$ to all $^{83}$ forms of education. ${ }^{84}$ Article 12 refers in rather general terms to "children of workers", but in Gaal (1995) it was argued that "independent" children, i.e. children who are not financially supported by the parent-worker, ${ }^{85}$ could not claim educational rights under Article 12 . The

82. In practice, children of workers who wish to attend schools or universities in the host State often encounter problems concerning the academic recognition of diplomas or other qualifications obtained in the State of origin. By means of analogy with Community rules on professional recognition (see Section 4.5), it could be argued that Member States and educational institutions are obliged to consider foreign diplomas, to compare these to national diplomas and, when equivalence is established, to recognise the diplomas. As a result, educational institutions could be prevented from requiring children to take additional exams or resit a school year before they are granted access to education at the same level as that which they had attained in their country of origin. See Stalford, Transferability of Educational Skills and Qualifications in the European Union: The Case of EU Migrant Children, in: Shaw (Ed.), Social Law and Policy in an Evolving European Union (2000) pp.243-258, at p.247.

83. See, however, footnote 59 . The same would seem to apply to family members.

84. Joined Cases 389 and 390/87 Echternach [1989] ECR 723 at 29. The fact that certain types of education are not explicitly mentioned is caused by the difficulty of detailing all possible forms of education. Case 76/72 Michel S. [1973] ECR 457 at 15 . Article 12 only applies to children who are residing in the State where the worker is employed. This does not mean, however, that children who have not established residence in that State cannot claim access to education. The ruling in Meeusen (see Section 3.3.2), in which the Court held that "non-resident" children who are dependent on the worker can rely on Article 7(2) in order to claim study grants in the State of employment, does not seem to leave room for any conclusion other that that such children can also claim access to education under this provision. Independent children residing outside the State of employment can claim access to (all forms) of education under Article 12(1) EC. See further Section 4.

85. The Court has never really indicated when children or other family members are to be regarded as dependants of a worker. In Lebon the Court indicated that in order to be classed as a dependent family member the person concerned must be "factually supported" by the worker. Case 316/85 Lebon [1987] ECR 2811 at 13-14. The Court did not indicate what the worker's support should consist of, but, arguably, this support has to be valuable in financial terms. Otherwise, and if for instance "moral support" would suffice, the requirement of dependency for relying on Article 7(2) would have no practical significance. Comparc also 
case concerned a Belgian child who had lived in Germany for many years where his father had obtained the status of Community worker. In 1989 the child applied for a study grant for a one year period of study in the United Kingdom. The grant was denied on the ground that Gaal was over 21 and no longer a dependent child. After the death of his father he received an orphan's allowance and was not dependent on his mother. Article 10 of Regulation No 1612/68 grants children of Community workers the right to reside with the worker in the State of employment only when they are younger than 21 years or when they are dependent upon the worker. The close relationship between Articles 10 and 12, so it was argued by the German authorities, would imply that children can only invoke Article 12 if they satisfy the conditions laid down in Article 10. The Court disagreed. The concept of child in Article 12 is not limited by an age limit or by the requirement of being dependent on the worker. To make the right to invoke this Article subject to these two conditions would be contrary to the letter and the spirit of Article $12 .^{86}$

\subsubsection{Study Grants}

The second sentence of Article 12 provides that "Member States shall encourage all efforts to enable .. children to attend .. courses under the best possible conditions". The sentence suggests that the drafters of Regulation No 1612/68 had not intended to confer upon children a legally enforcable right to claim study grants in the host State. Nonetheless, children do have such a right. In Casagrande (1974) the Court held that the first sentence of Article 12, which states that children can participate in education "under the same terms as the citizens" of the host State, must be interpreted to apply to all "general measures intended to facilitate

\footnotetext{
Bernini where the Court held that benefits can only be regarded as a social advantage for the worker where the worker continues to support the family member. Case C-3/90 Bernini [1992] ECR I-1071 at 25. Article 10 of Regulation No 1612/68 suggests that children below the age of 21 are in all cases assumed to be dependants of the worker. If indeed so, this would imply that the requirement of financial support only applies to children of 21 years and older and other family members.

86. Case C-7/94 Gaal [1995] ECR I-1031 at 23-31. On Gaal see Denys, Het Begrip Kind, in: NTER (1995) pp.115-116; van der Mei, Kinderen van EG-werknemers: Het Recht op Onderwijs en Studiefinanciering, in: NTOR (1995) pp.211-217; Szczekalla, EuGH: Begriff des "Kindes" in Art.12 Verordnung (EWG) Nr.1612/68, in: EuZW (1995) pp.670-672 and White, Children and Right to Education under Article 12 of Regulation 1612/68, in: ELRev (1995) pp.501-507.
} 
educational attendance"87 including study grants. In Echternach (1989) the Court specified that the status of a child of a Community worker implies that "children must be eligible for study assistance from the State in order to make it possible for them to achieve integration in the society of the host country". ${ }^{88}$

The drafters of Article 12 only considered the situation in which the children live together with the parent-worker in the State of employment and claim access to education, and study grants for studies, in that State. On a number of occasions, however, the Court has been confronted with cases which deviated from this standard situation. These cases concerned children of workers who had asked for grants for studies outside the State of employment. The Court has accepted that children of workers can rely on Community law in order to transfer study grants

87. Case 9/74 Casagrande [1974] ECR 773 at 9. See also Case 68/74 Alaimo [1975] ECR 109 at 5; Joined Cases 389 and 390/97 Echternach [1989] ECR 723 at 33 and Case C308/89 di Leo [1990] ECR I-4185 at 9.

88. Joined Cases 389 and 390/87 Echternach [1989] ECR 723 at 35. In addition to the right to equal treatment in educational matters children of Community workers enjoy special rights with respect to language education. These rights are granted by Directive No 77/486 on the education of children of migrant workers. OJ 1977 L 199. The Directive can be seen as an implementation of the second sentence of Article 12 of Regulation 1612/68 according to which Member States must encourage all efforts to enable children of Community workers to attend educational courses under the best possible conditions. The Court ruled that this sentence "is intended to encourage special efforts, to ensure that the children may take advantage on an equal footing of the education and training facilities available". See Case 9/74 Casagrande [1974] ECR 773 at 8 . The Directive obliges Member States to promote the teaching of ( $i$ ) the (or one of the) official language(s) of the host State and (ii) "the mother tongue and culture of the country of origin". The aim is to promote not only the integration of children of migrant workers into the host State, but also their possible future re-integration in the Member State of origin. The Directive orders the Member States to adopt special educational measures for children of Community workers in order to compensate certain "cultural handicaps" which such children may have when they reside in a Member State other than their own. Member States cannot restrict themselves by extending their existing educational policy to children of Community workers; special programmes have to be set up for them. Member States have to take "affirmative action" in order to avoid material inequality between children of national workers and Community workers. Most probably, however, the rights mentioned in the Directive cannot be enforced in the national courts. The terms used in the provisions of the Directive seem too vague in order for the provisions to have direct effect. This conclusion is unfortunate particularly because of the difficulties which exist with regard to the implementation of the Directive. On this Directive see Cullen, From Migrants to Citizens? European Community Policy on Intercultural Education, in: EJFL (1996) pp.109-129; Domhof, Untersuchung zur Entstehung der Richtlinie des Rates der Europäischen Gemeinschaften von 25.7.1977 über die schulische Betreuung der Kinder von Wanderarbeitnehmern, in: X (source unknown) (1979) and Wittek, Eine Europäische Dimension von Ausländerpolitik - Zur Richtlinie der EG vom 25.7.1977, in: RJB (1982) pp.40-50. 
abroad and, step by step, it has extended the possibilities for doing so. A first case in which the issue arose was di Leo (1990). The case involved an Italian national who was living in Germany with her Italian father who had acquired the status of Community worker there. On account of a numerus clausus applied in the medical faculties at German universities, Ms di Leo was unlikely to gain admission to a German medical faculty and she therefore decided to study medicine at the University of Sienna in Italy. In 1987 she applied for an educational grant in Germany. The German authorities denied her application because grants for studies outside the national territory could, according to the German laws applicable at the material time, only be granted to German nationals who were habitually residing in Germany. In 1988 the German law was amended as to include in its scope children of Community workers provided such children were not studying in the Member State of which they are nationals. The latter condition was introduced in order to prevent abuses which could occur where children would claim grants in both Germany and the State of origin. Ms di Leo contested the refusal by invoking Article 12 of Regulation No 1612/68. In the proceedings before the Court, the German Government argued that Ms di Leo could not rely on Article 12 because this provision explicitly requires children to reside in the State where the parent-worker is employed. The Court could not agree. The requirement contained in Article 12:

"is designed to restrict equal treatment as regards the advantages referred to in that article solely to the children of Community workers who reside within their parents' host country. However, it does not mean that the right to equal treatment depends on the place in which the child concerned pursues his studies". 89

The Court also rejected another argument of the two Governments according to which studies outside the territory of the host State would not contribute to the integration of the worker and his family in the society of the host State. If:

"such integration is to be successful, it is essential for the child of a Community worker who resides with his family in the host Member state to have the opportunity to choose a course under the same conditions as a child of a national of that State". 90

This interpretation of Article 12 was not, according to the Court, any different for children of workers who (wish to) study in the Member State

89. Case C-308/89 di Leo [1990] ECR I-4185 at 12.

90. Ibid, at 13 . 
of which they hold the nationality. ${ }^{11}$

The ruling in di Leo did not imply that the residence criterion in Article 12 had lost its meaning. The judgment implied for children what Matteucci meant for Community workers: the de facto residence during the period of the studies abroad cannot affect the right to claim study grants. ${ }^{92}$ di Leo did indicate, however, that Article 12 can only be invoked by children who actually reside in the State of employment prior to commencing a study in another State. ${ }^{93}$ Subsequent cases, however, demonstrate that children who do not reside in the State where the worker is employed prior to their studies can claim equal treatment as regards study grants for "foreign" studies under Article 7(2) of Regulation No 1612/68. In Bernini (1992) the Court was faced with the case of an Italian student residing in Italy who had embarked on architectural studies at the University of Naples. She applied for a study grant in the Netherlands where her Italian father was working and living. Her request was denied. The Netherlands Law on Study Finance did provide for the possibility of receiving a grant for architectural studies at the University of Naples, but this possibility was reserved for Dutch students and foreign students residing in the Netherlands. The Dutch court which had to rule upon the case asked the Court of Justice whether the provisions of the Netherlands law under challenge were compatible with Article 7(2) of Regulation No 1612/68. The Court answered the question in the negative. The Court confirmed earlier judgments in cases such as Deak ${ }^{94}$ (1984) and Le$b n^{95}$ (1987) by holding that the principle of equal treatment embodied in Article 7(2) is also directed towards family members in the descending line who are dependent on the Community worker. Unlike Article 12, Article 7(2) does not contain a residence requirement and this led the Court to the conclusion that if a national rule imposes no residence requirement on the children of national workers, such a condition may neither be imposed on the children of Community workers". ${ }^{96}$

Thus, dependent children of workers do not have to reside in the Member State where the parent-worker is employed in order to claim

91. Ibid, at 16.

92. See Section 3.2.2.

93. Compare the Opinion of Advocate General Darmon in Case C-308/89 di Leo [1990] ECR I-4185 at 24

94. Case 94/84 Deak [1985] ECR 1873 at 24.

95. Case 316/85 Lebon [1987] ECR 2811 at 13.

96. Case C-3/90 Bernini [1992] ECR I-1071 at 28. Family members may invoke Article 7(2)

in their own right. Ibid, at 26. 
study grants for studies outside that State's territory. ${ }^{97}$ Bernini, however, did not imply that all non-resident children hold such a right. Ms Bernini's father was resident in the Netherlands and the ruling could be interpreted as to mean that children residing (and studying) in another Member States can merely claim benefits under Article 7(2) because this promotes the integration of the parent-worker into the host State. Meeusen $(1999)^{98}$, however, indicates that Article 7(2) can also be relied in cases where both the student child and the worker reside outside the territory of the State of employment. The case concerned a Belgian student whose Belgian parents were working in the Netherlands but had kept their private residence in Belgium. The child, who resided in and studied chemistry in Antwerp, could not claim a study grant in Belgium and she therefore decided to apply for a study grant in the Netherlands. Dutch students were entitled to study grants for studies at universities in the Netherlands as well as a number of foreign educational institutions which, for the purposes of the study grant scheme, had been put on a par with Dutch educational institutions. The Antwerp Institute for Chemistry was among these institutions. Ms Meeusen's application was denied, however, on the ground that she did not possess Dutch nationality and did not reside in the Netherlands. Because of Bernini, the mere fact that Ms Meeusen herself did not live in, and studied outside, the Netherlands could not be a reason for refusing her the grant. The Dutch government, however, interpreted Bernini as to mean that Article 7(2) can only be relied upon because, and when, this may help to promote the integration of the workers themselves into the host State's society. This rationale could not be extended to Ms Meeusen whose parents had chosen not to reside, and thus not to integrate, into the State of employment. As stated in Section 3.2.2, the Court did not agree. It rejected the "integration-argument" by holding that the preamble to Regulation No 1612/68 expressly stipulates that frontier workers also enjoy the right not to be discriminated against. Nowhere does Article 7(2) indicate that the right to equal treatment as regards social advantages can be made conditional upon workers'

97. van den Bossche (1992) supra footnote 73, at p.796.

98. Case C-337/97 Meeusen [1999] ECR I-0000. On Meeusen see e.g. van der Mei, Annotation Meeusen, in: USZ (1999) pp.687-688; Mortelmans, Annotation Meeusen, in: AA (1999) pp.841-848 and van der Steen, Studiefinanciering ook voor Kinderen van Grensarbeiders, in: NTER (1999) pp.210-215. 
residence in the State concerned and this, so the Court concluded, implied that:

"in a situation where national legislation .. does not impose any residence requirement on the children of national workers for financing of their studies, such a requirement must be regarded discriminatory if it is imposed on the children of workers who are nationals of other Member States". 99

The Court's interpretation of Article 7(2) in Meeusen seems quite broad. On the basis of national law, study grants are usually only offered to students who are both residing and studying in the national territory. Children as Ms Meeusen, however, who have never lived in the State where they claim grants, who do not study there and whose sole link with that State is that they are dependent on a worker who is merely employed there, are nevertheless entitled to claim study grants. In one significant respect, however, Meeusen is still limited. The Court merely held that Ms Meeusen could claim a study grant because Dutch students studying at the same Antwerp Institute for Chemistry were entitled to obtain a grant. The Court only condemned the nationality criteria contained in the Dutch rules; it did not express its view of the legality of the rule that study grants are in principle reserved for nationals or residents who are studying at a recognised educational institution in the national territory or a foreign institution which, for study grant purposes, had been put on a par with national institutions. In other words, Meeusen does not imply that children of workers enjoy an independent right to export study grants.

The question whether children of Community workers have such a right did arise, however, in the recent case of Fahmi and Esmoris Cerdeiro-Pinedo Amado (2001). The case concerned a Spanish national who had previously worked in the Netherlands and who, after having become unfit for work, had returned with her daughter to Spain. In 1996 the daughter began studying at the University of La Coruña which was not among the foreign institutions which, for study grant purposes, had been put on a par with Dutch educational institutions. Although the case itself concerned a decision refusing to pay child allowances, the question arose whether Mrs Esmoris Cerdeiro-Pinedo Amado and/or her daughter could possibly (have) claim(ed) a study grant under Article 7(2) of Regulation No 1612/68. Advocate General Alber was of the opinion that a national rule which in principle reserves study grants for students who are attending a school, college or university in the national territory mainly affects nonnationals because, for linguistic or cultural reasons, they are likely to be

99. Ibid, at 23 . 
more interested in studying abroad than nationals. Therefore, such a rule would only be able to escape the classification of a prohibited indirect discrimination on grounds of nationality when demonstrated to be necessary for, and proportional to, a public interest. The Court, however, did not go into the issue. It held that Mrs Esmoris Cerdeiro-Pinedo Amado could not rely on Article 7(2). This provision aims to promote the integration of the worker and the family into the host State and the Court concluded that, as a general rule and except in special circumstances, Article 7(2) "cannot be extended to workers who, after ceasing to exercise their occupational activity in the host Member State, have decided to return to their Member State of origin". 100

The scope of Article 7(2) of Regulation No 1612/68 is thus not infinitely broad. The Court did not state so explicitly, but it would seem that in order to be entitled to invoke Article 7(2) a Community worker must either still be in employment or, in the case of unemployment, still reside in the host State. Fahmi and Esmoris Cerdeiro-Pinedo Amado does not clarify whether children of workers who are still working and/or residing in the host Member State can rely on Article 7(2) in order challenge national rules denying their children study grants for foreign studies. The question whether, and if so, under which conditions, family members of workers, and probably the workers themselves, are entitled to export study grants is thus still open. ${ }^{101}$

Finally, it is important to recognise that the rulings in Bernini and Meeusen are based on Article 7(2) of Regulation No 1612/68. It is settled case law that children and family members of workers can rely on this provision only when the claimed rights or benefits can be regarded as social advantages for the workers themselves. This is only the case for dependants of the worker. ${ }^{102}$ Children who are not dependent on the worker can rely on Article 12 of the Regulation (Gaal) in order to claim study grants for studies both within and outside the host State when they, before beginning their studies, are residing in that State (di Leo). Independent children who do not reside in the State of employment cannot as a child of Community workers claim educational rights under Regulation No 1612/68. De facto, they are in a position akin to the category of "real" Community students which will be examined in Section 4. Arguably, it is

100. Case C-33/99 Fahmi and Esmoris Cerdeiro-Pinedo Amado [2001] ECR I-0000 at 47-

101. See further Section 9.3.1.

102. Case 316/85 Lebon [1987] ECR 2811. See further Chapter 2 Section 2.3. 
only in this capacity that independent children who are residing in a State other than the one in which the worker is employed, can claim educational rights.

\subsubsection{The Status of Child of a Community Worker}

All the rights discussed above, are granted to persons holding the status of a child of a Community worker. On a number of occasions the Court has been confronted with cases in which it was asked whether this status could be relied upon. The problem in (most of) these cases did not so much concern the family relationship with the parent-worker. Rather, the question was whether the parent could (still) be classed as a Community worker, and thus whether the child could (still) be regarded as a child of a Community worker.

In Humbel (1988), for instance, the Court was faced with the case of a French national who had acquired the status of worker in Luxembourg, but who had sent his son to school in Belgium. Mr Humbel challenged the school fee (the Minerval) which he had to pay for his son. Since the fee was not imposed on Belgian nationals, Mr Humbel claimed that the Minerval was based on a discriminatory rule and therefore at odds with Article 12 of Regulation No 1612/68. The Court rejected his argument: "Article 12 of the regulation lays obligations only on the Member State in which the migrant worker resides". ${ }^{103}$ In other words, from Humbel it follows that children can only be regarded as children of a Community worker in the State where the parent holds the status of Community worker. ${ }^{104}$

In Brown (1988) the question arose whether a child who was born after its parents had returned to the country of origin could derive any rights from Article 12 in the Member State where one of the parents had worked. The Court answered that Article 12 "grants rights only to a child who has lived with his parents or either one of them in a Member State whilst at least one of his parents resided there as a worker". ${ }^{105}$ Children

103. Case 263/86 Humbel [1988] ECR 5365 at 24-25.

104. Arguably, a person as Mr Humbel can invoke Article $12 \mathrm{EC}$ in order to challenge discriminatory enrolment fees to be paid for children attending schools in another Member State. See further Sections 4.1 and 4.2.

105. Casc 197/86 Brown [1988] ECR 3205 at 30. 
who are born after the parent has lost ${ }^{106}$ or given up the status of worker do not acquire the status of family member of a Community worker. As a result, they cannot invoke Article 12 of the Regulation.

Brown left room for the conclusion that a child who had once lived with a Community worker in the State of employment, could always return to this State and invoke Article 12 even if the parent-worker has already returned to the State of origin. Echternach (1989) demonstrates, however, that such an interpretation of Article 12 is incorrect. One of the children who invoked Article 12 in this case was a German national who was born and had lived with his parents in the Netherlands when his German father was working there. The family had returned to Germany, but the child could not continue his studies there because the Dutch qualifications he had acquired were not recognised there. The child therefore returned to the Netherlands for the purpose of completing his studies. His application for a study grant was refused by the Dutch authorities. The Court ruled, however, that the child could rely on Article 12 of the Regulation. A genuine integration of the worker and his family in the society of the host country can only be achieved if children of workers have the possibility of going to school and pursuing further education in order to be able to successfully complete that education. ${ }^{107}$ The judgment indicate, however, that children do in principle lose the status of child of a Community worker at the time the worker retruns to the Member State of origin. This would seem to imply that a child cannot rely on

106. Children may also lose the status of child of a worker, and the right to claim educational rights under Article 12 or Article 7(2), as a result of the parent-worker's death. Children who are entitled to remain in the host State permanently by virtue of Regulation No 1251/70 (see Chapter 2 Sections 2.2 and 2.3) retain the right to equal treatment on the basis of Article 7 of this regulation. See e.g. Case C-7/94 Gaal [1995] ECR I-1031. As regards children who do not meet the criteria for the right to remain (see Article 3(2) of Regulation No 1251/70) more difficult questions could arise. It could be argued that they retain the right to reside, and the right to rely on Article 12 or 7(2), for as long as the residence card given to them remains valid. Compare Chapter 2 Section 2.2.4. Upon expiry of the residence card, however, it would seem that children holding the nationality of one of the Member States will have to bring themselves within one of the other categories of beneficiaries of the free movement of persons (i.e. worker, student or a non-economic resident). For children who only hold the nationality of a third country the death of the parent-worker could lead to loss of the right to reside. As regards third country family members who lose their status as a result of a divorce the Commission has proposed to grant them a residence right and corollary rights (see Article 10(4) of the proposed new Regulation No 1612/68 - COM(1998) 394 def), but the proposal does not refer to third country family members who lose their status as a result of death.

107. On this jugdment see e.g. Mortelmans, Annotation Echternach, in: SEW (1989) pp.736747 and Dcfalque, Annotation Echternach, in: JT (1989) pp.426 et seq. 
Article 12 in order to commence, as a child of a Community worker, new studies and claim study grants in the State where the worker used to be employed. ${ }^{108}$

\subsection{Other Family Members of Community Workers}

Spouses, grandchildren and grandparents (may) enjoy the right to join the worker in the State of employment under Article 10(1) of Regulation No 1612/68. ${ }^{109}$ They cannot benefit, however, from Article 12. This provision only applies to children of Community workers. The exclusion from Article 12 does not imply that these family members cannot claim any educational rights in the State where the Community worker is employed. As to the family members who are dependent on Community workers, one may assume that they, on the basis of Article 7(2) of Regulation No $1612 / 68$, are entitled to gain access to education and study grant schemes under the same conditions as nationals of the host State. ${ }^{110}$ Lair indicates that access to (all forms of) education and study grants constitutes a social advantage ${ }^{111}$ and, as follows from Lebon, when given to dependent family members, this benefit may be regarded as a social advantage for the workers themselves. ${ }^{112}$ The legal status of dependent family

108. In his Opinion in Fahmi and Esmoris Cerdeiro-Pinedo Amado Advocate General Alber proposed that this conclusion should be modified as regards children of workers who have returned to their State of origin and who $(i)$ are in receipt of a pension from the State of employment and (ii) pay taxes in respect of such such a pension in the latter State. In Alber's view, such workers (and, presumably, children of workers - APvdM) retain the right to rely on Article 7(2) in order to claim study grants in the State of former employment (for studies in the State of origin and, as one may assume, the State of former employment APvdM). Opinion of Advocate General Alber in Case C-33/99 Fahmi [2001] ECR I-0000 at 79. The Court, however, seems to have rejected this view. Case C-33/99 Fahmi [2001] ECR I-0000 at 47.

109. See Chapter 2 Section 2.3.

110. The judgment in Forcheri (1983) (see Section 4.1) suggests that family members will have to rely on Articles 12,149 and $150 \mathrm{EC}$ in order to claim educational rights. Forcheri, however, was decided before the Court developed the rule that (dependent) family members can claim rights under Article 7(2) of Regulation No 1612/68 and it may assumed that the Court today would decide cases concerning educational rights of (dependent) family members under Regulation No 1612/68.

111. See Section 3.2 above.

112. Case 316/85 Lebon (1987) ECR 2811 at 13. 
members in the field of education thus seems identical to that of dependent children examined in Section 3.3. ${ }^{113}$

The legal status of family members who are not dependent on the Community worker is more difficult to determine. The difficulties do not so much concern access to education itself. As will be shown in Section 4, on the basis of Article 12(1) EC juncto Articles 149 and $150 \mathrm{EC}$, all Community citizens have the right to gain access to education in other Member States. ${ }^{114}$ The uncertainty about the rights of independent family members relates to the question whether, or to what extent, they can claim study grants in the State where the worker is employed. Independent family members can invoke Article 12 EC in that State, but, as will be shown in Section 4.3, the Court ruled in Lair (1988) that this provision only applies to student financial aid in as far as it is intended to cover tuition and enrolment fees. ${ }^{115}$ In as far as they cover maintenance cost, grants fall outside the scope of Article 12 EC. This would seem to imply that independent family members only have a limited right to claim study grants. The judgment in Martinez Sala (1998), however, suggests that the Court has moved away from Lair. As stated earlier in this book, ${ }^{116}$ in this judgment the Court ruled that $(i)$ all benefits which can be classed as a social advantage in the sense of Article 7(2) of Regulation No 1612/68 also fall within the material scope of Article 12(1) EC and (ii) that all Community citizens lawfully established in another Member State can rely on Article 12(1) EC. If Martínez Sala indeed implies that Lair has been overruled, ${ }^{117}$ Member States seem no longer entitled to refuse "full" study grants to family members residing on their territory. Such family members would seem to enjoy the same rights as regards study grants as the children of workers. If correct, both dependent and independent family members would be entitled to equality of treatment as regards grants for studies in the host State and for studies outside that State, where they reside there prior to their studies. In addition, family members who are dependants of the worker but who do not reside in the State where the worker is employed, would seem entitled to claim grants for studies

113. The same could be said to apply to family members who are not covered by Article 10(1) of Regulation No 1612/68 but who have been admitted by virtue of Article 10(2).

114. See further Forcheri (1983) in which the Court held that spouses of Community workers who have lawfully installed themselves with the worker in the State of employment can rely on Article $7 \mathrm{EEC}$ (now $12 \mathrm{EC}$ ) in order to claim access to education under the same conditions as nationals of the host State. Case 152/82 Forcheri [1983] ECR 2323 at 17-18.

115. Case 39/86 Lair [1988] ECR 3161 at 14-15. See also Case 197/86 Brown [1988] ECR 3205 at $17-18$

116. See in particular Chapter 2 Section 3.3 and Chapter 3 Section 4.2

117. See further Section 4.3. 
outside that State where, and under the same conditions as, nationals are given such a right. For the reasons stated in Section 3.3.2, however, it is doubtful whether independent family members enjoy the same right. Until there is further clarification by the Court no definitive conclusions can be drawn, but it is submitted that unlike dependence and residence, the specific family relationship between a worker and a family member should not make a difference in determining the educational rights of family members. ${ }^{118}$

\subsection{Conclusions}

The drafters of the Treaty of Rome may not have granted educational rights to workers and their family members, but, in the course of the last four decades, the legal status of the two categories in educational matters has been strengthened considerably. The political Community institutions took the first step by including Article 7(3) and 12 in Regulation 1612/68. Further steps have been taken by the Court which has appeared willing to give quite a broad interpretation of the concept of Community worker and Articles 7(2) and 12 of Regulation No 1612/68. Basically, Community workers and their (dependent) family members must be treated equally in the field of education in virtually all respects. They may even enjoy educational rights when they do not reside in the State of employment or when they wish to study in another State. The Court, however, has not given an infinitely broad interpretation of the relevant provisions. By laying down the requirement of "effective and genuine" activities for obtaining the status of worker and by prohibiting abuses of that status of worker, the Court has prevented all the educational rights and benefits linked to the status of Community worker and family member of a

118. Arguably, the same conclusions can be drawn as regards the family members mentioned in Article 10(2) of Regulation No 1612/68 who have been admitted for residence on the basis of national law. In Martinez Sala the Court referred to Community citizens lawfully residing in other Member States. Lawful residence may derive from national law or international law. Fries/Shaw, Citizenship of the Union: First Steps in the European Court of Justice, in: EPL (1998) pp.533-559, at p.547. As regards family members who do not hold the nationality of one of the Member States the situation would seem to be more complicated. As regards third country nationals who hold a right of residence under Community law it may safely be assumed that they also come within the personal scope, but it is far from certain whether the same holds true for third country family members who have been admitted on the basis of national law. The Commission has proposed to extend the scope of Articles 12 and 7(2) to all family members who have been admitted to the State of employment by virtue of Article 10 of Regulation. COM(1998) 394 fin. 
Community being "too easily" obtained by Community citizens who are in fact "real" students. The educational rights guaranteed by Article 39 as set out in Regulation No 1612/68 are functional rights which are aimed at facilitating the free movement of workers. They do not constitute independent rights for Community citizens to study and claim student financial aid in other Member States. ${ }^{119}$

\section{Community Students}

In 1984 Françoise Gravier contended before the Court of Justice that if the concept of the European Community had any real meaning, it should enable all students to move to educational institutions in other Member States. ${ }^{120}$ Ms Gravier's call for a free movement of students was not new. From the early years, Community institutions had frequently recognised the promotion of student mobility as one of the main objectives of the common vocational training policy referred to in Article 128 of the EEC Treaty. In particular, such mobility could contribute to the realisation of a genuine free movement of workers within the Community. ${ }^{121}$

119. van der Mei (1998) supra footnote 74, at pp.397-398.

120. See Opinion of Advocate General Slynn in Case 293/83 Gravier [1985] ECR 593 at p.595.

121. In Decision No 63/266 the Council stated that every person should be able to receive "adequate training, with due regard for freedom of choice of occupation, place of training and place of work". In a Resolution of the Ministers of Education meeting within the Council of 6 June 1974 it was held that co-operation in the field of education should be aimed at encouraging "the freedom of movement and mobility of teachers, students and research workers, in particular by the removal of administrative and social obstacles to the free movement of such persons and by the improved teaching of foreign languages". Two years later, in the Resolution of 9 February 1976 comprising an action programme in the field of education, the Council and the Ministers called for a discussion to develop a common policy on the admission of students from other Member States to higher education institutions and for proposals designed to eliminate obstacles to mobility of students. In 1980 the Education Committee (which was set up by the action programme just mentioned) presented a general report on how such policies were to be developed. In this report, which was approved by the Council and the Ministers for Education, a wide range of ideas and proposals were made which included inter alia the notion that Member States should treat students from other Member States equally with respect to the application of numerus clausus regulations and tuition fees. On 2 June 1983 the Council and the Ministers adopted a conclusion specifically dealing with the promotion of mobility in the field of higher education. The Resolution called upon the States to support student mobility within the Community by asking for flexibility with respect to the academic recognition of diplomas and by entrusting the European Commission to grant schemes for the support of joint study 
Ms Gravier's assertion was of course not motivated by the policy objectives that the Community institution had had in mind. The immediate reason for her contention was that she wished to challenge the Minerval, the additional enrollment fee she had to pay as a foreign student in Belgium. ${ }^{122}$ Ms Gravier was a "real" student. She could not claim to be a Community worker or a family member of a Community worker. ${ }^{123}$ She argued, however, that she could invoke the principle of non-discrimination in her capacity of recipient of (educational) services. Gravier's argument would not succeed. In the Gravier judgment (1985) the Court did not even consider it. ${ }^{124}$ One might therefore have expected that Community law would leave Ms Gravier with empty hands. The possibility of reading the Treaty a free movement of students seemed to have been exhausted and the Commission's draft directive of 1979 on a general right of residence, which would have implied a free movement of students, ${ }^{125}$ had not yet been adopted by the Council. Nonetheless, Ms Gravier won her case. The Court ruled that she could merely in her capacity as a national of a Member State invoke the principle of non-discrimination in order to gain access to educational institutions in other States. ${ }^{126}$ In Gravier the Court laid down the legal foundations for a free movement of students within the European Community.

programmes with the aim of intensifying academic mobility. Furthermore, in a "Solemn Declaration on European Union" the Heads of State or Government agreed to promote exchanges of teachers and students. All the above documents are contained in Council of the European Communities-General Sectretariat, European Educational Statements (1987).

122. On the Minerval see Section 2.2 .

123. In the 1960 s the Social Committee of the European Parliament had already studied the possibility of applying the regulation of the free movement of workers to young persons who go to other Member States for the purpose of attending courses. Yet, due to the expected "legal difficulties" the Committee did not advise including such young persons in the regulation. See European Parliament Documents 1963-1964, 25 maart 1963, Document 7 , Rapporteur Rubinacci). Also in the literature it had been suggested that Article $39 \mathrm{EC}$ could possibly serve as the legal basis for a free movement of students. See e.g. Steindorff, Ausbildungsrechte im EG-Recht, in: NJW (1983) pp.1231-1233. Yet, as described in Section 3.2.3, the Court has not taken up these suggestions.

124. See further Section 4.8.

125. See Chapter 2 Section 3.1.

126. Case 293/83 Gravier [1985] ECR 593. On Gravier see e.g. Flynn, Gravier: Suite de Feuilleton, in: De Witte, European Community law of Education (1989) pp.95-112; Arnull, Of Strip Cartoonists, Vets and Gunsmiths, in: ELRev (1988) pp.260 et seq; Oppermann, Europäisches Gemeinschaftsrecht und Deutsche Bildungsordnung - Gravier und die Folgen (1987); Schermers, De Minerval voor Buitenlanders, in: AA (1986) pp.37-40; Timmermans, Annotatie Gravier in: SEW (1986) pp.86-94; Foblets, Extra-Collegegeld voor Buitenlandse Studenten aan Belgische Universiteiten?, in: JF (1985) pp.535-544 and Steiner, Annotation Gravier, in: CMLRev (1985) pp.348-352. 
Gravier heralded a series of judgments in which the Court was asked to clarify what the free movement of students precisely entails. This Section describes and analyses the case law of the Court and aims to establish the conditions under which Community citizens who cannot benefit from the provisions described in the previous Section, can gain access to education in other Member States. For a proper understanding of Community law on the subject, however, it is useful first to go back into history and to consider why, and how, the Court created the free movement of students.

\subsection{The Judicial Creation of a Free Movement of Students}

The establishment of the principle of a free movement of students is generally ascribed to the Court's ruling in Gravier. A description of this judgment alone, however, does not suffice for understanding why and how the Court realised a free movement of students within the European Community. Gravier had been foreshadowed ${ }^{127}$ by Forcheri $(1983)^{128}$ and, strictly speaking, the Treaty based principle of a free movement of students was only finalised in Raulin (1992). ${ }^{129}$ The creation of the free movement of students may best be described as a three-step process.

Forcheri involved the wife of an Italian national who was working for the European Commission in Brussels. Mrs Forcheri attended a course at an educational institution which trained students to become social workers. Unlike Belgian nationals, she was required to pay the additional enrollment fee known as the Minerval. Mrs Forcheri was not entitled to an exemption from the Minerval on the ground that such a privilege was only granted to students whose spouses were in paid employment and paid taxes to the Belgian Treasury. Officials of the European Community are not taxable in Belgium. The Belgian court which had to decide the case called upon the Court of Justice to determine whether the duty to pay the Minerval was consistent with the principle of non-discrimination as embodied in the Articles 7 EEC (now 12 EC), 48 EEC (39 EC) and Article 12 of Regulation No 1612/68.

127. Flynn (1989) supra footnote 4, at p.62.

128. Case 152/82 Forcheri [1983] ECR 2323. On Forcheri see Moore, Article 7 of the Treaty of Rome Bites, in: MLRev (1985) pp.452-459 and Starkle, Extension du Principe de Non-Discrimination en Droit communautaire au Ressortissant d'un Etat membre licitement Installé dans un autre Etat membre, in: CDE (1984) pp.672 et seq.

129. Case C-357/89 Raulin [1992] ECR I-1027. On this judgment see e.g. O'Keeffe, Annotation Raulin, in: CMLRev (1992) pp.1215-1228 and van den Bossche (1992) supra footnote 73 . 
The Court first referred to Article 7 EEC and observed that the Belgian rule under consideration was clearly discriminatory in nature. The Court was of the opinion that the issue brought before it was whether the payment of the Minerval fell within the scope of the Treaty. In other words, did access to educational courses, and in particular those concerning vocational training, fall within the scope of the Treaty? At the outset, the Court stated that EC officials fall within the personal scope of the Treaty on a dual basis by reason of their post within the Community and by virtue of Article 48 EEC. As regards the material scope, the Court quoted some of the statements in the preamble to Regulation No 1612/68, Article 128 of the EEC Treaty and Council Decision No $63 / 266^{130}$ in which the general principles for implementing a common vocational training policy were laid down. This enabled the Court to conclude that

"although it is true that educational and vocational training policy is not as such part of the areas which the Treaty has alloted to the competence of the Community institutions, the opportunity for such kinds of instruction falls within the scope of the Treaty". ${ }^{131}$

Consequently,

"if a Member State organises educational courses relating in particular to vocational training, to require of a national of another Member State lawfully established in the first Member State an enrolment fee which is not required of its own nationals in order to take part in such courses constitutes discrimination by reason of nationality, which is prohibited by Article 7 of the Treaty." 132

By ruling that the opportunity for educational and vocational training courses fell within the scope of the Treaty the Court established the principle of equal access to education and vocational training in other Member States. The Court concluded that this principle could be invoked by nationals of the Member States who are "lawfully established" in another Member State. The principle of equal access was, however, formulated in such a broad way that the question $\operatorname{arose}^{133}$ whether the principle could possibly also be relied upon by Community citizens without a pre-existing right of residence. This question was submitted to the Court in Gravier.

130. See above Section 2.3 .

131. Case 152/82 Forcheri [1983] ECR 2323 at 17.

132. Ibid, at 18 .

133. O'Leary, The Principle of Equal Treatment on Grounds of Nationality in Article 6 EC A Lucrative Source for Member State Nationals?, in: O'Leary/Tiilikainen (Eds), Citizenship and Nationality Status in the New Europe (1998) pp.105-136, at p.118. 
Françoise Gravier was a young French woman whose normal residence was in France. She had been admitted to the Academie Royale des BeauxArts in Liège, Belgium, to study the art of strip cartoons. The academy charged all students a registration fee of 10000 Belgian Francs a year. In addition, Ms Gravier had to pay an extra enrolment fee (the Minerval) of about 25.000 Belgian Francs, which students of Belgian nationality were not required to pay. Her application for exemption from this enrolment fee was rejected. After she refused to pay the fee and was denied enrolment, Ms Gravier brought an action before a Belgian court claiming that the Minerval was discriminatory and contrary to Community law. The national court, which had obviously read the Court's judgment in Forche$r i$, asked the Court whether EC nationals who move to another Member State for the sole purpose of following courses in an institution offering instruction, in particular, to vocational training fell within the scope of the Treaty.

In resolving the issue the Court of Justice first defined the nature of the problem. The Court delimited the issue under consideration by stipulating that:

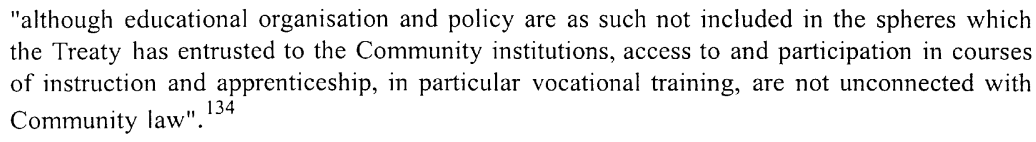
the Treaty has entrusted to the Community institutions, access to and participation in courses of instruction and apprenticeship, in particular vocational training, are not unconnected with Community law". 134

The Court illustrated this by referring to Articles 7 and 12 of Regulation No 1612/68, Article 128 of the Treaty and Council Decision No 63/266. It further referred to a number of Council resolutions and guidelines which showed that the Community institutions had given particular attention to access to vocational training and its improvement throughout the Community. The Court stated that the:

"common vocational training policy referred to in Article 128 of the Treaty is thus gradually being established. It constitutes, moreover, an indispensable element of the activities of the Community, whose objectives include inter alia the free movement of persons, the mobility of labour and the improvement of the living standards of workers.

Access to vocational training is in particular likely to promote free movement of persons throughout the Community, by enabling them to obtain a qualification in the Member State where they intend to work and by enabling them to complete their training and develop their particular talents in the Member State whose vocational training programmes include the special subject desired". ${ }^{135}$

134. Case 293/83 Gravier [1985] ECR 293 at 19.

135. Ibid, at 23-24. 
The Court concluded that it:

"follows from all the foregoing that the conditions of access to vocational training fall within the scope of the Treaty". ${ }^{136}$

Subsequently, the Court applied this conclusion to the facts of the case under consideration:

"the imposition on students who are nationals of other Member States, of a charge, a registration fee or the so-called 'minerval' as a condition of access to vocational training, where the same fee is not imposed on students who are nationals of the host Member State, constitutes discrimination on grounds of nationality contrary to Article 7 of the Treaty". ${ }^{137}$

The Court's holding implied that not only Community citizens with a preexisting right of residence, but all Community citizens, regardless of their nationality and State of residence, could invoke the principle of equal access to vocational training in other Member States.

The fact that all Community citizens were granted the right to gain access to vocational training in other States did not yet imply that the Court had formally established a free movement of students within the Community. In Gravier the Court had not explicitly stated that students also have a right to reside in other Member States for the duration of their studies. The Commission, however, drew the rather logical ${ }^{138}$ conclusion that the right to gain access to vocational training also includes the right to stay in the Member State concerned and it submitted to the Council a proposal for a directive in which the conditions for exercising this Treatybased right were worked out. ${ }^{139}$ In Raulin the Court confirmed the Commission's interpretation of Gravier by holding that the right to equal

136. Ibid, at 25 .

137. Ibid, at 26 .

138. Compare van Gerven/van den Bossche (1993) supra footnote 4, at p.424. In Gravier the Court did not deal with the issue of the right to reside probably because the Belgian authorities had granted Ms Gravier such a right during the proceedings. See Case 293/83 Gravier [1985] ECR 593 at 6-8.

139. The Council adopted the proposal as Directive No 90/366. On this Directive, which has now been replaced by Directive No 93/96, and the right of residence for students see Section 4.4 . 
treatment regarding the conditions of access to vocational training does not only apply

"to the requirements laid down by the educational establishment in question, such as enrollment fees, but also to any measure that may prevent the exercise of that right. It is clear that a student admitted to a course of vocational training might be unable to attend the course if he did not have a right of residence in the Member State where the course takes place". 140

In Raulin the Court thus took the final necessary step for the establishment of the principle of a free movement of students. After it had read into Article 7 juncto Article 128 EEC the principle of equal access to vocational training in Forcheri for all Community citizens "lawfully established" in another Member State and had extended this principle to all Community citizens in Gravier, the Court finalised a Treaty based free movement of students in Raulin by concluding that Article 7 EEC also confers upon students a right of residence for the duration of the studies. After the amendments of the Maastricht Treaty and the renumbering of the Treaty of Amsterdam, the free movement of students is now based on, and governed by, Articles 12, 149 and 150 EC.

From the perspective of promoting student mobility, the establishment of a free movement of students was of course to be welcomed. In just a few judgments the Court had achieved more than the political Community institutions had been able to do in the two previous decades. From a legal perspective, however, the above discussed judgments were rather curious. Even at first glance it is clear that the Court read much more into Articles 7 and $128 \mathrm{EEC}$ than the drafters of the provision had ever envisaged. Had the Court not reached, or even crossed, the limits of its powers of interpretation? The "Article 7-Article 128 construction" was first applied in Forcheri. In light of Casagrande, in which the Court had accepted that the Community may also enter the field of education in as far as necessary to promote the free movement of workers, ${ }^{141}$ the conclusion seemed rather obvious that Mrs Forcheri could not be required to pay the Minerval which, in the Court's own words, was "so clearly discriminatory in nature". The problem, however, was that neither Article 48 EEC nor Regulation No 1612/68 mentioned educational rights for spouses of Community workers. Thus, in order to reach the desired conclusion, the Court had to fill a gap in the provisions on the free movement of workers. The Court chose Articles 7 and 128 EEC for this purpose. This

140. Case C-357/89 Raulin [1992] I-1027 at 34.

141. Scc Section 3.1. 
choice may have been innovative but the Court's conclusion that a spouse of a Community worker cannot be discriminated against in educational matters did fit within the Community's objectives in the field of the free movement of persons. The same cannot be said for the conclusion drawn in Gravier. In this judgment the Court did not recognise unwritten educational rights for persons who already fell within the personal scope of the free movement of persons as guaranteed by Community law. In Gravier the Court recognised an independent right for all Community citizens to study in other Member States. One might have expected that this fundamentally different and potentially much further reaching conclusion would have been supported by a different and more extensive justification. Remarkably, however, the reasoning in Gravier did not add much to the one the Court had followed in Forcheri. In Gravier the Court did explain more extensively the importance of a free movement of students, ${ }^{142}$ but in support of the conclusion that the Treaty guarantees such a freedom the Court did not do much more than refer to the Council Decision of 1963 and a number recommendations and conclusions adopted by the Council and the Ministers of Education meeting within the Council. From neither one of the measures mentioned by the Court, however, could the conclusion be drawn that the Council and the Member States had envisaged, let alone taken, concrete legally binding measures aimed at promoting student mobility. In fact, the various resolutions did not do more than to call upon and incite the Member States to voluntarily promote student mobility. ${ }^{143}$ It may very well be that the common vocational training policy was "gradually being established", but this policy had not yet been developed as far as to include a legally enforceable right for all Community citizens to study in other Member States. ${ }^{144}$ Indeed,

142. Case 293/83 Gravier [1985] ECR 593 at 19

143. Interestingly, the Court did not refer to a 1976 Resolution comprising an action programme in the field of education (see supra footnote 121, at IV.14(a)) which merely spoke of arranging a "discussion .. on the question of developing a common policy on the admission of students from other Member States". Compare also Timmermans (1986) supra footnote 126, at p.92.

144. Furthermore, the Community institutions had only adopted conclusions, recommendations, etc. Even though one may dispute whether, or to what extent, such soft-law measures have legal force (see e.g. Oertzen (1992) supra footnote 4, at pp.46-67 and van Crayenest, La Nature juridique des Résolutions sur la Coopération en Matière d'Education, in: De Witte, European Community Law of Education (1989) pp.127 et seq), it is clear that the Member States when adopting these measures, had not intended to transfer to the Community their powers to grant or refuse non-nationals access to their educational systems. On the contrary, if they had wished to do so, they would probably have adopted legally binding measures on the basis of Article $100 \mathrm{EEC}$ (94 EC) or Article $235 \mathrm{EEC}$ (now $308 \mathrm{EC}$ ). The fact that they chose instead soft-law measures suggests that the Member States represented in 
the vocational training policy the Court saw, was nothing but a "fata morgana". ${ }^{145}$ The right to study in other Member States had not, as the reasoning in Gravier seemed to suggest, already been established by the political Community institutions. Rather, it was the Court itself which created this right and included Community students in the free movement regime.

\subsection{The Scope of the Free Movement of Students}

As revolutionary as it may have been, the judicial creation of a free movement of students did not automatically mean that many students could actually take up studies in other Member States. The practical relevance of the newly created freedom would first of all depend on the meaning to be given to the term "vocational training" in Article 128 EEC. If the term were to be interpreted in accordance with the meaning it traditionally has under the national laws of the Member States, or the meaning which the Court itself has given to the concept of "vocational school" in Article 7(3) of Regulation 1612/68, ${ }^{146}$ the practical impact of Gravier would have been relatively limited. Basically, the right to study in other Member States would then only be guaranteed to students who follow forms of education and training which are aimed at preparing students for a particular profession or type of work. In particular, a free movement for university students would not be guaranteed.

In Gravier, however, the Court had already indicated that the concept of vocational training was to be determined within the realm of Community law rather than national law. The Court had held that:

\footnotetext{
"any form of education which prepares for a qualification for a particular profession, trade or employment or which provides the necessary training and skills for such a profession, trade or employment is vocational training, whatever the age and the level of training of the pupils or students, and even if the training programme includes an element of general education". ${ }^{147}$
}

the Council only wished to promote student mobility on a voluntary basis free from any legal restraints imposed by the Community.

145. See Opperman, Von der EG-Freizügigkeit zur gemeinsamen europäischen Ausbildungspolitik? Die "Gravier"-Doktrin des Gerichtshofs der Europäischen Gemeinschaften (1988) at p.23.

146. See above Section 3.2.1.

147. Case 293/83 Gravier [1985] ECR 593 at 30. 
The definition given by the Court was still rather vague, but did indicate that many types of education which are normally not considered as vocational training under national laws or regulations, could also fall within Article $128 \mathrm{EEC}$ and the scope of the free movement of students. The important question whether university studies are covered had not yet been answered in the Gravier. That question came before the Court in Blaizot (1988). ${ }^{148}$ The case concerned a numbveterinary students who were studying at a university in Belgium and who claimed that they were entitled to repayment of the Minerval they had paid prior to the judgment in Gravier. In support of their claim the students reasoned that university studies constituted "vocational training" in the sense of Article 128 EEC. The Belgian authorities objected by arguing that such studies would essentially be academic in nature and that they would not directly prepare a person for a certain profession. ${ }^{149}$ The Court agreed with the students. University studies are not necessarily excluded from Article 128. On the contrary, university studies generally fulfill the criteria laid down in Gravier. According to the Court, this was only different for certain courses which are intended for persons wishing to increase their general knowledge rather than prepare themselves for an occupation. ${ }^{150}$

From the case law the conclusion can be drawn that Community citizens have the right to gain access in other Member States to all forms

148. Case 24/86 Blaizot [1988] ECR 379.

149. The argument of the Belgian government was not necessarily without force. Compare e.g. Watson, Annotation Gravier, in: CMLRev (1987) pp.89-97, at p.95.

150. Case 24/86 Blaizot [1988] 379 at 20. See also Case 197/86 Brown [1988] ECR 3205 at 10 and Case 242/87 Commission v Council (Erasmus) [1989] ECR 1425 at 25. This conclusion indicated that the Court had rejected the so-called "teachers-argument" which implied that a course in, for instance, ancient arabic literature could be classed as vocational in nature because it would prepare students for the profession of teacher in ancient arabic literature. See Flynn (1989) supra footnote 4, at p.71.

In Blaizot the Court further held that the fact that university education is sometimes divided into two stages of which only the second would prepare for a qualification for a particular profession, cannot be taken in account for purposes of Article 128. Access to the second stage is usually dependent on completion of the first stage, so that the two stages must be regarded as single. It is not possible to make a distinction between one stage which does constitute vocational training and a second which does not. Case 24/86 Blaizot [1988] ECR 379 at 21. In Humbel the Court specified that the "various years of a study programme .. must be considered within the framework of the programme as a whole, .. provided that the programme forms a coherent single entity and cannot be divided into two parts, one of which does not constitute vocational training while the other does". Case 263/86 Humbel [1988] ECR 5365 at 12. 
of education with the exception of primary and secondary education ${ }^{151}$ and courses which are essentially aimed to "increase knowledge or cultural awareness or 'develop the mind'". ${ }^{152}$ Somewhat oversimplified, it can be concluded that the Court had recognised a free movement of students, but not a free movement of pupils. This, however, does not necessarily imply that Community law does not provide for a right to get equal access to primary and secondary education in other Member States. On the contrary, it probably does. The judgments mentioned above were all based on the "old" Article 128 EEC. This provision has been replaced by the Articles 126 and 127 EC, now renumbered as Articles 149 and 150 EC. ${ }^{153}$ By analogy with Gravier it can be argued that education in general has been brought within the scope of the Treaty and that the principle of equal access to education in other Member States now applies to all forms of education. ${ }^{154}$ Community law does not only provide for a free movement of students, but also for a free movement of pupils.

\subsection{Study Grants}

In Gravier the Court had held that the "conditions of access to vocational training" fall within the scope of the Treaty. Quota regulations for foreign students $^{155}$ and tuition and enrolment fees are obviously covered, ${ }^{156}$

151. Primary and secondary education cannot be classed, as one may conclude from the Court's judgment in Humbel (1988), as "vocational training". Case 263/86 Humbel [1988] ECR 5365 at 12 .

152. Opinion of Advocate General Slynn in Case 293/85 Commission v Belgium [1988] ECR 305 at p.337.

153. See Section 2.3 .

154. See also Vermeulen/Kuijer (1997) supra footnote 4, at p.23; Devroe/Wouters, De Europese Unie (1995) at p.511 and van der Mei, Vrij Dienstenverkeer in de EG en Toegang tot het Onderwijs, in: NTOR (1994) pp.102-107, at p.107. Further support for this view can be found in the Martinez Sala-ruling in which the Court held that all benefits (and thus all forms of education - see Section 3.2.1) which can be classed as a social advantage for the purposes of Article 7(2) of Regulation No 1612/68 fall within the scope of Community law and thus the material scope of Article 12 EC. Case C-85/96 Martinez Sala [1998] ECR I2691 at 57 .

155. See e.g. the judgment in Commission v Belgium (1988). It may be recalled (see Section 2.2.) that Belgium introduced in the mid-1970s a new financing system for higher education according to which the amount of government funding was made dependent upon the number of registered students. Foreign students were only taken into account in as far as they did not exceed two percent of the total number of Belgian students. The Belgian State was not financially responsible for other foreign students and the principals of educational establishments institutions were entitled to refuse to enrol students who are not taken into account for funding. In the Commission's view the Belgian legislation was in breach of 
Articles 7 and $128 \mathrm{EEC}$ and it initiated an infringement procedure against Belgium under Article 169 EEC (now Article 226 EC). The Court ruled that the Belgian legislation had the direct effect of excluding students from other Member States from vocational training once the $2 \%$ quota had been reached. The legislation constituted a direct discrimination on grounds of nationality contrary to Article 7 EEC (Article 12 EC). Case 42/87 Commission v Belgium [1988] ECR 5445 at 8. The ruling in Commission v Belgium (1988) demonstrates that the Court strictly observes whether Member States act in accordance with the principle of non-discrimination embodied in Article $12 \mathrm{EC}$ and that it does so even if significant changes in the organisation and funding of educational systems are to be made. The judgments further show that the distinction between "conditions of access" (which fall within the scope of the Treaty) and "educational organisation and policy" (falling within the domain of the Member States) is rather fluid.

In response to the judgment in Commission v Belgium (1988) the Flemish community brought its legislation into conformity with Community law. The Walloon community, however, did not do so with the result that Belgium was again convicted for not having obeyed Community law. Case 47/93 Commission v Belgium [1994] ECR I-1593. On the latter judgment see Nihoul, Le Minerval Réclamé aux Etudiants communautaires en Belgique, in: JdT (1994) pp.705-712 and van der Mei (1995) supra footnote 20.

156. Shortly after Gravier, the Belgian legislator had made an attempt to limit the possibility of students reclaiming the fees paid prior to Gravier. The law governing the Minerval was amended as to imply that fees charged between 1 September 1976 and 31 December 1984 could not be refunded. An exception was made for Community students who had started legal proceedings before 13 February 1985, the day the judgment in Gravier was delivered. In the view of the European Commission the Belgian law was after the amendment of 21 June 1985, still incompatible with Article 7 of the EEC Treaty. The Commission started an infringement procedure against Belgium. The Court concluded, however, that the time-limits fixed by the Commission in the pre-litigation procedure were too short and it dismissed the Commission's action as being inadmissible. See Case 293/85 Commision v Belgium [1988] ECR 305 at 20. The same issue was later adressed by the Court in Barra (1988) and Blaizot (1988). In both cases the Belgian government had argued that the Court should restrict the temporal effect of Gravier because this judgment constituted "a new development in Community law" the effects of which would lead to a "complete financial catastrophe". In Barra, which concerned students all of whom pursued technical and vocational studies at a Technical Institute in Liège, the Court refused to do so. Such a temporal restriction could only be made "in the judgment ruling upon the interpretation sought". Since the Court had in Gravier not restricted the effect of the judgment, it could not do so in Barra. Case 309/85 Barra [1988] ECR 355 at 13-14. In other words, it was too late for such a temporal restriction. Gravier applied ex tunc. In its judgment in Blaizot, which was delivered on the same day, the Court was willing to somewhat decrease the financial burden on Belgium. As stated above in Section 4.2, the case concerned university students. The Court recalled that a common vocational training was gradually being established and that it was only on the basis of that development that it became possible to regard university studies as "vocational training". The Court said, however, that in particular the attitude of the Commission, which had changed its opinion on the classification of university studies as "vocational training", might have led the Belgian authorities to consider that the Belgian legislation on the Minerval was in conformity with Community law. In such circumstances pressing considerations of legal certainty required the effect of the ruling in Blaizot to be limited in time. University funding should not retroactively be thrown into confusion and unforeseeable 
but does the same hold true for study grants? As noted earlier, grants may facilitate access, but they are not in all cases, or for all persons, a prerequisite for attending courses. Due to its significance, the question was bound to be submitted to the Court and, two years after Gravier, this happened in Lair (1988). It may be recalled ${ }^{157}$ that the Court was asked in this case to determine whether a German law, which made the eligibility of foreign students for study grants conditional upon five years of employment and residence in Germany, was compatible with Community law. The Court concluded that such a requirement constitutes a direct discrimination on grounds of nationality and violated Article 7(2) of Regulation No 1612/68. It was not certain, however, whether Ms Lair could claim to be a Community worker and if she could not, the question was raised whether Ms Lair could possibly claim the desired grant under Articles 7 and 128 EEC.

On legal grounds it could very well have been argued that Community students have a right to claim study grants in the State of their studies. As regards Community workers and their family members, the Court had already indicated that the right to gain access to education under the same conditions as the host State's nationals includes the right to equal treatment as regards student financial aid. ${ }^{158}$ Furthermore, in some of the soft-law measures the Council and the "Ministers of Education meeting within the Council" had adopted, reference was made to study grants and scholarships. ${ }^{159}$ By analogy with the line of reasoning in Gravier, it could thus be argued that student financial aid would also fall within the scope of the Treaty. On political-economic grounds, however, quite compelling arguments could be made in support of the opposite view. If Member States, and especially those with more developed student financial aid systems, were obliged not only to admit students from other States to their schools and universities, but to award them study grants too, such Member States might attract many students from other States

\footnotetext{
consequences for the proper functioning of universities should be avoided. The Court concluded that Article 7 EEC (now 12 EC) could not be relied upon by university students who wished to reclaim the fees paid unnecessarily prior to the date of the Blaizot judgement. An exception was made for students who had already started proceedings prior to the judgement. Case 24/86 Blaizot [1988] ECR 379 at 31-35. In as far as university studies are concerned, Gravier thus applied only ex nunc.

157. See Section 3.2.2.

158. See Sections 3.2.2 and 3.3.2.

159. See e.g. Resolution of the Council and the Ministers of Education meeting within the Council of 9 February 1976 Comprising an Action Programme in the Field of Education. OJ $1976 \mathrm{C} 38$, at point 14.
} 
where no, or less developed, study grant systems exist. ${ }^{160}$ The ability of the "more generous" States to maintain study grant systems, and possibly their entire educational systems, could be affected.

The question whether Article 7 EEC (now 12 EC) would also apply to student financial aid was thus quite delicate. The legal arguments supporting an affirmative answer did not seem to lead to an economically and politically desirable result. ${ }^{161}$ In Lair (1988) the Court settled the issue as follows:

"It is only to the extent to which assistance of that kind is intended to cover registration and other fees, charged for access to education that by virtue of the judgment in Gravier it falls, as relating to conditions of access to vocational training, within the scope of the Treaty and that consequently the prohibition of discrimination on grounds of nationality laid down by Article 7 of the EEC Treaty is applicable.

Subject to that reservation, it must be stated that at the present stage of development of Community law assistance given to students for maintenance and for training falls in principle outside the scope of the EEC Treaty for the purposes of Article 7. It is, on the one hand, a matter of educational policy, which is not as such included in the spheres entrusted to the Community institutions ... and, on the other, a matter of social policy, which falls within the competence of the Member States in so far as it is not covered by specific provisions of the EEC Treaty." 162

The Court thus chose the "political solution". The thrust of Lair is that the Courts wished to avoid imposing on Member States an obligation to offer study grants to students from other Member States which could put their study grant schemes, and possibly even their entire educational systems, in jeopardy. ${ }^{163}$

160. Compare the observations of the government of the United Kingdom in Case $39 / 86$ Lair [1988] ECR 3161.

161. Compare von Wilmowsky, Zugang zu öffentlichen Leistungen anderer Mitgliedstaaten, in: ZfaöR (1992) pp. 231-277, at pp.243-246.

162. Case 39/86 Lair [1988] ECR 3161 at 14-15. See also Case 197/86 Brown [1988] ECR 3205 at $17-18$.

163. Compare Arnull, The General Principles of EEC Law and the Individual (1990) at p.37. The distinction between the cost of maintenance and tuition fees was necessary in order to avoid a conflict with Gravier. If the Court had denied students the right to equal treatment as regards study grants in as far as they cover tuition fees, a discrimination as regards the fees would de facto have been present. In Raulin the Court was asked whether Article 7 EEC (12 EC) also applies to study finance systems which make no distinction between the cost of access to courses and maintenance costs. According to the Dutch government, any attempt to break down the basic study grant would be artificial and alien to the basic philosphy of the Dutch study finance legislation, which was to make a contribution towards the students' maintenance costs. The Dutch system would be an instrument of social policy falling outside the scope of the Treaty. The Court rejected the argument reasoning that the Dutch grants were made up of various elements including the cost of access to courses. In order to 
The outcome of Lair was thus understandable, but the legal reasoning which led the Court to its conclusion fit uneasily in the case law on the free movement of persons. ${ }^{164}$ In Lair the Court made the answer to the question whether Community students enjoy a right to equal treatment as regards student financial aid dependent on the degree to which the Member States had transferred their educational and social powers to the Community. This "transfer-of-powers approach" was similar to the one the Court had applied in Gravier, but at odds with the way in which the Court has traditionally determined the material scope of the right to equal treatment of the beneficiaries of the free movement of workers. In cases such as Casagrande the Court had ruled that the beneficiaries of Article $39 \mathrm{EC}$ (48 EEC) enjoy equality of treatment when, and in as far as, this is necessary for promoting freedom of movement. ${ }^{165}$ In Lair the Court did apply this functional approach to Community workers, but it did not do so as regards Community students. Ever since Casagrande the Court has continued to apply a functional line of reasoning in the context of the free movement of workers ${ }^{166}$ and persons ${ }^{167}$. In fact, it is only in cases concerning study grants for Community students that the Court has so far continued to apply the "transfer-of-powers" approach. ${ }^{168}$

The more recent judgment in Martínez Sala (1998), however, could be interpreted to imply that the Court is now also willing to apply the functional approach to the right to equal treatment of Community students. In Martinez Sala the Court held that any right or benefit which may be regarded as a social advantage in the sense of Article 7(2) of Regulation No 1612/68 "indisputably" falls within the scope of Community law and, thus also, Article 12 EC. In addition, the Court stated that Community citizens are entitled to invoke this provision in other Member States when they are lawfully established there. ${ }^{169}$ Article $7(2)$ covers

guarantee students from other Member States equal treatment with regard to grants covering tuition fees, the Court obliged Member States to determine which part of the grants covered the costs of admission. Case C-357/89 Raulin [1992] ECR I-1027 at 27-28.

164. Compare O'Leary (1998) supra footnote 133, at p.108; von Wilmowsky (1991) supra footnote 161, at pp.243-246 and von Wittkowski (1991) supra footnote 4, at p.182 et seq. 165. In order to facilitate freedom of movement for workers, Community law may cross the boundaries of policy areas which have as such not (yet) been brought within the ambit of Community law. See Chapter Section 3.1.

166. See e.g. Case C-18/95 Terhoeve [1999] ECR I-345.

167. See e.g. Case 186/87 Cowan [1989] ECR 195 and Case C-43/95 Data Delecta [1996] ECR I-4661.

168. See e.g. Case C-357/89 Raulin [1992] ECR I-1027 and Case C-3/90 Bernini [1992] ECR I-1071.

169. See Chapter 2 Section 3.3 and Chapter 3 Section 4.2. 
grants without making any distinction between fees and the cost of maintenance. Transposed to study grants, Martinez Sala could thus be interpreted to imply that grants now fall within the scope of Article 12 $\mathrm{EC}$ in respect of the part that covers the cost of maintenance, and that Community students can now claim such grants under the same conditions as nationals of the State of the studies. Admittedly, Martinez Sala was not an education case and until the Court explicitly rules so, one cannot be certain that the Court actually meant to say that study grants now fall within the scope of Article $12 \mathrm{EC}$ in respect of the part that covers living cost. ${ }^{170}$ Yet, much can be said for such a conclusion. Lair was correctly decided but badly reasoned. In Martinez Sala the Court seems to have corrected the legal reasoning of Lair, but the judgment does not compel the conclusion that the Court has also moved away from the "political" conclusion reached in Lair. The mere fact that Community students have the right to claim study grants under the same conditions as nationals of the host State does not necessarily imply that they can actually obtain such grants. Member States could secure their financial interests by making eligibility for grants conditional upon "habitual residence" or "domicile"171 rather than "simple" residence in the national territory. ${ }^{172}$ By doing so, Member States could reserve study grants for their own population and exclude students who have merely come to, and are only

170. Compare Tomuschat, Annotation Martínez Sala, in: CMLRev (2000) pp.449-457.

171. Neither residence nor domicile has a fixed meaning and it may be difficult to distinguish the two concepts. Compare the discussion in Chapter 3 Section 6. Somewhat oversimplified, however, domicile can be classed as "the place where a person has his/her principal establishment .. which serves either to link a transaction to the territorial competence of an authority, or to permit contact with a person at the place where he/she is found". Residence, by comparison, is the place "where a natural person effectively lives .. but which many not be his/her domicile". See Garot, A New Basis for European Citizenship: Residence?, in: La Torre, European Citizenship: An Institutional Challenge (1998) pp.229-248, at p.236.

172. After all, Community students enjoy the right to reside in the State of the studies. As regards students who only hold the nationality of another Member State, it is rather easy to determine whether they are to be regarded as domiciliaries or as mere residents. This could be done by simply refusing grants to students who have acquired a residence card under Directive No 93/96 and giving such grants to non-nationals who have acquired the right to reside under Article 39 EC, Article 43 EC, Directive No 90/365 or Directive No 90/364. As regards, students holding their "own" nationality some difficult issues would seem to arise, however. Mere registration as a resident would not suffice since this would entail direct discriminaton on grounds of nationality. In order to determine whether or not national students are "free-riders" who merely return from abroad for educational purposes, concepts like habitual residence or domicile may have to be applied. The American experiences, examined in Section 8, demonstrate, however, that application of such definitions in practice is far from easy. 
staying or residing in, the State for educational reasons. ${ }^{173}$ Such policies are likely to work mainly to the detriment of non-nationals and could thus possibly constitute an indirect discrimination for reasons of nationality. Arguably, however, national rules which make eligibility for full grants conditional upon domicile in the national territory may be justified as being necessary for securing the financial stability of study grant schemes.

\subsection{The Right to Reside in the Host State}

In Raulin the Court concluded that the right to study in other Member States encompasses a right to reside in the State concerned. In doing so, the Court confirmed the view of the political Community institutions which shortly after Gravier had reached that conclusion and had adopted Directive No 90/366, in which the conditions under which students can establish residence in the host State were set out in further detail. These conditions are now laid down in Directive 93/96. ${ }^{174}$

173. In order to have regard to States' financial and educational interests, there is no need to exclude altogether grants covering maintenance costs from Article 12(1) EC. Lair, for instance, allows Member States to give full grants to their own nationals who reside abroad and who have merely returned to their State of origin for educational reasons and to deny such grants to non-nationals who are in a comparable position. Such direct discrimination on grounds of nationality is hard to compare with the notion of Union citizenship; there seem to be no sound political, economic or other reasons for allowing Member States to make such distinctions.

174. OJ 1993 L 317. Directive No 93/96 replaced the original Directive No 90/366 which was annulled by the Court in Case C-295/90 Parliament v Council [1992] ECR I-4193. The Commission had initially proposed that the students directive should be based on Article $7(2)$ (now 12(2)) of the E(E)C Treaty. OJ 1989 C 191/2. When the Council reached political agreement on this proposal in December 1989, however, it decided to base the directive on Article 235 (now 308) which only requires the Council to consult the European Parliament and only allows unanimous decision making by the Council. By choosing Article 235, the Council presumably wished to avoid a precedent for the application of Article 7(2) which allows for quality majority voting. Taschner, Free Movement of Students, Retired Persons and other European Citizens - A Difficult Legislative Process, in: Schermers et al (Eds), Free Movement of Persons in Europe (1993) pp.427-436, at p.436. The European Parliament, however, claimed that the Directive should have been based solely on Article 7(2) of the Treaty since Article 235 can only be applied when the Treaty does not provide for the powers necessary for attaining the Community's objectives. When the Council definitively adopted the directives in June 1990 it ignored Parliament's arguments. Directive 90/366 was based on Article 235. In order to safeguard its prerogatives in the legislative procedure, the Parliament susequently started proceedings under Article 173 (now 230) of the Treaty asking the Court to annull Directive 90/366. In its ruling the Court reiterated Raulin and concluded that the residence directive should indeed have been based on Article 7(2) alone. Case C295/90 Parliament $v$ Council [1992] ECR I-4193 at 18. On this judgment see O'Leary, 
According to Article 1 of the Directive, Member States shall recogni$\mathrm{se}^{175}$ the right of residence for students who $(i)$ are enrolled in a recognised educational establishment for the principal purpose of following a vocational training course, ${ }^{176}$ (ii) assure the relevant national authority, by means of a declaration or any other equivalent means, that they have sufficient resources to avoid becoming a burden on the social assistance system of the host Member State and who (iii) are covered by sickness insurance in respect of all risks in the host Member State. ${ }^{177}$ These are

Annotation Case C-295/90 Parliament v Council in: CMLRev (1993) pp.639-651; Röttinger, Bedeutung der Rechtsgrundlage einer EG-Richtlinie und Folgen einer Nichtigkeit, in: EuZW (1993) pp.117-121; Kampf, La Directive 90/366/Cee relative au Droit de Séjour des Etudiants communautaires: sa Transposition en France, in: RMCE (1992) pp.303-317 and Kampf, Die "richtige" Rechtsgrundlage der Richtlinie über das Aufenthaltsrecht der Studenten, in: EuR (1990) pp.397-404. On 29 October 1993 the Council adopted Directive No $93 / 96$ on the right of residence for students which is qua substance virtually identical to the original Directive No 90/366, on the basis of Article 7(2) alone.

175. Article 1 of Directive No 93/96 states that Member States "shall recognise" the right of residence of students and not, as the first Article of the original (see previous footnote) Directive No 90/366 did, that Member States shall "grant the right of residence" to students. The change in wording was introduced in order to underline that the right of residence is based on the Treaty itself. European Commission, Right of Residence - Report to the Parliament and the Council on the Implementation of Directives 90/364, 90/365 and 93/96 (1999) at pp.6-7.

176. This first requirement does not seem to be very controversial. One could question. however, precisely what is meant by the phrase "for the principal purpose" of following a vocational training course. In particular, the question could be raised whether students who have enrolled in an educational establishment must actually study. Do students who never attend classes or who consistently refuse to do exams, benefit from the right to reside in the host State as a "student"? By analogy with the Court's definition of the concept of Community worker (see Chapter 2 Section 2.4) the argument could be made that only students who "effectively and genuinely" study, are entitled to reside as Community students in the State in which they are enrolled at an educational establishment. Vermeulen and Kuijer have claimed that students must spend at least $50 \%$ of the time normally required for their studies and that students who in fact only exist "on paper", cannot benefit from the residence right governed by Directive No 93/96. Vermeulen/Kuijer (1997) supra footnote 4, at pp.67-68.

Furthermore, it is not entirely clear why a student must be enrolled in a "recognised" educational establishment. A recognised educational institution may be described as a school or university which has been permitted by the Member State concerned to provide education and to issue recognised diplomas. Vermeulen/Kuijer (1997) supra footnote 4, at p.67. Public schools and universities will generally be classed as "recognised" institutions. Since Directive No 93/96 seems primarily relevant to public education (see Section 4.8), one might doubt whether the requirement of being a recognised educational establishment has any substantial meaning. Compare Martin/Guild, Free Movement of Persons in the European Union (1996) at p.210.

177. On this requirement see further Chapter 4 Section 3.3.3. 
conditions both for obtaining and maintaining the right to reside. ${ }^{178}$ Students are entitled to reside in the host State for the duration of their studies. ${ }^{179}$ During this period they have the right to be accompanied by their spouse and their dependent children. ${ }^{180}$

The formulation of the "financial means requirement" is rather cumbersome. Unlike the other 1990 residence directives, ${ }^{181}$ the students directive does not state that students must possess sufficient financial means. ${ }^{182}$ Rather, by means of a declaration, students must assure the competent national authority that they possess sufficient financial means in order not to become a burden on the host State's social assistance system. What does this mean? The drafters of Directive No 93/96 intended to

178. See Article 4 of Directive No 93/96: "the right of residence shall remain for as long as beneficiaries of that right fulfil the conditions laid down in Article 1".

179. Article 2 of Directive No 93/96 and Case C-357/89 Raulin [1992] I-1071 at 39. The right of residence is evidenced by a residence card which may be limited to the duration of the course of studies or to one year where the course last longer. In the latter event the card shall be renewable annually. Article 2 (1) of Directive 93/96.

180. Unlike Community workers (Article 10 Regulation No 1612/68), pensioners (Article 1 Directive No 90/365) and the remaining category of "other" European citizens (Article 1 Directive No 90/364), students do not have the right to be accompanied by their dependent grandchildren and dependent family members in the ascending line. Residence rights for such family members of students were not considered necessary in order to effectuate the free movement of students. Taschner (1993) supra footnote 174, at p.433. In view of the fact that students are often not married but rather living together, one could raise the question whether a genuine free movement of students would not require a right for boy- and girlfriends to be included in the Directive. Compare House of Lords - Select Committee on European Communities, 27th Report on Student Mobility in the European Community (1989-1990) at p.27. The question is not purely theoretical. In fact, in view of the judgments of the Court in Case 59/85 Reed [1986] ECR 1283 (the right to live with an unmarried partner can be regarded as a social advantage for purposes of Article 7(2) of Regulation No 1612/68) and Case C-85/96 Martinez Sala [1998] ECR I-2691 (the material scope of Article 12 EC covers all rights and benefits which may be regarded as social advantages), it could be argued that Community students have a right to be joined by their boy- or girlfriend in the Member States where nationals hold such a right. Compare further the Opinion of Advocate General La Pergola in Case C-65/98 Eyüp [2000] ECR I-0000.

181. See Chapter 2 Section 3.2. The differences between the students directive, on the one hand, and the directives for pensioners and the residual category of "other" Community citizens, on the other hand, is explained by the fact that the duration of students' residence is limited to the duration of their studies. Students are less likely to become a burden on the social assistance scheme of the host State. See further Case C-424/98 Commission v Italy [2000] ECR I-0000 at 45 juncto 40.

182. Students do not actually have to possess sufficient financial means. In Commission v Italy (2000) the Court held that Article 1 of Directive No 93/96 does not contain any requirement as regards a specific level of means of subsistence. A national rule which requires from students to actually possess sufficient financial means runs counter to Article 1. Case C-424/98 Commission v Italy [2000] ECR I-0000 at 44-46. 
reduce the burden of proof on students. Students would not have to present full proof of their financial resources. It would suffice if they could make it appear plausible to the competent national authority that they would not burden the host State's public purse. ${ }^{183}$ Yet, how much proof is necessary? What should the declaration entail? Do competent national authorities have to accept a declaration which they suspect is false? ${ }^{184}$ Furthermore, the directive nowhere indicates at what point students' financial resources are to be considered "sufficient". Should the minimum subsistence level or, the often lower, amount of full study grants be considered? ${ }^{185}$

\subsection{Recognition of Diplomas}

The practical relevance of the right to study in other Member States would be minimal if the diplomas which students have obtained in the Member State of origin were not recognised in the States where they wish to continue their education. Apart from the measures which have been taken in the context of the Socrates-Erasmus programme, ${ }^{186}$ the political Community institutions have so far not undertaken much activity as regards the so-called academic recognition ${ }^{187}$ of diploma's. Legislative

183. Taschner (1993) supra footnote 174 , at p.434. The formulation of the requirement is the result of a compromise reached between the Community institutions. The Council simply wished to impose the same requirements on students as on the beneficiaries of the other two 1990 residence directives. The Commission had initially proposed (OJ 1989 C 191) that students would not have to prove at all that they posses sufficient financial means. It was even proposed that students were to have a right to benefit from the host State's social security system, provided the students' Member State of origin would reimburse the host state upon request. The Council rejected the proposal. During the last Council meeting a compromise was reached the result of which is now contained Article 1 of the Directive.

184. Compare van Nuffel, Een bijna Algemeen Verblijfsrecht in de Europese Gemeenschap Commentaar op de Verblijfsrichtlijnen van 28 juni 1990, in: SEW (1990) pp.887-903, at p.902.

185. In order to avoid legal uncertainty, it has been suggested that it would have been better if the Directive had stated that the right to reside would remain for as long as the student does not actually become a burden on the host State's social assistance system. Vermeulen/Kuijer (1997) supra footnote 4, at p.66. One could even go further and raise the question whether the financial means requirement might be deleted altogether. See further Section 9.3.2.

186. See below Section 4.9.

187. Academic recognition is to be distinguished from the professional recognition of diplomas. The former concerns recognition for access to education, whilst the latter relates to access to employment or a profession in other Member States. See Zilioli, The Recognition of Diplomas and its Impact on Educational Policies, in: De Witte, European Community 
measures comparable to the ones adopted for professional recognition do not exist. ${ }^{188}$ It is up to the Member States and national educational institutions to decide whether or not a diploma obtained in other Member States will be recognised. The Community is only empowered to "encourage" academic recognition of diplomas "by supporting and supplementing the action of the Member States through the adoption of incentive measures". ${ }^{189}$

The fact that academic recognition is primarily a matter for

Law of Education (1989) pp.51 et seq, at p.52. On the academic recognition of diplomas see e.g. Frazier, L'Education et L'Union européenne, in: RMC (1997) pp.476-491; De Witte, Equivalentie van Studieperiodes en Erkenning van Diploma's, in: TOO (1992-1993) pp.290296; Dalichow, Academic Recognition within the European Community, in: EJE (1987) pp.39-58 and Hagen, University Co-operation and Academic Recognition in Europe: The Council of Europe and the Communities, in: EJE (1987) pp.77-83. Academic and professional recognition may not always be easily distinguishable. See e.g. the Communication from the Commission on recognition of qualifications for academic and professional purposes (COM(94) 596 final at p.5) and De Witte (1992-1993) supra p.293. De Witte mentions a number of examples covered by a "grey zone" in which the classification (professional or academic recognition?) may be difficult. One of these concerns the so-called AIOs (Assistenten in Opleiding - "Assistants in Training") at Dutch Universities. Under Dutch law AlOs have a rather ambiguous status. On the one hand, they are assistants who pursue research and have teaching tasks in return for which they receive a (rather low) remuneration. On the other hand, AIOs are still in training and are according to Dutch law governing their status, in "the second stage" of their university education. Should diploma requirements for access to the position of AIO be classed as academic or professional recognition? One may safely say that it concerns conditions for professional recognition. There is no doubt that AIOs perform "effective and genuine activities" under the supervision of another person in return for which they receive a remuneration (see Chapter 2 Section 2.2.4) and that they can obtain the status of Community worker.

188. This might be explained by the fact that various measures aimed at academic recognition have already been taken outside the framework of the Community (see Dalichow (1987) supra footnote 187 , at p.39 - for a short overview of the various "extra-Community" measures see Vermeulen/Kuijer (1997) supra footnote 4, at pp.46-48) as well as the fact that the Community only holds limited powers in this field (see next footnote).

189. See Article 149 EC. The first paragraph of Article 149 further provides that the Community must fully respect "the responsibility of the Member States for the content of teaching and the organization of education systems and their cultural and linguistic diversity". It has been argued that the Community is not empowered to lay down substantive rules aimed at the mandatory recognition of educational results achieved in other Member States. Vermeulen/Kuijer (1997) supra footnote 4, at p.43. On how the European Commission aims to encourage the Member States and educational institutions to promote the academic recognition of diplomas see e.g. Memorandum on Higher Education within the Community of 5.11 .91 (COM(91) 349 fin); Communication from the Commission on the Recognition of Qualifications for Academic and Professional Purposes (COM(94) 596 final) and the Green Paper on "Education, Training, Research: The Obstacles to Transnational Mobility (Bull.EU Supplement 5/96). 
Member States does not imply, however, that Community law is of no relevance. By analogy with the Court's jurisprudence on the professional recognition of diplomas, one may assume that Community law does impose certain limits on Member States and ducational institutions. ${ }^{190}$ In Vlassopoulou (1991) the Court ruled that when deciding upon an application for authorisation to practise a profession, Member States must take account of diplomas, certificates and other qualifications which have been obtained in other Member States. These "foreign" qualifications have to be compared with national qualifications. When this comparative investigation leads to the conclusion that foreign diplomas indicate that the knowledge and/or skills of the holders are equivalent to those of evidenced by national diplomas, ${ }^{191}$ that diploma should be recognised. ${ }^{192}$ The same line of reasoning could be applied to academic recognition. This means that Member States and educational institutions must consider foreign diplomas, compare these to national diplomas and, when equivalence is established, recognise the diplomas.

\subsection{Language Requirements}

In order to be admitted to educational institutions in other Member States students must often demonstrate that they have a certain level of working knowledge of the language of the State concerned. In principle, institutions are entitled to apply language requirements. In the field of education, Community institutions must, as Article 149(1) EC puts it, fully respect the "cultural and linguistic diversity" of Member States. This is not to say that Member States and their educational institutions are entirely free to apply language requirements. These requirements are generally far more

190. See also Vermeulen/Kuijer (1997) supra footnote 4, at pp.43-44.

191. A right to appeal a possible negative decision must be guaranteed. See Case $222 / 86$ Heylens [1987] ECR 4097 at 10-13.

192. Case C-340/89 Vlassopoulou [1991] ECR I-2357 at 23. While comparing the equivalence of foreign diplomas attention may only be paid to the level of knowledge and qualifications the holders presumably have, taking into account the nature and the duration of their studies or training. When it appears that there is only partial equivalence of knowledge and skills, the host State may require the persons in question to prove that they have acquired the knowledge and qualifications which they were lacking. Case C-340/89 Vlassopoulou [1991] ECR I-2357 at 17-19. See further e.g. Fierstra, Annotation Vlassopoulou, in: SEW (1992) pp.640-649; Stein, Annotation Vlassopoulou, in: CMLRev (1992) pp.625-636; Lonbay, Picking over the Bones: Rights of Establishment Revisted, in: ELRev (1991) pp.507-520 and Nachbauer, Art.52 EWGV - Mehr als nur ein Diskriminierungsverbot?, in: EuZW (1991) pp.470-472. 
difficult for non-nationals to meet than for nationals of the host State. They may constitute an indirect discrimination on grounds of nationality which would mean that Member States could only lay down language conditions required for the specific studies students wish to follow and that the level of the required working knowledge should not be disproportionally high. One may doubt, however, if the Court of Justice would apply the "indirect discrimination test"193 very strictly. In the case of Groener (1989) the Court upheld an Irish rule which required a certain level of Irish language for teaching posts even though the lessons were given in English. ${ }^{194}$ Groener was decided under the provisions on the free movement of workers, but strongly suggests that the Court will in general leave the Member States considerable discretion in applying language requirements. ${ }^{195}$

\subsection{Family Members of Community Students}

According to Article 1 of Directive No 93/96, a spouse and dependent children have the right to accompany the Community student to the State of the studies. TNowhere in the Directive is the question answered whether these family members have the right to attend educational institutions in the host State. This does not seem to have any consequences for family members who hold the nationality of a Member State. They may claim access to education in their own right in the State concerned on the basis of Article 12 juncto Articles 149 and $150 \mathrm{EC}$. Both as regards admission to education and eligibility for study grants, the legal status of these family members coincides, as may safely be assumed, with the status of the Community students themselves.

More difficult questions arise as regards family members who lack the nationality of one of the Member States. It has been argued that such family members have no right to gain access to education on the basis of Community law as long as the Community legislator has not explicitly

193. See Chapter 2 Section 7.2 .

194. Case 379/87 Groener [1989] ECR 3967 at 15-19. See further Mortelmans, Annotation Groener, in: AA (1989) pp.736-747

195. In practice, language requirements may seriously impede student mobility and it may therefore not come as a surpise that Community institutions aim to promote the learning of various Community languages. See the Green Paper on "Education, Training, Research: The Obstacles to Transnational Mobility (Bull.EU Supplement 5/96), at p.26 and p.30 and Resolution of the Council and the Representatives of the Governments of the Member States, Meeting within the Council of 14 December 2000 Concerning an Action Plan for Mobility. 
conferred this right upon them. ${ }^{196}$ The argument is based on the judgment in European Parliament $v$ Council (1992) in which the Court confirmed Raulin by holding that Community students enjoy a right to reside in the State of the studiesunder Article 12 EC. ${ }^{197}$ In response to the view advocated by the Council and the Dutch government that the original Directive No 90/366 (now No 93/96) would encompass more than a right to reside for students, and that therefore Article 235 (now 308) of the Treaty should have been the legal basis for the directive, the Court held that the measures which can be adopted on the basis of the former Article 7(2) EEC (now 12(2) EC) are not necessarily confined to the rights which follow from the first paragraph of the Article. They may also concern aspects which may be necessary for a genuine exercise of these rights. Various elements of the contested directive concern the exercise of the right to reside and the Court explicitly mentioned the residence rights conferred upon a spouse and children of the Community student. ${ }^{198}$ In other words, according to the Court only the Community student itself can directly rely on the first paragraph of Article 12 in order to gain access to education and reside in another Member State. Family members would only enjoy the right to reside in the host State by virtue of secondary legislation.

On the basis of the judgment in Parliament $v$ Council alone, one might indeed conclude that a spouse and children holding only the nationality of (a) non-Member State(s) have no right to gain access to the educational system of the State where the Community student is studying as long as the Community legislator has not granted them such a right. However, the judgment in Martinez Sala also casts doubt on this point. As described earlier in this book, this judgment suggests that any person falling within the personal scope of Community law can rely on Article $12 \mathrm{EC}$ in order to claim equality of treatment as regards all rights or benefits which fall within the material scope of the Treaty. ${ }^{199}$ If indeed true, then the afore mentioned family members would seem to have the same educational rights as the Community students themselves. Directive No 93/96 has brought these third country family members within the personal scope of Community law and, as follows from the previous subSections, the right to be admitted to educational institutions as well as the

196. See Vermeulen/Kuijer (1997) supra footnote 4, at p.38 and Wapenaar, Personenverkeer binnen de Europese Unie - Het Communautaire Recht inzake Personenverkeer, met Bijzondere Aandacht voor de Positie van Derdelanders (1997) at p.157.

197. Case C-295/90 European Parliament v Council [1992] ECR I-4193 at 18-19.

198. Ibid.

199. See Chapter 2 Section 3.2. 
right to claim student financial aid are covered by the Treaty's material scope. It is submitted that the legal status of third country children of Community students in the field of education is, or at least should be, identical to the status of children who hold EC-nationality without there being a need to adopt specific legislative measures for this purpose.

\subsection{Education and The Concept of Service}

Prior to Forcheri and Gravier, Articles 49 (formerly 59) et seq EC on the free movement of services had been suggested as the legal basis of a free movement of students. ${ }^{200}$ In Luisi and Carbone (1981) the Court had held that recipients of services in the sense of Article 50 EC (60 EEC) have a right to move to and stay in other States and that "persons travelling for the purpose of education" can be regarded as recipients of services. $^{201}$ Understandably, Françoise Gravier relied on the Luisi and Carbone judgment in defense of her claim that the Minerval was inconsistent with the Treaty. The Court, however, remained silent on Article 49 EC and the fact that the judgment in Gravier was decided solely on the basis of Articles 7 and 128 EEC, suggested that the Court had rejected the "services argument". The explanation for this had in fact already been given by Advocate General Slynn in his Opinion in Gravier. Article 50 EC stipulates that services shall be considered "services" within the meaning of the Treaty when they are "normally provided for remuneration". In determining whether educational courses meet this requirement, the Advocate General had made a distinction between private and public education as regards the application of the Article 49 et seq. The former type of education is usually provided by institutions with a view to making a profit. The very purpose of such institutions in providing education is to receive remuneration. The fees which students of private schools have to pay is largely fixed at a level which is related to the actual economic cost of the education. Commercial criteria determine the level of the fees. The situation is different with respect to education provided by the State. The fees to be paid by students bear little relation to the true economic cost of the education. State education is largely funded from the State budget. It is ultimately the resident tax-payer who finances State education. The State does not intend to engage in economic activitys or to make a profit. State education is basically a matter of social

200. See e.g. Maresceau (1989) supra footnote 4, at pp.181-183.

201. See Chapter 2 Section 4.1. 
policy. ${ }^{202}$ Three years later the Court endorsed the view of the Advocate General in Humbel:

"The essential characteristic of remuneration lies in the fact that it constitutes consideration for the service in question, and is normally agreed upon between the provider and the recipient of the service. [ ] That characteristic is, however, absent in the case of courses under the national education system. First of all, the State, in establishing and maintaining such a system, is not seeking to engage in gainful activity but is fulfilling its duties towards its population in the social, cultural and educational fields. Secondly, the system in question, as a general rule, is funded from the public purse and not by pupils or their parents". ${ }^{203}$

The scope of Articles 49 et seq is thus limited to private education; students who wish to attend public educational establishments in other Member States have to rely on Article 12 read in conjunction with Articles 149 and $150 .^{204}$

202. Opinion AG Slynn in Case 293/83 Humbel [1985] ECR 293 at pp.602-604.

203. Case 263/86 Humbel [1988] ECR 5365 at 17-18. See further Völker, Passive Dienstleistungsfreiheit im Europäischen Gemeinschaftsrecht (1990) Chapter 5.

204. The above conclusion is simply stated, but raises many more questions which are often not easily answerable. A first set of questions concerns the demarcation between private and public education. In determining whether or not education can be regarded as a service in the sense of Article $50 \mathrm{EC}$, the Court in Humbel seemed to have attached importance to two factors: the (public or private) source out of which education is mainly funded and the (economic or social) motives for providing education. In Wirth (1993), however, the Court held that "courses given in an establishment of higher education which is essentially financed out of public funds do not constitute services within the meaning of Article 60" of the Treaty. Case C-109/92 Wirth [1993] I-6447 at 19. See further e.g. van der Mei (1994) supra footnote 155, at pp.102-107. In Wirth the Court did not seem to attach much significance to the fact that the State may be fulfilling a "welfare duty" towards its population. Does this imply that the "public/private funding distinction (O'Leary (1996) supra footnote 4, at p.75) is the sole and decisive criterion for the classification of education as a service? Does this mean that public universities are to be regarded as providers of services when they offer post-graduate courses or masters-programmes which are (at least in the long run) to operate independently of any public funding? Do Humbel and Wirth imply that students attending privately established schools do not fall within Articles 49 and 50 EC when these schools are in the main financed by State subsidies? The "line between wholly state-funded and partly state-funded services, or between services which are economic in nature and those which are provided within the context of educational and cultural policy" is far from clear (Craig/de Búrca, EU Law - Text, Cases \& Materials (1998) at p.770) and needs further clarification.

Further questions arise once it is established that a given type of education is covered by Articles 49 and 50 EC. Are private schools or universities obliged by Community law to admit non-resident students? Can admission to private colleges be made conditional upon possession of a diploma awarded by a school in the State concerned? Can non-residents be required to pay additional tuition fees? Can Article $49 \mathrm{EC}$ be relied upon in cases against private schools or colleges? The article can be invoked in order to challenge rules set by private bodies which regulate certain activities in a collective manner (compare e.g. Case 


\section{$4.9 \quad$ Erasmus/Socrates Students}

Community institutions have always stressed the importance of student mobility. The most important initiatives are those which have been taken in the context of the Erasmus programme. ${ }^{205}$ The programme, which is now falling under the umbrella of Socrates, ${ }^{206}$ aims to promote student mobility by a number of "Actions". Action 1 concerns the establishment of a European University Network under which universities in the different Member States are encouraged (by financial incentives) to conclude agreements aimed at the exchange of students (and teachers). Action 2 involves making available special study grants for students who participate in the programme. The grants, which may be granted for a period of three up to twelve months, cover the cost of linguistic preparation for study in another Member State, travel expenditure and the higher cost of living in the host State. Action 3 concerns the European Community Course Credit System (ECTS) under which participating universities are essentially obliged to recognise periods of studies fulfilled in other Member States for the purposes of their "own" studies. Tuition fees are to be paid in the State of origin; no fees are due in the State of the (temporary) studies. The goal of Erasmus is thus limited. It only aims to promote the exchange of students who wish to pursue part of their studies "at home" in another Member State. The programme does not aim to promote or facilitate the right of Community students to follow their entire studies in another Member State. ${ }^{207}$

36/74 Walrave [1974] ECR 1405 and Joined Cases C-51/96 and C-191/97 Deliège [2000] ECR I-0000), but does the same hold true for rules applied by individual colleges or universities?

205. Council Decision 87/327 establishing the European Community Action Scheme for the Mobility of Students (Erasmus). OJ 1987 L 166. On Erasmus (and the legal status of Erasmus-students) see e.g. Davies, The EU Higher Education Exchange and Mobility Programmes (1997); André de la Porte/Zegveld, Het Europa van de Student - Studentenmobiliteit binnen de Europese Unie, in: AA (1995) pp.685-693; Gazan/Oomen, Internationaliseringsprogramma's en het Nederlandse Hoger Onderwijs; Van Erasmus naar Socrates in de Europese Unie, in: IS (1995) pp.155 et seq and Feuchthofer, Europäische Förderprogramme in Bildungswesen, in: RJB (1992) pp.180-192.

206. See above Section 2.1.3.

207. On the experiences with the Erasmus programme see in particular Teichler/Maiworm, The Erasmus Experience - Major Findings of the Erasmus Evaluation Research Project (1997). 


\subsection{Student Mobility within the European Community}

The impact which Gravier and its progeny have had on student mobility within the European Community is quite considerable. At the end of the 1970s, many Member States did receive quite a number of foreign students, but most of these came from non-Member States and former colonies in particular. ${ }^{208}$ Student mobility of Community citizens among the Member States was modest. Since the judgment in Gravier, and in particular since the establishment of the Erasmus programme, the mobility of European students has increased. ${ }^{209}$ Even though the original goal of enabling ten percent of European students to follow part of their studies abroad has not been achieved, more than 500.000 students have participated in the programme in the period between 1987 and 1995. ${ }^{210}$ The "spontaneous" mobility of students outside the context of Erasmus is also quite considerable today. Even though statistics do not always make a clear distinction between Erasmus students and "free-movers", it has been estimated that for instance in the year 1993/1994 almost 100.000 Community students were registered at universities in other Member States. Three quarters of these "free movers" were studying in the United Kingdom $(37 \%)$, France $(23 \%)$ and Germany $(13 \%)$. A look at the net balance between incoming and out-going students demonstrates that five Member States may be regarded as "net-importers" of students: the United Kingdom, France, Belgium, Austria and Sweden. The United Kingdom is by far the most important "student-importer". In 1993 and 1994 it received almost 27 thousand more foreign students than it "send abroad". France and Belgium had a net-balance of 8400 and 1800 respectively. Virtually all other Member States appear to be "exporters of students". Greece is the biggest exporter. The number of out-going students exceeds the incoming number by almost 17.000. Germany (5.000), the Netherlands (3.000) and Luxembourg (2400) are in view of the size of their populations also relatively large student exporters. Interesting are the figures about

208. To be sure, statistical systems monitoring student mobility and exchanges did not exist at the time. See Education Institute of the European Cultural Foundation, La Mobilite intraeuropéenne des Etudiants des premier et deuxième Cycles, as quoted in Gordon/Jallade, Student Mobility within the European Union: A Statistical Analysis (1995) at p.4.

209. For student mobility figures see e.g. Gordon/Jallade, 'Spontaneous' Student Mobility in the European Union: A Statistical Survey, in: EJE (1996) pp.133-151; Gordon/Jallade (1995) supra footnote 208; Baligant et al, Analyse economique de la Mobilité Etudiant à l'Echelle de l'Union Européenne (1994) and De Jonge/Dillo, Student Mobility within the European Community (1991).

210. Verli-Wallace, Le nouveau Programme communautaire 'Socrates', in: RMCUE (1995) at p.518. 
the movement of student between specific countries. The number of German students going to the United Kingdom, for instance, is almost nine times as high as the number of UK-students going to Germany. Vis$\grave{a}$-vis other countries (France, Ireland), the United Kingdom also absorbs a comparatively mlarge number of students. Belgium receives about eight times as many Dutch students as the Netherlands receives Belgian students.

The reasons why "free-movers" decide to study in other Member States vary. Often movement abroad is caused by shortcomings in the supply of education in the home State. Thus, in Luxembourg students move abroad simply because a university system does not exist and in Greece, Ireland and the Netherlands numerus clausus regulations constitute the main "push factor".211 The large number of Dutch students at medical and veterinary faculties at Belgian universities, for instance, is largely explained by the fact that for such studies a numerus clausus is applied in the Netherlands and that the Dutch Minister of Education allows Dutch students of medicine to export their study grants when they study at certain enlisted foreign universities. Further, student mobility is often caused by the quality of education, the conditions of student life or cultural aspects in other Member States. The language of a given country appears to be one of the main criteria that students apply when making their choice of a specific country or universitiy. The fact that Member States such as the United Kingdom and France are net-importers of students is largely explained by the fact that the languages in which the courses and studies are offered are relatively well-spoken by students from other Member States, ${ }^{212}$ whilst British and French students often lack sufficient knowledge of foreign languages.

\subsection{Conclusions}

From the early Community years, the Community institutions have frequently stressed the importance of promoting student mobility for the achievement of the Community's objectives, and the free movement of persons in particular. Looking back, one must conclude that, in spite of the Member States' reluctance to co-operate, institutions have been quite successful. Today, all Community citizens have the right to study in other Member States and student mobility has increased. This is not to say,

211. Gordon/Jallade (1996) supra footnote 208, Section 9.2.

212. Ibid, at p. 137. 
however, that Community law on the free movement of students has remained free from criticism. The current rules are still debated. On the one hand, it is claimed that Community law does not give sufficient regard to the educational interests of in particular the Member States which "import" more students than they "export", and who are thus faced with an unequal financial burden. Measures should be taken to protect or compensate the "net-importers" of students. ${ }^{213}$ On the other hand, however, it is generally felt that there are still (too) many obstacles to student mobility within the Community. In its 1996 Green Paper on "Education,

213. The fact that it has been the Court rather than the Council which has developed the most relevant legal rules on the free movement of students has provoked critical comments. See e.g. Hartley (1989) supra footnote 4, at p.343; Hartley (1991) supra footnote 4 at p.192193 and O'Leary (1996) supra footnote 4, at p.143. It has been argued that significant and potentially far-reaching decisions such as the free movement of students should not be made by a judicial body like the Court of Justice which would not be sufficiently equipped for making such decisions. Student movements would not be likely to be in balance and the effects of the principle of a free movement of students would not be equally felt by or in all Member States. As a result, both the funding and organisation could be seriously affected by the Court's case law. O'Leary (1996) supra footnote 4, at p.106. The Court has been accused of not having seriously adressed the possible implications of its case law and it has been suggested that it would have been better if the Court had left it "to the Council to adopt a policy on migrant students". No doubt such a policy would have taken more time to develop, but "the end result would probably have been preferable from the educational point of view". Hartley (1991) supra footnote 4 at p.192-193.

Such criticism cannot be wholly dismissed. One must be critical when a significant decision such as the establishment of a free movement of students is made by the judiciary and it indeed appears that the financial burden of a free movement of students is not equally felt by all Member States. It is submitted, however, that the previously mentioned criticism is too one-sided. From the early years, the Council and the "Ministers of Education meeting within the Council" had frequently stated that they would promote and take common measures in the fields of education and vocational training and, in particular, that they would promote student mobility. Yet, during the first two decades they did not do much more than pay lip-service to these proclaimed objectives. When cases such as Forcheri, Gravier and Erasmus were sent to "Luxembourg", the Court found itself in a situation where the importance of common activities in the field of education such as promoting student mobility was increasingly recognised, but where, due to the absence of specific educational powers for Community institutions and an unwillingness on the part of Member States, no concrete measures had yet been taken. The Court's genuine motives may be hard to find, but the rulings in question suggest that the Court deliberately wished to make a breakthrough. It is not certain, but one may seriously doubt whether all the "European achievements" could have been made if it had not been for the Court. Arguably, the positive aspects of the Community's educational activities overshadow the negative ones and one could therefore cvaluatc the Court's role more positively than the afore mentioned authors do. 
Training, Research: the Obstacles to Transnational Mobility"214 the European Commission identified various legal, bureaucratic and psychological hindrances and problems which still hamper student mobility. "Free movers", i.e. the students who (wish to) study in other Member States outside the framework of the Socrates-Erasmus programme, especially still appear to face many obstacles. These include problems concerning the recognition of previously obtained diplomas and qualifications, the lack of sufficient knowledge of the language of the State of the studies and the non-transferability of study grants. ${ }^{215}$ Thus, progress may have been made, but the conflict between the aim of promoting freedom of movement for students and safeguarding States' educational interests, has still not been settled satisfactorily. ${ }^{216}$

\section{$5 \quad$ The "other" Non-Economic Residents}

So far little attention has been paid to the question whether, or to what extent, the "other"217 non-economic residents can claim access to education and study grants systems in the State in which they have chosen to reside. Directives Nos 90/365 and 90/364 do not mention any educational rights for pensioners, the residual category of "other" Community citizens or the family members of both categories. So far, the Court has not yet been in a position to clarify the legal status of these categories in the field of education. This does not mean that non-economic residents are denied

214. Bull.EU, Supplement 5/96. See also COM(96) 462 final. For a comment on the Green Paper see Verbruggen, The Commission's Green paper "Education, Training, Research: The Obstacles to Transnational Mobility": Content and Comment, in: EJELP (1997) pp.41-48.

215. See further also the Resolution of the Council and of Representatives of the Governments of the Member States, Meeting within the Council of 14 December 2000 Concerning an Action Plan for Mobility (OJ 2000 C 371).

216. In Section 9 some observations will be made as to how the situation could possibly be improved.

217. For the purposes of this book the category of "non-economic" residents consists in principle of students, pensioners and "other" Community citizens. See Chapter 1 Section 3. In this Chapter, however, the first category was dealt with in the previous Section on Community students (or non-residents). The reason for this is that, from the perspective of the conflict between promoting the free movement of persons and protecting the educational interests of Member States, Community students are to be regarded as non-residents (or "outsiders"). It concerns Community citizens who move to other Member States for the sole purpose of studying and who have generally not contributed to the financing of public education through the payment of direct taxes. The same does not apply to pensioners and "other" Community citizens; they are to be regarded as (non-economic) residents. See further Section 9 of the present Chapter. 
Community rights in the field of education. As persons falling within the scope of Community law, they can rely on Article 12(1) EC (read in conjunction with Article 149 and 150 EC) in order to claim admission to all forms of education under the same conditions as the nationals of the host State. ${ }^{218}$ Less certainty exists as regards student financial aid. If the conclusions drawn in Lair still stand, one would have to conclude that the non-economic residents can only invoke Article $12 \mathrm{EC}$ in order to claim study grants in as far as it covers tuition and enrolment fees. If, however, Lair has indeed been overruled by Martínez Sala, ${ }^{219}$ the conclusion would have to be that both categories enjoy a "full" right to equal treatment as regards student financial aid. As argued before, Article $12 \mathrm{EC}$ as interpreted by the Court in Martínez Sala allows Member States to make eligibility for full grants conditional upon "habitual residence" or "domici$1 \mathrm{e} "$ in the national territory. Unlike Community students, as a rule, the beneficiaries of Directives Nos 90/365 and 90/364 meet this requirement. Further, the question arises as to whether the application for, or receipt of, study grants could possibly affect the right to reside in the host State. Assuming the financial means requirements contained in the 1990 residence directives are still valid, non-economic residents have a right of residence when, and for as long as, they do not become a burden on the State of residence. ${ }^{220}$ Study grants are funded out of the public purse and it could thus be argued that the host State is entitled to end legal residence the moment a non-economic resident applies for student financial aid. However, the financial means requirements contained in the residence directives for pensioners and the residual category of Community citizens have never been included primarily with study grants in mind. The main concern of the drafters of the directives was to avoid Community citizens who are not able to provide for themselves moving to other States and claiming social assistance benefits there. ${ }^{221}$ The Treaty provisions on European Citizenship demand a restrictive interpretation of the "limitations and conditions" 222 to which the residence rights of the two categories may be subjected and this, so it could be argued, leads to the conclusion that application for, or enjoyment of, study grants in itself cannot be a valid reason for ending lawful residence.

218. This also holds true for the family members of pensioners or "other" Community citizens who do not hold a nationality of one of the Member States. Compare Section 4.7.

219. See in particular Section 4.3.

220. See Chapter 2 Section 3.2.

221. See in particular Chapter 2 Section 3.1 and Chapter 3 Section 4.

222. See Article 18(1) EC. 
Third country nationals are in principle excluded from Community rules on the free movement of persons. ${ }^{223}$ They only enjoy rights under these rules in as far as these rights promote the exercise of free movement rights by Community citizens. More concretely, this means that third country nationals in principle can only benefit from the rights conferred upon the family members of the various categories discussed in the previous Sections. ${ }^{224}$ This is not to say, however, that Community law and policy have nothing else to offer to third country nationals in the field of education. In particular, ${ }^{225}$ third country nationals may enjoy educational rights under agreements the Community (and its Member States) have concluded with third countries. For the purposes of this book, the Agreement on the European Economic Area (EEA), the E(E)C-Turkey Agreement and the agreements concluded with Maghreb countries have been selected for examination.

223. See Chapter 2 Section 5.

224. The benefits which derive from Directive No 77/486 (see supra footnote 88) are in principle preserved for children of Community workers. In a Declaration adopted at the time the Directive itself was adopted, the Council and the Member States expressed their "political will" to include children of third country nationals in the measures taken in furtherance of this Directive. See Vermeulen/Kuijer (1997) supra footnote 4, at p.41 (footnote 99). See further also the Council Resolution on the Admission of Third-Country Nationals to the Territory of the Member States of the European Union for Study Purposes (as published in Guild, The Developing Immigration and Asylum Policies of the European Union - Adopted Conventions, Resolutions, Recommendations, Decisions and Conclusions (1996).

225. Further, the Socrates/Erasmus programme is open not only to Community citizens, but also to nationals of the three EEA countries, ten associated countries in Eastern Europe as well as Cyprus, Malta and Turkey. See European Commission, Socrates - Opening of the Actions of the Socrates programme to Certain Additional Countries (http://europa.eu.int/comm/education/socrates/new-co.html) and European Commission, Gateway to Education - Socrates - European Community Action Programme in the Field of Education (2000-2006) (available on website just referred to) at p.4. Nationals of the States concerned can only benefit from the Community's support provided under the programmes if the "sending" or "receiving" country is a Member State of the Community. For instance, student mobility among Cyprus and the EEA countries is not supported. See further also the definition of the term "student" in Article 2 of the Socrates programme (OJ 1995 No L 87) which nowhere indicates that nationality of one of the Member States is a preriquisite for participation in the programme. 


\subsection{EEA Nationals}

One can be relatively brief with regard to the educational rights offered to EEA nationals. The EEA Agreement has extended the scope of the Community's provisions on the free movement of workers to (the nationals and territories of) Norway, Iceland and Liechtenstein. ${ }^{226}$ In addition, the residence directives Nos 93/96, 90/364 and 90/365 have been extended to EEA nationals and Article 4 EEA contains a non-discrimination provision which is phrased in identical terms to Article 12(1) of the EC Treaty. As a result, EEA-nationals and their family members seem to enjoy, in each of the 15 Member States and the other two EEA Sta$t_{e s}{ }^{227}$ the same rights in the field of education as those which have been discussed in Sections 3 and 4 of this Chapter. ${ }^{228}$

226. See further Chapter 2 Section 5.1.

227. In reverse, Community citizens may enjoy these educational rights in the territory of the three countries concerned. See Chapter 2 Section 5.2. Amongst each other, the Nordic countries have always promoted international student mobility. Foreign students, and in particular those holding the nationality of one of the other Nordic countries, have generally been admitted to education without having to pay additional tuition and enrolment fees. Further, Nordic students have been encouraged to study abroad by exporting student financial aid benefits especially for studies in one of the other Nordic countries. Denmark and Sweden have traditionally been net-importers of students, the other three States netexporters. Initially, student mobility was largely "spontaneous"; formal agreements between the States and/or their educational institutions aimed at regulating student movements did not exist. Since the late 1980s, however, several attempts to organise student mobility have been made. In 1988 Nordplus was set up. This programme allows student to follow part of their studies at home in other Nordic States and may be regarded as the Nordic equivalent of the Socrates/Erasmus programme. See further e.g. Nyborg, International Student Mobility: The Nordic Experience, in: EJE (1996) pp.193-203.

228. To be sure, it is not wholly certain whether the right to freedom of movement for EEA students and the other economically inactive EEA nationals is based on the EEA Agreement itself. Article $4 \mathrm{EEA}$ contains a non-discrimination provision which is phrased similarly to Article 12(1) EC, but "common EEA policies" in the field of education comparable to the policies now based on Articles 149 and $150 \mathrm{EC}$, do not exist. In Article 78 of the Agreement it is merely stated that the Contracting Parties shall strengthen and broaden cooperation in the framework of the Community's activities in the fields of "education, training and youth". Therefore the line of reasoning followed by the Court in Gravier cannot be automatically transposed to the EEA. However, the possibility cannot be wholly excluded that the Court, if it were directly asked, would recognise that the right of EEA students to study in EC Member States is based on the EEA Agreement itself. See e.g. Handoll, Free Movement of Persons in the EU (1996) at p.323. Further, a "common EEA citizenship" does not exist. Therefore, one cannot be wholly certain that the conclusions following from the Court's ruling in Martinez Sala (i.e. Community citizens who are lawfully established in the territory of another Member State can, as persons falling within the scope of the Treaty provisions on European Union citizenship, invoke the non-discrimination provision contained in Article 12 


\subsection{Maghreb Nationals}

Maghreb nationals are in a less privileged position than EEA nationals. The 1978 co-operation agreements concluded with Algeria, Morocco and Tunisia and the more recent Euro-Mediterranean agreements concluded with the latter two countries, do not confer upon Maghreb nationals free movement rights. Provisions specifically dealing with educational rights are nowhere to be found and equivalents of Article 12(1) EC or Article $7(2)$ of Regulation No $1612 / 68$ do not exist. ${ }^{229}$ In principle, the legal status of Maghreb nationals in the field of education is governed by national law, not Community law. It could be argued, however, that Maghreb nationals are entitled to gain access to vocational training courses. The Maghreb agreements provide for a right to equal treatment as regards working conditions which, it could be argued, ${ }^{230}$ may encompass access to vocational training in the host State. ${ }^{231}$

$\mathrm{EC}$ in order to claim social advantages such as "full" study grants under the same conditions as the nationals of the host State) can be extended to EEA nationals. Strictly speaking, it could therefore still be argued that EEA students (compare Section 4.4) and other economically inactive EEA nationals (Section 5) can be denied study grants in as far as these cover maintenance costs (see in particular Article 3 of Directive No 93/96) for reasons of their nationality.

229. See Chapter 2 Section 5.3 .

230. See Martin/Guild (1996) supra footnote 176, at 14.6 (referring to Case C-116/94 Meyers [1995] ECR I-2131 in which the Court held that vocational training may be regarded as a working condition for the purposes of Directive No 76/207 on the principle of equal treatment for men and women). On an extensive interpretation of this right to equal treatment as regards working conditions, one could even argue that this right to vocational training also encompasses a right to claim study grants. Compare footnote 62 above.

231. In the recent Fahmi and Esmoris Cerdeiro-Pinedo Amado (2001) case the question arose whether Moroccan workers could possibly rely on Article 41 of the 1978 Morocco Agreement in order to claim study grants for children pursuing a study. Article 41 offers a right to equal treatment in social security matters (paragraph 1) and a right to receive family allowances for family members who are resident in the European Community (paragraph 3 ). The concept of social security in Article 41(1) "must be understood by analogy with the identical concept in Regulation No 1408/71" (Case C-18/90 Kziber [1991] ECR I-199 at 2526) and the question could be raised whether study grants can be regarded as family benefits for the purposes of Regulation No 1408/71 (see Section 9.3.1). The Court, however, avoided answering this question. The case concerned a Moroccan worker, $\mathrm{Mr}$ Fahmi, who had worked in the Netherlands and who, upon return to Morocco, claimed child allowances for his son, Rida, who was studying there. The Court held that it followed both from the wording and spirit of Article 41(1) and (3), that the non-discrimination principle can only be applied to children residing within the Community. Case C-33/99 Fahmi and Esmoris Cerdeiro-Pinedo Amado [2001] ECR I-0000 at 57-58. It is uncertain whether the Fahmis would have been entitled to claim a study grant under Article 41 of the Agreement if they had resided in the Community. At first glance, Fahmi would seem to call for a negative 


\subsection{Turkish Nationals}

The drafters of the 1963 Association Agreement between the Community (and its Member States) and Turkey, the Additional Protocol of 1970 and Decision $1 / 80$ of the E(E)C-Turkey Association Council had not paid much attention to the legal status of Turkish nationals in the field of education. ${ }^{232}$ The prime beneficiaries, Turkish nationals who have been admitted for employment to one of the Community's Member States, are nowhere expressly granted educational rights. Article 37 of the Additional Protocol and Article 10 of Decision No 1/80, which confer upon Turkish workers a right to equal treatment as regards remuneration and conditions of work, could possibly be interpreted as to encompass a right to gain access to vocational training courses, ${ }^{233}$ but in the absence of an equivalent in Decision No $1 / 80$ of Article 7(2) of Regulation No 1612/68, Turkish workers do not seem entitled to be admitted to general education or to claim study grants in the host State.

The only provision of Decision No $1 / 80$ which expressly mentions educational rights is Article 9. It provides that Turkish children of Turkish nationals who are or have been legally employed in a Member State of the Community, are to be "admitted to courses of general education, apprenticeship and vocational training under the same educational entry qualifications as the children of nationals of the Member States". Article 9 is phrased similarly to Article 12 of Regulation No 1612/68 and, as the

answer. The Court held that the Co-operation Agreement aims to consolidate the position of Moroccan workers and members of their families living with them in the host State as regards social security and that, with specific regard to family allowances, the "prohibition laid down in Article 41(1) of the Agreement is guaranteed only within the limits of the conditions laid down in Article 41(3)". Ibid, at 56. Article 41(3) merely speaks of "family allowances" which, according to the definition of Article 1(u)(ii) of Regulation No 1408/71), only covers benefits granted exclusively by reference to the number and, where appropriate, the age of the members of the family. Study grants, as the Court indicated, do not constitute "family allowances" for the purposes of Regulation No 1408/71. Ibid, at 34-36. In his Opinion in Fahmi Advocate General Alber concluded, however, that it would be incorrect to give the term "family allowances" in Article 41(3) of the Morocco Agreement the same meaning as the same concept used in Regulation No 140/71 and he suggested that Maghreb nationals ought to be entitled to "family benefits" in the sense of Article 1(u)(i) of Regulation No 1408/71 which cover all benefits intended to meet family expenses. Even though Alber himself denied it, Fahmi does not wholly rule out the possibility that study grants can be classified as "family benefits". The Court did not see a need to "adjudicate on the precise legal classification" of study grants and the question whether Moroccan (and other Maghreb) nationals may have a claim to study grants for children residing is thus still open.

232. On these measures see further Chapter 2 Section 5.2.

233. Compare the observations made in Section 6.2 as regards Maghreb nationals. 
latter provision, it is intended to promote the integration of the family of the Turkish worker into the host Member State. ${ }^{234}$ Therefore, one may assume that Article 9 is to be interpreted, as far as possible, ${ }^{235}$ in accordance with the principles on which Article 12 of the Regulation is based. ${ }^{236}$ If so, Turkish children of Turkish workers would seem to have a directly enforceable right ${ }^{237}$ to gain access to all forms of education made available in the host State. ${ }^{238}$ However, Article 9 does not encompass a right to equal treatment for study grants for Turkish children. Turkish children only have to be admitted to education under the "same educational entry qualifications" and not, as Article 12 of Regulation No $1612 / 68$ provides, under the "same conditions". ${ }^{239}$ Turkish workers are entitled to claim indirect student financial aid offered in the form of family benefits for children residing with themunder Decision No $3 / 80$ on the application of social security schemes. ${ }^{240}$ In Sürül (1999) the Court

234. See Martin/Guild (1996) supra footnote 176, at 13.76

235. The provisions of Decision No $1 / 80$ are "as far as possible" to be interpreted in accordance with the principles in the case law on Article 39 EC. See Case C-434/95 Bozkurt [1995] ECR I-1475 at 20 and O'Leary, Employment and Residence for Turkish Workers and their Families: Aanlogies with the Case-Law of the Court of Justice on Article $48 \mathrm{EC}$, in: Scritti in Onore di Giuseppe Federico Mancini - Volume II Diritto Dell/Unione Europea (1998) pp.731-767.

236. Peers, Annotation Akman, in: CMLRev (1999) pp.1027-1042. Until further clarification by the Court uncertainty about the precise meaning and scope of Article 9 and the degree to which the principles developed under Article 12 can be applied to Article 9, will remain. For instance, Article 9 only speaks of Turkish children, whilst Article 12 of Regulation No $1612 / 68$ seems to apply to all children regardless of their nationality. Does this imply that children of Turkish workers who do not have Turkish nationality cannot rely on Article 9? Further, the text of Article 9 suggests that children must not only reside in the host State's territory but also be living with their parents. Does this mean that they must live under the same roof? Compare Martin/Guild (1996) supra footnote 176, at 13.74.

237. Case C-210/97 Akman [1998] ECR I-7519 at 41 and Peers (1999) supra footnote 236, at p. 1040 .

238. See Martin/Guild (1996) supra footnote 176, at 13.72 and Wapenaar (1997) supra footnote 196, at p.157.

239. The wording of Article 9 was intended to avoid the Court's interpretation of the previously mentioned phrase in Article 12 encompassing a right to equal treatment as regard study grants being extended to Turkish children covered by Decision No 1/80. See Peers, Towards Equality: Actual and Potential Rights of Third-Country Nationals in the European Union, in: CMLRev (1996) pp.7-50, at p.27. Further, the second sentence of Article 9 stipulates that Turkish children may be eligible to benefit from the advantages provided for by the legislation in the field of education in the host State. The use of the word "may" suggests that the provision does not have direct effect.

240. On this decision see in particular Chapter 3 Section 7.3 
concluded that the equal treatment provision contained in Article 3(1) of Decision No $3 / 80$ can be directly relied upon in court by Turkish workers claiming family allowances. ${ }^{241}$

\section{$7 \quad$ Conclusions}

Community law on cross-border access to education has come a long way. The legal status of third country nationals in the field of education is fragmented and generally not very well developed, but as regards Community citizens considerable progress has been made. Today, all the categories of Community citizens whose legal status has been discussed in this Chapter enjoy quite extensive rights in the field of education. Community workers and their (dependent) family members have a virtually unlimited right to equal treatment in educational matters. They are to be admitted to any educational institution and they can claim study grants under the same conditions as nationals of the host State, even in relation to studies outside that State's territory. The legal status of the category of non-economic residents (i.e., for purposes of this Chapter, pensioners and the residual class of Community citizens covered by Directive No 90/364) has so far not been clearly defined, but they do seem to have the right to gain access to all forms of education in the host State and a right to claim

241. Case C-262/96 Sürül [1999] ECR I-0000 at 74. Thus, at the present stage of Community law, the legal status of Turkish nationals in the field of education is not well developed, but the possibility cannot be excluded that improvements will be made in future years. In particular, Article 9 of the 1963 Assocation Agreement, which contains a general nondiscrimination clause comparable to Article 12(1) EC, could provide a weapon for Turkish nationals who wish to challenge national rules denying them educational rights. In Sürül (1999), a social security case discussed in Chapter 3 Section 7.3, Advocate General La Pergola concluded that this provision has direct effect. The Court refrained from clarifying the legal status and scope of Article 9. It answered the preliminary questions on the basis of the equal treatment provision of Article 3 of social security Decision No 3/80 which was referred to as the "implementation and the concrete expression, in the particular field of social security, of the general principle of non-discrimination laid down in Article 9" of the 1963 Agreement. Case C-262/96 Sürül [1999] ECR I-0000 at 64. These observations of the Court show resemblances with its case law on Article $12 \mathrm{EC}$ which has proved to be a lucrative legal source for Community citizens. If, as one may assume, Article 9 indeed has direct effect, Turkish nationals may be able to claim additional educational rights. In the absence of a common EC-Turkey policy in the field of education and vocational training, it does not seem likely that the Gravier case law can by means of analogy be extended to Turkish students (Peers (1996) supra footnote 236, at p.27), but Article 9 could possibly be relevant to Turkish workers and their family members who wish to claim educational rights including study grants (Peers, Social Security Equality for Turkish Nationals, in: ELRev (1999) pp.627-637, at p.635). 
study grants there. In addition, all Community citizens have a right to go to other Member States in order to take up studies and to claim study grants there in as far as these cover tuition and/or enrolment fees. The Court of Justice, the main initiator of the extension of cross-border educational rights, however, cannot be accused of having ignored the educational and financial interests of the Member States. In particular, the Court has wished to avoid the admission of non-nationals, and nonresidents in particular, affecting study grant schemes and educational systems. First, the Court has denied Community students a right to claim study grants in the State where they study in as far as these cover the costs of maintenance. Second, by making the status of Community worker conditional upon the requirement of "effective and genuine work", the Court has put a threshold for Community students who, through the pursuit of small jobs, may try to obtain the status of worker and to claim, in this capacity, "full" study grants.

The Court has sought to reconcile the potentially conflicting interests of promoting freedom of movement and the need to safeguard Member States' educational interests, but the compromise it has reached, is not undisputed. This particularly holds true for the rules governing the rights of Community students. As concluded in Section 4.11 , it is claimed that Community law and policy does not give sufficient regard to the fact that some Member States receive far more students than they "send" abroad. In one way or another, these States ought to be compensated for the burden imposed on them. It is also argued, however, that there are still too many obstacles to the cross-border access to education. Due to problems concerning the recognition of their diplomas, insufficient knowledge of foreign languages and/or a lack of sufficient student financial aid, many Community citizens are still in practice unable to take up a course of study in other Member States. In Section 9 some observations will be made as to whether, and if so, how, this conflict can be settled more satisfactorily. Before doing so, however, this Chapter proceeds with an analysis of American constitutional law on cross-border access to public education. To what extent are United States' citizens entitled to move and to gain access to public education in other States? To what extent are the American States entitled to protect themselves against "educational tourism"? What lessons can the European Community possibly learn from the American experience? 
As in the European Community, education is highly valued in the United States. In the words of the American Supreme Court, education is to be regarded as a prerequisite for individuals' effective participation in political, cultural and economic life $\mathrm{e}^{242}$ and it has played a "fundamental role in maintaining the fabric"243 of American society. The importance attached to education has resulted in a vast and diverse educational system in which governments at local, State and Federal level as well as private institutions play a role in the delivery, organisation and/or funding of education. The public education system, to which this Section is limited, is essentially local in character. The role of the Federal government is limited. Education is primarily a matter for individual States and the systems of each of the States are characterised by a high degree of decentralisation. In the area of higher education individual colleges and universities enjoy considerable autonomy. Government influence on the organisation of the institutions, admission policies and educational programmes is, by comparison with most European educational systems, minimal. Colleges and universities are mainly funded out of the States' budgets and, to a lesser extent, federal funds and tuition fees. In the fields of primary and secondary education, States are divided in school districts which are mandated to implement the States' educational policies. In fulfilling this task the districts enjoy considerable freedom. They control the operation and the management of the schools, often have an important say in the substance of the educational programme offered and they are responsible for a big part of the funding of the institutions. Often, the districts have own taxing powers. The revenue from taxes (on property) covers about $50 \%$ of the funding of education; the remaining parts are funded from the States' $(40 \%)$ and the federal $(10 \%)$ budget.

The local funding of the public school system has resulted in large differences in the amount of money spent per pupil/student. Consequently, the quality of schools in the different districts varies. Constitutional law does not object to these differences. In San Antonio Independent School District $v$ Rodriguez (1973) the Court was asked on behalf of a number of children living in "poor districts" to rule upon the constitutionality of

242. Brown v Board of Education, 347 US 483 (1954) at 493. 243. Plyler $v$ Doe, 457 US $202(1982)$ at 221. 
Texas' school funding system which was largely based on local property taxes. The Supreme Court showed deference vis-á-vis the State legislatures. According to the Court, the case involved "difficult questions of educational policy", an area "in which this Court's lack of specialised knowledge and experience counsels against premature interference with the informed judgments made at the state and local levels". ${ }^{244}$ The Court refused to class "wealth" as a suspect classification and did not recognise education as a fundamental right for equal protection purposes. The Court did not apply strict or intermediate scrutiny. It limited itself to rational relation review and concluded that the Texas system was not "so irrational as to be invidiously discriminatory". ${ }^{245}$

Governments at various levels, companies, trade unions as well as educational institutions themselves have often established study grant or loan programmes in order to facilitate admission to higher education. The scope of these programmes is generally rather limited, however. Eligibility is often reserved for certain categories of students and most of the grant or loan programmes cover only part of the study cost. The cost of maintenance are in principle to be borne by the students themselves who may have to take out private loans. Universally accessible public student financial aid systems comparable to the ones which have been developed in some European countries, do not appear to exist in the United States. $^{246}$

\subsection{Conditions of Access}

The disparity among the educational systems of the various States may provide an incentive for students to move to and to study in other States.

244. San Antonio Independent School District v Rodriguez, 411 US 1 (1973) at 42.

245. On Rodriguez and "territorial" discrimination see e.g. Neuman, Territorial Discrimination, Equal Protection and Self-Determination, in: UPennLRev (1987) pp.261-382. Compare also Kadrmas (188) in which the Court held that there was no fundamental right to education which could trigger strict scrutiny and that the denial of free transportation to public schools to "poor" children was not so arbitrary or invidious as to violate the Equal Protection Clause. Kadrmas v Dickinson Public Schools; 487 US 450 (1988).

246. For this reason as well as the fact that there have been any relevant cases before the Supreme Court, this Section does not discuss questions concerning student financial aid. For (limited) information on student financial aid schemes in the United States see Oijen et al (1990) supra footnote 15, at pp.21-22 and 28. 
States have been aware of this. In their admission policies ${ }^{247}$ they have built in safeguards intended to protect the funding and organisation of educational systems against the consequences of a possible large influx of pupils or students from other States. The measures for safeguarding access to primary and secondary education, on the one hand, and higher education, on the other hand, differ.

Admission to primary and secondary education has in many cases been made conditional upon residence in the school-district; non-resident pupils have been denied admission. Children are only entitled to go to school in the district (and thus the State) where they live and where their parents can be required to pay property taxes. Generally, parents who wish to send their children to schools in another district (or State) can only do so by moving to that district themselves. Children who leave their parents' house in order to go to school in another district (and who live with family members, friends .. etc) are in most States/districts treated as non-residents who, in principle, can be denied access. In some States or districts cross-border admission policies are less strict. Non-residents are admitted to schools but on condition that they pay an additional tuition fee.

Such non-resident tuition fees are much more common in the field of higher education. States have allowed non-residents admission to their colleges and universities, ${ }^{248}$ but they have all imposed on non-residents a duty to pay additional tuition fees. The argument for imposing differential tuition fees on residents and non-residents runs as follows. Residents pay taxes to the State and thus contribute indirectly to the funding of public education. Since non-residents do not contribute equally, States require non-residents to pay their "equal share" by charging them higher tuition fees. Differential tuition policies enable States to distribute the cost of operating and supporting educational institutions more evenly among

\footnotetext{
247. In practice, the variety of admission policies is enormous. Often, it is not the States but the universities, colleges or school districts which establish the conditions of access. For an overview of the policies governing admission to higher education, see further Hellmuth, Residency for Tuition Purposes: A Study of the Rules in Use at the Fifty State Universities (1981). The description of the conditions of access to public education is necessarily oversimplified and merely discusses the main and most common principles on which admission policies are based. For purposes of convenience, this Section will simply speak of the States' conditions of access.

248. To be sure, some States have occasionally limited the percentage of the total student body which may consist of non-residents. Note, the Constitutionality of Nonresident Tuition, in: MinnLRev (1971) pp.1139-1162, at p.1150.
} 
resident and non-resident students. ${ }^{249}$ This so-called cost-equalisation argument is not based on the contributions paid during the period of the studies. The economic status of resident and non-resident students is, during this period, more or less the same. The argument relates to the situation before and after the course of study. Prior to studying, nonresident students have not resided in the State and they are more likely to leave after graduation. Prior to stuyding, they (or their parents) have not paid taxes to the State to the same degree as residents have and more so than residents, non-residents are likely to "use" their education in other States. The higher tuition fees to be paid by non-residents compensates the States for the fact that they often do not receive the benefits of the investment they have made in educating non-residents.

For tuition purposes, States do not apply the traditional definition of residence. If they did, differential tuition policies would be ineffective. Residence normally requires physical presence within the State plus an intention to stay there for at least a certain period of time. ${ }^{250}$ If States were to apply this concept for tuition purposes, they could only collect higher tuition fees from the relatively small group of "real" non-resident students, i.e. the students who continue to live in another State during their studies. Even the students who have merely come to the State for educational purposes and who will leave upon graduation, would have to be classed as residents and be admitted at the lower in-state tuition rate. Such "free-riding students" are strictly speaking residents of the States and for many governmental purposes they are indeed treated as such. They have the right to vote, to register their car, etc. From the perspective of tuition policy, however, they are viewed as "educational tourists" who should pay their "equal share" in the funding of public education by paying higher tuition. For tuition purposes, States define residents as all students who prior to enrolment have resided or been domiciled in the State for a minimum period of time (usually one year). This definition implies that higher out-of-State tuition fees are not only to be paid by the "real" non-residents and "free-riders". They are also to be paid by students who have primarily come to the State in order to work, to live with their spouses or parents and students who initially came for educational purposes but who have later decided to live and work in the State after graduation. The cost-equalisation argument does not apply to these so-called bona fide residents in the same way as it does to the "real" non-resident

249. Note, The Constitutionality of Nonresident Tuition (1971) supra previous footnote, at p. 1147.

250. See Chapter 2 Section 8.3 . 
and free-riding students. States claim, however, that the one-year residence requirement serves as a test of bona fide residency. One-year of residence in the State would give an indication as to the motives of students for coming to the State. From students who prior to enrolment have resided in the State for more than a year, it can be assumed that they are bona fide residents. Student who do not satisfy the durational residence requirement are likely to be "free-riders". Occasionally, some States have held the classification as non-residents at the moment of enrolment to be conclusive for the entire duration of the studies. Most States, however, have allowed recently arrived students to ask for a re-classification. Students are given the opportunity to demonstrate that they are or have become bona fide residents (or domiciliaries) of the State. They can submit employment contracts, evidence of registration as a voter of the State, registration of a car in the State, etc. or any other means of evidence which can demonstrate "domiciliary intent". Students who are able to demonstrate such intent can be re-classified; students who cannot do so, retain the status of non-resident. Students are, however, only entitled to rebut the presumption of non-residence after one year. This one-year postponement has been defended by States on the ground that recently arrived bona fide resident-students have, prior to studying, not paid taxes to the same extent as long-term residents (past-contributions-argument). ${ }^{251}$ Furthermore, the one-year postponement rule has been said to avoid the administrative burden and cost caused by re-classification procedures on behalf of whose claims are, at the outset, unfounded.

In sum, States have traditionally imposed a duty to pay the higher out-of-state tuition fees on (i) the real non-resident students, (ii) freeriding students and (iii) bona fide residents who have not resided in the State in the year prior to their studies. The first two categories usually have to pay the higher tuition fees throughout the course of their studies; the latter category can, upon proof of "domicilary intent", become eligible for in-state tuition one year after their arrival in the State.

251. The past-tax-contributions-argument explains why States generally impose durational residence requirement of one year. Taxes are payable annually and the payment of taxes was thought to prove that a person was living in the State for other purposes than "securing advantages" from other taxpayers. Masters, Comment - Nonresident Tuition Charged By State Universities in Review, in: UMKCLRev (1970) pp.341-354, at pp.343-344 (quoting Bryan $v$ Regents of University of California, 188 Cal.559, 205 P.1071 (1922)). 


\subsection{Non-Residents}

\subsubsection{Higher Education}

Differential tuition policies for admission to higher education have never been controversial. The practice of charging non-residents higher tuition is so common and widely accepted that the Supreme Court has not once been confronted with a case in which tuition residence requirements were challenged. The case law of the Court does indicate, however, that tuition residence requirements are constitutional. In Vlandis $v$ Kline (1973), a case which will be discussed in further detail in Section 8.4, the Court held that "a State has a legitimate interest in protecting and preserving the quality of its colleges and universities and the right of its bona fide residents to attend such institutions on a preferential tuition basis". The Court added that a State does not have to class "students in its university system as residents, for purposes of tuition and fees, just because they go to school there". ${ }^{252}$ More specifically, the Supreme Court has allowed States to apply the concept of domicile for tuition purposes which has been defined as an individual's "true, fixed and permanent home and place of habitation". It "is the place to which, whenever, he is absent, he has the intention of returning". ${ }^{253}$ In the more recent case Saenz $v$ Roe (1999) the Court indicated that by requiring non-residents to pay additional tuition fees, States do not violate the Privileges and Immunities Clause of Article IV $\S 2$ of the Constitution. ${ }^{254}$ In Saenz the Court rejected the view that States could impose durational residence requirements for welfare benefits. One of the reasons given by the Court was that welfare benefits are consumed in the State itself and there was no danger that citizens of other States would come and establish residence "in order to acquire some readily portable benefit, such as .. a college education, that will be enjoyed after they return to their original domicile"

252. Vlandis $v$ Kline, 412 US 441 (1973) at 452.

253. Ibid, at 454 . The concept of domicile is, as the Court itself admitted, not always easy to apply in individual cases. Students must demonstrate "something" which shows that they are more than just "educational tourists", but the Court has never precisely indicated what this "something" should entail. The Court has merely given some criteria which may be considered in individual cases. These include year-round residence, voter registration, place of completing tax returns, property ownership, driver's licence, car registration, marital status, vacation employment, etc. Vlandis $v$ Kline, 412 US 441 (1973) at 454. The Court thus leaves the States considerable discretion in determining whether or not a student has acquired domicile status.

254. On the Privileges and Immunities Clause see further Chapter 2 Section 8.6.1 
(ital: APvdM). ${ }^{255}$ Tuition residence requirements for admission to higher education, and as one may safely assume primary and secondary education, are thus valid. As brief as they may be, the above observations suggest that the cost-equalisation argument, the only justification offered by the States for charging non-residents higher tuition, has been accepted by the Supreme Court. ${ }^{256}$

\subsubsection{Primary and Secondary Education}

In the field of primary and secondary education, residence requirements have more often been applied as a condition for admission. Non-residents have been denied admission altogether. At first glance, there does not seem to be a real need for such exclusions. The States' ability to maintain the quality of their primary and secondary schools is not likely to be affected by the admission of non-residents. As may be assumed, the interState mobility of pupils is relatively low. As a rule, pupils live with their parents and, usually, it is not the education of the children but rather the employment opportunities of the parents which will determine where the familiy will move to and live. Even if families move for educational reasons, this does not seem to pose a real "problem" because, by paying taxes, the parents contribute to the funding of the schools. Saenz (1999) further indicates that State statutes governing access to education are "fundamental" for the purposes of the Privileges and Immunities Clause. In principle, States will have to demonstrate that they have a substantial reason for excluding non-residents and that there are no less restrictive means for securing their educational interests. If, however, States can maintain the quality of their higher educational institutions by charging non-residents higher tuition fees, why would they not be able to do so in the field of primary and secondary education?

\footnotetext{
255. Saenz v Roe, 119 S.Ct 1518 (1999). On Saenz see in particular Chapter 3 Section 9.4.4. 256. Compare also Reeves, Inc. v State (1980) in which the Court was asked to rule upon the constitutionality of the refusal of South Dakota to sell to non-residents cement produced by a public plant. In reaching the conclusion that the refusal to sell to non-residents was constitutional the Court observed: "The State's refusal to sell to buyers other than South Dakotans is 'protectionist' only in the sense that it limits benefits generated by a state program to those who fund the state treasury and whom the States was created to serve. Petitioners' argument apparently also would characterize as protectionist' rules restricting to state residents the enjoyment of state educational institutions .. police and fire protection .. Such policies, while perhaps 'protectionistic' in a loose sense, reflect the essential and patently unobjectionable purpose of state government - to serve the citizens of the state" (ital: APvdM). Reeves, Inc. v State, 447 US 429 (1980) at 443.
} 
Nonetheless, the judgment in Martinez $v$ Bynum $^{257}$ (1982) indicates that States are constitutionally permitted to deny residents of other States admission to public schools. The case concerned an 8 year old United States citizen, Roberto Morales, who had moved from Mexico to Texas where he lived with his sister. Roberto was a true free-rider. His sole motive for coming to Texas was to attend school there and he was planning on returning to Mexico after finishing his education. Roberto was denied free-tuition admission to the schools in Texas. A Texas Code provided that free-tuition admission to public schools was granted to all children who lived within the school district except for those minors who lived apart from their parents and who were merely staying in Texas in order to go to school there. In reviewing the Texas Code, the Supreme Court held that States may "of course" require children to reside in the school district before admitting them to public schools. ${ }^{258} \mathrm{~A}$ residence requirement:

"furthers the substantial state interest in assuring that services provided for residents are enjoyed only by residents. Such a requirement with respect to attendance at public free schools does not violate the Equal Protection Clause of the Fourteenth Amendment. ... It does not burden or penalize the constitutional right to travel, ... for any person is free to move to a State and establish residence there. A bona fide residence requirement simply requires that the person does establish residence before demanding the services that are restricted to residents". ${ }^{259}$

There was, according to the Court, a further, independent justification for local residence requirements in the public-school context. The provision of primary and secondary education is one of the most important functions of local governments. In the absence of residence requirements there was "little doubt that the proper planning and operation of the schools would suffer significantly ... The State thus has a substantial interest in imposing bona fide residence requirements to maintain the quality of public schools". ${ }^{260}$

257. Martinez v Bynum, 461 US 321 (1982).

258. Ibid, at 329

259. Ibid, at 328-329.

260. Ibid, at 329-330. In a footnote the Court added that invalidating residence requirements "would cause substantial numbers of inter-district transfers, which would ... cause schools populations to fluctuate. .. Fluctuating school populations would make it impossible to predict enrollment figures- even on a semester-by-semester basis, causing over-or-underestimates on teachers, supplies, materials, etc. .. The increased enrollment of students would cause overcrowded classrooms and related facilities; over-large teacher-pupil ratios; expansions of bilangual programs; the purchase of books, equipment, supplies and other customary items for support; all of which would require a substantial increase in the budget of the 
States are thus indeed entitled to deny children from other States admission to their public schools. The Court merely subjected residence requirements for admission to public schools to the rational relation test of the Equal Protection Clause, but remained wholly silent on the Privileges and Immunities Clause. Why? The reason, it seems, is that the provision in question of the Texas Code did not contain a requirement of residence in the State but a requirement of residence in the school district. Texas residents who resided in another district were equally denied admission. In other words, the Code did not discriminate between State-residents and residents of other States, but merely between residents of the school district and residents of other districts. In Martinez the Court was primarily concerned with the consequences of the invalidation of these residence-inthe-district requirements. The invalidation of the residence requirements in question was not likely to cause a huge increase in the inter-State movement of pupils, but could have triggered an increased inter-district movement of pupils within the State. The distance between childrens' homes and other school districts will often be relatively short and children can return home every evening. Many parents might choose to send their children to "better" schools in other districts. In the absence of residencein-the-district-requirements the inter-district movement of pupils within the State could be considerable and the "proper planning and operation of the schools" might be affected. Basically, in Martinez the Court upheld residence-in-the State requirements as constitutional because it did not wish to invalidate residence-in-the-district requirements.

school districts". Martinez v Bynum, 461 US 321 (1982) footnote 9 at 329. The Court did not wish to suggest that "findings of this degree of specifity are necessary in every case" but they would "illustrate the problems that prompt States to adopt regulations" such as the one contained in the Texas Code.

The only question left, then, was whether "free-riding" children, like Roberto Morales, were to be classed as residents for educational purposes. The Court held that States are under no obligation to do so. In order to reach this conclusion the Court did not, as it had done in the field of higher education (see Section 8.3.1), rely on the concept of domicile. Instead, the Court gave a somewhat stricter definition of the term residence than the classic definition of the term. A State may not only require a pupil to be physically present in the State and to have the intention to stay there for at least some time; a State may also demand from pupils a "present intention to remain" in the State. Pupils (or their parents) must not have any concrete plans to leave the State. Free-riders do not meet this standard. They already plan to leave the State after finishing school and thus, as nonresidents, they can be denied admission to public schools. The Court itself claimed that the definition it gave of the term residence was the classic definition. This was hard to understand, however. In previous cases the Court had never indicated that an "intention to remain" was an essential component of the residence definition. See Martinez v Bynum, 461 US 321 (1982) at 339-341 (Marshall, dissenting). 


\subsection{Residents}

The target group of higher out-of-state tuition fees consists of "real" and "free-riding" non-resident students. Yet, the so-called bona fide residents also have to pay the non-resident tuition if they have not resided in the State for at least one year prior to commencement of the studies. Up until the late $1960 \mathrm{~s}$, the constitutionality of tuition waiting-periods was beyond doubt. Courts merely employed rational relation scrutiny and considered the waiting-periods to be reasonably related to the legitimate purposes of cost-equalisation and "proof of domiciliary intent". ${ }^{261}$ The Supreme Court decision in Shapiro v Thompson (1969), however, cast doubt on the validity of tuition waiting-periods. In that decision the Court invalidated waiting-period requirements for welfare benefits under the Equal Protection Clause by holding that "any classification which serves to penalize the exercise" of the fundamental right to travel is, "unless shown to be necessary to promote a compelling State interest, unconstitutional". ${ }^{262}$ Even though the Court had explicitly stated in Shapiro that the decision did not imply a view as to the validity of tuition waiting-periods, ${ }^{263}$ it could have been, and it indeed was, ${ }^{264}$ argued that such requirements were no longer permissible. Tuition waiting-period requirements deny "new" residents the right to be admitted at the lower in-State tuition fee rate. The requirements thus seemed to penalise the right to travel with the result that they were to be scrutinised under the virtually insurmountable "compelling State interest test". Further, it seemed that the Court had not left any room for the traditional justification grounds for tuition waitingperiods. In particular, in Shapiro the Court had held that States cannot apportion state services among citizens according to past tax contributions $^{265}$ and that one-year waiting-period requirements cannot be justified as an "efficient rule of thumb" for determining the residence of those who have moved to other States. ${ }^{266}$

261. See Parent, Tuition Residence Requirements: A Second Look in Light of Zobel and Martinez, in: IndLJ (1986) pp.287-314, at pp.291-293; Note (1971) supra footnote 249, at p.1147 and p.1153 and Segal, Residency, Tuition and the Twelve Month Dilemma, in: HousLRev (1969) pp.241-256, at pp.249-251.

262. Shapiro v Thompson, 394 US $618(1969)$ at 634.

263. Ibid, at 638 (footnote 21).

264. Note, Residence Requirements for Tuition: An Unresolved Dilemma, in: IndLRev (1972) pp.283 et seq and Masters (1970) supra footnote 251, at pp.341 et seq.

265. Shapiro $v$ Thompson, 394 US 618 (1969) at 632-633.

266. Ibid, at 636-637. 
In spite of their apparent strength, the above arguments have not been seen as persuasive on the Supreme Court. Shortly after Shapiro the Court summarily affirmed ${ }^{267}$ the decision of a California Court in Kirk $v$ Board of Regents (1969) ${ }^{268}$ in which tuition waiting period requirements had been upheld. Kirk involved an Ohio resident who had moved to California in order to live with the husband that she had recently married. Three months after arrival, she enrolled in a State university where she was classified as a non-resident for tuition purposes. A State statute provided that the resident status for tuition purposes could only be acquired by students who had been bona fide residents of California for more than one year before the opening of a semester. Ms Kirk challenged the one-year waiting-period in court thereby mainly relying on Shapiro. The California court, however, was not willing to invalidate the tuition waiting-period and it took pains to explain why Shapiro's penalty analysis did not have to be applied in tuition cases. The Court stated that a tuition waiting-period did not have a deterrent effect on the right to travel. Persons such as Ms Kirk, who came to the State in order to accompany their spouses, would not take into consideration that they might have to pay higher tuition fees and the Court considered it to be absurd that a person would marry a resident of the State in order to obtain one year of higher education at a lower cost. Furthermore, the court in Kirk recognised the value of higher education, but it considered it not as important as welfare. Unlike welfare, education was not a "basic necessity of life" the denial of which "could cause great suffering and even loss of life". In the California court's view, the requirements underchallenge did not constitute a penalty on the right to travel; the requirements were not subject to strict scrutiny. In applying the less demanding rational relation test, the court in Kirk accepted cost-equalisation as a justification-ground for the tuition waiting-period. California:

"has a valid interest in providing tuition free education to those who have demonstrated by a year's residence a bona fide intention of remaining here and who, by reason of that education will be prepared to make a greater contribution to the state's economy and future. Accordingly, we hold that the regulation classifying students as residents and non-residents for tuition purposes is not arbitrary or unreasonable and bears a rational relation to California's objective and purpose of financing, operating and maintaining its many publicly financed educational institutions ..". 269

267. Summary affirmance implies that the Supreme Court, without writing a full opinion itself, agrees with a lower court in the result. Zobel $v$ Williams, 457 US 55 (1982) at 64 (footnote 13).

268. Kirk v Board of Regents, 78 Cal.Rptr.260 (1969).

269. Ibid, at 269 . 
The fact that the decision in Kirk has been summarily affirmed indicates that also in the view of the Supreme Court tuition waiting-periods were valid. Summary affirmance, however, does not necessarily imply that the Supreme Court also agrees with the lower court's reasons for its decisions. $^{270}$ It seems very unlikely that the Supreme Court would have approved of the California court's reasoning. In support of the view that strict scrutiny did not have to be applied, the California court placed emphasis on the deterrent effect of tuition waiting periods on the exercise of the right to travel. It was implicit in Shapiro, however, and this was explicitly confirmed by the Court in Dunn $v$ Blumstein $(1972,)^{271}$ that the degree to which travel is actually discouraged is irrelevant for equal protection analysis. In Dunn the Court spoke in this regard of "a fundamental misunderstanding of the law". Furthermore, the court in Kirk held that strict scrutiny did not have to be applied because education could not constitute a "basic necessity of life". In Shapiro the Supreme Court had not given any indication, however, that the importance of a given benefit or right would be decisive for the test to be applied under the Equal Protection Clause. ${ }^{272}$

Thus, Kirk indicated that tuition waiting-periods are valid, but the case left uncertain why this should be the case. ${ }^{273}$ Three years later,

270. Zobel v Williams, 457 US 55 (1982) at 64 (footnote 13).

271. Dunn v Blumstein, 405 US 330 (1972).

272. Furthermore, it does not seem very likely that the Supreme Court agreed with the California court's response to the argument that the one-year waiting-period requirement would constitute an irrebuttable presumption of non-residence. The latter court had rejected the argument by holding that a "student from another State .. is classified as a nonresident because he is presumed to be in California primarily for educational purposes. If appropriate facts and circumstances arise subsequent to a student's classification as a nonresident, there is nothing in the regulation that would prevent petitioner's reclassification as a resident". Ibid, at 268-269. The view that the presumption of nonresidency was rebuttable only seemed correct, however, in as far as students had been bona fide residents for one year. During the waiting-period the presumption of non-residence was clearly irrebuttable. Further, the California court had suggested that the cost-equalisation-argument was invalid under the compelling state interest test, but that the argument would be valid under the rational relation test. In Shapiro, however, the Court had made no distinction between the two tests and it had held the past contribution rationale to be constitutionally impermissible per se. Shapiro $v$ Thompson, 394 US 618 (1969) at 632-633.

273. After Kirk the Court also summarily affirmed two other decisions of lower courts which had upheld tuition waiting-period requirements. See Starns v Malkerson, 326 F.Supp.234 (D.Minn.1970) aff'd mem., 401 US 985 (1971) and Sturgis v Washington, (368 F.Supp.38 (W.D.Wash.1973). There is no need to discuss these decisions here in further detail because both courts followed the same line of reasoning as court in Kirk. On Sturgis see Note, Durational Residence Requirements From Shapiro through Sosna: The Right to Travel Takes a New Turn, in: NYULRev (1979) pp.622 et seq., atpp.652-653. On Starns see Note, State 
however, the Supreme Court did give a full opinion in Vlandis $v$ Kline $(1973)^{274}$ in which it attempted to give some clarification as to why, in its view, tuition waiting-periods were constitutional. Vlandis concerned two students who upon application for admission to the university were classed as non-residents for tuition purposes. The students attacked a section of the statute which read: "The status of a student, as established at the time of his application for admission ... shall be his status for the entire period" of the studies (ital: APvdM). The students attacked the conclusiveness of the initial classification as nonresidents for the rest of the studies. They claimed to have a constitutional right to controvert the presumption of nonresidence by presenting evidence that they are, or have become, bona fide residents of the State. The Court held that the conclusive presumption of non-residence was indeed unconstitutional. Standards of due process, the Court said, require that States allow an individual the opportunity to present evidence showing that he is a bona fide resident entitled to in-state rates. ${ }^{275}$

Vlandis itself did not concern tuition waiting-periods and the case was decided under the Due Process Clause. The Court stated, however, that it was well aware of the special problems involved in determining the bona fide residence of students who come from out of State to attend public education. Its holding should:

"in no wise be taken to mean that Connecticut must classify the students in its university system as residents, for purposes of tuition and fees, just because they go to school there. Nor should our decision be construed to deny a State the right to impose on a student, as one element in demonstrating bona fide residence, a reasonable durational residence requirement. (..) We fully recognize that a State has a legitimate interest in protecting and preserving the quality of its colleges and universities and the right of its bona fide residents to attend such institutions on a preferential tuition basis. (..) The State can establish such reasonable criteria for in-state status as to make virtually certain that students who are not, in fact, bona fide residents of the State, but who have come there solely for the educational purposes, cannot take advantage of the in-state rates". 276

University's One-Year Waiting Period Requirement to Attain Resident Status for Tuition Payment does not Violate Fourteenth Amendment, in: AlabLRev (1971) pp.147-162.

274. Vlandis $v$ Kline, 412 US 441 (1973).

275. Ibid, at 452 .

276. Ibid, at 452-454. In a footnote the Court explained why the provision challenged in Vlandis was to be distinguished from cases involving tuition waiting-period requirements. The latter type of requirements enable a student who was initially classed as non-resident for tuition purposes, to rebut the presumption of non-residence after one year by presenting evidence to show bona fide residence. In Vlandis, on the other hand, a student was prevented from ever rebutting the presumption of non-residence during their studies. Ibid, at 452 (footnote 9). 
Thus, waiting-period requirements could not be justified, as the California court in Kirk had held, on the basis of the "cost equalisation argument". In the view of the Supreme Court, this argument "would give rise to grave problems under the Equal Protection Clause"277. Vlandis shows that tuition waiting-periods are in the view of the Supreme Court constitutional only when, and is so far as, they serve as an objective test of bona fide residence or "domiciliary intent".

In later cases the Court has confirmed that ${ }^{278}$ tuition waitingperiods are constitutional, but, unfortunately, the Court has never given any additional reasons in support of this conclusion. ${ }^{279}$ This is indeed

277. Vlandis $v$ Kline, 412 US 441 (1973) at 450 (footnote 6).

278. See e.g. Zobel $v$ Williams, 457 US 55 (1982) at 64 (footnote 13 - holding that the oneyear tuition residence requirement is "a test of bona fide residence, not a return on prior contributions to the commonweal").

279. In Vlandis the Court had explained why tuition waiting-periods are constitutional, but it did not clarify how this conclusion fitted in Shapiro's penalty-on-the-right-to-travel analysis. One year after Vlandis, however, the Court did attempt to clarify the issue in Memorial Hospital v Maricopa County (1974). The case concerned durational residence requirements for non-emergency medical care. In support of the view that waiting-periods for medical care were to be subjected to the compelling State interest test the Court held that "whatever the ultimate parameters of the Shapiro penalty analysis" may be, "it is at least clear that medical care is as much a "basic necessity of life" to an indigent as welfare assistance". Memorial Hospital v Maricopa County, 415 US 250 (1974) at 259. As stated earlier, it seemed unlikely that the Supreme Court supported most of the reasoning of the California court, but the Supreme Court now did adopt the reasoning of the court in Kirk on this point. In support of its conclusion that waiting-periods for medical care did constitute a penalty, the Supreme Court made (in a footnote) reference to tuition waiting-periods and it quoted in full some observations of the court in Kirk: "While we fully recognize the value of higher education, we cannot equate its attainment with food, clothing and shelter. Shapiro involved the immediate and pressing need for preservation of life and health of persons unable to live without public assistance, and their dependent children. Thus, the requirement in Shapiro could cause great suffering and even loss of life. The durational residence requirement for attendance at publicly financed institutions of higher learning do not involve similar risks. Nor was petitioner precluded from the benefit of obtaining higher education. Charging higher tuition to non-resident students cannot be equated with the granting of basic subsistence to one class of needy residents while denying it to an equally needy class of residents". Ibid, at 260 (footnote 15). Vlandis and Memorial Hospital, read together, thus implied that tuition waiting-periods do not violate the Equal Protection Clause because it was in the view of the Supreme Court not wholly irrational to require from students, who have not yet resided for a minimum period of time in the State concerned, to demonstrate that they are bona fide residents rather than free-riding students who have merely come to the State for educational purposes.

This conclusion, however, no longer seems very relevant. Quite recently, the Court has abandoned Shapiro's penalty-on-the-right-to-travel analysis in Saenz v Roe (119 S.Ct. 1518 (1999)). The constitutionality of durational residence requirements is now to be judged under the Privileges or Immunities Clause of the Fourteenth Amendment. The precise 
unfortunate because the "bona fide residence explanation" is hard to grasp. The Court has never held much more than that States should have the possibility of ascertaining for themselves that free-riding students do not "dress up" as bona fide residents in order to become entitled to the lower in-State tuition fees and that States may encounter "special problems" in determining the bona fide residence status of students. These observations merely explain why students who have not resided in the State concerned for one year prior to commencing their studies may be presumed to be free-riders. The non-fulfillment of this one-year residence rule, however, is not the real reason why "new" bona fide residents are temporarily denied the benefit of lower resident tuition fees. This benefit is denied because newly arrived bona fide residents can only rebut the presumption of non-residency after one year of residence within the State. It is this second durational residence requirement which temporarily withholds from bona fide residents the benefit of lower in-state tuition fees and which constitutes in fact the tuition waiting-period. Why should not all students have the opportunity to demonstrate "domicilary intent" directly upon arrival or at any other moment they may choose? The answer to the question whether students are free-riders or bona fide residents ultimately depends on their subjective intent and does not seem in any rational way related to the time at which students are given the opportunity to demonstrate their true intentions.

\subsection{Aliens}

Constitutional law on cross-border access to public education, as examined so far, applies in principle equally to aliens. Aliens can be required to pay the higher out-of-state tuition fees when they have not resided in the State for at least one year and for as long as they have not established domicile in the State. Alien children can only go to school in the State where they, together with their parents, reside. This sub-Section explores

\footnotetext{
countours of the test to be applied under this Clause are still far from clear. The Court did not say much more than that the appropriate standard of review to be applied may be more categorical than the one applied in Shapiro but that the test would surely be no less strict. See further Chapter 2 Section 8.5.2 and Chapter 3 Section 9.4.4. Saenz itself concerned welfare waiting-period requirements, but the decision does indicate that the new legal framework for reviewing durational residence requirements has not altered the Court's view on the constitutionality of tuition waiting-periods. More than once the Court referred to Vlandis and it suggested that the "bona fide residence argument" still stands.
} 
the constitutionality of alienage classifications in the field of education. ${ }^{280}$ Do States have to grant aliens access to public education and, if so, under which conditions? Can States charge aliens higher tuition fees than United States citizens on the sole ground that they lack United States citizenship? The answers to such questions vary and depend on the immigration status of the alien and the level of the education.

\subsubsection{Permanent Residents}

Permanent resident aliens (or immigrants) are entitled to gain access to public education under exactly the same conditions as United States citizens. Illustrative is Nyquist $v$ Mauclet ${ }^{281}$ (1977). The case concerned a New York statute which barred resident aliens from State financial assistance for higher education. Resident aliens could only become eligible for such financial assistance once they had applied for United States citizenship. Two foreign students holding permanent residence status had applied for but were refused the assistance on the ground that they were not willing to relinguish their own nationality. In reviewing the New York statute, the Supreme Court, largely following its opinion in Graham v Richardson, ${ }^{282}$ held that State classifications based on alienage are "inherently suspect and subject to close judicial scrutiny". ${ }^{283}$ New York sought to justify the statute inter alia on the ground that its purpose was to enhance the educational level of the electorate. The Court held this to be an legitimate objective but said that the objective would hardly be frustrated by including resident aliens in financial assistance programmes.

280. On these classifications see Chapter 2 Section 8.7.

281. Nyquist v Mauclet, 432 US 1 (1977).

282. See Chapter 2 Section 8.5 .

283. Nyquist $v$ Mauclet, 432 US 1 (1977) at 7 . The Court rejected the argument that the New York statute was not based on alienage but would only distinguish within the heterogenous class of aliens. The Court concluded, as it had also done in Graham, that only aliens and not United States citizens were harmed by the statute and that the statute therefore did discriminate against aliens. Nyquist v Mauclet, 432 US 1 (1977) at 8-9. 
Resident aliens, the Court said, are:

"obligated to pay their full share of the taxes that support the assistance programmes. There is thus no real unfairness in allowing residents aliens an equal right to participate in programs to which they contribute on an equal basis. .. The State is surely not harmed by providing resident aliens the same educational opportunity it offers to others". ${ }^{284}$

In conclusion, the statute was held to violate the Equal Protection Clause. Nyquist was only concerned with student financial aid for higher education but the above observation puts beyond doubt that resident aliens enjoy the right to equal treatment in all educational matters. They are "full members of society" who contribute on the same basis to the funding of public education and who, as a result, can equally benefit from public education at whatever level. Alienage requirements which subject resident aliens to higher tuition fees than United States citizens or which deny them admission are unconstitutional.

\subsubsection{Non-Immigrants}

Non-immigrants may sometimes enjoy similar educational rights as immigrant aliens. The decision in Toll $v$ Moreno $^{285}$ (1982) shows that whenever the Federal immigration authorities (implicitly) indicate that aliens have be treated equally in educational matters, States have to act accordingly. Toll itself involved students holding a so-called "G-4 visa". This was a visa issued to employees of international organisations and their family members. G-4 visaholders were in principle non-immigrants who are generally not entitled to establish domicile in the United States. The Federal authorities had, however, made an exception for G-4 visaholders. Such persons were expressly granted the right to establish domicile. In addition, the Federal authorities had granted them important tax exemptions. The purpose of this federal policy was to induce international organisations to establish themselves and to operate in the United States. The students challenged the tuition policy of the University of Maryland. Only United States citizens and permanent resident aliens were entitled to

284. The Court also rejected the argument brought forward by the State of New York that the statute could be justified because it offered an incentive for aliens to become naturalised. Encouraging naturalisation is not a matter for the States because immigration and naturalisation are under the exclusive control of the Federal government. Nyquist v Mauclet, 432 US 1 (1977) at 10.

285. Toll v Moreno, 458 US 1 (1982). 
obtain residence status, whilst all non-immigrant aliens were ineligible for such status. The latter had to pay higher tuition fees. Maryland argued that the salaries of students' parents were exempt from Maryland's income tax and that the students had to pay their "equal share" to the funding of public education in the form of higher tuition fees. The Supreme Court rejected this view. The States could not recoup indirectly the taxes that the Federal government had expressly barred the States from collecting by requiring G-4 visaholders to pay the higher out-of-state tuition fees. ${ }^{286}$ As a general principle, the Court stated that "state regulation not congressionally sanctioned that discriminates against aliens lawfully admitted to the country is impermissible if it imposes additional burdens not contemplated by Congress". ${ }^{287}$ The Court could not conclude that Congress had ever contemplated that a State could charge G-4 visaholders higher tuition fees. ${ }^{288}$

Generally, however, federal immigration policy gives little guidance as to whether non-immigrants have to be treated equally in educational matters. Often, pre-emption analysis does not enable courts to decide upon alienage classifications in education cases. They will have to resort to equal protection analysis. ${ }^{289}$ In general, non-immigrants enjoy a less privileged status in educational matters than immigrants do. For tuition purposes States generally treat non-immigrants as non-residents who have to pay the higher out-of-state tuition fees. The decision in Elkins $v$ Moreno $^{290}$ (1978) suggests that they are indeed constitutionally entitled to do so. As in the case of Toll, Elkins involved non-immigrant students holding a G-4 visa who were suing the University of Maryland. The University classed the students as non-residents on the ground that holders of G-4 visas could not be regarded as, and could not demonstrate that they are, permanent residents. The Court did not agree. The Immigration and Nationality Act did not rule out the possibility that non-immigrants could adjust their status to that of permanent resident. The Court certified the case for decision by the State court arguing that the question whether G-4 visa holders can acquire domicile in a State was ultimately a matter of State law, not of Federal law. Even though the issue was not directly adressed in Elkins, the opinion of the Court did seem based on the assumption that unlike permanent residents, non-immigrants can be subjected to the higher out-of-State tuition fees.

286. Ibid, at 16 .

287. Ibid, at $12-13$

288. Ibid, at 17.

289. See Chapter 2 Section 8.7.3.

290. Elkins v Moreno, 435 US 647 (1978) 


\subsubsection{Undocumented Aliens}

In the field of primary and secondary education States have generally offered aliens' children the right to go to school in the district in which they reside. An exception, however, has occasionally been made for children of undocumented aliens. Children must be legal residents of the State, actual residence does not suffice. The constitutionality of such lawful residence requirements was considered by the Supreme Court in Plyler $v D_{0} e^{291}$ (1982). In this case the Court was asked whether the policy of Texas according to which undocumented school-age children were denied access to free public education, violated the Equal Protection Clause. Texas contended that it simply did not have to afford the same educational benefits to undocumented aliens as it does to legal residents. The denial of access would further the State's interest in preserving its limited resources for the education of its lawful residents. In reviewing the Texas statute the Supreme Court had no difficulty in concluding that undocumented aliens are entitled to the protection offered by the Equal Protection Clause. ${ }^{292}$ The Court did not apply strict scrutiny because undocumented children, because of their illegal status, could not be treated as a suspect class and because education, as the Court had already ruled in Rodriguez, does not constitute a fundamental right which is able to trigger strict scrutiny on its own. ${ }^{293}$ The Court, however, did not wish to limit itself to mere rational relation review because the case involved, on the one hand, undocumented children who could "affect neither their parents' conduct nor their own status" and, on the other hand, concerned

\footnotetext{
291. Plyler v Doe, 457 US 202 (1982). See further on Plyler e.g. Hull, Undocumented Alien Children and Free Public Education: An Analysis of Plyler v. Doe, in: UPittLRev (1983) pp. 431 et seq.

292. The Court held that "the protection of the Fourteenth Amendment extends to any one, citizen or stranger, who is subject to the laws of a State ... That a person's initial entry into a State, or into the United States, was unlawful .. cannot negate the simple fact of his presence within the State's perimeter .. Given such presence .. he is entitled to the equal protection of the laws that a State may choose to establish". Plyler v Doe, 457 US 202 (1982) at 215.

293. See Section 8.1.
} 
education which was not just "some" governmental benefit. The Texas statute, the Court said:

"imposes a lifetime hardship on a discrete class of children not accountable for their disabling status. The stigma of illiteracy will mark them for the rest of their lives. By denying these children a basic education, we deny them the ability to live within the structure of our civic institutions, and foreclose any realistic possibility that they will contribute in even the smallest way to the progress of our Nation". ${ }^{294}$

The court held that the Texas statute could only be upheld if shown to further a "substantial state interest". In response to the contention that a State like Texas would not owe the same duty to undocumented aliens as it does to legally admitted aliens, the Court said that it was in principle for the Federal authorities to determine the legal status of aliens within the country. The Court was reluctant though to:

"impute to Congress the intention to withhold from these children, for as long as they are present in this country through no fault of their own, access to a basic education .. and we perceive no national policy that supports the State in denying these children an elementary education. The State may borrow the federal classification. But to justify its use as a criterion for its own discriminatory policy, the State must demonstrate that the classification is reasonably adapted to the "purposes for which the state desires to use it". ${ }^{295}$

In answering the question whether the Texas policy furthered a substantial state interest, the Court said that a concern for the preservation of resources standing alone can hardly justify the classification used. Texas had to come with stronger justification grounds. One of the grounds that were asserted was that Texas was entitled to protect itself from an influx of illegal immigrants. The Court did not deny that States had, in spite of exclusive federal control of external borders, some power to deter the influx of illegal aliens in order to protect the States' economy or other traditional State interests. ${ }^{296}$ No evidence was found, however, that Texas' interests were affected. The dominant incentive for illegal entry was, as the Court said, the availability of employment. Only few, if any, illegal immigrants would come to Texas or the United States in order to gain access to education. Charging "tuition to undocumented children constitutes a ludicrously ineffectual attempt to stem the tide of illegal immigration". ${ }^{297}$ Secondly, Texas had suggested that the category of

294. Plyler v Doe, 457 US 202 (1982) at 223

295. Ibid, at 223 .

296. Ibid, at 228 (in particular footnote 23 )

297. Ibid, at 228 . 
illegal children would impose a burden on the State's ability to provide high quality public education. The Court responded that, even if access by some children affected the quality of the education that was provided, the State had to justify its selection of the group of illegal children as the appropriate target group for exclusion from schools. Texas could not do so because the Court said that, in terms of educational cost and need illegal children were "basically indistinguishable" from legally resident aliens. ${ }^{298}$ Lastly, Texas had suggested that undocumented children were less likely than other children to remain within the State and to put their education to productive social or political use within the State. The Court responded that, even if thought to be legitimate, such an interest was difficult to quantify. Apart from the fact that many of the illegal children were likely to remain within the State, the Court considered it to be clear that whatever savings might be achieved by denying illegal children an education, they are "wholly insubstantial in light of the cost involved to these children, the State, and the Nation". ${ }^{299}$ In conclusion, the Statute was held to be unconstitutional.

Children of illegal aliens thus have to be granted access to public primary and secondary education. It is doubtful whether a similar conclusion could be reached as regards illegal aliens' access to public higher education. In Plyler the Court said that "persuasive arguments support the view that a State may withhold its beneficence from those whose very presence within the United States is the product of their own unlawful conduct" and that "those who elect to enter our country by stealth and in violation of our law should be prepared to bear the consequences, including, but not limited to, deportation". ${ }^{300}$ Aliens who enter the United States illegally, can thus probably be denied access to public education. ${ }^{301}$

298. Ibid, at 230 .

299. Ibid, at 230 .

300. Ibid, at 219-220.

301. Recently, the legal status of undocumented aliens in the field of education again attracted considerable attention when Proposition 187 was passed in California. The Proposition denies undocumented aliens a variety of public benefits including public elementary and secondary education. The denial of access to public education is hard to compare with Plyler. See further Schuler, Equal Protection and the Undocumented Immigrant: California's Proposition 187, in: BostCTWLJ (1996) pp.275-312. 


\subsection{Conclusions}

The main rules and principles governing cross-border access to education within the United States have hardly altered in the course of the last decades. The Supreme Court has left the States' traditional admission policies largely untouched. In the field of higher education, States are still entitled to $(i)$ charge non-residents higher tuition fees, (ii) to class the category of so-called free-riders as non-residents for tuition purposes and (iii) to charge bona fide residents out-of-state tuition fees when they have not resided in the State for one year prior to their studies. The only limitations the Court has imposed on States are $(i)$ that bona fide residents must be given the opportunity to rebut the presumption of non-residence after a reasonable period of time (one year) and (ii) that aliens who have been allowed by the Federal immigration authorities to establish domicile in the United States, are to be treated equally with United States citizens. In the area of primary and secondary education, the Court has given constitutional approval to the classic policies according to which children can only go to school in the district, and thus the State, in which they reside. The sole adjustment the Court has made is that all children, including illegal aliens' children, who actually reside in a given district/State are to be admitted to schools in the district in which they reside.

Since the admission policies of the American States have largely survived constitutional challenges, it is not surprising that the subject of cross-border access to public education has never triggered much debate in the United States. The main issues which have been the subject of debate have concerned the implications for the field education of decisions in other policy areas such as welfare. Nonetheless, the lack of attention paid to the subject is somewhat surprising. Some of the conclusions and reasonings of the Supreme Court are not as obvious as they appear. This not only holds true for the conclusion that tuition waitingperiod requirements are constitutional, ${ }^{302}$ but also, for instance, for judicial approval of differential tuition policies. ${ }^{303}$ The Court has never said much more than that States must have a substantial reason for charging non-residents higher tuition fees and that differential tuition policies, "while perhaps 'protectionistic' in a loose sense, reflect the essential and patently unobjectionable purpose of state government - to serve the citizens of the state". ${ }^{304}$ Saenz, however, indicates that tuition

302. See Section 8.4

303. Compare Coenen, State User Fees and the Dormant Commerce Clause, in: VdbiltLRev (1997) pp.795-842, at p.807 (footnote 60).

304. Reeves, Inc. v State, 447 US 429 (1980) at 443. 
residence requirements are subject to scrutiny under the Privileges and Immunities Clause of Article IV Section 2. If the Clause's "substantial reason test" as developed in areas other than education were actually to be applied, it might be questioned whether tuition residence requirements could withstand scrutiny. Would funding and organisation be affected if non-residents were not, or could not, be charged additional tuition fees? $?^{305}$ Furthermore, why has the Court accepted that non-resident children can be denied admission to public schools altogether? In Martinez the Court merely applied rational relation scrutiny. It may not indeed be wholly arbitrary to deny children whose parents have not contributed to the funding of public education through the payment of taxes admission to schools and it may be true that "the proper planning and operation of the schools would suffer significantly" if bona fide residence requirements were not applied. Yet, could this planning and operation not be protected by merely charging non-residents higher tuition fees or by applying non-resident admission quota? Why did the Court not apply the "rational relation test" with some "more bite"?

More questions could be raised, but the point to be made is that the conclusions drawn by the Court in cases concerning cross-border access to public education sit uneasily with the more general case law. Arguably, if the Court had applied the general principles on the right to travel and the right to equal treatment in other States ${ }^{306}$ as developed in other areas to the field of education, it might have reached quite different conclusions. This is not so much meant as a criticism, or as a call upon the Supreme Court to moved away from some of its conclusions, but merely intended to demonstrate that the Supreme Court has taken quite a lax and deferential attitude vis-à-vis States (and/or their educational institutions). Why has the Court been so lenient towards States? Why has the Court not taken an affirmative stance against discriminatory State policies as it has done in the field of welfare? Why has the Supreme Court not been as active in the field of education as the European Court

305. Arguably, this would only be the case where States are confronted with an influx of non-resident students whose numbers (far) exceed the number of residents who move to other States in order to obtain education. In particular, States which may be regarded as netexporters of students would not seem to have any substantive reason for charging incoming students higher tuition fees. Compare also Clarke, Validity of Discriminatory Nonresident Tuition Charges in Public Higher Education under The Priviliges and Immunities Clause, in: NebLRev (1971) pp.31-64 who has argued (before Vlandis) that a State must give "full" equal access to non-resident students to the extent that it has surplus educational facilities. In this author's view, States have surplus facilities and for this reason there would be no need to charge non-residents higher tuition.

306. See Chapter 3 Scction 8. 
of Justice? What explains the passivity of the Supreme Court?

It is not possible to a single definite answer, but various factors may help to explain the Court's approach. The Court's observation that differential tuition policies "reflect the essential and patently unobjectionable purpose of state government - to serve the citizens of the state"1307 suggests that the explanation for the Court's reluctance to impose limits on the States' powers derives from the legal-political structure of the American federal Union. In the constitutional framework, States are not viewed as "conveniently local administrative departments of the national government designed to assist in the implementation of national policy". Rather, they are seen as governmental entities which hold independent lawmaking powers aimed at the provision of public benefits and services within their territory. ${ }^{308}$ This power, so it has been argued, not only provides the basis for the right of States to exclude nonresidents from public services when, or in as far as, this is necessary for upholding these services. The range of this lawmaking power goes even further to provide the rule that in principle States can preserve public benefits for their residents. Like other groups

"free to combine their members' efforts to produce collective benefits to be shared among the group, political communities, including states, have a prima facie justification for limiting distribution of their public goods to those who combined to provide them". ${ }^{309}$

This view of States and their constitutional position in the federal Union, however, merely explains the Court's reluctance to impose limits on States' powers to discriminate against non-residents. It does not explain why the Court has accepted that students who are bona fide residents must submit proof of their status, and only become entitled to lower inState tuition fees, after one year of residence nor does the above view explain why aliens who have lived in the (United) States for many years without having acquired permanent resident status can be required to pay higher out-of-State tuition fees.

It is hard to establish the Court's genuine motives, but the case law suggests that the Court's deferential attitude towards States is also, if

307. Reeves, Inc. v State, 447 US 429 (1980) at 443.

308. Varat, 'State Citizenship' and Interstate Equality, in: UChicLRev (1981) pp.487-571, at p.520.

309. Ibid, at p.523. The "reality of the existence of states qua states, rather than as departments of a national government, requires a conception that the state's citizens own stateowned resources, and that a state is not required to share its treasury with the nation at large". Cohen, Equal Treatment for Newcomers: The Core Meaning of National and State Citizenship, in: ConstComm (1984) pp.9-19, at p.17. 
not primarily, prompted by mere practical reasons. States' admission policies in the field of education have never been perceived as unfair, inefficient or overly protectionist. The public school systems have been subject of much debate, but criticism has primarily been focused on the disparity in the quality in the different districts/States, not on the fact that children cannot attend schools in other districts or States. The quality of education offered to children in "poorer" districts should be improved by changes to the funding systems, not by granting such children a right to gain access to schools in other districts/States. Children should have a right to quality education in the district in which they, together with their parents, reside. Increasing the inter-district mobility of pupils has never been seen as a means of improving the quality of education of "poor" pupils. If anything, such mobility is seen as a threat to the quality of public school systems. The reverse seems to be the case, however, in the area of higher education. Increasing the possibility of studying at universities or colleges in other States has always been and still is seen as a valuable objective. It enables students to choose among a larger number of colleges, universities and courses and in this way increases the knowledge and professional skills of the American population. Where States have always attempted to discourage indigents from exercising their right to travel, they have always accepted and even promoted inter-State student mobility. They have never discouraged residents from studying in other States and have accepted that residents of other States will come to study at their State universities. Charging non-residents enables States to protect their educational systems and has never been proven to obstruct or hinder inter-State student mobility. The motive for applying waitingperiod requirements may not be very persuasive, but it is to be noted that, unlike welfare waiting-periods, tuition waiting-period requirements have never been imposed in order to discourage freedom of movement and they do not deny admission to education itself. Generally, differential tuition policies are considered to strike a fair balance between the national interest in inter-State student or pupil mobility and the States' interest in maintaining adequate systems of higher education. Thus, where the European Court has been faced with Member States which were quite protectionistic and reluctant to promote student mobility, the Supreme Court has never been in a position where it saw a need to take steps to ensure that individuals can move to and gain access to education in other States. A free movement of students has always existed and the opinions of the Court suggest that it simply did not wish to intervene in practices and policies which "did not seem to bother anybody" or which did not seem to seriously obstructed any valuable constitutional goal. 


\subsection{Introduction}

Returning to the European Community, it may be recalled that the Community has achieved much in promoting cross-border access to education in the last two decades. In the original EEC Treaty no mention was made of educational rights for workers and the free movement of students was not provided for. Today, Community law confers upon all Community citizens a right to gain access to education in other Member States and for many of them this includes a right to claim study grants in those States. Nonetheless, Community law on cross-border access to education, as it stands today, is still debated. This particularly holds true for the category of the Community students, i.e. the group of students who move to other Member States for the sole purpose of studying there and who do not fall within the scope of the provisions on the free movement of workers. ${ }^{310}$ On the one hand, it is claimed that Community law does not give sufficient regard to the educational and financial interests of Member States. Some Member States "import" more students than they "export". The imbalances in student movements would "constitute a significant burden on the resources of some Member States"1311 for which they should be compensated. On the other hand, it is claimed that there are still too many obstacles to cross-border access to education. In particular, "free-movers", i.e. the Community students who study in other Member States outside the context of the Socrates/Erasmus programme, still face many obstacles. The question is where to go from here. Should future activities be focused on the protection of the educational and financial interests of Member States who receive more students than they "send" abroad or should emphasis be placed on the promotion of student mobility? Or, ideally, is it possible to combine both efforts? Given the fact that some educational systems have a stronger magnetic effect on students than others, is it possible to alter the current legal rules with a view to increasing student mobility while giving full respect to the educational interests of Member States? Can some lessons be learned in this regard from the United States?

310. See Sections 4.11 and 7.

311. O'Leary (1996) supra footnote 4, at p.171. 
9.2 Free Movement of Students versus the Preservation of Educational Systems

In exploring how the conflict between the objective of promoting the free movement of students, ${ }^{312}$ on the one hand, and the need to safeguard the educational interests of the Member States, on the other hand, could be settled more satisfactorily, one could approach the conflict from a political-economic perspective. As in the case of minimum subsistence benefits,${ }^{313}$ elements of theories on fiscal federalism may be of help. ${ }^{314}$

\subsubsection{Race to the Bottom Hypothesis}

One of the commonly cited advantages of a federal or multi-level system of government is that it allows for a decentralised supply of public benefits. Decentralisation enables the federal entitity to respond to the different preferences which citizens in the various States (or other local governmental entities) may have for public services. In every State citizen-voters can make collective choices as to what public benefits will be made available, what the "quality" of these benefits should be, how public benefit systems are to be organised and how much taxes have to be paid in order to finance these benefits. The advantages of decentralisation are particularly relevant for the organisation of education in an entity like the European Community where the financial means available for, and the views on how to organise, education differ so considerably.

Fiscal federalism theories start from the presumption that freedom of movement is guaranteed among local government entities. On the one

312. In recent years (as regards the initial years see footnote 121) Community institutions have frequently stated that the promotion of student mobility constitutes a key role in the common educational and vocational training policies. See e.g. the Resolution of the Council and of Representatives of the Governments of the Member States, Meeting within the Council of 14 December 2000 Concerning an Action Plan for Mobility (OJ 2000 C 371); the Bologna Declaration on the European Space for Higher Education (http://europa.eu.int/comm/education), the Green Paper of the European Commission mentioned in Section 4.11, the Council Resolution of 24 May 1988 (OJ 1988 C 177) and the Council conclusions of 27 November 1992 (OJ 1992 C 336).

313. See Chapter 3 Section 10.2 .

314. On the theories on the economics of federalism (or fiscal federalism) see e.g. Hyman, Public Finance - A Contemporary Application of Theory to Policy (1999) Chapter 18; Rosen, Public Finance (1985) Chapter 19; Due/Friedländer, Government Finance (1977) pp.456 et seq; Musgrave/Musgrave, Public Finance in Theory and Practice (1976) and Oates, Fiscal Federalism (1972). 
hand, freedom of movement is positively valued. According to the socalled Tiebout-hypothesis, the right to move elsewhere enables individuals "to vote on their feet". ${ }^{315}$ Individuals who prefer public benefits such as public education of a comparatively high quality, and who are willing to pay the "price" in the form of comparatively high taxes, are able to move to a State where such a pattern has been selected. Others who are not willing to pay such a price, may move to States where the quality of public education and taxes are lower. On the other hand, the theories warn of the possible negative implications for the right to freedom of movement. Inter-State mobility may be a threat to the efficient supply of public benefits such as education. The social benefits of the States' investments in education may spill-over to other States. Upon graduation, students may decide to work in other States and use their knowledge and skills in, and to the benefit of the economies of, other States. A full freedom of movement may even enable students to move to other States for the sole purpose of receiving education and then to leave the State once they have finished their studies. Such "free-riding students" are neither before nor after their studies fully taxable in the States of their studies and the economies of the States concerned do not benefit from the investment made in educating these students. Fiscal federalism theories teach that public benefits can only be efficiently provided for at local level if the persons who make the collective choices are also the ones who finance and consume the benefits. ${ }^{316}$ In the area of education, the group of consumers (i.e. the students) will often not coincide with the group of contributors (i.e. the tax-payers). In the case of free-riding students the necessary coincidence of consumers and contributors may even be virtually absent.

Spill-over effects (or negative externalities) could possibly trigger a "race to the bottom". Consider the following model. State A is grouped together with several other States in federal entity X. State A has to make a decision as to the nature and quality of its educational systems. If State A were to opt for high quality, and thus rather expensive, education, it would have to levy high taxes. If it were to do so, State A might attract students from other States seeking high quality education. The more "freeriding" students who come from other States, the greater the pressure on the funding of the educational system. Should the net-inflow of noncontributing benefit recipients would prove to be considerable, State A

315. Tiebout, A Pure Theory of Local Expenditures, in: JPolEc (1956) pp.416 et seq.

316. Ideally, there should be a "triple identity" of "voters", "contributors" and "consumers". See Scholsem, A Propos de la Circulation des Etudiants: Vers un Federalisme Financier Européen?, in: CDE (1989) pp.306-323, at p.309-310. 
might have to choose either to decrease its investment in education or to increase its tax rates. If State A were to choose the latter option, taxpaying citizens might move to other States leading to a reduction in tax revenues. In order to avoid such a situation, State A might decide in advance not to spend too much on education in the hope that "free-riding" students from other States will move to State B. If State A did indeed choose to do so, this would indirectly increase the magnetic effect of the benefit scheme in State B. This State would be faced with problems comparable to those which State A initially encountered and State B might decide to lower educational investment to reach a level lower than that of State $\mathrm{C}$ in the hope that free-riders would move to C. State C might respond similarly and try to shift the burden to State D. The fear of becoming an educational magnet could trigger competition between States lowering investment in education in the hope that other States will educate students. This competition may result in a downward movement ("a race to the bottom") leading to a decrease in educational investment in the entire federal entity $\mathrm{X}$.

\subsubsection{A Race to the Bottom in the European Community?}

Fiscal federalism theories teach us that when spill-over effects or (negative) external effects occur, measures have to be taken to internalise these effects. Before considering what such "internalising measures" might entail, the question needs to be addressed whether there is any need to take such measures within the European Community. The "race to the bottom hypothesis" is based on a number assumptions some of which do not necessarily hold true in practice, and in European practice in particular. An initial assumption is that students are mobile and that they move to the States where the best, and often the most expensive education, is offered. European students, however, do not seem as mobile as free-riders in the above described model. Mobility is severely restricted by linguistic barriers, problems concerning the recognition of diplomas and the lack of sufficient student financial aid. Also, the quality of educational systems does not seem to be the main criterion which European students apply when choosing the State in which they study. Practice demonstrates that the main criterion European students apply is knowledge of the language 
of the State concerned or in which the courses are taught ${ }^{317}$ and this explains why the "big language countries" (the United Kingdom, France and, to a lesser extent, Belgium) especially are faced with a net-import of students. The second assumption on which the above model of a race to the bottom is based, is that Member States actually limit investment in education in order to avoid becoming educational magnets. This assumption does not seem to hold true, however. Decisions concerning the quality of and investment in education are not primarily, or at least not solely, made on the basis of student mobility figures. There are no indications that the mentioned three countries have ever raised, or will raise, taxes or reduce educational investment in response to an influx of foreign students. Generally, States attach great importance to, and often take pride in, making available high quality education and public schools and universities are important providers of employment which play a significant economic role in the communities in which where they are established. $^{318}$

The significance of the above model for the European Community thus seems rather limited. European students are not as mobile as the Tiebout-hypothesis assumes and even if student mobility were to increase in future years, an educational race to the bottom is unlikely to occur. In fact, it could be argued that the problems which some Member States face are not caused by student mobility but rather by "student immobility". In the United Kingdom, for instance, it has been recognised that the imbalance in students movements, and the resulting financial burden, is not only caused by the number of foreign students attending British universities but also, if not primarily, by the small number of British students studying at foreign universities. In principle, foreign students are "more than welcome" in the United Kingdom. Financial and educational prob-

317. See House of Lords - Select Committee on European Communities (1998-1999) supra footnote 180, at point 84 (Professor Teichler) and Gordon/Jallade (1996) supra footnote 208, at p.137.

318. von Wilmowsky (1991) supra footnote 161, at pp.265-266. A third assumption is that tax-payers might leave a State if, due to an (expected) increase in educational costs caused by an influx of foreign students, tax-rates were actually raised. Statistics or scientific proof to support this point does not seem to be available, but it is doubtful whether individuals or companies will leave the Member State in which they reside or are established when they have to pay more taxes in order to maintain the quality of education. For many tax-payers high quality education, from which they themselves can also benefit, would seem to be one of those public benefits to which they are willing to contribuen by paying taxes. The reverse might even hold true. Even if this were to lead to a higher tax-burden, companies might move to States with comparatively well-developed educational systems because they may necd highly cducated cmployecs. 
lems do not necessarily have to dealt with by discouraging foreign students or asking for some kind of compensation. They could just as well be tackled by encouraging more British students to study abroad. ${ }^{319}$

In principle, there seem to be no compelling reasons why one should not consider how student mobility can be further promoted. In Section 9.3 a few options will be discussed. Nonetheless, the relevance of fiscal federalism theories cannot be dismissed altogether. Applied to the European Community, the above described model may be seen as a warning that one cannot wholly ignore the position of States which are "net-importers" of students while promoting student mobility. A mismatch between "contributors" to and "beneficiaries" of educational systems may cause funding or capacity problems for some States which may occur when initiatives for promoting student mobility prove to be successful. In Section 9.4 a few observations will therefore be made as to how the financial and/or educational interests of these States could be safeguarded.

\subsection{Options for Promoting Student Mobility}

Community citizens who wish to study in other Member States outside the framework of the Erasmus/Socrates programme still face a number of obstacles. As both the Commission ${ }^{320}$ and the Council ${ }^{321}$ have indicated, these include a lack of knowledge of the language in which courses are taught, the recognition of diplomas or other qualifications acquired in the Member State of origin, the absence of a right to study grants covering the cost of maintenance and issues relating to the financial means requirement contained in Directive No 93/96. This Section does not consider how the first two obstacles could be minimised or eliminated. By promoting the teaching and dissemination of the European languages, and the "small languages" in particular, the Community could

319. Compare the discussion in House of Lords - Select Committee on European Communities (1998) supra footnote 180, at points 64-96. The various points raised in the discussion primarily concerned Erasmus students and it was admitted that the problems concerning the imbalance in student movements might be somewhat different and more worrying as regards as the category of "free-movers". Nonetheless, the rationale of the argument that the problems could just as well (and preferably) be dealt with by promoting mobility of British students, would also seem to apply to free-movers.

320. See supra footnote 214

321. See supra footnote 215 
facilitate student mobility ${ }^{322}$ and possibly reduce the problems caused by the imbalance in student movements. Yet, in order to achieve this the legal rules and principles governing the free movement of students do not need to be altered. The necessary policy measures willd have to take the form of some kind of financial incentive for Member States which can be taken within the current legal framework. The same would seem to hold true for the academic recognition of diplomas. National rules concerning such recognition may run counter to the Treaty's free movement and nondiscrimination provisions, but they may be justified for educational reasons. ${ }^{323}$ Rules or practices which can pass judicial scrutiny will have to be tackled by the political Community institutions which only hold the power to support and supplement "the action of the Member States through the adoption of incentive measures". ${ }^{324}$ Both the language and the diploma obstacles to student mobility are intrinsically linked with the substance of education itself and will ultimately be lessened by encouraging voluntary action by Member States rather than by restricting their educational powers. Arguably, however, the approach to be followed may differ as regards the "student financial aid obstacle" and the financial means requirement. Study grants and other forms of financial aid do not relate directly to or affect the substance of education itself. In order to promote the mobility of European students, one could consider tackling these obstacles by developing "hard" legal rules.

\subsubsection{Study Grants}

At the present stage of Community law, "free-movers" only have a limited right to study grants. These Community students cannot benefit from grants made available under the Erasmus-Socrates programme, they can only claim limited grants in the State where they study and, due to territorial restrictions contained in national laws, they usually are not

322. See Article 149(1) EC. The Community has already taken various initiatives to promote language learning within its Erasmus, Comenius and Grundtvig programs as well as the specific language programme Lingua. In addition, 2001 has been proclaimed as the European Year of Languages which is described as "a celebration of Europe's linguistic diversity" and which promotes language learning and related skills through various activities. For an overview of the various activities see http://europa.eu.int/comm/education/languages.

323. See Section 4.5.

324. See Article 149(1) EC. Compare also the Commission's proposal of 31 January 2000 for a recommendaton of the European Parliament and of the Council on mobility within the Community for students, persons undergoing training, young volunteers, teachers and trainers. Document 599PC0708. 
entitled to transfer study grants abroad. In principle, the cost of maintenance are to be borne by the students themselves (or their parents) and this may, for students from less well-off backgrounds in particular, constitute an obstacle to study abroad. In order to surmount this obstacle, one could consider imposing the burden of maintenance cost on an "actor" other than the students themselves (or their parents). The most logical candidate $^{325}$ would seem to be the State in which students are residing prior to the commencement of their studies in another Member State. It is this State where taxes have usually been paid and to which students will often return upon graduation and it is this State which is most likely to benefit from the skills and knowledge obtained by the students. More specifically, one could consider the option ${ }^{326}$ of making study grants exportable. ${ }^{327}$

\section{A Right to Export Study Grants?}

In doing so, it is worthwhile recalling ${ }^{328}$ that study grants are only one means of making education financially accessible. An alternative means,

325. Two alternatives could be considered. The first would be the State where students are attending a course of education. Arguably, this option should be rejected. If the host State had to bear the cost of both Community students' education and the costs of their maintenance, it might attract so many students from countries where no or less developed financial aid schemes exist, that their study grant scheme could be seriously affected. Compare the comments made in Section 4.3. A second candidate could be the Community itself. For instance, one could explore whether "Action 2" of the Erasmus-Socrates programme could be extended to "free-movers" or whether a common student financial aid scheme taking the form of a loan scheme could be established. Given the financial and administrative implications, however, it would seem that the chances of having such proposals adopted, are quite small.

326. In the alternative, one could consider setting up some kind of reimbursement scheme under which the host State would be obliged to give Community students "full" study grants under the same conditions as national students and which would impose on the State of origin a duty to reimburse the host State for the costs incurred. The prospects for introducing such a scheme seem remote, however. Students might move to States with the most generous aid systems with the possible result that the total amount to be spent on study grants in the Community would increase. Ultimately, the financial burden would be imposed on the "poorer" States which could be faced with additional expenditure. These States may not be able to bear this financial burden or prefer to spend the amounts involved in (further) developing (their) own student financial schemes.

327. In its 1996 Green Paper on the obstacles to student mobility the European Commission took the view that there is indeed "room for greater transferability of grants". European Commission, Green Paper on "Education, Training, Research" (1996) supra footnote 214, at p.24 and p. 29 .

328. See Section 2.1. 
for which quite a few Member States have opted, consists of offering financial aid to children who are studying in the form of family benefits or child allowances. Regulation No 1408/71 contains various provisions which intend to co-ordinate national family benefit and child allowance schemes in order to avoid Community citizens being deterred from exercising their free movement rights because of a possible loss of such benefits or allowances. ${ }^{329}$ The main rule is laid down in Article 73 which provides that workers subject to the legislation of a Member State are entitled to family benefits for children who are residing in the territory of another Member State. The benefits are to be paid at the rate applicable in the State of employment, even when living cost in the State where the children are living (and/or studying) are lower. ${ }^{330}$ Thus, children of workers who are subject to legislation in a Member State where financial aid for children who are studying is given in the form of family benefits, are entitled to public financial support regardless of the Member States where they reside or study. Indirect student financial aid is exportable. At the present stage of Community law, the same conclusion cannot yet be drawn as regards direct student financial aid. In cases like Matteucci, di Leo, Bernini and Meeusen ${ }^{331}$ the Court has gradually extended the possibility of workers and their family members obtaining study grants for "foreign" studies, but in two respects the current rules applicable to study grants are still more restrictive than the rule contained in Article 73 of Regulation No 1408/71. First, workers and their family members are only entitled to grants for foreign studies under Article 7(2) of Regulation No 1612/68 where the host State has given its own nationals such a right. Ultimately, it is still up to the Member States to decide whether or not study grants can be transferred abroad. Direct student financial aid is not exportable. Second, Article 7(2) can only be invoked by those who hold the status of worker or family members in another Member State. Article 73 of Regulation No 1408/71, however, can also be relied upon by workers who have never exercised their free movement rights and who wish to claim in their own State financial aid for children who are residing and studying in another Member States. ${ }^{332}$

The four judgments referred to, however, do show that the Community rules governing entitlement to study grants for foreign studies are

329. Compare Case C-228/88 Bronzino [1990] ECR I-531 at 12. For a brief introduction to this Regulation (and the implementing Regulation No 574/72) see Chapter 2 Section 6.

330. Case 41/84 Pinna [1986] ECR 1 at 23-24.

331. See Sections 3.2.2 and 3.3.2.

332. Scc Casc C-194/96 Kulzer [1998] ECR I-921 at 27-31. 
evolving and that these rules show more and more resemblance to the Article 73-rule for family benefits. ${ }^{333}$ The question arises whether this development can be taken one step further to make study grants exportable too. When indirect student financial aid can be transferred abroad, why should the same not hold true for direct student aid? The pertinence of the question is demonstrated by the recent case Fahmi and Esmoris Cerdeiro-Pinedo Amado (2001), which has already been briefly discussed in Section 3.3.2.

\section{Fahmi and Esmoris Cerdeiro-Pinedo Amado}

Until 1986 the Netherlands offered financial aid for children who were studying in the form of child allowances. In that year, however, the Dutch legislator decided that financial aid would no longer be given to parents, but rather, in the form of study grants, to the children themselves. This new funding arrangement was designed, in particular, to enable students to be financially independent of their parents, to ensure equal treatment for students and to enhance the status of students. ${ }^{334}$ Entitlement to study grants, however, was limited to students who $(i)$ hold Dutch nationality or are residing in the Netherlands and (ii) are studying at Dutch universities or foreign universities which, for study grant purposes, have been put on a par with Dutch educational institutions. The latter condition was imposed because $(i)$ the number and variety of educational facilities and courses in the Netherlands were deemed sufficient and (ii) the Netherlands Minister for Education lacked the powers to impose conditions regarding the quality of education in other States. ${ }^{335}$ For the latter reason, the Netherlands Minister of Education has been willing to offer study grants to nationals and residents of the Netherlands who are following studies in other Member States which have been the subject of harmonisation measures within the framework of "vertical" directives on the mutual recognition of diplomas for, in particular, the medical professions. ${ }^{336}$ Studies falling, however, within the scope of the "horizontal" Directive No $89 / 48$ on the mutual recognition of diplomas, which is

333. Compare the Opinion of Advocate General La Pergola in Case C-337/97 Meeusen [1999] ECR I-0000 at 19. On the comparison between the rules governing family benefits and student grants see also Steinmeyer, Familienleistungen und Ausbildungsförderung, in: Deutschen Sozialrechtsverbandes, Europäisches Sozialrecht (1992) pp.169-192.

334. Case C-33/99 Fahmi and Esmoris Cerdeiro-Pinedo Amado [2001] ECR I-0000 at 10.

335. Kamerstukken, II 1985/86, 19 125, nr.6, at pp.30-31.

336. Sec supra footnote 22. 
not based on a prior harmonisation of educational systems, have not been put on a par with recognised institutions on the national territory. ${ }^{337}$

The new arrangements did not become applicable with immediate effect. In 1986 a transitional arrangement was established according to which child allowances could still be obtained for children who were studying aged between 18 and 27 years. In 1996 this arrangement was amended as to limit entitlement to child allowances for student children who were already entitled to such an allowance and who continued to follow the same type of education as they had been following on 1 October 1995. The 1996 amendment worked out negatively for Erika Esmoris Cerdeiro-Pinedo Amado, a Spanish student who was born in the Netherlands whilst her mother was working and residing there. After having become unfit for work, Mrs Esmoris Cerdeiro-Pinedo Amado returned with her daughter to Spain. She continued to receive a Dutch incapacity for work allowance by virtue of which she was also entitled to child allowances for the time that Erika was still in secondary school in Spain. Payment of this allowance was stopped, however, when Erika, upon completion of her secondary education, embarked in 1996 on a course of study at the Faculty of Economics of the University La Coruña. She no longer met the requirement laid down in the 1996 transitional arrangement for child allowances. Mrs Esmoris Cerdeiro-Pinedo Amado appealed in a Dutch court the decision to refuse payment of the child allowance and the court decided to refer the case for preliminary ruling to the Court of Justice. In brief, the Dutch court wished to know whether the replacement of a right to child allowances for children who were studying with a right to study grants is compatible with Community law where the effect of this replacement is that persons like Mrs Esmoris CerdeiroPinedo Amado are deprived of financial aid for their student children.

The Court did not review the two-step legislative process in its entirety; the old rules for child allowances and the new rules applicable to study grants were judged separately. ${ }^{338}$ As regards the abolition of child allowances, the Court held that Member States are free to organise their social security systems in the way they deem appropriate and that there was nothing which indicated infringements of Community law. The main questions to be answered concerned the compatibility of the Dutch rule that study grants are in principle only offered to students pursuing studies within Dutch territory with $(i)$ Article 3 or any other provision of Regula-

\footnotetext{
337. Stb, 1990, 660 .

338. Case C-33/99 Fahmi and Esmoris Cerdeiro-Pinedo Amado [2001] ECR I-0000 at 2326.
} 
tion No 1408/71 and (ii) Article 7(2) of Regulation No 1612/68. ${ }^{339}$ The Court rephrased the preliminary questions in order to limit them to the specific situation of the plaintiff. The Court held that pensioners like Mrs Esmoris Cerdeiro-Pinedo Amado cannot claim study grants under Regulation No 1408/71. Pensioners do not fall within the scope of Article 73 of Regulation No 1408/71. They can only rely on Article 77 of the regulation which, in brief, provides that pensioners are entitled to "family allowances" in the State where they draw a pension irrespective of the Member State in whose territory they or their chidlren are residing. According to Article 1(u)(ii), "family allowances" only cover benefits granted exclusively by reference to the number and, where appropriate, the age of members of the family. ${ }^{340}$ The Court concluded that study grants do not fall within that definition. Neither Article 7(2) of Regulation No 1612/68 be of help to persons like Mrs Esmoris Cerdeiro-Pinedo Amado. Article $7(2)$ is intended to facilitate freedom of movement by eliminating obstacles to the integration of workers and their families in the State of employment. The Court concluded that, as a general rule and except in special circumstances, the non-discrimination rule of Article 7(2) cannot be extended to workers who, after ceasing all occupational activity in the host State, have decided to return their State of origin. ${ }^{341}$

\section{Article 7(2) of Regulation No 1612/68: Children of Community Workers}

In view of the specific facts of the case, there was indeed no real need for the Court to answer the question whether national rules limiting the export of maintenance grants are compatible with Article 7(2) of Regulation No 1612/68. The case does indicate, however, that it is pertinent to raise the question and the careful way in which the Court avoided going into the issue suggests that the legality of such rules, at the very least, cannot be automatically assumed. Would Mrs Esmoris Cerdeiro-Pinedo Amado have been entitled to claim a study grant for her daughter under Article 7(2) of Regulation No 1612/68 if she had not returned to Spain. A

339. Ibid, at 27. The fact that most questions submitted by the national court concerned Dutch law on study grants, whilst Mrs Esmoris Cerdeiro-Pinedo Amado had started the case on the basis of the law governing child allowances, was no reason for the Court to deny admissibility. Ibid, at 28-29.

340. Ibid, at 35 .

341. Ibid, at 47-51. Workers who have stopped working altogether and have decided to return to the State of origin can only claim under Article 7(2) rights or benefits which relate to the previous occupational activity. Case C-389/99 Rundgren [2001] ECR I-0000 at 34. 
genuine integration of Community workers and their families into the host State's society would seem to require that children of Community workers, just as national children, can study at educational institutions which suit their preferences, interests and career prospects. For linguistic and cultural reasons, family members of Community workers are likely to be more interested in studying in other Member States than children holding the nationality of the host State and, as Advocate General Alber stated in his Opinion in Fahmi and Esmoris Cerdeiro-Pinedo Amado, it could thus be argued that national rules denying study grants for foreign studies constitute prohibited indirect discrimination on grounds of nationality, ${ }^{342}$ unless it can be demonstrated that such rules are necessary for, and proportional to, a legitimate public interest. ${ }^{343}$

On what ground, then, can the non-exportability of study grants possibly be justified? In the proceedings before the Court in Fahmi and Esmoris Cerdeiro-Pinedo Amado the United Kingdom had argued that study grants cannot be made exportable because they are based on the "socio-economic circumstances" of national university cities. Advocate General Alber rejected the argument reasoning that Member States can take the differences in living cost into account when determining the level of grants. ${ }^{344}$ Indeed, it is hard to understand why for this reason study grants should be non-exportable. A possible right to export study grants might provide an incentive for children of workers to embark on studies in States where the cost of living is higher than at home, but Article 7(2) of Regulation No 1612/68 does not seem to oblige Member States to increase the level of study grants. ${ }^{345}$ In reverse, children of workers may decide to study in relatively cheap States or universities, but nothing would seem to prevent States from lowering the level of grants in such cases. $^{346}$ The exportability of study grants does not have to lead to an increase in expenditure. In fact, the opposite may be the case.

342. Opinion of Advocate General Alber in Case C-33/99 Fahmi and Esmoris CerdeiroPinedo Amado [2001] ECR I-0000 at 79. Alber did go into the importance of Article 7(2) because, in his view, former workers who have returned to their State of origin would retain the right to rely on this provision in order to claim tax-funded benefits (such as study grants) when they (i) receive a pension from the State of employment and (ii) pay taxes in respect of such a pension in that State.

343. See Chapter 2 Sections 7.2 and 7.3 .

344. Ibid, at 83.

345. Such a rule may be indirectly discriminatory (compare Case 41/84 Pinna [1986] ECR 1 at 23-24), but, by analogy with the Court's reasoning in cases as Decker and Kohll (see Chapter 4 Section 4.2.4), it would seem that Member States can limit the payment of grants up to the maximum paid to students attneding education on the national territory. 346. Compare Case C-237/94 O'Flynn [1996] ECR I-2617 at 28-29. 
Another argument to be made in favour of limits on the exportability of study grants relates to the quality of education in other Member States. ${ }^{347}$ Indeed, the main ${ }^{348}$ reason why the Dutch legislator decided to limit the export of study grants was that the Minister of Education would lack the powers to impose conditions regarding the quality of education in other States. In Fahmi and Esmoris Cerdeiro-Pinedo Amado Advocate General Alber was of the opinion that study grants primarily aim to enable students to qualify for a certain profession and that, for this reason, it would indeed be legitimate to finance only studies which meet certain quality norms. Alber referred to Directive No $89 / 48^{349}$ which obliges Member States to recognise diplomas awarded in other Member States for the purposes of access to regulated professions. Within the scope of this directive, education provided in the Member States is presumed to meet the required quality standards. By virtue of Article 4 of this directive, however, Member States are allowed to impose additional requirements on the holders of foreign diplomas when the matters covered by, and the duration of, "foreign" education substantially differs from

347. Another possible argument to be made in support of the non-exportability of study grants relates to the need to protect the infrastructure of educational systems. In order to provide adequate education, governments must ensure that there are enough universities, courses, libraries, professors, etc. available. Undercapacity implies a limitation on the accessibility of education and is to be avoided. At the same time, the number of educational facilities should not be too large in relation to the demand. Overcapacity implies an unnecessary waste of human and financial resources. Proper capacity planning, so it could be argued, requires that States anticipate how many students will attend their universities and the power to refuse grants for studies abroad enables them to control student movements to the extent necessary for safeguarding their educational infrastructure. Also, this argument is not persuasive. In times where educational funding is increasingly under pressure, where class- and lecture-rooms are overcrowded and where it is increasingly difficult to provide adequate housing and other student-related facilities, it is hard to understand how a possible increase in the number of students studying abroad could affect the quality and accessibility of national universities and schools. Rather, it would seem that the recognition of a right for children of workers to export study grants could contribute to improving the quality and accessibility of educational systems on the national territory. Admittedly, the States hosting the students might encounter some infrastructural problems, but this does not seem a good enough reason for the State of origin to justify the non-exportability of study grants. Compare the comments made in Chapter 4 Section 4.3.5. On the question what protective measures might be available for the States receiving the students, see Section 9.4.

348. As noted above, the other argument made in support of the decision to limit the export of study grants was that there were enough educational facilities and courses available in the Netherlands itself. In a Community where a right to freedom of movement for students is guaranteed, however, this cannot in itself be a ground for the justification of rules limiting the export of study grants.

349. OJ 1989 L 19. 
national requirements. The Advocate General concluded that Member States, which offer study grants for national studies which prepare students for certain professions, can justify the refusals of study grants for foreign studies when they subject the holders of foreign diplomas to the additional requirements mentioned in Article 4 of Directive 89/48. ${ }^{350}$

The central thesis of the Advocate General that Member States are entitled to make the award of study grants conditional upon the pursuit of studies which meet certain quality standards would seem in order. Further, his implicit conclusion that not only the "vertical directives" on the recognition of in particular medical diplomas, but also the "horizontal" Directive $89 / 48$ can limit the powers of the Member States to refuse study grants for studies in other Member States, already implies a significant extension of the possibility of exporting grants. His conclusion, however, that Member States are entitled to refuse study grants in cases where foreign studies do not (wholly) meet the educational standards applied at home, is open to dispute. Alber's reasoning seems based on the presumption that students, upon graduation, will return to and take up a profession in their national territory. Even though many may do so, it is to be recognised that children of workers who have decided to study in the State of origin have the right, and may very well decide, to work in that State and that, as a rule, the diplomas they have acquired will suffice for admission to professions. Why would the quality standards applied in the State offering the grants have to serve as the sole standard of reference? In a Community where freedom of movement for students, workers and self-employed persons is legally guaranteed, it would seem far more logical to conclude that children of Community workers who have chosen to study in the State of origin are also entitled to grants when the university or school they attend, meets the quality standards applied in that State. Further, children of Community workers are entitled to study, and after graduation to work, in any Member State and it could thus be argued that, for study grant purposes, all educational institutions which, in the Member State where they are established, are permitted to issue diplomas which suffice for admission to professions in that State or any other Member State must be presumed to provide "sufficient quality". In other words, it could be argued that the refusals of study grants for studies in other member States are only justifiable in the few cases where children have decided to study at educational institutions whose diplomas

350. Opinion of Advocate General Alber in Case C-33/99 Fahmi and Esmoris CerdeiroPinedo Amado [2001] ECR I-0000 at 80-87. 
are not recognised for admission to professions in any of the Member States.

From the perspective of the Community's objective of promoting freedom of movement for workers and integration of workers' families into the host State, it seems wholly immaterial whether financial aid for children studying in other Member States is granted in the form of study grants or in the form of family benefits. Study grants are primarily aimed at making education financially accessible and, for this reason, it is doubtful whether they can be classified as "family benefits" for the purposes of Regulation No 1408/71..$^{351}$ Nevertheless, there do not seem

351. In Fahmi and Esmoris Cerdeiro-Pinedo Amado the Court concluded that study grants do not constitute "family allowances", but the question whether they could possibly be regarded as "family benefits" was left open. Case C-33/99 Fahmi and Esmoris CerdeiroPinedo Amado [2001] ECR I-0000 at 35. The two notions indeed have different meanings. According to Article 1(u)(ii), family allowances are benefits granted exclusively by reference to the number and, where appropriate, the age of members of the family. Study grants indeed do not seem to fall within that definition. Article 1(u)(i), however, defines family benefits as "all benefits in kind or in cash intended to meet family expenses under the legislation provided for under Article 4(1)(h)". On the basis of national law, entitlement to study grants is often made dependent of the income of the parents and they would thus seem aimed at meeting family expenses. In his Opinion in Fahmi and Esmoris Cerdeiro-Pinedo Amado Advocate General Alber recognised this but he nonetheless concluded that study grants cannot be classified as family benefits. In his view, grants are intended to cover the needs of children who, as a rule, are no longer minors and are responsible for their own personal life. The commencement of studies would be the distinguishing moment at which children extricate themselves from the family relationship serving as the model family expenses. In addition, study grants are expensive benefits for which no premium duties exist and for this reason it would not be justified to extend the notion of "family benefits" to benefits such as study grants which only indirectly compensate family expenses. Opinion of Advocate General Alber in Case C-33/99 Fahmi and Esmoris Cerdeiro-Pinedo Amado [2001] ECR I-0000 at 45-46. The arguments given by Alber are not truly persuasive. The distinctive moment he refers to would rather seem to be the day of graduation following which children will enter the labour market (compare Peers (1999) supra footnote 236) and the mere fact that study grants are "expensive" and not premium based (compare Case C78/91 Hughes [1992] ECR I-4839 at at 21) would seem immaterial factors for their classification. Yet, his conclusion that grants do not fall within the definition of Article 1(u)(i) of Regulation No $1408 / 71$ is understandable. The mere fact that study grants may reduce family expenses does not in itself suffice for the classification as a "family benefit". Compare Opinion of Advocate General Jacobs in Case C-43/99 Deaconescu (http://www.curia.eu.int/jurisp) at 50 . Study grant schemes aim to make education financially accessible, a goal which Regulation No 1408/71 does not seek to achieve. Further, because of this more specific purpose, it could be argued, as noted above, that Member States ought to have the right to make entitlement to study grants conditional upon fulfilment of certain educational requirements such as the pursuit of studies at institutions which are permitted to issue recognised diplomas. It is not certain whether such an educational requirement could be upheld under the family benefit provision of Article 73 of Regulation No 1408/71. Compare 
to be any sound or compelling reasons why the basic premises concerning direct and indirect student financial aid for children studying in other Member States ought to be different. Arguably, the substantive principle embodied in Article 73 of Regulation No 1408/71 that children who are residing (and studying) in other Member States are for the purposes of entitlement to family benefits to be treated as though they were residing (and studying) within the national territory can in principle be extended to Article 7(2) of Regulation No 1612/68 in relation to study grants.

\section{Article 12(1) EC: Community Students}

The conclusion that national rules limiting the export of study grants are at odds with Article 7(2) of Regulation No 1612/68 implies a break with the long-held assumption that Member States are in principle free to determine whether, or the conditions under which, they offer study grants for studies in other Member States. In one significant respect, however, the conclusion is still limited in scope. It only applies to children of Community citizens who have taken up employment and/or established residence in another Member State. ${ }^{352}$ For the vast majority of Community students, whose parents have never exercised their free movement rights and who live in their own Member State prior to the commencement of studies in another Member State, the above observations and conclusions are of no relevance because they cannot invoke Article 7(2) against their own State. Regulation No 1612/68 merely aims to promote a free movement of workers, not a free movement of students. Recent case law, however, leaves room for the suggestion that Community students can invoke Article 12(1) against their own Member State in order to

Case C-228/88 Bronzino [1990] ECR I-531 at 14. Second, a possible classification of study grants as family benefits would imply that study grants are subject to the priority rules laid down in Article 76 of Regulation No 1408/71 and Article 10 of the implementation Regulation No 574/72 which seek to avoid an overlap in rights to family benefits. Such priority rules would seem desirable for study grants too, but it is doubtful whether rules laid down in the Articles 76 and 10 give sufficient regard to the specific nature of study grants. See further the observations made under "Overlap of Study Grants".

352. Arguably, however, the conclusion that study grants are exportable can be extended to all Community citizens and their family members who are lawfully residing in the territory of another Member State. Workers can also rely on Article 7(2) of Regulation No 1612/68, independent children of workers can claim the right to export grants under Article 39 (or 12(1) EC), the self-employed and their children can do so on the basis of Article 43 EC (see Chapter 2 Section 2.4) and non-economic residents and their children can invoke Article 12(1) EC for this purpose (compare Chapter 2 Section 3.3) 
claim study grants for studies in other Member States. ${ }^{353}$ The argument to be made is not that Community students should be entitled to invoke Article 12(1) EC in order to avoid Member States treating their own nationals less favourably than non-nationals. In principle, Community law does not object to such reverse discrimination. ${ }^{354}$ Rather, the argument that can be made, is that national rules limiting the export of study grants unlawfully and unnecessarily restrict the Community right to study in other Member States. First, as argued in Section 4.3, the ruling in Martinez Sala (1998) strongly suggests that study grants, including the part that is intended to cover maintenance costs, now fall within the scope of the Treaty. ${ }^{355}$ Second, the case law reveals that Community law may also preclude the application by the State of origin of rules which hamper the right to work, ${ }^{356}$ establish a company ${ }^{357}$ or live ${ }^{358}$ in other Member States. In principle, there do not seem to be any sound reasons why the prohibition of non-discriminatory rules ${ }^{359}$ cannot be applied to the free movement of students. If correct, it could be argued that national rules limiting the export of study grants can only be upheld under Article 12(1) EC when it can be demonstrated that they are necessary for, and proportional to, a legitimate public interest. ${ }^{360}$ On the basis of observations

353. The question whether Community law requires the exportability of study grants has once been referred to the Court, but never been answered. The question was submitted in Wirth (1993). The case involved a German student who pursued a course in jazz saxaphone at an Arts College in Arnhem, the Netherlands and who had applied for a study grant in Germany. The German authorities refused him a grant. Mr Wirth challenged the refusal in court arguing that the refusal of the study grant was incompatible with Article $49 \mathrm{EC}$ and the "general principle of non-discrimination". The Court of Justice did not support Mr Wirth's arguments. First, recalling Humbel (see Section 4.8), the Court held that courses given in a establishment of higher education which is essentially funded out of public funds, as was the case with the Art College in Arnhem, do not constitute services within the meaning of Article $50 \mathrm{EC}$. As a result, the rule in question could not be said to restrict the free movement of services. Case C-109/92 Wirth [1993] ECR I-6447 at 19 and 22. The "general principle of non-discrimination" did not preclude the refusal to offer Wirth a grant either. With reference to Lair, the Court held that "assistance given to students for maintenance and for training" falls outside the scope of the Treaty. Ibid, at 24-25. On Wirth see further van der Mei (1994) supra footnote 156. Humbel's conclusion still stands, but, as noted below in the text, since Martinez Sala the same does not seem to hold true for the conclusion drawn in Lair.

354. See Chapter 2 Section 7.4 .

355. See Section 4.3 .

356. See e.g. Case C-18/95 Terhoeve [1999] ECR I-345.

357. Case 81/87 Daily Mail [1988] ECR 5483.

358. Case C-135/99 Elsen [2000] ECR 1-0000.

359. See further Chapter 2 Section 7.3.

360. Compare C-55/94 Gebhard [1995] ECR 1-4165 at 37. 
made above in relation to Article 7(2) of Regulation No $1612 / 68$, it can be seriously questioned whether rules limiting the exportability of grants have much chance of withstanding judicial scrutiny. The rules do not seem to be truly necessary for securing the financial stability of study grant schemes, an increased outflow of students is unlikely to seriously affect the infrastructure of educational systems within the national territory and arguments relating to the quality of education in other Member States are only persuasive where foreign diplomas afford no entitlement to admission to professions in one of the Member States. One could object and claim that a possible right to export study grants for all Community students would encourage nationals and/or residents upon graduation to work in other Member States and Member States would not be able to receive the benefits from the educational investment they have put into nationals and/or residents. In a Community where a free movement of workers and self-employed persons is guaranteed, however, such an objection to the exportability of study grants is not persuasive. Further, the objection could be raised that the exportability of grants would open the door to educational tourism. Community citizens living in States where no study grants schemes exist, could seek to establish residence in another Member State where generous study grant schemes are available and, after a brief period of time, claim grants for their studies in the State of origin or another Member State. The argument has some strength and it could indeed be argued that Member States, under certain circumstances, may refuse to offer study grants where they can prove that nationals of other Member States have merely taken up employment or established residence within their national territory with a view of subsequently exporting study grants. ${ }^{361}$ The argument, however, does not seem sufficiently compelling to deny all nationals or residents a right to obtain grants for studies in other Member States. In sum, it is sub-

361. Compare Case 39/86 Lair [1988] ECR 3161 at 37-38 (Community law does not cover abuses of the status of Community worker) and Case C-212/97 Centros [1999] ECR I-0000 at 39 (Community law does not prevent Member States from adopting measures aimed at preventing or penalising fraudulent use of their rules on the formation of companies). Member States do not seem entitled, however, to adopt a rule stating that, for study grant purposes, only persons who have resided within the national territory for a fixed period of time can be regarded as residents. Compare Swaddling (1999) in which the Court held that the length of a person's residence cannot be regarded as an intrinsic element of the concept of (habitual) residence. The question whether or not a person can be regarded as a resident is to be answered on a case-by-case basis in accordance with various factors such as the person's family situation, the reasons which led him to move, the fact that a person is in stable employment and the length and continuity of residence. Case C-90/97 Swaddling [1999] ECR I-0000 at 30. 
mitted that there do not seem any compelling reasons why the conclusion drawn above as regards children of Community workers cannot be extended to all Community students. Arguably, the refusal study grants for studies in other member States can only be justified under Article 12(1) EC where students have decided to study at educational institutions whose diplomas are not recognised for admission to professions in any of the Member States.

\section{Overlap of Study Grants}

The possible recognition of a right to export study grants would also raise several questions about the possible overlaps of study grants and how this might be prevented. In the absence of anti-cumulation rules, a right to export grants could mean that students might be able to receive financial compensation for tuition and enrolment fees in both the State where they study and the State of origin. Further, students whose parents have taken up employment in another Member State might be able to obtain maintenance grants in two or even more States. A student who resides and studies in State A and whose parent works in State B, may have a right to get a grant in State A and, on the basis of Article 7(2) of Regulation No $1612 / 68$, in State B. If the other parent were working in State C, the student might also be able to claim a study grant there and if the student in question decided to live in State $\mathrm{D}$, he might even be able to obtain (partial) grants in four States.

Such overlap could be avoided in various ways. ${ }^{362}$ First, Member States could unilaterally adopt and apply anti-cumulation rules on the basis of which grants are reduced or denied in cases where students (are entitled to) receive grants in other States. ${ }^{363}$ This unilateral method for combatting such overlap may be problematic, however. Member States are not always fully informed about the laws and regulations concerning study grants in other States and there might be a risk students falling between two stools where both States involved claim to be entitled to apply their anti-cumulation rules. An alternative way in which overlaps could be avoided is to promote the conclusion of agreements among the Member States in which the contracting parties would lay down rules determining which State is to pay a grant. Community law does not object

362. Compare T.M.C. Asser Instituut, Studiefinanciering buiten Nederland in het Licht van de Europese Jurisprudentie (2000) pp.37-41.

363. Comparc van der Stecn (1999) supra footnote 98, at p.214. 
to such agreements provided they respect the rights which students enjoy under Community law. ${ }^{364}$ If a right to export study grants were to be recognised, such agreements would only seem useful in multi-lateral settings. In situations where only two States are involved, Community law prescribes that the State of the studies is to offer grants in as far as these cover tuition and the State of origin would have to give aid for the cost of maintenance. Arguably, the best method would be to develop priority rules for study grants comparable to those contained in Regulation No 1408/71 for family benefits. Article 76 of Regulation No 1408/71 and Article 10 of the implementing Regulation No 574/72 contain various rules which seek to avoid overlap in entitlements to family benefits in cases where a child's parents work and/or live in different Member States. In brief, the priority rules determine which State is to pay family benefits and they entitle other States to suspend payment up to the level paid in the assigned State where a right to family benefits may exists on the basis of national law or Regulation No 1408/71. Without elaborating on the numerous and detailed questions which would have to be adressed in developing priority rules for study grants, one could consider bringing grants within the scope of Regulation No 1408/71 and inserting a basic provision comparable to Article 73 which would in principle entitle students to study grants in the State from which they have moved. In addition, a provision could be included which would entitle this State to suspend payment up to the amount that students are entitled to grants covering tuition fees in the State where they study and, possibly, in so far as cost of maintenance in the State where beneficiaries study are lower than "at home". Where entitlement to maintenance grants exists in more than one State, one could consider a provision comparable to Article 76 of Regulation No 1408/71 which would establish the rule that maintenance grants are in principle to be paid by the State where the student resided prior to taking up their studies in another Member State. For situations in which students would have a right to grants in two Member States other than the one in which they lived before their studies, one could further draw inspiration from Article 10(3) of Regulation No $574 / 72$ and establish a rule that the State with the highest maintenance is to pay such a grant and will be entitled to be reimbursed by the "other" State for half of the sum involved.

364. Casc 235/87 Matteucci [1988] ECR 5589 at 19 


\subsubsection{Right to Reside and the Financial Means Requirement}

In considering how the legal status of Community students could be improved, some comments are finally to be made on the conditions that students must fulfil in order to reside in the State of their studies. According to Article 1 of Directive No 93/96, students must be sufficiently insured for medical care and they must assure the relevant national authorities that they have sufficient resources to avoid becoming a burden on the social assistance system of the host Member State. The formulation of the latter requirement is far from clear. ${ }^{365}$ In order to avoid legal uncertainty, it has rightly been suggested that it would have been better if the Directive had stated that the right to reside remained as long as the student did not actually become a burden on the host State's public purse. $^{366}$ One could, however, go one step further and ask whether the financial means requirement might not be deleted altogether.

In Raulin (1992) the Court held that the residence right of students is not granted unconditionally. As a corollary of the right to non-discriminatory access to education, the right of residence is confined to what is necessary to allow the student to study in other Member States. ${ }^{367}$ Consequently, the right may be limited to the duration of their studies and be made subject to conditions deriving from the legitimate interests of the host Member State "such as the covering of maintenance cost and health insurance" to which the principle of non-discrimination was said not to apply. ${ }^{368}$ The reasoning of the Couwas not persuasive. ${ }^{369}$ In Lair the Court had held that study grants covering maintenance cost fall outside the scope of Article 12(1) of the Treaty because such grants are matters of "educational policy, which is not as such included in the spheres entrusted to the Community institutions" and "social policy, which falls within the competence of the Member States". ${ }^{370}$ On the basis of these observations one would have to conclude that not only study grants but also social assistance benefits fall outside the scope of Article 12(1) EC. Yet, the exclusion of maintenance grants and social benefits from the scope of Community law would rather seem to support the view that there is no need to make students' residence conditional upon fulfillment of the

365. See Section 4.5.

366. Vermeulen/Kuijer (1997) supra footnote 4, at p.66.

367. Case C-357/89 Raulin [1992] ECR I-1027 at 39.

368. Ibid, at 38 .

369. Compare O'Leary, The Social Dimension of Community Citizenship, in: Rosas/Antola A Citizens' Europe - In Search of a New Order (1995) pp.156-181, at pp.174-176.

370. Case 39/86 Lair [1988] ECR 3161 at 14-15. 
financial means and health insurance requirements. Why should Community students have to make it plausible that they will not become a burden on the host State's public purse, when they are not entitled to claim study grants or social assistance benefits there in any event? The protection of the financial stability of study grant and social assistance schemes is no doubt a legitimate interest which deserves protection under Community law, but if students cannot gain access to these schemes, this interest would not seem to be affected. The ruling in Martinez Sala does not necesarrily change the picture. Even if study grants covering maintenance cost and social assistance benefits do indeed fall within the scope of Article 12(1) EC, Member States, arguably, could still make eligibility for the grants and benefits conditional upon domicile in the national territory, a requirement which students need not meet. ${ }^{371}$ A possible abolition or invalidation of the financial means requirement is not likely to have many, if any, financial implications for the host State. ${ }^{372}$ The opposite might even hold true. The administrative cost of enforcing the requirement ${ }^{373}$ could be saved. It is to be assumed that the conclusions drawn in Raulin still stand, but it is submitted that the duty imposed on students to persuade immigration authorities that they will not become a public burden constitutes an unnecessary burden on their Community right to study in other Member States.

371. As regards study grants see Section 4.4 of the present Chapter and as regards social assistance benefits see Chapter 3 Section 6. An alternative line of reasoning may be possible, however. See the Opinion of Advocate General in Grzelczyk as discussed in footnote 172.

372. Indeed there are no signs that students have, or will, become a burden on the social assistance schemes of host States. In a report to the Parliament and Council on the implementation of the 1990 residence directives the Commission stated that it had asked the Member States how many students had become a burden on their social assistance schemes since the implementation of the directives and what steps had been taken in response. None of the Member States provided any data. This may not come as a real surprise. As a rule, students will not be able to claim benefits because they may not be able to meet substantive criteria for benefit entitlement such as being obliged to look for and accept (full-time) work. Compare also the Opinion of Advocate General in Case 42/98 Commission v Italy [2000] ECR I-0000 at 28. Admittedly, the above does not necessarily imply that no students have obtained social assistance benefits, but the States' responses do strongly suggest that the issue does not have much practical relevance.

373. Compare Hoepelman, Het Verblijfsrecht van Studenten uit EU-Staten: De Praktijk aan een Nederlandse Universiteit, in: Fernhout (Red.), Dertig Jaar Vrij Verkeer van Werknemers (1999) pp.103-116. 
9.4 Options for Protecting the Educational Interests of the Member States

As stated in Section 9.2, student mobility is unlikely to trigger an educational "race to the bottom" within the Community. Arguments for promoting student mobility further are more persuasive than calls for compensating or protective measures for the (few) Member States that are netimporters of students. Nonetheless, the problems which these States may face cannot be wholly ignored. An increase in student mobility could also increase the imbalances in student movement and this may cause (additional) financial or capacity problems for the net-importers. How can such problems possibly be avoided or minimised?

\subsubsection{Reimbursement Mechanisms}

In response to concerns about the imbalances in student movement and the unequal financial burdens imposed on some Member States, it has been suggested that student mobility could be better promoted by requiring Member States to pay the true economic cost of the education which their nationals and/or residents receive abroad. ${ }^{374}$ Such reimbursement systems have been expected to produce the dual effect of encouraging governments to improve the quality of their educational courses as an element of educational "competition", while guaranteeing the quality of national education by not subjecting it to an open-ended and undetermined influx of foreign students. ${ }^{375}$ In developing such a scheme, one might draw inspiration from Chapter 4 and consider setting up a reimbursement scheme comparible to the one established by Regulations Nos 1408/71 and $574 / 72$ for cross-border health care rights. ${ }^{376}$ Reimbursement

374. O'Leary (1996) supra footnote 4, at pp.189-190; Kampf, La Directive 90/366/CEE relative au Droit de Séjour des Etudiants communautaires: Sa Transposition en France, In: RMC (1992) pp.307 et seq, at p.317; Hartley (1991) supra footnote 4, at p.193 and Scholsem (1989) supra footnote 316 , at p.318.

375. O'Leary (1996) supra footnote 4, at pp.189-190. Such ideas for a repayment system to the benefit of student importing countries show similarities with the ideas for introducing a student voucher system which -being be guided by the principle that "money will follow the student"- would enable students to choose in which of the Member States they wish to study at the expense of their "own" State. Undervisnings Ministeriet, A Short Presentation of the Danish Presidency's Main Themes in Education (1993).

376. See Chapter 4 Section 3. See also the Opinion of Advocate General Slynn in Humbel: "The analogy with health care is striking since, although Community nationals by and large are entitled to medical care throughout the Community, that entitlement is underpinned by a 
schemes seem appealing because they take into consideration the fact that student movement within the Community is not in balance. They releave the net-importers of students of the unequal financial burden they bear and the schemes impose this burden on the States where taxes have been paid by the students (or their parents) and where they may (or are likely) to return to upon graduation.

Nonetheless, the feasibility and, arguably desirability, of reimbursement mechanisms scheme is questionable. The core problem is that such schemes compel States to repay the costs incurred by other Member States. They would be required to invest in the educational systems of other States. Since students may move to States with more expensive educational systems, such reimbursement mechanisms would imply that the "poorer" Member States are required to reimburse the richer Member States. Educational expenses of the poorer States would increase and it is likely that these States would prefer to invest in the development of their own educational systems. The Nordic countries have been working on a repayment scheme but so far they have not been succesfull. ${ }^{377}$ If the Nordic States are unable to reach agreement on such a scheme, then in view of the much bigger differences in public expenditure on public education among the Community's Member States, one may doubt whether a system in which the State of origin has to "pay the educational

complex system designed to determine which State should ultimately bear the cost of treatment. It is to my mind unfortunate that no such system for education throughout the Community exists". Case 263/886 Humbel [1988] ECR 5365 at p.5380.

377. As stated above in footnote 233, the Nordic countries (Iceland, Norway, Sweden, Finland and Denmark) have always promoted international student mobility. In 1991 the "Cooperation Programme for Higher Education in the Nordic Countries" was adopted in which the five States agreed to further promote student mobility and competition among educational institutions with a view to improving the quality of education. In 1994 an additional agreement on admission to higher education was signed in which Nordic students were not only granted several equal treatment rights, but in which the five States also indicated that the promotion of student mobility should be planned in gradual stages. Thus, on a temporary basis quotas for Nordic students were envisaged and the Nordic States declared their intention to reach a mutual agreement on the settlement of the costs of education. More concretely, it was intended that the State of origin should bear the cost of the education which their "free-moving" students, i.e. students who study outside Nordplus, receive in other Nordic States. Even though the total cost involved did not seem exhorbitant, it has appeared quite difficult to reach agreement on establishing a reimbursement scheme. It was intended that such a scheme would only be set up for a limited group of studies, but no agreement could be reached on the selection of these studies. In addition, States have been unable to agree on the possibility of student-sending countries limiting the number of students on behlaf of whom hey have to bear the educational costs. Partial reimbursement from a special Nordic fund has been considered as an alternative, but such a fund has not yet been set up. See further e.g. Nyborg (1996) supra footnote 227, at pp.193-203. 
bill" is viable. ${ }^{378}$ In the alternative, one might consider setting up a fund at Community level out of which the "net-importing" States would be reimbursed. The chances of having such a fund approved by the Member States may be somewhat greater, but still seem to be minimal. In whatever way such a common reimbursement fund might be financed, it can probably only operate effectively if richer Member States were the netrecipients and poorer States the net-contributors. The latter, as one might expect and arguably should respect, would be unwilling to co-operate.

\subsubsection{Differential Tuition Policies}

If it is neither feasible nor desirable to impose the cost of education of free-riding students on either the Community or the Member State of origin, then one could consider protecting the educational interests of the student importing countries by allowing them to apply differential tuition policies comparable to those applied by American States (or universities).

In order to do so, it is first necessary to look again at Gravier and to ascertain whether the Court has already ruled out the possibility of pursuing such policies. When the Belgian legislator introduced the Minerval in early 1970s, it seemed inspired by American differential tuition policies. The Minerval was introduced in order to ensure "a certain financial stability" of the educational system. ${ }^{379}$ Foreign students had to compensate for the fact that, unlike Belgian nationals and residents of Belgium, their income is not taxable and thus they cannot be required to contribute to the education they enjoy in Belgium. In Gravier the Court did not go into this "tax-payer argument". It merely concluded that the inequality of treatment inherent in the Minerval rules constitutes discrimination on grounds of nationality. The Court's silence on the "tax-payer argument" has been understood to imply that the Court also rejected the rationale behind the Minerval and that this, for practical reasons, would

378. See also van der Mei (1998) supra footnote 74 , at p.400. The possibility cannot be excluded that a reimbursement system will act as a brake on mobility within the EU. The cost incurred by mobile students, might encourage the "poorer" Member States to "keep their nationals at home". Baligant et al, Economic Analysis of Student Mobility on a European Scale (quoted in Nyborg (1996) supra footnote 227, at p.202). Furthermore, in the field of health care Member States may have set up a reimbursement scheme, but it is precisely as regards patients who would move to other States for the sole purpose of obtaining benefits that Member States have always opposed a duty of reimbursement. See Chapter 4 Section 3.3

379. See the Opinion of Advocate General Slynn in Case 293/83 Gravier [1985] ECR 593, at p.596. 
have been a correct decision for the Court. ${ }^{380}$ During their studies foreign students pay indirect taxes and they (or their parents) may before or after their studies work and be taxed in the State concerned. Also, not all residents pay taxes, but they can nonetheless benefit fully from public education. ${ }^{381}$ The relationship between the paying of taxes and the right to benefit from education funded out of the tax revenues would be too confusing to make a connection between the taxes paid and the rates for tuition.

With respect, this interpretation of Gravier is not wholly persuasive. First, under Belgian legislation Belgian students did not have to pay the Minerval. The law governing the Minerval was partly based on nationality criteria and thus constituted direct discrimination on grounds of nationality. The question whether the Belgian rules could be justified was not, and did not have to be, addressed by the Court. Second, the above reading of the "tax-payer-argument" does not seem based on a correct reproduction of the arguments for pursuing differential tuition policies. Neither the Belgian authorities nor any of the American States have ever claimed that the amount of tuition to be paid should be calculated on the basis of the taxes which have been, are or will be paid. In the logic behind differential tuition policies there is no scope for non-resident students to prove that they have in the past paid "more than enough" taxes. Such policies are not based on the principle of juste retour. As part of redistributive policies, they are based rather on a notion of residence or membership. As a class, non-residents have not contributed to the funding of public education through the payment of taxes and, as a class, they cannot benefit from the lower tuition rate for residents.

In Gravier the Court did not express a view on the rationale behind the Minerval. The question whether national rules which, without making any distinction on grounds of nationality, impose higher fees on students who have merely come to the Member State concerned for educational reasons, remains in principle unanswered. In his Opinion in Gravier Advocate General Slynn suggested that such rules might be compatible with Article $12 \mathrm{EC}$ where he held that there "is force in the argument that it is not discriminatory to require those who do not contribute directly or indirectly to the common weal to make some contribution". ${ }^{382}$ In practice, such rules would primarily work to the detriment of nationals from other Member States and they may therefore constitute

380. Timmermans (1986) supra footnote 126, at p.91.

381. Compare also von Wilmowsky (1991) supra footnote 161, at p.256 (footnote 91).

382. Opinion of Advocate General Slynn in Case 293/83 Gravier [1985] ECR I-593 at p.604. 
indirect discrimination on grounds of nationality. However, differential tuition fees could possibly escape the prohibition enshrined in Article 12(1) EC where it can be demonstrated that they are necessary for, and proportional to, the legitimate financial and educational interests of the Member States. ${ }^{383}$ As regards Member States which are structurally faced with a net-import of European students, and which set the nonresident tuition fees at such a rate as to cover the marginal cost of foreign students, it could be argued that there is indeed force in the "tax-payer argument". Whereas other alternatives such as e.g. non-resident quotas directly restrict or hinder admission to universities, differential tuition policies merely make admission more expensive. If States were to calculate non-resident tuition fees in such a way as to cover the total cost of education offered to non-resident students, student mobility would not impose additional pressure on their educational budget and they would possess the funds to cope with possible capacity problems. With "nonresidents completely paying their own way", Member States could spend whatever amount they wished to educate their own "citizens and .. accomodate non-residents at the same time". ${ }^{384}$

Nonetheless, differential tuition policies also have clear disadvantages. If States were to have the right to charge non-resident students higher tuition fees, they could set the fee at a rate which exceeds the marginal cost of the education offered to non-resident students. In theory, they could shift part of the burden of funding resident students on to nonresident students. Moreover, differential tuition policies would enable Member States to regulate or control the admission of students from other Member States. Tuition fees for non-resident students could even be made so high that not a single student would consider studying in the Member State concerned. In other words, there is no guarantee that the power to charge higher tuition fees on non-resident students will not be excessively used or even abused. In the United States no "abuses" have been reported, but this does not mean that these could not occur in the European Community. Member States have no experience of differential tuition policies

383. See van der Mei (1994) supra footnote 20, at pp.206-207.

384. Paraphrasing Note, The Constitutionality of Nonresident Tuition (1971) supra footnote 249, at pp.1150-1151. Furthermore, the mere fact that non-resident students have to pay higher tuition fees than resident students does not have to affect student mobility. The threshold for studying in another State where "free-riders" have to pay 2000 Euro and domiciled students only 1000 Euro, is much lower than in a State where all students have to pay 3000 Euro. The degree to which student mobility is hampered does not depend on a difference between the fees to be paid by the various students, but on the question of how much tuition must be paid. 
and, more than the American States, they have always expressed concerns about the impact of student mobility on (the financing of) their systems of higher education. Differential tuition policies would seem to require some form of supervision as to how the power to charge higher tuition fees to non-residents will be used. The possibility cannot be wholly excluded, but in view of the judicial reluctance to second-guess economic choices, one may doubt whether differential tuition policies have a good chance of being accepted. ${ }^{385}$

\subsubsection{Quantitative Restrictions}

If reimbursement schemes and differential tuition policies are neither feasible nor desirable, one might consider the alternative of allowing Member States that are net-importers of students to impose limits on the number of students they admit to their universities. The lawfulness of quotas would seem to depend on the criteria applied. Numerus clausus regulations which limit the number of student places on the basis of social need would seem in order, ${ }^{386}$ whilst the oppositie holds true for rules limiting the number of students on the basis of nationality. The question to be addressed is whether Member States, with a view to protecting their educational interests, are permitted to adopt rules limiting the number of non-residents, i.e. students who prior to the commencement of their studies resided in other Member States, that will be admitted to their universities. At first glance, the prospect of having such rules accepted by

385. Furthermore, the policies would also raise some questions as to who is to be regarded as a resident for tuition purposes. The rationale behind differential tuition policies demands that Community students are to be regarded as non-residents. The mere fact that they enjoy under Article 12(1) EC juncto Directive No 93/96 a right to reside in the State of their studies cannot suffice. As regards Community students who hold the nationality of another Member State no difficult issues arise. Those who reside as Community students in the State concerned can be classed as non-residents, whilst the nationals of other Member States whose right to reside is based on Article(s) 39 (or 43) EC or one of the other two 1990 directives can claim to be residents for the purposes of tuition policy. Administrative problems comparable to the ones American States and universities confront, could arise as regards national students who have returned from abroad. Should they be treated as nonresidents or as residents? How can they prove that they are not free-riders who have merely retrurned for educational purposes?

386. Oertzen (1992) supra footnote 4, at p.225 and Verbruggen (1992) supra footnote 4, at p.61. In Bertini (1986) the Court still suggested that the Council could possibly introduce quantatitive limitations (Joined Cases 98, 162 and 258/85 Bertini [1986] ECR 1885 at 11), but in view of Article 149(4) (prohibition of harmonisation of educational laws and regulations) this would seem very doubtful. 
the Court or the Council seem very remote. The rules would seem to hamper student mobility far more than differential tuition policies do and they may even be regarded as a de facto denial of the right to study in other Member States once the fixed number has been reached. Nonetheless, one cannot wholly exclude the possibility that such quantitative restrictions, albeit in exceptional circumstances, might be compatible with Community law. Restrictions on the number of non-residents that will be admitted could possibly escape the classification of a prohibited indirect discrimination on grounds of nationality where it can be proven that they are necessary for maintaining the quality and accessibility of educational systems. It does not seem wholly impossible that such evidence could be provided. A substantial influx of students from other Member States could have implications for the funding and infrastructure of educational systems. Such an influx could cause overcrowded lecture rooms, affect professor-student ratios or limit housing and other student-related facilities. States which decided to expand educational facilities might face problems of overcapacity if in subsequent years the number of enrolments were to drop. Such problems might affect the quality and/or funding of higher education and they might be avoided if States were entitled to control and limit numbers of students. ${ }^{387}$ It could be argued that some form of preferential treatment of residents, might be necessary for maintaining adequate educational systems. For instance, due to numerus clausus regulations applicable in the Netherlands, many Dutch students have decided to study in Belgium. Dutch students are even encouraged to do so by "their own" Minister of Education who has allowed them to export study grants when they embark on certain studies at Belgian universities. As a result, in some Flemish faculties more than $50 \%$ of the students are Dutch. In such situations, would it not be desirable to allow Belgium or the Flemish community to impose certain limits on access of students from the Netherlands? In Belgium much importance has traditionally been attached to freedom of choice in the field of education, but, as a result of numerus clausus applied in the Netherlands, the Flemish community may be forced to take certain measures which might consist of the introduction of numerus clausus. The Court may not be easily persuaded, but it is submitted that Member States should be entitled to limit the number of non-residents that will be admitted to their education systems in (exceptional) cases where such measures are needed in order to

387. Compare Varat, 'State Citizenship' and Interstate Equality, in: ChicLRev (1982) pp.487 et seq, at pp.553-554. 
guarantee a "balanced educational system open to all"388 or de facto force them to adopt measures which inflict upon their autonomy in the field of education.

\subsection{Conclusions}

The main rules and principles governing the cross-border access to education, and the free movement of students in particular, were developed in the mid and late 1980s. The Court, the main initiator, has made a significant contribution to achieving the goal of promoting the free movement of persons by conferring upon Community citizens quite extensive educational rights. At the same time, the Court has taken into consideration the educational interests of Member States in particular by allowing them to preserve "full" study grants for those who are domiciled or working within the national territory. The way the Court has attempted to strike a balance between the free movement goal and States' educational interests has not gone without criticism, but the main rules developed by the Court seem to be widely supported. This is not to say that Community law on cross-border access to education is wholly satisfactory. As the Commission indicated in its 1996 Green paper on educational mobility there are still quite a lot of obstacles which may dissuade students from studying in other Member States. The Commission itself has taken various initiatives to decrease or eliminate many of these obstacles, but one cannot wholly exclude the possibility that the Court may have to assist. Such judicial help could be particularly welcome with attempts to promote the transferability of study grants.

388. Indeed, a comparison may again be made with health care. In Kohll the Court took into consideration the impact which patient mobility might have on the infrastructure of medical and hospital services by allowing the States to impose restrictions on the free movement of services which are necessary for protecting a "medical and hospital service open to all". Chapter 4 Section 4.2.4. Kohll was primarily concerned with States from which patients move, but as stated in Chapter 4 Section 4.5, it could be argued that the possibility of imposing restrictions on the free movement of patients is also, if not above all, relevant to the "receiving" State. 
Chapter 6

CONCLUSIONS 

In the course of the last four decades, European Community law has increasingly imposed restraints on Member States' powers to regulate access of non-nationals to their territories and welfare state services. In the late 1950s, when the Community was established and the foundations of the current welfare states were laid down, Member States were still largely sovereign to control immigration and to determine whether, when and the conditions under which, non-nationals were accorded access to their public services. ${ }^{1}$ For non-nationals access to public benefits was most often a privilege, not a right. Today, nationals of the Member States enjoy, as citizens of the European Union, a whole set of legally enforcable rights which entitle them to enter, reside in and gain access to public services in other Member States. This book has also shown, however, that the gates to the territories and welfare states ${ }^{2}$ have not been opened completely. Community law on freedom of movement and non-discrimination has not been construed so broadly as to enable Union citizens to freely "shop around" for public benefits. Member States still hold significant powers to protect themselves against "welfare tourism" and to secure the funding and/or organisation of their benefit systems. In each of the three fields discussed in this book, Community law governing crossborder access to public benefits entails a compromise between the competing interests of promoting freedom of movement and protecting public benefit systems.

Standing back from the more detailed issues which have already been addressed and the concrete questions which arise in individual cases, this final chapter will draw certain horizontal comparisons and consider how Community law has sought to reconcile the previously mentioned competing interests. The aim is to explore whether Community law provides for general rules or principles which have been, and are to be, applied when answering questions on cross-border access to public services which, no doubt, will continue to arise in future years. ${ }^{3}$ In doing

\footnotetext{
${ }^{1}$ Compare Leibfried/Pierson, Semisovereign Welfare States: Social Policy in a Multitiered Europe, in: Leibfried/Pierson, European Social Policy - Between Fragmentation and Integration (1995) pp.43-77, at p.50).

${ }^{2}$ Compare Entzinger, De Andere Grenzen van de Verzorgingsstaat - Migratiestromen and Migratiebeleid, in: Engbersen, Zorgen in het Europese Huis - De Grenzen van Nationale Verzorgingsstaaten (1994) pp.142-172.

${ }^{3}$ The main focus will be on the general provisions governing freedom of movement and equality of treatment. The more specific rules and principles of the social security Regulations Nos $1408 / 71$ and $574 / 72$ are not the subject of analysis.
} 
so, only three categories of persons will be dealt with: residents, nonresidents and third country nationals. The first category is discussed in Section 2 and consists, for purposes of this Chapter, of all Union citizens who are lawfully residing in the territory of another Member State. Section 3 considers "non-residents" which includes all Union citizens who merely travel to another Member State without relocating their economic base or private residence. In Section 4 some brief comments are made on third country nationals.

\section{$2 \quad$ Residents}

\subsection{Introduction}

Community law confers residence rights upon various categories of Union citizens and each of these enjoys legal protection against discriminatory treatment in other Member States. The conditions under which residence rights can be exercised still differ from category to category, but as regards the legal status of those who have exercised the right in the host State, a comparable development can be detected. In brief, Community law has gradually been heading in the direction, and, arguably, can be interpreted as already having reached the point, of guaranteeing all Union citizens the right to gain access to (virtually all) public benefits under the same conditions as the nationals of the host State from the moment they establish residence in another Member State until the day they voluntarily give up or are involuntarily deprived of their status of lawful resident. Under certain conditions, Member States are still empowered to refuse, or end, residence of nationals of other Member States, but the case law suggests that they are no longer entitled to protect the funding and/or organisation of their public benefits systems by making distinctions among Union citizens lawfully residing within their borders on grounds of nationality or length of residence. Union citizenship may not (yet) give entitlement to a general and unconditional right of residence, but it does guarantee "full and equal membership" of the welfare state for all those citizens who have established residence in another Member State. This membership status may be labelled "denizenship", a concept which has been used to describe the status of non-nationals who have acquired 
secure or permanent resident status and who enjoy the same rights as do nationals with the exception of political rights such as the right to vote and stand as a candidate in elections. ${ }^{4}$

\subsection{Community Workers}

The roots of this development are found in the case law on the free movement of workers. In the late 1960s, when it formally realised the free movement of workers, the Council spoke in the preamble to Regulation No 1612/68 of a "fundamental right" which can be exercised in "freedom and dignity", can improve workers' "living and working conditions" and which may help to promote their "social advancement". 5 These promising goals were not supported by the grant of an extensive set of rights in the substantive part of the Regulation. Besides rights directly concerning the taking up of employment, ${ }^{6}$ workers were not given much more than a right to equal treatment with respect to vocational training, ${ }^{7}$ trade union activities, ${ }^{8}$ other "social advantages" ${ }^{19}$ related to employment $^{10}$ and housing facilities. ${ }^{11}$ Workers were supposed to provide for themselves through full-time work and if they were unable to generate sufficient financial means due to sickness, incapacity for work or unemployment, they could claim benefits under the Community rules on the co-ordination of social security schemes. In the view of the Community legislator, equality of treatment was to be guaranteed in the fields of labour law and social security law, but the access to residence-based benefits such as social assistance, general education and study grants was, and would remain, regulated by national law. Workers were still primarily seen as "economic agents" who were offered some social protection but

${ }^{4}$ See Hammar, Democracy and the Nation State: Aliens: Denizens and Citizens in a World of International Migration (1990) at pp.12-13; Layton-Henry, Citizenship or Denizenship for Migrant Workers, in: Layton-Henry (Ed.), The Political Rights of Migrant Workers in Western Europe (1990) pp.186-195, at p.188 and Brubaker, Membership without Citizenship: The Economic and Social Rights of Non-citizens, in: Brubaker, Immigration and the Politics of Citizenship in Europe and North America (1989) pp.145-162.

${ }^{5}$ See the third and fifth recitals of the preamble to Regulation No 1612/68.

${ }^{6}$ Articles 1-6 of Regulation No 1612/68.

${ }^{7}$ Article 7(3) of Regulation No 1612/68

${ }^{8}$ Article 8 of Regulation No $1612 / 68$.

${ }^{9}$ Article 7(2) of Regulation No 1612/68.

${ }^{10}$ The notion of "social advantages" was probably understood to cover only employment related issues. O'Keeffe, Equal Rights for Migrants: The Concept of Social Advantages in Article 7(2), Regulation 1612/68, in: YEL (1986) pp.93-123, at p.95

${ }^{11}$ Article 9 of Regulation No $1612 / 68$. 
were not viewed as "fully-fledged" and "equal members" of the host States' society and welfare state.

Since the mid-1970s, however, the Court of Justice has assumed responsibility for promoting freedom of movement for workers. It has largely filled the gap between the intentions proclaimed in the preamble and the concrete provisions contained in the substantive part of Regulation No 1612/68. Two issues have been particularly relevant. The first concerns the Court's interpretation of the concept of worker. Unemployment and changing patterns in the labour market, have led to new forms of labour (e.g. on-call contracts, part-time work and home-work) which are for many persons the main, if not the sole, possibility of making a living and improving their living conditions. The emergence of these new forms of labour has encouraged, and in fact compelled, ${ }^{12}$ the Court to recognise that "flexible" workers, even when their income is "lower than what is considered to be the minimum required for subsistence", ${ }^{13}$ can benefit from the free movement regime. ${ }^{14}$ The second significant development concerns the notion of "social advantages" of Article 7(2) of Regulation No 1612/68. The broad definition the Court has given to the notion of social advantages not only implies an extension of the scope of the right to equal treatment, but also reflects a change in perception. The concept not only covers benefits granted to national workers "primarily because of their status of workers", but also benefits which are offered "by virtue of the mere fact of .. residence" in the territory of the host State. ${ }^{15}$ Workers

${ }^{12}$ O'Leary, The Principle of Equal treatment on Grounds of Nationality in Article 6 EC A Lucrative Source for Member State Nationals? in: O'Leary/Tiilikainen (Eds), Citizenship and Nationality Status in the New Europe (1998) pp.105-136, at p.116.

${ }_{13}^{13}$ Case 53/81 Levin [1982] ECR 1035 at 15.

${ }^{14}$ Ibid (part-timer workers) and Case C-357/89 Raulin [1992] ECR I-1027 at 11 (on-call contracts).

${ }^{15}$ Case $207 / 78$ Even [1979] ECR 2019 at 22. In a proposal for amending Regulation No $1612 / 68$ (COM(1998) 394 def) the Commission has suggested replacing the current Article $7(2)$ by a provision which reads that a "worker who is a national of a Member State shall enjoy the same financial, fiscal, social, cultural and other advantages as nationals workers". The reference to "other advantages" suggests a significant extension of the scope of the right to equal treatment. See e.g. Sewandono, Het Commissievoorstel tot Wijziging van Verordening (EEG) nr.1612/68: Meer Bescherming van Familie- en Gezinsleven en Meer Gelijke Behandeling, in: SEW (1999) pp.284-290, at p.287). On the face of it, the proposed new Article 7(2) leaves room for the suggestion that political rights such as the right to vote and stand as a candidate in elections or other rights typically linked to posession of the nationality of the host State might be covered. This, however, is not the intention. The proposal does not intend to more than to codify the case law of the Court. COM(1998) 394 def, Explanatory Memorandum at p.15. In its explanatory memorandum the Commission refers to various advantages such as those concerning leisure activities and this might possibly be understood to imply that the notion of "other" advantages is intended as the codification of a ruling such 
are thus not only (to be) viewed and treated as "members" of the work force, but, indeed, also as residents who, as "members" of the host State's welfare state, are to be offered access to virtually all ${ }^{16}$ public services available in the host State. ${ }^{17}$

The Court has recognised, however, that the concept of worker and the notion of social advantages cannot both be interpreted too broadly. In order to give regard to States' legitimate concerns about the funding of their welfare state facilities, some safeguard had to be built into the free movement regime. The Court has not chosen ${ }^{18}$ the option of allowing Member States to apply rules which make entitlement to benefits conditional upon minimum period of residence or employment. ${ }^{19}$ Rather,

as Case C-334/94 Commission v France [1996] ECR 1307. Further, in the proposed Article(s 7(1) and) 7(2) the phrase "in the territory of another Member State" can no longer be found. In the Explanatory Memorandum this change is not explained, but it might be understood as a codification of Matteucci (1988) in which the Court held that whenever a Member State offers its own nationals residing within the national territory benefits to be enjoyed outside that territory (i.e. study grants) it is obliged to offer such rights under the same conditions to Community workers. Case 235/87 Matteucci [1988] ECR 5589 at 16.

${ }^{16}$ Only certain benefits linked to military service (Case C-315/94 De Vos [1996] ECR I4117 at 22) or benefits for war veterans (Case 207/78 Even [1979] ECR 2019 at 23) are excluded.

${ }^{17}$ The fact that benefits fall within, or derive from, policy areas which have not been brought within the ambit of the Treaty is of no significance. It is settled case-law that in areas (still) falling within their domain, Member States must also obey the Community principles of freedom of movement and non-discrimination. See e.g. Case 65/81 Reina [1982] ECR 33 at 15 (demographic policy) and Case C-279/93 Schumacker [1995] ECR I225 at 21-24 (tax law). The scope of the right to equal treatment of workers is determined by a functional criterion which means that equality of treatment is to be guaranteed in as far as it may facilitate freedom of movement and the integration of the worker in the host State's society. See Chapter 2 Section 2.2.3.

${ }^{18}$ Compare e.g. Steiner, The Right to Welfare: Equality and Equity under Community Law, in: ELRev (1987) pp.477 et seq, at p.41 and Hailbronner, Die neuere Rechtsprechung zum EG-Freizugigkeitsrecht, in: ZAR (1988) pp.3-13, at p.6.

${ }^{19}$ Waiting-period requirements applied to non-nationals only, constitute direct discrimination on grounds of nationality and are consequently prohibited. Case 249/83 Hoeckx [1985] ECR 982 at 23-24 and Case 39/86 Lair [1988] ECR 3161 at 42. Further, the Court has held that durational residence requirements applied to nationals and non-nationals alike constitute indirect discrimination on grounds of nationality. Case C-111/92 Commission v Luxembourg [1993] ECR I-817 at 10 and Case C-326/90) Commission v Belgium [1992] ECR I-5517 at 3. To be sure, it could still be argued that waiting-period requirements applied to both nationals and non-nationals can possibly be justified on the ground that States, in order to protect the funding of their benefit schemes, should be entitled to reserve social benefits for those who for a given period of time have contributed to the funding of benefits by making tax-contributions. So far, the Court has never gone into such a "past contributions argument", but, because of the protection offered by the requirement of "effective and genuine work", one may doubt whether waiting-period requirements can be said to be 
the Court has opted to impose a threshold for obtaining the status of Community worker and the accompanying right to reside. This status can only be obtained by Community citizens whose work in another Member State can be considered "effective and genuine". Those whose activities are merely "marginal and ancillary" do not obtain the status of Community worker and the right to reside. ${ }^{20}$ Basically, the Court seems to have established the rule that Member States can only protect their welfare state interests by refusing residence to nationals of other Member States whose work cannot be regarded as "effective and genuine", but that Community citizens who meet that requirement are to be admitted for

necessary for, and proportional to, the public interest of safegurading the financial stability of public benefit systems. Further, national rules which make entitlement to certain benefits covered by Regulation No $1408 / 71$ conditional upon minimum periods of insurance or employment are not necessarily outlawed. The regulation prescribes that the competent institutions must take periods of insurance or employment in other Member States into account as if these were fulfilled under their own legislation (see e.g. Articles 18 (sickness and maternity benefits) and 67 (unemployment benefits)), but where this aggregation does not suffice for meeting the minimum period requirement, benefits can still be denied for the remaining period. Such waiting-period requirements cannot be circumvented by relying on Article $7(2)$ of Regulation No 1612/68. This regulation, as its Article 42 indicates, does not affect the regime of Regulation No $1408 / 71$. It could possibly be argued that Community citizens who, even with help of the aggregation rules, are unable to meet eligibility criteria concerning minimum periods of insurance or employment, can claim benefits under Articles $39 \mathrm{and} /$ or $12 \mathrm{EC}$ on the ground that the criteria constitute indirect discrimination on grounds of nationality, but the chances of the argument being accepted appear slim.

${ }^{20}$ See Case 53/81 Levin [1982] ECR 1035 at 17. It is of course hard to know the Court's true motives, but it would indeed seem that the Court has deliberately chosen to take into consideration Member States' welfare state interests through the interpretation of the notion of worker rather than by accepting the legality of durational residence or employment requirements (or by making enjoyment of right under Article $39 \mathrm{EC}$ conditional upon the motive of workers - Case 53/81 Levin [1982] ECR 1035 at 16). The concept of worker may not be defined by reference to national law (Case 53/81 Levin [1982] ECR 1035 at 11), but the three requirements of work, remuneration and subordination which the Court has laid down (Case 66/85 Lawrie Blum [1986] ECR I-2121 at 17) do indicate that the Court itself has been inspired by national definitions of the concept of worker. The requirement that work must also be "effective and genuine", however, cannot, at least to the knowledge of this author, be found in the labour laws of any of the Member States. The work performed by Community citizens whose jobs are according to the Court to be considered as "marginal and ancillary" may very well be economic in nature and, as a rule, part-time workers are seen and treated as workers under national labour laws. The "new" and "unique" requirement that work must be "effective and genuine" for the purposes of Article $39 \mathrm{EC}$ has been established by the Court itself and it is hard to find any other explanation than that this was done in defence of the Member States' welfare state interests. 
residence and to be treated as "equal members" of their society ${ }^{21}$ and welfare state from the moment they actually exercise that right.

\subsection{Family Members of Community Workers}

In the preamble to Regulation No 1612/68 the Council had stated that a freedom of movement requires $(i)$ a right for workers to be joined by family members and (ii) the elimination of obstacles to the integration of the family into the host country. ${ }^{22}$ The first point was taken seriously by the Community legislator. Article 10(1) confers the right to reside on quite a broad group of family members including the workers' spouse, their children below the age of 21 and other family members in the descending and ascending line who are dependent on the worker. ${ }^{23}$ The

\footnotetext{
${ }^{21}$ In this regard it may further be pointed out that the Commission has proposed to insert in Regulation No 1612/68 a new Article 1a which provides that within the scope of the Regulation "all discrimination on grounds of sex, racial or ethnic origin, religion, belief, disability, age or sexual orientation shall be prohibited". This proposed provision is to be set against the background of Article $13 \mathrm{EC}$ (inserted by "Amsterdam") which confers upon the Council the power to take appropriate action to combat discrimination based on the same grounds as those mentioned in the proposed new Article 1a of Regulation No 1612/68. On Article 13 EC see e.g. Bell, Equality and Diversity: Anti-Discrimination Law after Amsterdam, in: Shaw (Ed.), Social Law and Policy in an Evolving European Union (2000) pp.157170); Barnard, Article 13: Through the Looking Glass of Union Citizenship, in: O'Keeffe/Twomey (Eds), Legal Issues of the Amsterdam Treaty (1999) pp.375-394; Bell, The New Article 13 EC Treaty: A Sound Basis for European Anti-Discrimination Law?, in: MJ (1999) pp.5-23; Waddington, Testing the Limits of the EC Treaty Article on Non-Discrimination, in: IndLJ (1999) pp.133-151; Barents, Het Verdrag van Amsterdam in Werking (1999) Chapter 7 and Bell/Waddington, The 1996 Intergovernmental Conference and the Prospects of a Non-Discrimination Treaty Article, in: IndLJ (1996) pp.320-326.

${ }^{22}$ See the fifth recital of the preamble to Regulation No $1612 / 68$.

${ }^{23}$ The Commission has proposed to amend Article 10(1) and to offer the right to reside to (i) "any person corresponding to a spouse under the legislation of the host Member State", (ii) descendants and (iii) ascendants of the worker and the spouse as well as (iv) any other family member of the worker or spouse "who is dependent on the worker or is living under his roof in the Member State whence he comes". COM(1998) 394 def. The first point concerning "quasi-spouses" is a codification of the Court judgment in Case 59/85 Reed [1986] ECR I-1283. On this point, the proposal has been critically commented upon in the literature. See e.g. Sewandono (1999) supra footnote 15, at p.285. It has been suggested that Article 10 should also include partners who are put on a par by the legislation of the State of origin. See e.g. Sewandono, Werknemersverkeer en Gezinsleven (1998) at pp.296-298 and Carlier, Proportionality and Citizenship in relation to the Free Movement of Persons, in: Carlier/Verwilghen, Thirty Years of Free Movement of Workers in Europe (2000) pp.41-57, at p.53. See further also Jesserun d'Oliveira, Vrijheid van Verkeer voor Geregistreerde Partners in de Europese Unic, in: NJB (2001) pp.205-210 and Elman, The Limits of
} 
second point concerning the family's integration into the host State's society, however, seems to have less relevance for the legislator. Regulation No 1612/68 only mentions a right to pursue employed activities (Article 11$)^{24}$ and, for children, a right to gain access to education (Article 12) in the host State. The status of family members was deemed to derive from the status of the workers themselves. Family members would only have the right to reside in the State of employment when, and for as long as, the workers live there and, apart from the two rights mentioned in Articles 11 and 12, they could not claim any other rights in their own capacity. ${ }^{25}$ In more practical terms, family members could join the worker, but they would either have to provide for themselves through the income earned from work or be taken care of by the worker. They were not supposed to become a burden on the host State.

Step by step, however, the Court has strengthened the legal status of family members and developed a legal framework which may actually help them to integrate, in their own right, into the host State. Apart from the fact that the Court has interpreted Article 12 as to provide a full right to equal treatment for both dependent and independent ${ }^{26}$ children in the field of education, ${ }^{27}$ two steps have been particularly relevant. The first concerns dependent family members. Even though Article 7(2) of Regulation No $1612 / 68$ only refers to workers, the Court has held that dependent family members, regardless of their nationality, ${ }^{28}$ can also invoke ${ }^{29}$ this

Citizenship: Migration, Sex Discrimination, and Same-Sex Partners in EU Law, in: JCMS (2000) pp.729-749. The Commission's proposal is not understandable, however. As desirable and necessary as it may be to promote equal treatment of unmarried partners (of the same sex) and to facilitate freedom of movement for them, in a European Community where views and policies on such issues in question still differ, one must be critical of a rule which would impose on some States the views developed in others.

${ }^{24}$ The Commission has proposed to alter Article 11 as to explicitly entitle family members (holding the nationality of only a third State) the right to pursue self-employed activities too. COM(1998) 394 def.

${ }^{25}$ The derived status of family members was also reflected in the common social security rules. Article 1(f) of Regulation No 1408/71 defines family members as persons who are defined or recognised as family members by the legislation of the host State. This was understood to imply that family members could only claim derived rights (i.e. rights which are under national law specifically offered to, or for, family members such as family allowances and co-insurance for health care) under the Regulation to the exclusion of "personal rights" (i.e. rights which are granted to beneficiaries in their capacity as workers, residents or nationals). The latter were under the regime of Regulation No 1408/71 reserved for the workers themselves.

${ }^{26}$ See Case C-7/94 Gaal [1995] ECR I-1031.

${ }^{27}$ See further Chapter 5 Section 3.3.

${ }^{28}$ See e.g. Case 94/84 Deak [1985] ECR 1873. 
provision in order to claim equality of treatment as regards "social advantages". ${ }^{30}$ By invoking Article 7(2) dependent family members of Community workers can claim all rights and benefits which the host State's nationals enjoy in the capacity of workers ${ }^{31}$ or by virtue of residence $^{32}$ on the national territory. ${ }^{33}$ Dependent family members are not to be put on a par with the family members of nationals of the host State; rather, they are to be treated equally with these nationals themselves. ${ }^{34}$ The second step, arguably, has been taken in Martinez Sala (1998). In this case the Court held that $(i)$ all rights and benefits covered by Regulation No $1408 / 71$ and/or Regulation No $1612 / 68$ fall within the scope of

\footnotetext{
${ }^{29}$ Article 7(2) Regulation No $1612 / 68$ cannot only be relied upon by workers who are claiming benefits for, or on behalf of, their family members (see e.g. Case C-310/91 Schmid [1993] ECR I-3011 at 26), but also by the family members themselves (see e.g. Case C-3/90 Bernini [1992] ECR I-1072 at 26).

${ }^{30}$ Family members qualify only indirectly for equal treatment under Article 7(2). Benefits constitute "social advantages" only when they can be regarded as social advantages for the workers themselves. Case 317/85 Lebon [1987] ECR 2811 at 12. Even though the Court has never ruled so explicitly, it may be assumed that this right to equal treatment under Article 7(2) cannot only be enjoyed by the family members mentioned in Article $10(1)$ of Regulation No $1612 / 68$, but also by those who have been admitted for residence by virtue of Article 10(2)

${ }^{31}$ Compare Case 94/84 Deak [1985] ECR 1873 (concerning special unemployment benefits for work-seekers)

${ }^{32}$ See e.g. Case C-3/90 Bernini [1992] ECR I-1071 (concerning study grants).

33 Until recently (see footnote 40 below), Article 7(2) was particularly relevant for family members in the field of social security law. As stated in footnote 25 , in the view of the Community legislator, family members would only enjoy derived rights under Regulation No 1408/71 to the exclusion of "personal rights". This view was approved by the Court. Case 40/76 Kermaschek [1976] ECR 1669 at 7. In many cases, however, the Court has held that family members could claim such "personal rights" under Article 7(2) of Regulation No 1612/68. See e.g. Case C-310/91 Schmid [1993] ECR I-3011 at 13.

${ }^{34}$ To be sure, in Taghavi (1992) the Court held that the Iranian spouse of an Italian worker could not rely on Article $7(2)$ in order to claim an invalidity allowance in Belgium because spouses of Belgian workers could not claim such an allowance either under the applicable law. Case C-243/91 Taghavi [1992] ECR I4401 at 11. Taghavi, however, fit uneasily into the case-law (see e.g. Verschueren, Het Arrest Taghavi en de Tegemoetkoming voor Gehandicapten aan niet-EG-Familieleden van EG-Werknemers, in: MR (1993) pp.7475) and the ruling in Schmid (1993), in which the Court wholly ignored Taghavi and, concluded that the child of a Community worker could claim in Belgium a disability allowance under Article 7(2) even though the family members of Belgian workers could not claim such an allowance either, suggests that the conclusion drawn in Taghavi no longer stands. See also Chapter 3 Section 3.2. The Commission also seems to share this view. In its 1998 proposal for amending Regulation No 1612/68 (COM(1998) 394 fin) it has inserted an Article 10(3) which states that all family members entitled to live in a Member State under Article 10(1) or 10(2) "shall be entitled to all financial, tax, social, cultural or other advantages available to nationals" (ital: $\mathrm{APvdM}$ ).
} 
Community law and, thus, Article $12 \mathrm{EC}$ too and that (ii) the latter provision can be relied upon by nationals of a Member State who are "lawfully residing in the territory of another Member State". ${ }^{35}$ Martinez Sala did not concern family members, and the Court confirmed that only dependent family members can rely on Article 7(2) of Regulation No $1612 / 68$, but the ruling does not seem to leave room for any conclusion other than that independent family members who hold the nationality of a Member State $^{36}$ can invoke Article 12(1) EC in order to claim equal treatment as regards (virtually) all public benefits from the moment ${ }^{37}$ they establish residence in the host State. ${ }^{38}$ The immigration status of family members may still be dependent on $^{39}$ the status of the workers, but the same no longer seems to hold true for the rights they enjoy upon

\footnotetext{
${ }^{35}$ Case C-85/96 Martínez Sala [1998] ECR I-2681 at 57-61.
}

${ }^{36}$ Arguably, independent family members who only hold the nationality of a nonmember State also enjoy equality of treatment as regards virtually all public benefits. In Martinez Sala the Court only spoke of Union citizens who are lawfully residing in the territory of another Member State, but it seems indisputable that third country family members who have exercised the right to reside guaranteed by Article 10(1) of Regulation No 1612/68 fall within the personal scope of Community law, and thus, Article 12(1) EC. The legal position of family members who have been admitted to the State of the workers' employment by virtue of Article 10(2) of Regulation No 1612/68 is not wholly clear. They can rely on Article $7(2)$ of the Regulation, but it is not certain whether they can, in their own capacity, claim rights under Article 12(1) EC.

${ }^{37}$ National rules which make eligibility of non-nationals for social benefits conditional upon a minimum period of residence constitute direct discrimination on grounds of nationality (Compare Case 7/75 Mr: and Mrs. F [1975] ECR 679 at 17) and, as concluded in Chapter 3 Section 3.2.2, one may assume that waiting-period requirements applicable to non-national and nationals alike constitute indirect discrimination on grounds of nationality

${ }^{38}$ One may of course object and claim that the conclusion that all family members are entitled to claim "social advantages" may increase pressure on the financial budgets of social assistance and other public benefits systems. One could also argue, as the German government had done in the Lebon-proceedings (see Chapter 3 Section 3.2.2) that workers, by temporarily giving financial support to family members, enable these family members to obtain the right to reside and to claim social advantages in their own right. There are no indications, let alone any proof, however, that such abuses actually occur in practice. From the perspective of protecting the welfare state interests of the host States, the Lebon-rule is overinclusive and, arguably, there is no need to adhere to it. Also the Commission does not appear to see a need for the rule. It has proposed to insert a new Article 10(3) in Regulation No 1612/68 which directly (Explanatory Memorandum - COM(1998) 394 def at p.13) confers upon family members a right to equal treatment as regards "financial, tax, social, cultural or other advantages" (compare footnote 15 above)

${ }^{39}$ Blake, Family Life in Community Law: The Limits of Freedom and Dignity, in: Guild, The Legal Framework and Social Consequences of Free Movement of Persons in the European Union (1999) pp.7-17, at p.8. 
arrival in the host State's territory. ${ }^{40}$ Once, and for as long as, they lawfully reside there, family members are to be treated as "equal" and "independent" members of that State's society. For the Member States, the message following from the case law, and Martinez Sala in particular, is the same as in the case of the workers. Member States can only protect their "welfare state interests" by using their (remaining) immigrations powers. They are not entitled to do so by adopting and applying discriminatory rules governing the access to their welfare states.

\section{$2.4 \quad$ Non-Economic Residents}

Migrant workers and their family members may always have been seen as a potential threat to the welfare state, but this holds even more true for the economically inactive nationals of other States. In the early 1990s, Member States, as members of the Council, promoted European citizenship by recognising a general right of residence (Directive No 90/364) and, one year later, they were even willing to formally establish a Union citizenship (Article $17 \mathrm{EC}$ ) and to "constitutionalise" the right of residence (Article $18 \mathrm{EC}$ ). The Member States made it patently clear, however, that the non-economically active should not become a burden on the host States' welfare state systems, and social assistance schemes in particular. ${ }^{41}$ The afore mentioned directive provides that the non-economically active are only entitled to reside in another Member State when, and for as long as, they are able to provide for themselves and are sufficiently insured for health care. The wording of Article 18(1) EC indicates that the provision was not intended to bring about any substantive changes in the free movement regime. The right to reside freely is subject to the "limitations and conditions" laid down in the Treaty and secondary

\footnotetext{
${ }^{40}$ The willingness of the Court to strengthen the status of family members, and to regard them as equal members of the host State's society, is further demonstrated by the ruling in Cabanis-Issarte (1996) in which the Court (largely) abandoned the distinction between personal rights and derived rights (see footnote 33 above). Case C-87/94 Cabanis-Issarte [1996] ECR I-2097 at 30-44.

${ }^{41}$ In the words of Tomuschat: "The main gist .. is clear. A person who is not actively involved in economic life must take care of his or her vital necessities in a manner congruent with taking his or her own responsibility, without enjoying the right to rely on public funds of the State of residence". Tomuschat, Annotation Martinez Sala, in: CMLRev (2000) pp.449-457, at p. 455 .
} 
legislation. ${ }^{42}$ By inserting Articles 17 and 18 EC in the Treaty, however, Member States did provide the Court with two legal tools which it could use for strengthening the legal status of the non-economically active. Martinez Sala and Elsen indicate that the Court is indeed willing to make use of these new tools. As stated above, in the former case the Court ruled that nationals of a Member State who are lawfully residing in the territory of another Member State fall within the scope of the Treaty provisions on European citizenship and that they, in this capacity, can rely on Article 12(1) EC in order claim equal treatment as regards all rights and benefits covered by Regulations No 1408/71 and No 1612/68. ${ }^{43}$ In Martinez Sala the Court thus seems to have established the rule that all Union citizens are entitled to gain access to welfare state benefits under the same conditions as nationals of the host State when they lawfully reside in that State.

One may object and claim that one cannot, and should not, read so much into a single judgment which might be confined to the rather unique facts of the case ${ }^{44}$ is not extensively reasoned, which seems to run counter to the intentions of the Treaty drafters and which has not been free from criticism. ${ }^{45}$ More specifically, it could be argued that the above conclusion cannot apply to social assistance benefits because, as Advocate General Alber has argued in Grzelczyk, being in need of such benefits, constitutes a ground for ending lawful residence. ${ }^{46}$ The sugge-

\footnotetext{
${ }^{42}$ Further, even though the Member States may have been aware of the fact that noneconomic residents were to be admitted to their educational institutions (see Chapter 5 Section 4) and that some of them could possibly benefit from certain provisions of Regulation No 1408/71 (see Chapter 2 Section 6), they had not included in the 1990 residence directives or the Treaty on European Union any provision offering beneficiaries additional protection against discriminatory treatment in, or by, the host States. Article 17(1) EC provides that Union citizens shall enjoy the rights accorded by the Treaty, but the insertion of this provision was not intended as an extension of rights. In fact, the only provision which did say something specific about the legal status of the non-economically active in the territory of another Member State, Article 3 of Directive No 93/96, expressly denies students a right to obtain maintenance grants in the host State

${ }^{43}$ Case C-85/96 Martínez Sala [1998] ECR I-2691 at 57-61.

${ }^{44}$ O'Leary, Putting Flesh on the Bones of European Union Citizenship, in: ELRev (1999) pp.6879, at p.77; Bulterman, Annotation to Bickel, in: CMLRev (1999) pp.13251334, at p.1329 and Fries/Shaw, Citizenship of the Union: First Steps in the European Court of Justice, in: EPL (1998) pp.533-559, at p.558.

${ }^{45}$ See e.g. Becker, Freizügigkeit in der EU - Auf dem Weg vom Begleitrecht zur Bürgerfreiheit, in: EuR (1999) pp.522-533 and, in particular, Tomuschat (2000) supra footnote 41 .

${ }^{46}$ Opinion of Advocate General Alber in Case C-184/99 Grzelczyk (http://www.curia.eu.int/jurisp) at 125 .
} 
sted interpretation of the ruling indeed implies quite a bold step. Virtually all rules and principles governing the right to equal treatment of workers residing in other Member States which have gradually been developed in a long series of cases would be transposed to all Union citizens in a single judgment. Yet, what are the true objections? The crux of the problem, and the critique which has been expressed, concerns the possible burden on social welfare systems. States may have to grant benefits which have not been anticipated and which "have not been earned by the claimant on account of his or her her participation in the collective work process of a given society". ${ }^{47}$ The category of non-economic residents, however, consists of persons who have demonstrated that they are able to provide for themselves and that they are insured for medical care and who can be required to make equal tax and/or premium contributions. Why, then, should they be denied access to welfare state services? Further, as regards non-economic residents who after some time cease to meet the financial means and health insurance requirements, it must be recognised that Member States still hold the power to end their lawful residence. When exceptions to the free movement and equal treatment rights of Union citizens are to be interpreted restrictively, why should Member States have both the power to deny them social assistance benefits and the power to expel them? ${ }^{48}$

\subsection{Lawful Residence}

When lawful residence in the territory of another Member State guarantees equality treatment as regards access to (virtually all) public services, it is of the utmost significance to determine when a Community citizen is actually to be regarded as a lawful resident. At first glance, the criteria for determining the legality of residence would seem to be quite clear. Community $^{49}$ legislation and case law indicate that lawful resident status can be acquired by $(i)$ workers who have found and accepted "effective

\footnotetext{
${ }^{47}$ Tomuschat (2000) supra footnote 41 , at p.455.

${ }^{48}$ The answer that Member States may already have given up the power of expulsion by becoming a party to an international agreement (such as the European Convention on Social and Medical Assistance) and that, if they had known about obligations following from a case like Martinez Sala, might never decided to become a State party to the agreement, is not persuasive. See further Chapter 3 footnote 116.

${ }^{49}$ Lawful residence can derive from Community, international or national law. Fries/Shaw (1998) supra footnote 44, at p.547. The discussion below is confined to the residence rights guaranteed by Community law.
} 
and genuine" paid employment in another Member State, (ii) economically inactive Community citizens who can prove they posses sufficient financial means and health insurance cover and (iii) a defined group of family members of these two categories. ${ }^{50}$ In many cases, however, it may not be so easy to determine whether actual residence also implies lawful residence. For instance, are economically inactive Union citizens who have actually moved to another Member State without reporting themselves to the immigration authorities, to be regarded as lawful residents? Workers who fail to do so hold that status, ${ }^{51}$ but does the same hold true for the economically inactive? Further questions arise as regards the conditions under which the right to reside can be retained when the previously mentioned conditions are no longer met. Do workers who voluntarily give up their job without commencing a course of study related to their prior work lose the right to reside? ${ }^{52}$ Is the answer to this question the same as regards the involuntary unemployed who actually overstay the period for which their residence card was issued? Such persons may as work-seekers continue their stay or they may apply for the non-economic residence right of Directive No 90/364, but what is their status when they no longer have genuine chances of finding new work or when they lack sufficient means? Do children who have been born in the State of employment actually lose their right to reside under Article 10 of Regulation No 1612/68 when, after many years of employment, the worker decides to return to the country of origin? Can they only continue their stay either when they find work or meet the requirements of Directive No 90/364 for the non-economic right of residence? ${ }^{53}$ Further, do

${ }^{50}$ See Chapter 2 Sections 2 and 3.

${ }^{51}$ Case 48/75 Royer [1978] ECR 497 at 50.

${ }^{52}$ Compare Chapter 5 Section 3.2.3.

${ }^{53}$ Do spouses who lack the nationality of a Member State lose the right to reside in the State of employment on the basis of Community law when the marriage is formally dissolved? The European Commission has proposed to grant third country family members of workers falling within the scope of Article 10(1) of Regulation No 1612/68 the right to retain residence if the marriage is dissolved on condition that they have lived in that country for a period of three consecutive years. In the proposed new Article 11 it is further stated that such family members retain the right to work when they have lived in the host State for a period of at least five consecutive years. See COM(1998) 394(01). The wording of the proposed provisions suggests that third country nationals whose marriage has been dissolved after more than three but less than five years of residence have no, or may even lose the, right to work as an (self-)employed person. This, however, is not the case. In its proposal for amending Directive No 68/360 the Commission has included a new Article 4a which provides that in the event of the dissolution of the marriage, Member States shall recognise the right of residence of family members who do not hold the nationality of one of the Member States, but who have lived in a Member State for threc ycars and who are still 
Union beneficiaries who have acquired the status of non-economic resident but later cease to meet the financial means and/or health insurance requirements, as Article 3 of Directive No 90/364 suggests, lose their right to live in and claim equality of treatment in the State concerned?

The answer to each of these specific questions depends on the answer to the more general question whether or not Article 18(1) EC now constitutes the source of the general non-economic right of residence. ${ }^{54}$ In case it is not based on this Treaty provision, the right to reside is to be seen as a right which Member States have granted to Union citizens in accordance with the conditions laid down in Directive No 90/364. Community citizens who do not or no longer meet the financial means or the health insurance requirement, would not have or would lose the right of residence with the result that they would fall outside the scope of Community law and, thus, Article 12(1) EC. In the alternative case, the phrase "subject to the limitations and conditions laid down in this Treaty and secondary legislation" in Article 18(1), is to be understood as merely concerning the exercise of free movement rights. Member States would still be entitled to end the lawful residence of the non-economically active who do not, or no longer meet, the requirements laid down in Directive No 90/364, but, if they do not make use of this power, Member States would be obliged to regard the Union citizens concerned as lawful residents and to treat them equally with their own nationals. So far the Court has never expressly indicated whether or not the right to reside in based on Article 18(1) EC, but, as argued in Chapter 3 Section 4.3, the rulings in Martinez Sala and Elsen (2000) do not seem to leave much room for any conclusion other than that the right is now indeed based on the Treaty. If indeed correct, the conclusion can be drawn that all Union citizens who are actually ${ }^{55}$ residing in the territory of another Member State are entitled to be treated equally as regards access to welfare state services until the moment the host State actually executes measures to end their lawful resident status.

pursuing economic activities on presentation of a contract or certificate of employment of a declaration of self-employment. Third country nationals who are not economically active must provide evidence that they have sufficient financial resources for themselves and their dependants and that they have health insurance cover. The provisions of Directive No 90/364 apply mutatis mutandis. See the proposed Article 4a(2) of Directive No 68/360 (COM(1998) 394((02). See also Sewandono (1999) supra footnote 15, at p.286.

${ }^{54}$ See Chapter 3 Section 4.3

${ }^{55}$ Lawful residence also demands that the person concerned is actually a resident. See further Chapter 3 Section 6. 
Community law can be interpreted as to have reached the point of guaranteeing all Union citizens a right to equal treatment as regards access to (virtually all) welfare state services from the moment they lawfully establish residence in the territory of another Member State on the basis of Community law, international law or national law until the moment they voluntarily give up, or involuntarily lose, their lawful resident status. Member States are no longer entitled to protect their welfare state interests by making any distinctions between nationals and non-nationals or "recently arrived" and "long-term" residents. Member States must protect their interests by using their (remaining) immigration powers. Union citizenship gives entitlement to a "full and equal membership" of the welfare state in the State of residence.

In spite of the progress which has been made, European Community law has not yet evolved as far as American constitutional law has. It still does not provide for an unlimited and unconditional right to reside freely and, unlike United States citizens, European Union citizens can still be denied political rights such as the right to vote and stand as a candidate in (national) elections. Nonetheless, the reason why, and the degree to which, Community law and American law protect citizens who have established residence in another State against discriminatory treatment in social-economic matters have become quite similar. Durational residence requirements, the main legal instruments which American States have used to protect their welfare state interests, have been condemned by the Supreme Court. ${ }^{56}$ In Shapiro (1969) the Court classed such requirements as unconstitutional penalties on the constitutional right to travel, ${ }^{57}$ but the main concern of the Court has never been that waiting-period requirements actually deter or burden the exercise of the right to travel. The problem with such requirements is that they make a distinction between two categories of persons who both hold citizenship of the State wherein they reside. In Saenz $v$ Roe (1999) the Court made clear that it is a privilege of United States citizenship to establish residence in any State and, from the moment this is actually done, to claim an equality of rights with every other State citizen. ${ }^{58}$ The Court formally still spoke of this right to equal treatment with other State citizens as a component of the right to travel, but it in fact wholly separated the right to freedom of

\footnotetext{
${ }^{56}$ To be sure, there is one exception: tuition waiting-period requirements. See further Chapter 5 Section 8.4 .

${ }_{57}^{57}$ See Chapter 2 Section 8.5.1.

${ }^{58}$ Chapter 2 Section 8.5.2.
} 
movement and the right to equal treatment. ${ }^{59}$ Durational residence requirements discriminate against United States citizens who have completed their "interstate travel" and acquired citizenship in their new State. As fundamental as the right to reside freely among the various States may be for United States citizens, it is in fact merely a means for choosing State citizenship and it is in this capacity that they are entitled to "full" equality of treatment. The comparison with the ruling of the Court of Justice in Martinez Sala may not be perfect but is nonetheless striking. The Court did not attach any importance to the (source of) right to freedom of movement (itself). It simply held that Mrs Martínez Sala, as a Union citizen lawfully residing in the territory of another Member State, could claim equality of treatment with the nationals of the host State. Community law may not entitle Union citizens to citizenship of, and all political rights in, the Member State where they reside, but those who have established residence in another Member State have acquired a kind of membership status which could be labelled "European Union Denizenship".

\section{$3 \quad$ Non-Residents}

\subsection{Introduction}

From a historical perspective, the above conclusions regarding the legal status of Union citizens lawfully residing in the territory of another Member State are no doubt revolutionary. Four decades ago, the Member States offered non-nationals only, if at all, access to (most) public benefits after a minimum period of residence or employment, and they could even end residence once non-nationals became in need of (social assistance) benefits. Today, States are obliged to grant nationals of other Member States access to public benefits under the same conditions as their own nationals from the moment they establish residence within their borders and the possibility of expelling ("needy") non-nationals have been severely restricted. Viewed from the perspective of the welfare state, however, the conclusions drawn in Section 2 cannot be said to be so revolutionary. Member States may be obliged to grant "unanticipated and costly"60

\footnotetext{
${ }^{59}$ Compare Saenz v Roe, 119 S.Ct. 1518 (1999), Chief Justice Rehnquist, dissenting.

${ }^{60}$ Steiner (1985) supra footnote 18 , at p. 41
} 
benefits to non-nationals, but they still hold the power to deny residence to economically inactive and "needy" nationals of other Member States, they can still levy taxes on Union citizens working and residing within their territory and, given the low mobility rates, the conclusions of the previous Section are not very likely to jeopardise welfare state benefits. In essence, Community law, as discussed above, merely implies an attack on the nationality principle, not on the territoriality principle. The case law, culminating in Martínez Sala, has evolved as to provide for a territorially defined form of membership which is in line with, and in fact only strengthens, the notions of equality and solidarity on which welfare states are internally based. Welfare states have largely been "de-nationalised", but the conclusions drawn in Section 2, in no way imply a "de-territorialisation" of public benefit systems.

The territoriality of the welfare state is questioned, however, when the attention is shifted to the category of Union citizens who merely travel to other Member States without relocating the centre of their economic and private interests. It is only when one considers the status and cross-border rights of this category, that the tension between the goal of guaranteeing freedom of movement and safeguarding welfare state interests fully comes to the surface. Territoriality entails various things, but, above all, it means that public benefits are in principle preserved for persons working and residing within the State borders. It is only such persons who can be required to contribute their equal share to the funding of public benefit schemes and who, as "members", can gain access to these schemes. If States were obliged to share all public benefits with non-residents who cannot be required to contribute their equal share, welfare state services would be put in jeopardy. ${ }^{61}$ At the same time, however, it is clear that freedom of movement and Union citizenship would be nothing but empty notions if non-residents could be denied access to all public benefits on the sole ground that they are "non-contributors". A right to freedom of movement which is practical and relevant requires enjoyment of certain public services and access by non-residents does not in all cases have to affect the funding or organisation of benefit schemes.

This section seeks to establish whether Community law provides some general rules which may help to separate benefits which can be preserved for residents from those to be shared with non-residents. This is not an easy task. Written Community law reveals little and the relevant Court judgments are so small in number, and they concern such unique

\footnotetext{
${ }^{61}$ See Chapter 1 Section 2.
} 
and different factual constellations, that it is quite difficult to draw general conclusions. Nonetheless, it is possible to distill some principles or rules from Community law. For instance, Member States are no longer entitled to protect their welfare state interests by use of their immigration powers. As regards residents the Court has prohibited States from applying discriminatory rules to Union citizens residing within their territory and has only allowed them to protect their welfare states services by using immigration powers. As to the non-residents, the situation is the reverse. Upon production of a passport or identity card, all nationals of other Member States must be admitted to the national territory. ${ }^{62}$ Member States can only protect their systems by applying discriminatory rules in the substantive policy area concerned. The discussion below focuses on the rules and principles to be applied when reviewing the legality of the two main discriminatory criteria which have traditionally been used by Member States in order to exclude non-residents from their public benefits systems: nationality and residence.

\subsection{Nationality Requirements}

The most ${ }^{63}$ important Treaty provision available to "Community travellers" who wish to challenge rules denying them access to public benefits on the ground that they lack the nationality of the State they visit, is Article 12(1) EC. Within the scope of application of the Treaty, the provision prohibits any discrimination on grounds of nationality. The prohibition is strict. Once it is established that Article 12(1) is applicable, nationality criteria are in principle prohibited. Thus, in order to establish whether Article 12(1) can be relied upon it must be determined whether the situation of Union citizens seeking access to public services in another State falls within the ambit of Community law. Two conditions must be met. First, the Union citizens themselves must fall within the personal scope of the provision. No problems seem to arise here. All Union citizens enjoy the right to travel to other States and those who exercise the right fall within the scope of Community law. Second, it must be established that Article 12(1) EC can also be relied upon in relation to the

\footnotetext{
${ }^{62}$ See Joined Cases C-286/82 and 26/83 Luisi and Carbone [1984] ECR 377 at 16; Case C-68/89 Commission $v$ the Netherlands [1991] ECR I-2637 at 13 and Case C-274 Bickel [1998] ECR I-7637 at 15.

${ }^{63}$ Besides Article 12(1), Union citizens travelling to other States may rely on Article 49 $\mathrm{EC}$ in order to challenge nationality requirements. See e.g. Case C-20/92 Hubbard [1993] ECR I-3777 at 14 and Joined Cases C-62 and 63/81 Seco [1982] ECR 223 at 8.
} 
desired benefit. On this point, interpretation problems do arise. In determining the material scope of the right to equal treatment, the Court has followed different approaches or methods which may lead to different answers to the question whether or not a given right or benefit is covered by Article 12(1) EC.

In the first judgments in which the provision was applied independently, the Court made the answer to the question whether or not a given right or benefit falls within the ambit of Article 12(1) EC dependent on the degree to which the powers in the substantive policy area concerned have been transferred to the Community. Thus, in Gravier (1985), after having referred to various measures which the Member States and the Community institutions had taken in the field of vocational training, the Court concluded that access to such training falls within the scope of the Treaty. ${ }^{64}$ Following a similar line of reasoning, the Court concluded in Lair (1988) that Article 12 EC does not extend to student grants covering the costs of maintenance since such grants were considered as matters of educational and social policy falling with the domain of the Member States. ${ }^{65}$ In later cases, however, the Court did not adopt such a "transfer of powers approach". ${ }^{66}$ In Cowan, for instance, the Court ruled that a recipient of services could rely on Article 12(1) in order to claim financial compensation for victims of crimes even though the powers in the area concerned (criminal law) were still in the hands of the Member States. The Court ruled that whenever Community law guarantees a natural person the right to go to another Member State the "protection of that person from harm in the Member States in question, on the same basis as that of nationals and persons residing there is a corollary of that freedom of movement". ${ }^{67}$ In subsequent cases such as Commission v Spain (1994), Data Delecta (1996) and Bickel (1998) the Court followed a similar line of reasoning as regards the rights to gain access to public museums ${ }^{68}$ courts $^{69}$ and to use minority languages in court proceedings. ${ }^{70}$ The powers in the respective areas remained in the hands of Member States but this did not free them from the obligation not to apply rules

\footnotetext{
${ }^{64}$ Case 293/83 Gravier [1985] ECR 293 at 19-25.

${ }^{65}$ Case 39/86 Lair [1988] ECR 3161 at 14-15.

${ }^{66}$ In fact, this approach has only been applied in educational cases. See e.g. also Case C357/89 Raulin [1992] ECR I-1027 and Case C-3/90 Bernini [1992] ECR I-1071. 
which "discriminate against persons to whom Community law gives the right to equal treatment or restrict the fundamental freedoms guaranteed by Community law". ${ }^{71}$ In these cases the Court followed a "functional approach" in determining the material scope of Article 12(1) EC comparable, if not similar, to the one it had applied in the context of the free movement of workers. Under this approach, equality of treatment is to be guaranteed when, and in as far as necessary for, guaranteeing an effective or practical and relevant free movement of persons. It is of no relevance whether, or the extent to which, powers in a given substantive policy area have been transferred to the Community.

Cowan and the other cases just mentioned suggest that the material scope of Article 12(1) EC is to be determined in accordance with the functional method initially developed in the context of the free movement of workers. This does not automatically imply, however, that the right to equal treatment of non-residents reaches as far as the equivalent right of workers. In a case like Cowan the Court spoke of the right to equal treatment as a "corollary" of the right to freedom of movement. As regards workers residing in the State of employment, the right to be treated equally in socio-economic matters can indeed be said to be a corollary of, or a prerequisite for, their rights to work, reside and integrate in the host State's society. The same cannot be said, as regards nonresidents. A possible right to claim social assistance benefits or admission to education in other Member States does not logically follow from the right to travel. Certainly, a right to equal treatment as regards social and educational benefits could promote, and indeed trigger, mobility, but the rulings cases such as Cowan and Data Delecta cannot be interpreted to imply that the Court has recognised such a right to equal treatment. The right to travel was not perceived as a concomitant of the right to equal treatment. Only the reverse holds true.

Nonetheless, the more recent ruling in Martinez Sala (1998) suggests that Community citizens do hold the right to move to other States in order to claim access to virtually all public services under the same conditions as the nationals of those States. In this case the German Government had argued that it was not obliged by Community law to grant a child-raising allowance to an economically inactive Spanish national residing within its borders. The allowance Ms Martínez Sala had applied for fell outside the material scope of Article 12(1) EC and she herself was not covered by the personal scope of the Treaty. The Court did not agree. As regards the material scope of Article 12 EC, it held that

\footnotetext{
${ }^{71}$ See e.g. Case 43/95 Data Delecta [1996] ECR I-4661 at 12.
} 
the child-raising allowance in question falls within the scope of both Regulation No 1408/71 and Article 7(2) of Regulation No 1612/68 and this implied, according to the Court, that the allowance "indisputably" fell within the scope of Community law. ${ }^{72}$ In addition, the Court held that Ms Martínez Sala, as a national of a Member State who was lawfully residing in the territory of another Member State, fell within the personal scope of the Treaty provisions on European Citizenship. Article 17(2) attaches to the status of citizen of the Union the rights and duties laid down by the Treaty, including the right laid down in Article 12 not to suffer discrimination on grounds of nationality. ${ }^{73}$

Martinez Sala suggests that the material scope of Article 12(1) EC is to be determined in accordance with the same criteria, and that it reaches as far as the scope of the right to equal treatment of workers. In fact, it would seem that the scope ratione materiae of Article 12(1) EC has been extended so far that the application of the non-discrimination principle depends almost exclusively on the scope ratione personae of Community law. ${ }^{74}$ All Community citizens enjoy the right to travel to other Member States for whatever purpose and all those who make use of that right would seem to fall within the personal scope of Community law. Consequently, Martinez Sala could be interpreted to imply that all Community citizens who travel to other Member States can gain access there to (virtually all) public services, including e.g. social assistance benefits, education and study grants schemes, under the same conditions as the nationals of the host State. Put differently, Martinez Sala can be interpreted as to imply that Member States are no longer entitled to deny social benefits to Community citizens residing outside their territory for reasons of their nationality.

Admittedly, one cannot be wholly certain of this conclusion. Martinez Sala concerned residents, not non-residents. Yet, it is submitted that such a conclusion should be drawn. Certainly, Community citizens who merely travel to other Member States should not be entitled to claim social assistance benefits there. ${ }^{75}$ The exclusion of non-residents would indeed seem a sine qua non for securing the financial stability of social

\footnotetext{
${ }^{72}$ Case C-85/96 Martínez Sala [1998] ECR I-2691 at 57.

${ }^{73}$ Ibid, at 60)-65.

${ }^{74}$ Compare Maduro, Europe's Social Self: 'The Sickness unto Death', in: Shaw (Ed.), Social Law and Policy in an Evolving European Union (2000) pp.325-349, at p.336.

${ }^{75}$ Compare e.g. Schockweiler, La Portée du Principle de Non-Discrimination del'Article 7 du Traité CEE, in: RDE (1991) pp. 3 et seq, at p.24 and Steiner, Recipients of Services Some More Equal than Others, in: ELRev (1985) pp.348 et seq, at p.352.
} 
assistance benefit schemes. ${ }^{76}$ Similarly, virtually anyone would agree that Community students should have no right to claim full study grants in the State where they have taken up their studies. A duty to admit non-residents to both education itself and study grant systems, could put the funding of the grant systems at least in jeopardy. However, the conclusion that the scope of Article 12(1) EC is broad enough to cover virtually all social and educational benefits does not imply that non-residents must actually be accorded such benefits. That conclusion merely means that States cannot deny benefits to non-residents on ground of their nationality. When applied equally to nationals and non-nationals, national rules which make access to public benefits conditional upon residence in the State territory can avoid being classed as a prohibited indirect discrimination by reason of nationality when they are necessary for, and proportional to, the legitimate goal of maintaining public services. As long as welfare state tasks are primarily carried out at Member State level distinctions between residents and non-residents are in many cases a "must" for protecting public benefit systems. Residence serves as one of the main criteria for tax or premium duties and it may therefore possibly also be applied as a criterion for determining entitlement to benefits. Nationality, however, is not a common criterion for imposing duties of contribution and, arguably, it cannot, or at least should not, serve as a condition for entitlement to social benefits. ${ }^{77}$ In Martinez Sala the Court did not make a direct link between free movement rights and the right to equal treatment. According to the Court, the latter right correlates to, and follows from, the combined status of Union citizen and lawful resident of another Member State. The same conclusion can be drawn as regards "Community travellers". Arguably, their right to equal treatment is not primarily granted in order to facilitate or promote the right to travel. All nationals of Member States have acquired the status of Union citizen and it is the corollary of that

\footnotetext{
${ }^{76}$ Compare von Wilmowsky, Zugang zu öffentlichen Leistungen anderer Mitgliedstaaten Das Integrationskonzept des EWG-Vertrages in der Leistungsverwaltung, in: ZfaöR (1991) pp.231-281, at p.258.

${ }^{77}$ Lair, for instance, allows States to offer maintenance grants to nationals who have never lived in the national territory, and to deny such grants to economically inactive Union citizens who are living within the national territory. Arguably, there is no need, and no room, for such direct discriminations based on nationality. See further Chapter 5 Section 4.3 , footnote 173 .
} 
status not to be discriminated against in "non-political matters" by any other Member State on the ground that this status has not been acquired by virtue of the nationality of that Member State. ${ }^{78}$

\subsection{Residence Requirements}

It follows from the foregoing that Member States are no longer entitled to protect their welfare states against an influx of residents from other States who may be in need, or who come for the sole purpose, of obtaining public benefits by $(i)$ refusing them entry to the national territory or (ii) denying them benefits on grounds of their nationality. The proper legal tool to be used is the residence requirement. ${ }^{79}$ In assessing the compatability of residence requirements with Community law two provisions may be of significance: Article $49 \mathrm{EC}$ and Article 12(1) EC.

${ }^{78}$ Further, in rulings in cases such as Data Delecta (1996) the Court held that Member States are prohibited, also in areas (still) falling within their domain from discriminating "against persons to whom Community law gives the right to equal treatment" or restricting "the fundamental freedoms guaranteed by Community law". The right to equal treatment is thus not only linked to the right to freedom of movement but also to Union citizens who, according to Article 17(2) EC, "enjoy the rights conferred by this Treaty" including the right not to be discriminated against on grounds of nationality (Case C-85/96 Martinez Sala [1998] ECR I-2691 at 61).

${ }^{79}$ The view that residence rather than nationality requirements are the proper legal tools for protecting welfare state interests finds further support from another observation of the Court in Martinez Sala. The Court expressly stated that "persons genuinely seeking work must also be classed as a worker". Case C-85/96 Martinez Sala [1998] ECR I-2691 at 32. Since Antonissen (1991) it is settled case-law that Community citizens have the right to enter and to stay for a "reasonable period of time" in the territory of another Member State in order to seek work (Case C-292/89 Antonissen [1991] ECR I-745 at 21), but in Lebon (1987) the Court held that work-seekers could not be regarded as workers entitled to claim equal treatment as regards social advantages under Article 7(2) of Regulation No 1612/68 (Case 316/85 Lebon [1987] ECR 2811 at 26). The fact that work-seekers are now classed as workers does not seem to leave room for any conclusion other than that work-seekers can rely on Article 7(2) of Regulation No 1612/68. Compare O'Leary (1999) supra footnote 12, at p.76. That conclusion, however, does not imply that Member States are now actually obliged to offer work-seekers access to all "social advantages". Work-seekers merely enjoy a right to stay in the State concerned; they have not acquired the right to establish residence there. Martinez Sala would seem to imply that work-seekers can still be denied access to benefits on the ground that they are not resident; the ruling merely seems to imply that they can no longer be denied benefits on the ground that they lack the nationality of the State where they seek work. On this point see also van der Steen, De Europese Burger Krijgt Handen en Voeten, in: NTER (1998) pp.163-166, at p.165. 


\subsubsection{Article $49 \mathrm{EC}$ or Article 12(1) EC?}

If Françoise Gravier's claim ${ }^{80}$ that she could invoke the principle of nondiscrimination in her capacity as recipient of (educational) services in order to challenge the tuition fee which she was required to pay as a foreign student had been successfull, Article 49 EC could have been a particularly lucrative source for European citizens who wished to avail themselves of public services in other States. The Article provides for a right to go to other States for the sole purpose of receiving services ${ }^{81}$ and, more than once, the Court has held that national rules which make the right to (provide or) receive services conditional upon (establishment or) residence in the national territory imply the very negation of the free movement of services. ${ }^{82}$ Such rules can only be upheld in the few instances in which they are necessary to protect public policy, security or health. ${ }^{83}$ Basically, if Françoise Gravier's argument had been accepted by the Court, Community citizens would have had a right to travel freely and "shop around" for public benefits.

Clearly, the drafters of the Treaty provisions on the free movement of services never intended, and the provisions simply cannot be interpreted in order, to create such "unique" opportunities for Community citizens. Gravier's argument was doomed to fail, and it indeed did so. Not all public services constitute "services" for the purposes of Articles 49 and 50 EC. According to the latter provision, services only constitute "services" for purposes of Article 49 when they are "normally provided for remuneration" 84 . In Gravier the Court remained silent on Articles 49 and 50 EC but three years later the Court explained in Humbel (1988) that the "essential characteristic of remuneration lies in the fact that it constitutes consideration for the service in question", and that it "is normally agreed upon between the provider and the recipient of the service". ${ }^{85}$ Such a characteristic was considered absent in the case of courses offered under national educational systems because $(i)$ in establishing and maintaining such systems States are not seeking to engage in gainful activity but are

\footnotetext{
${ }^{80}$ See Chapter 5 Section 4.

${ }^{81}$ See e.g. Case C-274/96 Bickel [1998] ECR I-7637 at 15.

82 See e.g. Case C-222/95 Parodi [1997] ECR I-3899 at 31; Case 39/75 Coenen [1975] ECR 1547 at 7 and Case 33/74 van Binsbergen [1974] ECR 1299 at 11.

${ }^{83}$ Case C-288/89 Mediawet $I$ [1991] ECR I-4007 at 11 and Case C-352/85 Bond van Adverteerders [1988] ECR 2085 at 32-34.

${ }^{84}$ Joined Cases C-286/82 and 26/83 Luisi and Carbone [1984] ECR 377 at 9.

${ }^{85}$ Case 263/86 Humbel [1988] ECR I-6447 at 17.
} 
rather fulfilling duties towards their population in the social, cultural and educational fields and (ii) such public educational systems are, as a rule, funded from the public purse. ${ }^{86}$

Humbel does not necessarily imply that all welfare state services fall outside the scope of Article 49 and 50 EC. ${ }^{87}$ The case concerned educational courses which were both provided and funded by the State itself. Neither students nor their parents were required to make a substantial financial contribution which bore a close relation to the genuine costs involved. No "remuneration" was paid. The education was offered largely free of charge and indeed seemed to lack the required economic character. More in general, Humbel seems to imply that in the case of bi-partite (i.e. provider-recipient) relationships, under which the State itself acts as the provider and does not require substantial payments from recipients, no economic activity is present. As regards such bi-partite relationships, the "public/private funding distinction" 88 may indeed constitute the main, and often decisive, criterion to be applied in determining whether or not a given benefit can be classed as a service in the sense of Article 50 . Privatisation processes, however, have largely eroded the traditional picture of the welfare state in which the State itself provides services to its population. In order promote efficiency and to reduce bureaucracy, governments have called in third parties to provide, organise, regulate and/or administer public benefits. These third parties, which may be responsible for managing their own budget and often operate quite independently of the State organ that installed, or contracted, them, may very well provide services in the sense of Article 50 EC. For instance, where public (e.g. national health service) institutions finance services which are performed by private actors (e.g. general practioners) operating on independent and/or commercial basis, the relationship between that private actor and the recipient (i.e. the patient) of the publicly funded service could very well be economic in nature. Further, the remuneration mentioned in Article 50 EC does not necessarily have to be paid by the recipient himself. Payment by a third party may suffice. ${ }^{89}$ This could for instance imply that services offered by a public institution (e.g. hospital) can be classed as services when these services are paid for by a third

\footnotetext{
${ }^{86}$ The fact that pupils, students and/or their parents may have to pay enrolment or tuition fees could not alter that conclusion. Ibid, at 16-18.

${ }^{87}$ See in particular Chapter 4 Section 4.6.

${ }^{88}$ O'Leary, The Evolving Concept of Community Citizenship - From the Free Movement of Persons to Union Citizenship (1996) at p.75.

${ }^{89}$ Joined Cases C-51/96 and C-191/96 Deliège [2000] ECR I-0000 at 56 and Case 352/85 Bond van Adverteerders [1988] ECR 2085 at 16.
} 
party (e.g. sickness funds). In such triangular settings it would seem that each of the three bi-lateral relationships involved is to be judged seperately. Difficult questions may arise, but, in a time where welfare states are increasingly privatised, Articles 49 et seq may be of greater importance than Humbel suggests.

At the same time, Humbel cannot be ignored. As part of the common market rules, Articles 49 and $50 \mathrm{EC}$ are based on the assumption that States are not entitled to intervene in the market with a view to favouring their own nationals or residents at the expense of non-nationals and non-residents. Such "selfish intents" ${ }^{190}$ frustrate the functioning of the market mechanism. By their nature, residence requirements are at odds with a common market for services. The same does not hold true for many public services. In many cases, residence requirements are a "must" for maintaining welfare state services. To some degree, welfare states must be allowed to be selfish. The Treaty provisions on the free movement of services have not been drafted with public services in mind and the private principles developed in the case law do not seem to have sufficient regard for the specific public nature of such services. Indeed, the application of the private principles governing the common market might threaten the "solidarity" on which welfare state services are based. ${ }^{91}$ Residence requirements are discriminatory and, for this very reason, they cannot, and should not, be wholly free from the limits imposed by Community law, but Articles 49 et seq do not seem to leave enough room for the application of residence requirements in the cases where these are actually needed for protecting public services. In other words, Articles 49 et seq do not seem the proper or ideal provisions under which residence requirements for enjoyment of public services are to be reviewed.

The Court seems to have recognised this. National rules concerning access to public education may not fall within Articles 49 and 50 EC, but Gravier indicates that such rules may run counter to Article 12(1) EC. Article 12(1) EC indeed seems a more appropriate provision for reviewing the legality of residence requirements for publicly funded services. ${ }^{92}$ Such requirements may constitute indirect discrimination on

\footnotetext{
${ }^{90}$ See Gergen, The Selfish State and the Market, in: TexLRev (1988) pp. 1099-1153.

${ }^{91}$ Compare Bosco, Are National Social Protection Systems under Threat? - Observations on the Recent Case-Law of the Court of Justice and Hervey, Social Solidarity: A Buttress Against Internal Market Law?, in: Shaw (Ed.), Social Law and Policy in an Evolving European Union (2000) pp.31-47.

${ }_{92}$ van der Mei, The Elusive and Exclusive Concept of Union Citizenship, A Review Essay, in: MJ (1998) pp.391-402, at p.397.
} 
grounds of nationality, and thus be incompatible with Article 12(1), but the possibility for justification is greater than under Article 49 EC. Under Article 12(1) EC, residence requirements can be upheld when the States applying them demonstrate that they are necessary for, and proportional to, the legitimate public interest of protecting the financial stability and/or maintaining public benefit schemes. ${ }^{93}$ Articles 49 et seq still are, and in future years might become even more, significant, but, read together, Gravier and Humbel could be interpreted as implying that national rules containing residence requirements for entitlement to publicly funded services are preferably to be reviewed under Article 12(1) EC

\subsubsection{Article 12(1) EC: The Prima Facie Illegality of Residence Requi-} rements for Access to Public Services

When one starts searching the case law for substantive rules or principles which indicate when, or under which conditions, residence requirements for entitlement to public services are permissible under Article 12(1), one finds that there is not much of substance to go by. Virtually all cases decided under the heading of Article 12(1) only concerned national rules containing nationality criteria. There is only one exception: Bickel (1998). The case concerned a decree of the Italian Province of Bolzano which conferred upon the minority of the German-speaking citizens of the province the right to use their own language in relations with the judicial and administrative authorities in the province. An Austrian lorry driver and a German tourist who had no knowledge of Italian, claimed that they should also be entitled to use the German language in legal proceedings which had been brought against them. After having established that the right requested could enhance the exercise of the right to move freely within the Community, ${ }^{94}$ the Court held that the Bolzano residence requirement mainly affected nationals of other Member States and that the requirement therefore "can be justified only if it is based on objective considerations independent of the nationality of the persons concerned and is proportionate to the legitimate aim of the national provisions". The Bolzano decree could not pass the test. It was argued that the aim of the rules being challenged was to protect the ethno-cultural minority residing in the province. The Court held this to be a legitimate aim, but it could

\footnotetext{
${ }^{93}$ Compare e.g. Case C-237/94 O'Flynn [1996] ECR I-2617 at 18. See further Chapter 2 Section 7.3

${ }^{94}$ Case C-274/96 Bickel [1998] ECR I-7637 at 16-18.
} 
not see how this aim would be undermined if a right of German-speaking nationals of other Member States to have their proceedings conducted in German would not, as the referring Italian court had expressly indicated, bring about additional complications or costs for courts. ${ }^{95}$

For the purposes of this discussion, not much can be learnt from Bickel. The judgment does not teach much more than that in cases where the non-residents' access does not in any serious way threaten the maintenance of public services, non-residents are to be accorded equal access. Indirectly, however, Bickel raises a significant question: are all residence requirements for the enjoyment of public services indeed prohibited unless a justification can be demonstrated? The procedural threshold for the indirect discrimination test is low. Union citizens merely have to state that a residence requirement is likely to affect them more than the nationals of the State concerned and, by doing this, they can impose on the State concerned the burden of proving that there is actually a need for denying them benefits. Do Community citizens actually have such a right? Can States actually be required to explain and justify the exclusion of nonresidents from any public service? Does Article 12(1) confer upon Community citizens the right to travel to other States for the sole purpose of collecting public benefits? Does Community law, in principle, confer upon Community citizens the right to choose the welfare state regime they prefer $^{96}$ or is it based on the premise that Member States, in principle, can preserve welfare state services for their residents?

In order to answer such questions, it is worthwhile taking a brief look at the United States. Under the Privileges and Immunities Clause of Article IV $\S 2$ of the Constitution, the main constitutional provision under which discrimination against non-residents is to be reviewed, ${ }^{97}$ the American Supreme Court has developed a "substantial relation test" which resembles the "indirect discrimination test" applied by the European Court of Justice. In brief, this test implies that residence requirements are unconstitutional unless the State concerned can demonstrate that the requirements are needed for the protection of a substantial State interest. ${ }^{98}$ At first glance, it would thus seem that American States can be required to explain and justify any rule denying non-residents access to their public services. A closer look at the Supreme Court's jurisprudence, however, suggests that this does not necessarily hold true. Most cases decided under the Privile-

\footnotetext{
${ }^{95}$ Ibid, at 27-30.

${ }^{96}$ Compare Poiares Maduro (2000) supra footnote 74, at p.336.

${ }^{97}$ See Chapter 2 Section 8.6.1

${ }^{98}$ Supreme Court of New Hampshire v Kathryn Piper, 470 US 274 (1985) at 284 and Barnard v Thorstenn, 489 US 546 (1989) at 552-553.
} 
ges and Immunities Clause concerned State rules governing the pursuit of commercial activities and the Court has suggested that the subtantial relation test does not, or does not always, have to be applied when reviewing State rules governing access to public rights or benefits. Illustrative is Reeves, Inc. v State (1980) in which the Court was asked to rule upon the constitutionality of the refusal of South Dakota to sell to non-residents cement produced by a public plant. In reaching the conclusion that the refusal to sell to non-residents was constitutional the Court observed that the:

"State's refusal to sell to buyers other than South Dakotans is 'protectionist' only in the sense that it limits benefits generated by a state program to those who fund the state treasury and whom the States was created to serve. Petitioners's argument apparently also would characterize as protectionist' rules restricting to state residents the enjoyment of state educational institutions .. police and fire protection ... Such policies, while perhaps 'protectionistic' in a loose sense, reflect the essential and patently unobjectionable purpose of state government - to serve the citizens of the state" (ital: APvdM). ${ }^{99}$

The Supreme Court has never developed a coherent set of rules for judging the constitutionality of residence requirements for access to public services, but in the literature it has been argued that the basic assumptions in judging the constitutionality of discrimination in the private and public sectors are indeed reverse. ${ }^{100}$ The constitutional aim of economic integration would indeed demand that discrimination against non-resident traders is to be outlawed unless a substantial interest dictates otherwise. Above all, however, the Constitution sets out the framework for a political Union based on a federal system of government. Individual States were not intended to be convenient "local administrative departments of the national government designed to assist in the implementation of national policy". Rather, they were perceived as governmental entities holding independent lawmaking powers aimed at the provision of public benefits and services within their territory. This power would not only provide the basis for the right of States to exclude non-residents from public services when, or in as far as, this is necessary for upholding these

${ }^{99}$ Reeves, Inc. $v$ State, 447 US $429(1980)$ at 443. By comparison, Justice Brennan held in Zobel $v$ Williams (1982) that permitting states to offer benefits and services to their citizens "inheres in the very idea of maintaining the States as independent sovereigns". Zobel $v$ Williams, 457 US 55 (1982) at 2317.

${ }^{100}$ See in particular Varat, 'State Citizenship' and Interstate Equality, in: UChicLRev (1981) pp.487-571 
services. The range of lawmaking powers would go even further to provide the rule that States can in principle preserve public benefits for their residents:

"Like other groups free to combine their members' efforts to produce collective benefits to be shared among the group, political communities, including states, have a prima facie justification for limiting distribution of their public goods to those who combined to provide them". 101

The correlation between residence and payment of taxes is not perfect; not all residents pay taxes whilst some non-residents may pay taxes. Yet, when a State uses revenues

"to create public goods and services, it has a prima facie justification for allocating .. resources to State residents .. simply because residents as a class combined to establish them, and non-residents as a class did not". ${ }^{102}$

This does not necessarily imply that claims of non-residents for public services must always yield. Non-residents do have a right to equal treatment which may prevail in particular cases or when particular circumstances so require. The appeal of non-residents' claim to public services would vary depending on the burden which might be imposed on the State if services are to be provided and the burden on the non-residents if access to benefits is denied. The "less nonresident access interferes with state ability to serve residents, or the greater the harm that would be inflicted on the non-resident by denying access, the stronger the nonresident claim" would be. ${ }^{103}$ Some factors may strengthen nonresidents' claims. A first one concerns a possible abundance of public services. In cases where "the supply of a public good seems ample enough to satisfy both resident and non-resident demand", the non-residents' claim of access will be strong. Another factor involves the need of nonresidents for certain services. Thus, the claim for medical emergency, police or fire protection would be much stronger than claims for gaining access to public golf and tennis facilities. Further, some public services may be necessary for the exercise of constitutional rights. For instance, if

${ }^{101}$ Varat (1981) supra previous footnote, at p.523

${ }^{102} \mathrm{Ibid}$, at pp.529-530. The "reality of the existence of states qua states, rather than as departments of a national government, requires a conception that the state's citizens own state-owned resources, and that a state is not required to share its treasury with the nation at large". Cohen, Equal Treatment for Newcomers: The Core Meaning of National and State Citizenship, in: ConstComm (1984) pp.9-19, at p.17.

${ }^{103}$ Varat (1981) supra footnote 100 , at pp.530-531. 
States were free to close their public roads, airports or transport facilities, constitutional rights such as freedom of trade and the right to travel would be curtailed. Lastly, in assessing the claims of non-residents one may have to include the (im)possibility of obtaining benefits elsewhere. Claims of non-residents would be weaker where they can also obtain the services from private actors or where they can do so in their home State. Nonresidents' claim to obtain medical treatment which is not available in their home State is stronger than if the treatment in question can be received in the home State. There might still be persuasive arguments for denying non-residents access, but the State's "creation of unique resources imposes greater equality obligations than its creation of resources also found in other States". ${ }^{104}$

At first glance, it would seem undisputable that the above analysis and conclusions also apply to the European Community. The private rules governing the common market are indeed based on the assumption that national rules discriminating against traders from other Member States are to be outlawed unless a compelling public interest requires otherwise. Further, when in a fully-fledged federal union like the United States, where freedom of movement and equality of treatment are firmly protected values, States are in principle entitled to exclude non-residents from their public services, then it would seem only logical to conclude that the same premise applies in the European Community where which does not even seek to become a federation.

Nonetheless, it is submitted that the above analysis and arguments do not compel the conclusion that Community law is, or ought to be, based on the premise that Member States have a prima facie justification for "allocating resources to State residents simply because residents as a class combined to establish them, and non-residents as a class did not". The fact that the United States and the European Community have developed a federal(-like) system of government does not necessarily dictate the premise that States have a prima facie justification for denying non-residents access to public services. Constitutional charters such as the United States Constitution and the EC Treaty safeguard a multiplicity of values which include, besides the preservation of locally provided welfare state services, a "common" citizenship and rights to freedom of movement and equality of treatment. These potentially conflicting constitutional values need to be balanced against each other and, in so doing, one constitutional value may have to be given priority over another. The federal(-like) structure of a system of government, however, does not

\footnotetext{
${ }^{104}$ Ibid, at p.540.
} 
determine which value is to be given a higher priority. The ranking of constitutional values is a matter of choice. ${ }^{105}$ Different federal(-like) entities can make different choices and each one of them can alter its choice of one constitutional value whenever the need is felt to strengthen another. Because the United States has matured into a true federation and because constitutional values of a common citizenship, freedom of movement and equal treatment are already firmly protected by the American Constitution, there might indeed be scope for stressing the need to preserve local welfare state services ${ }^{106}$ and for accepting the premise that States have a prima facie justification for denying such services to non-residents. The European Community, however, could decide to make another choice. Precisely because the notions of Union citizenship, freedom of movement and equality of treatment are still not fully developed, the Community could opt for the premise that its citizens have a prima facie entitlement to gain access to public benefits in States other than the one in which they reside which can only be rebutted when Member States have compelling reasons for denying non-residents access to their public services.

For a long period of time, there did not seem to be a real need for the Community to make a choice. Because of the limited scope of the integration process, questions concerning possible access by non-residents rarely arose and it was simply and implicitly assumed that Community law did not prevent Member States from preserving public services for their own residents. The recent introduction of a Union citizenship and the increased recognition that rights to freedom of movement and equal treatment are no longer restricted to the pursuit of economic activities, however, raise the question whether Member States actually, or still, have a prima facie justification for excluding non-residents from their welfare state. Member States will claim that they, in principle, cannot be required to admit non-residents to their facilities, but the case law casts some serious doubt as to whether this holds true. In Gravier, for instance, the Court clearly established the rule that Member States must open their universities and schools for nationals of other Member States who are residing in their own States. The Court gave all Community citizens the right to study in other Member States without imposing on them a duty to demonstrate their reason for wishing to do so, or why there was a specific

\footnotetext{
${ }^{105}$ Compare Carens, Immigration and the Welfare State, in: Gutmann (Ed.), Democracy and the Welfare State (1988) pp.207-230, at pp.222-226.

${ }^{106}$ Compare Varat, Economic Integration and Interregional Migration in the United States Federal System, in: Tushnet (Ed.), Comparative Constitutional Federalism (1990) pp.21-61, at p.49.
} 
need for them to study abroad. Further, in Bickel, and in fact all other cases in which it has been asked to establish the validity of residence requirements, ${ }^{107}$ the Court has simply applied the standard indirect discrimination test which is based on the very notion that non-residents are entitled to benefits unless States can justify refusal. Moreover, in the Court's view, Union citizenship is not just a symbolic notion. Rulings in cases such as Martinez Sala and Elsen demonstrate that the Court is willing to give substance to Union citizenship and strongly suggest that the general non-economically determined rights to move and reside freely within the Community are now indeed based on the Treaty itself. ${ }^{108}$

The initial assumption that States have a prima facie justification for excluding non-residents from their public services seems to have been eroded and, although the Court has never said so explicitly, the case law leaves room for the suggestion that Community law is gradually shifting towards the premise that Community citizens have a prima facie entitlement to gain access to public benefits in other Member States. No certainty exists, but much can be said for this premise. If taken seriously, the constitutionally protected values of Union citizenship, freedom of movement and equality of treatment would seem to require that Community citizens are entitled to travel to other States for whatever purpose and that they are under no obligation to explain, or to submit any specific reason as to their need to be treated equally. Further, the premise in favour of Union citizens does not have to affect or undermine Member States' capacity to uphold these systems and it does not necessarily have to lead to legal uncertainty. The premise is not absolute. It merely implies a prima facie entitlement to gain access to public services; Member States are still entitled to impose restrictions or to deny access to public benefits whenever these are necessary for safeguarding the funding and/or organisation of their systems. Due regard can be given to the Member States' interests by giving them room to rebut the prima facie entitlement of nonresidents to gain access to public services and to develop a clear and coherent set of criteria determining when, or what kind of, limitations on non-residents' access are permissible.

\footnotetext{
${ }^{107}$ These include in particular also cases concerning frontier workers such as e.g. Case C-57/96 Meints [1997] ECR I-6689 and Case C-337/97 Meeusen [1999] ECR I-0000.

${ }^{108}$ See in particular Chapter 3 Section 4.3 .
} 


\subsubsection{Justification of Residence Requirements for Entitlement to Public} Services

A prima facie entitlement of non-residents to gain access to public benefit systems in other Member States implies that residence requirements are to be regarded as being incompatible with Article 12(1) EC unless the States in question can demonstrate that the requirements are necessary to uphold the systems. This indirect discrimination test implies a limited balancing act. It is a balancing act in that Member States' claims for maintaining their public services are to be weighed against the constitutional values of Union citizenship, free movement and equal treatment. The test, however, entails only a limited balancing act because it only requires weighing-up the States' need to exclude from, or to impose additional conditions on non-residents seeking access to, public services. The right to equal treatment is a given and fixed value which does not have to be supported by any additional arguments. The strength of the claim of the individual Community citizen seeking access to public services does not vary according to the importance of the desired benefit or the degree to which the benefit is needed. The burden of proof is not on the non-residents, but on the Member State that wishes to deny access to public services. The weight to be given to States' claims varies from benefit to benefit. A (rough) distinction can be made between three types of public services

The first group consists of services which can be attributed to the classical "night watch State" and the "industrial welfare state". ${ }^{109}$ It concerns benefits such as police and fire protection, court systems, public roads, transport facilities, and benefits for victims of crime. Refusal to grant such services to non-residents is hard, if not impossible, to justify. The magnetic effect of such services on non-residents is minimal. The number of Community citizens who would move to other States in order to gain access to such services is minimal. Further, spill-over effects are basically absent; these services are only effective at the place where they are consumed. ${ }^{110}$ For business or touristic reasons, some countries may receive comparatively high numbers of non-residents, and thus potential users of such services, but these numbers are not likely to be so high as to cause serious difficulties in maintaining such services. States may be entitled to charge certain fees for the use of these services when these

\footnotetext{
${ }^{109}$ See Chapter 1 Section 2.1.

${ }^{110}$ Compare von Wilmowsky (1991) supra footnote 76 , at pp.272-273.
} 
reflect the true costs involved and are fixed at a non-discriminatory rate, ${ }^{111}$ but they are not entitled to impose tolls or user fees on nonresidents for the sole reason that they, unlike residents, are as a rule not taxable. Arguments in favour of such compensatory fees could possibly be made if the premise of a prima facie justification for States to exclude non-residents were applicable, but they are not needed in order to protect the quality of public roads, public parks, etc.. In fact, such fees would seem to constitute wholly gratuitous discriminations against non-residents and, arguably, this is one of the reasons why the premise of a prima facie entitlement for non-residents to gain access to public services is to be preferred above the premise that States have a prima facie justification for preserving public benefits to their residents.

The second group of public services comprises social assistance benefits, maintenance grants and other tax-funded benefits which seek to offer beneficiaries a "minimum income" for meeting basic costs of living. Member States are fully entitled to make enjoyment of such cash benefits conditional upon residence requirements. The magnetic effect of such benefit systems is strong and spill-over effects would occur if non-residents were to be awarded such benefits. Budgets available for such benefit schemes are scarce and the grant of any additional benefit leads to an increase in costs. The claims of States to deny residents such benefits seem to be so strong that the prima facie entitlement of non-residents to obtain such benefits is in fact automatically reversed in a blanket permission for States to deny benefits to all non-residents. ${ }^{112}$ To be sure, this is not to say that such benefits can never be enjoyed outside the national territory. For instance, social asisstance recipients do not necesarily lose

${ }^{111}$ See e.g. Directive No 93/89 on the application of taxes to certain vehicles used for the carriage of goods by road and tolls and charges for the use of infrastructures (OJ $1993 \mathrm{~L}$ 279) which states in Article 7 that tolls and user charges may not discriminate, directly or indirectly, on grounds of nationality of the haulier or of origin of the vehicle and that toll rates shall be related to to the costs of constructing, operating and developing the infrastructure net work concerned. On this directive see further Case C-205/98 Commission v Austria ("Brenner Motorway") [2000] ECR I-(0000. In the context of the free movement of goods the Court has been even more strict. Member States may be permitted to apply veterinary and public health inspections, but they cannot recover the costs by charging fees to traders wishing to import products. See e.g. Case 87/75 Bresciani [1976] ECR 129. In principle, the costs of inspections aimed at protecting public health are to be borne by the general public. Craig/De Búrca, EU Law - Taxt, Cases \& Materials (1998) at p.558. Charges can only be levied in order to meet the costs of inspections mandatorily required by Community law. Case 18/87 Commission v Germany [1988] ECR 5427.

${ }^{112}$ In theory, this would be different, however, if States were entitled to have the costs reimbursed by the State in which the "visitor" resides. 
entitlement to benefits when they are vacationing in other Member States $^{113}$ and Community students could make a claim for a right to export study grants. ${ }^{114}$ As regards such tax-funded "income benefits", Community law is based on the assumption that benefits can be obtained in one Member State only and that it is in principle the State of (habitual) residence which is responsible for paying benefits.

The third group of benefits consists of welfare state services that are offered in kind such as education and health care. ${ }^{115}$ The legality of residence requirements for entitlement to such benefits is far more difficult to predict than in the case of the other two groups of benefits. The weight to be given to States' interests and claims may vary and is often quite difficult to determine. Such social benefit-in-kind systems have a much bigger magnetic effect on residents of other Member States, and they are more likely to be affected by non-residents' access, than the first group of benefits discussed above. At the same time, benefit-in-kind systems are not as "fragile" as the cash income benefits of the second group. Any additional grant of the latter benefits implies an increase in costs, but this is not necessarily the case with benefits offered in kind. Further, the impact of access by non-residents may differ for the various benefits in kind. For instance, the claim of Member States to exclude nonresidents from primary schools or general practioner services does not seem as strong as their claim to refuse non-residents access to intramural health services such as heart transplants or hip replacements for which waiting lists may already exist.

So far, Community law has not developed a clear and coherent set of criteria determining the legality of residence requirements for such benefits in kind. On the basis of existing case law, one cannot conclude much more than that Member States can make entitlement to such benefits conditional upon residence within the national territory where they can demonstrate that this is necessary for, and proportional to, the legitimate interests of maintaining the "financial stability" and/or protecting the "infrastructure" of such benefit-in-kind systems. The precise contours of the test to be applied have not yet crystallised. First, the interests which may constitute a ground for justification are not clearly defined.

${ }^{113}$ Chapter 3 Section 5.2.

114 See Chapter 5 Section 9.3.1.

${ }^{115}$ To be sure, questions concerning cross-border access to health care are in many cases to be answered by the Treaty provisions on the free movement of services. In cases where Articles 49 et seq cannot be applied, which is the case for national health services, it would seem, however, that patients can benefit from Article 12(1) EC. See Section 3.3.1 above and Chapter 4 Section 4.6. 
For instance, it could be argued that any increase in costs or expenditure caused by non-residents affects the equilibrium between expenditure and revenue and that non-residents can be denied access whenever the (marginal) costs are not compensated for. It could also be argued, however, that the financial stability is only affected where the additional cost of nonresidents' access forces the host State to increase its budgets for the services in question or to compromise the quality of the services. What, then, is precisely meant by the financial stability of welfare state services? Comparable issues arise as regards the protection of the organisation or infrastructure of welfare state services. In deciding on the provision of education and health care facilities, States will have to make a certain assessment about the expected demand for such services. Thus, States, on a long-term basis, will have to consider how many students are likely to attend schools or universities and, subsequently, will have to decide on the number of teachers to be appointed, the types of courses that will be offered and what housing or other facilities for students are required. Similarly, States will have to make an assessment of the expected need for medical facilities and to establish the number of hospitals to be built, the doctors to be appointed and the beds to made available. Access by non-residents could affect capacity planning, but at what point is quality or infrastructure affected? Where access by non-resident patients causes, or leads to longer, waiting lists for certain medical and hospital services, is the quality of such services affected? In reverse, where residents decide to obtain treatment abroad, is the maintenance of hospital services only affected, as Kohll suggests, ${ }^{116}$ when Member States are forced to close down certain departments or clinics or could the mere occurrence of a surplus of facilities possibly suffice for drawing that conclusion? Further, access by non-resident pupils or students could impact on the size of classes or tutorial groups. Where the size of classes is increased by 2 or 3 students or pupils the quality of education would not seem to be affected, but this, so it might be argued, could very well happen with increases of 10 pupils or students. At what point could the educational infrastructure possibly justify restrictions on non-residents' access?

Second, it is uncertain how strictly the necessity and proportionality requirements are to be applied under Article 12(1) EC. A case like Bickel demonstrates that the Court is willing to strike down residence requirements where the maintenance or quality of public services is unlikely to be affected by access by non-residents. This would seem to imply, for instance, that the Court will not allow Member States to rely

\footnotetext{
${ }^{116}$ See Chapter 4 Section 4.5 .
} 
on the financial stability ground for justification where they are entitled to have the cost reimbursed by other States or "other" social security institutions or when the non-resident is willing to pay the cost. In other cases, however, it is far more difficult to predict how the Court would rule. The proportionality requirement imposes on Member States a duty to seek the least restrictive means for protecting their systems, but is not always easy to determine what the least restrictive means are. For instance, it could be argued that Member States that are net-importers of students have no strong claim to limit the number of non-residents to be admitted to their universities when they can also protect their interests by imposing on these students a duty to pay additional tuition fees. Yet, tuition fees may have a much more restrictive effect on student mobility than quotas when the fees are set at a high rate. Answering the question as to which means are the least restrictive may require such a detailed examination of the pros and cons of the various alternatives, that a strict application of the proportionality test would lead to a serious intrusion upon the States' autonomy in the fields of education and health care. In judging the compatability of national rules with common market freedoms the Court has applied the proportionality requirements so strictly, and it has scrutinised national rules so thoroughly, that it has often actually substituted Member States' views on the need to apply a certain rule for its own view. However, because the European Community lacks the power to harmonise the national health care and educational systems and because it is bound to respect the autonomy of the States to organise such systems in the way they deem appropriate, the Court may, and indeed it would seem desirable if it were to, show some restraint in applying the proportionality test under Article 12(1) EC.

\section{$4 \quad$ Third Country Nationals}

Cross-border welfare rights are essential components of European citizenship. The previous Sections may therefore be understood as a modest contribution to the discussions about how that membership status could be given more substance. ${ }^{117}$ One message which the Court has been sending out is that in a Community where a Union citizenship now formally exists, there is no longer scope and need for national rules making entitlement to welfare state benefits conditional upon posession of natio-

\footnotetext{
117 For a discussion as to how Union citizenship could more generally be strengthened see e.g. O'Leary, European Union Citizenship - Options for Reform (1996).
} 
nality of the State concerned. Unfortunately, that message still has limited meaning. It is only relevant for Union citizens, not for the majority of the third country nationals residing within the Community. When it comes to cross-border welfare rights Community law has little to offer to third country nationals. They are still denied freedom of movement and even in the Member State where they reside, and are required to make tax contributions, they have no right to gain equal access to the welfare state. ${ }^{118}$ From a social and political perspective the weak status of third country nationals under Community law is, to put it mildly, "problematic" and it is submitted that there is no need to go into the question whether it is necessary to improve that status. The sole question to be addressed is how that status is to be strengthened. So far, the Community has not developed a coherent set of rules protecting the legal status of third country nationals residing within the Community. The main activities so far have been taken within the inter-governmental framework of the Third Pillar of the Treaty on European Union. The measures that have been adopted usually took the form of legally non-binding measures such as resolutions and recommendations and most of these soft law measures were primarily motivated by the desire to restrict the entry of third country nationals rather than to strengthen their legal status upon admission. ${ }^{119}$ The Treaty of Amsterdam, however, may provide an incentive to improve the situation and to develop a more coherent policy regarding the status of admitted third country nationals. The Treaty has transferred all issues relating to freedom of movement of third country nationals from the third pillar to the first pillar. The Community institutions are empowered to adopt measures "with a view of ensuring .. the absence of any

${ }^{118}$ For an extensive overview of the legal status of third country nationals under Community see e.g. Staples, The Legal Status of Third Country Nationals Resident in the European Union (1999)

${ }^{19}$ See e.g. the various resolutions on workers, self-employed persons, students, family reunion and long-terms residents (as published in Guild/Niesen, The Developing Immigration and Asylum Policies of the European Union - Adopted Conventions, Resolutions, Decisions and Resolutions (1996)) and the Commissions proposal for a Convention on Rules for Admission of Third Country Nationals to the EU Member States (COM(97) 387 def). On these resolutions, and the afore mentioned proposal of the Commission, see see e.g. Staples (1999) supra footnote 118, at pp.278-282; Peers, EU Justice and Home Affiras Law (2000) Chapter 5; Peers, Raising Minimum Standards, or Racing to the Bottom? - The Commission's Proposed Migration Convention, in: Guild (Ed.), The Legal Framework and Social Consequences of Free Movement of Persons in the European Union (1999) pp.149-166 and Hedemann-Robinson, From Object to Subject?: Non-EC Nationals and the Draft Proposal of the Commission for a Council Act Establishing Rules for the Admission of Third Country Nationals to the Member States, in: YEL (1998) pp.289-335. 
controls on persons, be they citizens of the Union or nationals of third countries, when crossing the internal borders", ${ }^{120}$, measures "setting out the conditions under which third country nationals shall have the freedom to travel .. during a period of no more than three months", ${ }^{121}$ measures on immigration policy including "conditions of entry and residence"122 and measures regarding the "conditions of employment for third country nationals legally residing in Community territory". ${ }^{123}$ Once such measures have been adopted, third country nationals would seem covered by Community law, but the EC Treaty does not indicate which rights third country nationals will enjoy. Article 12 EC prohibits any discrimination on grounds of nationality, and may possibly be relied upon by third country nationals, but more specific provisions such Articles 39, 43 and 49 EC and Article 2 of Regulation No 1408/71 expressly require Member State nationality for enjoyment of rights. ${ }^{124}$

When using the powers offered by the Amsterdam Treaty, Community institutions will have to make choices as to how they wish to shape the legal status of third country nationals and to what extent they will give them the right to integrate into the labour market and society of the Member States. In the literature some models have been suggested. The first is the "worker model". ${ }^{125}$. It basically implies that the status of third country nationals is (to be) developed in accordance with the principles applicable to association agreements such as the one concluded with Turkey. ${ }^{126}$ An alternative is the "citizen model" which is to be developed in on the basis of Community rules and principles governing freedom of movement of European citizens. Arguably, for the purposes of cross-border access to public services, the "citizenship model" is to be chosen. On a short term basis, the "worker model" may have a greater chance of being accepted by the Member States. It does not necessarily

\footnotetext{
${ }^{120}$ Article 61(1) EC.

121 Article 62(3) EC.

${ }^{122}$ Articles 63(4) EC.

${ }_{123}$ Article 137(3) EC.

${ }^{124}$ Some specific proposals to bring third country nationals within the scope of more specific provisions have been made. As regards Regulation No 1408/71, see COM(1998) 779 final and COM(1997) 561 final and for Article $39 \mathrm{EC}$ see e.g. Curtin et al, Free Movement for non-EC-Workers within the European Community (1997).

${ }^{125}$ See Peers, Aliens, Workers, Citizens or Humans? - Models for Community Immigration Law, in: Guild/Harlow (Eds), Implementing Amsterdam - Immigration and Asylum Rights in EC Law (2000) pp.291-308.

${ }^{26}$ See e.g. Groenendijk, The Growing Relevance of Article 39 (ex 48) EC Treaty for Third Country Nationals, in: Carlier/Verwilghen, Thirty Years of Free Movement of Workers
} in Europe (2000) pp.207-223, at p.220. 
include free movement rights for third country nationals and the right to equal treatment does not have to reach as far as the equivalent right of Community citizens. Precisely for these reasons, however, the "worker model" is not desirable. Under this model third country nationals are still regarded as "less deserving". In spite of the fact that third country nationals can be required to contribute to the funding of social services, they could still be denied access to such services. A "second class citizenship" can only be avoided by putting the legal status of third country nationals on a par with the status of Union citizens. The rules and principles governing cross-border access to public benefits as described in this Chapter have regard to both the Community objective of a free movement of persons and the need to protect and uphold public services. In the short term, it may not be feasible to develop a common immigration policy framed on the basis of a "citizenship model" and some restrictions on, in particular, the right to freedom of movement of third country nationals who have only recently arrived in the Community, may be required. Yet, it is submitted that Community law should ultimately be based on this model because it is the only one which gives due regard to the notions of citizenship $^{127}$ and equality embedded in Community law.

\section{Conclusions}

Lurking beneath the numerous questions concerning cross-border access to public services which have been discussed in this book lies a potential conflict between, on the one hand, the goals of realising freedom of movement and securing equality of treatment and, on the other hand, the need to develop and maintain adequate public services. Initially, the

\footnotetext{
${ }^{127}$ In the literature it has been suggested that the status of third country nationals could be strengthened by extending Union citizenship to third country nationals who have lawfully resided in the Community for a given number (five) of years (see e.g. Staples (2000) supra footnote 118, at pp.354-355; Castro Oliveira, The Position of Resident Third Country Nationals: Is it Too Early to Grant Them Union Citizenship?, in: La Torre (Ed.), European Citizenship: An Institutional Challenge (1998) pp.185-199; Rubio Marín, Equal Citizenship and the Difference that Residence Makes, in: La Torre (1998) supra, pp.210-227; Sørensen, The Exclusive European Citizenship - The Case for Refugees and Immigrants in the European Union (1996) at pp.170-171 and Dummett, The Acquisition of British Citizenship. From Imperial Traditions to National Definitions, in: Bauböck (Ed), From Aliens to Citizens: Redefining the Status of Immigrants in Europe (1994) pp.75-84) or by encouraging the Member States to offer their nationality to third country nationals. See e.g. Hansen, A European Citizenship or a Europe of Citizens? - Third Country Nationals in the EU, in: JEMS (1998) pp.751-768 and Sørensen (1996) supra, at pp.169-170.
} 
conflict was decided in favour of Member States. Community law hardly imposed any limits on States' power to control immigration and to determine whether, when and the conditions under which, nationals and/or residents of other Member States were accorded access to their public services. Over the years, however, Community law has limited Member States' powers and significantly extended the possibilities for European (Union) citizens to move to other Member States and to get access there to public benefits.

This particularly holds true for Union citizens who have decided to establish residence in other Member States. Today, Community law can be interpreted to confer upon all Union citizens a right to equal treatment as regards access to (virtually all) welfare state services from the moment they establish lawful residence in the territory of another Member State on the basis of Community law, international law or national law until the moment they voluntarily give up, or involuntarily lose, their lawful resident status. Community law allows the Member States to deny lawful residence status to nationals of other Member States who do not perform "effective and genuine" work and who are not able to provide for themselves, but they can no longer protect their welfare state interests by making distinctions between nationals and non-nationals or "recently arrived" and "long-term" residents. Union citizens lawfully residing in the territory of a Member State other than the one(s) of which they hold the nationality are to be treated as equal members of the welfare state.

Community law governing the legal status of Community citizens who are merely visiting other Member States is still less well developed. The case law demonstrates that all Union citizens enjoy the right to travel to other Member States and to claim access to public benefits there under the same conditions as nationals of the host State. Member States are no longer entitled to protect their welfare state regimes against an influx of residents of other States who may be in need, or come for the sole purpose, of obtaining public benefits by refusing them entry to the national territory or by denying them benefits on grounds of their nationality. Member States can only protect their interests by applying residence requirements. So far no precise criteria for judging the legality of residence requirements have been developed. Until recently, it seemed undisputable that Community law is based on the premise that Member States are, in principle, under no obligation to grant non-residents access to their "territorial" welfare states, but recent case law casts some serious doubt as to whether that premise stands. The assumption that States have a prima facie justification for making access to public services conditional upon residence in the national territory has been eroded. The case law suggests that Community law is now based on, or at least that it is heading in the 
direction of, the premise that there is a prima facie obligation for States to accord non-residents access to their welfare state facilities. No certainty exists, and the conditions for rebutting this obligation certainly need further clarification, but it is submitted that this premise in favour of citizens is to be accepted. Without necessarily undermining the ability of Member States to maintain their public services, recognition of a prima facie entitlement to gain access to public services in other Member States could contribute to a more efficient use of public services and provide a basis for strengthening the currently still underdeveloped notion of Union citizenship. 




\title{
SAMENVATTING
}

\author{
Vrij Verkeer van Personen binnen de Europese Gemeenschap \\ Grensoverschrijdende Toegang tot Collectieve Voorzieningen
}

\section{Inleiding}

Dit boek is het resultaat van een onderzoek dat tot doel had na te gaan in hoeverre het Europees Gemeenschapsrecht (hierna: EG-recht) aan individuen het recht geeft toegang te verkrijgen tot collectieve voorzieningen in andere Lid-Staten. Drie voorzieningen stonden centraal in het onderzoek: bestaansminimumuitkeringen, gezondheidszorg en onderwijs.

In essentie, betreft het onderwerp van de grensoverschrijdende toegang tot collectieve voorzieningen een confrontatie tussen twee potentieel tegengestelde belangen. Het eerste betreft de Verdragsdoelstelling een vrij verkeer van personen te verwezenlijken. In de eerste plaats lijkt deze doelstelling te vereisen dat begunstigden die gebruik maken van hun recht op vrij verkeer toegang kunnen verkrijgen tot (in ieder geval bepaalde) collectieve voorzieningen tijdens hun verblijf op het grondgebied van een andere Lid-Staat. Individuen zullen veelal niet bereid zijn zich naar een andere Lid-Staat te begeven indien zij aldaar niet het recht hebben om, bijvoorbeeld, onderwijs te volgen, medische zorg te verkrijgen of indien dit mogelijk zou kunnen leiden tot een verlies van sociale uitkeringsrechten. In de tweede plaats zou het recht op vrij verkeer mogelijk zo kunnen worden uitgelegd dat het ook een recht omvat naar andere LidStaten te gaan teneinde toegang te verkrijgen tot welvaartsstaatsvoorzieningen. Het tweede belang betreft de instandhouding van collectieve voorzieningen. Dit belang lijkt bepaalde beperkingen op de toegang tot voorzieningen te vereisen. Een ongelimiteerd vrij verkeer voor "bijstandstrekkers", studenten en patiënten kan mogelijk een bedreiging vormen voor de financiering, organisatie en kwaliteit van sociale voorzieningen. Dergelijke voorzieningen lijken enkel in stand te kunnen worden gehouden indien Lid-Staten, waar nodig, het recht hebben restrictieve voorwaarden op te leggen aan niet-onderdanen en/of niet-ingezetenen of hen zelfs geheel uit te sluiten van bepaalde collectieve voorzieningen. Naast talloze 
specifieke vragen betreffende de grensoverschrijdende toegang tot collectieve voorzieningen, beoogt dit boek de vraag te beantwoorden hoe het EG-recht de potentieel tegenstrijdige belangen van de verwezenlijking van een vrij verkeer van personen en de noodzaak collectieve voorzieningen in stand te houden, met elkaar tracht te verzoenen.

De Europese Gemeenschap (EG) heeft nog relatief weinig ervaring met het onderwerp van de grensoverschrijdende toegang tot collectieve voorzieningen. Kennisneming en analyse van de ervaringen van andere organisaties en (bonds)staten met het onderwerp kan van belang zijn teneinde na te gaan hoe het genoemde konflikt op de meest adequate wijze kan of dient te worden beslecht en of het wenselijk is, en zo ja, hoe, de huidige EG-regels mogelijk kunnen worden aangepast. Voor dit doel wordt in dit boek onderzocht in hoeverre het constitutionele recht van de Verenigde Staten van Amerika (VS) individuen het recht geeft toegang te verkrijgen tot welvaartstaatsvoorzieningen in andere Staten.

Het boek bestaat uit zes hoofdstukken. In het eerste hoofdstuk wordt het onderwerp van de grensoverschrijdende toegang tot collectieve voorzieningen ingeleid, afgebakend en gedefinieerd. Het tweede hoofdstuk plaatst het onderwerp in het vereiste juridisch-historisch kader. Het beschrijft hoe de belangrijkste regels inzake het verkeer van personen in de EG en de VS zich in de loop van jaren hebben ontwikkeld en wat zij vandaag de dag inhouden. De volgende drie hoofstukken vormen de kern van het boek. Zij beschrijven en analyseren in hoeverre het EG-recht aan begunstigden van het recht op vrij verkeer het recht geeft toegang te verkrijgen tot bestaansminimumuitkeringenstelsels (Hoofdstuk 3), gezondheidszorgvoorzieningen (Hoofdstuk 4) en onderwijs (Hoofdstuk 5). De struktuur van de drie hoofstukken komt nagenoeg overeen. $\mathrm{Na}$ een inleidende paragraaf waarin onder andere de belangrijkste karakteristieken van de nationale voorzieningenstelsels worden beschreven, wordt nagegaan in hoeverre het EG-recht aan de verschillende categoriën van (begunstigden van het vrij verkeer van) personen (werknemers, economisch niet-actieven, niet-ingezetenen en de zogenaamde derdelanders) het recht toe kent in andere Lid-Staten toegang te verkrijgen tot de respektievelijke voorzieningen. Vervolgens wordt in ieder van deze hoofdstukken nagegaan in hoeverre het Amerikaanse recht aan Amerikaanse staatsburgers en "vreemdelingen" het recht geeft in andere Staten toegang te verkrijgen tot de aan de orde zijnde voorzieningen. In de slotparagraaf van de Hoofdstukken 3, 4 en 5 wordt de vraag gesteld of het wenselijk is de regels van het EG-recht aan te passen, en zo ja, hoe, dit kan of dient te gebeuren. In Hoofstuk 6, tenslotte, worden enkele "horizontale" vergelijkingen getrokken met als doel na te gaan hoe het EG-recht het potentiële konflikt tussen "vrij verkeer" en "instandhouding van collectieve voorzie- 
ningen" heeft gepoogd op te lossen en of het voorziet in een aantal aantal meer algemene regels of beginselen die kunnen of dienen te worden toegepast bij het beantwoorden van vragen betreffende de toegang tot collectieve voorzieningen.

\section{Het Vrij Verkeer van Personen}

In het oorspronkelijke EEG-Verdrag was het recht op vrij verkeer economisch gedetermineerd. Migratierechten werden enkel toegekend aan werknemers (artikel 39 EG) en zelfstandigen (artikel 43 EG) teneinde hen in staat te stellen economische activiteiten te verrichten in andere Lid-Staten. Het recht op gelijke behandeling was in beginsel beperkt tot aan het werk gerelateerde aangelegenheden. Reeds in de jaren '60 werd echter erkend dat het vrij verkeer van werknemers niet primair dient te worden begrepen in macro-economische termen van een vrij verkeer voor de productiefactor arbeid, maar veeleer als het begin van een Europees Burgerschap. De introduktie van deze term heeft de verdere ontwikkeling van het vrij verkeer van werknemers en personen beïnvloed. De term "burgerschap" symboliseert dat het recht op vrij verkeer is uitgegroeid tot een fundamenteel, individueel en in rechte handhaafbaar recht. Van meet af aan heeft het Hof van Justitie van de Europese Gemeenschappen (hierna: het Hof) zich op het standpunt gesteld dat het door artikel 39 gegarandeerde, en met name in Verordening Nr.1612/68 nader uitgewerkte, vrij verkeer van werknemers ruim dient te worden uitgelegd. Het Hof heeft de rechtspositie van werknemers en hun familieleden in het gastland versterkt onder andere door het toepassingsgebied van het recht op gelijke behandeling enorm uit te breiden tot vrijwel alle beleidsterreinen. Voorts heeft het Hof Artikel 49 EG-verdrag inzake het vrij verkeer van diensten aldus uitgelegd dat het aan iedere Europese burger een recht op vrij reizen binnen de Gemeenschap toekent. De term burgerschap heeft de "politieke" EG-instellingen geïnspireerd het recht op verblijf ook toe te kennen aan niet-economisch actieven. De sinds het begin van de jaren ' 70 genomen initiatieven hebben uiteindelijk geleid tot drie verblijfsrichtlijnen voor studenten, gepensioneerden en "overige" EG-onderdanen, de formele invoering van een Burgerschap van de Europese Unie (artikel 17 EG) en de erkenning in het verdrag van een algemeen recht op verblijf voor alle Unieburgers (artikel $18 \mathrm{EG).}$

Het feit dat er sprake is van een Europees Burgerschap symboliseert een signifikante beperking van het recht op vrij verkeer: het is in beginsel voorbehouden aan onderdanen van de Lid-Staten. In de periode 
1958-1970, kon het vrij verkeer van werknemers enkel worden verwezenlijkt omdat de Lid-Staten insisteerden dat zij volledig bevoegd bleven de toegang van zogenaamde "derdelanders" tot hun grondgebied, arbeidsmarkt en welvaartsstaat te reguleren. Doordat het Europees Burgerschap de ontwikkeling van het vrij verkeer van personen sterk heeft beïnvloed, hebben de derdelanders niet kunnen profiteren van de geleidelijke uitbreiding van de rechten die de vrij verkeersbepalingen toekennen. Sommige groepen van derdelanders genieten bepaalde rechten onder het EG-recht (in de hoedanigheid van familielid van Europese burgers en onder verdragen die de EG en de Lid-Staten met derde landen hebben gesloten zoals bijvoorbeeld het EER-Verdrag, de Associatieovereenkomst met Turkije en de Maghreb-verdragen), maar, kort gezegd, is de rechtspositie van derdelanders minder goed ontwikkeld dan die van EG-onderdanen.

De Amerikaanse Grondwet noemt nergens een recht op vrij verkeer, maar dit betekent echter geenszins dat dit recht grondwettelijke bescherming ontbeert. Integendeel, in de visie van de opstellers van de Grondwet was het zo vanzelfsprekend dat een ieder die op het nationaal grondgebied aanwezig is het recht geniet zich vrij te verplaatsen, dat zij het simpelweg niet nodig vonden dit recht expliciet op te nemen. Het recht op vrij verkeer binnen de VS is van meet af aan erkend als een logisch uitvloeisel of element van het Amerikaans Burgerschap en een fundamenteel recht vormt dat ook aan niet-Amerikanen toekomt. Het recht op vrij verkeer omvat ook een recht op gelijke behandeling in andere Staten. Amerikaanse burgers die zich vestigen in een andere Staat verkrijgen automatisch het burgerschap van die staat en genieten, in die hoedanigheid, alle rechten en voordelen die die Staat aan haar burgers toekent. Zij die enkel een andere Staat bezoeken, genieten een recht op gelijke behandeling onder, met name, de "Equal Protection Clause", de "Privileges and Immunities Clause" en de zogenaamde "dormant Commerce Clause".

\section{Bestaansminimumuitkeringen}

De Lid-Staten van de EG hebben zich altijd verzet tegen een recht op vrij verkeer dat ook personen die afhankelijk zijn van een bestaansminimumuitkering in staat stelt zich elders te vestigen. Met name de Lid-Staten die zich vandaag de dag in het geografische hart van de EG bevinden, zijn altijd bevreesd geweest dat hun relatief goed ontwikkelde uitkeringenstelsels een aantrekkende kracht zouden hebben op onderdanen van andere Staten waar uitkeringsniveaus lager zijn. "Sociaal tourisme", zo hebben de Lid-Staten altijd gesteld, vormt een bedreiging voor de financiering van 
bijstandsstelsels en dient te worden vermeden. In de beginjaren hoefden de Lid-Staten hun bezwaren niet te uiten. Het recht op vrij verkeer was voorbehouden aan werknemers en zelfstandigen die werden geacht in hun eigen bestaan te voorzien door het door werk gegenereerde inkomen. $\mathrm{Zij}$ die door ziekte, arbeidsongeschiktheid, werkloosheid of pensionering niet (langer) konden werken, konden zich, indien nodig, beroepen op de socialezekerheid Verordening $\mathrm{Nr}$.1408/71 teneinde een inkomensvervangende vervangende socialezekerheidsuitkering te ontvangen. Echter, toen vanaf het begin van de jaren ' 70 het Hof van Justitie de bepalingen van het EG-recht inzake het vrij verkeer van personen ruim begon uit te leggen en de eerste initiatieven voor de verwezenlijking van een algemeen recht op verblijf werden genomen, kwam het konflikt tussen de doelstelling van het vrij verkeer en de bescherming van uitkeringenstelsels aan de oppervlakte. Lid-Staten hebben zich altijd verzet tegen een uitbreiding van de rechten van "behoeftigen", maar dit heeft het Hof niet weerhouden de relevante bepalingen van het EG-recht ruim uit te leggen. Werknemers, hun familieleden en naar alle waarschijnlijkheid ook de economisch inactieven genieten een recht op gelijke behandeling ten aanzien van bestaansminimumuitkeringen wanneer, en voor zo lang, zij rechtmatig op het grondgebied van een andere Lid-Staat verblijven. Het Hof en de EGwetgever hebben de financiële belangen van de Lid-Staten echter niet uit het oog verloren. Woonplaatsvereisten voor het recht op bijstands- en andere bestaansminimumuitkeringen kunnen rechtmatig worden toegepast en Lid-Staten zijn bevoegd het recht van verblijf van onderdanen van andere Lid-Staten op hun grondgebied afhankelijk te stellen van de voorwaarde dat zij of "reële en daadwerkelijke" arbeid verrichten of beschikken over voldoende bestaansmiddelen.

De laatste twee voorwaarden voor de uitoefening van het recht op verblijf stellen de Lid-Staten in staat zich te beschermen tegen "sociaal tourisme" en de mogelijke financiële gevolgen daarvan. Vanuit het perspectief van het Europees burgerschap zijn deze voorwaarden echter problematisch. Dit burgerschap is een politiek concept dat slechts beperkte betekenis heeft zolang bepaalde Europese burgers vanwege hun economische status zijn uitgesloten van het fundamentele recht op vrij verkeer. Ervaringen in de VS, waar "financieel behoeftigen" een onbeperkt recht op vrij verkeer genieten en in de Staat alwaar zij woonachtig zijn een grondwettelijk gewaarborgd recht op gelijke behandeling genieten ten aanzien van de toegang tot bestaansminimumuitkeringenstelsels, roepen de vraag op of er in de EG daadwerkelijk behoefte is vast te houden aan het bestaansminimumsvereiste. In de VS, waar burgers over het algemeen veel mobieler zijn dan in de EG, doet sociaal tourisme zich niet of nauwelijks voor en is nog nooit aangetoond dat het vrij verkeer van 
"behoeftigen" de financiering van uitkeringenstelsels daadwerkelijk bedreigt. De tijd lijkt nog niet rijp, maar er lijken weinig inhoudelijke bezwaren te zijn tegen de verwezenlijking of erkenning van een algemeen en onvoorwaardelijk recht op verblijf voor alle Europese burgers.

\section{Gezondheidszorg}

De EG-instellingen zijn zich van meet af aan bewust geweest van het feit dat een daadwerkelijk recht op vrij verkeer grensoverschrijdende rechten inzake de toegang tot medische zorg vereist. Reeds in het eind van de jaren '50 heeft de EG-wetgever maatregelen genomen die aan begunstigden dergelijke rechten toekent. De artikelen 18-36 van de huidige Verordening Nr.1408/71 en de relevante bepalingen van de implementatieverordening Nr.574/72 bevatten bepalingen die de nationale zorg(verzekerings)stelsels op elkaar af stemmen en die, heel in het kort, aan alle begunstigden een recht op toegang tot medische zorg in het woonland en een recht op noodhulp tijdens een kort verblijf in andere Lid-Staten, toekennen. Medische zorg wordt verstrekt volgens de in de betreffende Lid-Staat geldende regelgeving; de kosten worden gedragen door de LidStaat alwaar begunstigden zijn "verzekerd". Verordening Nr.1408/71 kent aan verzekerden in beginsel geen recht toe zich naar een andere Lid-Staat te begeven teneinde aldaar, op kosten van het "verzekeringsorgaan", medische zorg te ontvangen. De vergoeding van de medische kosten is afhankelijk van de voorafgaande toestemming door het bevoegde orgaan. Een recht op dergelijke toestemming bestaat slechts in zeer exceptionele gevallen en is, in de regel, niet veel meer dan een zelden gedane gunst.

Onder het regime van Verordening Nr.1408/71 is het recht op toegang tot zorg territoriaal beperkt. Tot voor kort leek het EG-recht zich niet te verzetten tegen deze beperking. Op 28 april 1998, echter, wees het Hof arrest in de zaken Decker en Kohll waarin het bepaalde dat nationale regels welke de vergoeding van medische verstrekkingen in een andere Lid-Staat afhankelijk stellen van de voorafgaande toestemming van het bevoegde verzekeringsorgaan in strijd zijn met de Verdragsbepalingen inzake het goederen en diensten, en dat dergelijke regels enkel rechtmatig kunnen worden toegepast indien kan worden aangetoond dat deze nodig zijn voor de bescherming van het "financiële evenwicht" van zorg(verzekerings)stelsels en/of de instandhouding van een "evenwichtig en voor eenieder toegankelijk stelsel van gezondheidszorg". Kern van de arresten in Decker en Kohll is dat de vergoeding van kosten voor in een andere Lid-Staat ontvangen medische prestaties niet langer dient te worden beschouwd als een door de bevoegde verzekeringsorganen toegekende 
gunst, maar als een afdwingbaar communautair recht dat slechts in bepaalde gevallen en onder bepaalde voorwaarden kan worden beperkt. De preciese betekenis en gevolgen van de arresten zijn echter nog verre van duidelijk. Vele vragen betreffende de betekenis van de arresten voor intramurale zorg, wachtlijsten, "natura-stelsels", nationale gezondsheidsdiensten, de vergoeding van niet in verzekeringspakketen opgenomen voorzieningen en de derdelanders zijn nog niet door het Hof beantwoord. Voor de EG valt er op het terrein van de gezondheidszorg niet veel te leren uit de ervaringen in de VS. Het Amerikaanse zorg(verzekerings)stelsel verschilt op talloze punten van de Europese stelsels en de mate waarin het Amerikaans recht aan (publiek) verzekerden een recht op "zorg over de grens" toekent, valt in het niet bij het EG-recht.

\section{Onderwijs}

Het Europese onderwijsrecht is pas relatief laat tot ontwikkeling gekomen. Het oorspronkelijke EEG-Verdrag kende aan de EG-instellingen geen wetgevende bevoegdheden op dit beleidsterrein toe en nergens werd melding gemaakt van onderwijsrechten voor de begunstigden van het vrij verkeer van personen. In de loop der jaren echter heeft de EG zich in toenemende mate met onderwijsaangelegenheden bezig gehouden. Het Hof heeft een bijzonder belangrijke rol gespeeld. Door een zeer ruime uitleg te geven aan een aantal bepalingen van het $E(E) G$-Verdrag, heeft het Hof wetgevende bevoegdheden voor de "politieke" EG-instellingen erkend die deze vervolgens hebben gebruikt voor de ontwikkeling van een Europees onderwijsbeleid dat het nationale onderwijsbeleid complementeert. Voorts heeft het Hof vergaande rechten inzake de toegang tot het onderwijs erkend. Alle Europese burgers die rechtmatig in een andere Lid-Staat verblijven hebben het recht aldaar onder dezelfde voorwaarden als de onderdanen van die Staat te worden toegelaten tot alle vormen van onderwijs en studiefinanceringsstelsels. Voorts heeft Hof in het arrest Gravier de juridische basis gelegd voor een vrij verkeer van studenten. Alle Europese burgers hebben het recht zich te begeven naar andere LidStaten teneinde onderwijs te volgen. Dit recht omvat een recht op verblijf voor de duur van de studie en een recht op gelijke behandeling ten aanzien van studiebeurzen voor zover deze college- en inschrijvingsgelden dekken.

Ondanks het algemeen erkende belang van grensoverschrijdende rechten inzake de toegang tot onderwijs, en de op dit terrein gemaakte vooruitgang, is er kritiek op de huidige regels. Deze kritiek betreft met name de categorie van Europese burgers die buiten het communautaire 
Erasmus-Socrates programma om een voltijds studie in een andere LidStaat willen volgen. Enerzijds, wordt gesteld dat de huidige regels inzake het vrij verkeer van studenten niet voldoende recht doen aan de financiële en onderwijsbelangen van Lid-Staten die als "netto-importeurs" van studenten kunnen worden bestempeld. Ten faveure van deze Lid-Staten zouden bepaalde beschermende maatregelen moeten worden genomen. Anderzijds, wordt gesteld dat er nog te veel belemmeringen voor het studentenverkeer bestaan. Deze omvatten problemen ten aanzien van de erkenning van diplomas, taalbarrières, de beperkte mogelijkheden om studiebeurzen te exporteren en administratieve problemen ten aanzien van het verblijfsrecht. In de laatste paragraaf van Hoofdstuk 5 worden, na kennisneming en analyse van het Amerikaanse recht inzake de grensoverschrijdende toegang tot publiek onderwijs, verschillende opties besproken voor $(i)$ een mogelijke bescherming van de belangen van de netto-importeurs (vergoedingensysteem, de toepassing van hogere college- en inschrijvingsgelden voor niet-ingezetenen en beperkingen op het aantal toe te laten niet-ingezetenen) en (ii) het bevorderen van studentenmobiliteit (export van studiebeurzen en afschaffing van het bestaansminimumvereiste voor het recht op verblijf van studenten)

\section{Conclusies}

In het afsluitende hoofdstuk wordt afstand genomen van de meer specifieke en concrete vragen die het onderwerp van de grensoverschrijdende toegang tot de geselecteerde collectieve voorzieningen oproept en wordt getracht na te gaan of het EG-recht in een aantal meer algemene regels of beginselen voorziet die dienen te worden toegepast bij het beantwoorden van vragen betreffende de toegang tot collectieve voorzieningen. Een aantal regels kan inderdaad worden "ontdekt". Ten aanzien van Europese burgers die gebruik hebben gemaakt van het recht in een andere Lid-Staat verblijf te vestigen, heeft het EG-recht zich aldus ontwikkeld dat het aan deze categorie een recht toekent toegang te verkrijgen tot (vrijwel alle) collectieve voorzieningen vanaf het moment dat zij zich vestigen tot het moment dat het gastland hun rechtmatig verblijft beëindigt. Lid-Staten kunen hun welvaartsstaatbelangen enkel beschermen door gebruik te maken van de (resterende) immigratiebevoegdheden. Die belangen kunnen niet langer worden beschermd door ingezetenen de toegang tot voorzieningen te weigeren op grond van hun nationaliteit of het toepassen van eisen inzake een minimum duur van verblijf. Ten aanzien van Europese burgers die enkel kortstondig op het grondgebied van een andere LidStaat verblijven, is de juridische situatie omgekeerd. Lid-Staten kunnen de 
toegang tot het grondgebied niet weigeren. Zij dienen hun welvaartstaatvoorzieningen te beschermen door de toepassing van discriminatoire maatregelen of regels. Nationaliteitscriteria zijn in beginsel verboden. Het juiste juridisch instrument voor de bescherming van collectieve voorzieningen is de verblijfsvoorwaarde. In beginsel, vormen dergelijke voorwaarden verboden indirecte discriminaties op grond van nationaliteit maar zij kunnen rechtmatig worden toegepast wanneer, en in zoverre, als zij nodig zij voor de bescherming van voorzieningenstelsels. Ten aanzien van bepaalde voorzieningen (openbare wegen, publiek parken, etc) is dat vrijwel onmogelijk, terwijl verblijfsvoorwaarden voor uit belasting gefinancierde geldelijke uitkeringen die voorzien in "minimuminkomen" vrijwel altijd de discriminatietest kunnen doorstaan. De meest lastige vragen rijzen ten aanzien van de toegang van niet-ingezetenen tot collectieve voorzieningen die in natura worden aangeboden zoals medische zorg en onderwijs. De rechtmatigheid van verblijfsvoorwaarden voor toegang tot dergelijke voorzieningen dient van geval tot geval te worden bepaald. Duidelijke criteria voor de toepassing van de discriminatie test op verblijfsvoorwaarden voor dergelijk natura voorzieningen zijn echter nog niet ontwikkeld. 



\section{CURRICULUM VITAE}

De op 26 augustus 1964 in Tilburg geboren en de in 1988 aan de Faculteit der Rechtsgeleerdheid van de Rijksuniversiteit Groningen afgestudeerde Anne Pieter van der Mei heeft het aan dit proefschrift ten grondslag liggende onderzoek verricht aan Universiteit Maastricht alwaar hij thans werkzaam is als Universitair Docent in het Europees Recht. 